HEDL -6617

\title{
COMPUTERIZED INTERFERENCE
}

\section{ELIMINATION REPORT}

FFTF CELLS

$489,422 E, 529 A \& 529 B$ This sonsored by the United States Govemates Department of United States nor the United Stales, nor any of then Energy, nor any of dhertors, or theis employees, makes contractors, subconress or implied, or assumes any tesess any warranty, exprssuthy for the accuracy, completuce or liability or tesp any information, apparatus, prould not or usefulness of any or represents that its use would not process disclosed, or red nght

\begin{tabular}{|c|c|c|}
\hline $\begin{array}{l}\text { Operated by the } \\
\text { Westinghouse } \\
\text { Hanford Company }\end{array}$ & 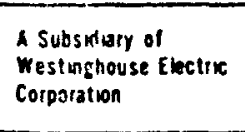 & 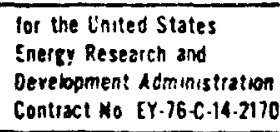 \\
\hline
\end{tabular}




\section{DISCLAIMER}

Portions of this document may be illegible in electronic image products. Images are produced from the best available original document. 


\section{NOTICE}

This report was prepared as an account of work sponsored by the United States Government. Neither the United States nor the U.S. DOE, nor any of their employees, nor any of their contractors, subcontractors, or their employees, makes any warranty express or implied, or assumes any legal liability or responsibility for the accuracy, completeness or usefulness of any information, apparatus, product or process disclosed, or represents that its use would not infringe privately owned rights.

\section{PRELIMINARY REPORT}

This report contains information of a preliminary nature prepared in the course of work under Department of Energy Contract DE-AC14-76FF02170. This information is subject to correction or modification upon the collection and evaluation of additional data. 


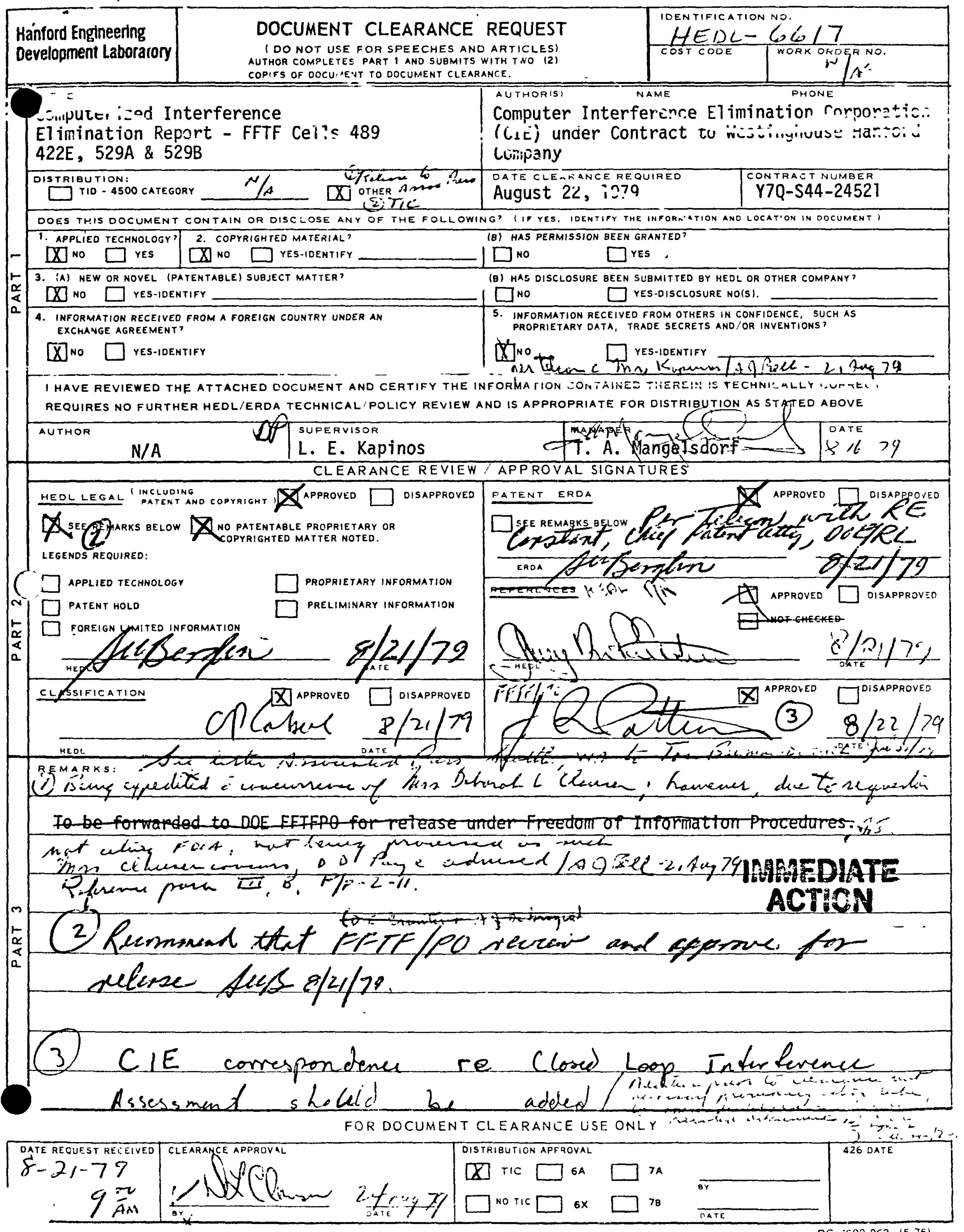


HEDL-PCA-(DDP) -261

From: FFTF Components Purchasing

Phone: $\quad 2-5390$

Date: $\quad$ August 15,1979

Subject: REQUEST FOR DOClivieivT RELEASE

Reference: Associated Press Letter, July 31, 1979 to DOE-?I

To: D. L. Clausen (W/C-115)

$\begin{array}{ll}\text { WE Kimball } & \text { (W/B-36) } \\ \text { TA Mangelsdorf } & \text { (W/B-63) } \\ \text { JC Richardson } & \text { (W/B-53) } \\ \text { TA Strom } & (W / A-21) \\ \text { DD Paye/LB/File } & (W / B-27)\end{array}$

We wish to release the information requested in the referenced Associated Press letter to the FFTF Project office under FOI Procedures for further release to Associated Press as appropriate. Since the release includes a report, a Document Clearance Request is enclosed.

Please advise if further information is required.

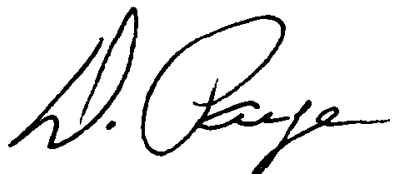

D. D. Paye, Manager

FFTF Components Purchasing

am1

Enclosure 


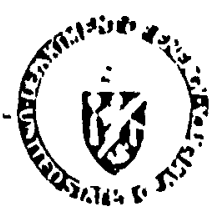

Department of Energy

Richlund Operations Office

P.O. Box 550

Richland, Washingiun 99352

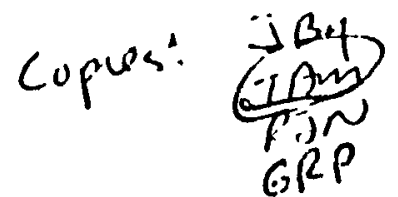

AUG 21979

Les Blumenthal

Vlashington State Editor

The Associated Press

20i Borsa A:oruc $\mathrm{N}$

P.0. Box 2144

Seattle, Washington 98111

Dear Les:

Thanks for your letter of July 31 requesting information concerning Westinghouse Hanford Company's contract with Computerized Interference Elimination Inc., Bellevue.

By copy of this letter I am asking Fred Zerza, Public Relations Wanager, Hestinghouse Hanford Company to pull together the available information for you and to work with you in setting up an interview after you have had a chance to read the documents. I already have discussed your request with fred and he should be getting in touch with you within a few days. Fred can be reached at 509-942-5101 if you need to phone him.

Please let me know if I can provide additional information.

Very truly yours,

PAO:TAC

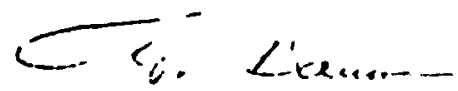

Tom Bauman, Director

Public Affairs Office

cc: Fred C. Zerza, HEDL w/incoming itr. 
THE ASSOCIATI:D PRESS

201 BOREN AVENUE NORTH'

P. O. DOX 2144

MAT.-E. WABHINGTON DOIII

\section{งนะฟ 37, 1999}

Tom Bauman

Public Relations

Energy Research and Development Administration

Dear Tom,

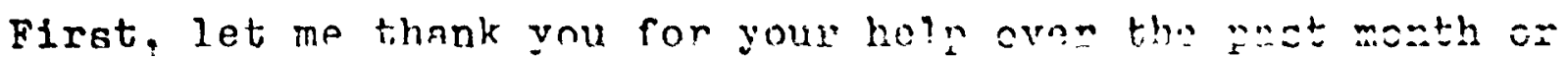
so in roundine up the material on the Hanford nuclear reservation I requested.

My latest request involves a contract that Westinghouse llanford Company had with Computerized Interference Eljmination Inc. of Bellevue. The contract, or purchase order, was Y72-i;-44-24521 and was qated $3 / 16 / 77$. I am interested in the finnl report that Computerized Interference submitted, Westinghousc's response and ang further correspondence between the two.

I an not sure whether it is you or Westinghouse who has the information, but figured you would be able to get it for me. The phone coversation we had on Tuesday scemed to indicate it will present no problems and I of course will want to meet with someone from Westinghouse or your office to discuss it.

I have not yet seen the FFTF and perhaps can free up some time to take a tour and meet with you. Keepme advised and thanks.

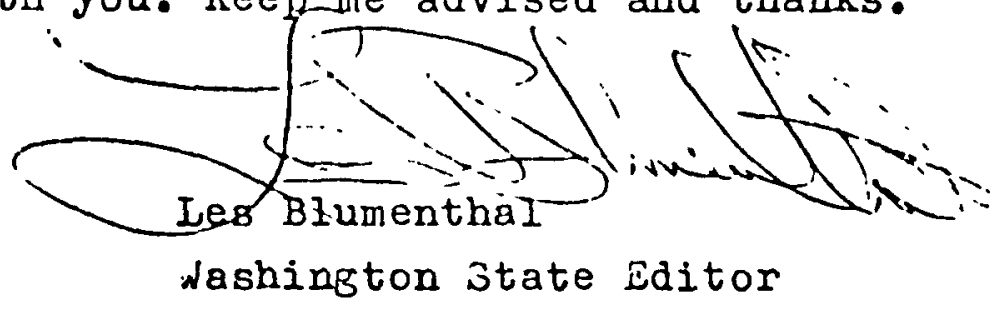

cc: brewer marlow 


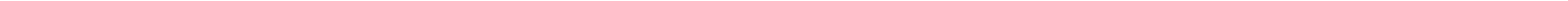


FURCHAS: ORDER

Y>Q $5.14-24521$

!

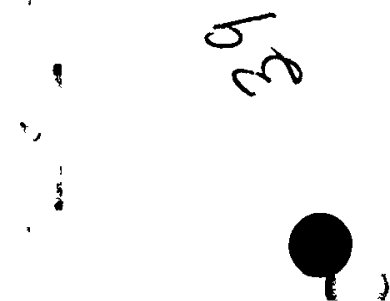


Hallfold wa

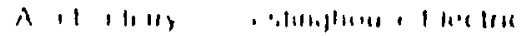

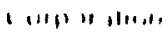

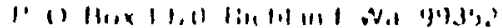

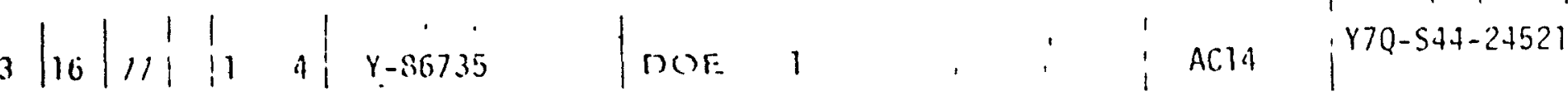

\section{RECEIVED BUYER: D. G. CAMPBELL \\ $(509) \quad 912-5,5,82$}

MAR 2 I 1977

(ONIIIIIRI,III INIIRIIRINCT II IMINAIION, INC.

14230 N.L BIII SIRLLT

BELLEVUE, WA 98007

D. G. CAMPBELL

FOB: BELLEVUE, WA

REQUIRED AT TOB POINT MAY ?, 19/1

conte 10

- IP VIA: MAIL

PAYMENT TERMS 0000

NET: $\quad 30$

BUYER: D. G. CAMPBELL

ITEM NO. $\quad \frac{\text { QTY }}{1} \quad \underline{\text { U/M }}$

CONFIRMING TWX RELEASE MARCH 7, 1977 UNIT TOTAL

DESCRIPTION

PRICE

PRICE

PERFORM COMPUTERIZED IDENTIFICATION OF $\$ 68,600.00 \$ 68,600.00$ INTERFERENCES TROM DRAWINGS FOR FFTF

CELLS 489, 422E, 529A, AND 529B.

TOTAL:

$\$ 683,6000.00$

1.0 GINLRAL PROVISIONS, ADMINISTRATIVE REQUIREMENTS, AND ADDITIONAI PROVISIONS.

1.1 THE FOLLOWING GENERAL PROVISIONS ARE A PART OF THIS ORDCR:

1.1.1 FIXED PRICE ORDER, 54-7600-027 (3/76) ARTICLES I THROUGII 37.

1.2 THE FOLLOWING ADMINISTRATIVE REQUIREMENTS ARE A PART OF THIS ORDER:

1.2.1 ADMINISTRATIVE INSTRUCTIONS FOR FIXED PRICE ORDERS BD-7600-189 (1-73).

1.3 OTHER ADDITIONAL PROVISIONS APPLICABLE TO THE ORDER ARE SHOWN IN PARAGRAPH 5.

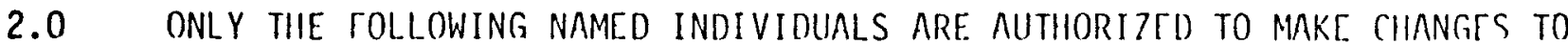
THIS OROFR:

D. G. CAMIIBELL, BUYCR, TITT PROCUREMLNT DFP'ARIMLNT

E. J. RENKEY, SECTION MANAGER, FFTF PROCUREMENT DEPARTMENT

J. L. UTZ, MANAGER, FITF PROCUREMLNT DEPARTMENT 


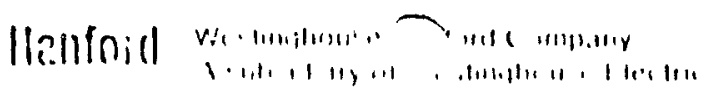

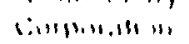

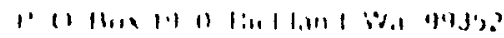

$\mathcal{O}$

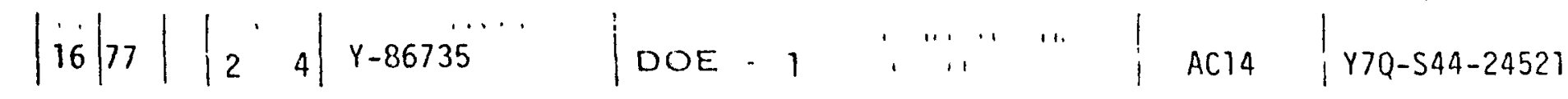

3.0 DELIVERY ADDRESS

3.1 ALL INTERFERENCE DOCUMCNTATION SHALL BE ADDRESSED AS FOLLOWS:

WESTINGHOUSE HANFORD COMPANY

P. O. BOX 1970

RICHLAND, WA 99352

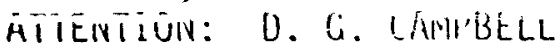

337 BUILDING/2N64 - 300 AREA

4.0 BILLING INSTRUCTIONS: IN ADDITION TO THE BILLING INSTRUCTIONS INCLUDED IN ADMINISTRATIVE REOUIRCMENTS, SHOW PURCHASE ORDER NUMBER, ON ALL PACKAGES, INVOICES AND CORRESPONDENCE. COMPLETE PACKING LIST MUST ACCOMPANY EACH SHIPMENT.

RENDER INVOICES IN TRIPLICATE.

ATTENTION: ACCOUNTS PAYABLE. INCLUDE YOUR VENDOR CODE NUMBER ON YOUR INVOICE. ATTACH ORIGINAL BILL OF LADING ON ALL COLLECT SHIPMENTS AND SUPPORT ALL PREPAID FREIGHT CHARGES WITH THE ORIGINAL PAID FREIGHT BILL AND BILL OF LADING.

5.0 OTHER INFORMATION

5.1 FIXED PRICE CHARGES FOR THE INTERFERENCE ANALYSIS IS BROKEN DOWN AS FOLLOWS:

5.1.1 CELLS 489 AND 422E A. LABOR:

1. INPUT OF DATA

2. ANALYSIS OF DATA

3. INTERFERENCE SKETCHES

B. COMPUTER AND PROGRAM USAGE TOTAL:
$\$ 1 \dot{9}, 800$

$\$ 2,200$

$\$ 4,500$

$\$ 25,000$

$\$ 51,500$

5.1.2 CLLLS 529A AND $529 B$ A. LABOR:

1. INPUT OF DATA

2. ANALYSIS OF DATA

3. INTERFERENCE SKETCHES

B. COMPUTER AND PROGRAM ISAGG

TOTAL:

GRANI TOTAL:
$\$ 7,425$

$\$ 825$

$\$ 1,350$

$\$ 7,500$

$\$ 1 /, 100$

$\$(i, .600$ 


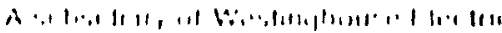
(in)

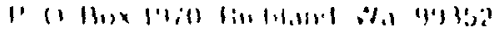

3

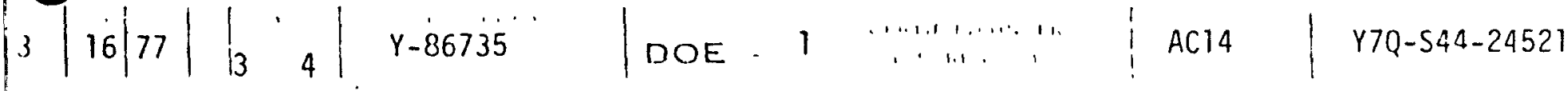

5.2 DOCUNENTATION OF INTERTERT.NCES SHAII. BE ACCOMPLISHED AS TOLLOWS:

5.2.1 INSULATION INTERFERING WITH ANYTHING ELSE EXCEPT PIPE SUPPORT PARTS WRITTEN DESCRIPTION (NO SKETCHCS).

5.2.2 METAL TO METAL INTERFERENCES EXCEPT THOSE INVOLVING PIPE SUPPORT PARTS WRITTEN DESCRIPTION (NO SKETCHES).

5.2.3 ANY INTERFERENCES WITH PIPE SUPPORT PARTS - SCALEO SKETCH WIWI IIRITIIN DÉSTRIPTIGUY Oir IT.

5.2.4 INTERFERCNCE NOTICES SHALL BE DELIVERED ON A WEEKLY BASIS WHILE BEING GENERATED.

6,0 PAYMENT

6.1 THE FOLLOWING MILESTONE SCHEDULE SHALL BE USED TO ESTABLISH PAYMENT AMOUNTS DURING THE COURSE OF PERFORMANCE UNDER THE ORDER:

6.1 .1 INPUT OF DATA TO COMPUTER $\$ 20,420 \quad \mathrm{l}$

O 6.1 .2 AnAlysis OF DATA $\$ 42,330 \quad \cdots, 12^{*} \cdot d ! ? ! \cdots \cdot \%$

6.1.3 COMPLETION OF INTRRFERLNCE SKETCHES $\$ 5,850 \cdots \cdot \cdot 5 . ?$

6.1.4 SKETCH SUBMITTAI TO BE MADE WEEKLYY STARTING IN APPROXIMATELY FOUR WEEKS. APPROVEO:

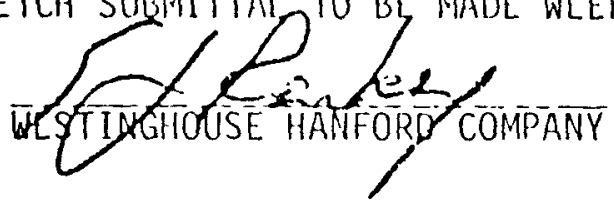

SELLER SHALL ACKNOWLEDGE AND ACCEPT THIS ORDER OR ALTERATION BY DATING AND SIGNING A COPY OF THIS ORDER OR ALTERATION IN THE SPACE PROVIDED BEI.OW, AND RETURNIIIG THE SIGNED COPY TO THE BUYER WITHIN FIVE WORKING DAYS OF RECEIPT.

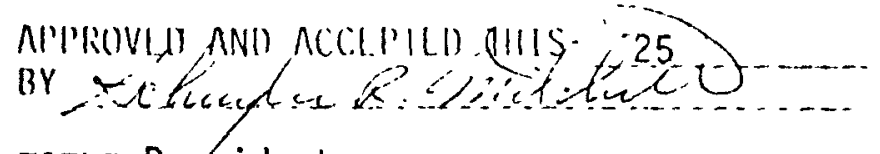
DnY or March 1977

TITLE President 


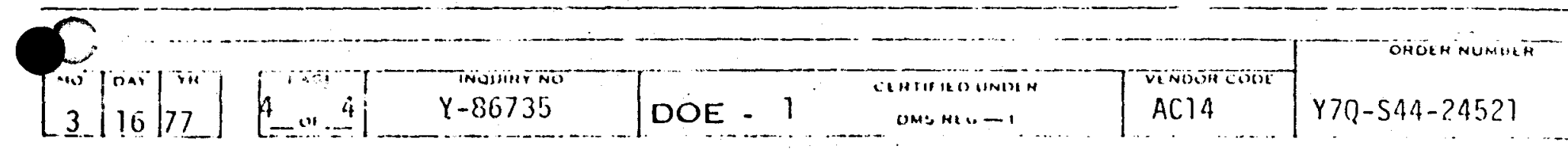

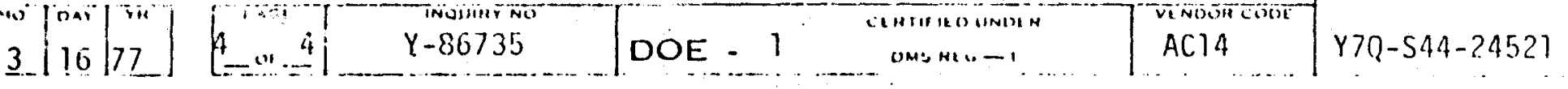

:

COST CENTER OR GENERAL LEDGER

ITEM NO.

1 ACCOUNT

\section{RDN ACCOUNT CLASS} TYPE OR SUBBACCOUINT

VN13000
$? 01930$

BUILDING

REQUISITION AUTHOR: L. E. KAPINOS 16/RM $50 \quad 400$

OA REPRESENTATIVE: J. E. CURTIS $16 /$ RM $50 \quad 400$

DELIVER TO: $\quad$ D. G. CAMPBELL 337

$\therefore$ OF ITIM COST

NPII.ICABLI. IO

EACII COST COUE

W.0., PROJECT

$T / S-S / R$

MrCintin
( $\cong$ MUST EQUUAL

ITEM

100: FOR EACH

ITEN)

$100 \%$
DEL.

BATE

$3 / 11$

$a m b$ 


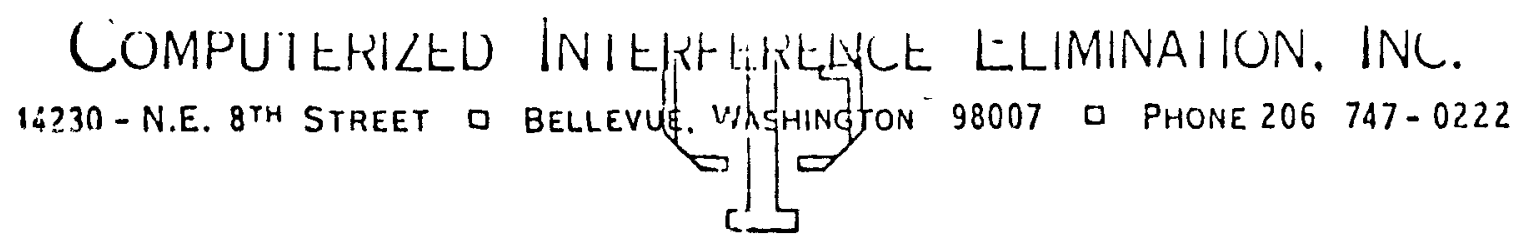

January 27,1977

Mr. Ray C. Mairson

Site Manager - FFTF Project

Westinghouse Hanford Company

P. 0. Box 1970

Richland, Washington 99352

Subject: Expedite interference analys is

Reference: Contract Y7J-544-42006

Dear Mr. Mairson:

Thank you and your fine staff for the many courtesies extended to Mr. Nicholson and myself at our meeting yesterday. Scott and I throughiy enjoyed our tour of the FFTF site with Mr. Kapinos and Mr. Curtis. We now understand more clearly the interference problems faced by construction of such a complicated facility.

At ycsterdays meeting you requested a written proposal from CIE to determine the costs of expediting the interference analysis in the following cells: 576, 489, 422E, 529A and 529B. Also, you reques ted CIE's standard proposal.

Our proposal for CIE to expedite the interference analysis of the above mentioned cells is as follows:

1. The specific areas to be analyzed consist of cells $576,489,422 \mathrm{E}$, 529A and 529B, all as set forth in contract Y7J-544-42006.

2. Work will commence on receipt of authorization from Westinghouse Hanfird for cells 439,422E, 529A and 529B. Work will continue on cecll 576 until completed.

3. Westinghouse Hanford will furnish to CIE an additional set of lurking Drawings for cells 489, 422E, 529A and 529B. These drawings will hin: lhe isometric and hanger plans. These plans will clearly depict the mecessary $X, Y$, and $Z$ coordinates and sizes of the systems. Westinghouse limford shall also furnish any additional engineering or vendor information that may be required

4. CIE shall furnish its own materials, working space, requisite labor, including all key punching and the needed computer time, all as required for the usage of CIE's Decider procedure. 
Mr. Ray C. Mairson

Page 2

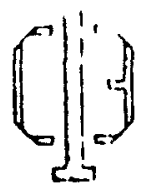

5. CIE, using its Decider procedures, will makc a complete inicrference analys is of the subject spaces (system to system and system to stricture). Each interference detected shall be depicted by a sketch showing the interference. Each sketch shall show all pertinent dimensional information.

6. CIE, Inc. does not hold itself out as a qualified engineering firm. It assumes no responsibility whatsoever for any engineering decisions or evaluations. CIE's function and responsibility is limited to the determination of space availability for the systems as established by the Working Drawings. Although CIE's interference procedure results in virtual 100\% detection of interferences, CIE specifically does not quarantee that each and every interference has, in fact, been detected, and assumes no

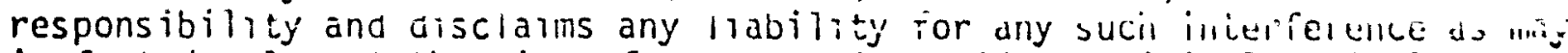
in fact develop at the time of construction. CIE specifically disclaims any responsibility for assuring compliance with the specifications or designs of the project. Where dimensions are not included on the drawings and CIE has had to derive dimension information by scaling, the scaling shall be done to the best of CIE's ability, but CIE shall not be responsible for dimensions if these exact dimensions are not ascertainable from the scaling procedure.

7. The completion date for the cells are as follows:

Cell 576

Cell 489 and $422 E$

Cell $529 \mathrm{~A}$ and 5298
$02 / 15 / 77$

$03 / 31 / 77$

$04 / 22 / 77$

8. CIE's charge to expedite the interference analysis (not including contract $Y 7 \mathrm{~J}-544-42006)$ is as follows:
Cel1 576
Cell 489 and $422 E$.
$\$ 7,500.00$
Cell 529A and 529B
$50,000.00$
$15,000.00$

The above costs are based on a not to exceed price. CIE shall submit its statement based on man hours for each two weeks worked. Westinghouse llanford shail promptly pay CIE as the work advances on the statements so submitted.

CIE's slatement shall be calculated on man hour cost of $\$ 15.00$ per man hour and on the CIE Billing Units at $18 \mathrm{t}$ per billing unit. The Billing Units represent the costs of computer and program usage of CIE's Decider Prouran. The Billing Units are printed at the end of each computer run and shall remain attached to the computer run.

9. Should there be any change orders or engineering design changes, this shall be considered as additional work for which CIE will make a time and material charge of $\$ 15.00$ per man hour plus CIE Billing Unit for computer charge. Any such changes shall be in writing and signed by an authorized agent of Westinghouse Hanford Company. 
Mr. Ray C. Mairson

Page 3

$\int_{2=1} \int_{1}^{1}$

Mr. Kapinos requested along with this proposal to submit the costs to date for cell 5\%. The following is the cost breakdown:

$$
\begin{aligned}
& \text { Labor: } \quad 264 \mathrm{~m} / \mathrm{h} \text { \& } \$ 75.00=\$ 3,960.00 \\
& \text { Computer: 41,637 Billing Units } \\
& \text { a } 18 \notin \text { per unit } \\
& =\quad 7,494.66 \\
& \text { Total Costs } \\
& \$ 77,454.66
\end{aligned}
$$

We look forward to your letter to proceed.

Sincerely yours,

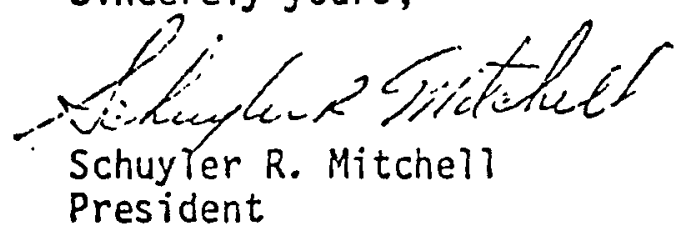

SRM:10

cc: Mr. Larry Kapinos 


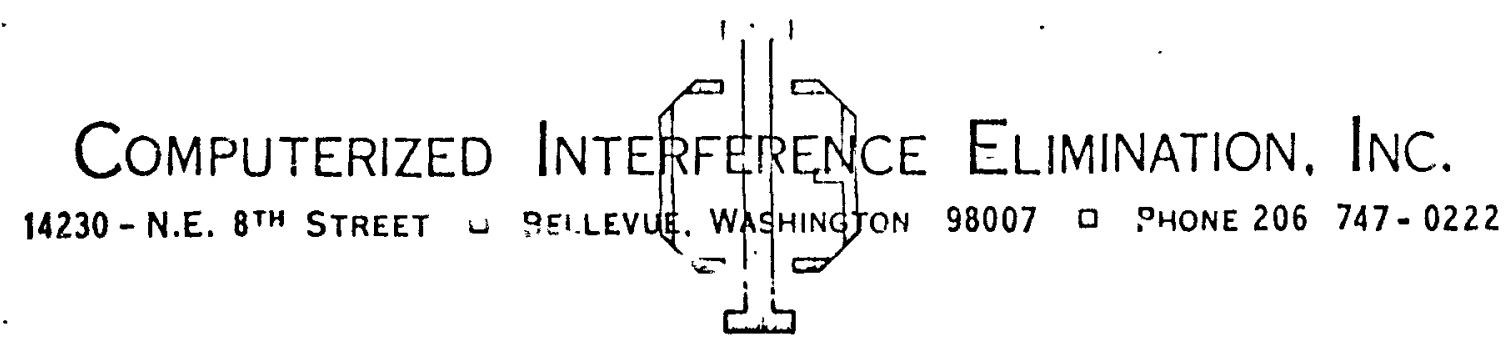

Feivary 3, 1977

Mr. D. G. Campbell

Purchasing Department

Westinghouse Hanford Company

P. 0. Box 1970

Richland, Washington 99352

Subject: Interference Analys is of Cells 489, 422E, 529A and 529B

Reference: CIE letter dated January 21, 1977

Dear Mr. Campbe 11:

This letter is in response to your telephone request today for a proposal from CIE to run an interference analys is of the above cells.

Our proposal for CIE to expedite the interference analys is of the above mentioned cells is as follows:

1. The specific areas to be analyzed consist of cells 489, 422E, $52.9 \AA$ and 529B.

2. Work will commence on receipt of authorization from Westinghouse Hanford.

3. Westinghouse Hanford will furnish to CIE an additional set of Working Drawings for cells 489, 422E, 529A and 529B. These drawings will be the isometric and hanger plans. These plans will clearly depict the necessary $X, Y$, and $Z$ coordinates and sizes of the systems. Westinghouse Hanford shall also furnish any additional engineering or vendor information that may be required.

4. CIE shall furnish its own materials, working space, requisite labor, including all key punching and the needed computer time, all as required for the usage of CIE's Decider procedure.

5. CIE, using its Decider procedures, will make a complete interference analys is of the subject spaces (system to system and system to structure). Each interference detected shall be depicted by a sketch showing the interference. Each sketch shall show all pertinent dimensional information. (see enclosed examples).

6. CIE., Inc. does not hold itself out as a qualified engineering firm. 
Mr. D. G. Campbell

Page 2

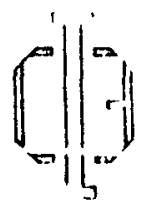

It assumes no responsibility whatsoever for any enginsering decisioni: ar evaluations. CIE's function and responsibility is limited to the determination of space availability for the systems as established by the Working Drawings. Although CIE's interference procedure results in virtual $100 \%$ detection of interferences, CIE specifically does not quarantee that each and every interference has, in fact been detected and assumes no responsibility and disclaims any liability for any such interference as may in fact develop at the time of construction. CIE specifically disclaims any responsibility for assuring compliance with the specifications or designs of the project. Where dimensions are not included on the drawings and CIE has had to derive dimension information by scaling, the scaling shall be done to the best of CIE's ability, but CIE shall not be responsible for dimensions if these exact dimensions are not ascertainable from the scaling procedure.

7. The completion date for all four Cells will be eight weeks after receipt of authorization to proceed from Westinghouse Hanford Company.

8. CIE's fixed price charge for the interference analysis of the four Cells is broken down as follows:

Cells 489 and $422 E$

A. Labor:

1. Input of Data

2. Analysis of Data

3. Interference Sketches

$\$ 19,800.00$

$-2,200.00$

$7,500.00$

B. Computer \& Program Usage

$\frac{25,000.00}{\$ 54,500.00}$

Cells 529A and 529B

A. Labor:

1. Input of Data

$\$ 7,125.00$

2. Analys is of Data 825.00

3. Interference Sketches

$2,250.00$

B. Computer \& Program Usage

$7,500.00$

$\$ 18,000.00$

The above costs are based on a total Fixed Price Contract or $\$ 72,500.00$

9. Payment - CIE shall submit its statements based on the following miterefones: (a) Upon completion of three-quarters of line items $A-1$ (Input of Data) CII shall invoice for three-quarters of line items $A-1$. (b) Upon completion of the remainder of line items $A-1$ (Input of Data), completion of line itemls $A-2$ (Analys is of Data) and line item B (Computer \& Progran Usage) CIE shall invoice for these services. (c) Upon completion of line items A-3 (Interference Sketches) CIE shall invoice for the remainder of funds. Westinghouse Hanford Company shall promptly pay CIE as the statements are so submitted. 
Mr. D. G. Campbe!1

Fage 3

10. CIE estimates that there will be a tota $i$ of 575 interference notices for all four Cells and makes a 5\% allowance for variance. Should there be more than 604 interference notices, CIE shall be paid $\$ 20.00$ for each additional notice. Should there be fewer than 546 notices, Westinghouse Hanford Company shall deduct $\$ 20.00$ for each said notice.

11. Should there be any change orders or engineering design changes, this shall be considered as additional work for which CIE will make a time and material charge of $\$ 15.00$ per man hour plus charge $18 \$$ per CIE Billing Unit for the coniputer and program usage. The Billing Units represent the costs

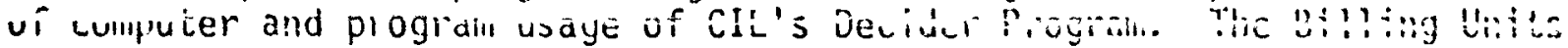
are printed out at the end of each computer run and shall remain attached to the coniputer run.

We look forward to a purchase order at your convenience. This letter may be used as a basis for a purchase order if you wish.

Sincerely yours,

$\bigcirc$

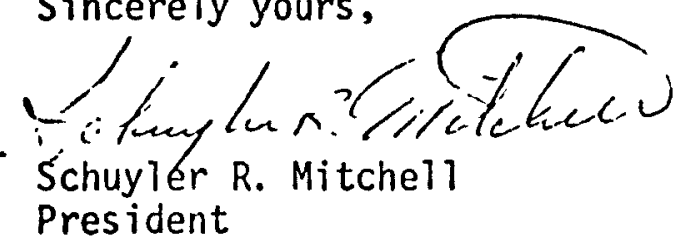

SRM: 10

cc: Mr. Ray C. Mairson

Mr. Larry Kapinos

enc. 


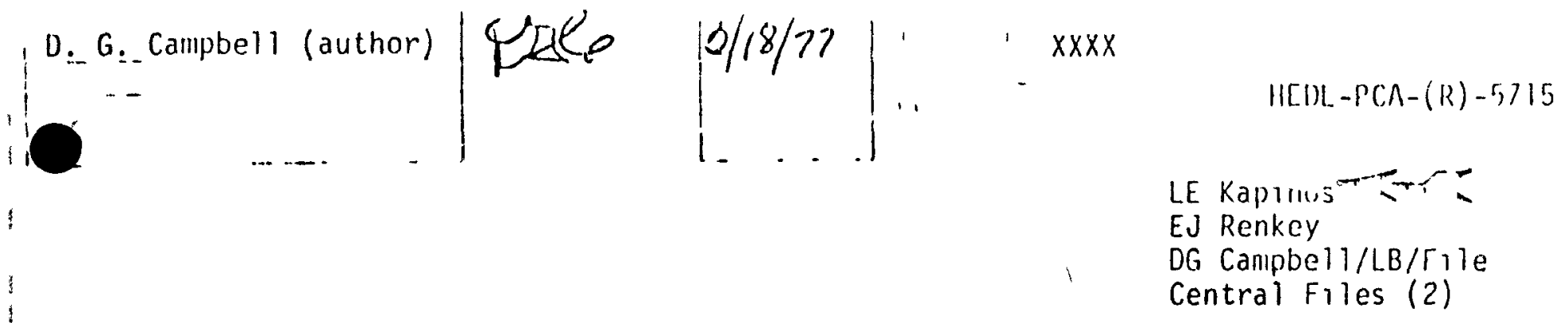

Teletype: CIE Incorporated

From: $\quad$ D. G. Campbell, FFTF Procurement

Date: $\quad$ February 18, 1977 $\begin{array}{ll}\text { Subject: } & \text { FEBRUARY } 3,1977 \text { PROPOSAL INTERFERENCE ANALYSIS } \\ & \text { CELLS } 489,422 E \text { AND } 529 \text { A\&B }\end{array}$ 


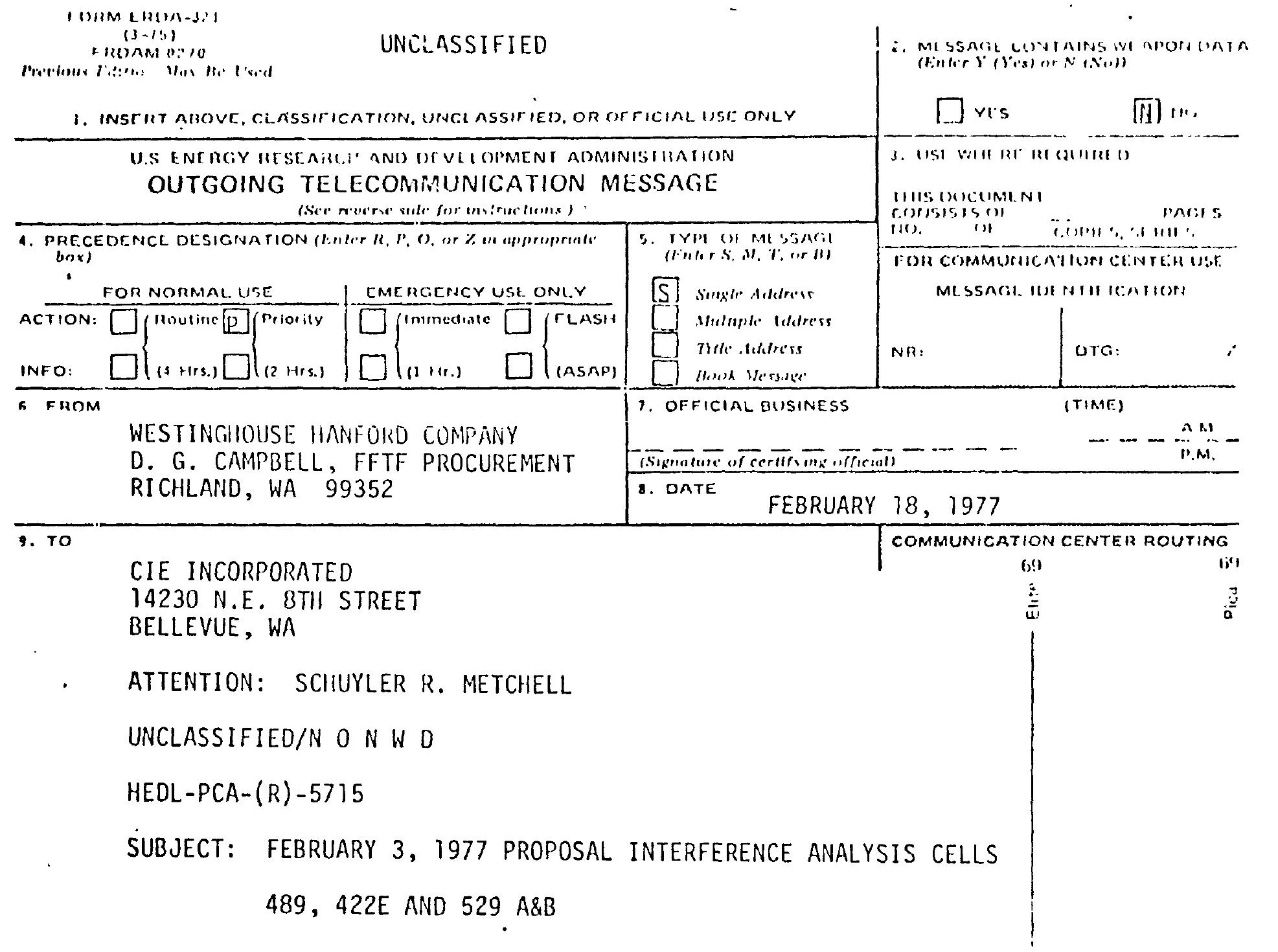

PLEASE ADVISE BY FEB̈RUARY 25, 1977 THE IMPACT THE FOLLOWING CHANriES HAVE TO SUBJECT PROPOSAL:

ALL WORK SHALL BE COMPLETED AND INTERFERENCE NOTICES DELIVERED TO WESTINGHOUSE WITHIN EIGHT WEEKS OF AUTHORIZATION TO PROCEED! INTERFERENCE NOTICES SIIALL BE REFERENCED TO THE NUMBERS OF THL INTERFERING PARTS AND THEIR LOCATION IN TIIE CELL.

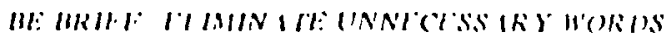

\begin{tabular}{|c|c|}
\hline 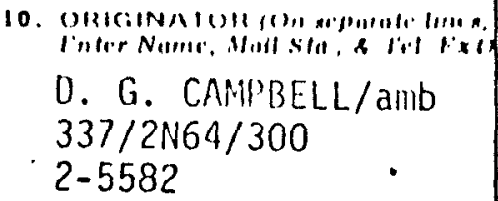 & 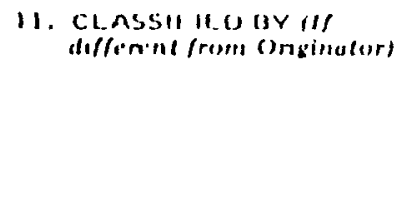 \\
\hline
\end{tabular}

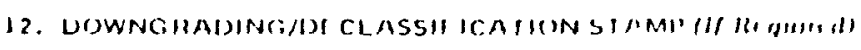

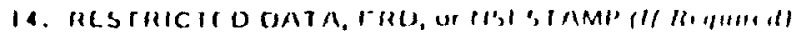


CIE INUURI'URAILII

HEDL - PCA-(R) -5715

PAGE 2

NOTICES SHALL BE DOCUMENIED AS FOLLOWS:

A) INSULATION INTERFERING WITH ANYTHING ELSE EXCEPT PIPE SUPPORT PARTS - WRITTEN DESCRIPTION.

B) METAL TO METAL INTERFERENCES EXCEPT THOSE INVOLVING PIPE SUPPORT PARTS - WRITTEN DESCRIPTION.

C) ANY INTERFERENCES WITH PIPE SUPPORT PARTS SCALED SKETCH WITH WQPITTFN RFSCRIPTION ON IT.

D) INTERFERENCE NOTICES SHALL BE DELIVERED ON A WEEKLY BASIS IHILE BEING GENERATED.

THE FOREGOING ARE THE INTENDED CHANGES DISCUSSED VIA TELECON FEBRUARY $17,1977$.

Erro 


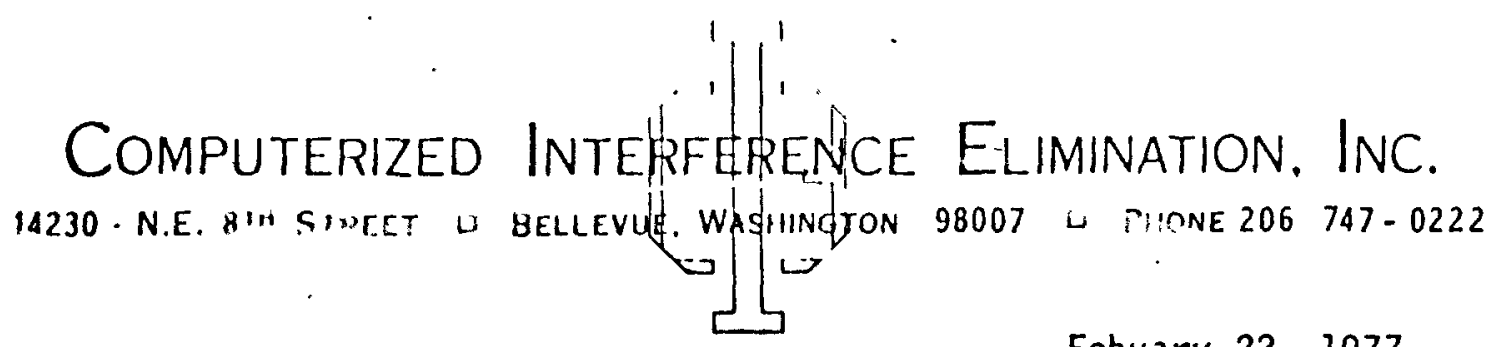

Febuary 22, 1977

Mr. D. G. Campbel1

- Purchasing Department

Westinghouse Hanford Company

P. 0. Box 1970

Richland, Washington 99352

- Subjezt: CIS Irtanforonza Dmnnnca?

Reference: CIE letter dated Febuary 3, 1977

Dear Mr. Campbe 11:

In response to your Telex of Febuary 18, 1977 CIE agrees to the following change in our proposal of Febuary 3, 1977:

A. CIE will provide documentation of interferences as follows:

1. Insulation interfering with anything else except pipe support parts - written description.

2. Metal to Metal interferences except those involving pipe support parts - written description.

3. Any interferences with pipe support parts - scaled sketch with written description on it.

4. Interference notices shall be delivered on a weekly basis while being generated.

CIE's fixed price for providing the notices in the above manner will be changed from $\$ 72,500.00$ to $\$ 68,600.00$ and is broken down as follows:

Cells 489 and $422 E$

A. Labor:

1. Input of Data

2. Analysis of Data

3. Interference Sketches

$\$ 19,800.00$ $2,200.00$ $1,500.00$

B. Computer \& Progran Usage $25,000.00$

$\$ 51,500.00$

Cells 529A and 529B A. Labor:

1. Input of Data

$\$ 7,425.00$ 
Mr. D. G. Campbell

Page 2

2. Analysis of Data

3. Interference Sketches

B. Computer \& Program Usage
825.00

$1,350.00$

$\frac{7,500.00}{\$ 17,100.00}$

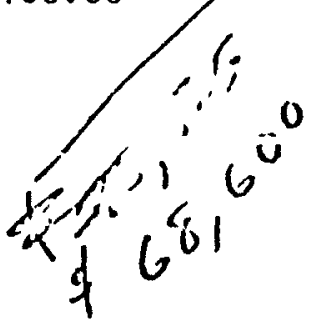

Should you have any questions please give me a call.

Sincerely yours,

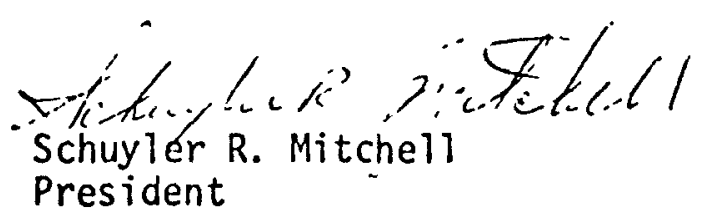

SRM: 10

cc: Mr. Ray C. Mairson

Mr. Larry Kapinos 


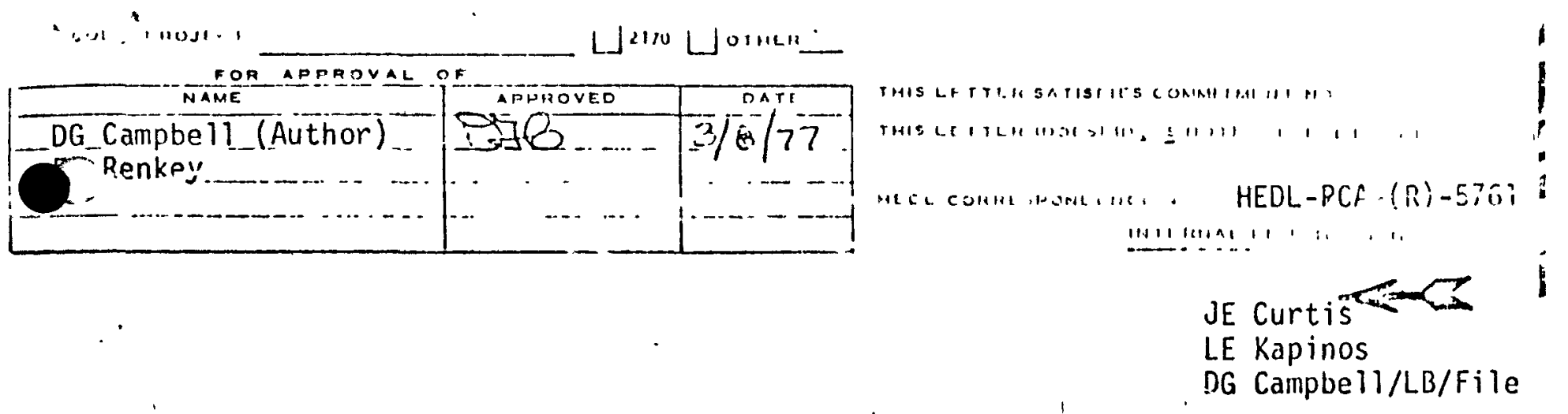

Teletype:

C.I.E., Inc.

- From:

E. J. Renkey

Date: March $8,19 / 7$

Subject: FEBRUARY 22, 1977 PROPOSAL, INTERFERENCE ANALYSIS CELLS 489, 422E AND 529A \& B 
$+1+11,11$

UHLLI,, 1111.1

1. INSERt auove, classitication, unclassified, on of ricial use only

U.S. ATOMIC ENTER: CORTIUISSION

CITGOINE: T: ECOMANA UNICATION MESSAGE

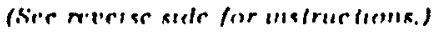

4. PRECE TENCE DESIGNATION (Enler R, I, O, or $Z$ in npproprialc bo.)

\begin{tabular}{|c|c|c|c|c|}
\hline \multicolumn{3}{|c|}{ FOMNORMAL LISE } & \multicolumn{2}{|c|}{ EMIREENCY USR ONLY } \\
\hline ACTION: & Routine & Priority & (Immediate & (FLASH \\
\hline INFO: & $\mid(4$ Hrs. $) \mid$ & ( 2 Hrs.) & $(1+H r)$. & ( $(A S A P)$ \\
\hline
\end{tabular}

5. TYPE OF ME SSAGE (Iinters. M. $T$, or I)

B. Simele dellene Maltuple Address Title Audress Book Mereige

6. FTOM

- WESTINGIIOUSE HANFORD COMPANY

$\therefore$ E. J. RENKEY, FFTF PURCHASING

! RICHLAND, WA 99352

9. '.

i C.I.E., INC.

14230 H.E. 8TII STREET

BELLEVUE, WA 98007

- ATTENTION: S. R. MITCHELL

UNCLASSIFIEO/N ONWD

HEDL - PCA - (R) - 5761

$\mathrm{O}$

SUBJECT: FEBRUARY 22, $19 \$ 7$ PROPOSAL, INTERFERENCE ANALYSIS CELLS 489, 422E ANU 529A \& B

C.I.E., INC. IS HEREBY AWARDED FIRM FIXED PRICE PURCHASE ORDER Y7Q-S44-24521 FOR $\$ 68,600$ TO PERFORM INTERFERENCE ANALYSIS OF CELLS 489, 422E, 529A AND 529B AND PROVIDE DOCUMENTATION AS FOLLOWS:

1. INSULATION INTERFERING WITH ANYTHING ELSE EXCEPT PIPE SUPPORT PARTS - WRITTEN DESCRIPTION.

2. METAL-TO-METAL INTERFERENCES EXCEPT THOSE INVOLVING PIPE SUPPORT PARTS - WRITTEN DISCCRIPTION.

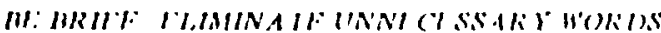

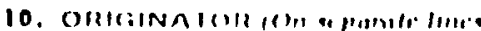

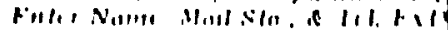

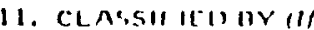
diffenellf from (Insinutur)

OG C.mpbell/d

$337 / 2 N / 300$

$2-5582$

SIAMP CLASSIFICATION RClanificd Meosnges Only

H

1

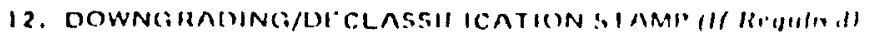

14. RESTRICTED DATA, FRD, or NSI STAMP (If Riquired) 

C.I.E., INC.
$-2-$
MARCH 83, 1977

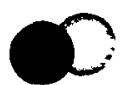

3. ANY INTERFERENCES WITH PiPE SUPPORT PART - SONLTH

SKETCH WI IIT WRITTEN DESCRIPTION ON IT.

4. INTERFERENCE NOTICLj SHALL BE DELIVERED ON A WEEKLY BASIS WHILE BEING GENERATED, AND COMPLETION WITHIN EIGHT WEEKS.

: THIS CONFIRMS TELECON OF MARCH 7, 1977. CONFIRMING PURCHASE

I ORDER FOR YOUR ACKNOWLEDGEMENT SHALL FOLLOW.

END. 

VE2000
o. G. Campbell (author)' PAfe

Harch 13, 1977

\footnotetext{
$\therefore$ C.I.E., Inc.

14230 N.E. 8th Street

Bellevue, HA 98007

Attention: S. R. Mitchell

;

PURCHASE ORDER Y7Q-544-24521
}

Enclosed you will find two (2) coptes each:

(a) Fonn $B D-7600-134(3-76)$ representatfons, certiffcations and notices

(b) Cost Accounting Stundards Curtifications, daled $22-i 2-i a$

Please complete the furus, retain one copy and return owe copy ior our files under the subject purchiase order.

Your cooperation and prompt attention in this malte; shall be greatiy appreclated.

D. G. Campbell, Contract Aurininistrator

FFTF Procurement

amb

Enclosure 


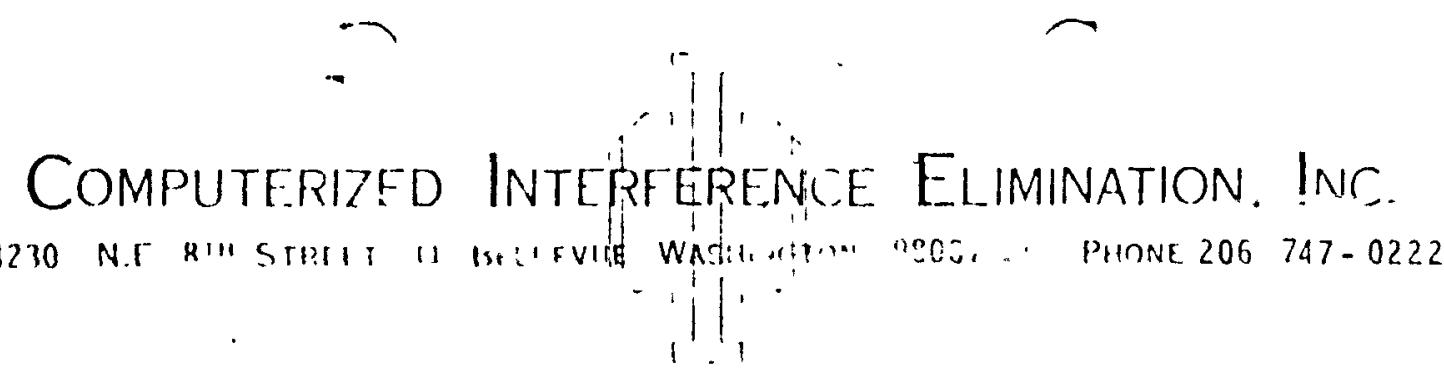

March 24, 1977

Mr. Larry Kapinos

FFTF Project

Westinghouse Hanford Company

P. 0. Box 1970

Richland, Washington 99352

Subject: Request for additional drawings

Reference: Contract No. Y7Q-544-24521

Dear Mr. Kapinos:

Attached is a list of drawings for Cells 489 and $422 E$ that we have not received. They may or may not be required?

If you have any questions please give me a call.

Sincerely yours,

Schuylér R. Mitchell

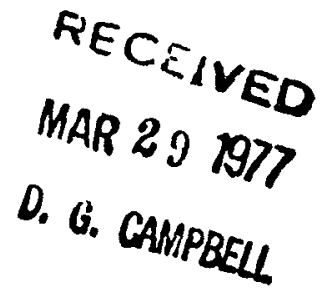

SRM: 10

CC: Mr. D. G. Campbell

Mr. Jim Curtis 
Cell 489 dis 4 is:

A. Critical Piping:

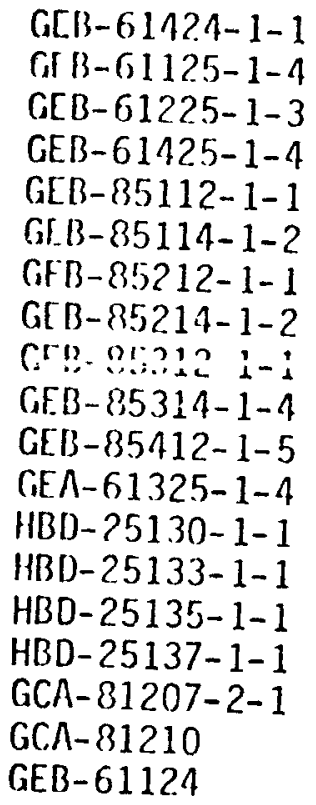

B. Piping Needed:

HBD-82910-BB

HBD-82919-BB3

HBD -829$] 9-M M$

IICB-85052-50

HCB $-85135-50$

HCB-85351

HCB $-85351-50$

HCB-85351-51

HCB-85353-50

HCB-85451

HCB-85451-50

HCB-85451-51

HCB-85451- 52

HCB -85453

HCB $-85453-50$

HCB-85453-51

$\begin{array}{lr}\text { Shret } & 75 \\ \text { Sheet } & 10 \\ \text { Shect } & 32 \\ \text { Sheet } & 76 \\ \text { Sheet } & 47 \\ \text { Shect } & 49 \\ \text { Shect } & 51 \\ \text { Sheet } & 55 \\ \text { Sneet } & 113 \\ \text { Sheet } & 61 \\ \text { Sheet } & 66 \\ \text { Sheet } & 54 \\ \text { Sheet } & 127 \\ \text { Sheet } 129 \\ \text { Sheet } 130 \\ \text { Sheet } 131 \\ \text { Sheet } 39 \\ \text { Sheet } 42\end{array}$

Rev. D

Rev. 11

Rev. 11

Rev. 0

Rev. 6

Rev. 6

Rev. 6

Rev. 6

iiev. 6

Rev. 6

Rev. 6

Rev. 0

Rev. 7

Rev. 7

Rev. 7

Rev. 7

Rev. 8 
B. Piping Needed:

HCD-82910

IICD- 82919

HCD -82990

HCD -82991

HCD-85353-51

C. Piping Needed:

$H B C-23946-A$

HBD- 82076-50

HBD-32255-AA

HCB $-82635-51$

HCB-82636-50

HCB-8502.3-50

HCB $-85050-50$

HCB $-85151-50$

HCB $-85251-50$

HCB-85253-50

HCB-85.351-50

HCB-85353-50

HCB $-85451-50$

HCB-85453-50

HC.D-82512-50

D. Piping Needed:

$H B C-25250$

HBD- $25250-51$

HBD-26509-AA

IHBD-82154-50

HBD-82172

HBD-82 172-50

HBD-82196-BB

GEB -85411

IIBC, - 25252- $-5 F$

HBD -82196

HBC-25252-FE

HBC-25253-DD 
D. G. CAnFBCII

April 14, 1977

D. G. GAirTBELL

Mr. Schuyler Mitchell

Computer Interference

Elimination Corporation

$14230 \mathrm{NE}$ 8th St.

Believue, irashingtun 9000 i

Dear Mr. Mitche11:

REQUEST FOR ADDITIONAL DRAWINGS

Reference: Letter, Mr. Mitchell to Mr. Kapinos, same subject, dated $3 / 24 / 77$.

We have completed review of the drawing list received under cover of the referenced correspondence. Our records indicate that the drawings listed are in your possession or are not required for this study.

Thank you for your concern.

$Y \sum_{\text {L. Kapinos, Manage }}$

Gas \& Sampling Cells

ip 337

Ip 337
$\frac{\text { OG Campbell, HEDL }}{J E \text { Curtis, HEDL }}$
RC Mairson, HEDL 


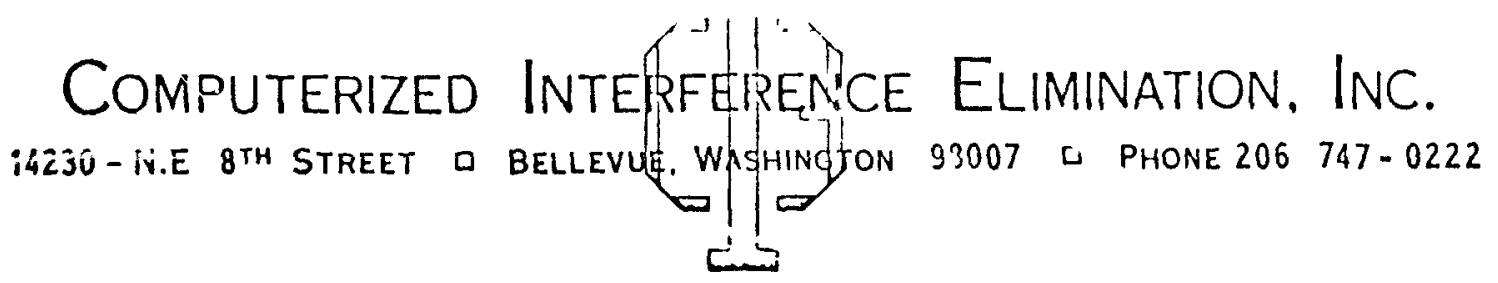

April 1, 1977

Mr. Larry Kapinos

FFTF Project

Wastinghouse Hanford Company

P. 0. Box 1970

Richland, Washington 99352

Subject: Interference Notices

Reference: Cuntract No. Y7Q-S44-24521

Dear Mr. Kapinos:

Attached our the interference notices 2-1 thru 2-125 (Cell 489) and interference notices 3-1 thru 3-61 (Cel1 529 A \& B).

If there are any questions please give me a call.

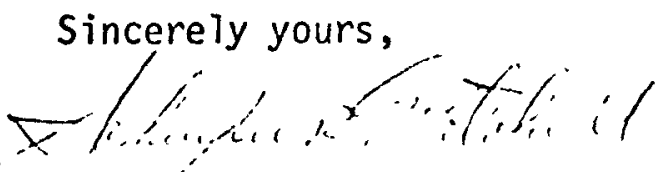

Schuyler R. Mitchell

SRM: 10

CC: Ray C. Mairson

D. G. Campbell

enc. 


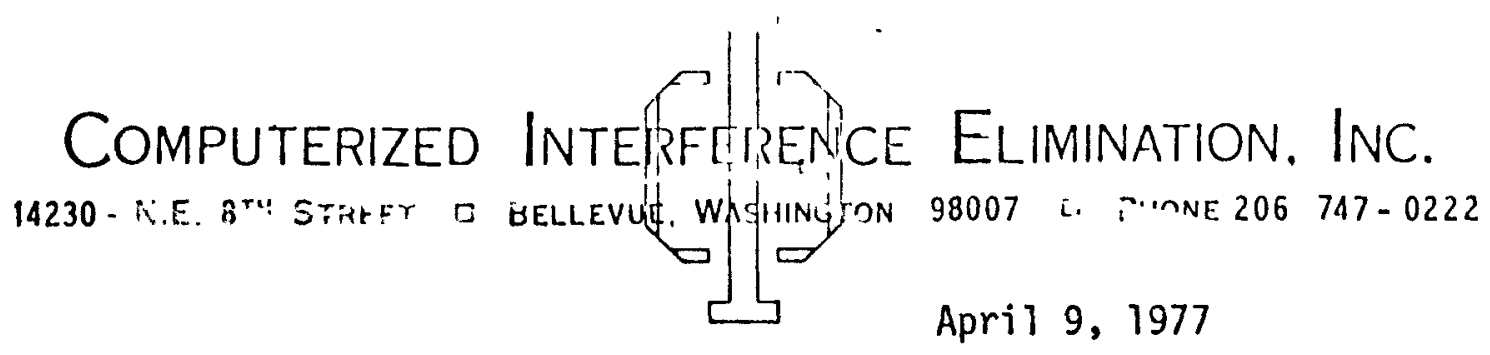

Mr. Larry Kapinos

FFTF Project

- Westinghouse Hanford Company

P. 0. Box 1970

Richland, Washington 99352

Subject: Interference Noticcs

Reference: Contract No. Y7Q-S44-24521

Dear Mr. Kapinos:

Attached are the following interference notices for cells 489 , and 529 .

Cel1 529 Interference Notices 3-62 thru 3-102

Cel1 489 Interference Notices 2-126 thru 2-284

If there are any questions please give me a call.

Sincerely yours,

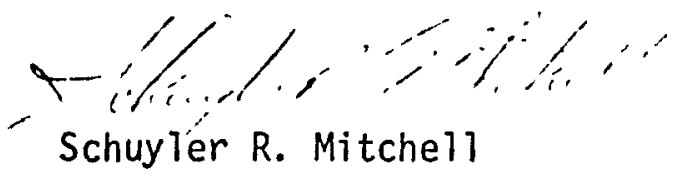

SRM: 10

CC: Ray C. Mairson

D. G. Campbe 11

enc. 


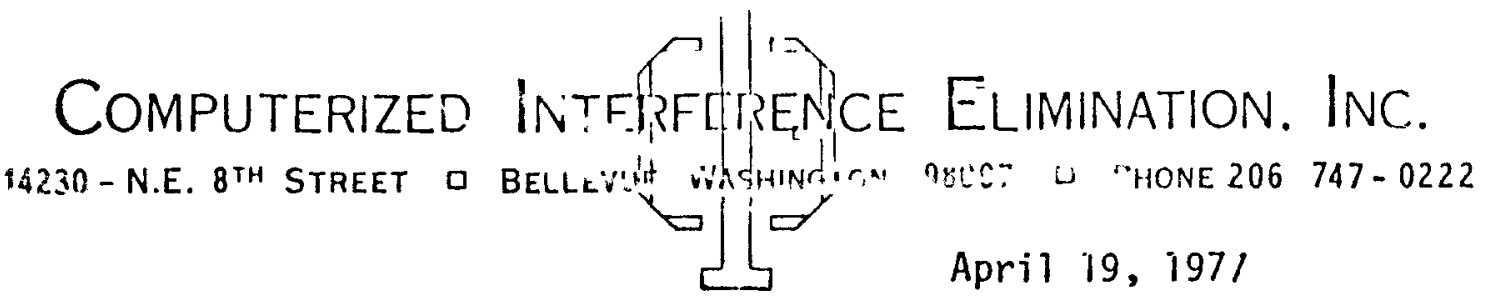

Mr. Larry Kapinos

FFTF Project

Westinghouse Hanford Company

P. 0. Box 1970

Richland, Washington 99352

Subject: Interference Notices

Reference: Contract No. Y7Q-S44-24521

Dear Mr. Kapinos:

Attached are the following interference notices for cells 489 , and 529 .

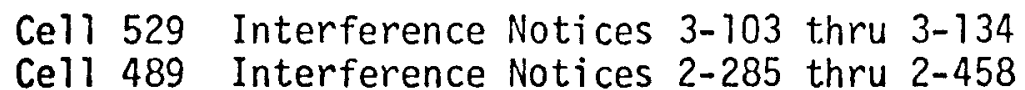

If there are any questions please give me a call.

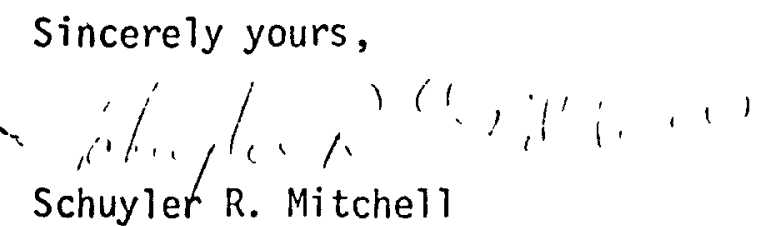

SRM: 10

cc: Mr. Ray C. Mairson

Mr. D. G. Campbell

enc. 
SB Burks

HEDL-PCA- (WEK)-2097

Jalluary 5, 1978

Coniputer Interference

E.limination Corporation

14.230 UE Bth St.

Bellevue, WA 98007

Attention: Mr. Schuyler Mitchell

PURCHASE ORDER Y7Q-S44-24521

. :

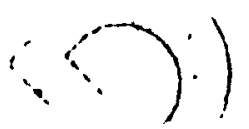

Attached is a Purchase Order Closeout Certificate and Certificate as to Reports, Notebooks, Inventions, and Background Patent Rights.

Please complete them and return to us so we may close our fille.

$\because:$ - Sharon Burks

FFTF.. Purchasing

Ivs

DRIGINAL SIGNED BY

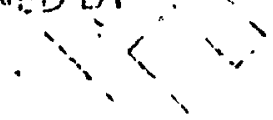




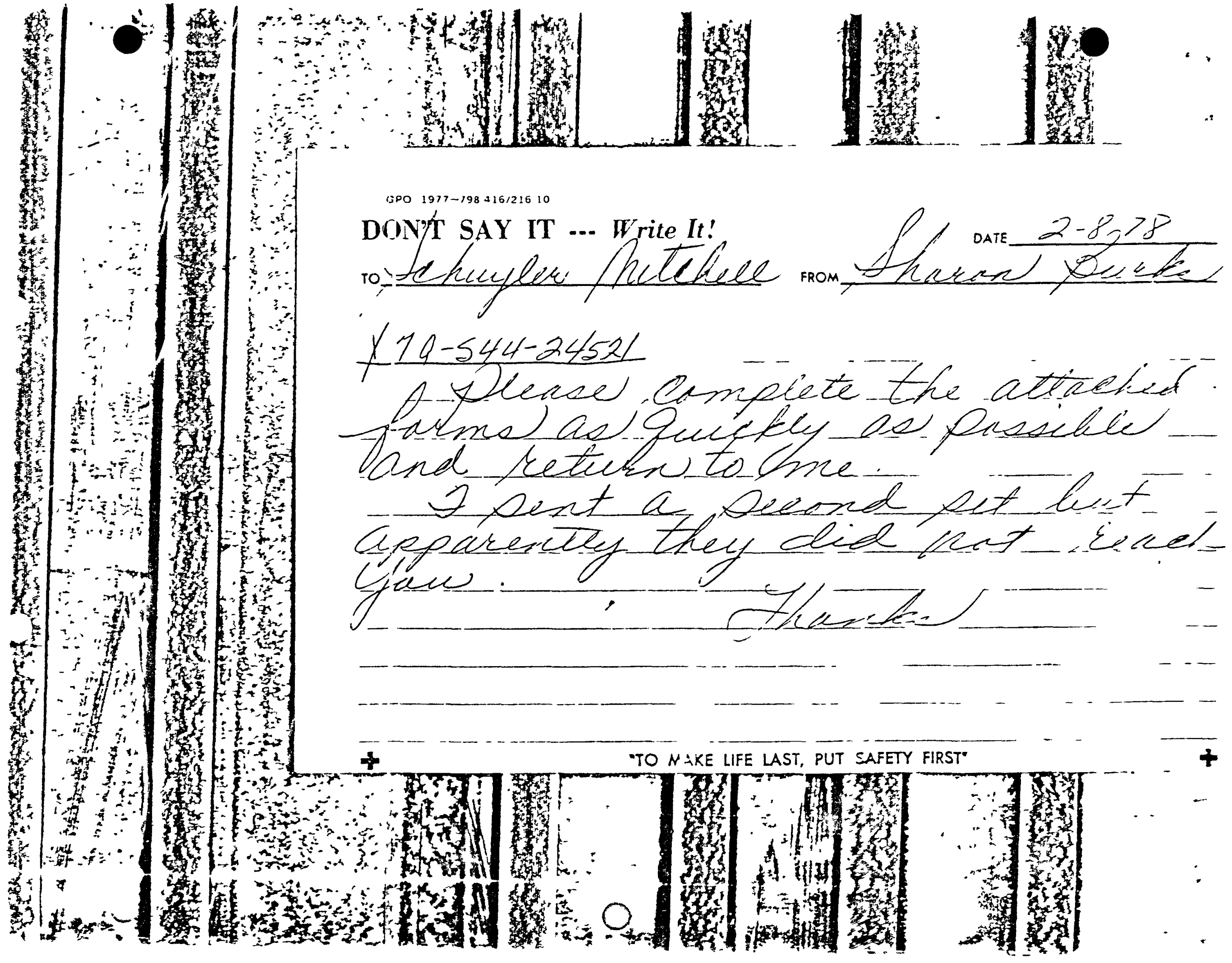




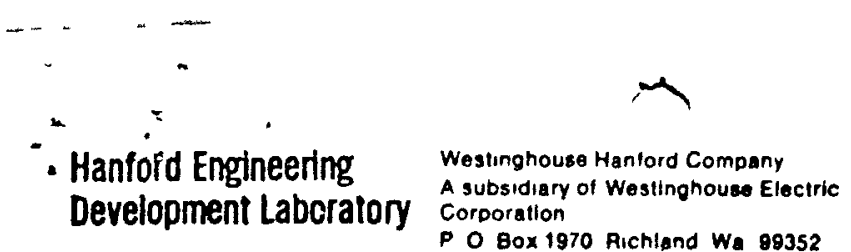

Q
RUEーEIVED

MAR $\perp 31978$

C. G. rfis:P酷ic

General Provisions Fixed Price Order

(54-7600-027)

\section{YUNCHASE ORDER CLOSEOUT CERTIFICATE}

Purchase Order Number Y70.544-24521

Indicate with a check mark in the space following each statement that the action has been taken. If not applicable, insert the letters "NA". The Supplier's signature on this form as well as Form A-7600-249 (if appropriate) and corporate seal are required to properly execute this Certificate.

1. Inventions and Patont roptifiratinn

If the "Patent Provision" Article of the General Provisions

for Westinghouse Hanford Fixed Price Orders Under Prime

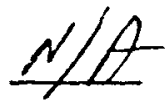

Contract with the Energy Research and Development Administration

is a part of the purchase order, a certificate, as set forth in

Form A-7600-249, of all inventions, invention disclosures,

technical reports, notebook records, original technical data,

including background patent rights, is attached.

2. Royalties

If the order involves royalty payments, or royalty payments are reflected in price of this order, a report of the royalty

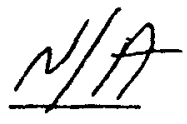
payments or royalties reflected in the price of this order has been made in accordance with the "Reporting of Royalty" Article.

3. Restricted Data/Formerly Restricted Data Release

All restricted data, formerly restricted data, and classified information generated under this purchase order has been transmitted to Buyer, or has been destroyed in accordance with the regulations of the Energy Research and Development Administration.

Retention of the restricted data, formerly restricted data and classified information generated under this purchase order is required. A Certificate of Possession for the items listed on the attached page is herewith requested. The justification for retention is provided on the attached pages.

4. Government Property

An accounting has been made or is herewith rendered to Buyer to all Government property which has come into the possession

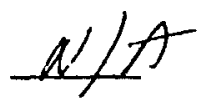
or custody of the Supplier under this purchase order. The information is presented on Form BD-7600-129. 
5. Copyright and Patent Infringements

There has been no claim of copyright or patent infringements with respect to this purchase order.

Any notice or claim of copyright or patent infringement received by the Supplier with respect to this purchase order has been reported to Buyer in accordance with the "Notice of Assistance Regarding Patent and Copyright Infringement" Articie.

6. General Completion

The work and a11 other requirements set forth in this purchase order have been complete in accordance with this purchase order.

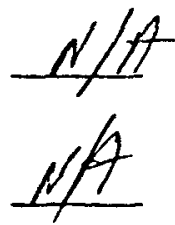

I certify that the above statements contained in items 1 through 6 are true and accurate.

Corporate

Seal Here

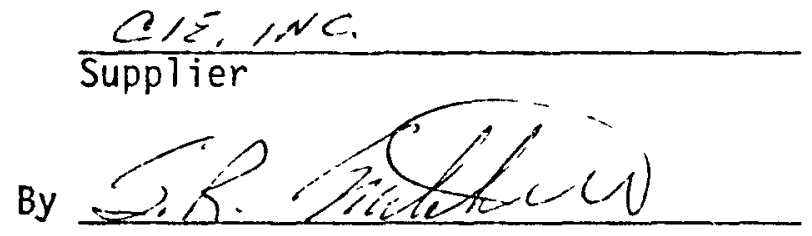

Title

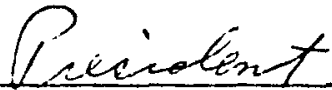


From Plant Equipment Purchasing

\section{Hainford Engineering Development Laboratory}

Pisap 2-558?

vale Uctober 17,1977

Subject BRIEF ON COMPUTERIZED INTERFERENCE ELIMINATION, INC. - 14230 N.E. $81 \mathrm{H}$ STREET BELLEVUE, WA 98007

HEDL-PCA- (R) -6486

To: E. J. Renkey

CC: JL Utz

DG Campbell/LB/File

In October 1976, Computcrized Interference Elimination, Inc. (CIE) contacted HEDL and requested an opportunity to present a procedure they had developed to detect interference problems growing out of the design complexities of nuclear power plants. CIE met with representatives of FFIF Project Control and subsequently submitted a proposal to demonstrate their capability. The proposal reflected their practice of performing a demonstration run of 40,000 to 60,000 cubic feet of plant space at a firm fixed price of $\$ 7,500$.

After review of the proposal and conversations with other companies who had purchased such demonstrations, Mr. L. E. Kapinos, Manager. of FFTF Gas and Sampling Cells, initiated a requisition for the denonstration.

HEDL furnished CIE with drawings of several cells and they in turn satisfactorily demonstrated their interference identification capabilities. IILDL has closed this order.

Based on this demonstration, purchase order Y7Q-\$44-24521 was placed with CIE on March 16, 1977, for $\$ 68,600$ on a negotiated bas is to perform computerized identification of interferences from drawings for FFTF cells 489, 422, 529A and 529B. Completion of the task was scheduled for May 2, 1977.

Submittal of interference notices was made by CIE to IIEDL during the period April 1, 1977 to April 19, 1977. The supplier has been paid for his efforts.

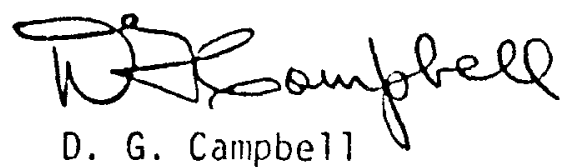

m11 


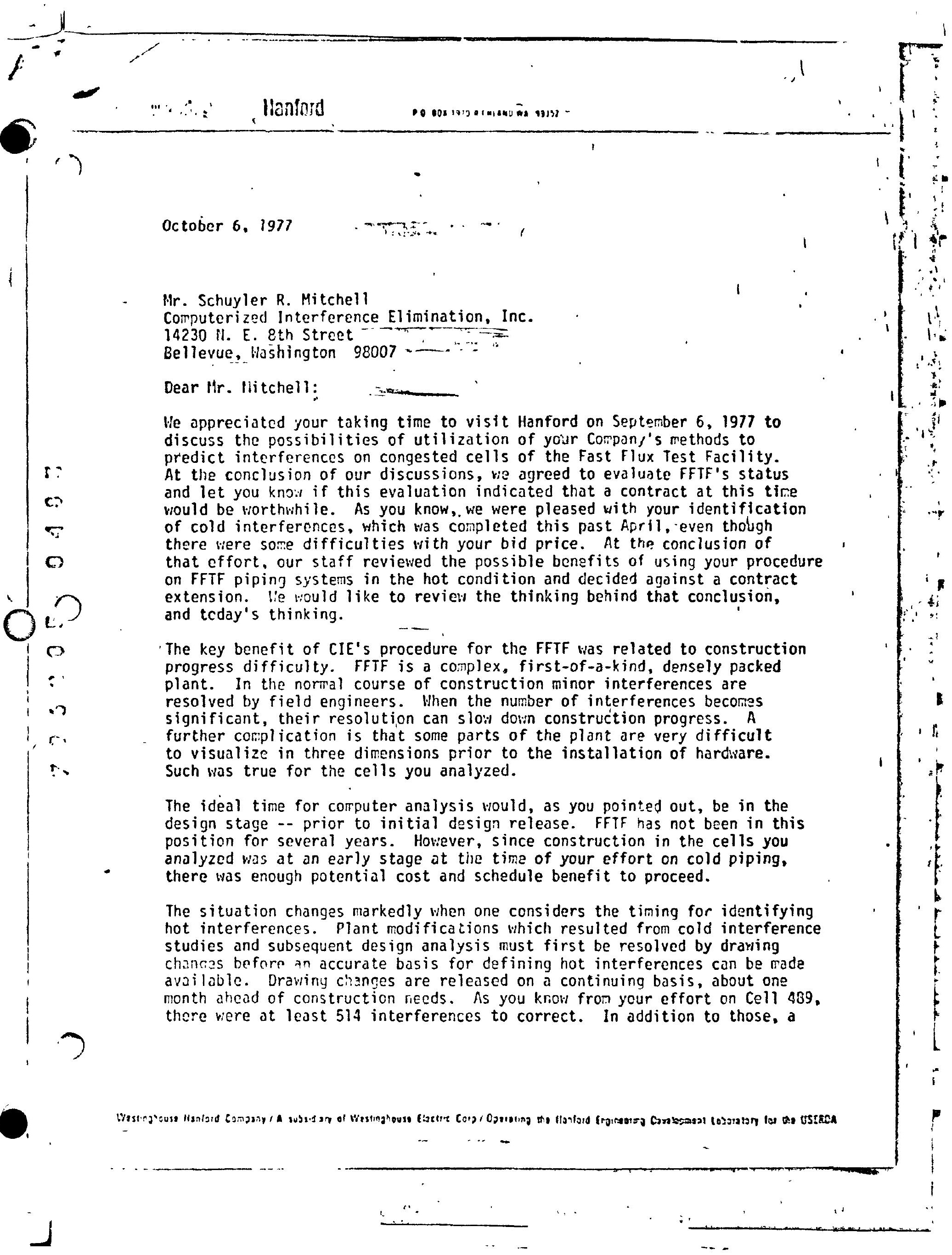


Nir. Schuyler R. Mitchell

Page $2^{\circ}$

number of hot interferences have been predicted. Thesp gre being corrected. Cell 489's drawings have been in a state of mapid change since Hay due to this work, and the drawings will continue to chanyi for several months ypt.

The earliest practical time for computer analysis would be at the completion of hanger installation, in llovember 1977. By then enough as-built drawings will be available to perform computer analys is effectively. Collection of drawings, release of a contract, and completion of CIE's effort then schedules out to llerch 1978. In Parch 1978, almost all of the work in Cell 489 will be done. Correction of hot interferences, if any, would require revork then, and consequently, no construction cost or schedule benefit will have been achieved by performing the hot interference studics yareus Yig:a? stasuration.

We plan to identify hot interferences in Cell 489 by manually reviewing the as-built configuration. This will be done using reasuring tools and the thermal rotion data. Very few of the approximately 2,500 drawings will be needed since enough hardware is already installed to sere how things will fit at higher temperatures. Since the availability of the as-built drawings is not essential to this manual review, we will be able to ; tart during october, and finish before we cculd even begin with CIE. Our estimated manpower cost (which is not truly incremental) and the potential construction benefit, because of the timeliness of the information, are substantially more favorable than computer analysis vould be at a later date.

As a last check, the actual pipe positions at higher temperatures will be observed. No matter how the hot interferences are identified prior to this, actual hot checks are needed to validate the predicted thermal motions on which either manual or computer forecasts are based.

He appreciate your interest in FFTF and your offer of help. In our judgtent, however, there is no opportunity for beneficial use of CIE's procedures on FFTF piping systems in the hot condition at this time. He believe the approach ve are taking is the best one, considering the current status of installed hardware. Again, we wish to thank you for your continuing interest in the Project.

aej

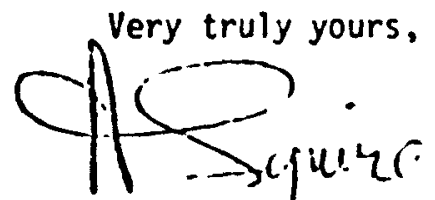

Cc: D. C. Shoof

Dr. Willis Smith

S. A. Heber 
COMPUTERIZED INTESFE?

Mr. Larry Kapinos

FFTF Project

Westinghouse Ilanford Company

P. 0. Box 1970

Richland, Washington 99352

Subject: Interference Noticts

Reference: Contract No. Y7Q-S44-24521

Dear Mr. Kapinos:

Attached are the following interference notices for cells 489 , and 529 .

Cell 529 Interference Notices 3-62 thru 3-102

Cell 489 Interference Notices 2-126 thru 2-284

If there are any questions please give me a call.

Sincerely yours,

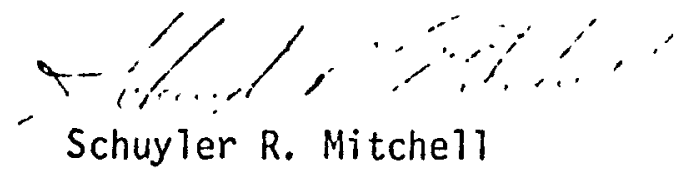

SRM: 10

-CC: Ray C. Mairson

D. G. Campbe 11

enc. 
1024

FFTF
$4-4-77$

$K M \omega$ $\therefore 16$

2

H.4-19017 REV.3 SH. 59 PPG. FABRICATION ISO I"GEB.35:11 H.4. 36509 REV.I SH. 434 PIPE SUPPORT GCB-35012 H. 43

$\angle 3^{\prime \prime} \times 3^{\prime \prime} \times 9^{\prime \prime} L G$, TOP EL. 543'-7". BELONGING TO GCB.85012 H-43 INTERFERES WITH 5" INSULATION ON "GEB-B53II IOS JHOWN

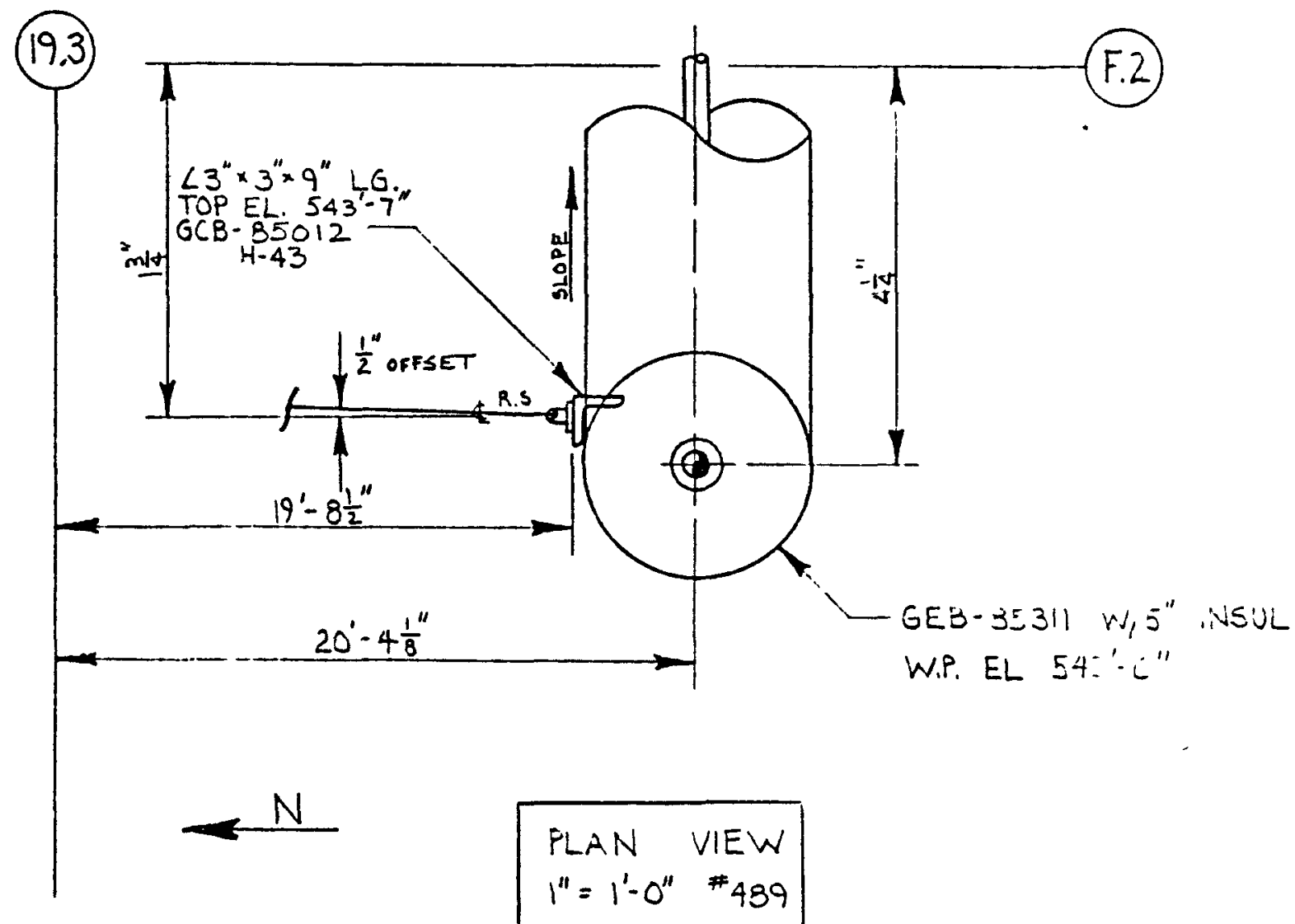


1024

FFTF
$4-4 \cdot 77$

$K M C$
2.127

2

H-4-19017 ReV. 3 SH I9 PPG. FabkILATION 1SO. GEB-85311

H-4-\$6509 REV.I SH. 370 PIPE SUPPORT GCB-85011 H.40

SNUB PART OF GLB-85011 H-40. AT $\&$ EL. 542'-11 $\frac{3 \prime \prime}{4}$ INTERFERES WITH VERTICAL "GEB.85311 W/S" INSULATION AS SHOLUA

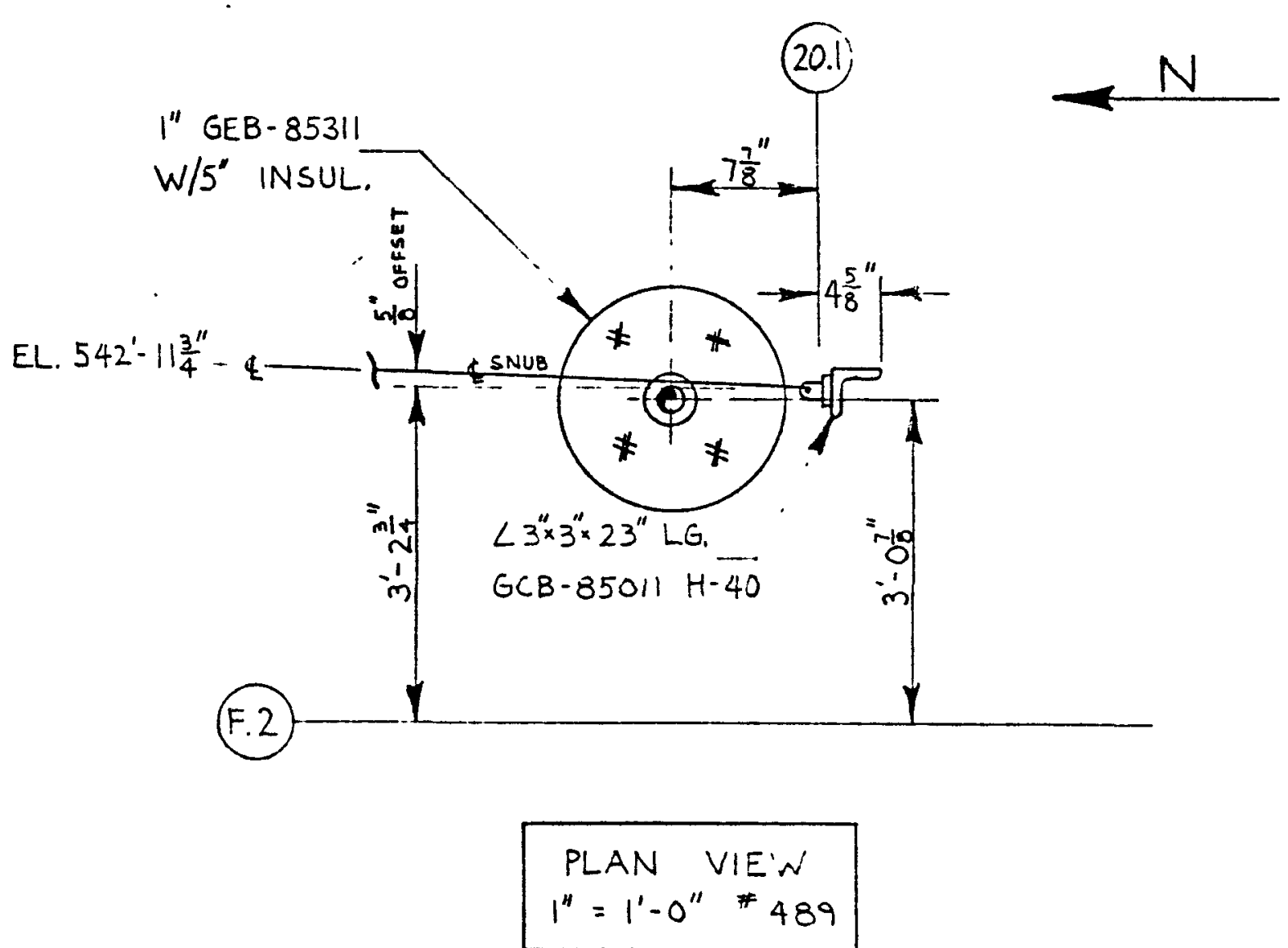


1024

$4 \cdot-4 \cdot-77$

$21 .: 2$

FFTF

Barry vert?

$\therefore$

H-4-10017 REV 3 SH.59 PPG FAE 1. . EEE S.:.11

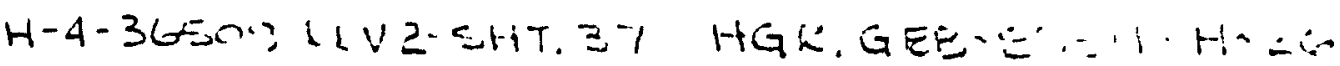
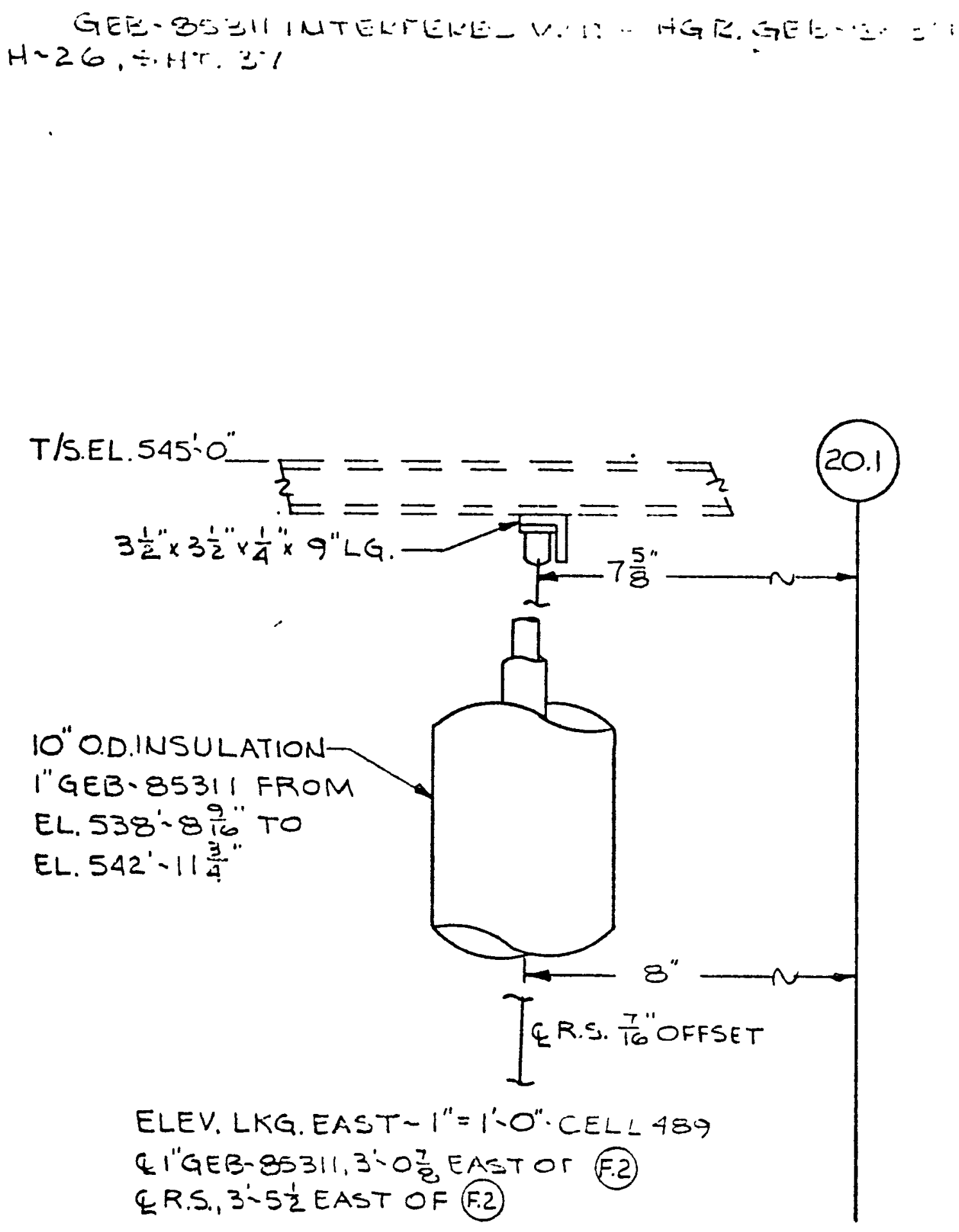


\begin{abstract}
$10 ? .7$

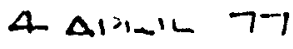

$2-1: 1$

FFTF

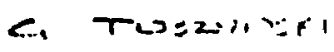

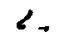

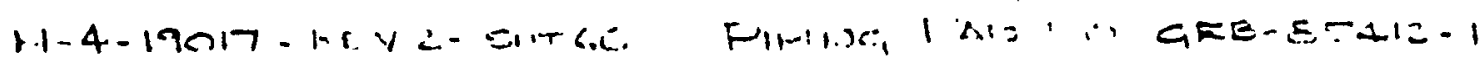

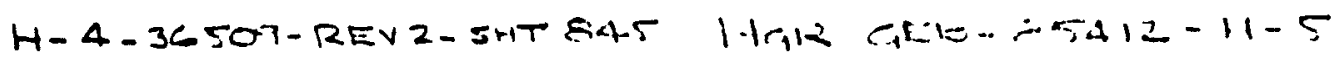

INSULATION ON $1 "$ "GEB- S5412 INTERIIIILII: :

WITH HANGER GEU- EJAIL-H-5 STRUETLRAL COMNONENT $\triangle \approx$ SHOWN.
\end{abstract}

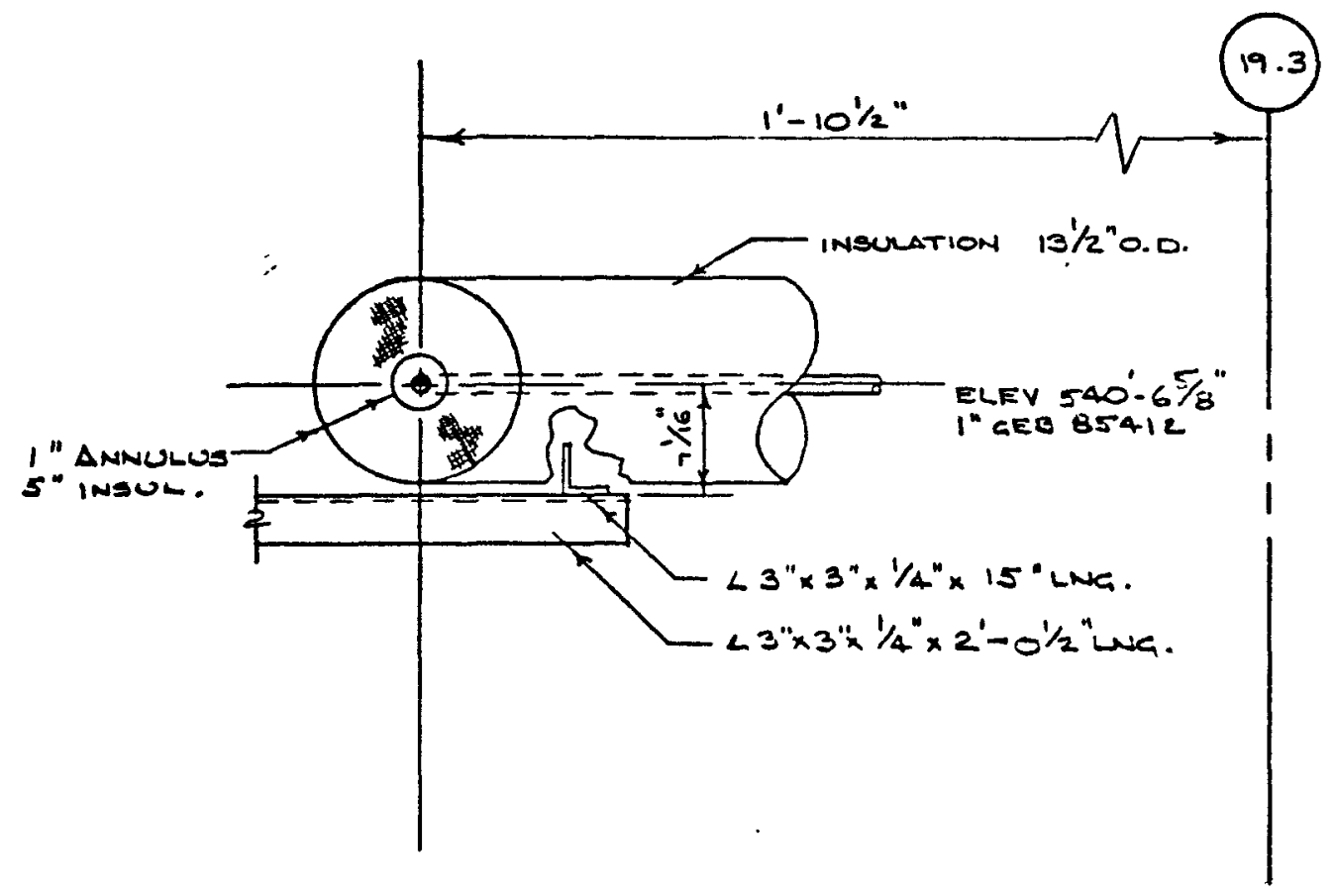

$\frac{\text { EL.TV. LKS EAST } 11^{\prime}-3 \text { "EAST F.2 N.T.S }}{\text { CELL } 489}$ 
1024

FFT・F
4 घ페.

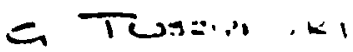

$2-130$

$\because$

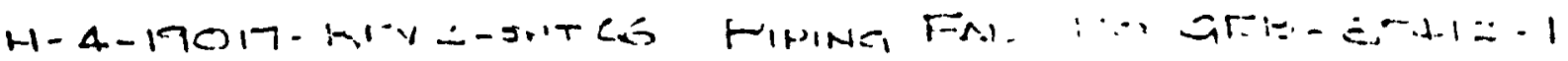
H-4-36509-RFVI-SHT 356 HLR FB-EF-211-11-26

INSULATION ON I" CEE - 851K INTERLIILIEWITI HANGESR $C_{1}=E-E 5011-11-26$ SNML二 $A=$ SH:NAN.

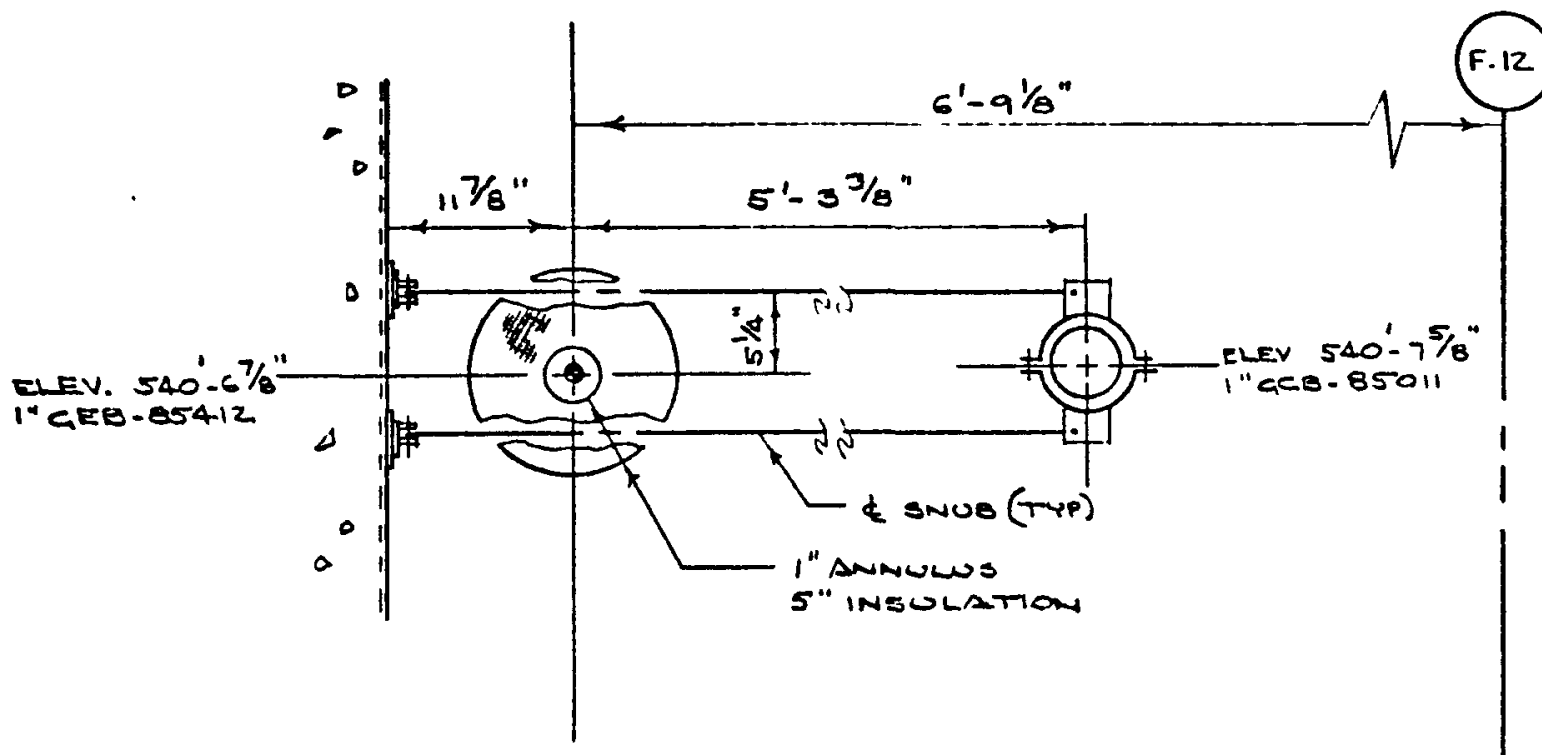

19.3

ELEV. LKG.SONTH@ 17 "SOUTII N.TS.

CELL 489 

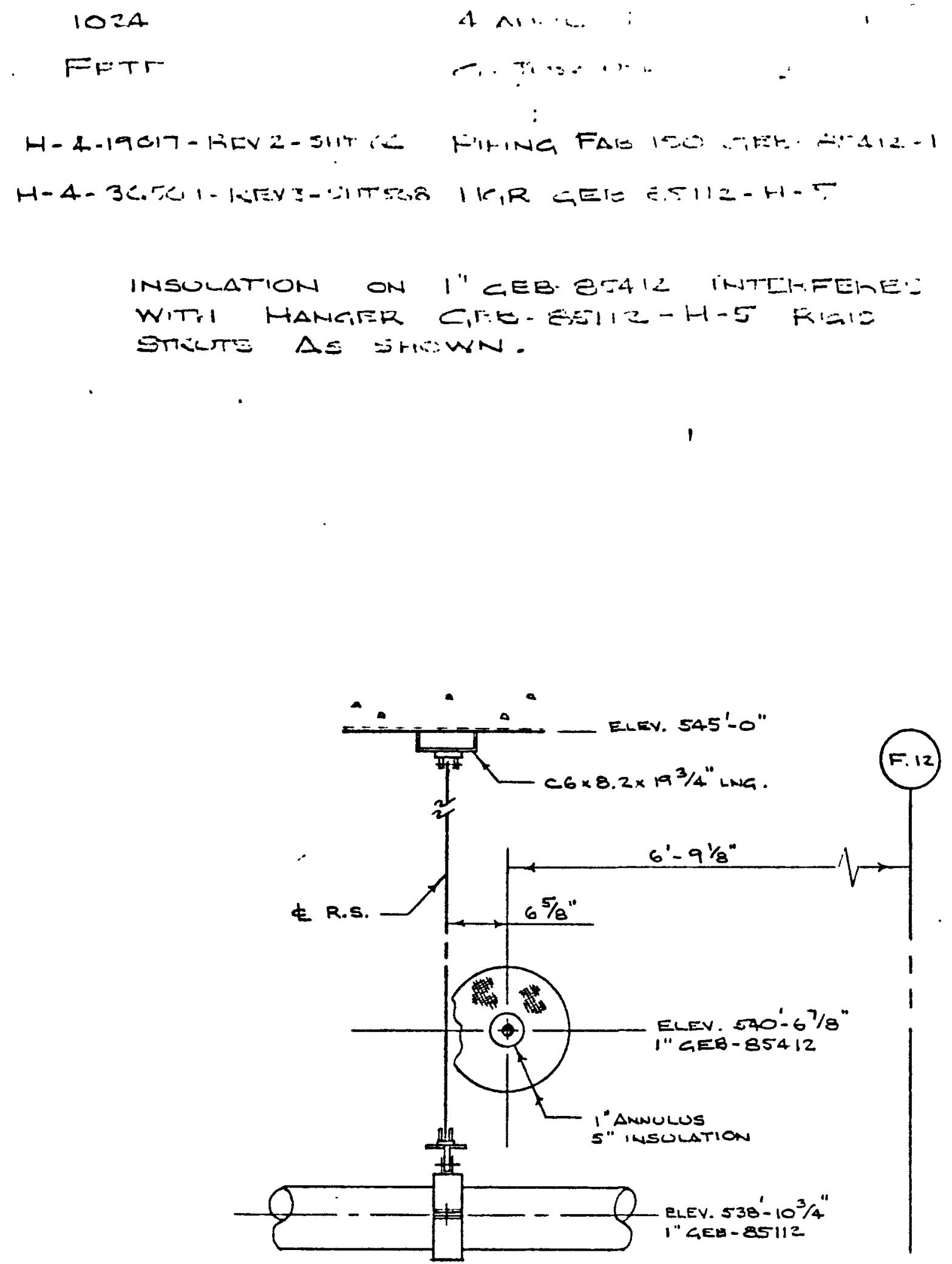

(19.3)

ELEV. LKG. SOUTH \& 16 "SOUTH N.T.S.

CEL 489 
$1 \because \because \dot{i}$

$1 \cdots 1: 7=$
$+1 \cdot \cdots-\cdots$

$-, \ldots, \cdots$,

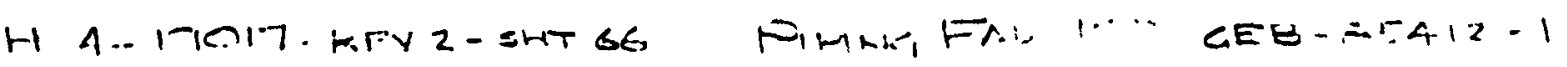

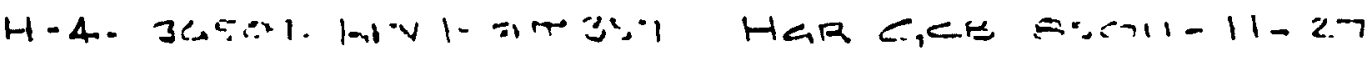

INSULATION ON 1 "GEE-8EAIZ INTTERTLLEFO WITI HAMGER CiCD.-E:-31:-11-7 Rlailo STruts $\Delta=$ Ullewn.

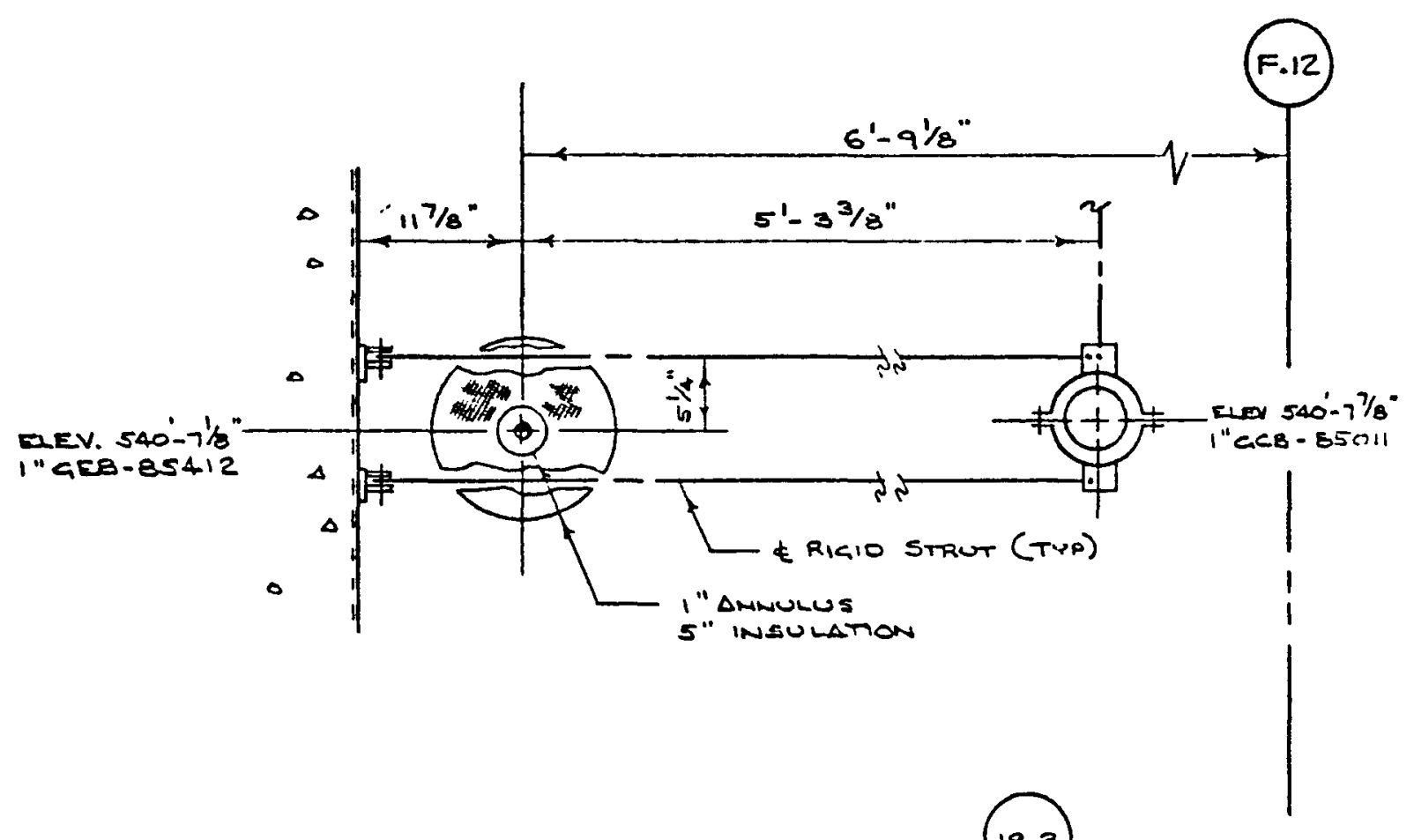

ELEV. LKG. SOUTH @ 5'-2" SOUTH1 19.3 N.T.S. CEU 48 : 


$$
\begin{aligned}
& 1024 \\
& 4 \wedge_{1} \ldots \ldots \\
& 2-1=\therefore \\
& \text { Fi-TF. } \\
& \therefore \text { Th } 50 \cdots \therefore 1 \\
& \dot{-}
\end{aligned}
$$

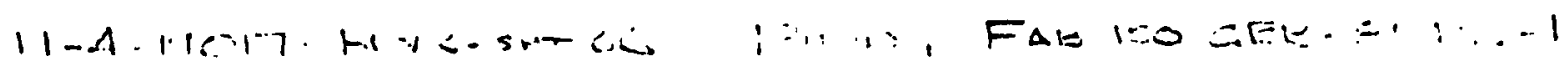

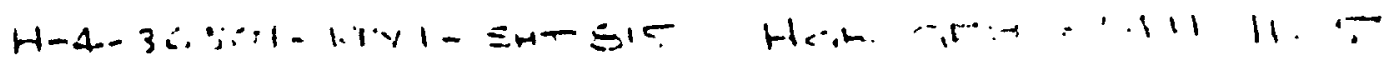
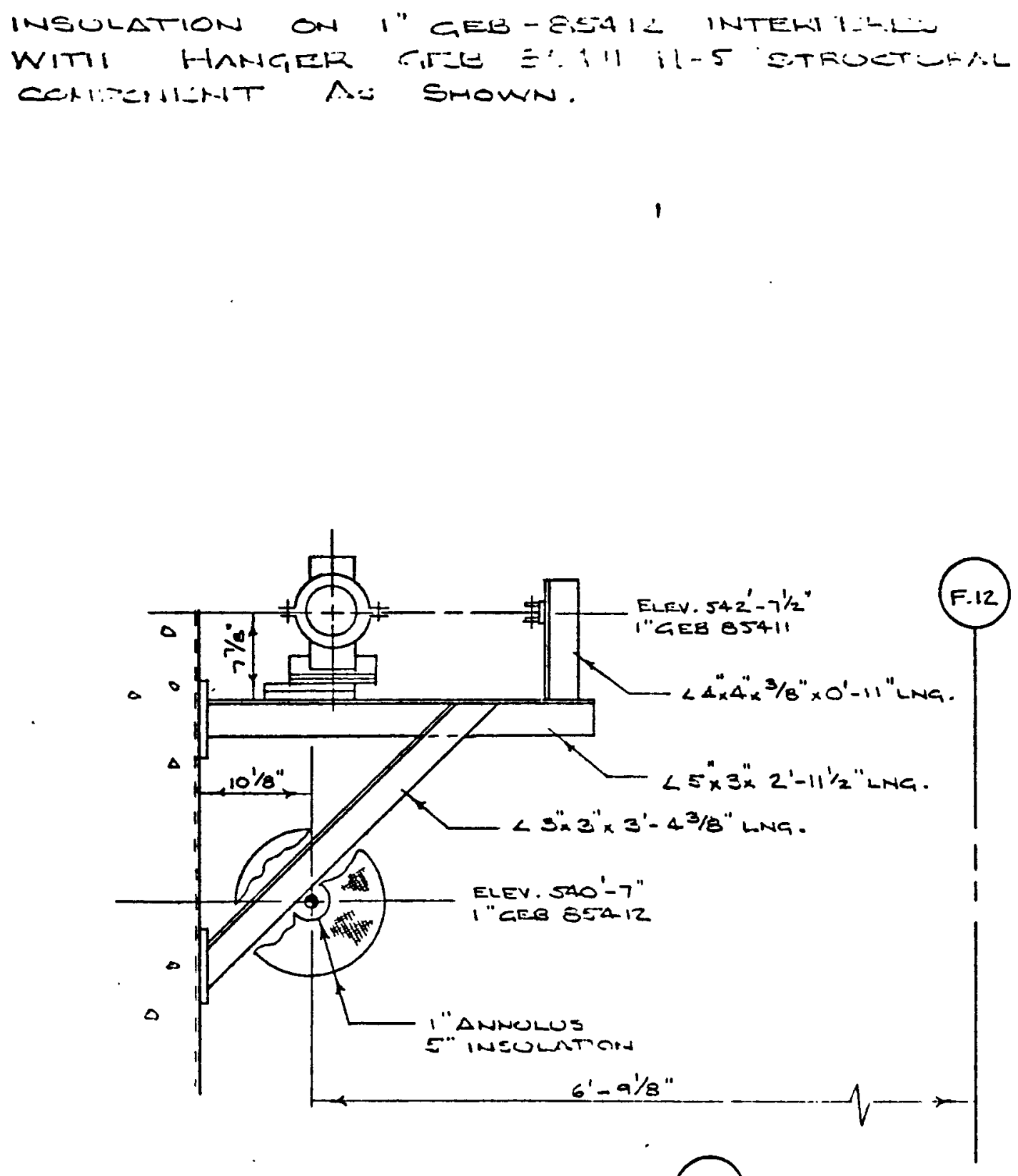

ELEV. LKK, SoxTH 9 4'-4"ENSTH (19.3) N.T.S. 


$$
\begin{aligned}
& \text { 102+ } \\
& 1 \Delta r_{1}=7 \\
& \therefore-1=\therefore \\
& \text {-. i, }, \ldots,+1 \\
& 2
\end{aligned}
$$

INSULATION ON 1 "GEW- BE4I2 INTIMFEFE:

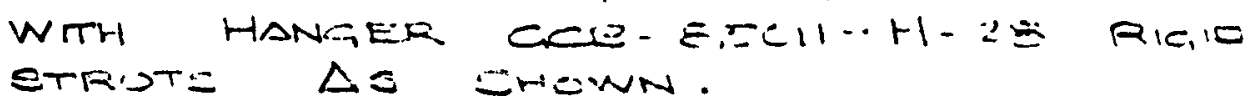

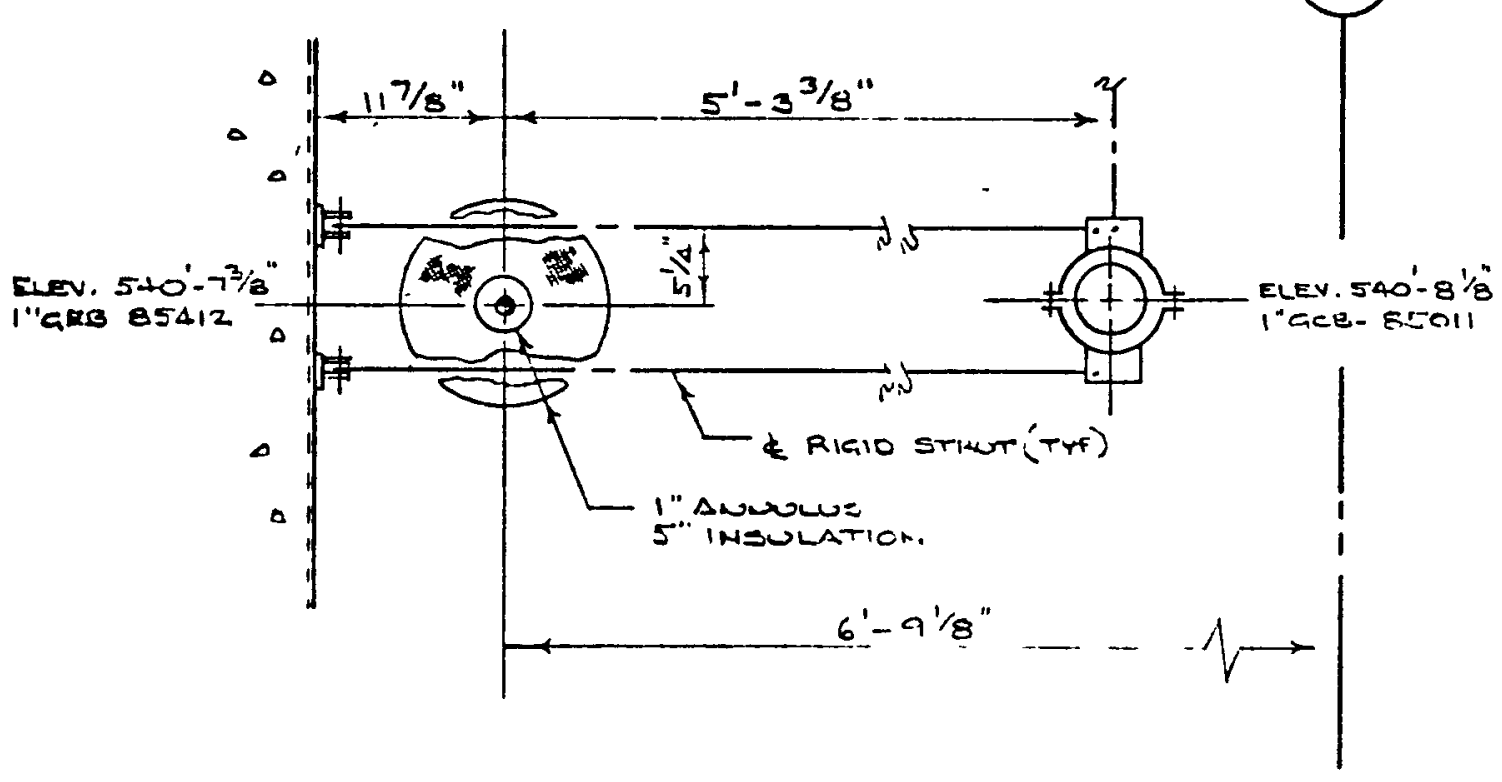

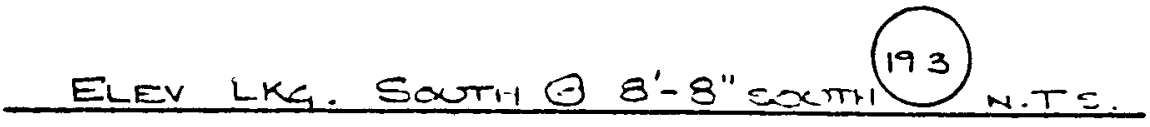

CEL MET 


$$
\begin{aligned}
& 1024 \\
& \text { 1. AHEL ᄀ7 } \\
& -1 \leq \div \\
& \text { FWTF } \\
& \therefore-T(J \cdots \cdots+\cdots \cdot 1 \\
& \therefore
\end{aligned}
$$
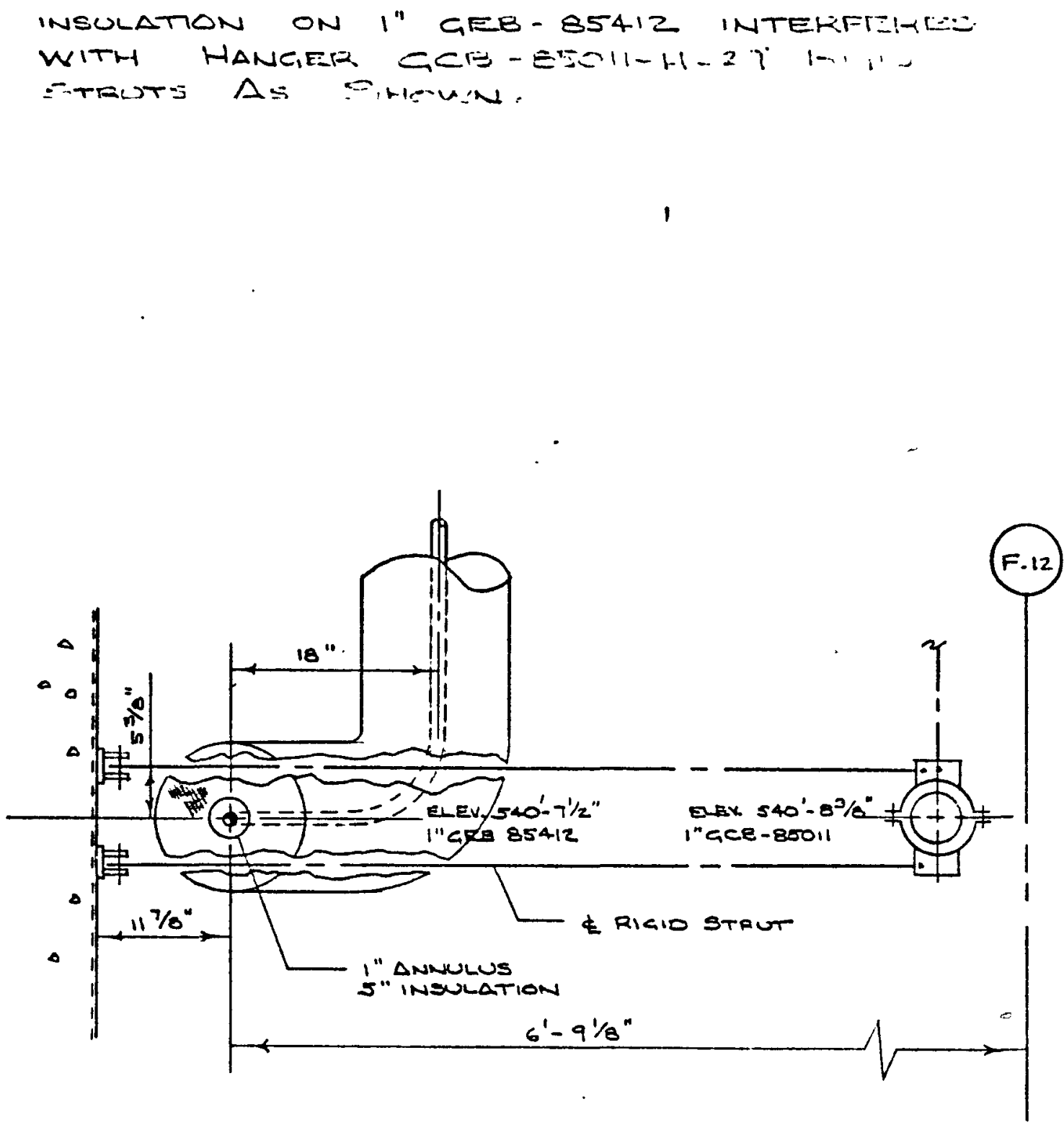

$\overbrace{\text { N.TS. }}^{19.3}$

ELEV. LKC. SOUTH @ $12^{\prime}-8$ 
1024

FFTF.

$H-4-19017-2.54166$

$H-4-36509-1$ SHT 822 $\triangle-477$

$s+10$

$G E B-85412-1-2$

GEB $-25411 H-12$
$2-130$

2

GEB - 85411 H-12 INTERFERES WITH GEB$86412-1.2$ AS SHOWN.

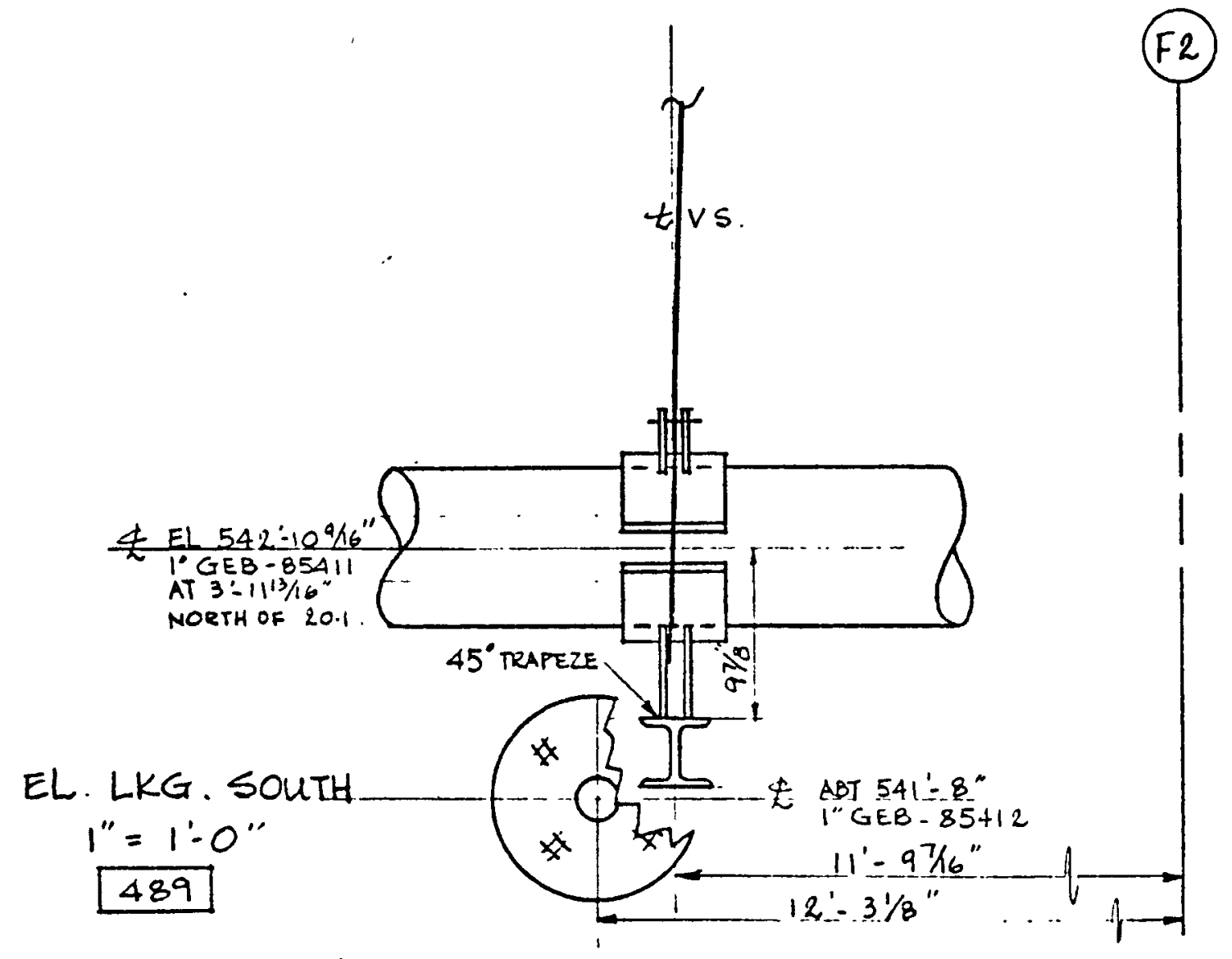


1024

FFTF
4. $4 \cdot 77$

$\mathrm{SHO}$
2 ・沙

2

$H=4-19017-2$ SHT 66

$G E B-854: 12-1-2$

H-4-36507-2 SHT 1061

GCB $-81138 \mathrm{H}-1$

GCB - 81138 H.1 INTERFERES WUITH GEB$85412-1-2$ AS SHOLUN.

1

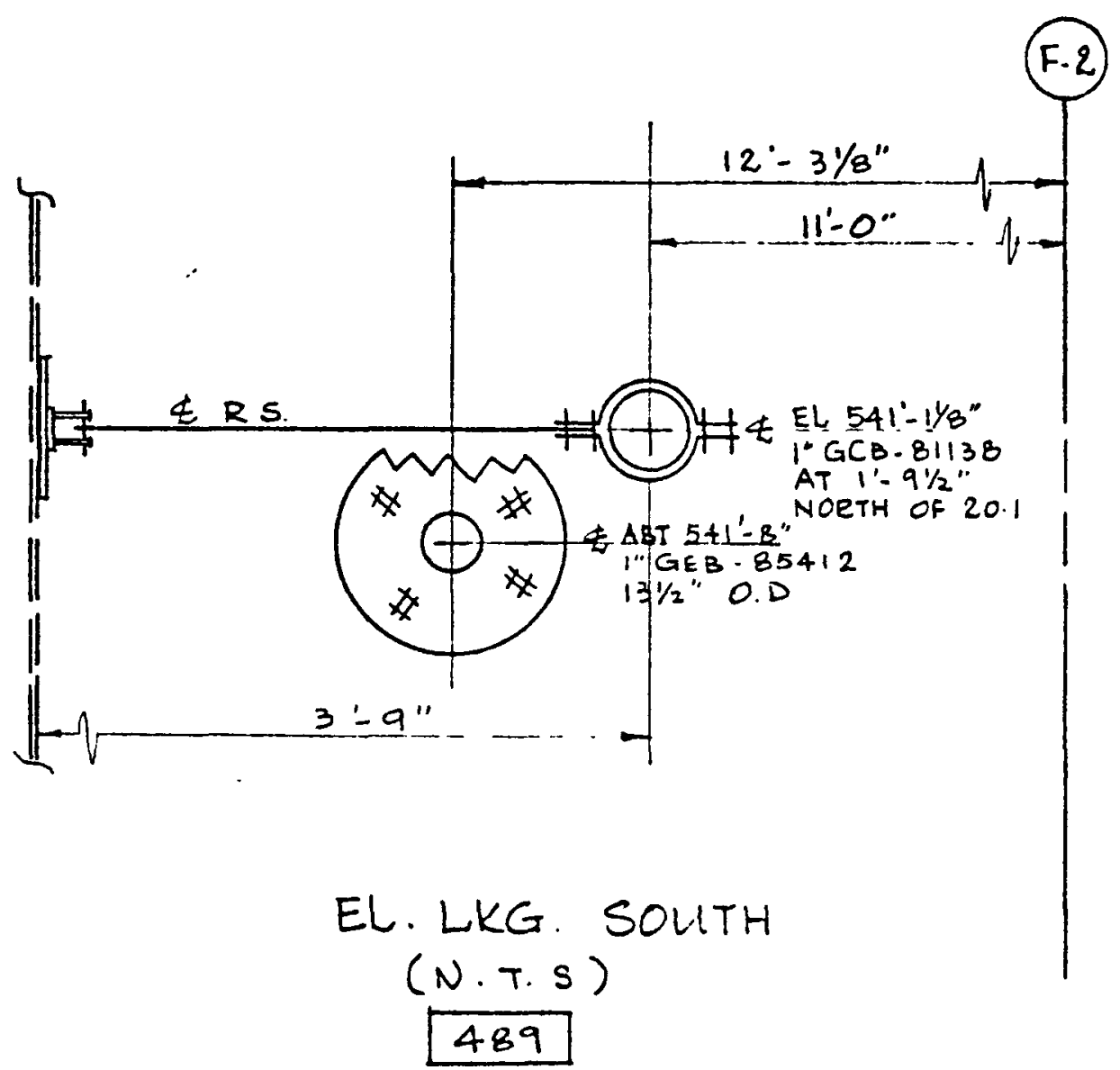




$$
\begin{array}{lcc}
\text { IOLA } & 4-4-77 & 2-13 E \\
\text { FFTF } & 5 . H O & 2
\end{array}
$$

H.4-19017-2 SHT 66

$G E B \cdot 85412-1 \cdot 3$

H.4 - 36507-2 SHT. 1065

$G C B-81338-H 1$

GCB-81338-HI INTERFERE; WITH GEB-854121.3 AS SHOWN.

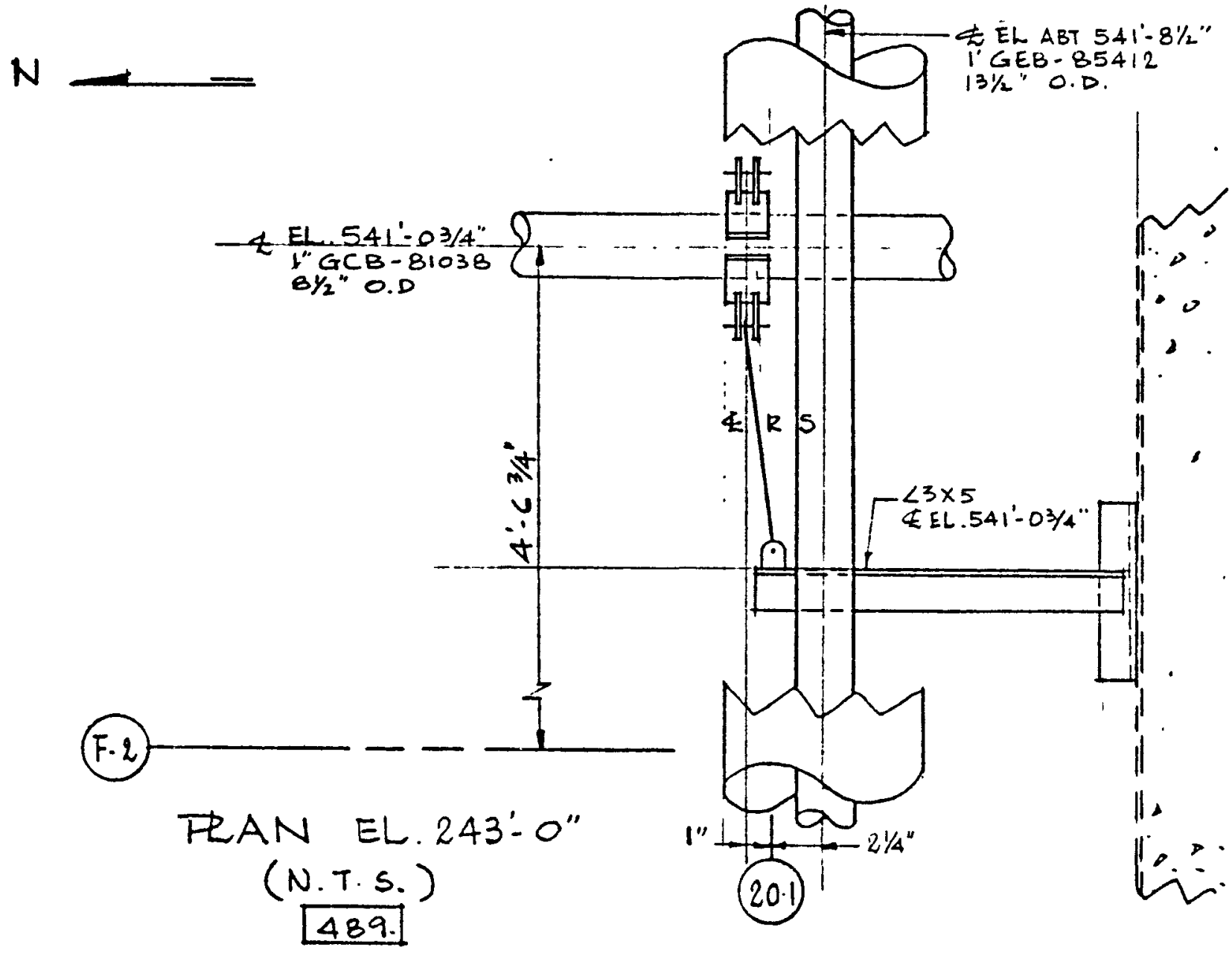


1024

FFT.F

H-4-19017-2 SHTG6

H-4-36507-3 SH71058

GCB- BII38-HC INTEEFELES WUITH EEE-EE412.

GCB- BII38-HC INTEEFELES WUITH GEE-EE412.
1-3 AS SHOLJT

$$
\begin{array}{cc}
A 7 & 2-139 \\
S H O & 2
\end{array}
$$

$G E B-E 5412-1-3$

$G C B-81138 H .6$

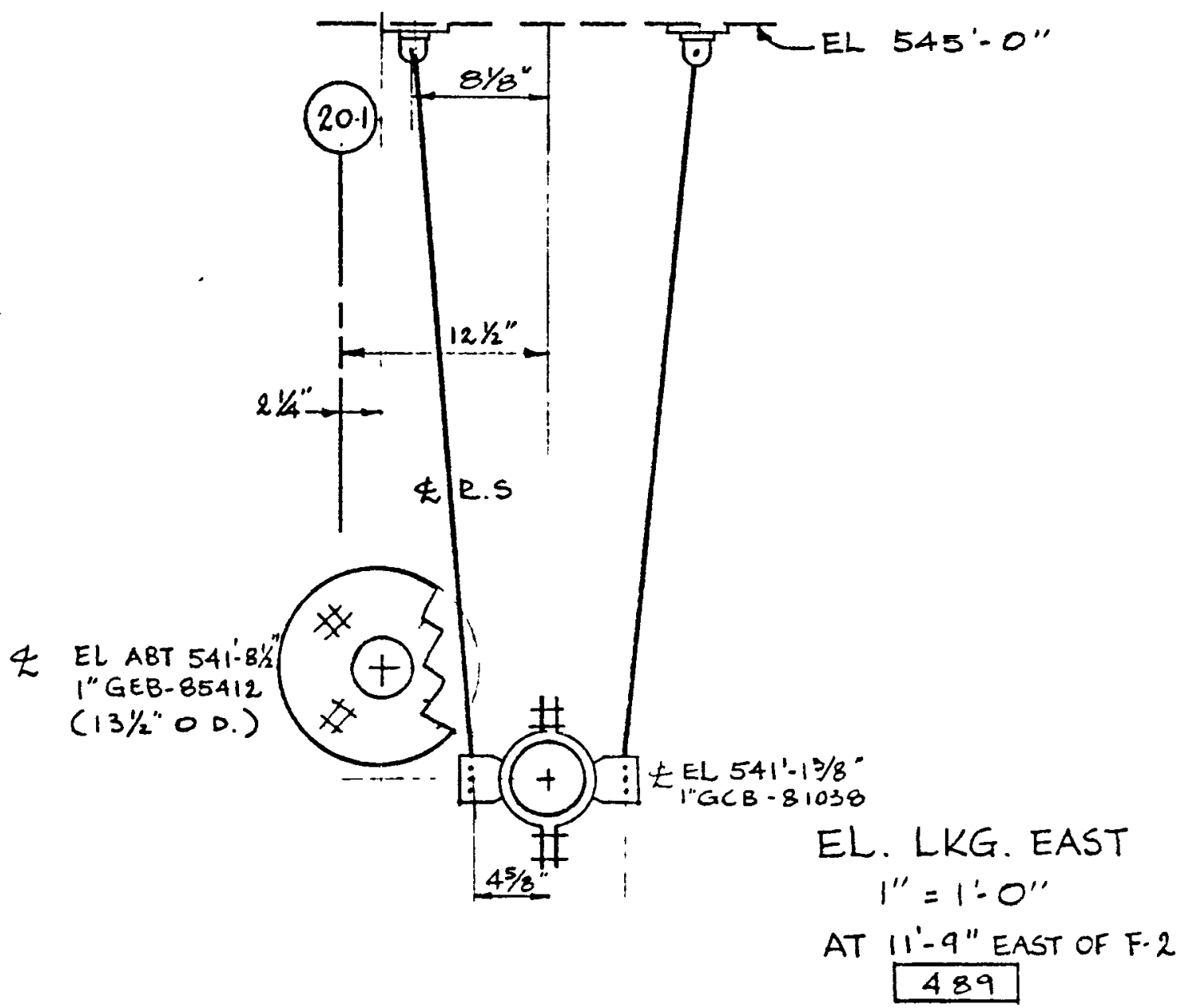


1024

FFTF

H.4 - $19017 \cdot 2^{\text {S SHT } 66}$

H. $4-36509-2$ SHT. 38
$4-4-77$

$5+10$
2 i- $\div: 0$

2

$G E B-85412-1-3$

$G E B-85311-H 27$

GEB- $85311-H 27$ INTERFERES WUITH GEB $-85412-1-3$ AS SHOWN.

)

$N$

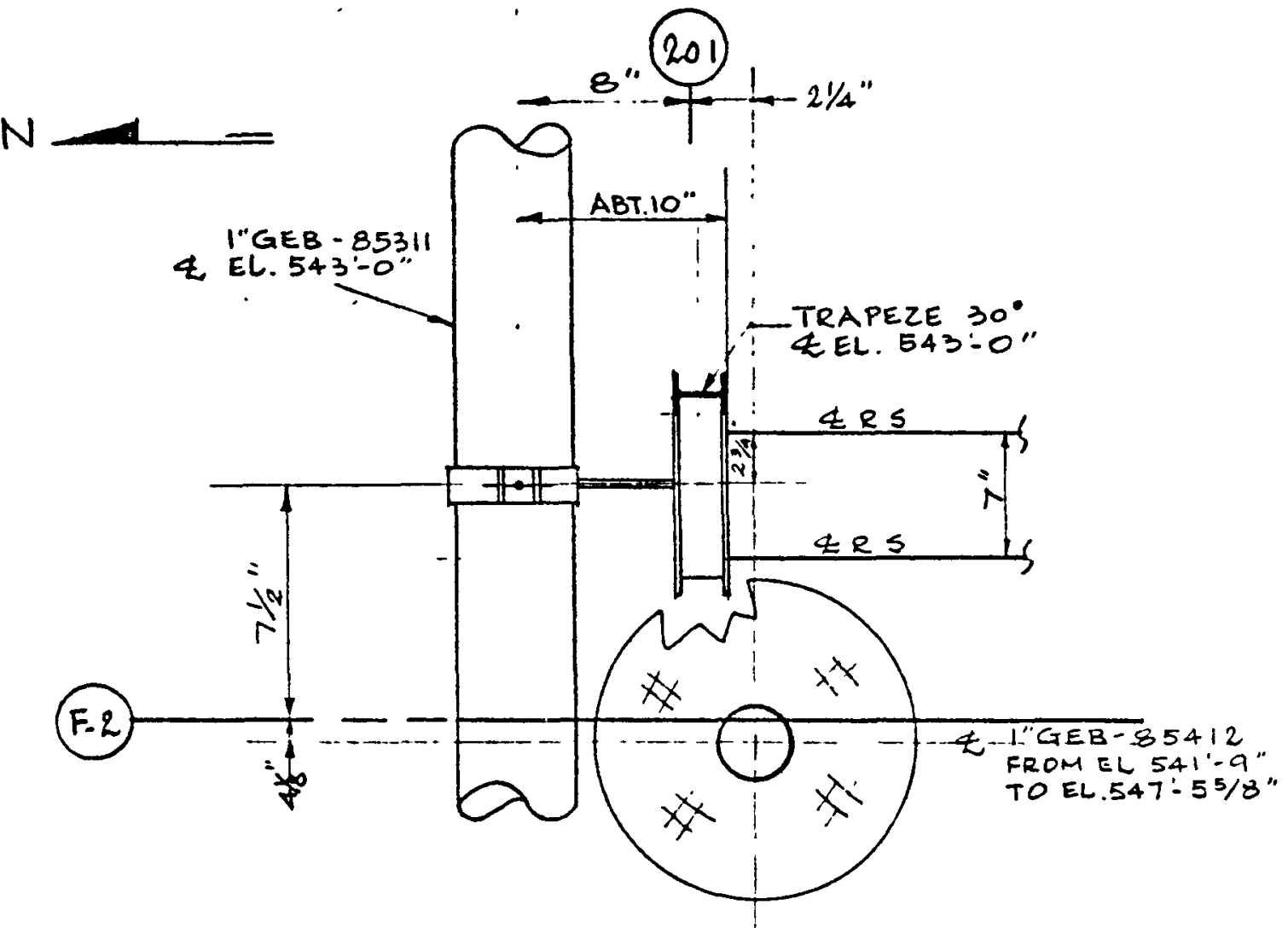

TAN EL. $545^{\prime}-0^{\prime \prime}$

(N.T.S) 489 
1524

\section{FFTF}

H-4.19017-2 SHT.GG

$H-4-36509-2$ SHT 829
4. $4 \cdot 7.7$

$s+10$
L- $|4|$

2

GER - 85412-1-3

$G E B-85411 H-19$

GEB - E5411 H-19 INTEKFEKE: WITH. GEE-85412-1-引 AS SHOLUN

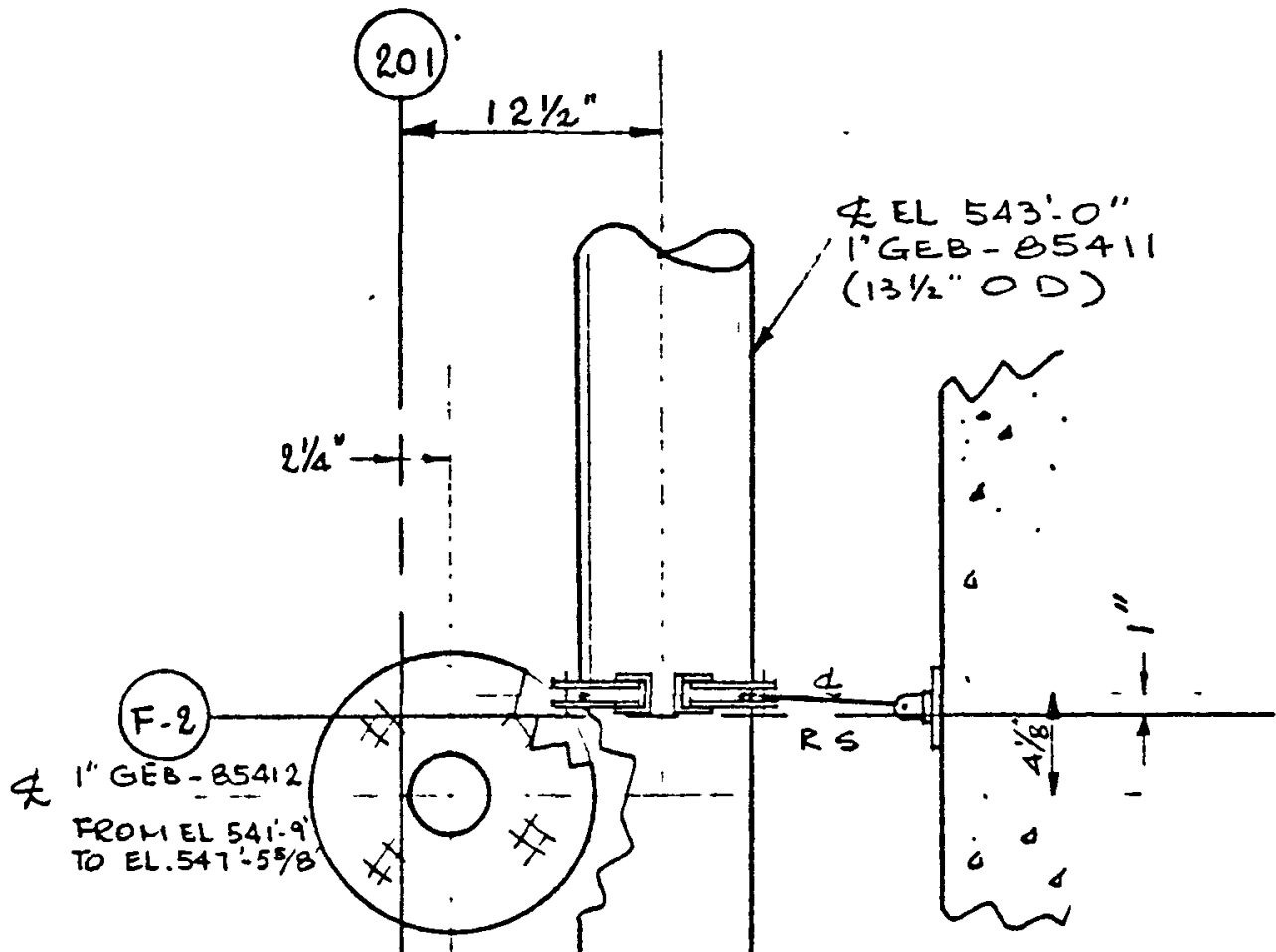

TLAN EL. 545'-0"

$$
\begin{gathered}
1^{\prime \prime}=1^{\prime}-0^{\prime \prime} \\
489
\end{gathered}
$$


1024

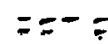

$H-4-11017$ FET $=$ SH $=4$

$H-4-36509$ REV I SH -727 $\therefore m=\because ?$

$2 \cdot 143$

=._E - -

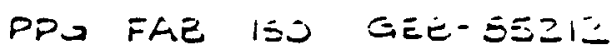

PIPE SLIPPURT GCB-SEOIZ H-
5" IN LLILATION ON I" GEB-85ZIZ INTERFERE- WITH

SNUB BELONGING TO GLB.35OI2 H.3I AS JHCVIII

NOTE : IXI3 BEAM WILL NOT TOLKH ENUB WITH GIVEN DIMENSIONS

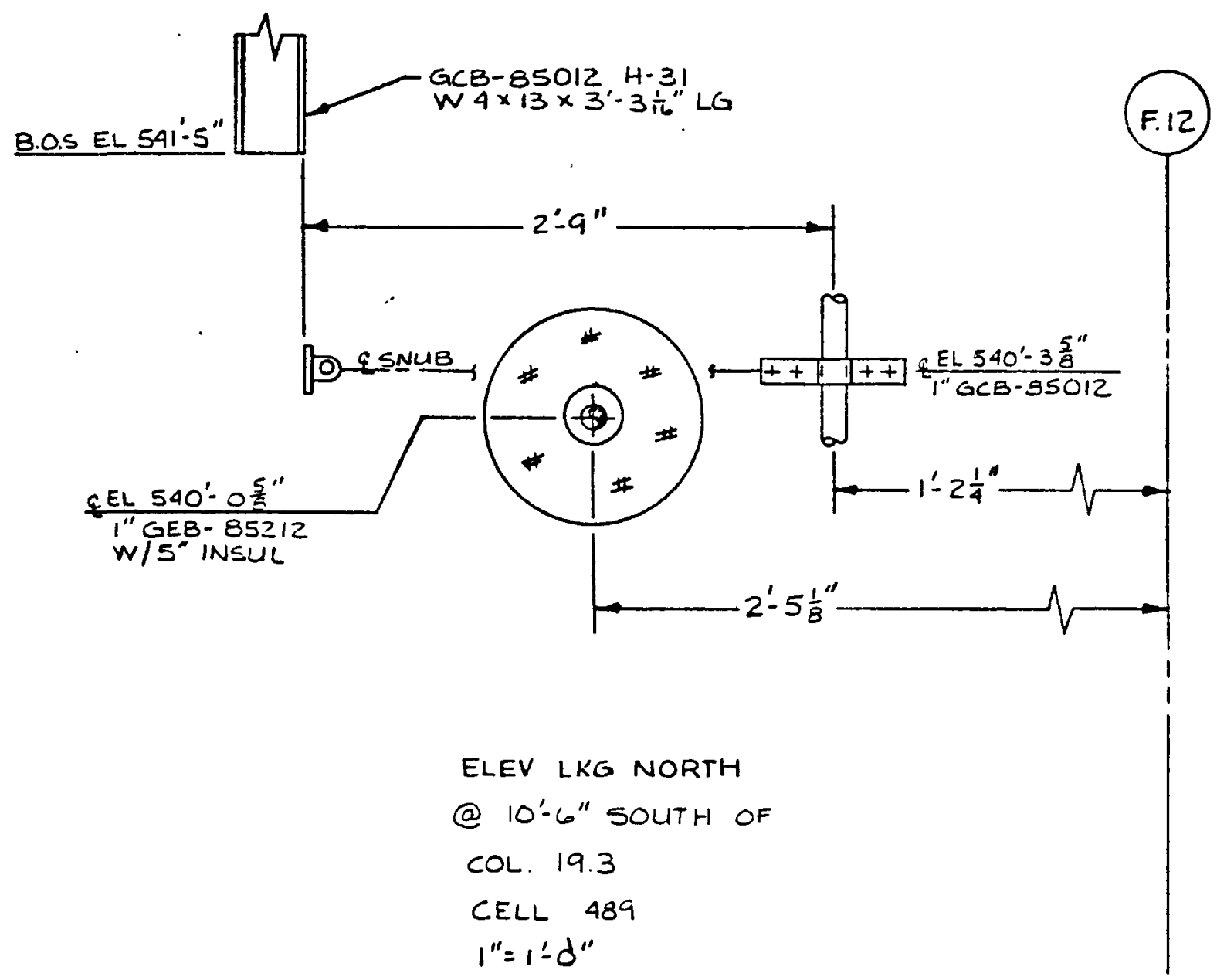




$\begin{array}{lll}102-1 & 2 \text { APRIL } 77 & 2-14 \mathrm{~A} . \\ \text { FFTF } & \text { ROJE DOLL } & 2\end{array}$

H-4-19017 REV 2 SH 54 PRG FAE :2 GEE-ẼI2

H.4.36509 REV I SH W37 PIPE SUPFUFT GEE- SE-11 H-19

5" IN=LILATION ON I" GEE- BSZI2 INTEMFEFES WITH

SNUB \&ं CLAMP BELONGING TO GEE-SS:II H-1.7 AS IHSWN

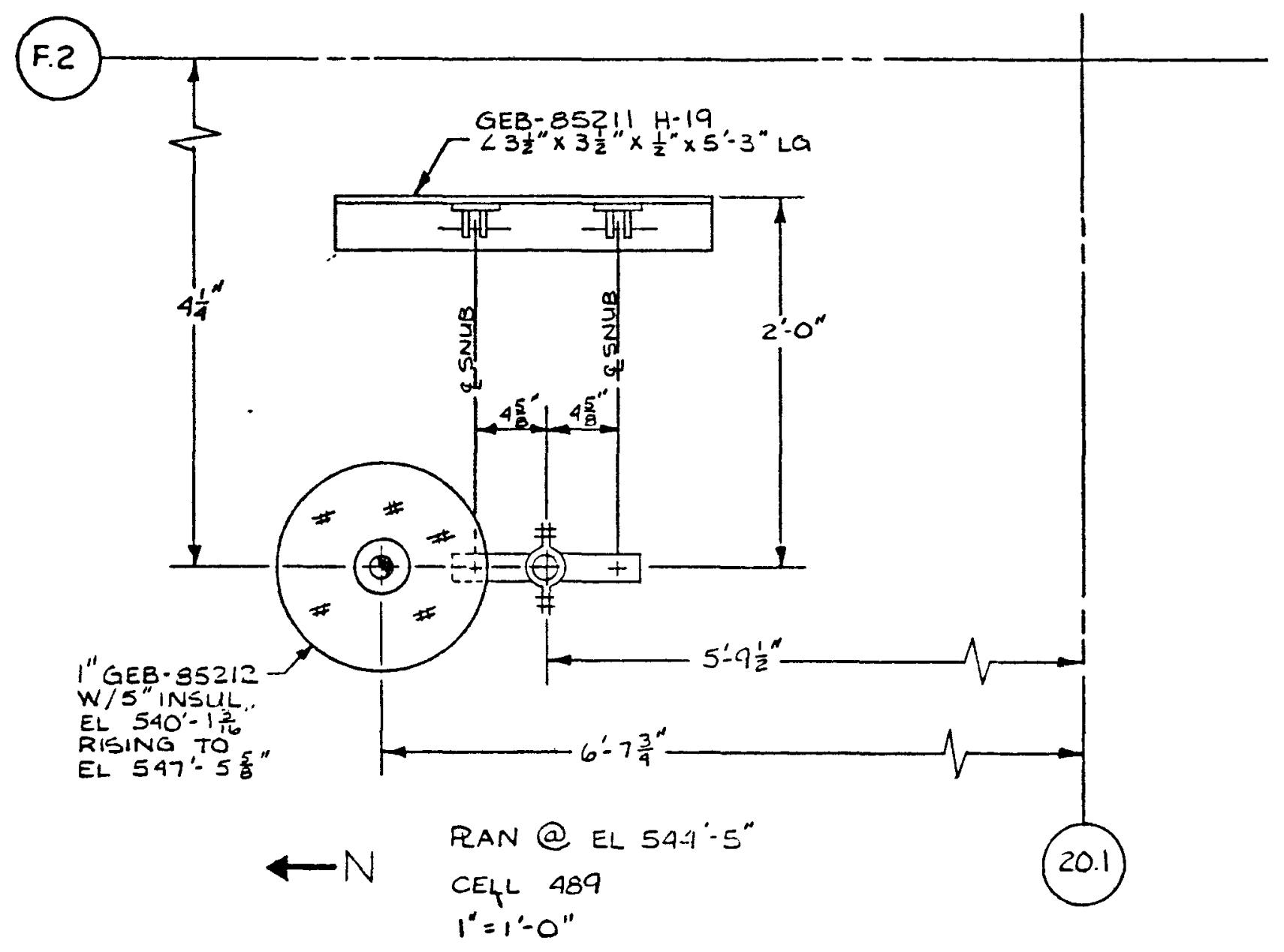




$$
\begin{aligned}
& \text { E-? } \\
& \text { FETF }
\end{aligned}
$$

H-A-1.1017 REV 2 SH 54

H-4- 36507 REV I SH 662
2 APRIL 77

ROSE DOLL

DPG FAB 150 NEB-55212

PIPE SUPPORT GEB- 35ZI H-IE

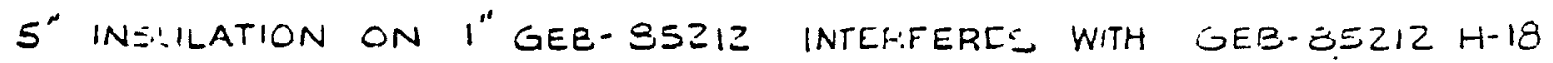
AS SHOWN
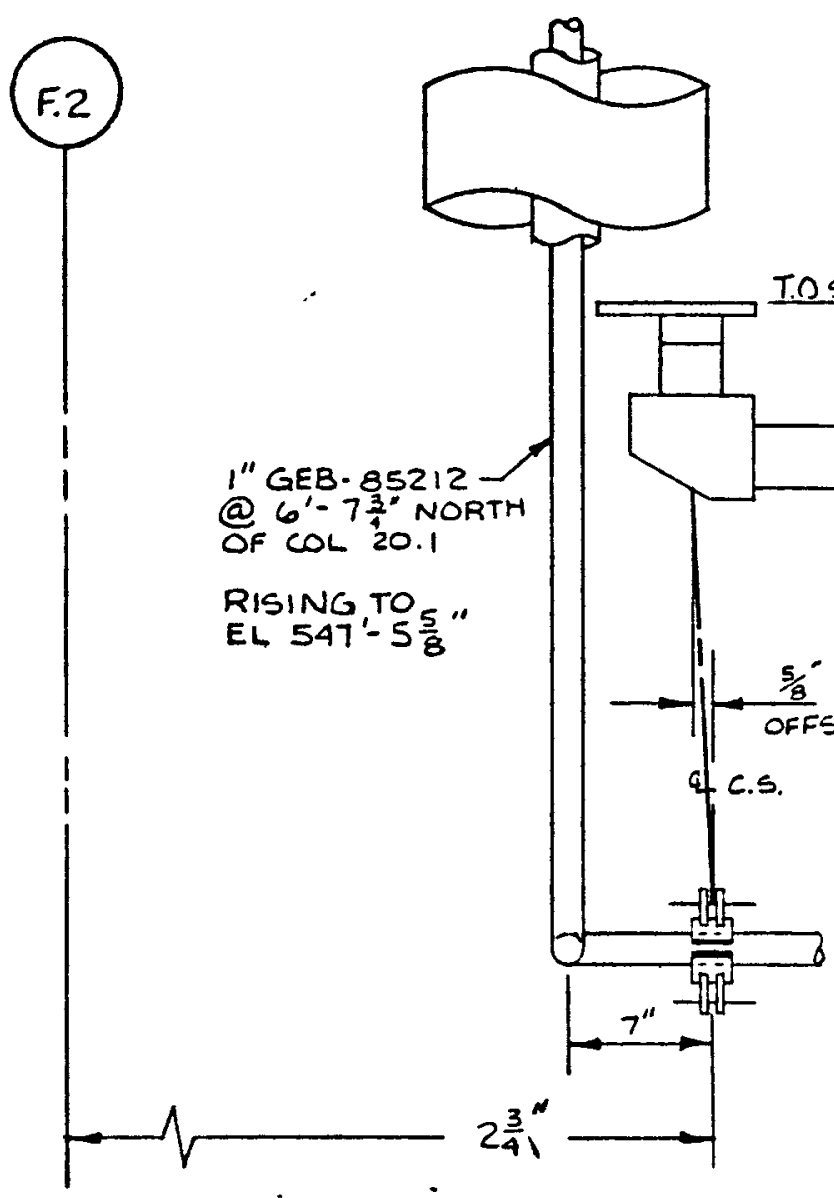

ELEV LKG NORTH

CELL 489

$1^{\prime \prime}=1^{\prime}-0^{\prime \prime}$

T.OS EL $545^{\circ}-0^{\prime \prime}$

TYPE "B" CS
LOAD $=4 O^{\circ}$

@ $7^{\prime}-2 \frac{1}{8} " N O R T H$

OF COL 20.1

$\frac{\text { WP EL } 540^{\circ}-1 \frac{3}{16} "}{\text { "GEB- G5212 }}$

w/ 5 "INSUL

อ 7 ' $1 \frac{3}{4}$ "NORTH

OF $\operatorname{COL}^{4} 20.1$ 


$$
\begin{aligned}
& 10=1 \quad ? 312 \ldots \ldots 2.146 \\
& \text { FFTF ROEE DOLL R }
\end{aligned}
$$

H-4.19017 REV $25 H \subseteq 4$ PAG FAB 150 TEB- 852II

H-4-36509 REV I SH WS5 PIPE ELIPPOAT GEB-85212 H.11

E" INSLILATION ON GEB-35Z12 INTERFERES WITH

SNUE \& $4 \times 13$ BEAM RELONGING TO GEE-BS212 H-11

AS SHOWN

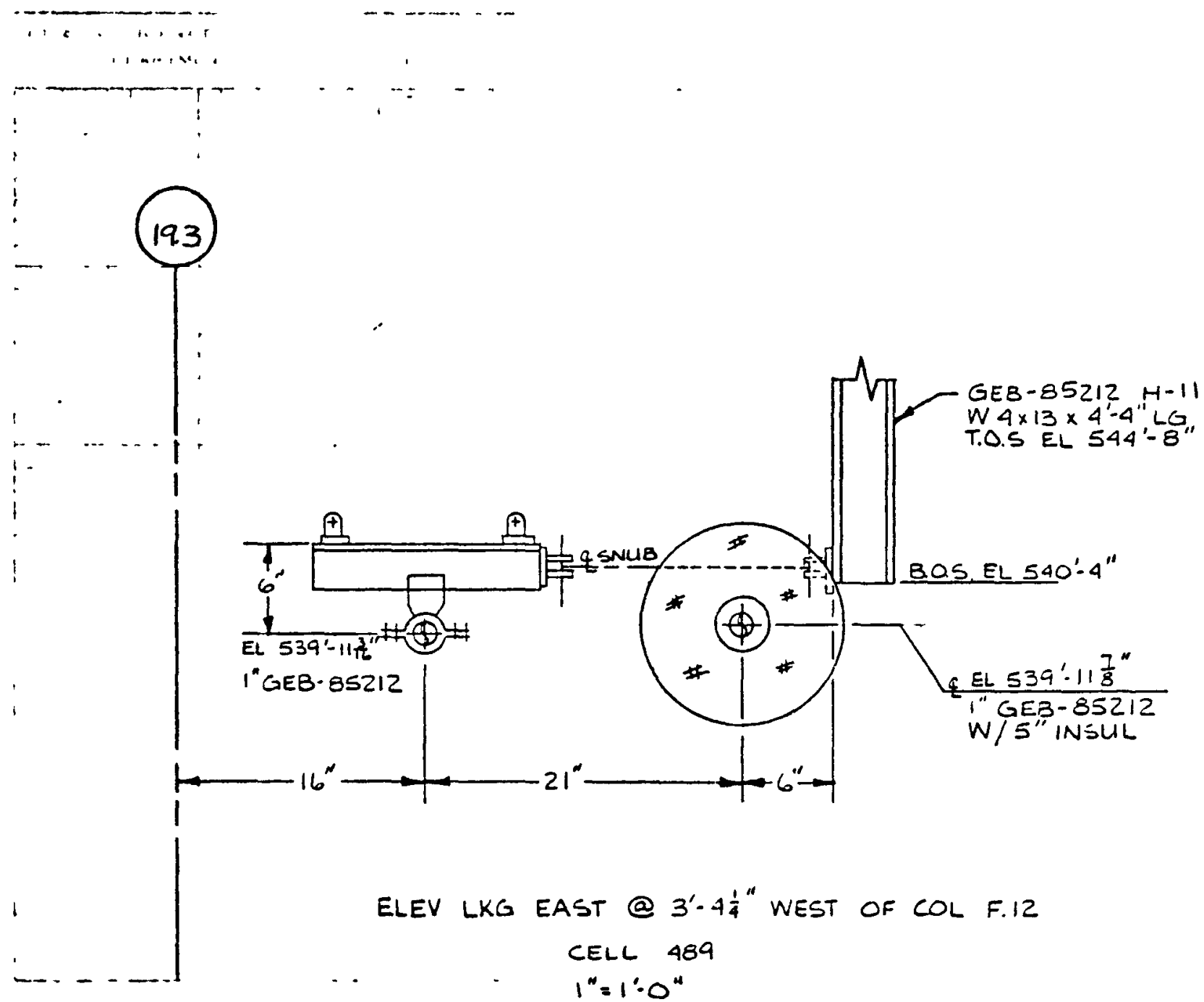




$$
10 \div \cdot 1
$$

FITF

H-4-1.7017 REV 2 SH 54

$=$ APRIL 71

7. $i a$

ROSE DOLL

2

H.4-3650.1 REV I SH L.52 PIPE SUPPURT GEB-ESZIR H.

5" INSLILATION ON I" GEB-852I2 INTERFERE:- WITH INLIB Ð $4 \times 13$ BEAM BELONGING TO SEE- -52212 H $\therefore$

$A=$ SHOWN

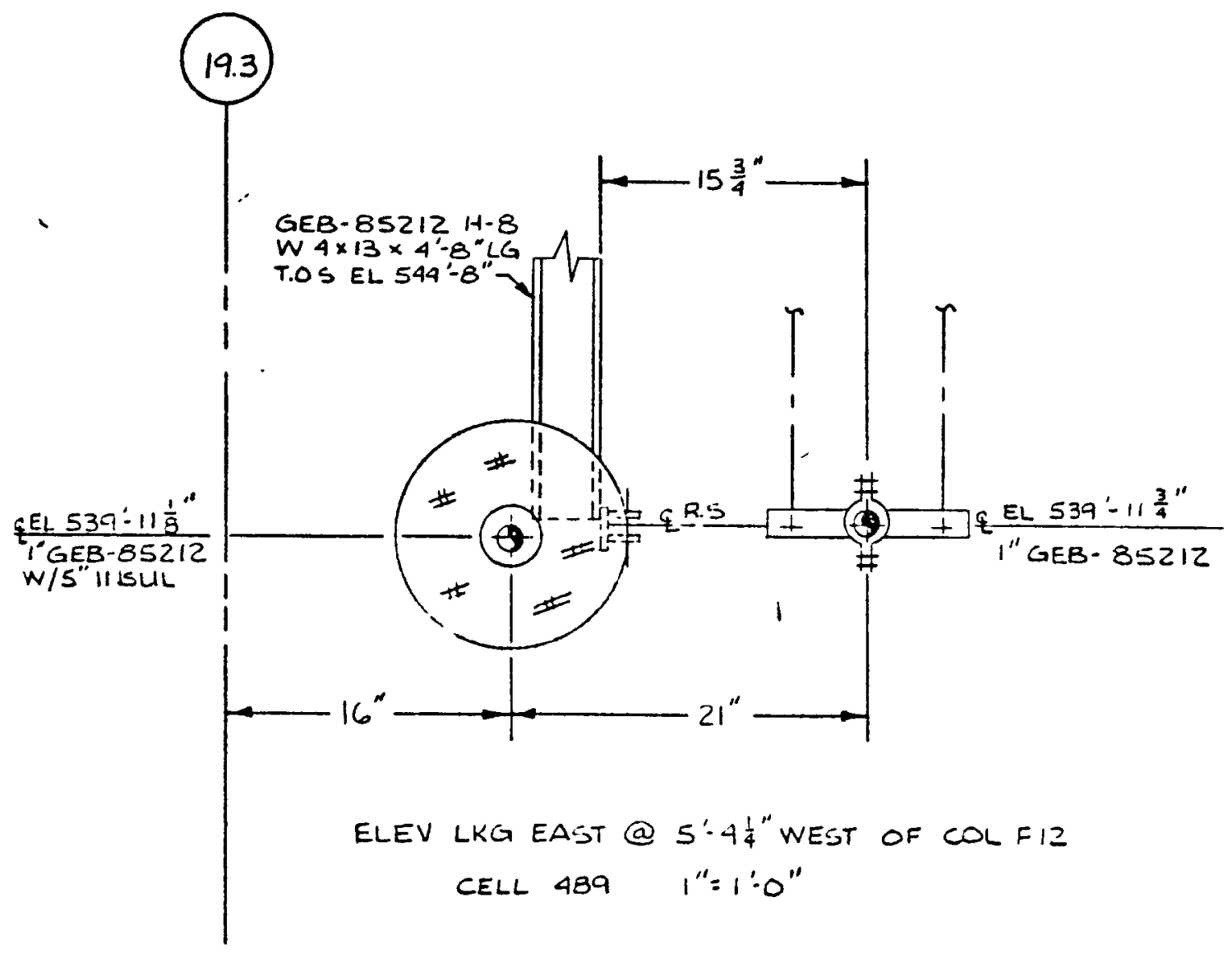




$$
\ln : !
$$

FFTF $\therefore$ APRIL 71

RUDE DOLL
$2-148$

2

H.4.19017 REY $=$ SH 54 PFA FAB 1:J EEB- 35212

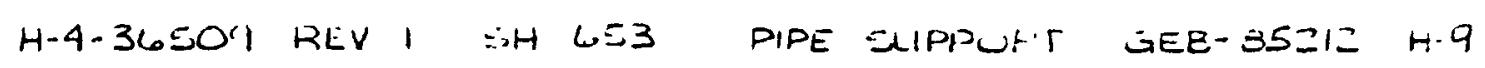

5" INEULATION ON I"GEB-352IZ INTERFEFES WITH HGR GEB-S5212 H.A AS SHOWN

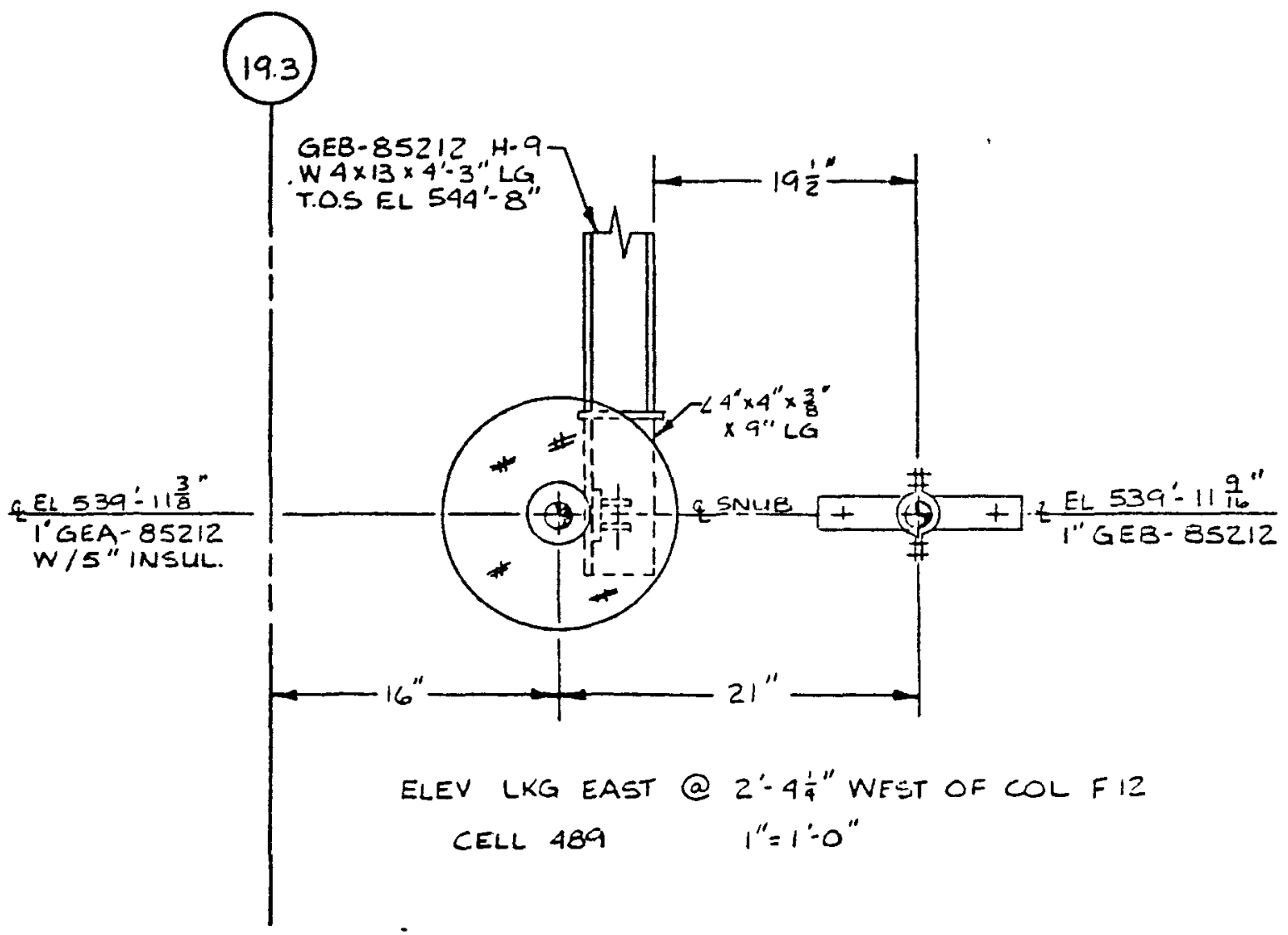




$$
\begin{aligned}
& 1024 \\
& \text { TFTF }
\end{aligned}
$$$$
\text { 1.-1-7? }
$$

$K M^{c}$

2

H-4-19017 ReV. 2 SH. 10 PPG. FABRICATION 150 I" GCB-85011 H.4-36509 REV SH. 413 PIPE SUPPORT GCB-85012 H-27

TWO I" RIGID SUPPORTS PART OF GCB-85012 H.27 INTERFERE WITH 5 " INSULATION ON I" GCB-85011 AS SHOWN IN VIEWS

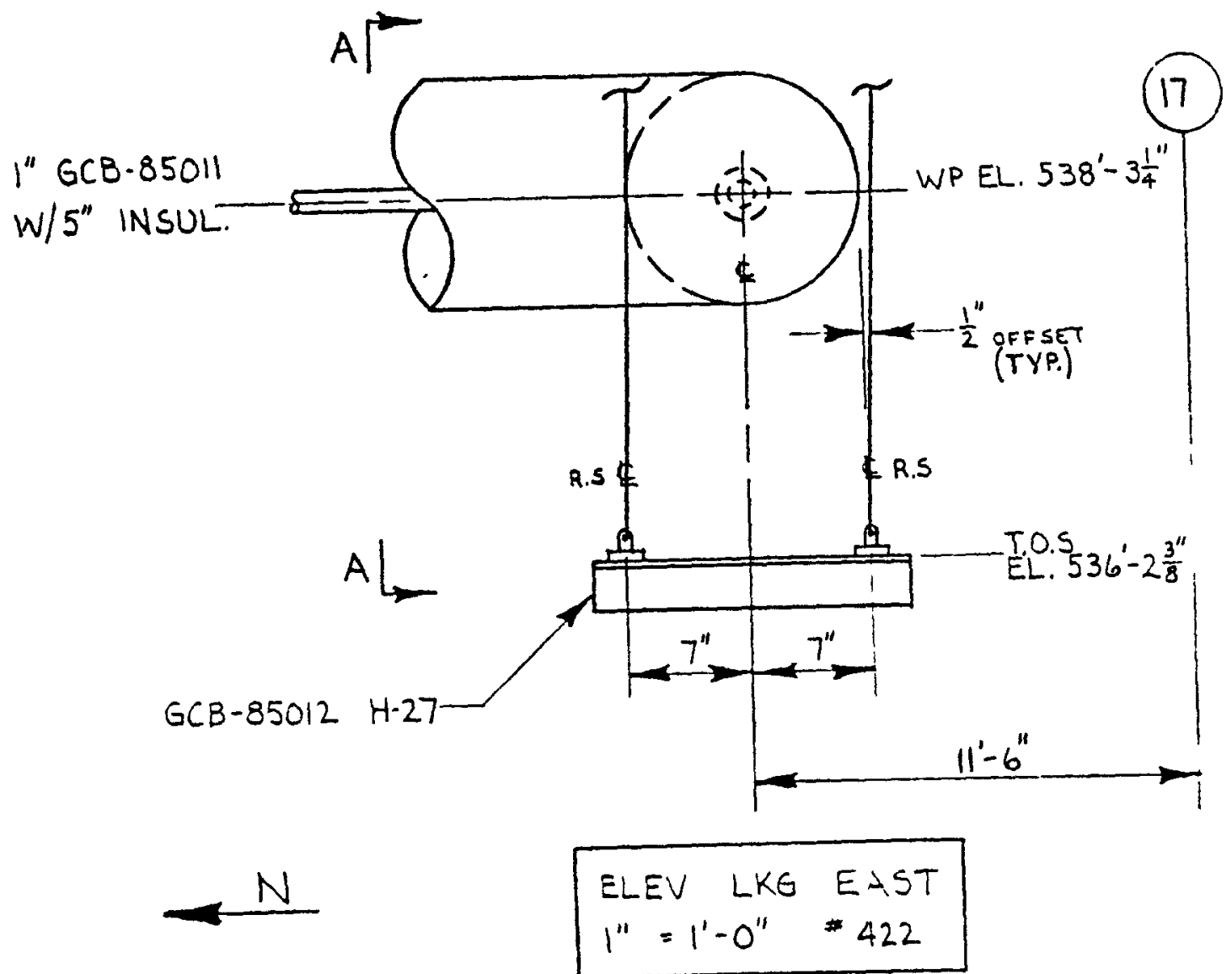




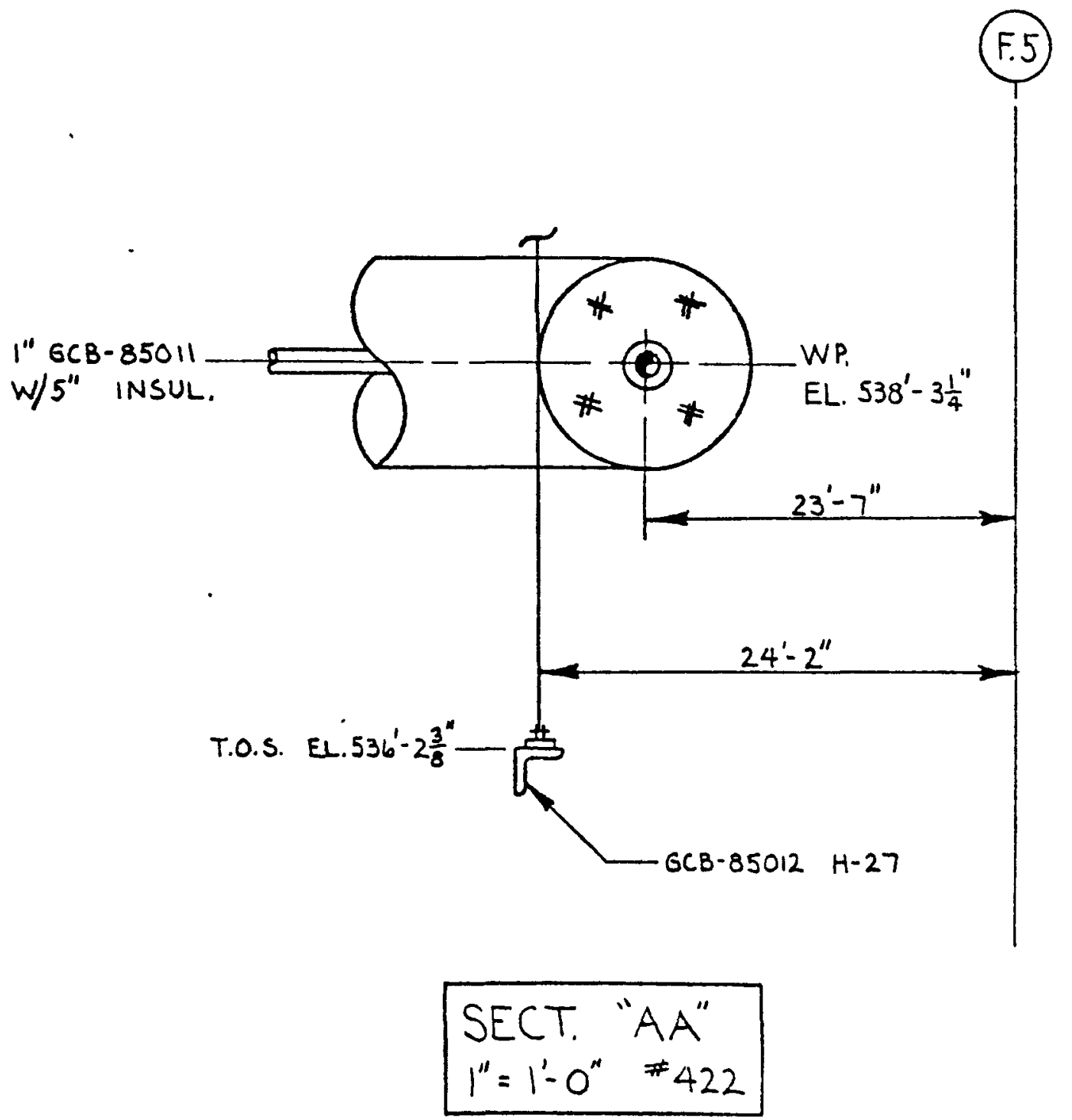

NOTICE NO.

2-149 


$$
1024
$$

FFTF

$$
4-4-77
$$

$K M C$ $2-i+i$

$!$

H.4.19017 REV. 2 SH. 10 PPG. FABRICATION 1SO. I" G'CB-85011 H.4.36509 REV. I SH. 417 PIPE SUPPORT GCB-85012: H-26

TWO $1^{\prime \prime}$ RIGID SUPPORTS PART OF GCB-850I2 H.26 INTERFERE WITH $5 "$ INSULATION ON I" GLB-85OII "AS SHOWN
IN VIEWS

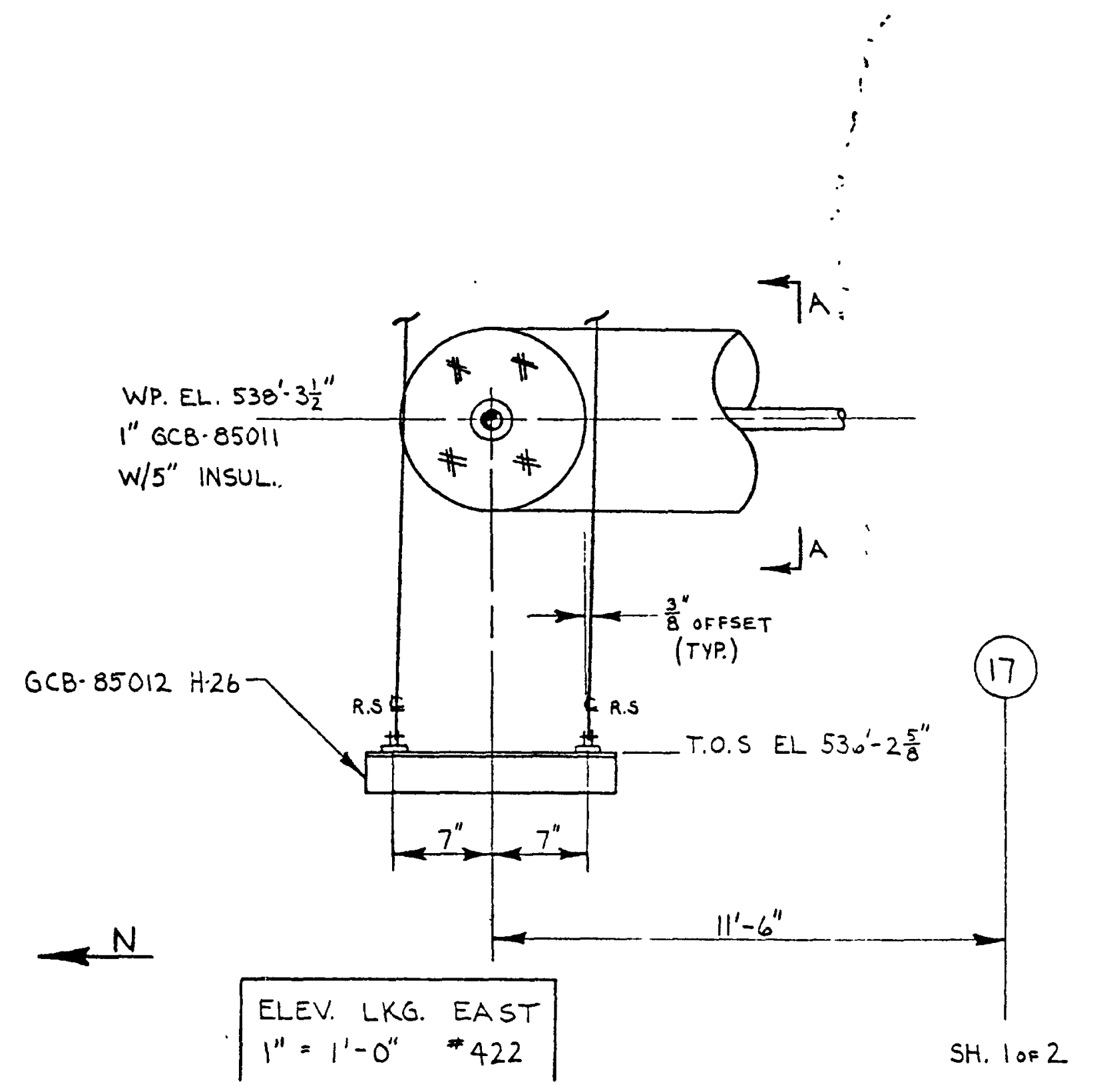




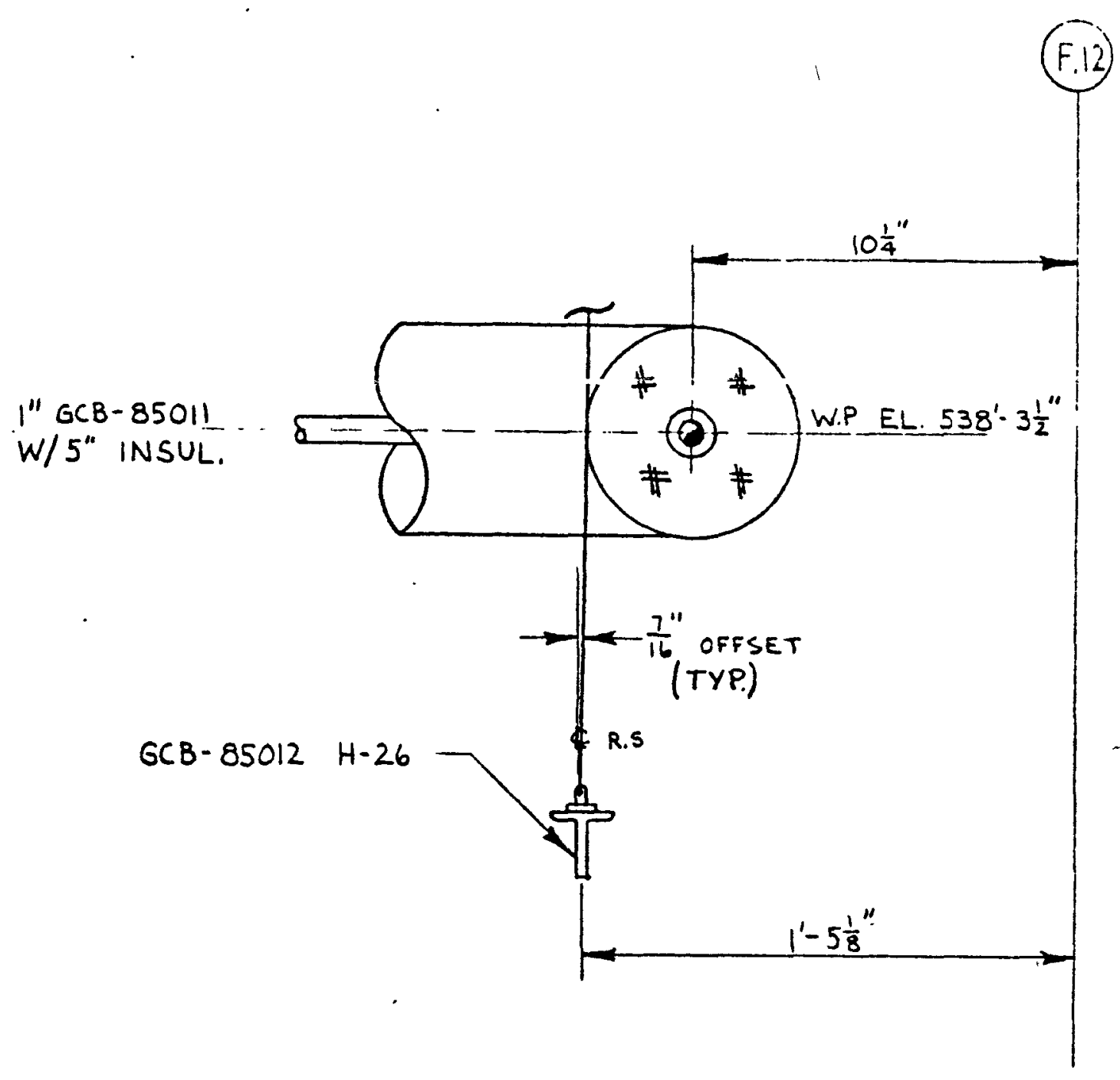

SECT. "A-A"
$I^{\prime \prime}=I^{\prime}-O^{\prime \prime}{ }^{ \pm} 422$

NOTICE NO.

2- 150 


$$
10 \div-1
$$

FFTF.
6 tirise it

RUJE DOLL
$=151$

2

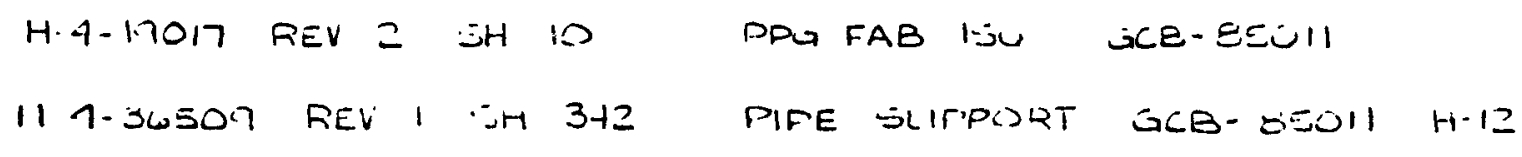

HER GCB-GEOI1 H.L INTERFERE= WITH E" INSULATICN ON I" GEB-35011 AS JHOWN

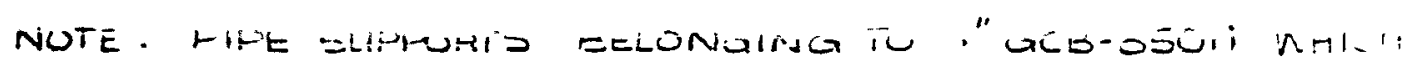
WAS MOVED I'O" WEST TO LLEAR JLINCTKKM OMKEAND IS NOW LOCATED 15'-T" WEET CF COL D... WERE NOT MIUVED WITH THEIR PIRE DISTREPANCY BETWEEN PIPE \& HGRE IS I'-O"

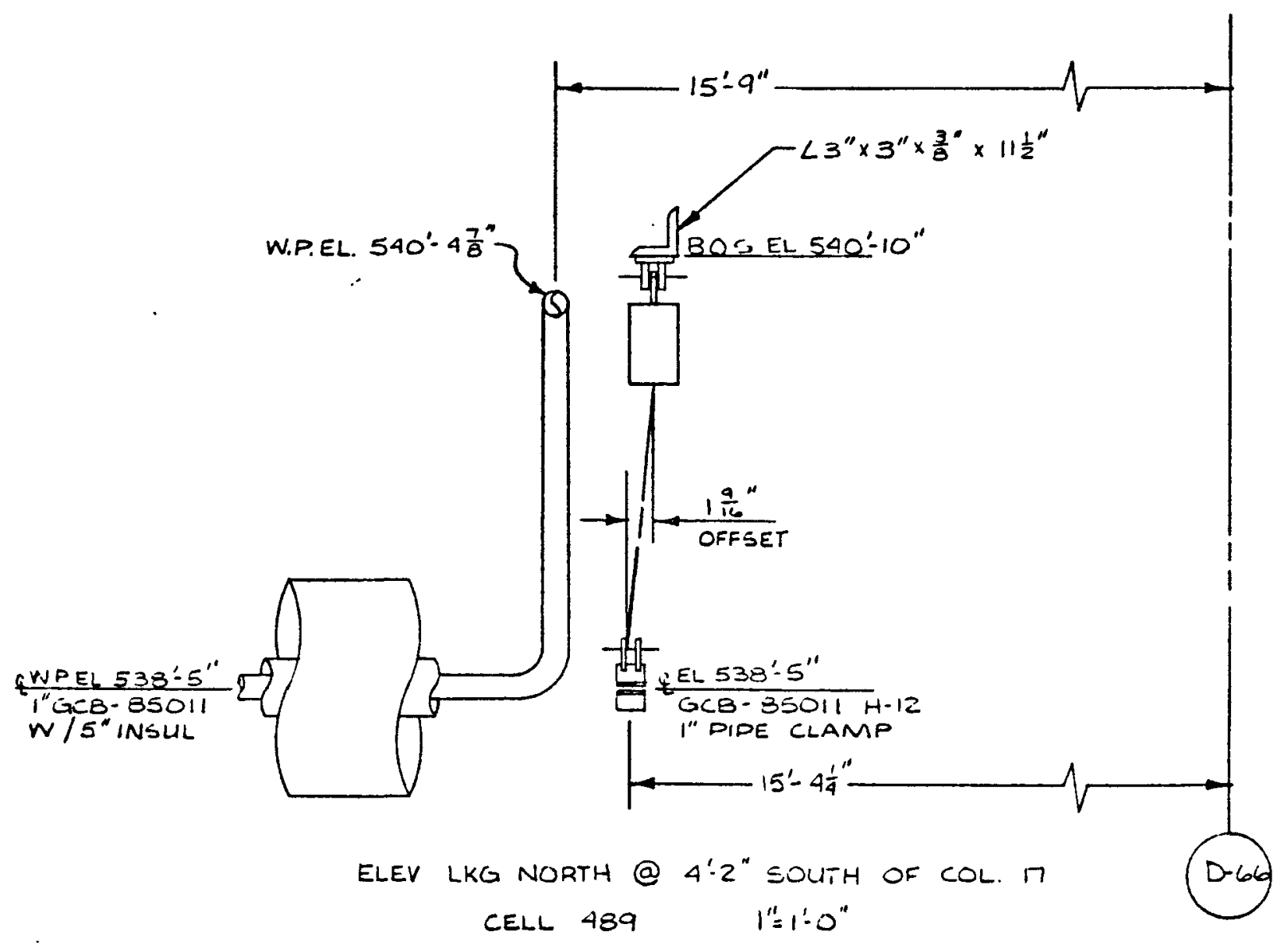


1024

FFTF
$4 \cdot 5 \cdot 77$

$K M-$
$2-1=$

2

H.4.19017 REV. 2 SH. 10 PPG. FABRILATION 1SO. "GLB.85011 H.4-36509 REV. I SH 598 PIPE SUPPORT GEB-85114 H.2

VARIABLE SUPPORT PART OF GEB-85114 H.Z INTERFERES WITH $5^{\prime \prime}$ INSULATION ON I" GLB-35CII AT 8 '- $\geq \frac{1}{8} "$ SOUTH OF
COLUMN 17

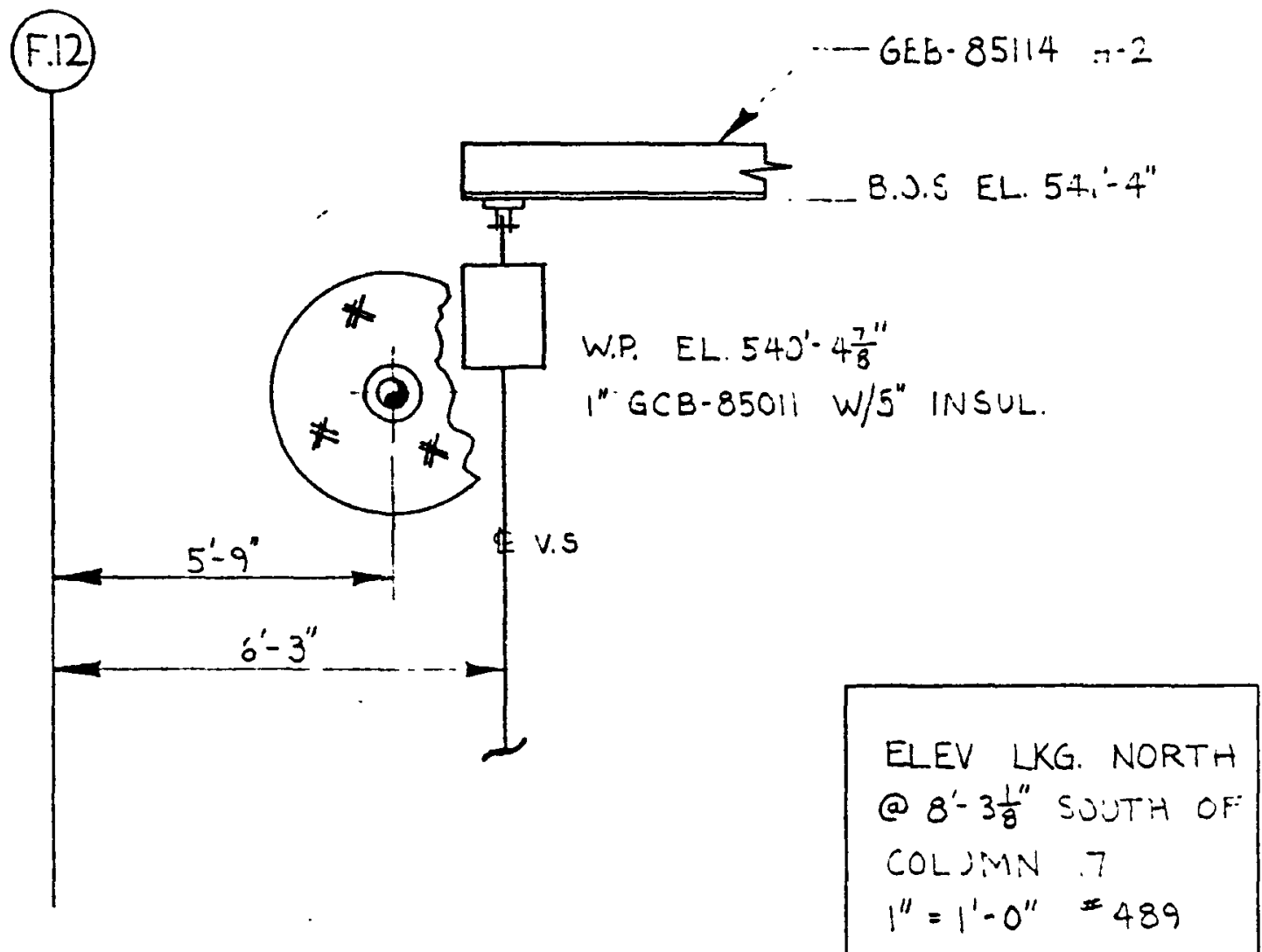


$10 \angle 4$

FFTF
$4 \cdot 5 \cdot 77$

$K M<$
$2-153$

2

H-4-19017 REV. 2 SH. 10 PPG. FABRILATION 150. I" GLB.85011 H-4-36509 REV I SH. 597 PIPE SUPPORT GEB.85114 H.1

VARIABle SUPPORT PART OF GEB-85114 H-1 INTERfERES WITH 5" INSULATION ON I" GCB-85114 AT 9'-11" SOUTH OF COLUMN 17

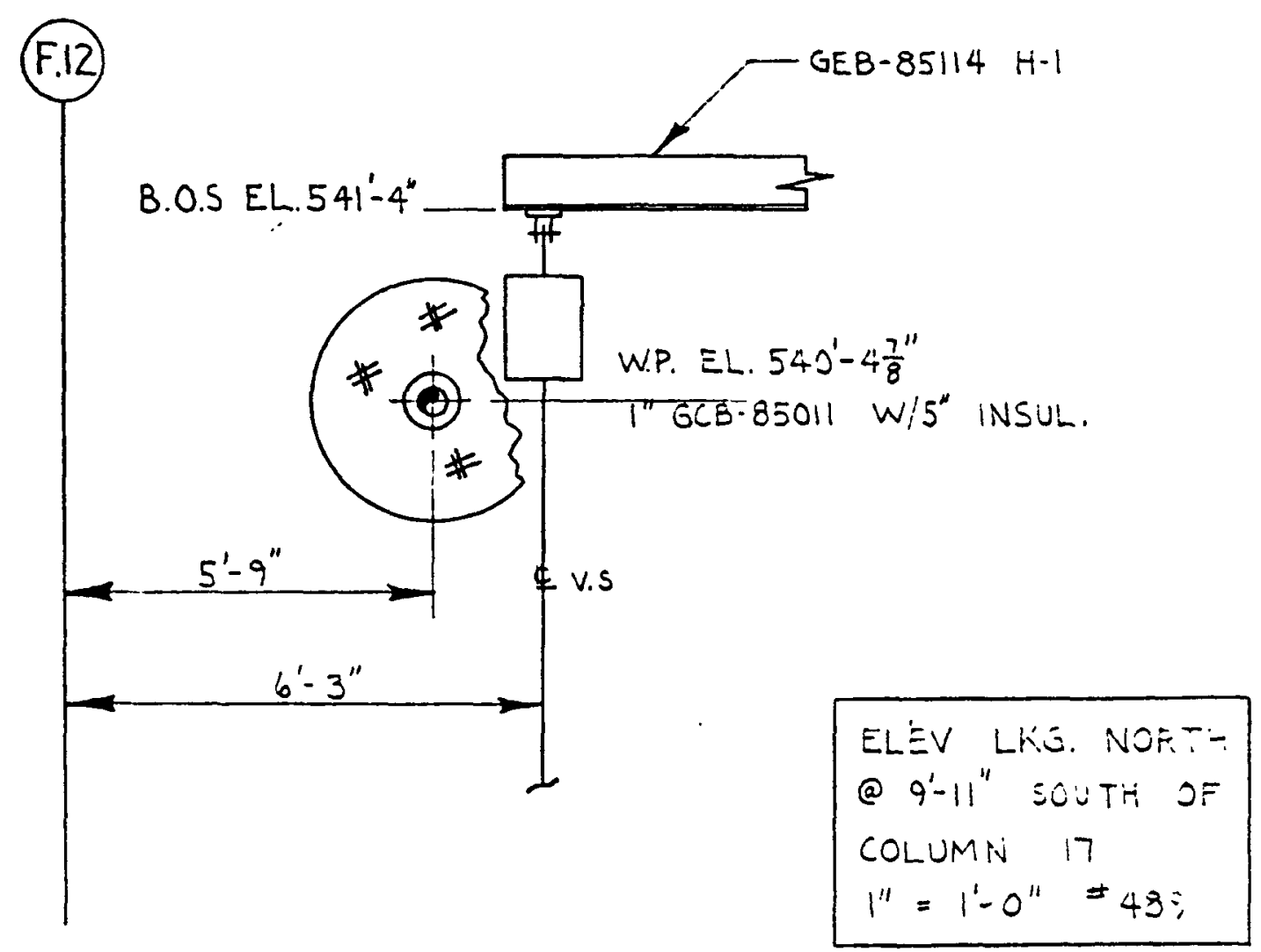


1024

FFiF

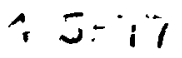

$K M^{c}$.
$2-154$

2

H-4-19017 REV. 2 SH. 10 PPG. FABRICATION 1SO. "GCB-85011 H-4.36509 REV. O SH. 498 PIPE SUPPORT GEB-61225 H.5

. SNUB PART OF GEB-61225 H-5 AT EL, 540'-27" INTERFERES, WITH 5 "INSULATION ON I" GCB-85011 $\leftleftarrows$ EI. $540^{\prime}-5 \frac{3}{4}$ "SS SHMMANI

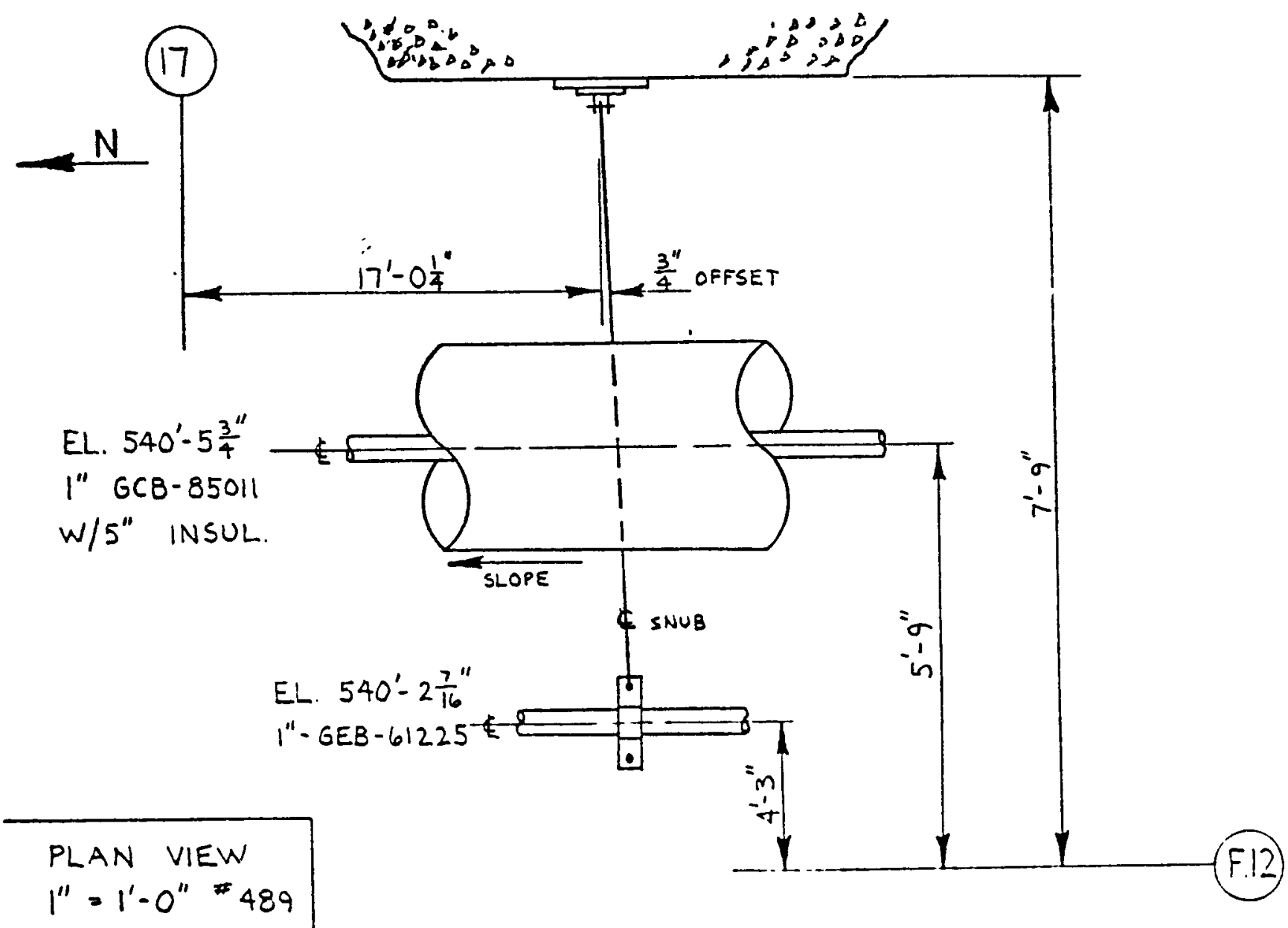




$\begin{array}{lcc}1024 & 4 \cdot 5 \cdot 77 & 2-1=5 \\ \text { FFTF } & K M C & =\end{array}$

H.4.19017 REV. 2 SH. 10 PPG. FABRILATION 150 I"GCB.85011 H-4-36509 REV. I SH. 687 PIPE SUPPORT GEB-L1325 H-7

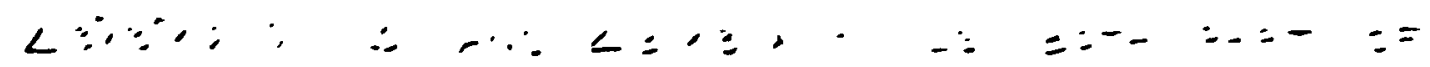

GEE-GIZZ5 TT NTEMFERE NITH E' INSULATION CN I GLE-

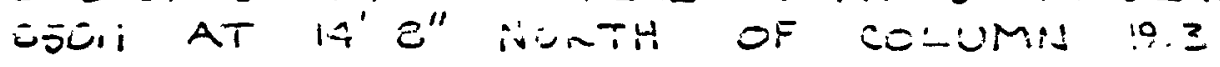

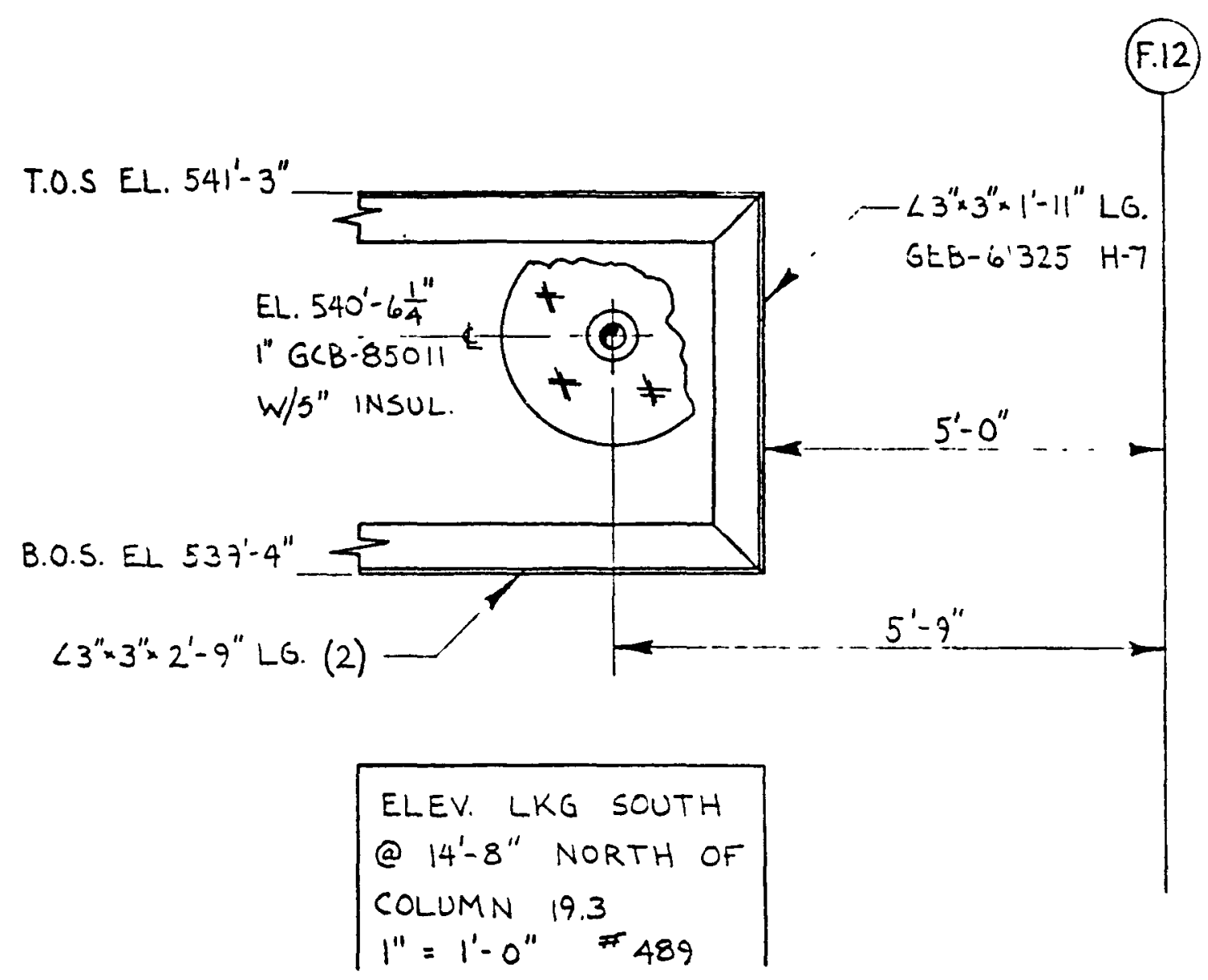


inc-

FFTF
$4 \cdot 5 \cdot 77$

$K M-$
$2-1=6$

2

H.4.19017 REV. 2 SH. 10 PPG. FABRICATION $1501 "$ GLB.85011 H.4-36509 REV. 2 SH. 400 PIPE SUPPORT GCB-85012 H.9

$\angle 4^{\prime \prime} \times 4^{\prime \prime} \times 11^{\prime}-11 \frac{1}{2} " L G$. PART OF GCB-85012 H-9 INTERFERES WITH 5" INSULATION ON I" GLB-850II AT THE ELBOW WITH WP EL. $54 D^{\prime}-6 \frac{5}{5}$ AS SHOWN

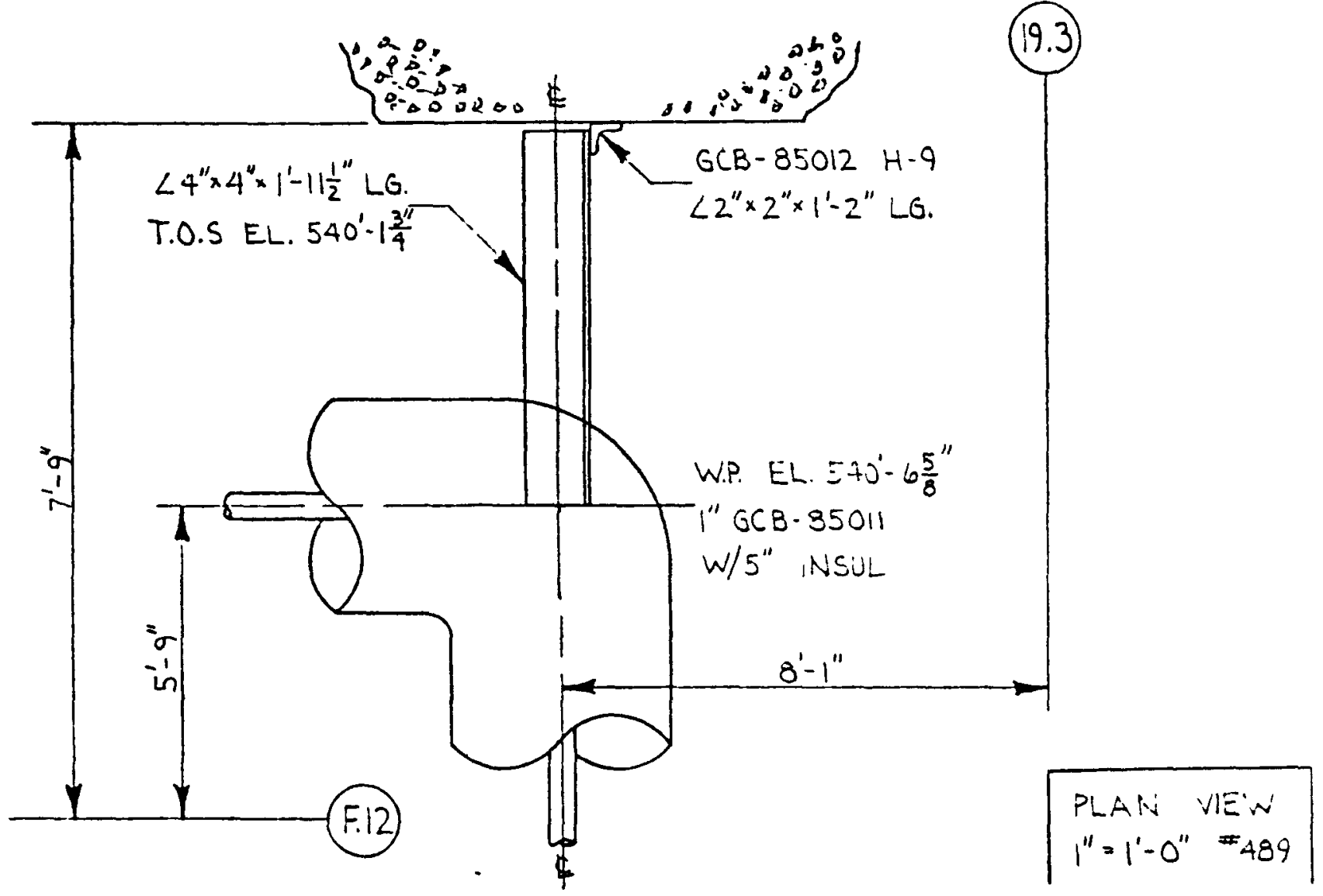




\section{$2 ? .4$}

FFTF
$A-4 \div 1$

ERisky K-LU
$2-15 \%$

2

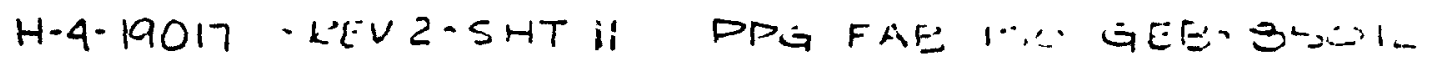

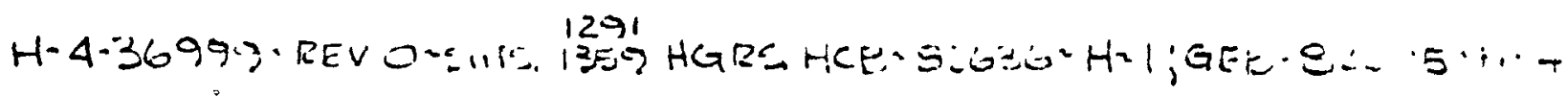

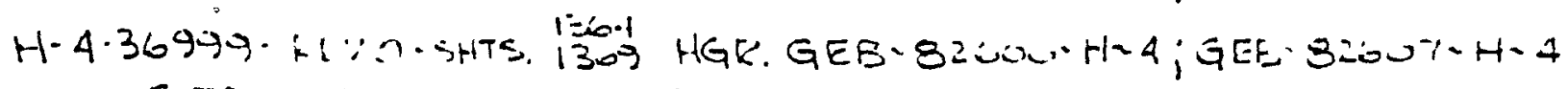

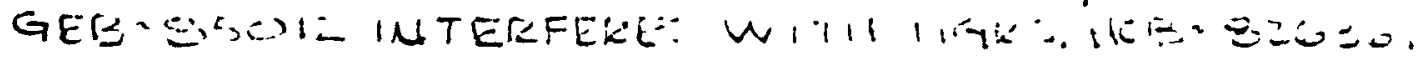

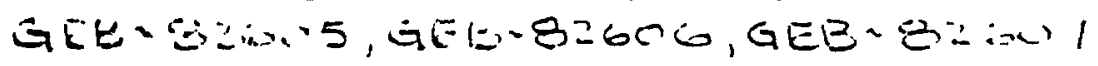

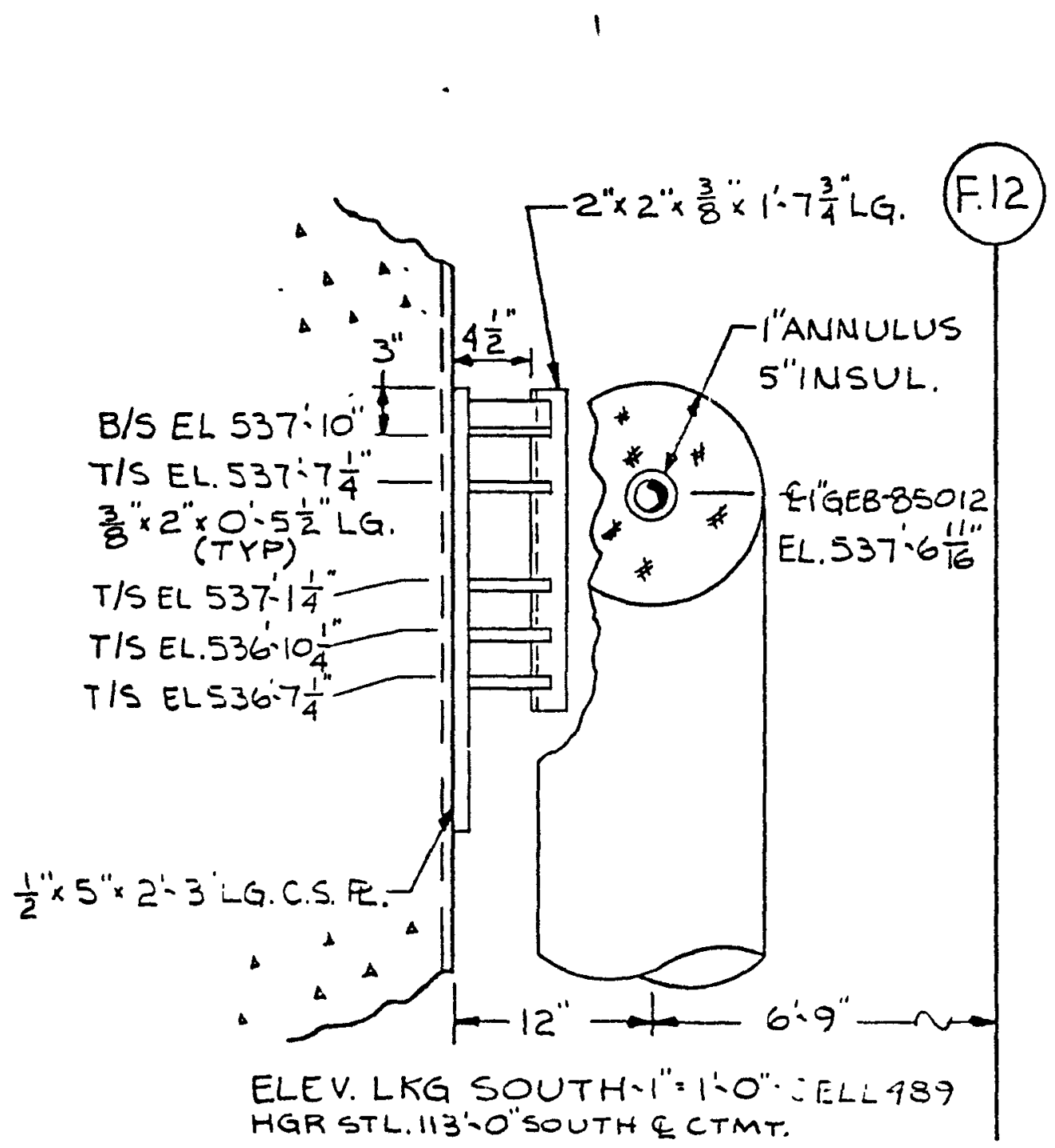


1024

FFTF
$1-4-79$

BARRY VE:-IEI $\because 15$

$\ddot{-}$

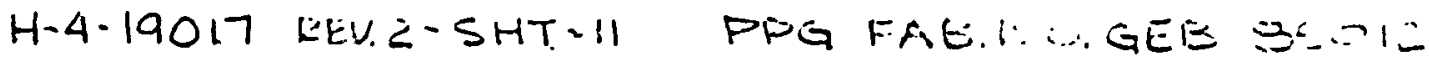
H.4.36509-REV.O SHT. 571 HGR GEB. 3.112-H-S

GEB-8:012 INTERTLEE: W: :H GEB-8-11. $H-8,5 H+r .5 \%$.

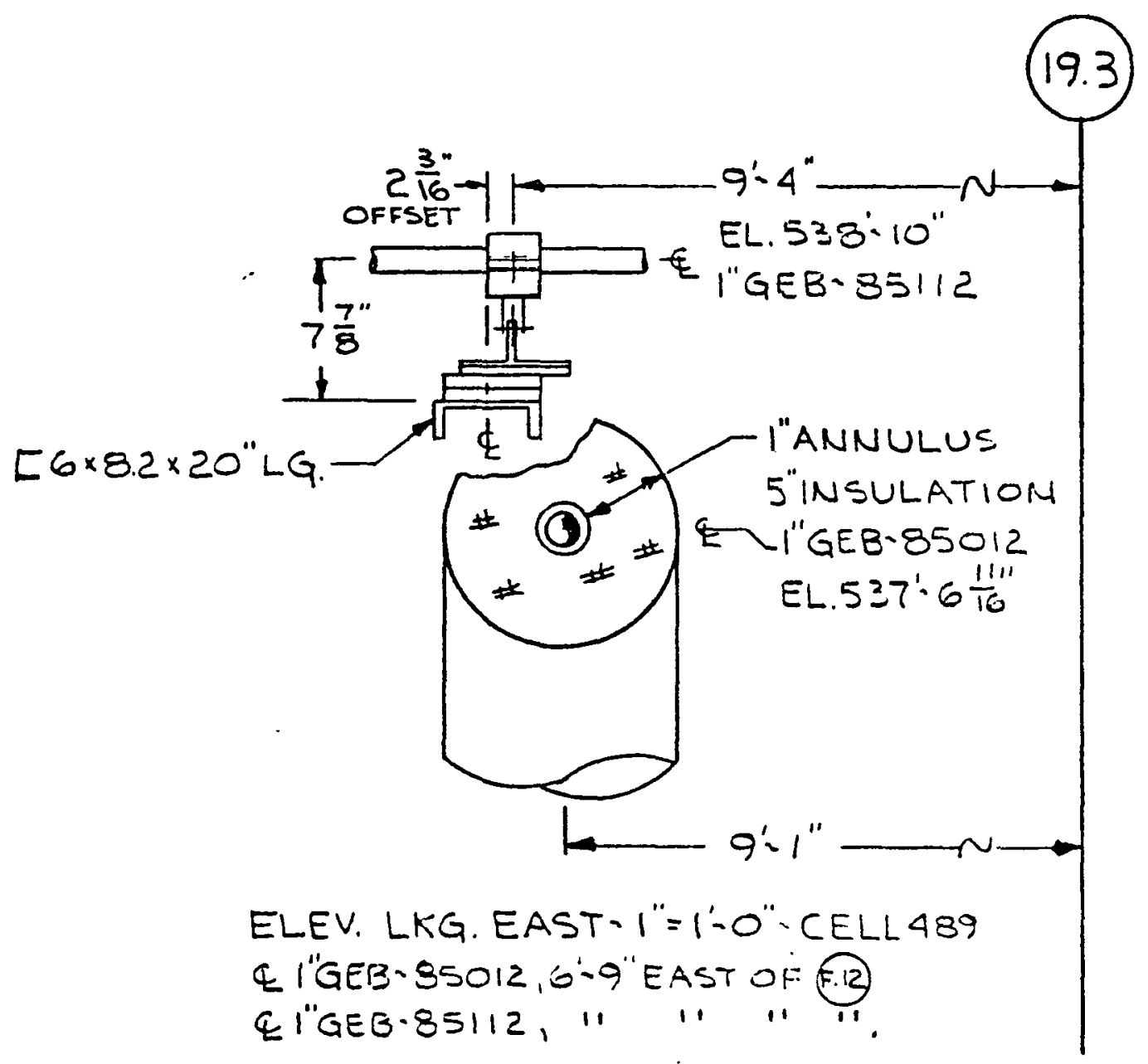


にこ்ட்

FFTF.
$4-4 \cdot 7-1$

BARRY VESTEZ
$-15>$

$=$

H-4-19017 HEVE SHT. II H.T.FAB ISO GEE.

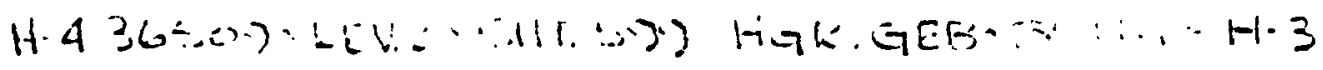

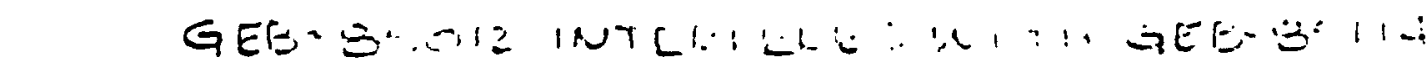

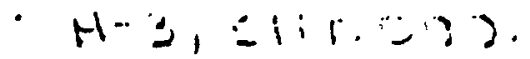

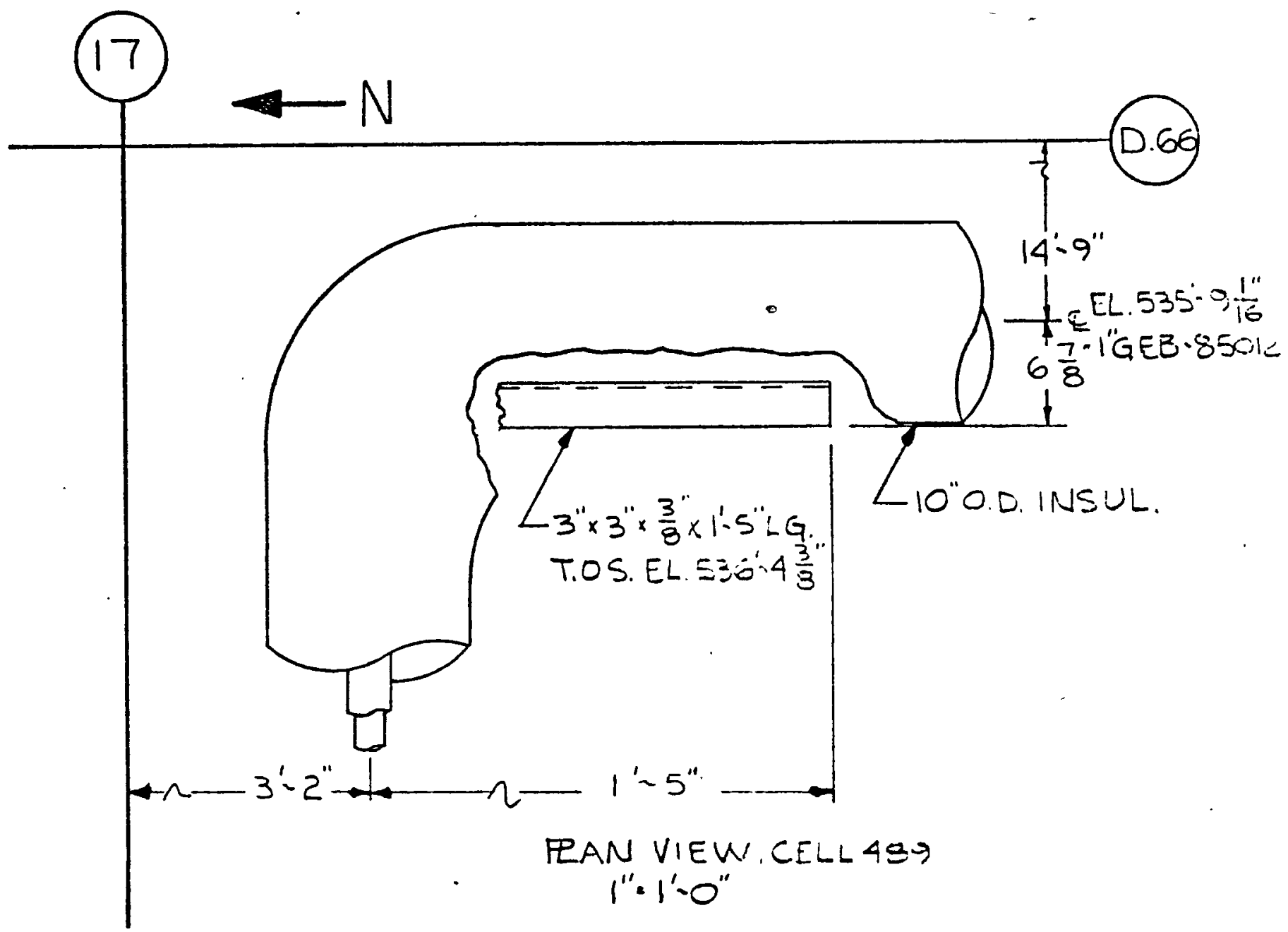


$i: 2 ? 4$

FFTF
$\Delta-\xi \because \cdot$

EARRY VE:-1: :
$2-160$

ב

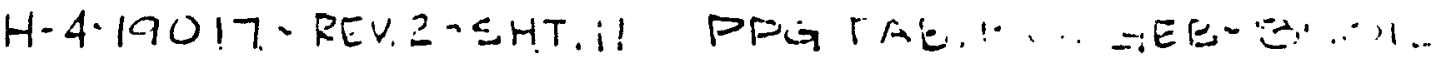

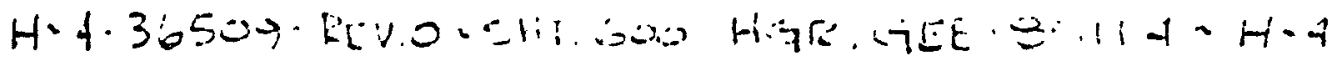

GEB-SiA12 INTEL:HE- W/TH GEB-8:-114 $H-4,-5 H T .600$.

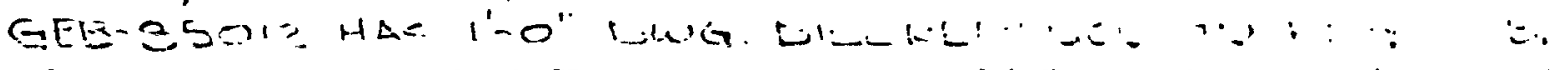

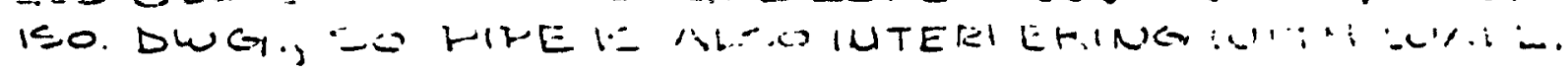

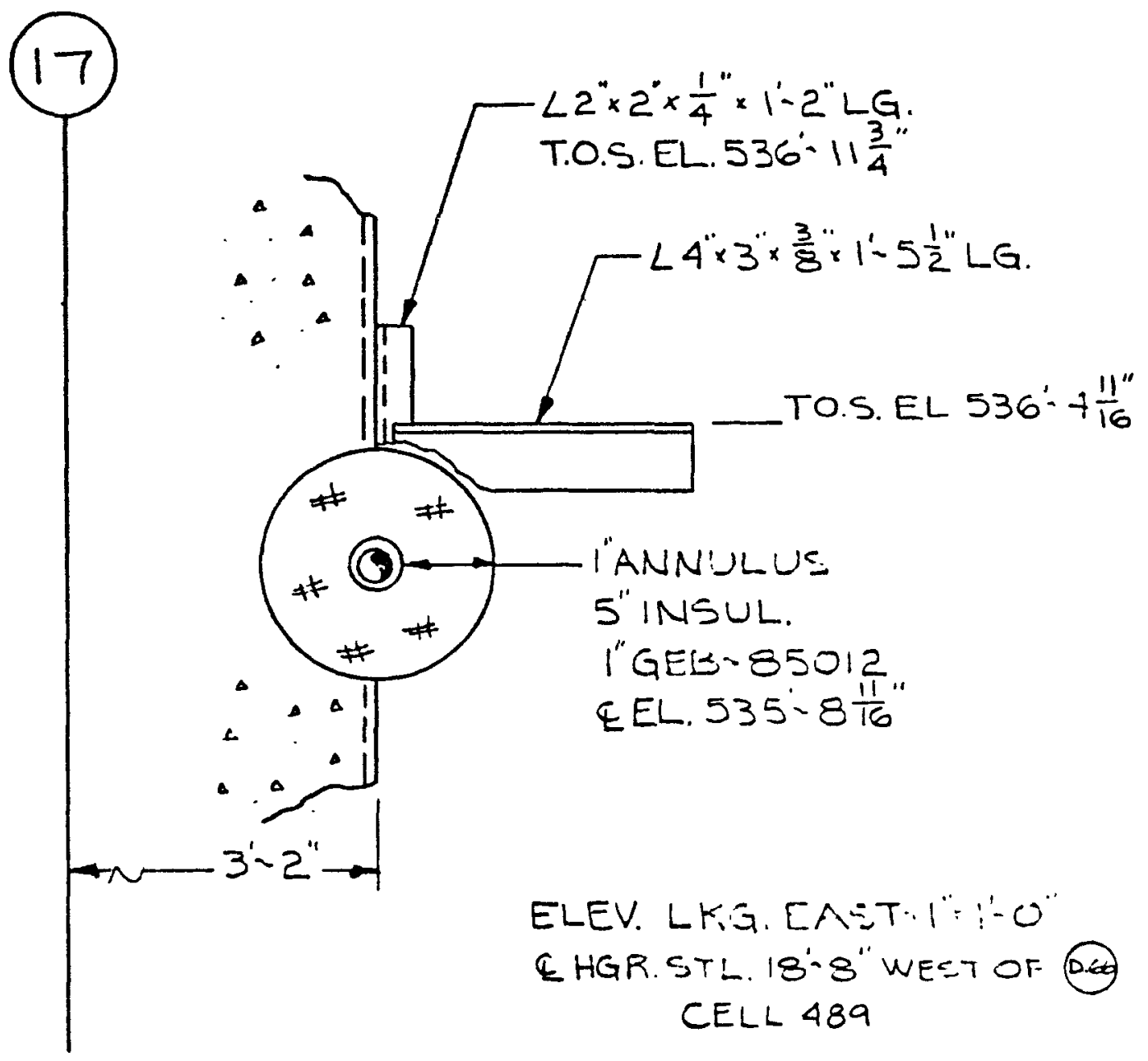


1024

FFTF
$4 \cdot 4 \cdot 77$

KARKY V:-1: $\therefore K:$

2

H-4-19017-REV.2-SHT.11 PPG.FAB-1EN. GEB. E35.61:

$H-1 \cdot 36509$-REV I - SHT. 605 HGR GES-3.11A-H- $\rightarrow$

GEB-3SO12 INTEKREKE=WITWAEB-3\%11H.9. SHT 605

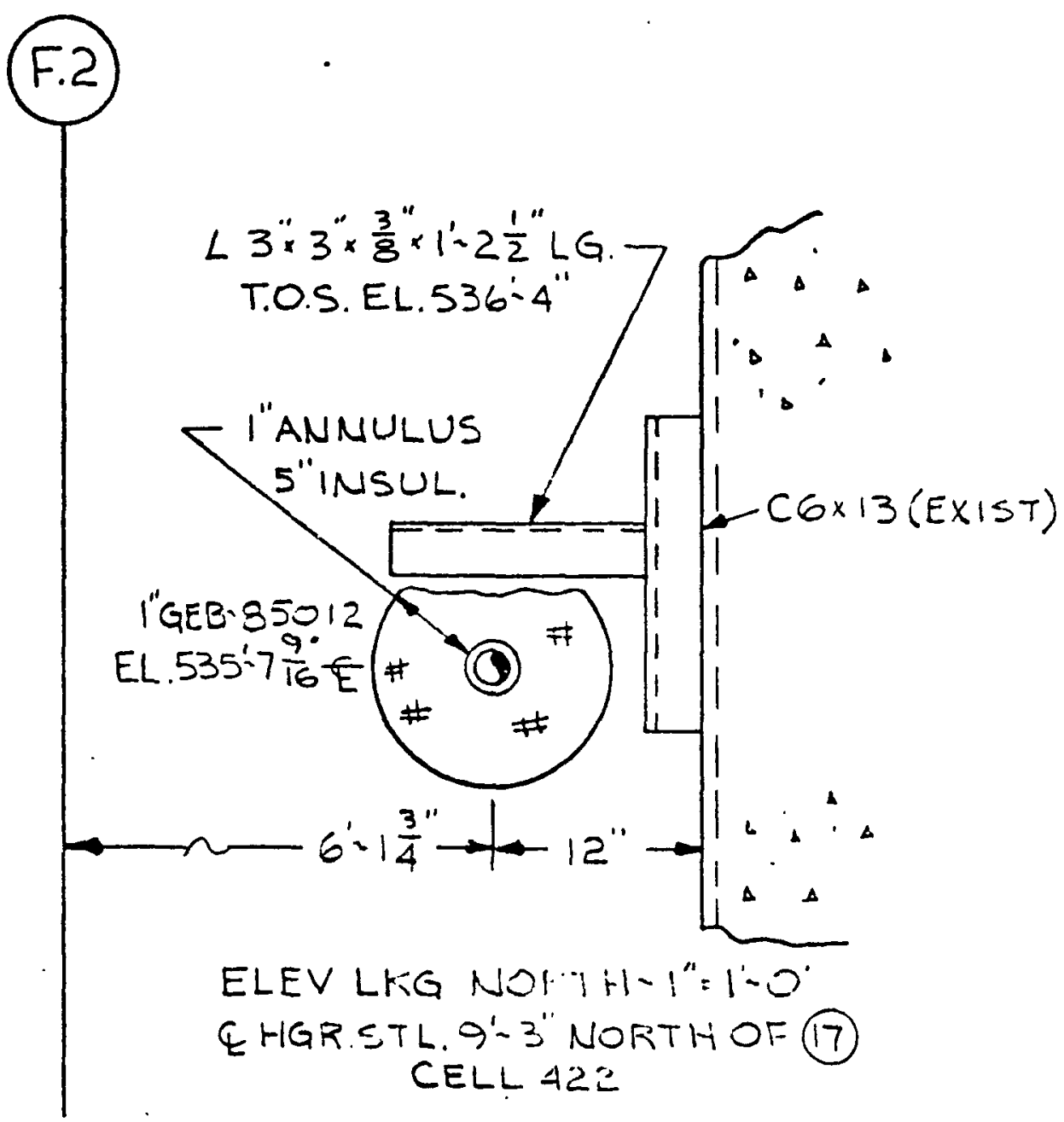


$10-4$

FRTF
$4-4 \cdot 77$

BAEEY VER I: :
$2 \cdot 162$

2

H-4-19017 HEVV.2-SHT.11 PPG FAB.1-

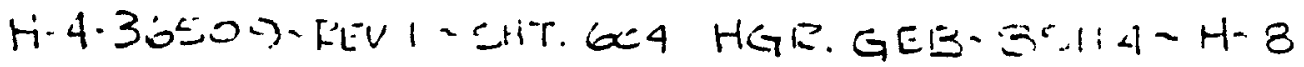

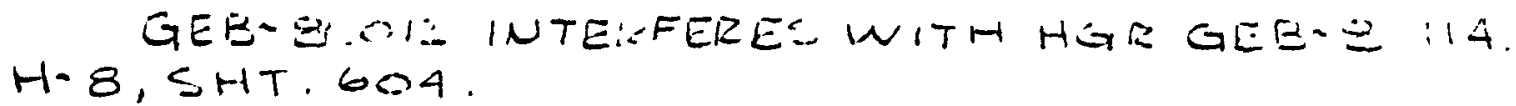

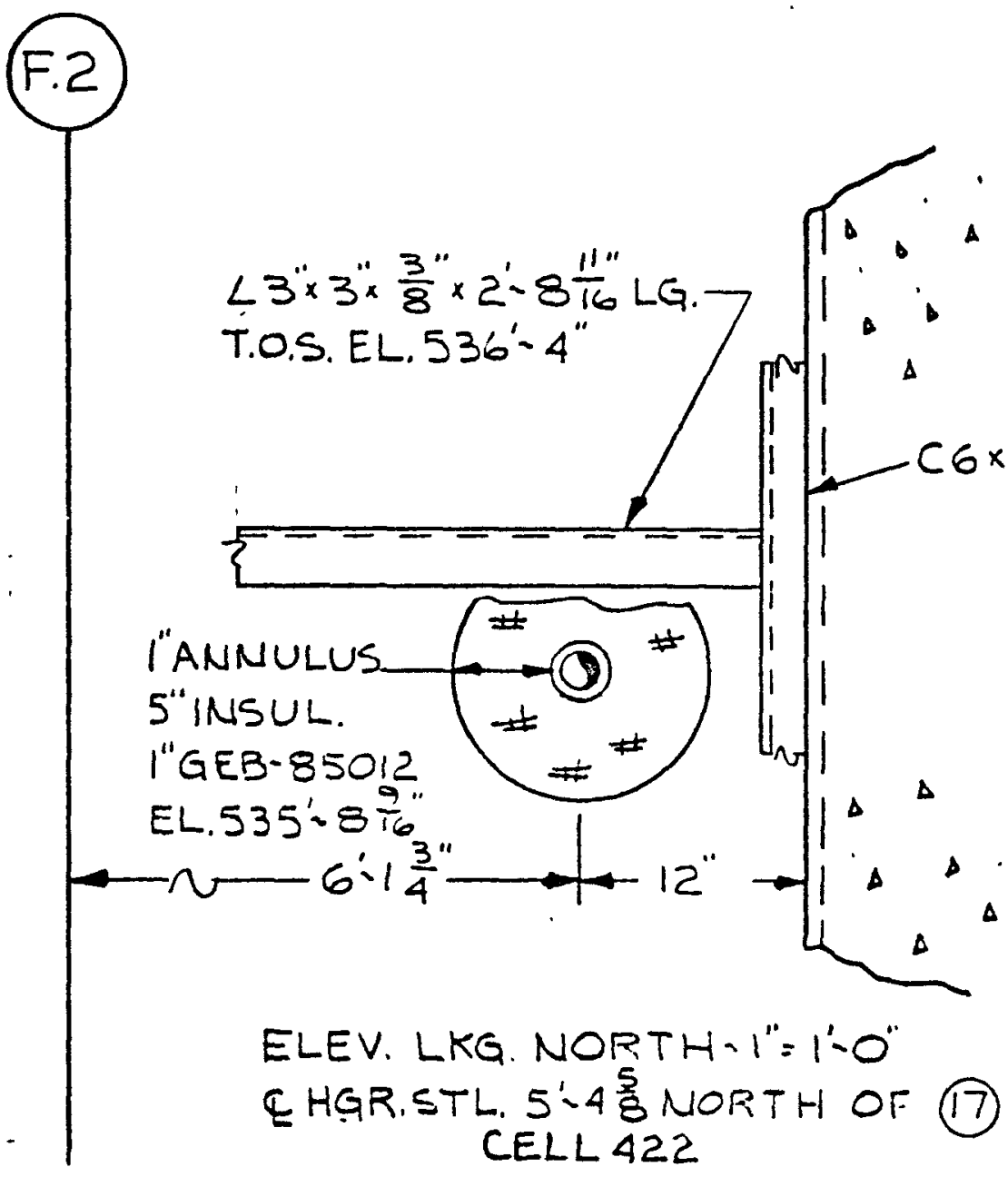


1024

FFTF.

$$
4-4-77
$$

BARRY V:E.' $\because:-\dot{1}$

2

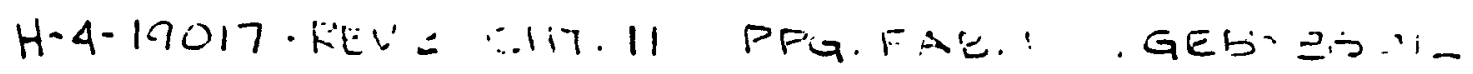

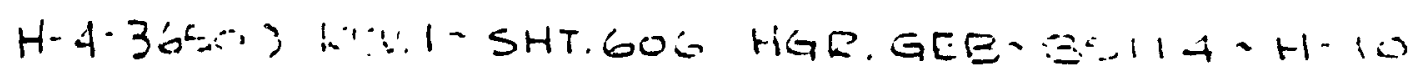

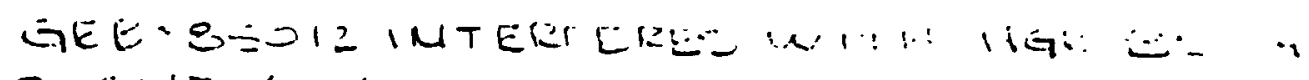

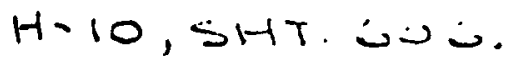

N

$\angle 3^{\prime \prime} \times 3^{\prime \prime} \times \frac{3}{8} \times 2 \dot{0}-5 \frac{13^{\prime \prime}}{16} \mathrm{LG}$. $12 \cdot 9$ T.O.S. EL. $536^{\prime}=3 \frac{5}{8} "$

$\angle 3^{\prime \prime} \times 3^{\prime \prime} \times \frac{3}{3} \times 7 \div 9 \frac{3}{4} " L G$ EL. $536^{\prime}-0 \frac{1}{8} . "$ TO EL. $543^{\prime}-9 \frac{7}{8}$
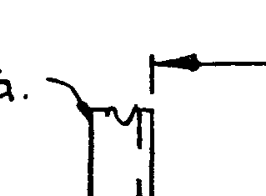

$\frac{5}{8}$ 
ひこー

FFTF
$4-5-77$

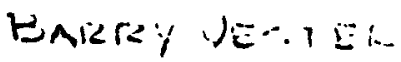

$=1 \%$

2

H-4-19Q1.7. REV.2-5HT. 11 PPG FAB. 1-0. GEB-85012

H-4-36509-REV.1 - SHT.923 HGR. GEB-35214-H-19

VALVE HV-9000B OF GEB-8EOIL INTEKIEKL-

WITH SNUBEER OF HGR.GEB- $8=214$-H $19,5 H T, 923$.

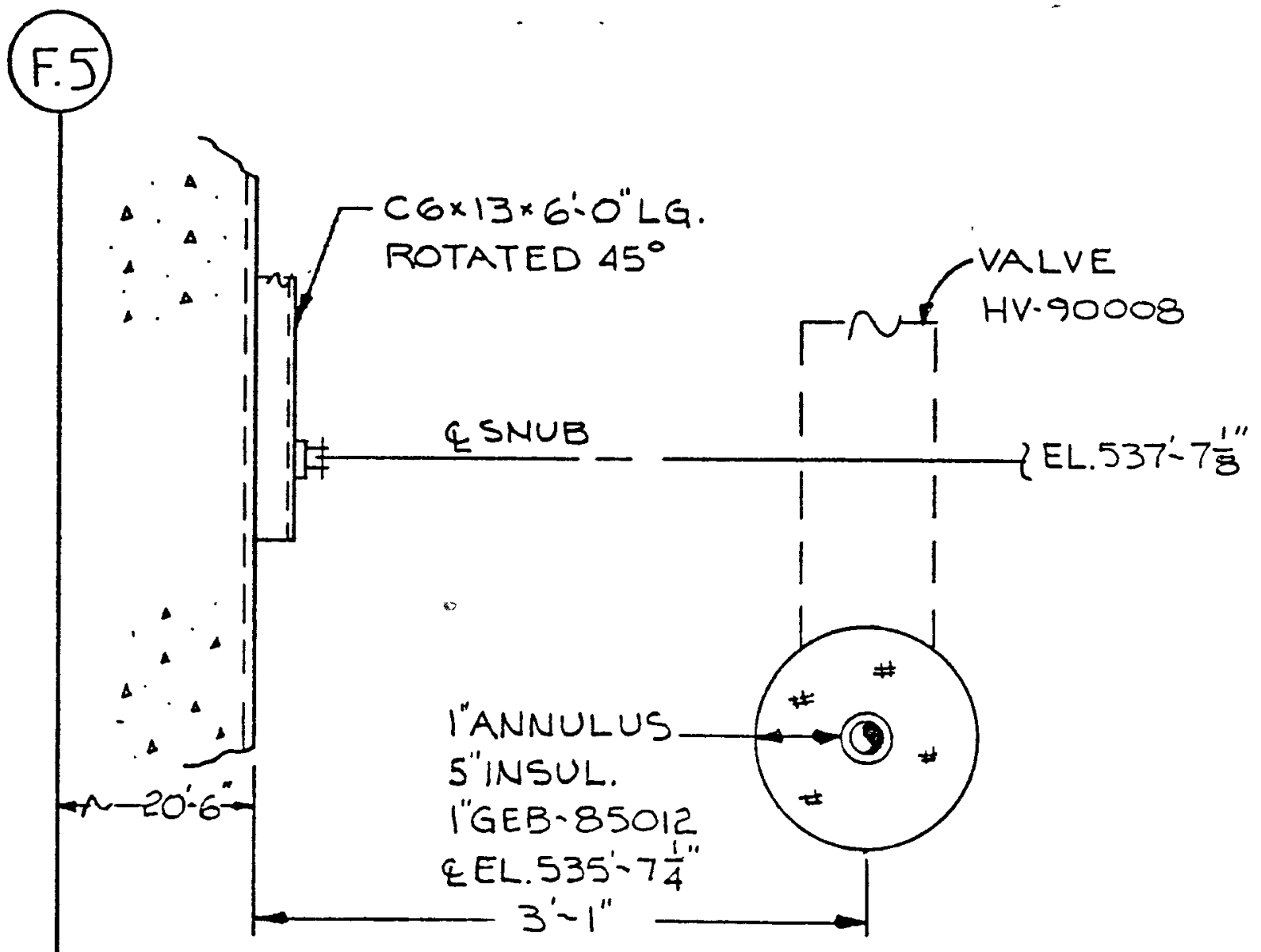

ELEV. LKG.NORTH=1" $=1-0^{\prime \prime}$ CELL 422 
$: 024$

$45-1 i$

$2 \cdot 155$

FFTF

BARRY VESTER

2

H-4-19017-REV.Z-SHT.II PPG FAB, $1 \leq 0$. SEE- 85012

$H-4 \cdot 3650$-REV.1 - SHT 923 HGR. GEB-35214 $=H-19$

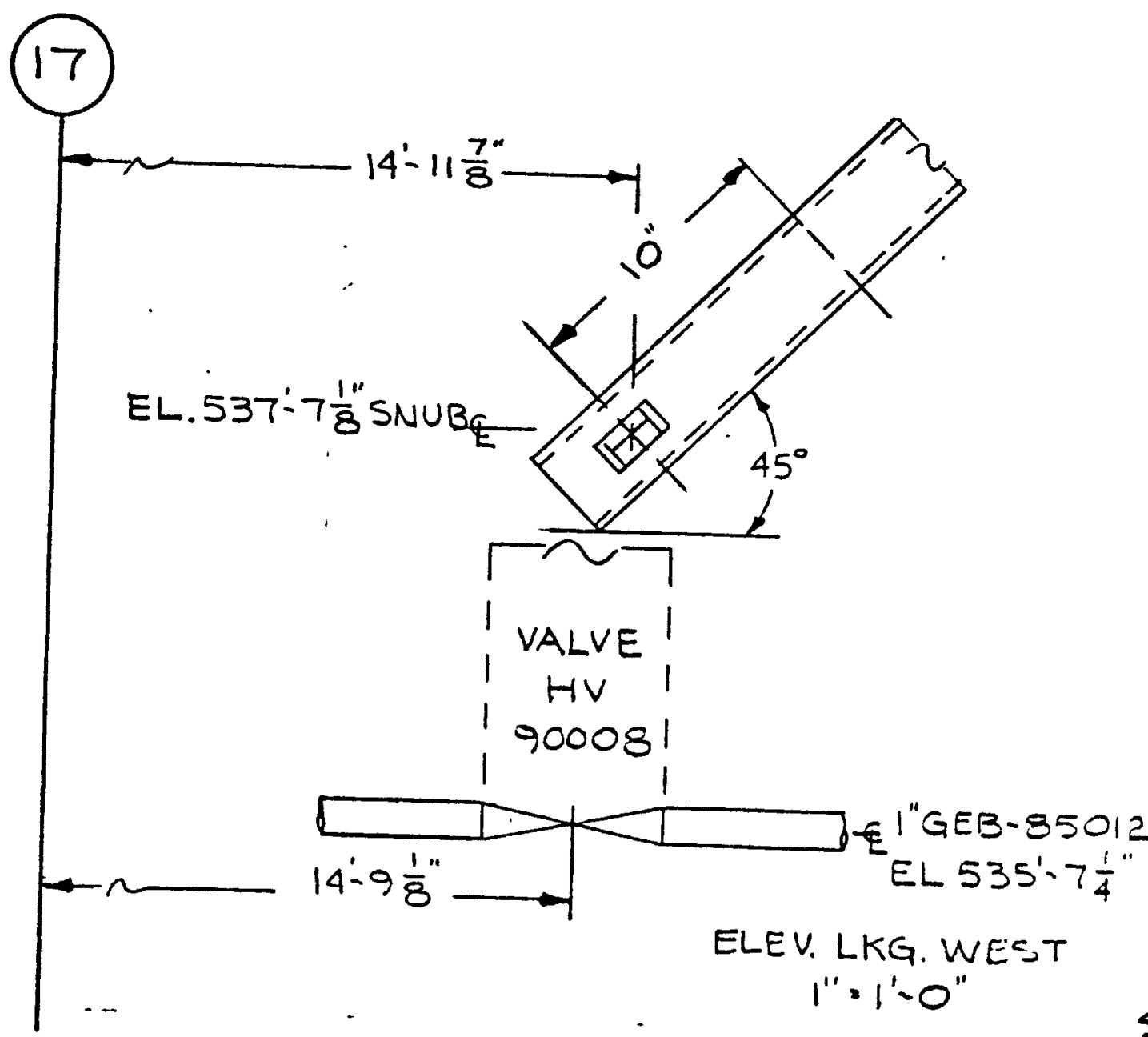

SHT $2 / 2$ 


$$
\begin{aligned}
& 1024 \\
& \text { FFTF } \\
& \therefore \text { APRIL } 17 \\
& \text { من } \\
& \text { ROSE DULL } \\
& 2
\end{aligned}
$$
5" INSULATION ON GEB-85III INTERfERES WITH tFapeze AND SNUBJ BELONGINA TO GEB-LII24 H-I A.S SHOWN

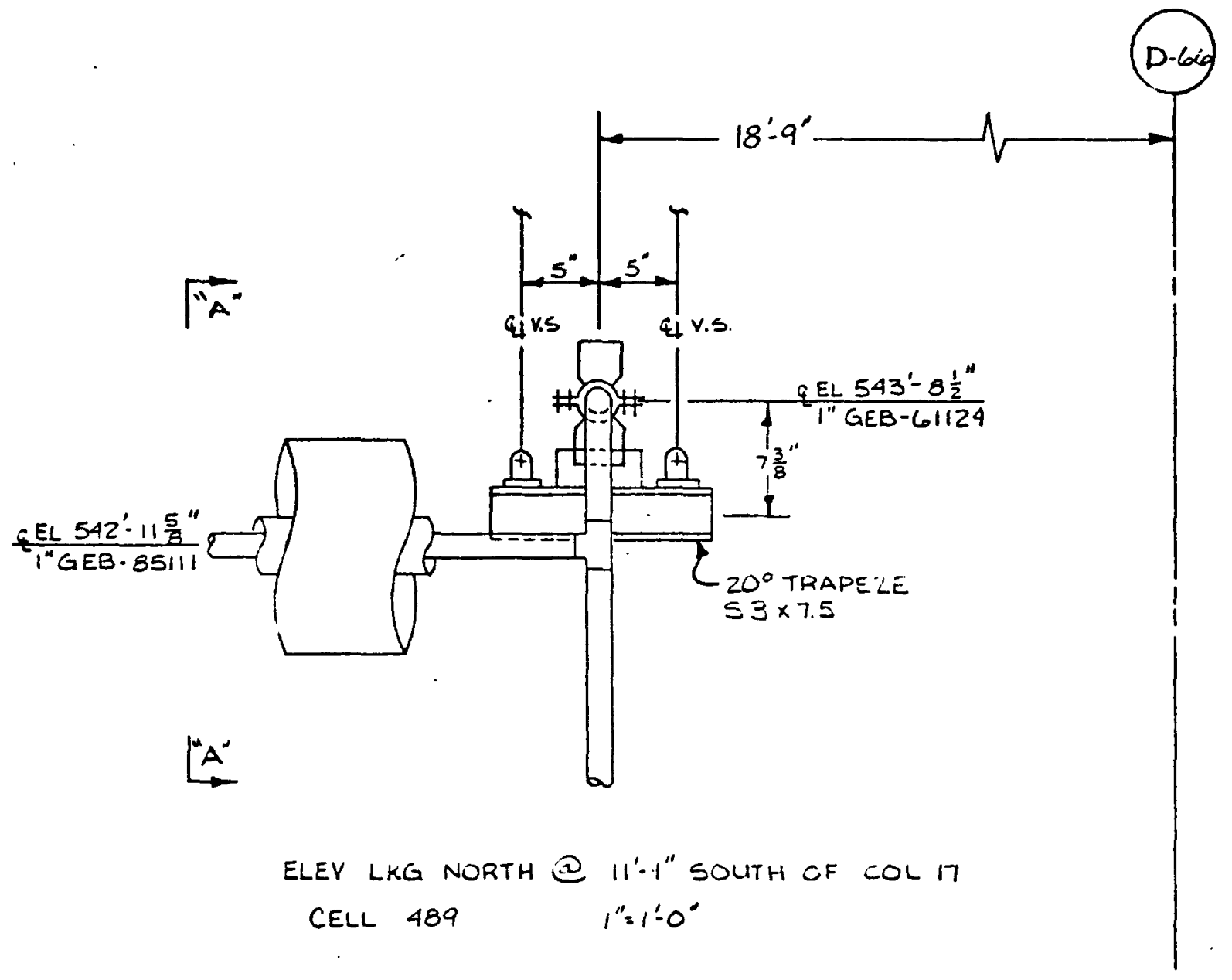




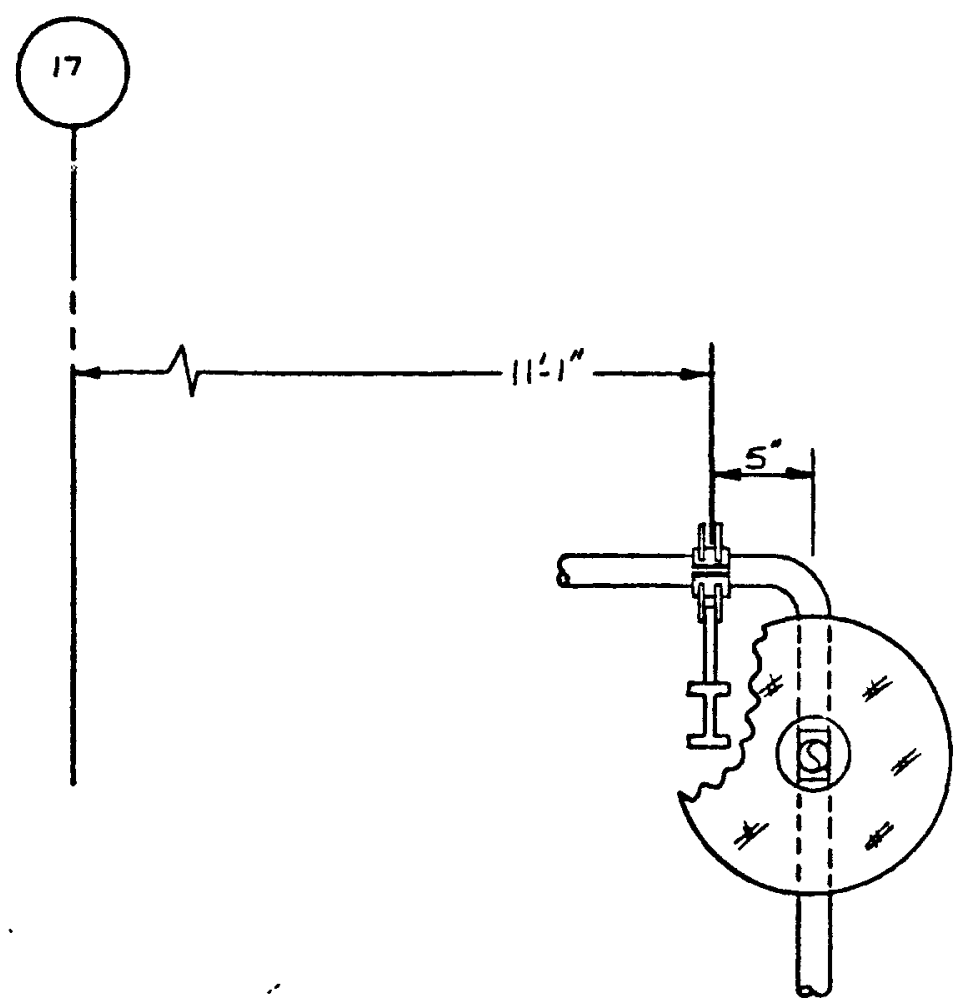

ELEV LKG EAST @ 18'-9" WEST OF COL D-66 SECTION 'A " "A"

CELL 489

$I^{\prime \prime}=1^{\prime}-0^{\prime \prime}$ 


$\begin{array}{lll}\text { 10:A } & 4 \text { ARRIL TI } & =1.7 \\ \text { FFTF } & \text { ROSE DOLL } & =\end{array}$

H-A-19017 REV 3 SH 45 PPG FAB I:D GEE-85111

H-4.36509 REV O SH 548 PIDE SUPPORT SEB- 85110 H.22

A POESIBLE INTERfERENICE MAY EXIST BETWEEN S' INELILATION ON I" GEB-85III \& ADJLISTABLE RIgID strLIT Belongins to sen-3iilo $\quad \therefore=2$

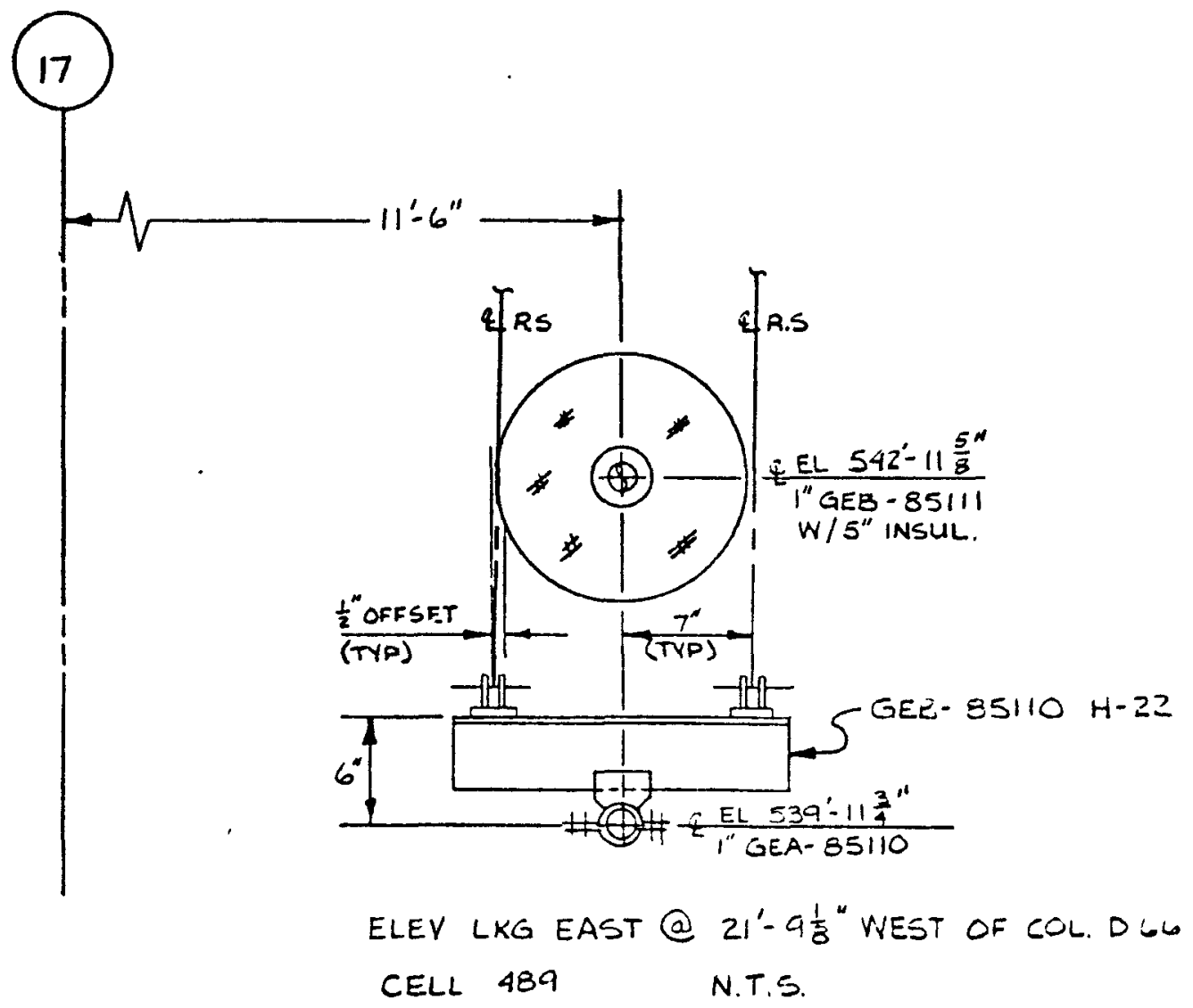


$102 \cdot 1$

FFTF
4 APRIL 77

ROSE DOLL
$=-160$

$=$

H.4.19017 REV 3 JH 45 PPA HO GEB-5Sill

H-4-3650I REV I EH 549 PIPE JUPPOHT GEB-S5111 H-1

5" INSILATION ON I"GEB-85111 INTERFERES WITH HQR GEB- ESIII H-I AS JHOWN

ELEY LKG NORTH

@ $11^{\prime}-6 "$ SOUTH OF COL 17 CELL 489

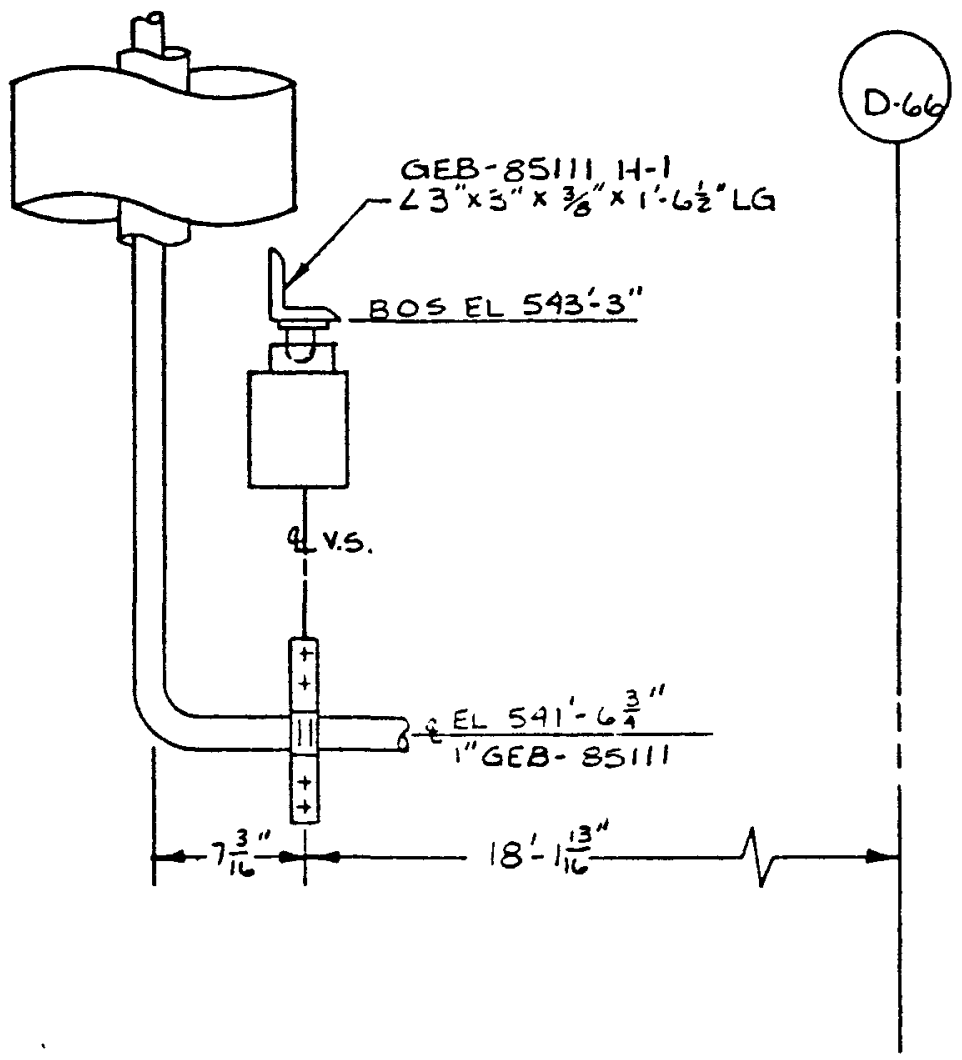


102

5 APRIL 77

$\Sigma \cdot 169$

EEIE

RQSE -DDLL

2

1.isere

H.4:-19017 REV 2 SH 46 PPG FAB 150 GEB- 85111 H-4I36509 REV O SH 548 , PIPE SUPPORT GEB-85IIO H-22 ‥" ADJUSTABLE RIGID STRUT BELONGING TO GEB-85IIO H-22 Ás SHOWvin

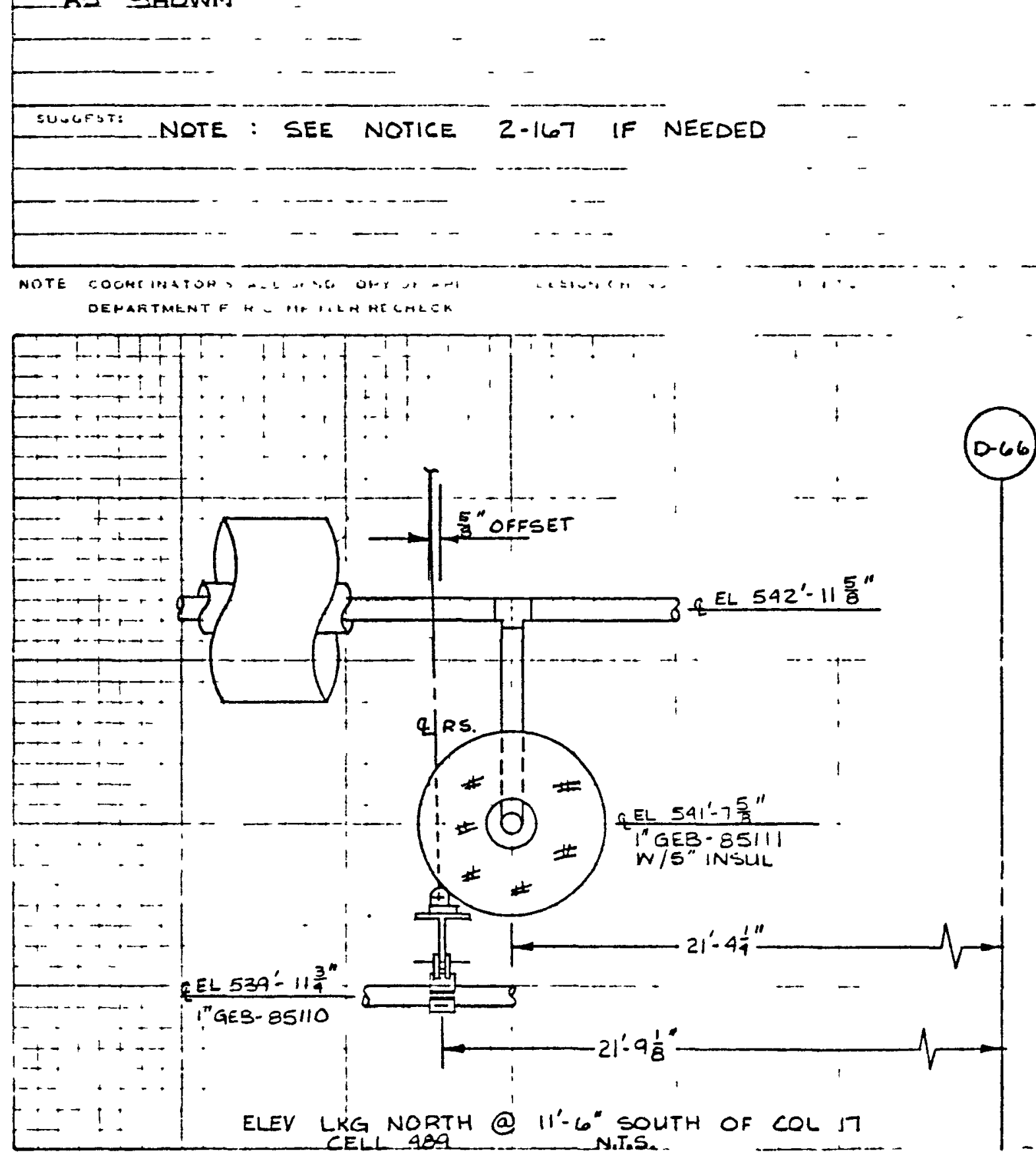


1024

Fr:TF
4 ヘルールフ7

a. Tu=2ง+1.,1
Fun, FAB $1=0$ GEE-

HGR CEt ESTII-H-33

INSULATION ON I"GEB-ESIIZ INTFKMMKY: WITH HANGER GEB S5III-11-33 CLAMP $\Delta s$ GHeWN.
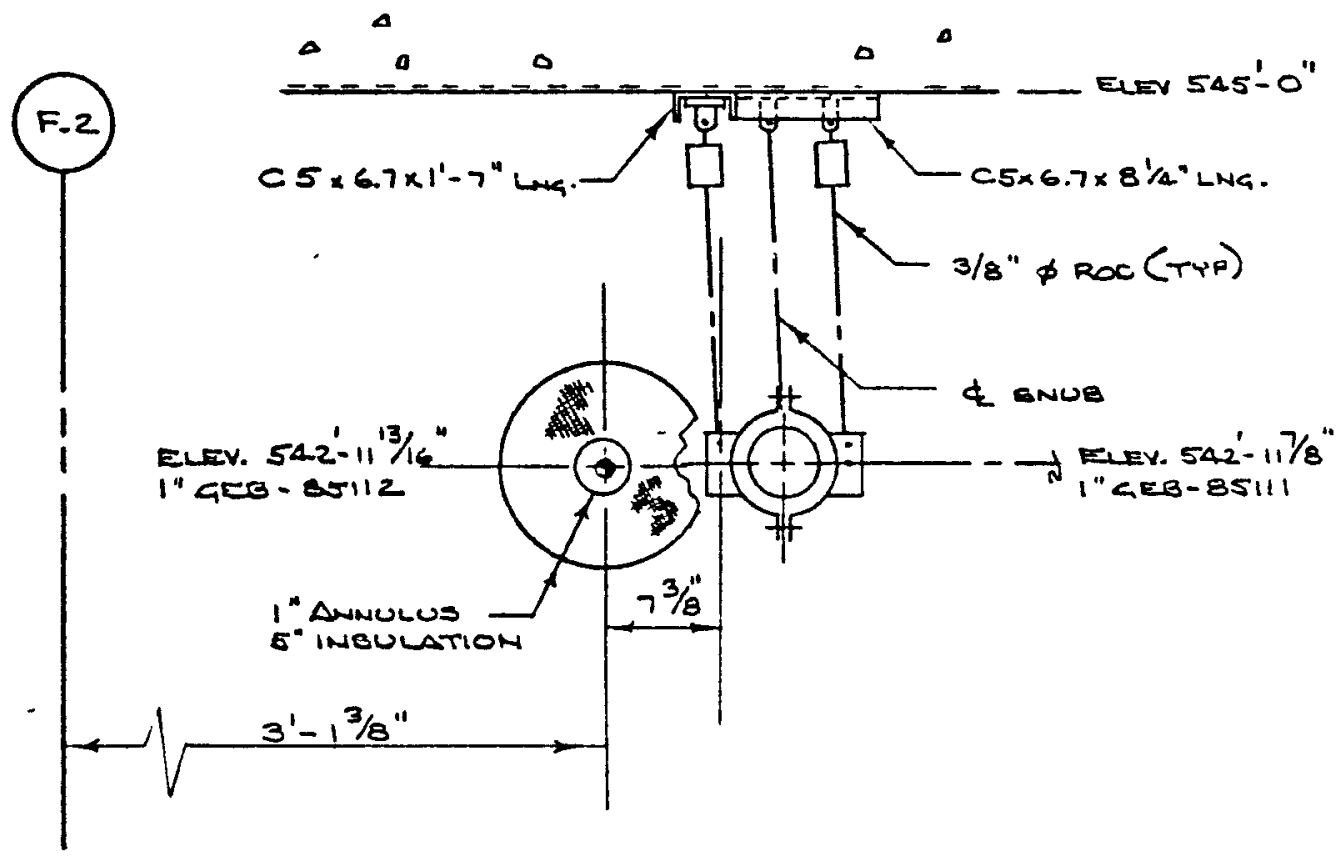

ELEV. LKK. NORTH O 10'-11" SOUTH 17

N.T.S.

CELL 489 


$$
\begin{aligned}
& 1.7 \div 1 \\
& \therefore \text { s: . . . } \\
& \text { Fトフト } \\
& r . r_{i}=\cdots+, \cdot 1
\end{aligned}
$$

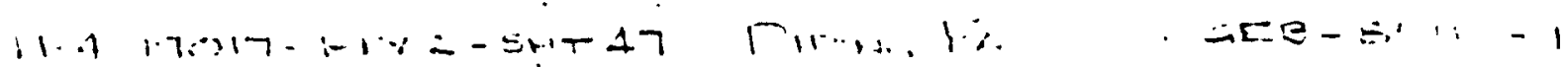

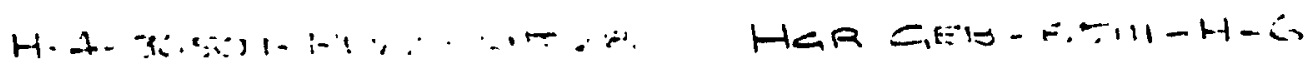

INSUUATON ON I"CEB - BEII2-1 WWTBKITHLO

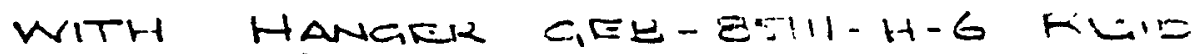
=rrast $\Lambda=$ Gr:m.:N.
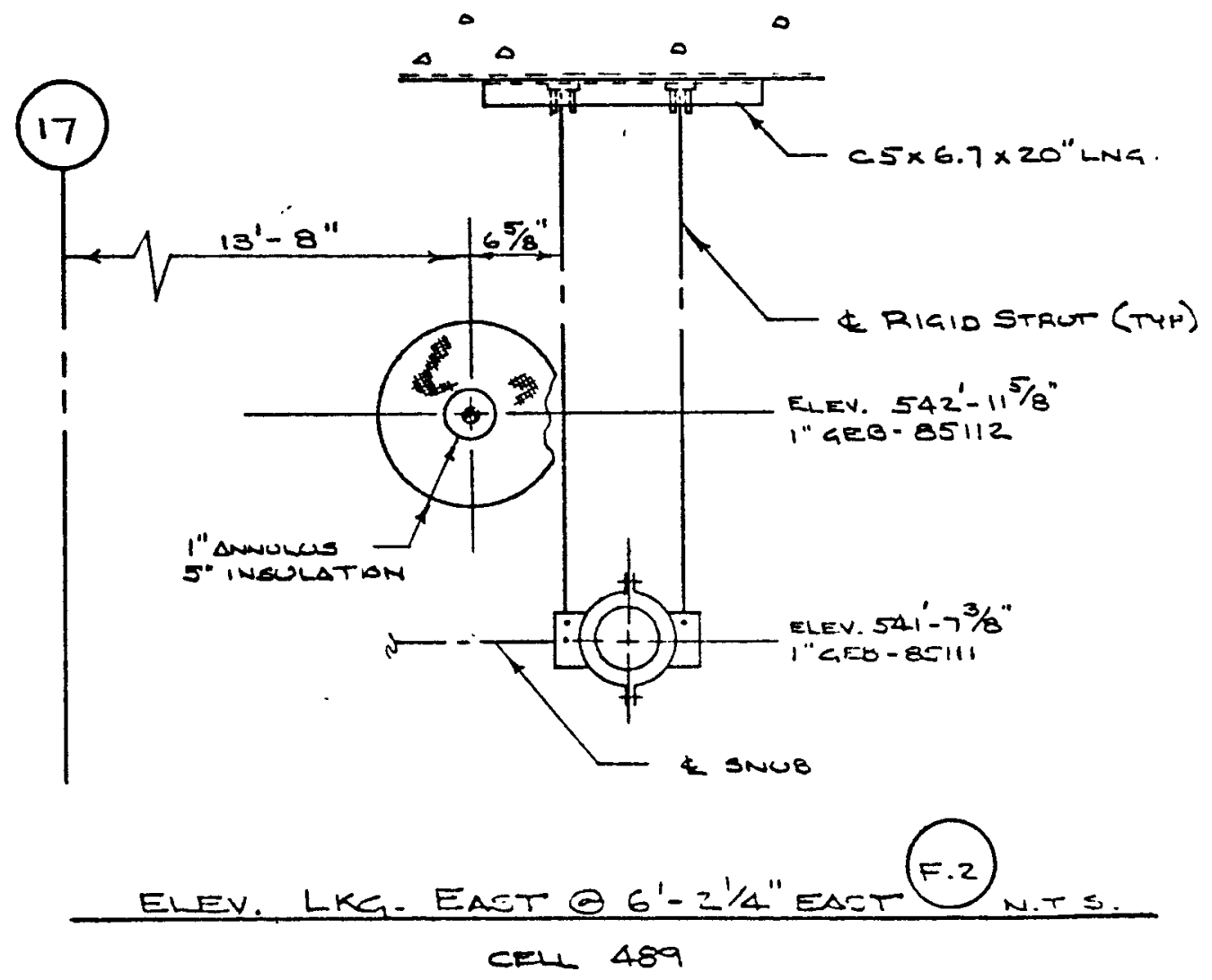

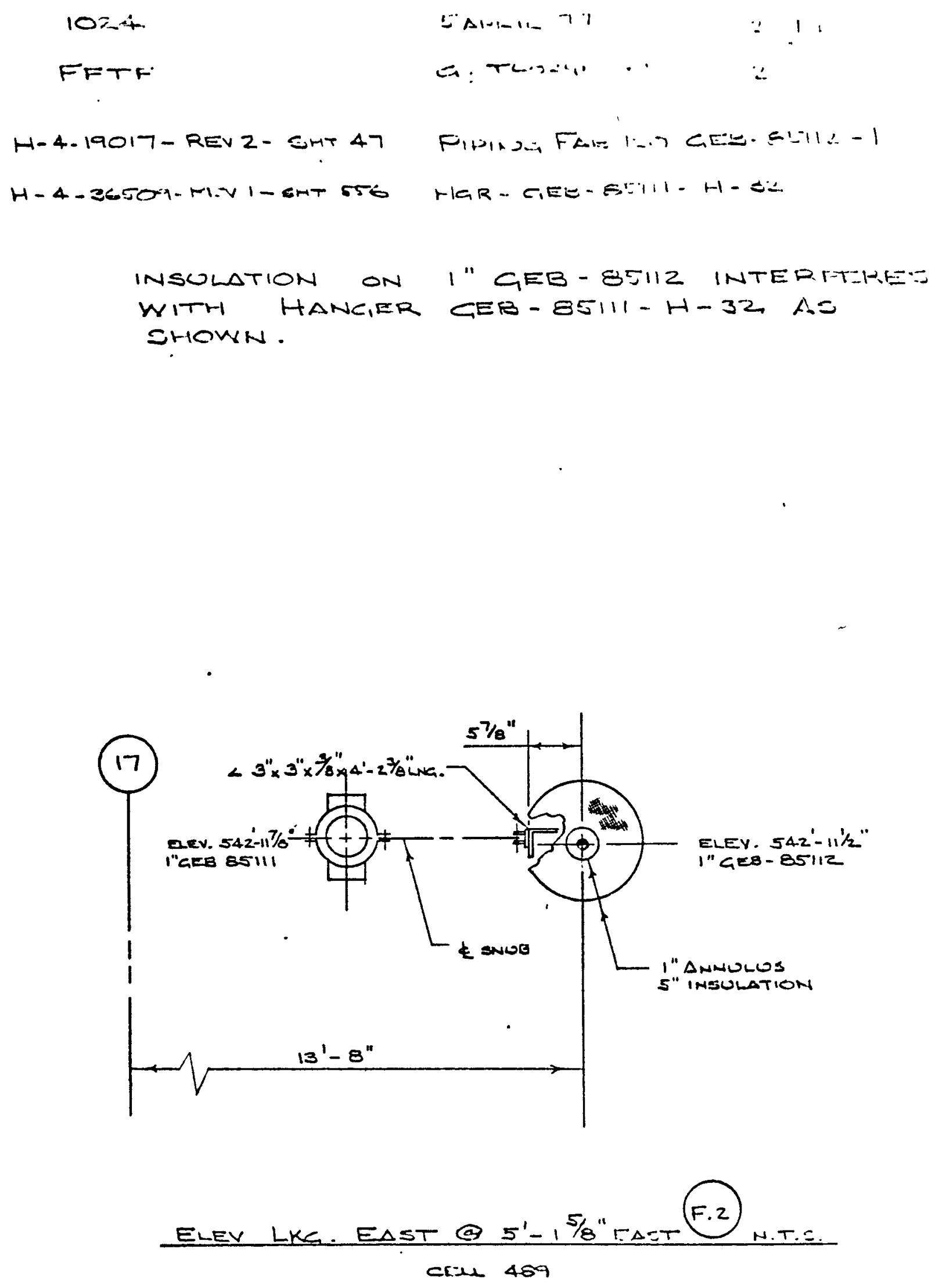
1021

FFTF .
$\underline{E} \rightarrow \cdots+\cdots+-\rightarrow$

C.. TUS $+\cdots+1$
$2-173$

2

H-4-19017-FEV $2-5+1 T:-7$

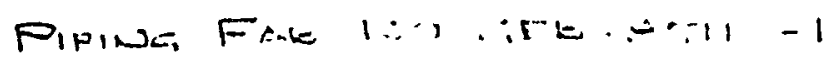

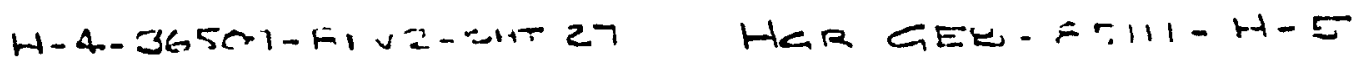

INSULATION ON 1 "CEB - BSIL INTERFI-KE:

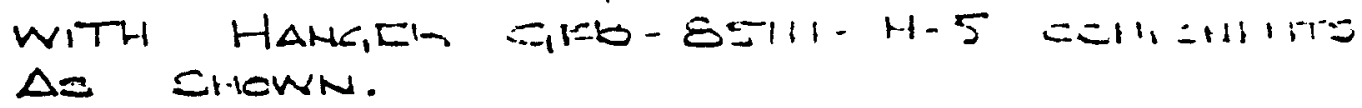

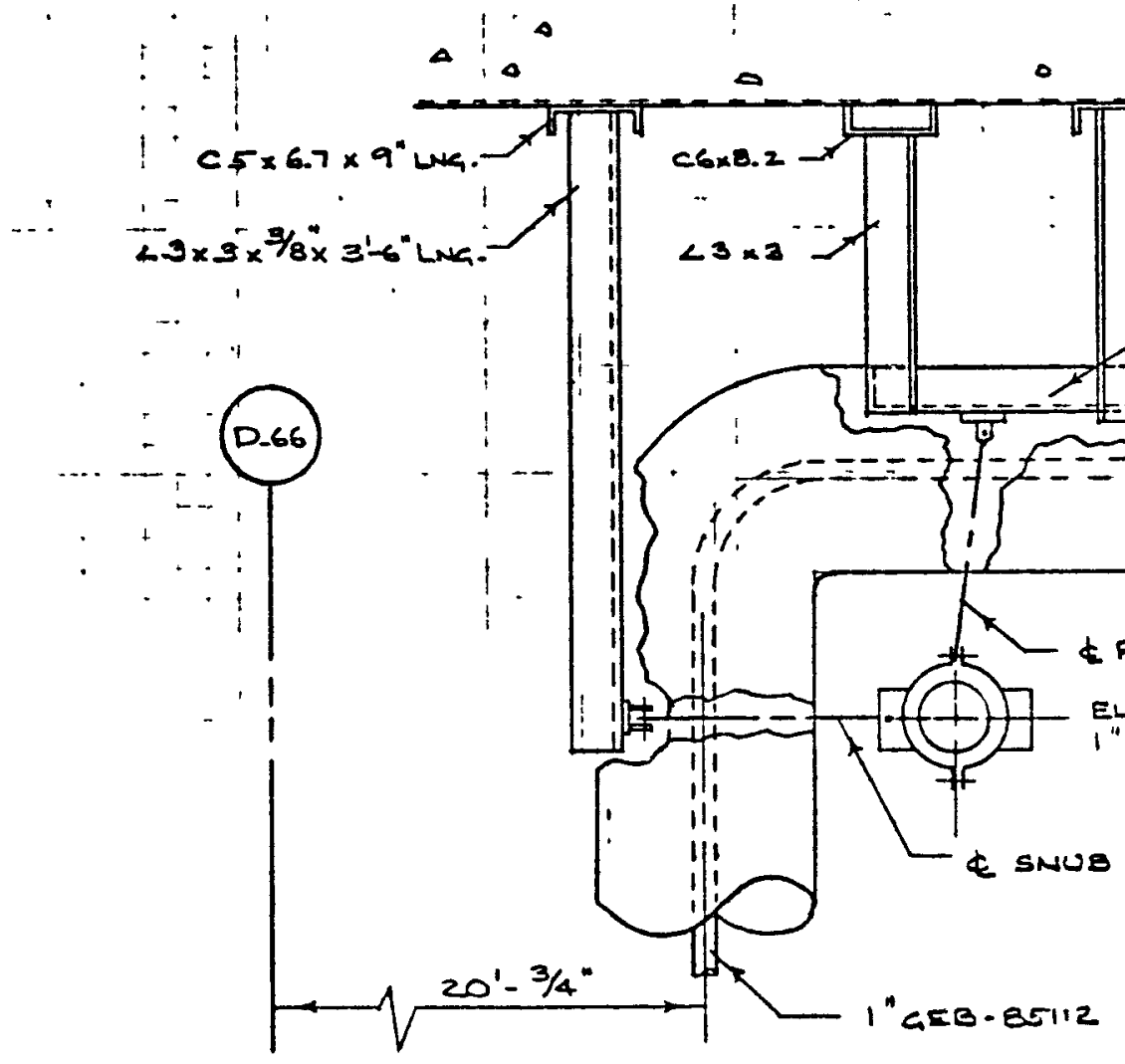

II ELEV. 545'-0. c $5 \times 6.7$

$23 \times 3 \times 1 / 4 \times 1-79 / 16^{\prime \prime} \operatorname{Ln}$.

$\angle 3 \times 3 \times 1 / 4 " \times 20^{\prime \prime}$ LNG. 
1024

FFTE $\because \Delta r-1-7\urcorner$

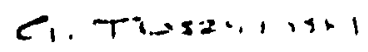

$\because .1 \div=$

ب.
$H-4.19017-1214 \cdot \therefore+7$

$11-4-\sin : 5 \cdot k 153-5117$

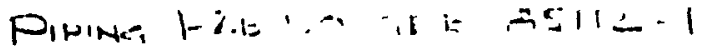

HGR CEE $=\because U R \cdot H-22$

INSUUATION ON 1 "CEB-BEII WWTEMFTHEL WITI HANGER GES-EFI.O-11.23 $\Delta=$ Sha:?:-

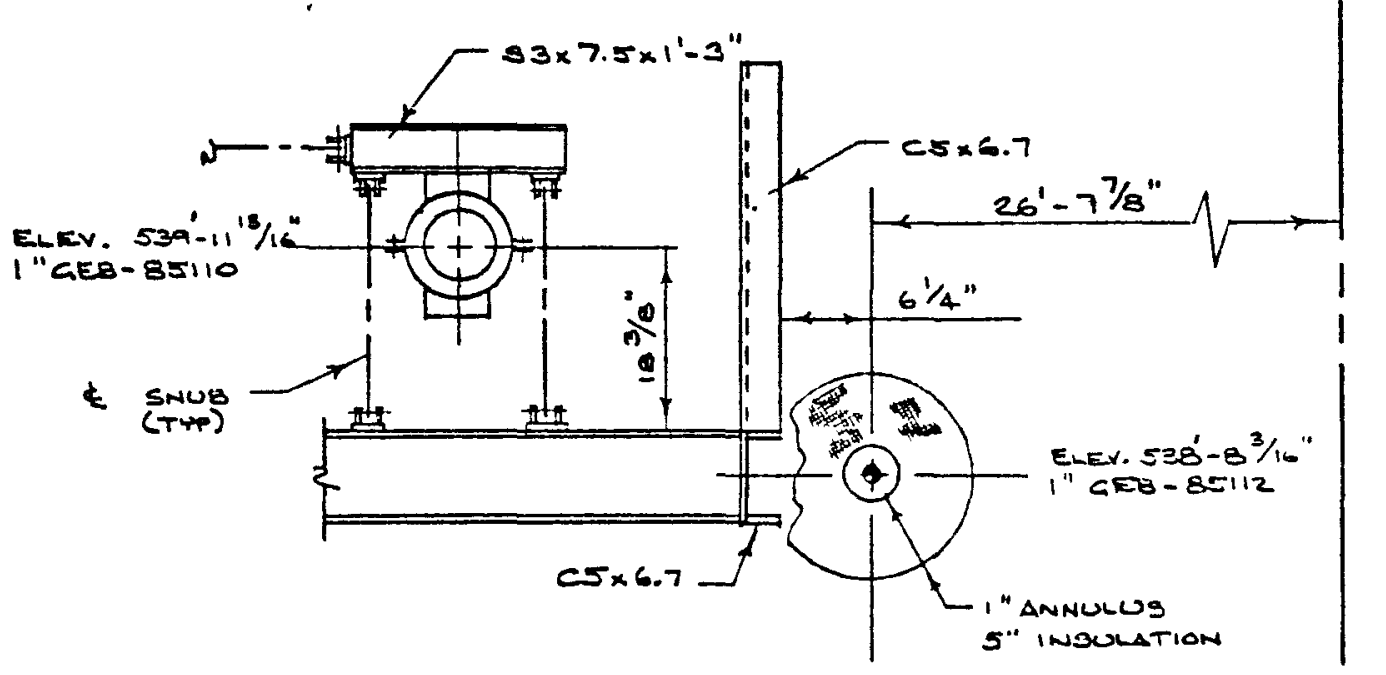

$\frac{\text { ELEV. LKG. EAST Q } 18^{\prime}-9^{\prime \prime} \text { WEST D.66 N.T.S. }}{\text { CELI } 489}$ 


$$
\begin{array}{llr}
i 02 i & 4-5-77 & 2-175 \\
\text { FFTF } & S H O & 2 \\
H-4-19017-4 \text { SHT } 48 & \text { GEB }-85112-2-1 \\
H-4-36506-1 \text { SHT } 687 & \text { GEB - 61325-H-7 }
\end{array}
$$

AS SHOUN

GEB - GI325-H-7 INTERFERES LUITH QEE-8EII:-2-1

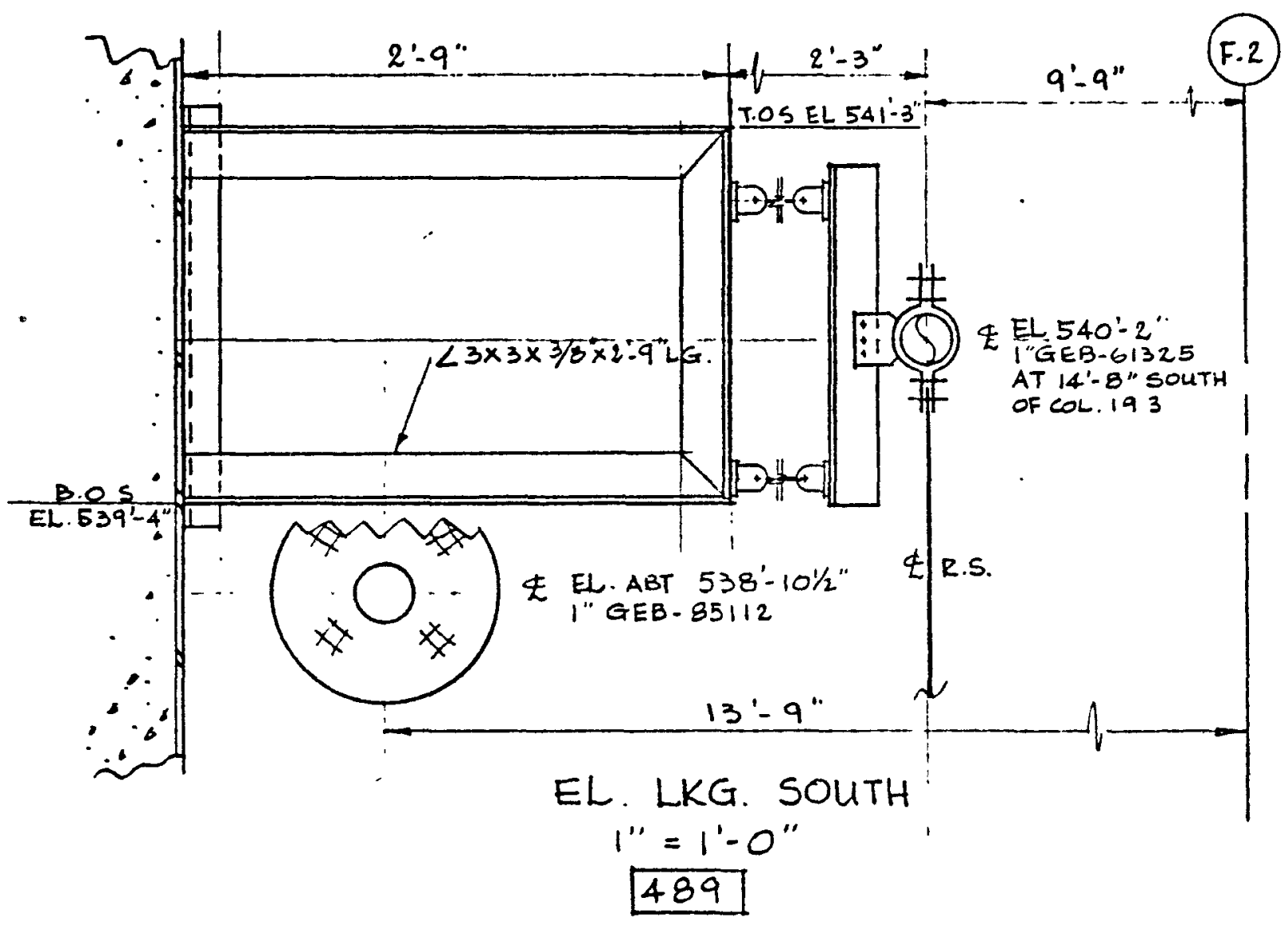




$$
\begin{aligned}
& 1024 \\
& \text { FFTF } \\
& H-4-19017-4 \text { SHT } 48 \\
& H-4-36509-1 \text { SHT } 351
\end{aligned}
$$

4. $4-77$

$S$ HO $\bar{x}-176$

2

GCB - 85011-H-21 INTERFERES WITH GEH$85112-2-1$ AS SHOWN.

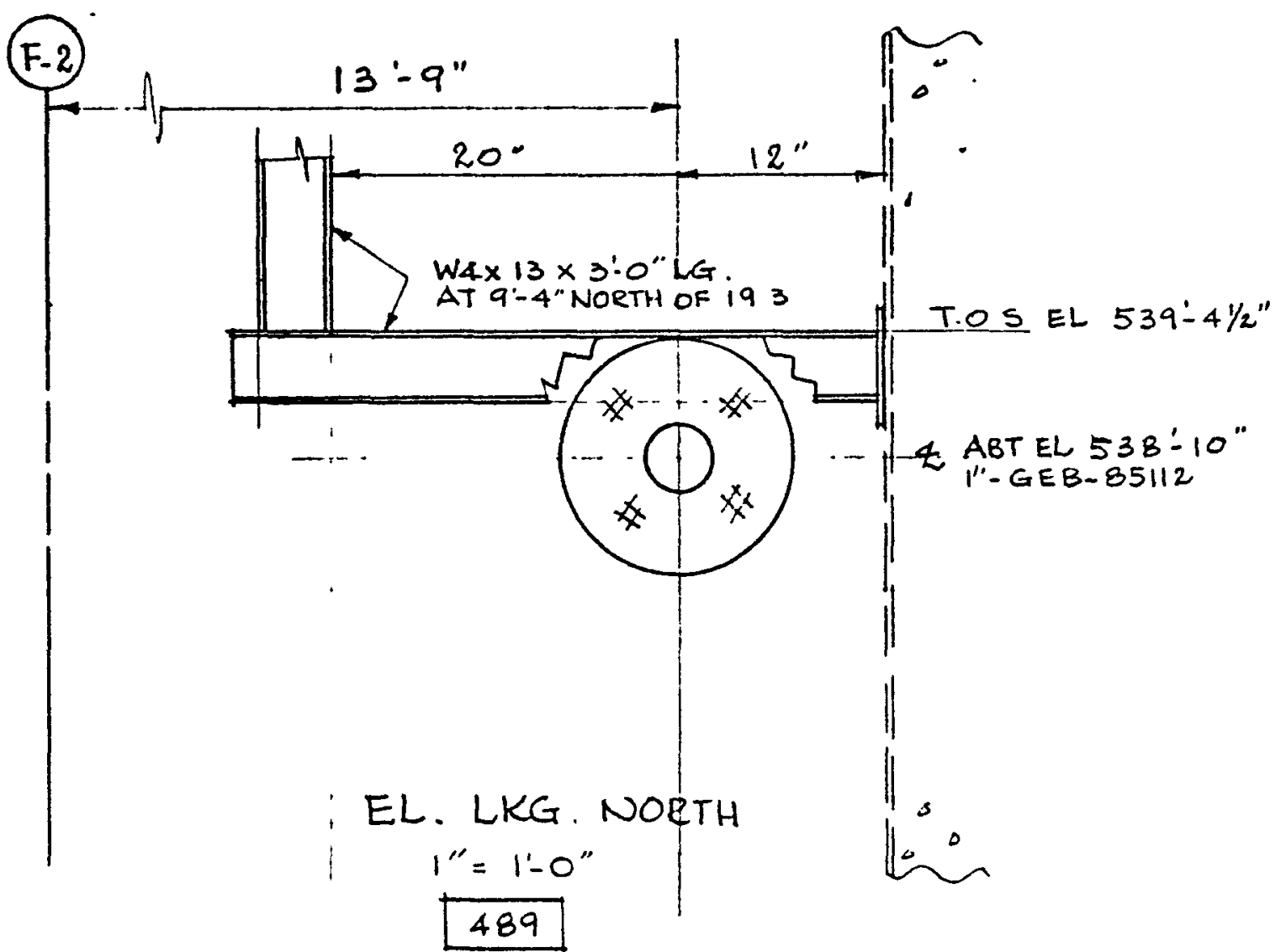


1024

FFTF

$H-4-19017-4$ SHT 48

H-4-36509.2 SHT 400
$4-5-77$

540

GEB - $85112-2-1$

GCB $-85012 \mathrm{H}-9$ $\therefore \quad:: 7$

2

GCB - 85012 H.9 INTERFERES WITH GEB-85112-2-1 AS SHOLUN.

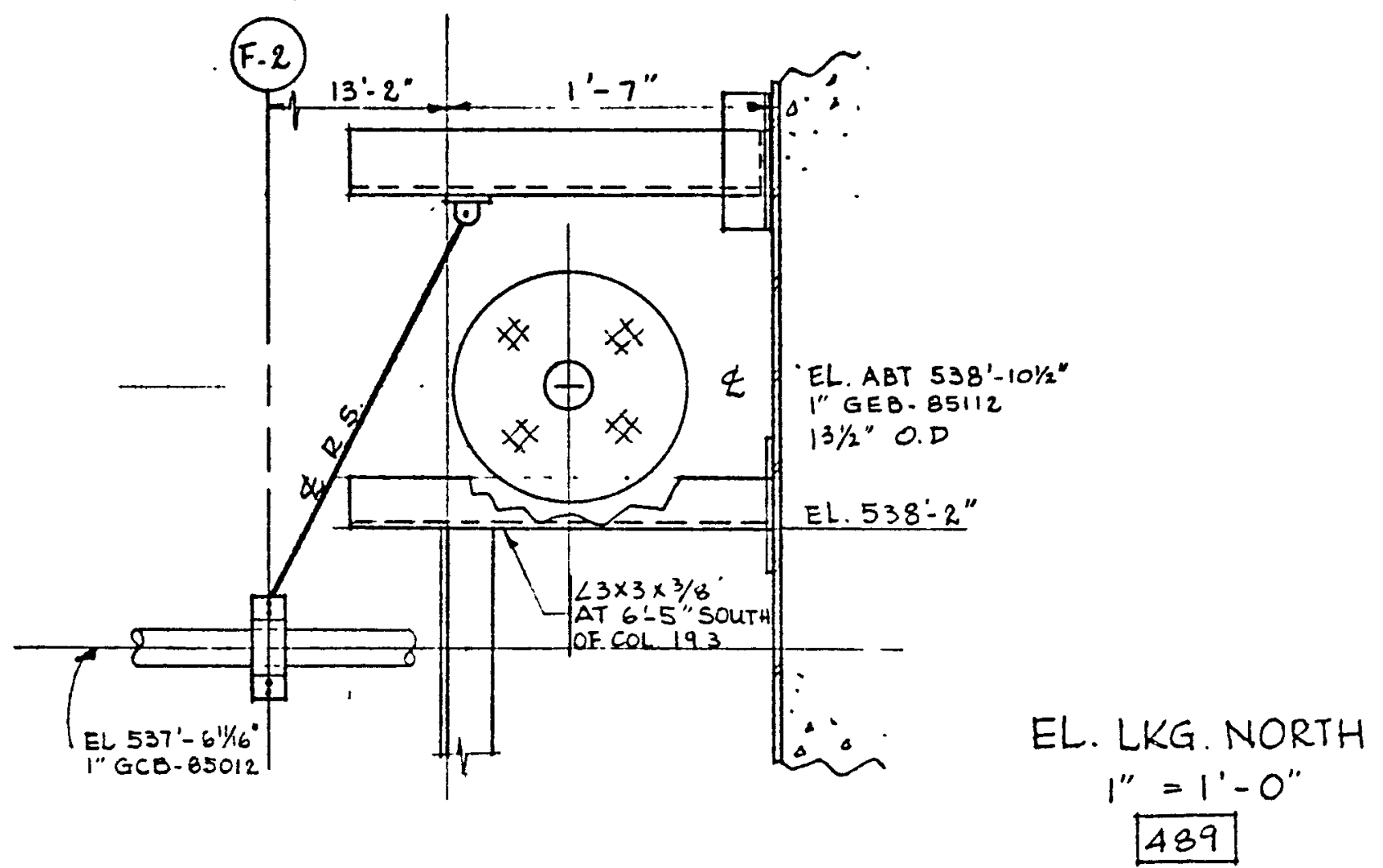




$$
\begin{aligned}
& 1024 \\
& \text { FFTF } \\
& \text { H. } 4-19017-4 \text {.SHT. } 48 \\
& 4-4-77 \\
& s+10
\end{aligned}
$$

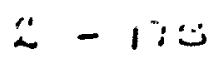

$$
\begin{aligned}
& 2 \\
& H-4-36506-1 \text { SHT } 476 \text { GEB }-61425 H \cdot 7 \\
& \begin{array}{l}
\text { 2-1 AS SHOWN. } \\
\text { GEB- } 1425 \mathrm{H}-7 \text { INTERFERES WITH GEB-85112. }
\end{array}
\end{aligned}
$$

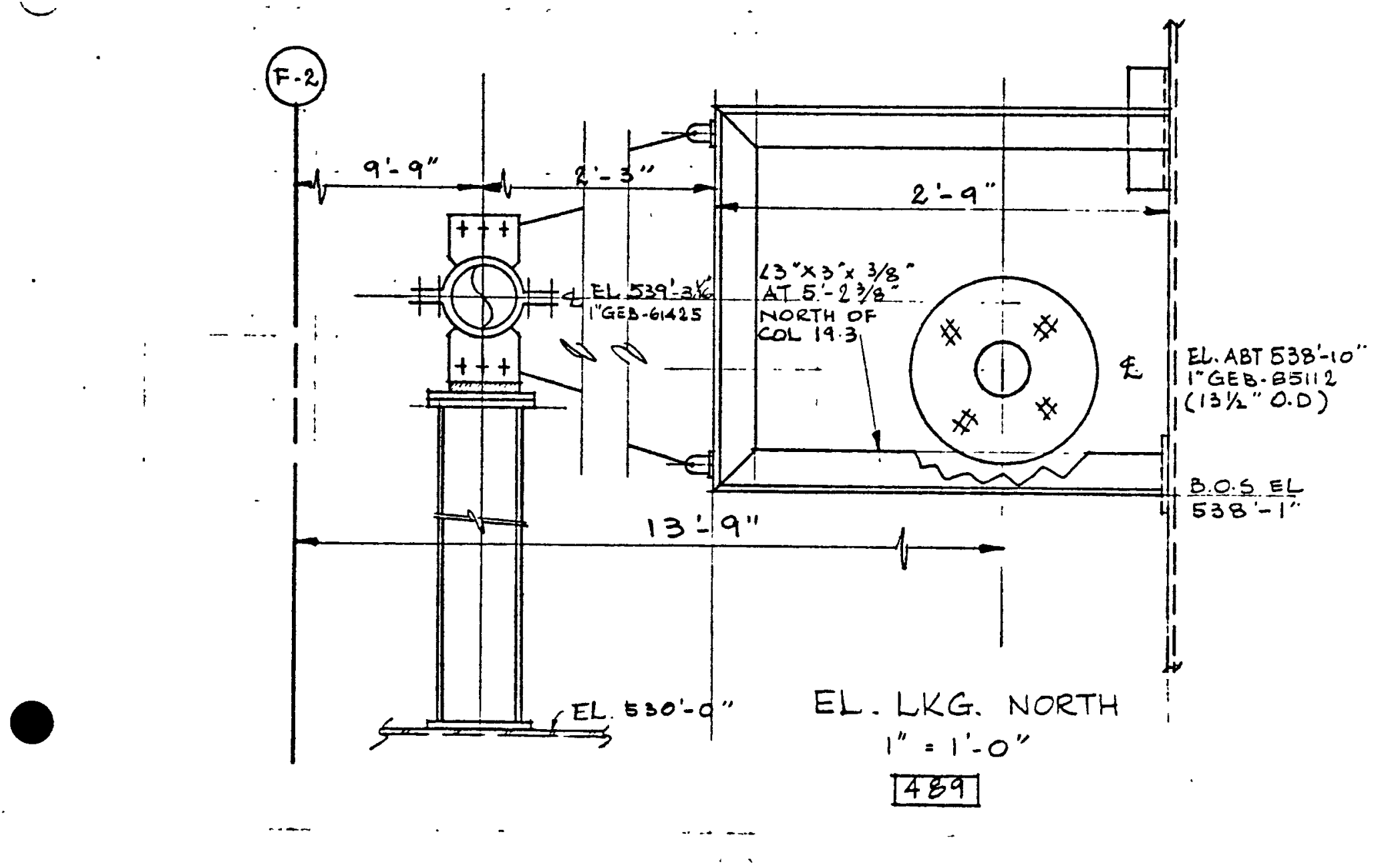




$$
\begin{array}{lcc}
1024 & 4.4-7 ? & 2-179 \\
\text { FFTF } & \text { S.HO } & 2 \\
H-4-19017-4 \text { SHT. } 48 & \text { GEB }-85112-2-1 \\
H-4-36506-15 H T .474 & \text { GEB }-61425-H-5
\end{array}
$$

GEB - 61425-4-5 INTERFERES LUITH GEB-85112-2-1 AS SHOWN.

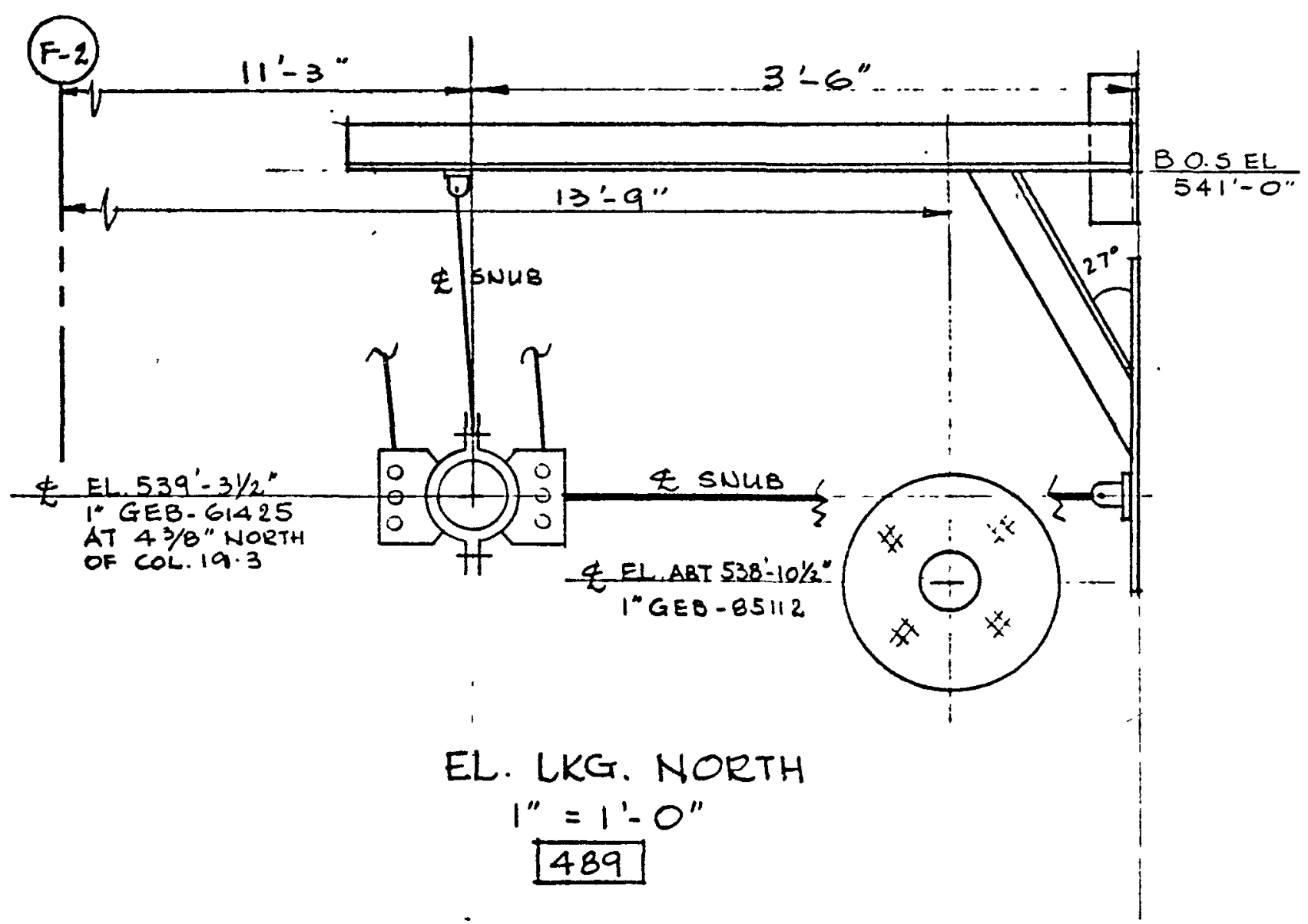


1024

FFTF

H-4-19017-4 S.TT 48

H.4. $36509-1$ SHT 355
ช. $4-7$

$S$ HO $k-150$

2

GEB - 85112-2-1

GCB - 85011- H25

GCB-85011-H25 INTERFERES WITH GEE$85112-2-1$ AS SHOWN.

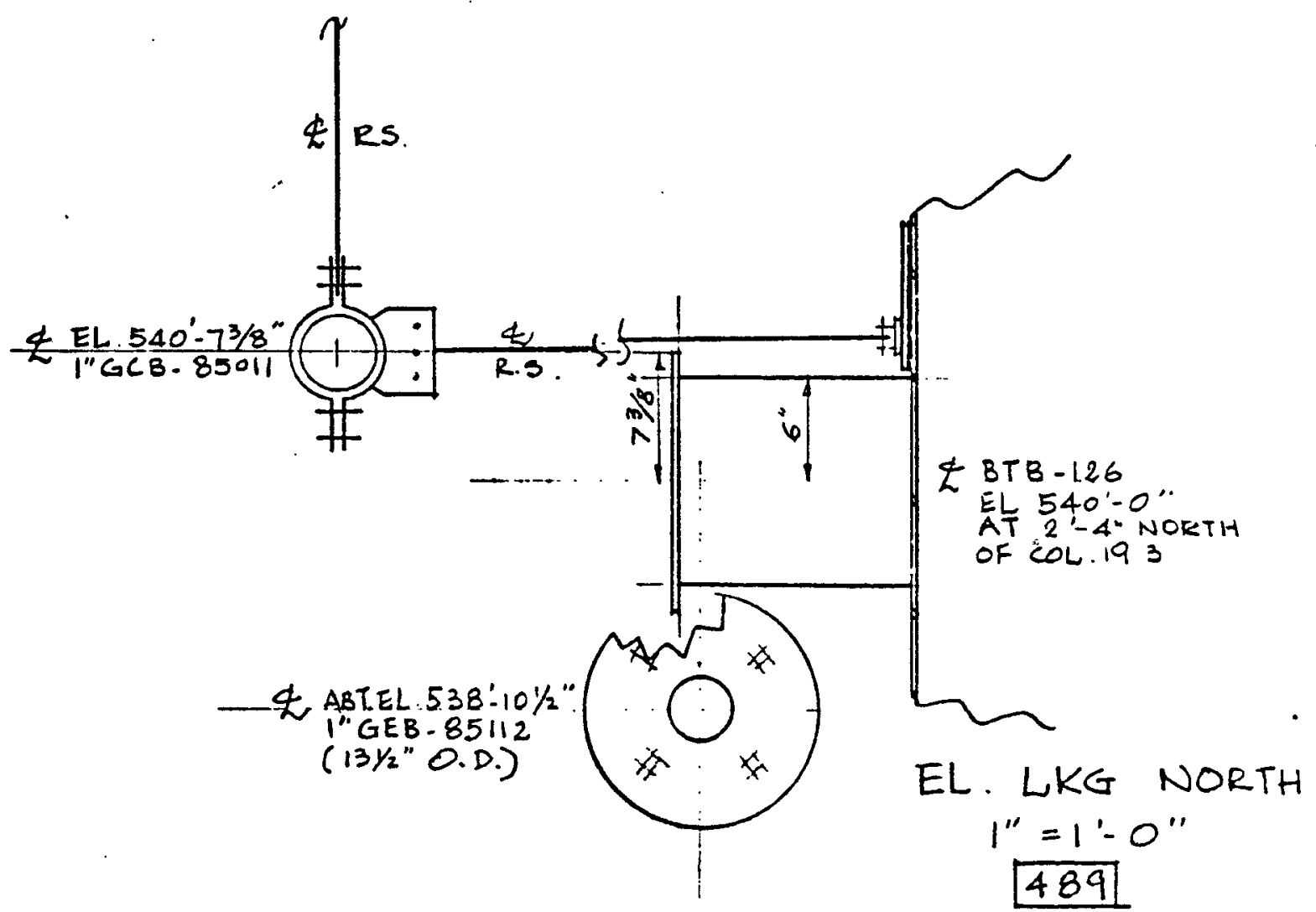


1024

FFTF

$H-4-1907-4$ SHT 48

H-4 $-36999-0$ SHT 1292
$4-5-11$

$5 \mathrm{HO}$

$G E B-85112-2-1$

$\mathrm{HCB}-82636-\mathrm{H}-2$
$2-!: 1$

2

HCB-82636-H-2 INTERFERES WITH GEB-55112-2-1 AS SHOWN.

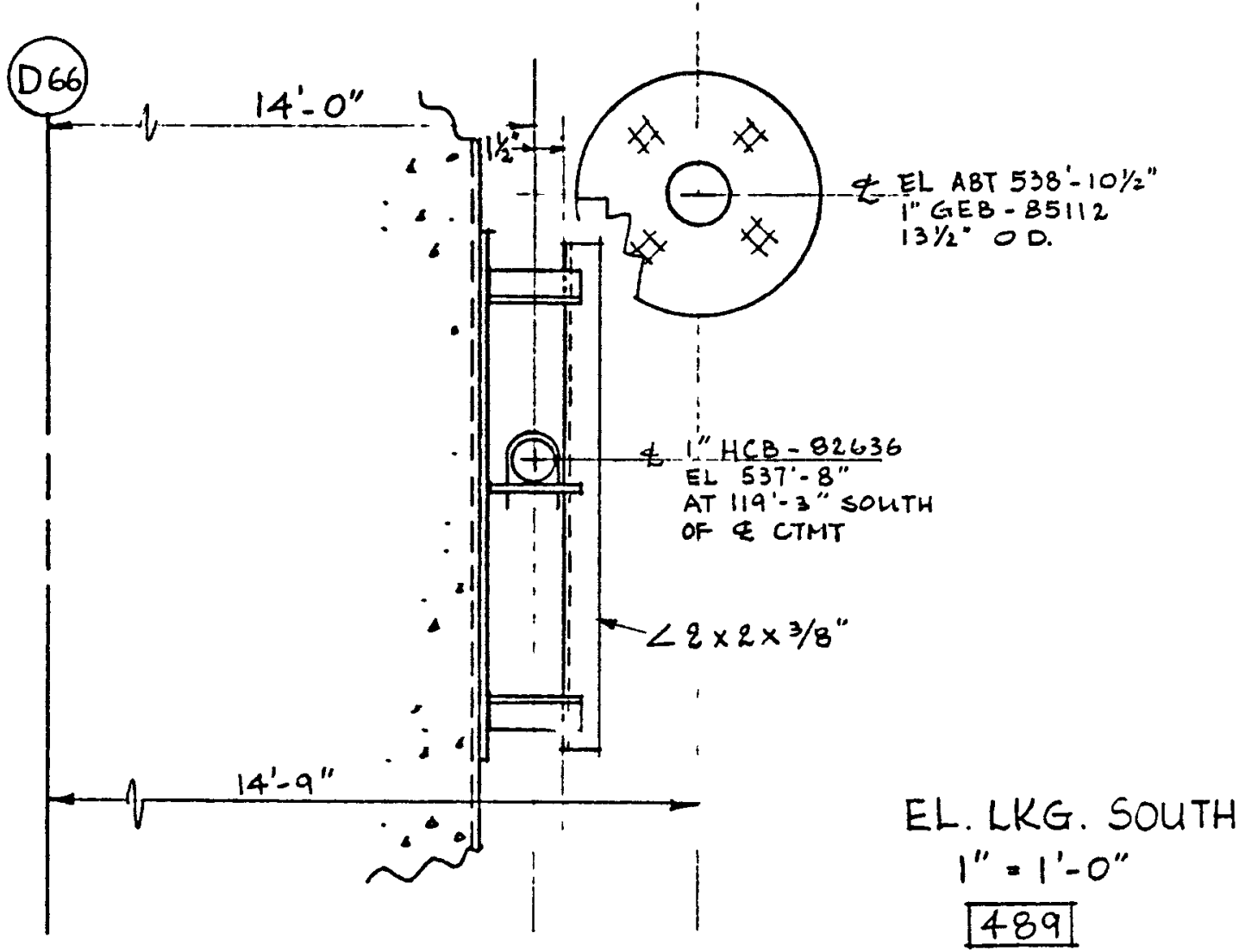




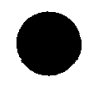

$: 024$

FFTF

H. $4-19017-4$ SHT. $4 B$

H.4-36509-1 SHT 597

$$
\begin{gathered}
4-5-77 \\
540
\end{gathered}
$$

GEB - $85112-2-1$

GEB - $85114-H-1$

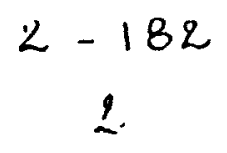

GEB-85114-H-1 INTERFERE: WUTH GEB-85112-2-1 AS SHOLN.

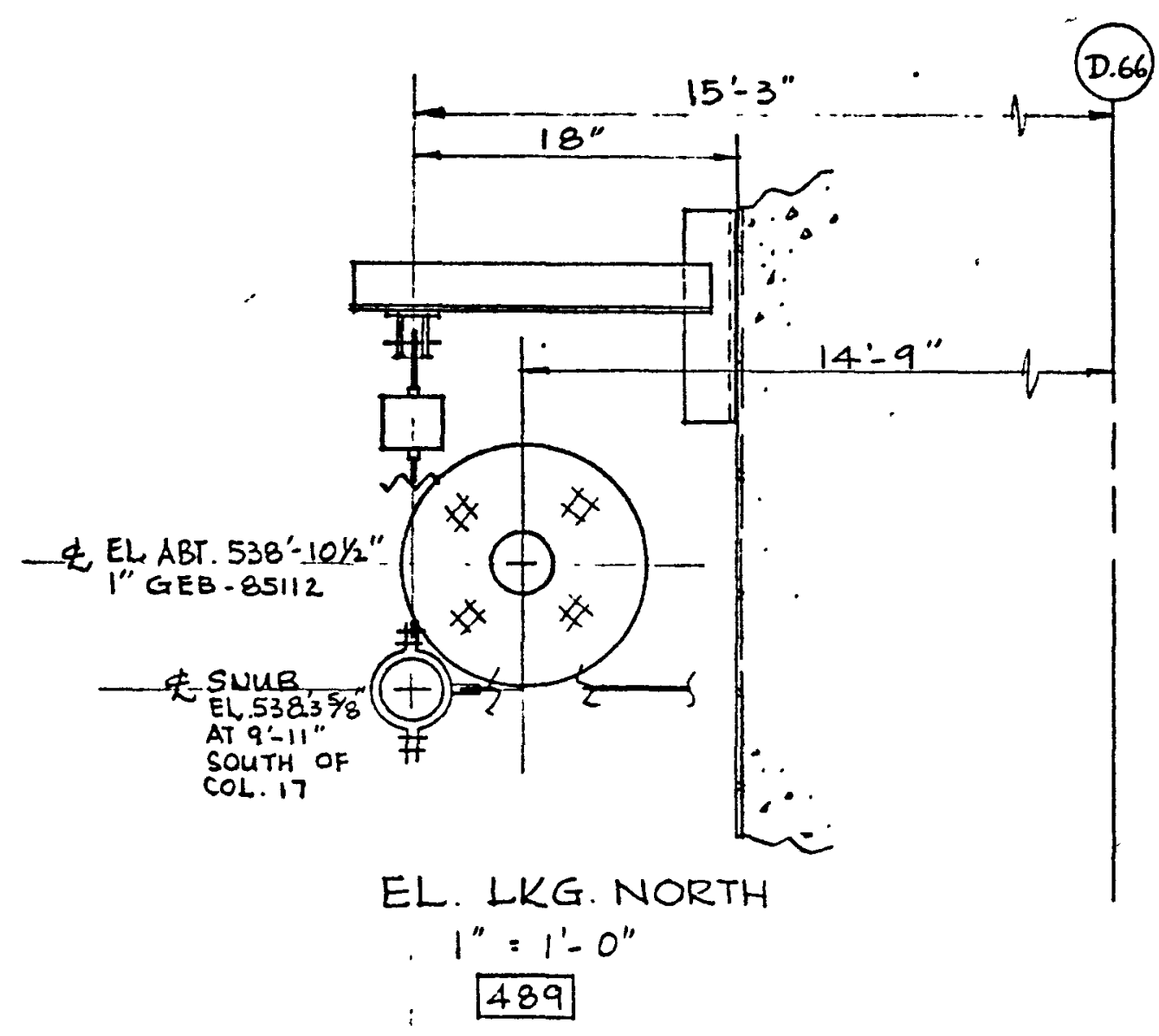




$$
\begin{aligned}
& 1024 \\
& 5 \text { AMะル } \neg 7 \\
& F=-T \\
& \therefore \text { T T } \rightarrow=-i, \ldots \\
& \text { L- 1:- }
\end{aligned}
$$

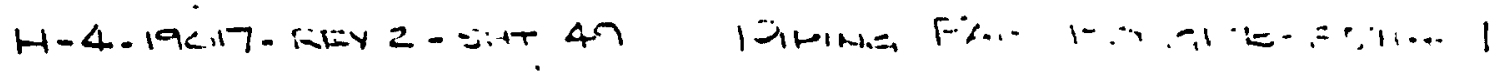

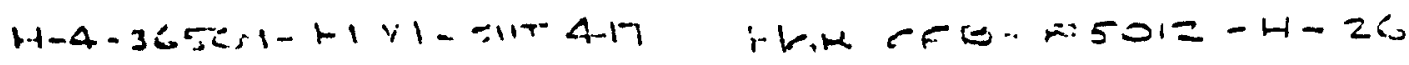
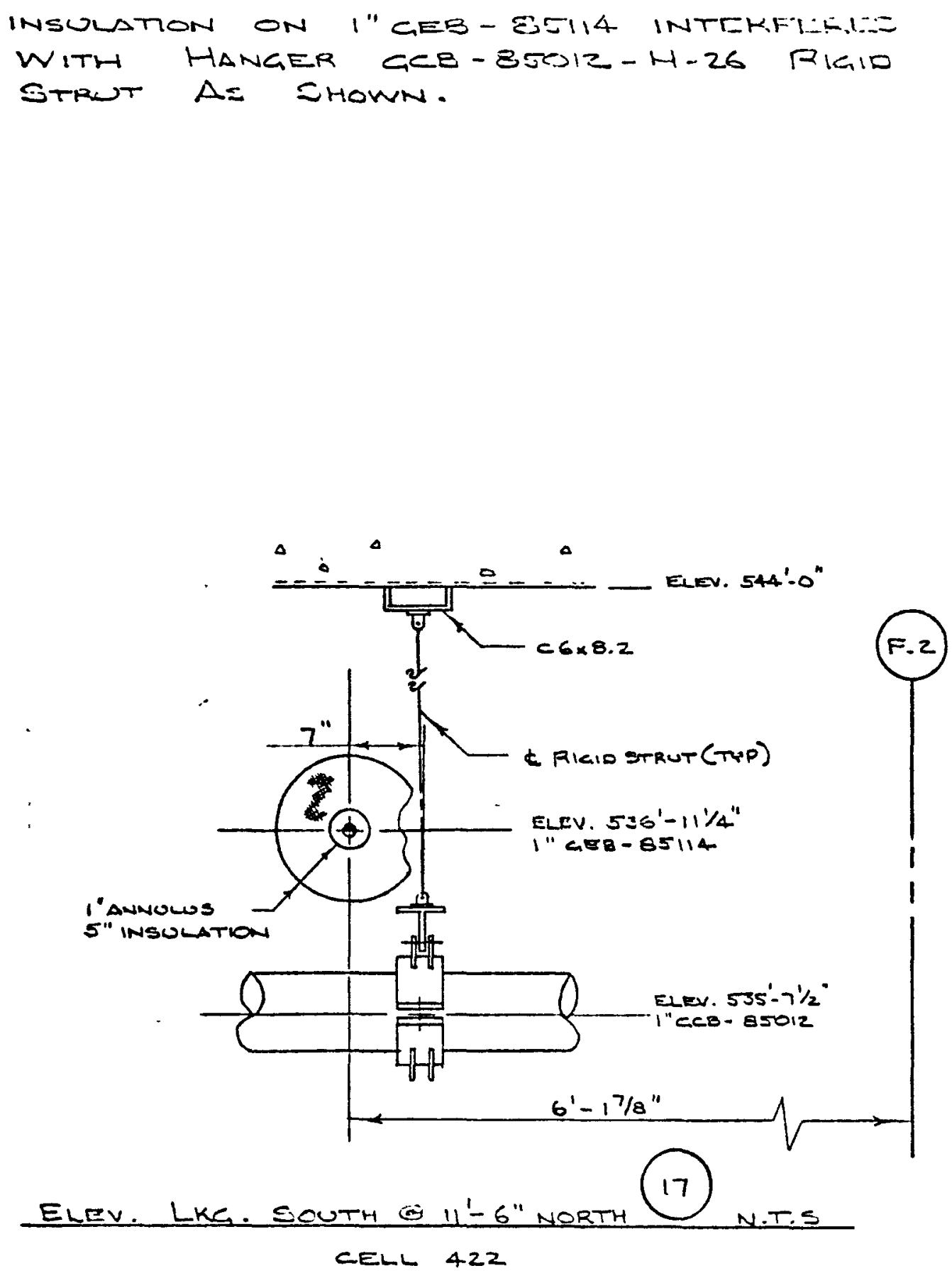
1024

FETF

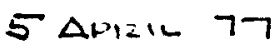

$\therefore$ Tuszunski
$2-184$

2

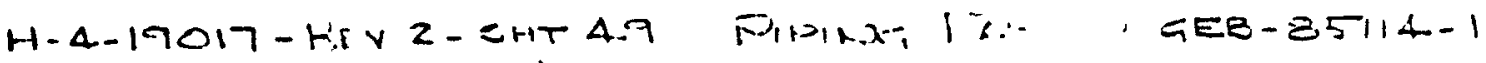

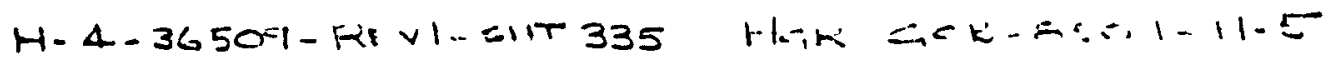

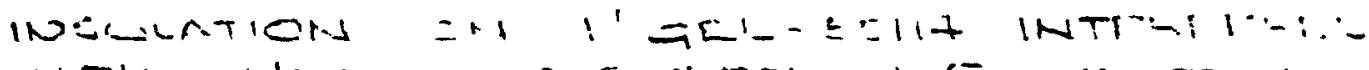

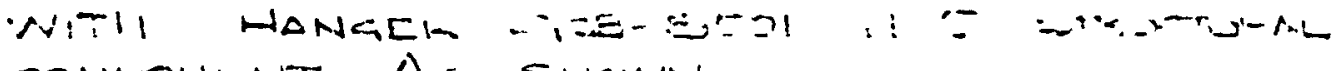
CRIMRIIIT $\lambda=$ SHOWN.
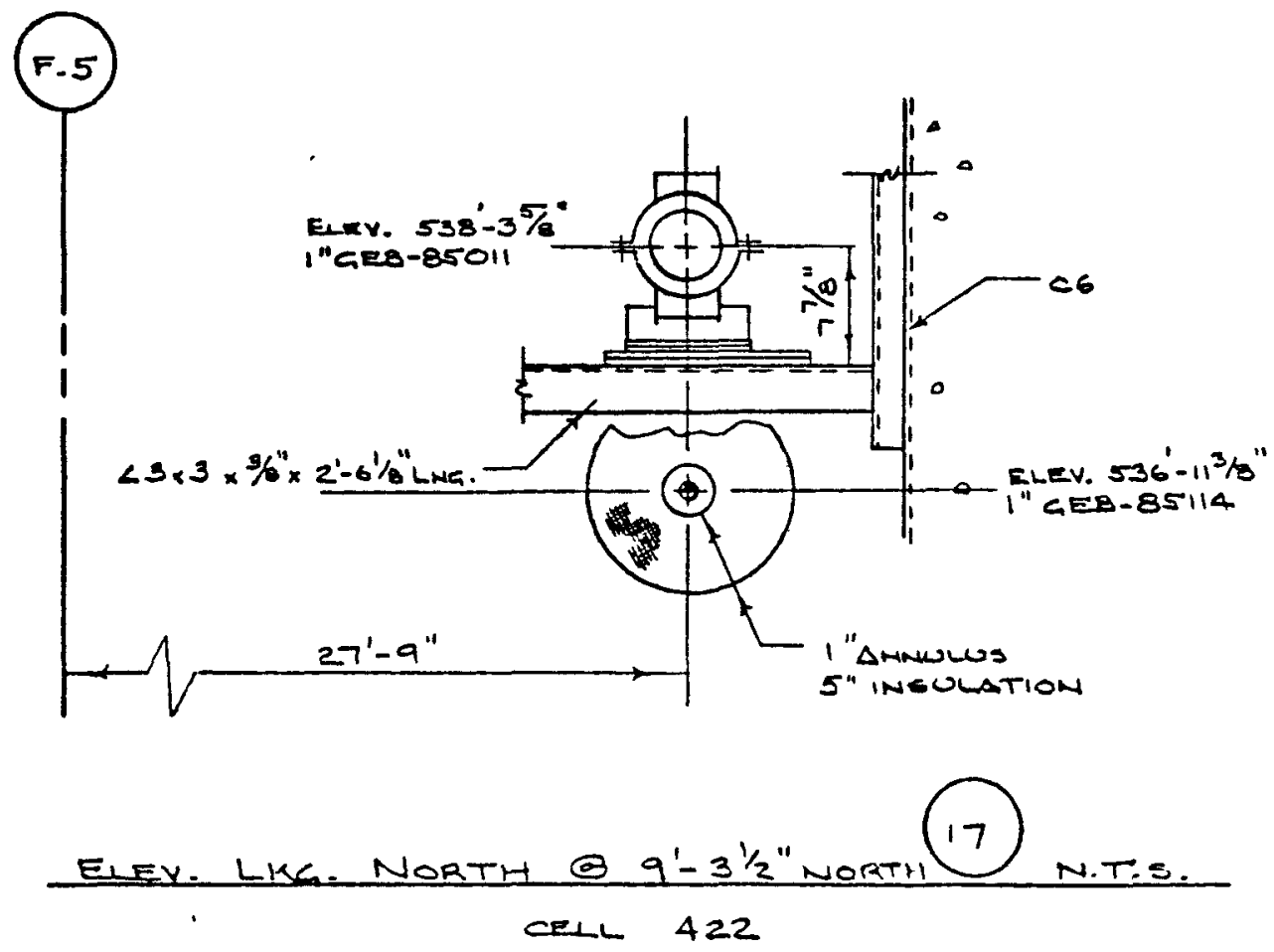
1024

FFTF

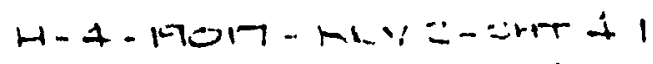

EAI-1ML - T:

$\therefore T-\cdots$,

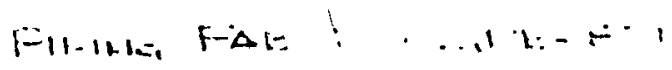

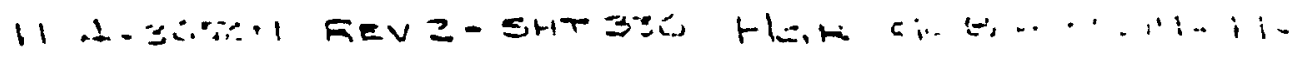

INSULATION ON I"CAEB-BEIIA INTERFFH"I WITH HANGER CEB-85OII-H-6 ETHMITU!-AL COMIONEANT $A S$ SHOWNA.

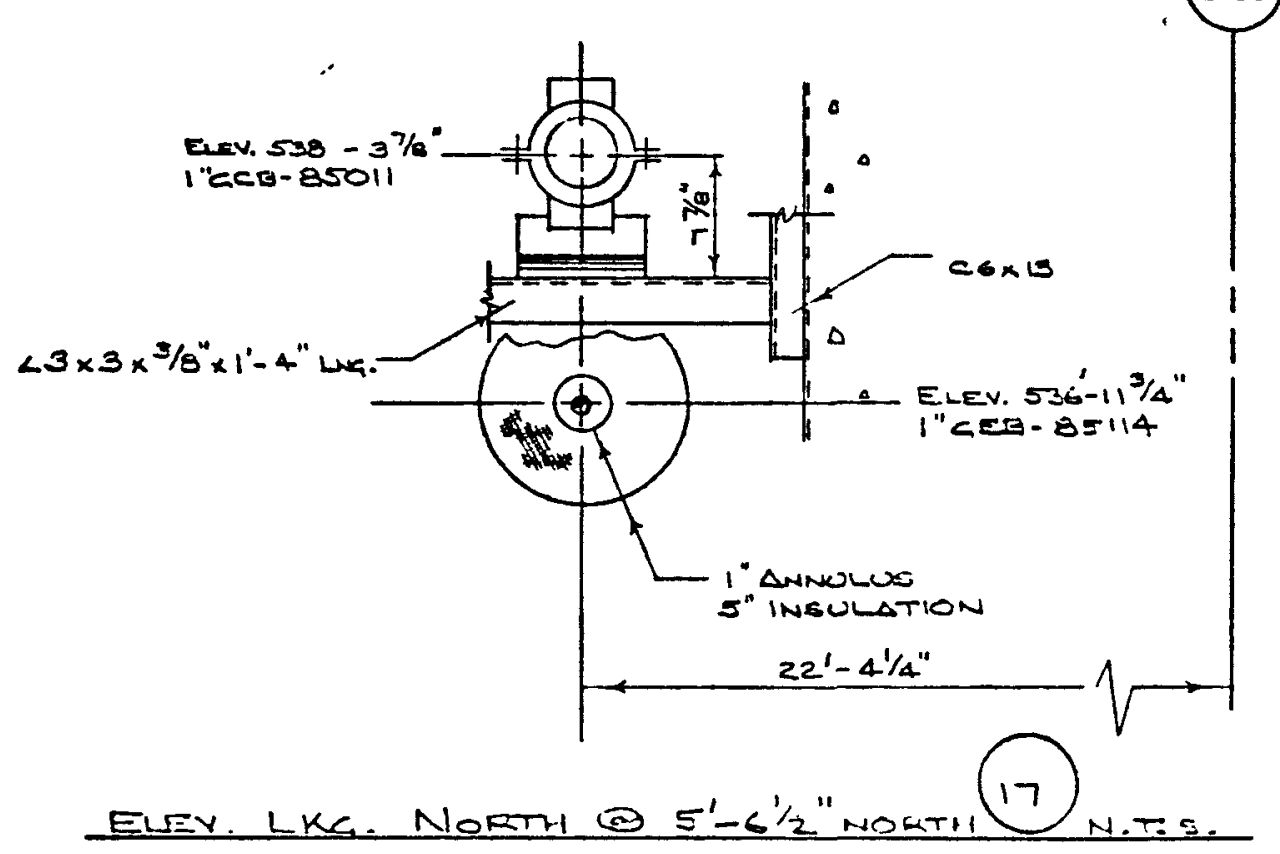

CELL 4222 


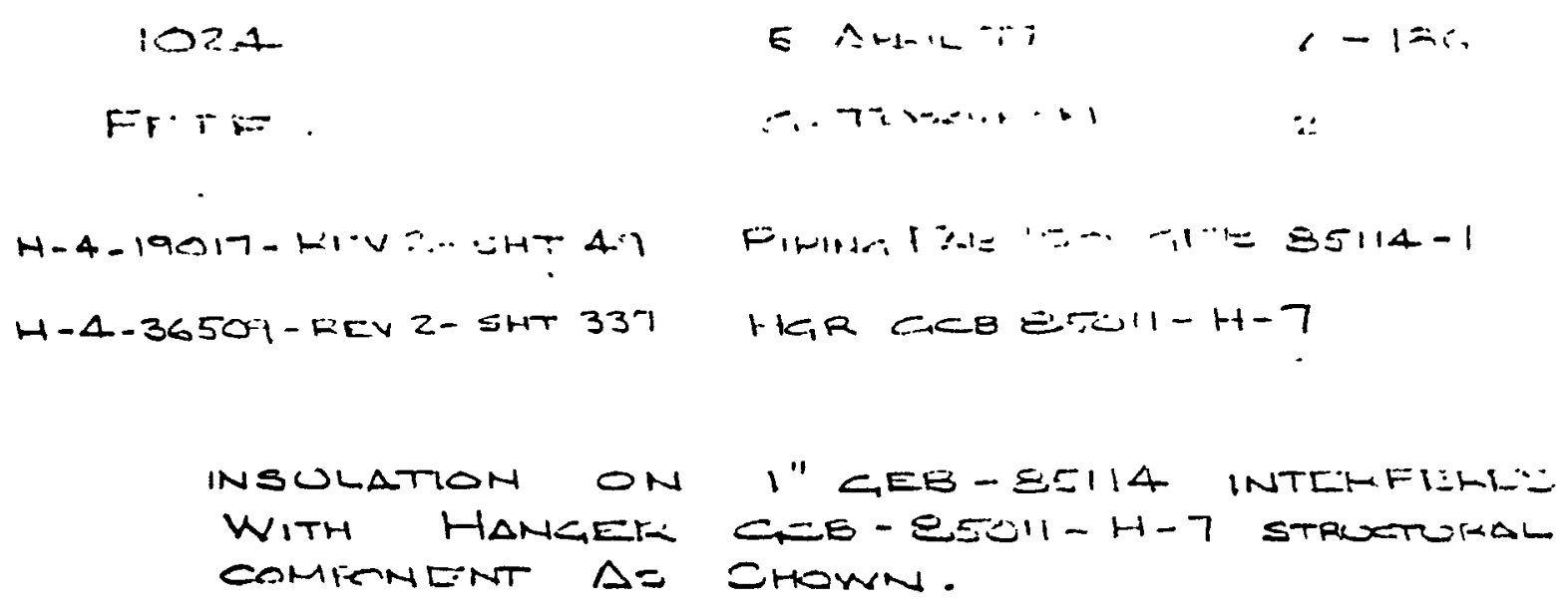

INSULATION ON I" CEB - EIII4 INTLHFIEHI:WITH HANGER CEE-EEOII-H-7 STRUTMRAL COMFENENT $A=$ IHOWN.

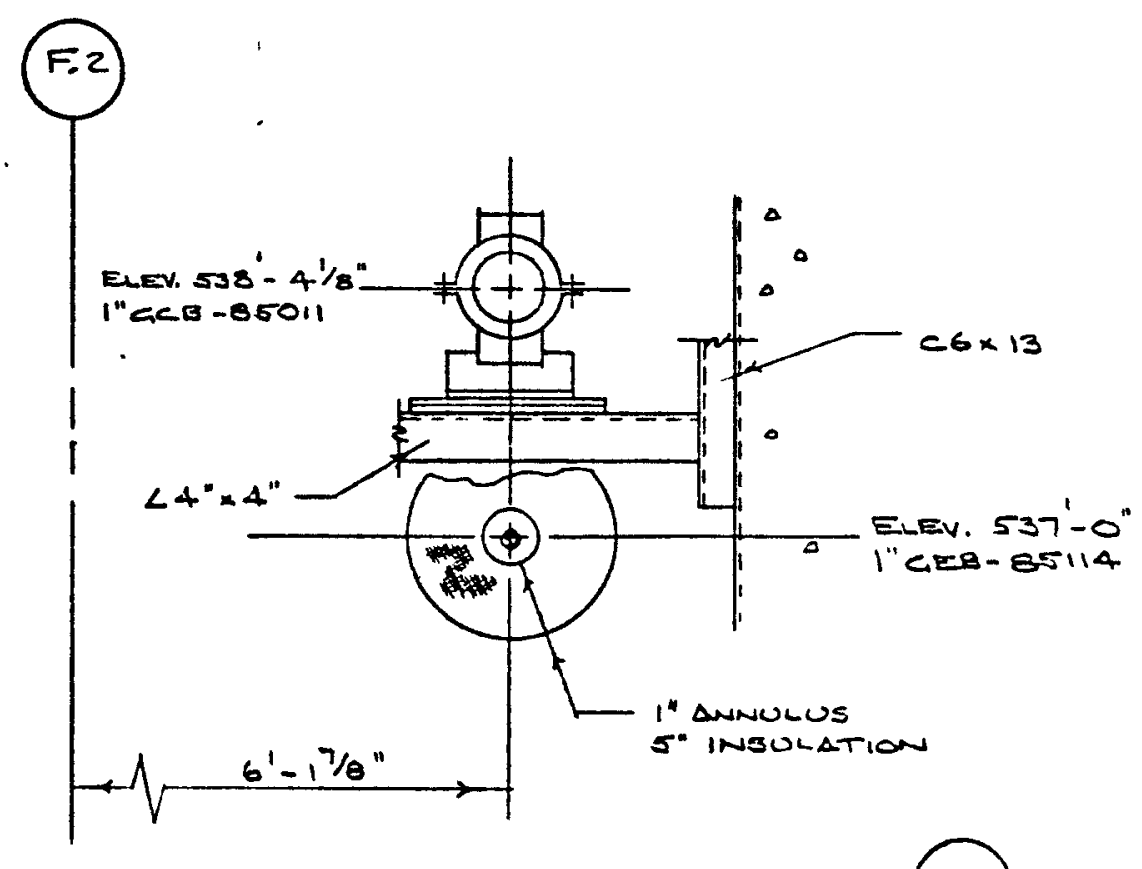

ELEV. LKG. NORTH \& $21 \frac{1}{2}$ "NORTH 17 


$$
\begin{aligned}
& 1024 \quad 5 \text { APMIL } 77 \quad<-1=-1
\end{aligned}
$$

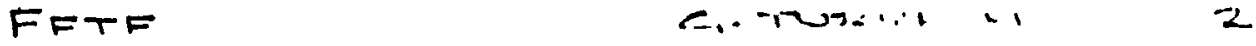

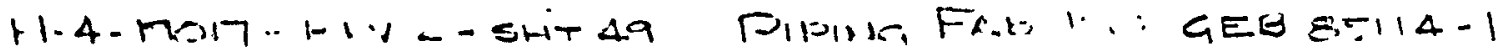
$H-4-36507$ - REYI- SHT 340 HER GE

INSWLATION ON I"GER-8STI4 INTERFERE= WITHI HANCER GCB - EE=II-H-

ITRCDTURAL COMPONENT $\Delta S$ EHCWH.
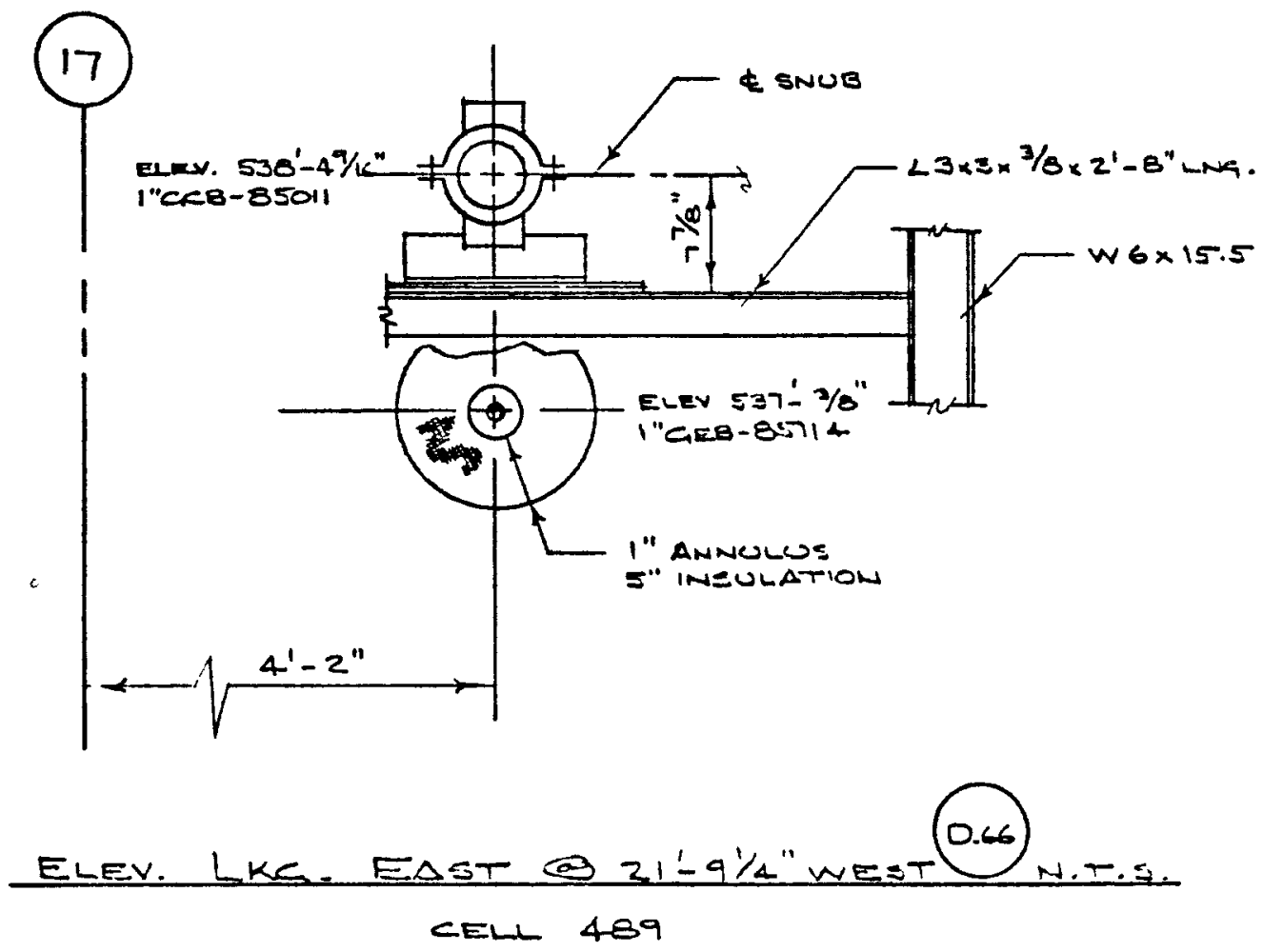

1026
ᄀ ApuL ᄀᄀ
$2-\therefore=6$
FFTE

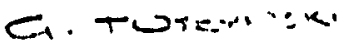
2

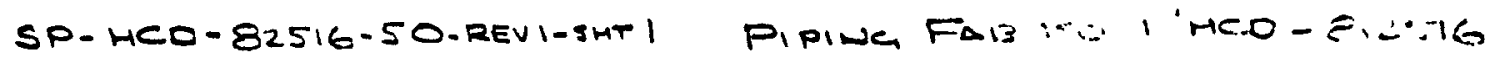
H-4-36994-REVO-SHIT 1421 HaK-C.FL $\therefore .-4-11$ ir

1" HCD 82516 INTERFERIE WITH HANGER CEB-E2604-H-10 AMELF As Surwan.

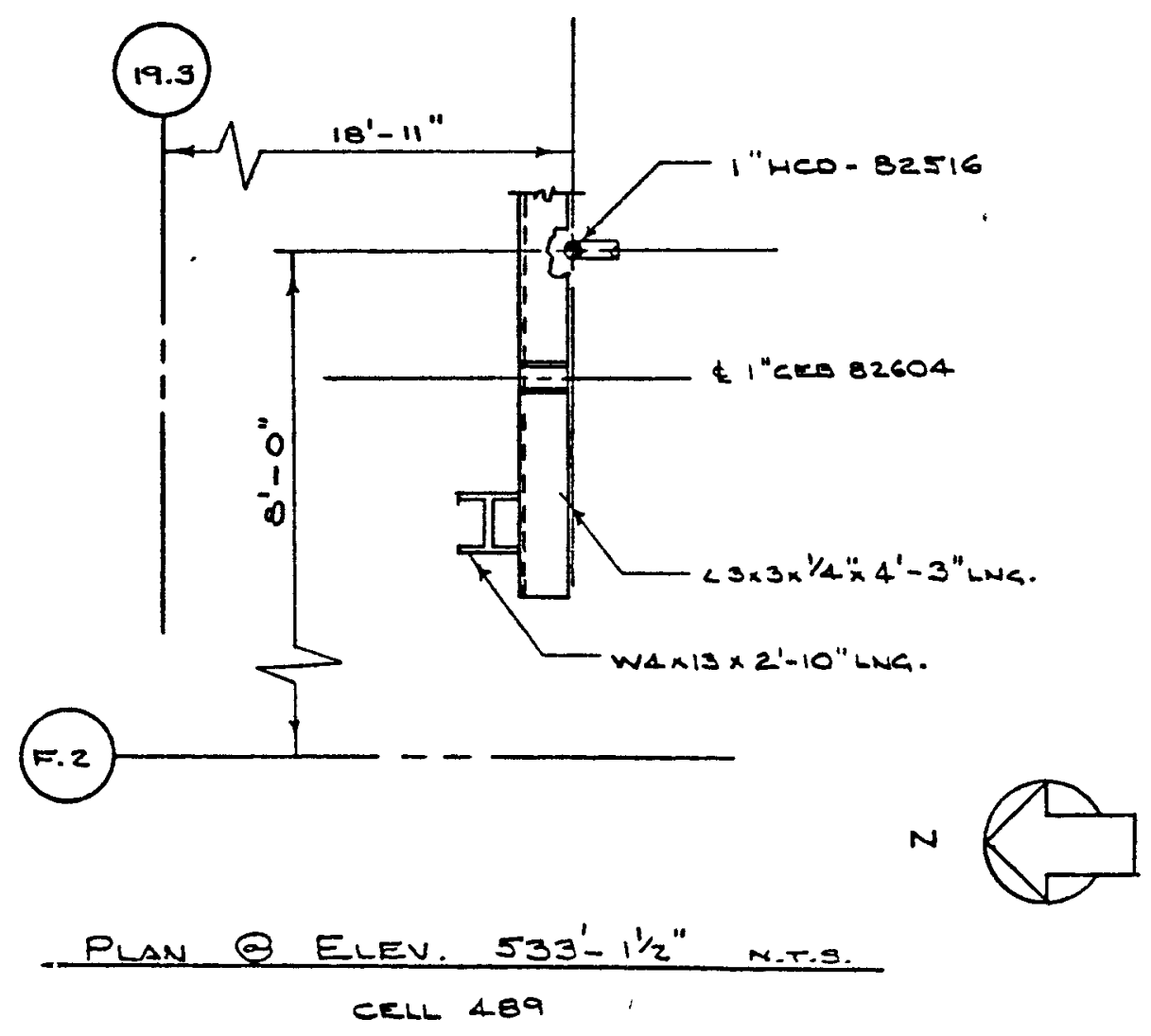




$$
\begin{aligned}
& 10 \geq 1 \\
& 5 \text { ArmL } 11 \quad \therefore \cdots: \cdots \\
& \text { トTTF } \\
& \text { E. TU⿴囗十, . . }
\end{aligned}
$$

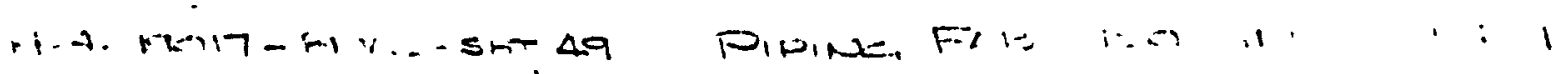

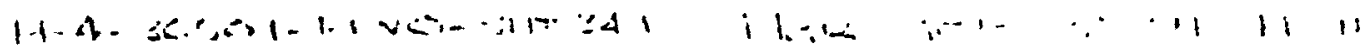

\begin{abstract}
INSULATION ON I"GEB - ETII4-1 INTERFERES WITH HANGER GCH-E5OII-H-II ETRETLIFAL COMIONIENT AS SHOWN.
\end{abstract}

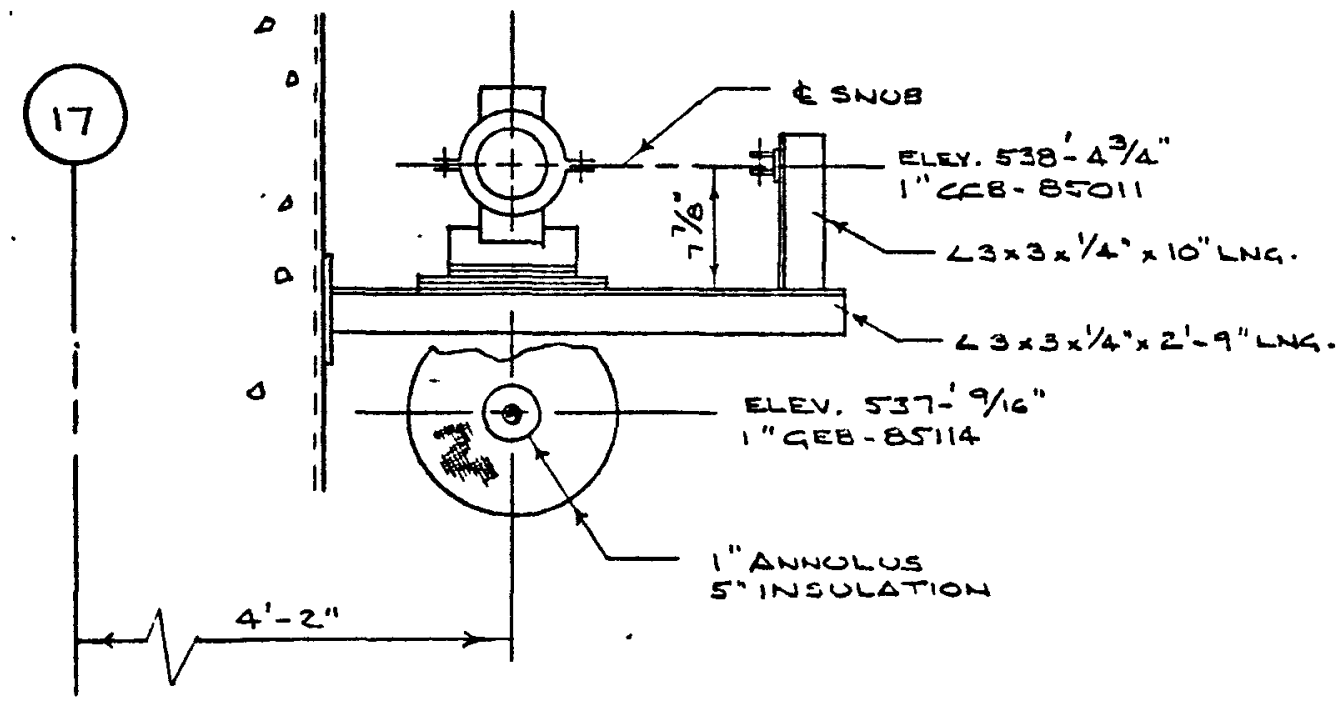

0.66

ELEX LKG. EAST \& $18^{\prime}-6^{3 / 4}$ WETT N.T.E. CELLL 487 
1024

FFTF

$+1-4 \cdot 176,17 \cdot+\cdots \cdot \ldots+.+47$

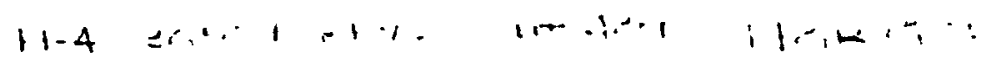

$5 \Delta 1 \cdots$

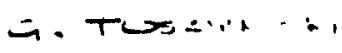

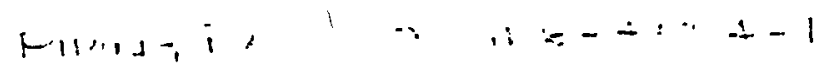

-. $\therefore \quad: \quad$

INGULATION CN I" GEE-EEHA-I MHTHLIH-1.

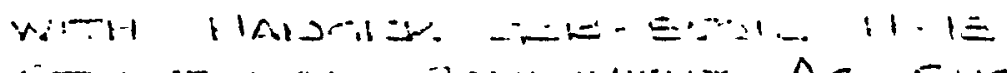

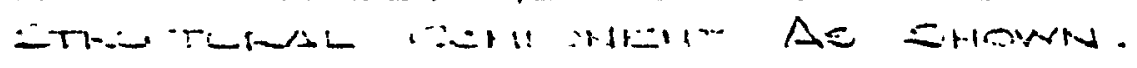

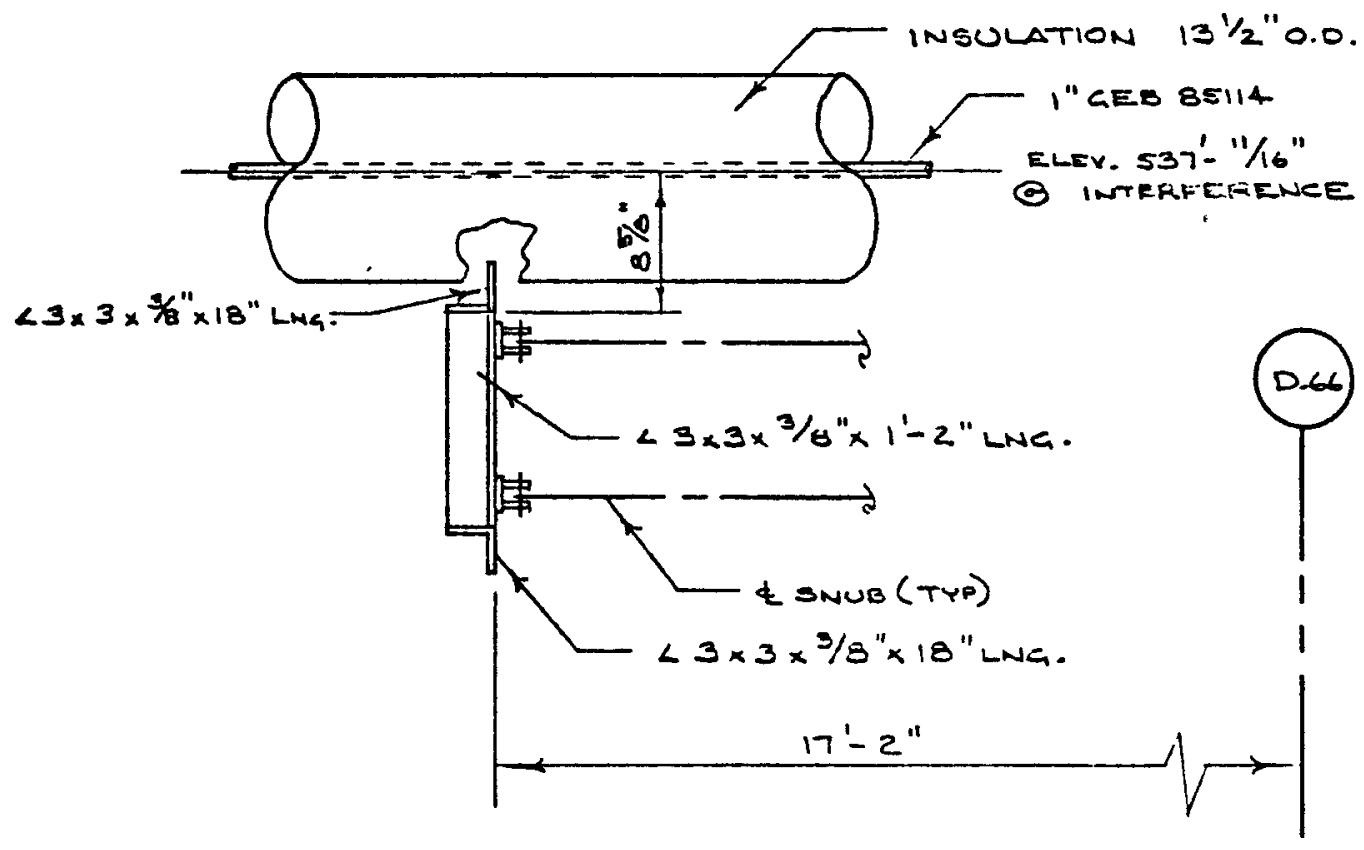

ELEV. LKa. NORTH Q 4'-9" SNWTH 17 1.T.J.

CELL 489 
1024

F TF

$H-4-19017.3=4 T .53$

$H-4-36506-2$ SHT. 481
$4-5-77$

$S H O$

$G E B-E 5211-1-1$

$G E B-61224-H-1$
$2-: 00$

2

GEB - G1824-H-1 INTERFERES WUITH GEE-EE:11-1-1 AS SHOLNN

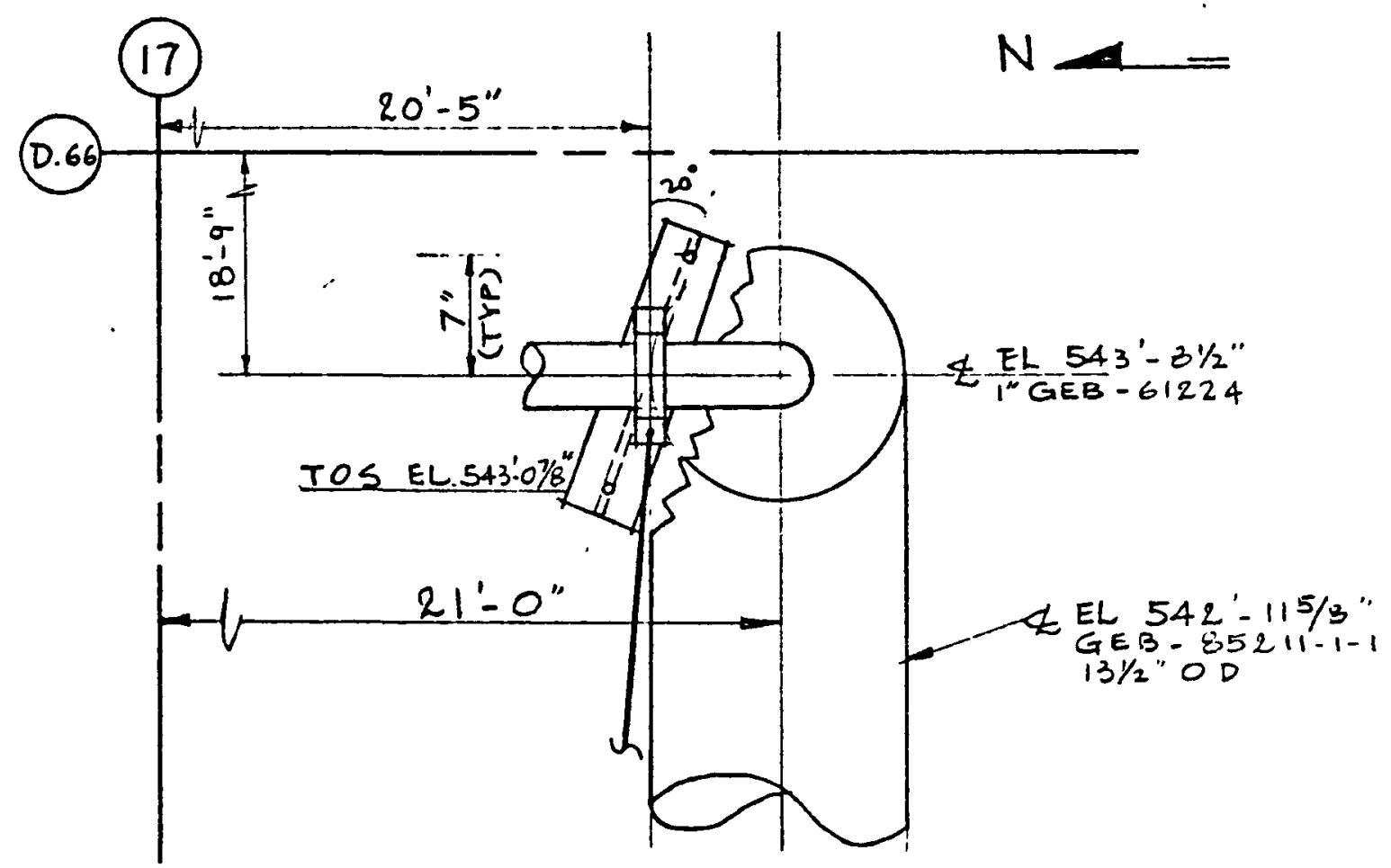

FAN EL 544'.0"

$$
\begin{aligned}
& 1^{\prime \prime}=1^{\prime}-0^{\prime \prime} \\
& 489
\end{aligned}
$$




$$
\begin{aligned}
& 1024 \\
& 4-5-7 \\
& 4 \quad: 9 ! \\
& \text { FFTF } \\
& S \text { HO } \\
& 2 \\
& \text { H-4-19017-3 SHT } 53 \\
& \text { GEB - 852:1-1-1 } \\
& H-4-36509-1 \text { SHT } 665 \\
& \text { GEB - } \$ 5212 \mathrm{H}-21
\end{aligned}
$$

GEB - 85212 H-21 INTERFERES LUITH GEB-E5211-1-1 AS SHOWN.

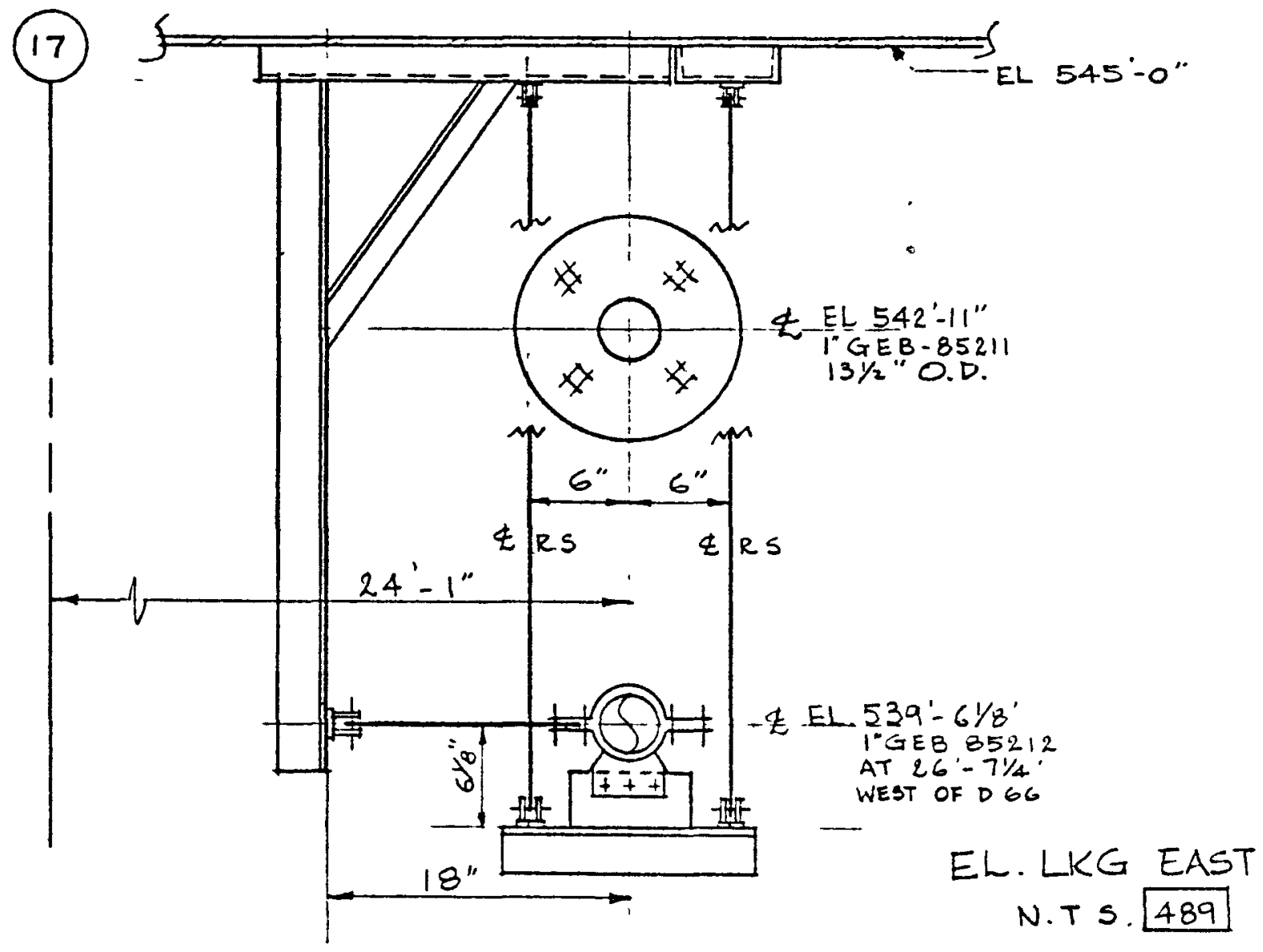


1024

FFTF

H-4 - $19017-3$ SHT 53

$H-4-36509-1$ SHT 666
$4 \cdot 5-7 \%$

$S+10$
2192

2

$G E Q-=5211-1-1$

$G E B-25212 H-22$

GEB. 85212 H.22 WTERHERES WUITH GEB-ËSDI1-!1 AS SHOWN

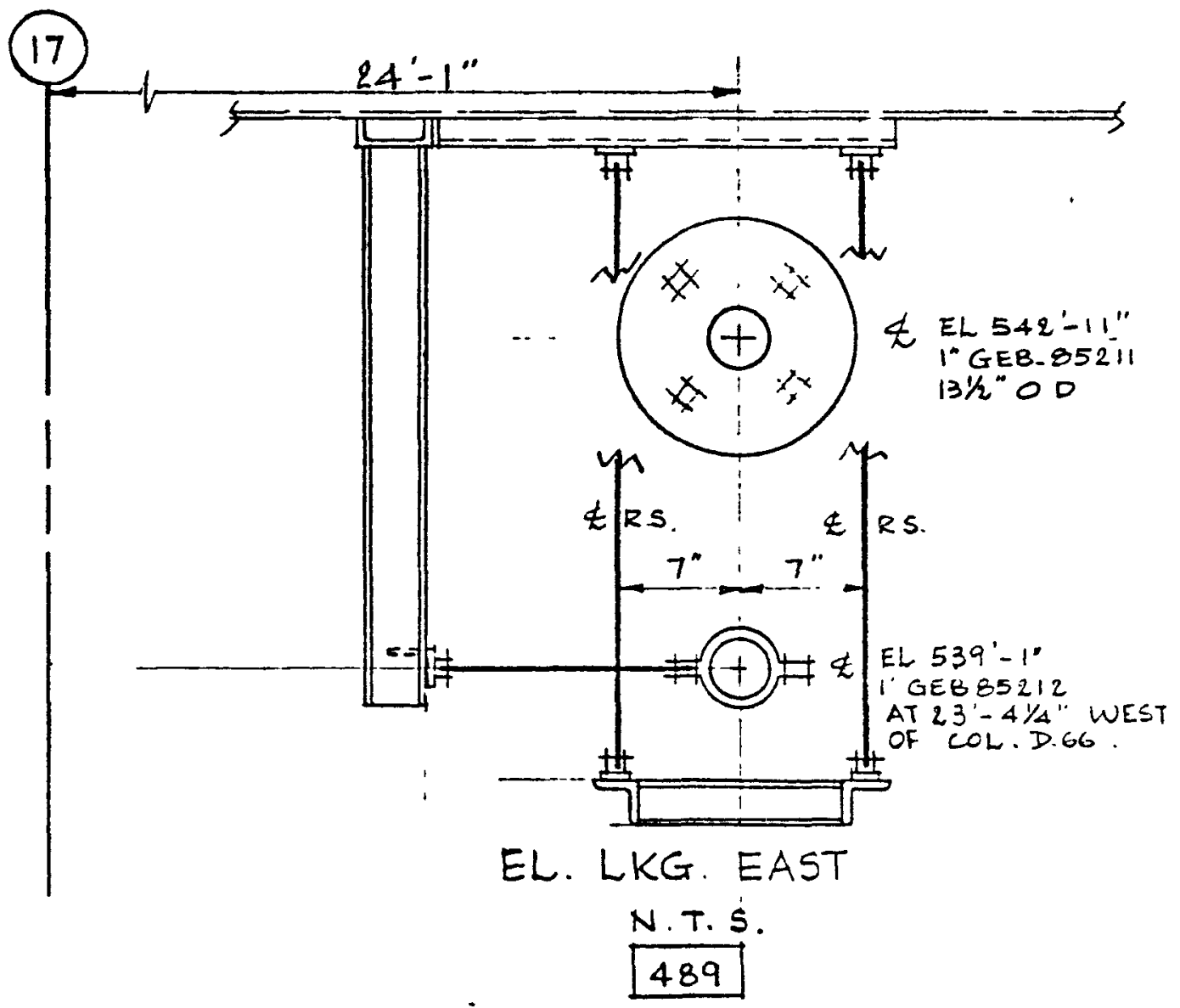


1024

ri $1 \mathrm{r}$
$4 \cdot 5$

BAKRY V.'.
$2-19=$

$\therefore$

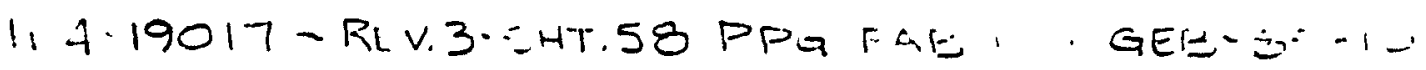

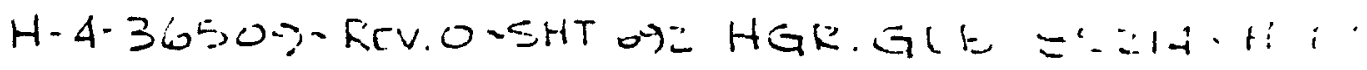
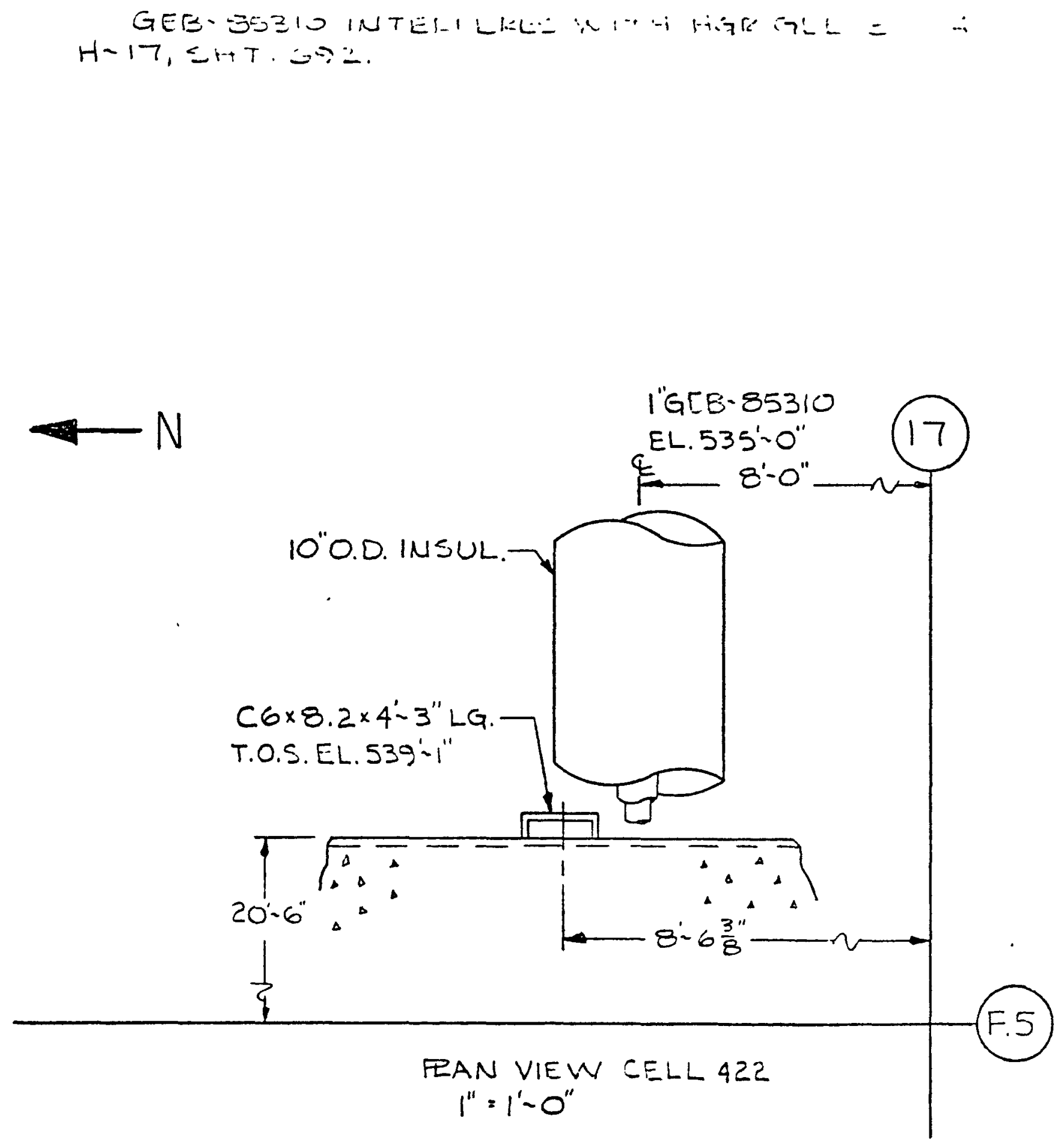
1024

FF'TF
$4-5-7 \%$

$\therefore-10,4$

EAEIGY VE:TE:

2

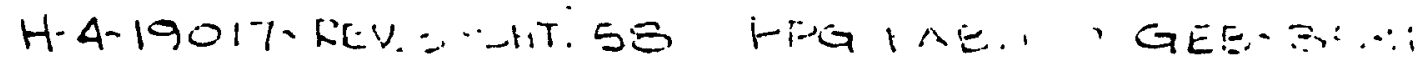
H-4-3650.3-LEV:D-SHT. 677 HGK. EEL-3E, -14-H-2

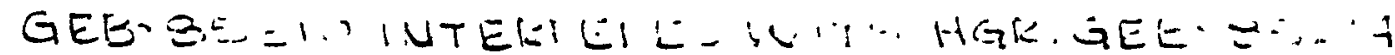
$H \sim 2, \because H T .6 \% 7$

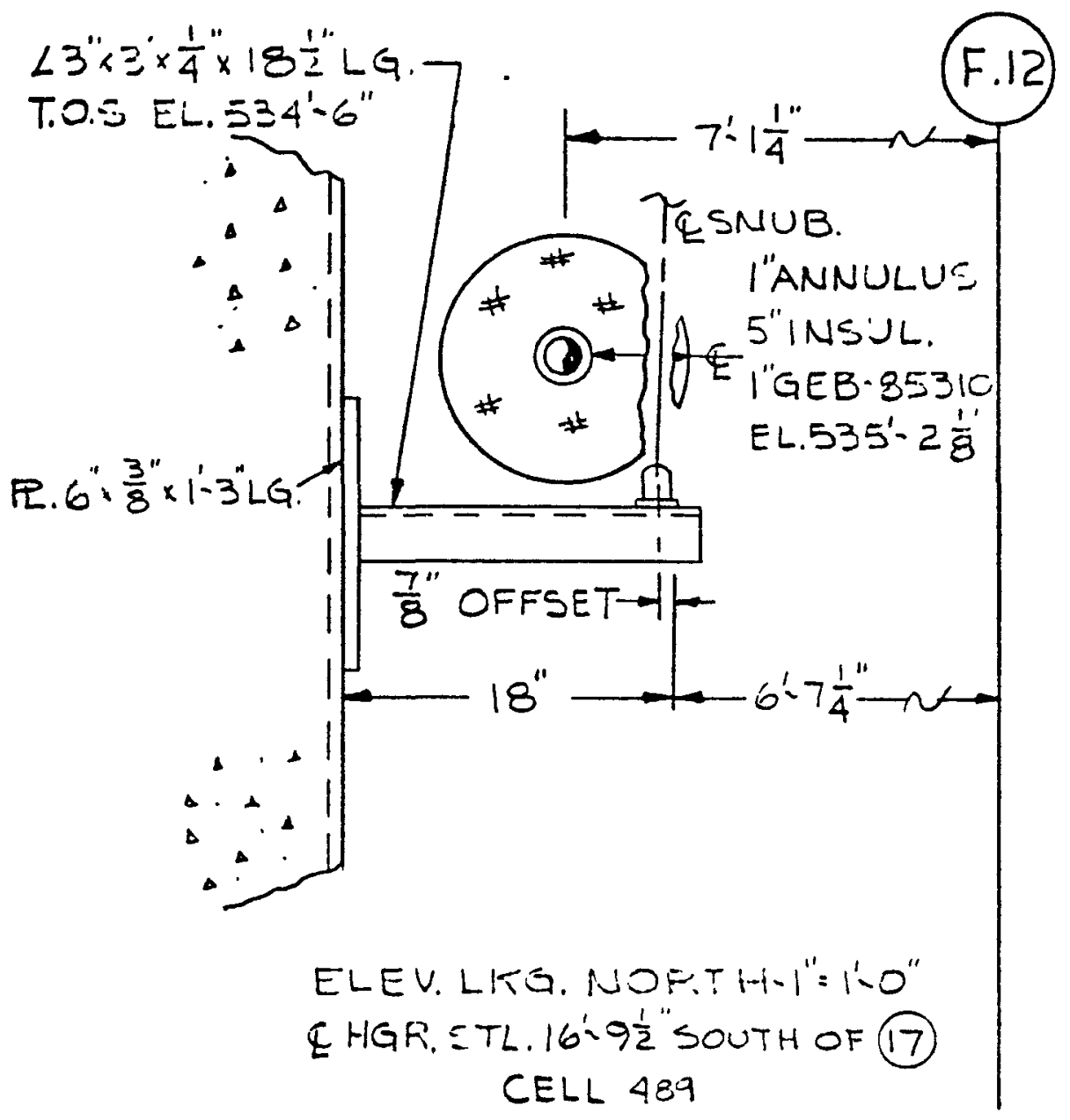



(6) $c^{\prime} A$
$A \cdot 6 \cdot 1$
$=-19:$
$11 F$
riskky ve:..t, :

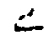

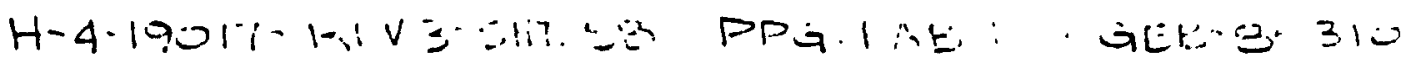

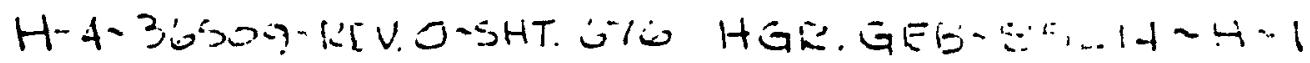

GEE$H-1,5 H T . \sigma^{-1}$.

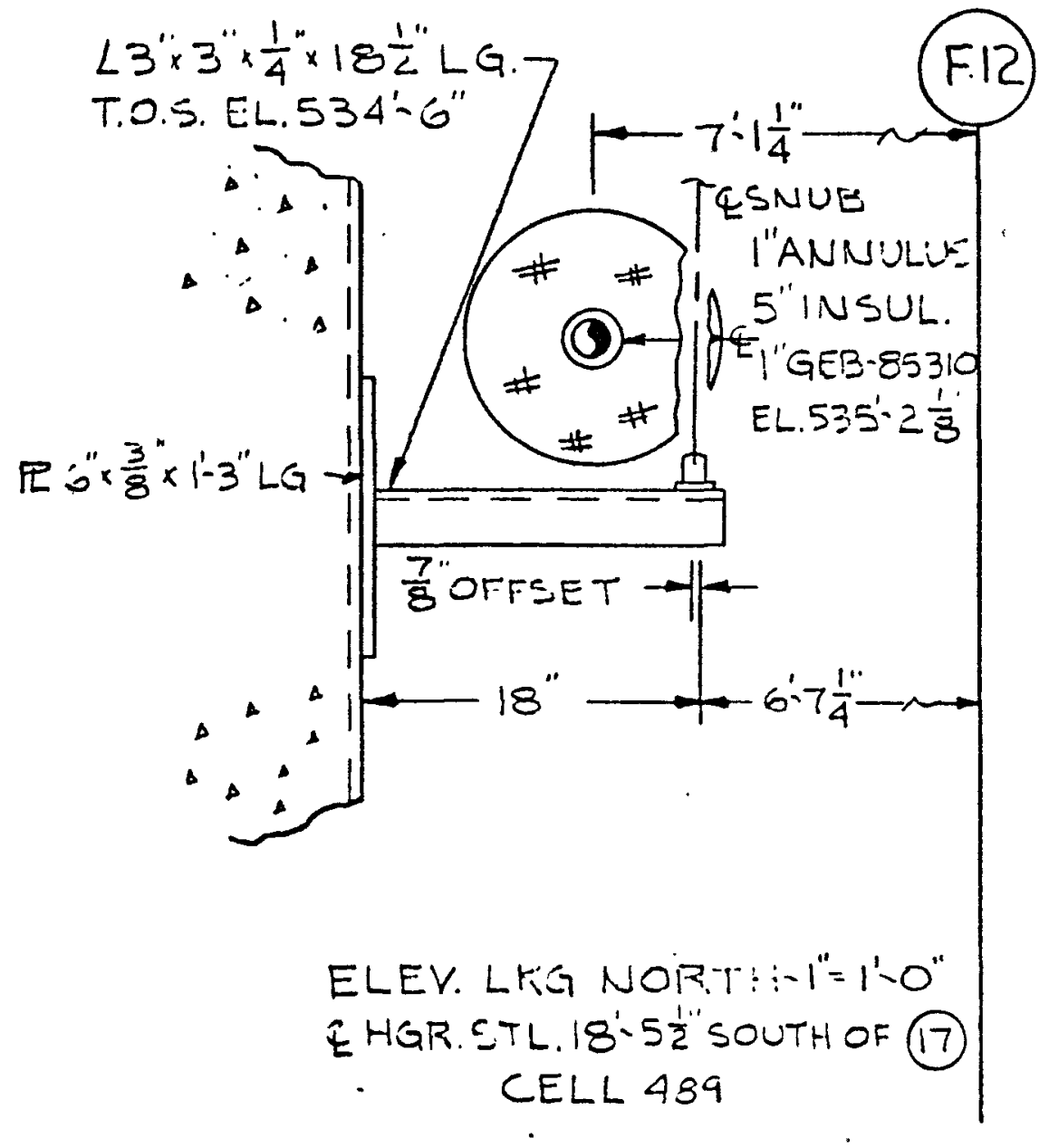



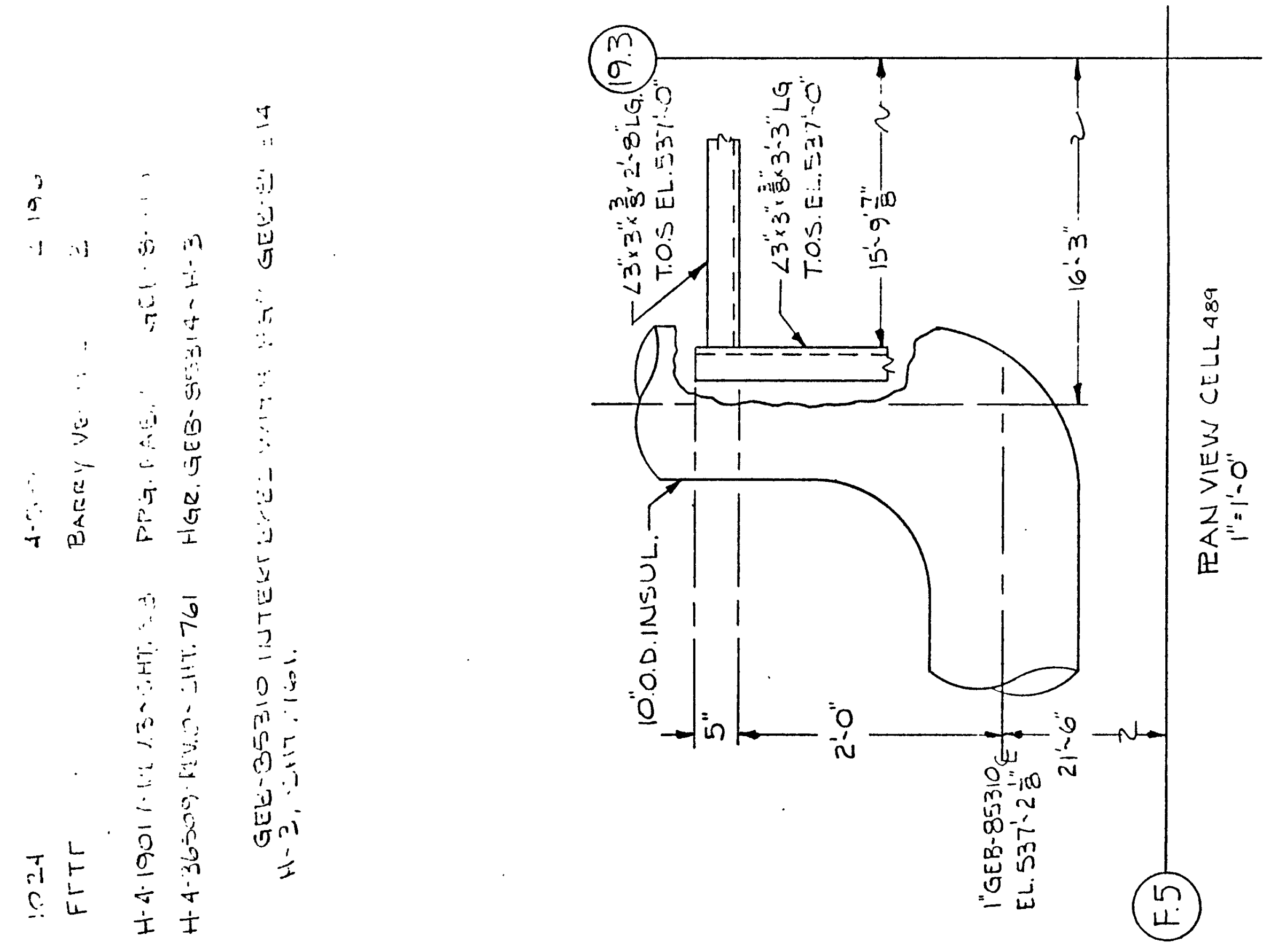

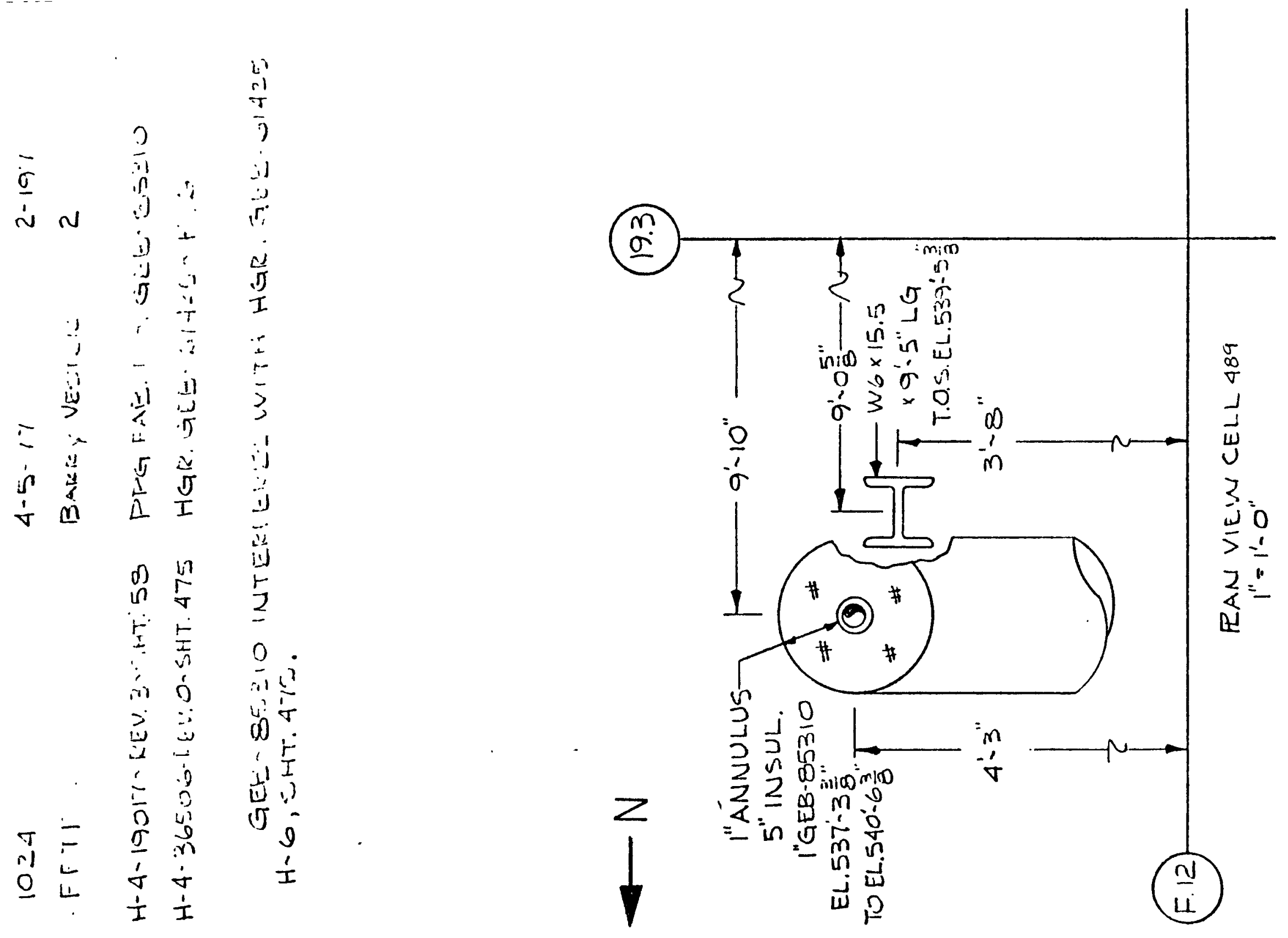

$10-\dot{*}$
$+5 \cdot 77$
$2-198$
FFTF
$K M C$
2

H.4-19017 REV. 2 SH.60 PPG FABKILATION 1SO. I" GEB.8Ë:12 H-4.36509 REV. 2 SH. 717 PIPE SUPPORT GEB.85 $\vdots 11$ H.15

$30^{\circ}$ trapeze and one $1 "$ snue both eelonging to GEB-85311 H.15 INTERFERE WITH 5" INSULATION ON I" GEB-85312 AS SHOWN

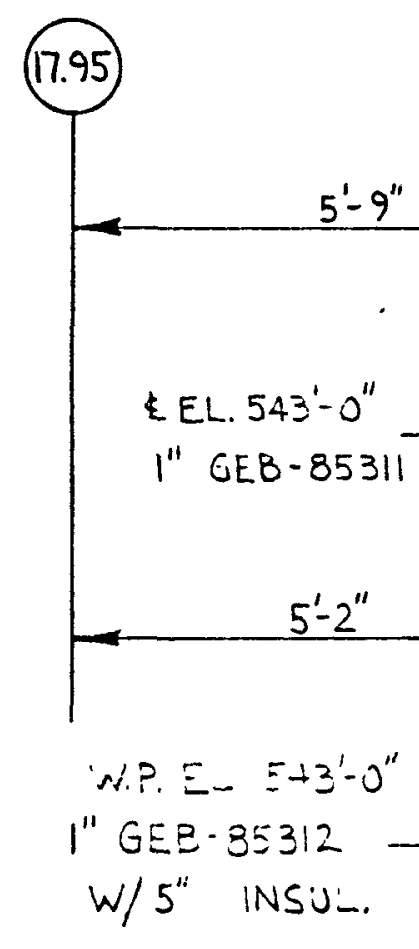

RAN VIEW

CELL 48 ก

N.T.S

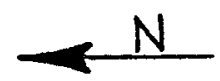

5'-9"

3EB-85311 $H-15$ $30^{\circ}$ TRIPEZE $1^{\prime}-7^{\prime \prime} L G$.

T.O.S. EL, $542^{\prime}-7 \frac{1^{\prime \prime}}{4}$ 

1024
$\therefore \div$
$2-199$
FFTF
$K M C$
2

H-4-19017 REV 2 SH. 1.0 PPG. FABRICATIUN ISO. I" GEB-85:12 H.4.36509 REV I SH. 659 PIPE SUPPORT GEB.8:212 H.15

$\angle 3^{\prime \prime} \times 3^{\prime \prime} \times 18^{\prime \prime}$ LG. WITH B.O J. EL. $53 \theta^{\prime}-11 \frac{1}{\prime \prime}$, PANT OF SEB-85212 H-15 INTERFERES WITH 5" INSULATION ON $1^{\prime \prime}$ GEB-95312 AT 8'-6" NURTH OF LULUMN 19.3

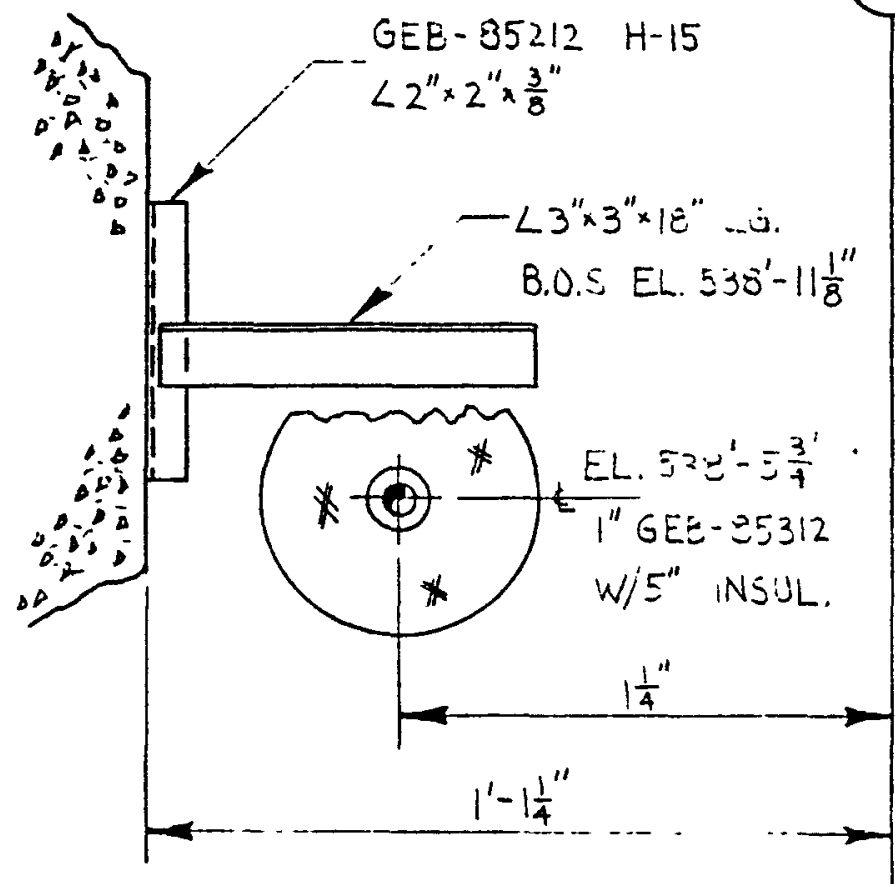

ELEV LS NORTH @ 8.6" VORTH. OF COLUMN 19.3 $1^{\prime \prime}=1^{\prime}-0^{\prime \prime}$ \#489 
1024

FFTF
$4-5 \cdot 77$

$K M C$
$2-3 c^{-2}$

2

H-4-19017 REV.2 SH.60 PPG. FABRIKATION 1SO. I" GEB-95312 H-4-36509 REV. O SH. 658 PIPE SUPPORT GEB-O5212 H-14

$\angle 4^{\prime \prime} \times 4^{\prime \prime} \times \frac{3 \prime \prime}{8}$, B.O.D EL. $538^{\prime}-10 \frac{5}{8}^{\prime \prime}$, PART OF GEB-85212 H.14 INTERFERES WITH $5 "$ INSULATION ON I"GEB-85312 \& EL. 538'-57" AS SHOWN

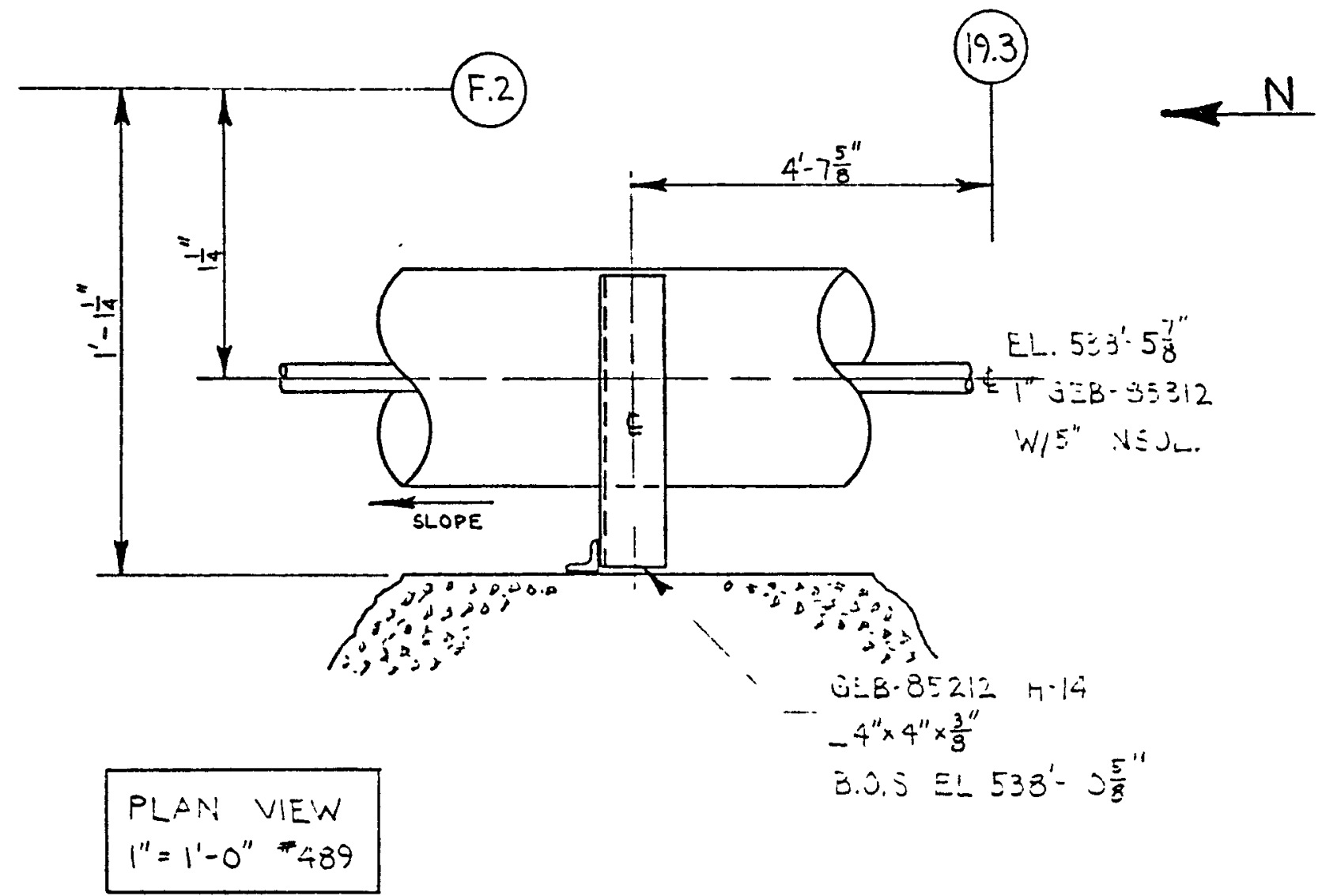


$102 \div$

FFTF
$4-6 \cdot 77$

$K M-$
2.201

2

H.4-19017 SH.6O REV.2 PPG. FABRICATION ISO I" GEB.85312 H-4-36509 REV. O SH 687 PIPE SUPPORT GEB-85414 H-I

1" SNUB, \& EL. 528'-O", PART OF GEB-ES414 H-1 INTERFERES WITH 5" INSULATION ON I" GER-8S 12,4 E.. SZO'-." AS CHA,X'AI

(F.2)

(19.3)

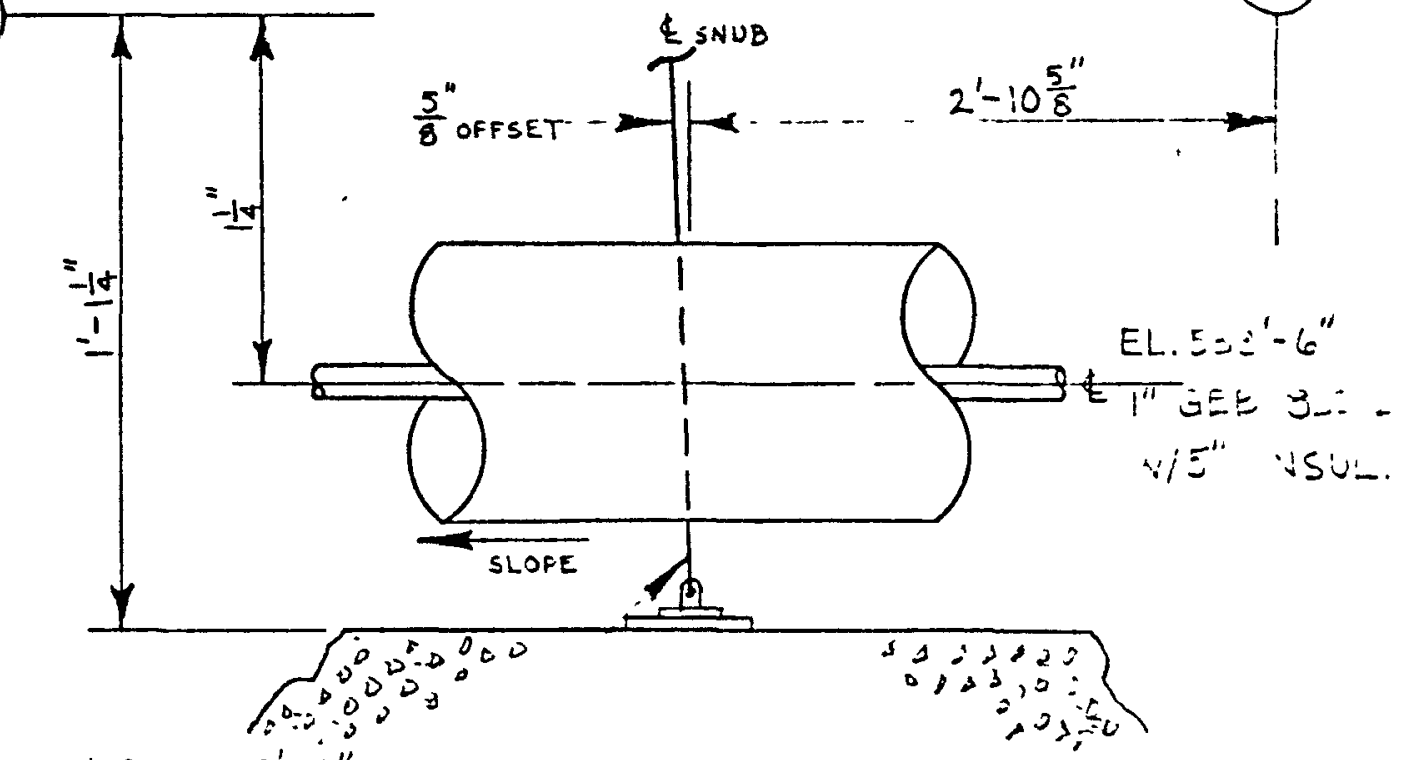

$E E L E \Xi 3^{\prime}-\dot{3}^{\prime \prime}$

GEB- 8E414 H-1

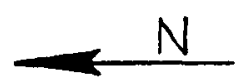

PLAN VIE:N

$I^{\prime \prime}=I^{\prime}-O^{\prime \prime} \# A B$ 

1024
$\therefore-\div-i$
$2-2 c 2$
$F F \mid F$
$S$ HO
2
$H-4-19017-4$ SHT. 64
GEB - $8.5410-1.4$
H-4-36509-1 SHT 772
$G E B-85314-H-14$
GEB
AS SHOWN.

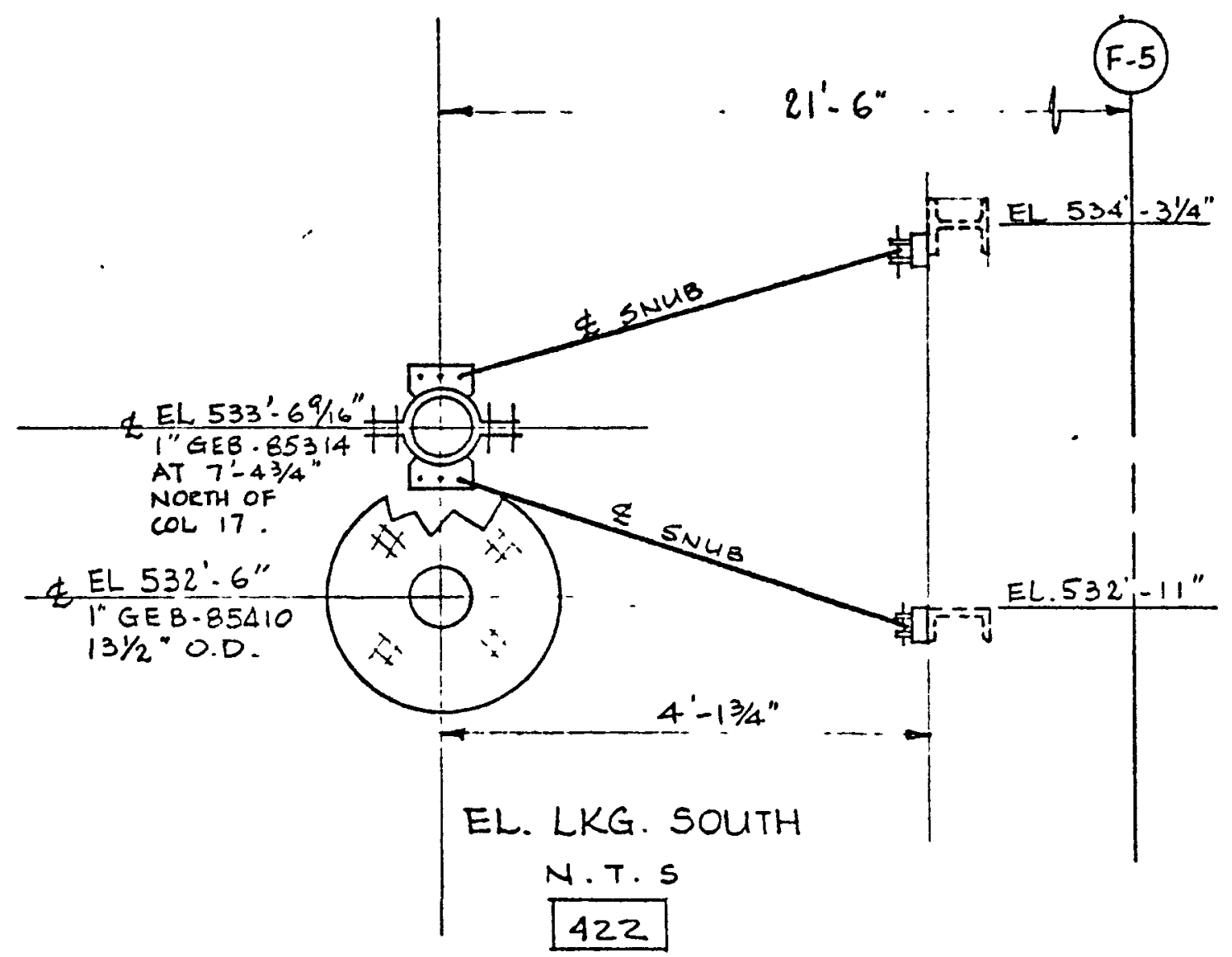



10,24
$4-5-77$
FFTF
$S H O$
$\because \quad \ddot{\sim}=\dot{0}$
2
H-4-14017-4 SHT. 64 I" GEB- $2.5410-1-5$
$H-4-36507-2$ SHT 747 GEB - 25512 H.19
GEB - \$5312 H-19 INTELFERE: WUITH GEB-SE+10-1-5 AS SHOLUN

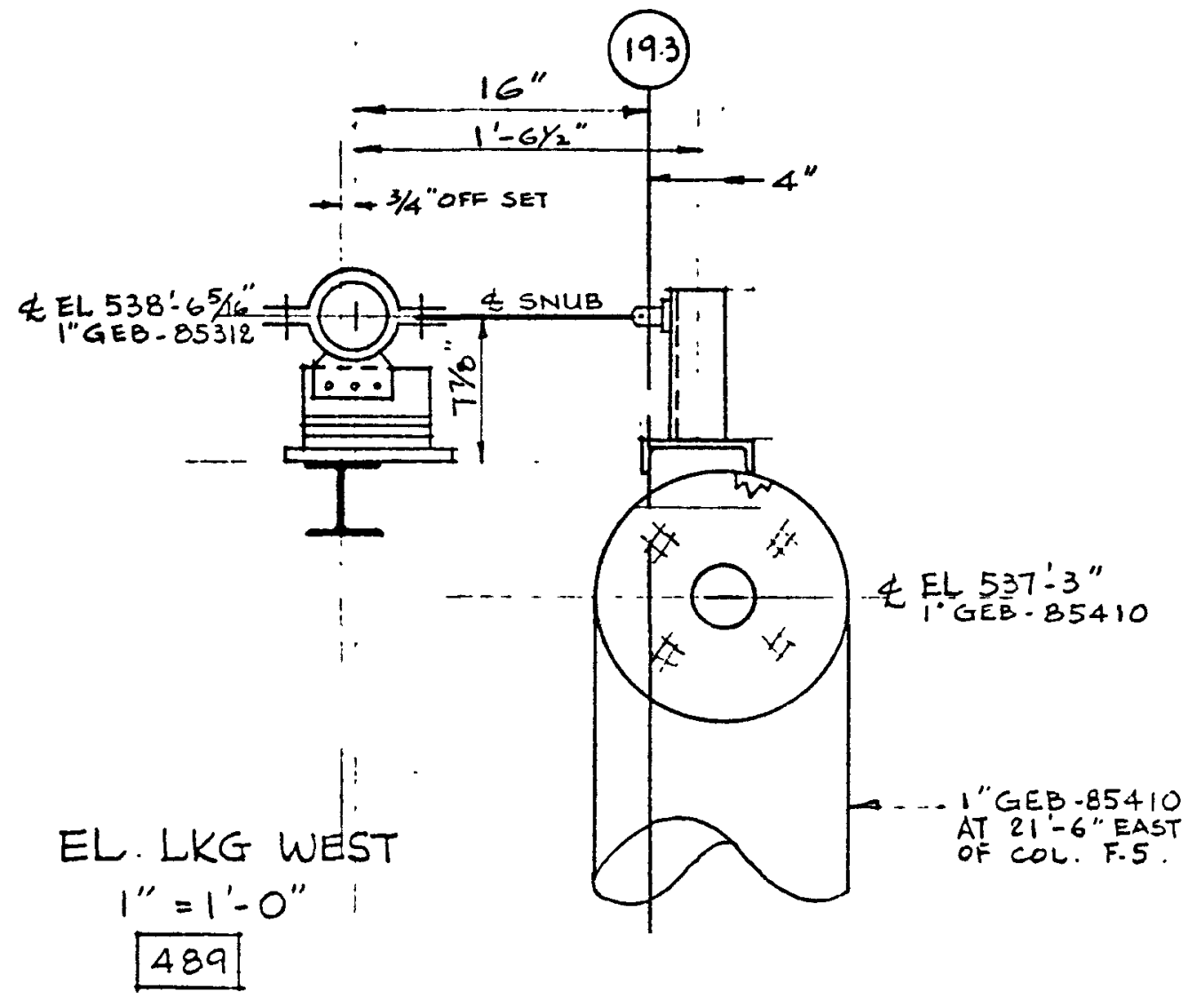


:024

FFTF

$$
\begin{aligned}
& H-4-19017-4 \text { SHT } 64 \\
& H-4-36509-2 \text { SHT } 809
\end{aligned}
$$

$4-5-77$

$\mathrm{SHO}$

$$
2-20+
$$

2

GEB - $25410-1-5$

GEB - $85410-H \cdot 31$

GEB - $85410-H-37$ INTELFELE: LUIT: GR.L- 85410.
AS SHOLNN.

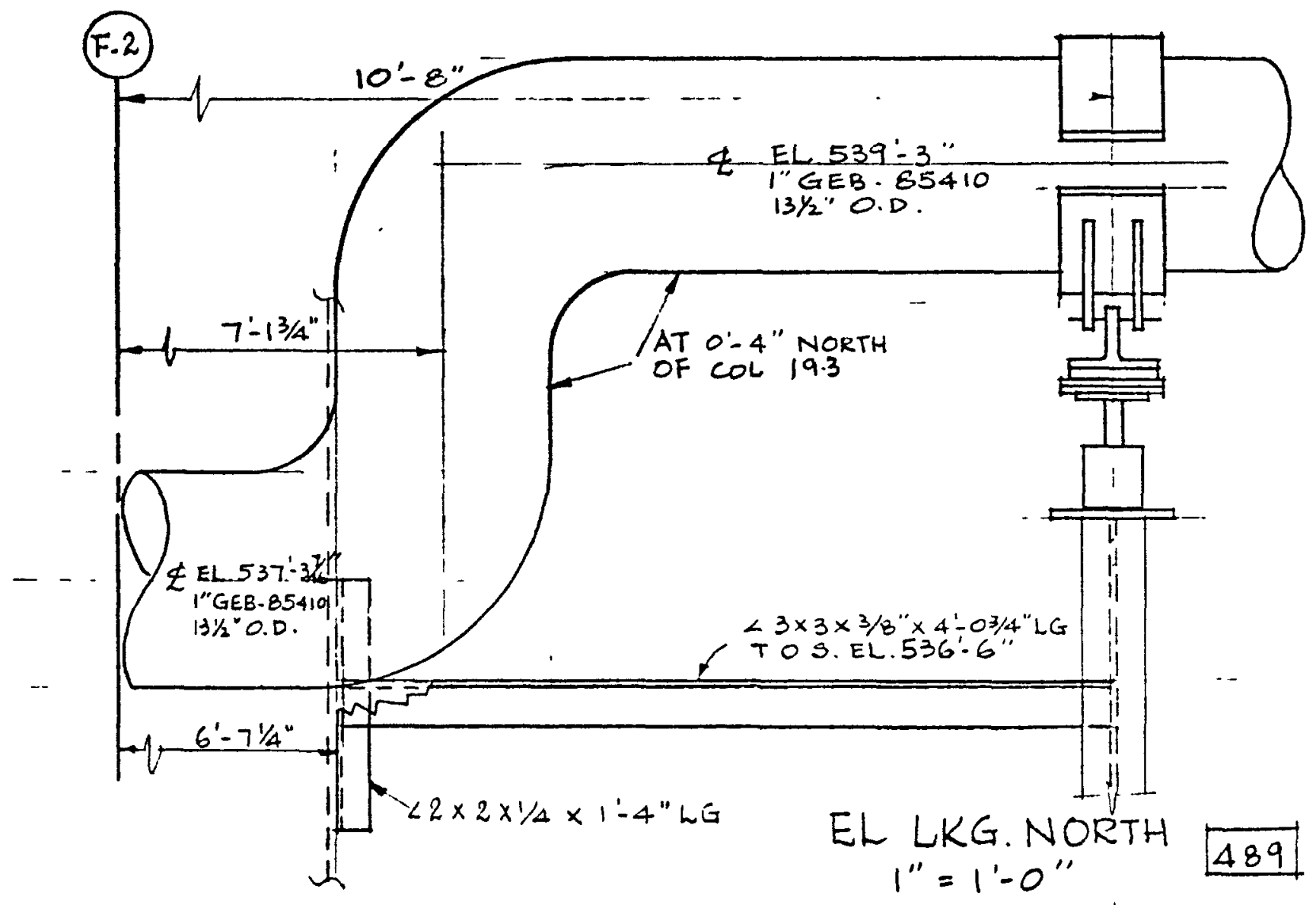




$$
\begin{aligned}
& 1024 \quad 4-2-7 ! 2-205 \\
& \text { FFTF. } \quad S+10 \quad 2 \\
& H-4-19017-3 \text { ENT } 65 \quad \text { GEB-85411-1.4 } \\
& H-4-36509.2 \text { SHT.663 GEB }-85212 H-19
\end{aligned}
$$

GEB - 85411-1-4 INTEKFERES LITH GEB- $\dddot{2}: 212+1-17$ + RLINS INJ THE WALL AS EHWWN

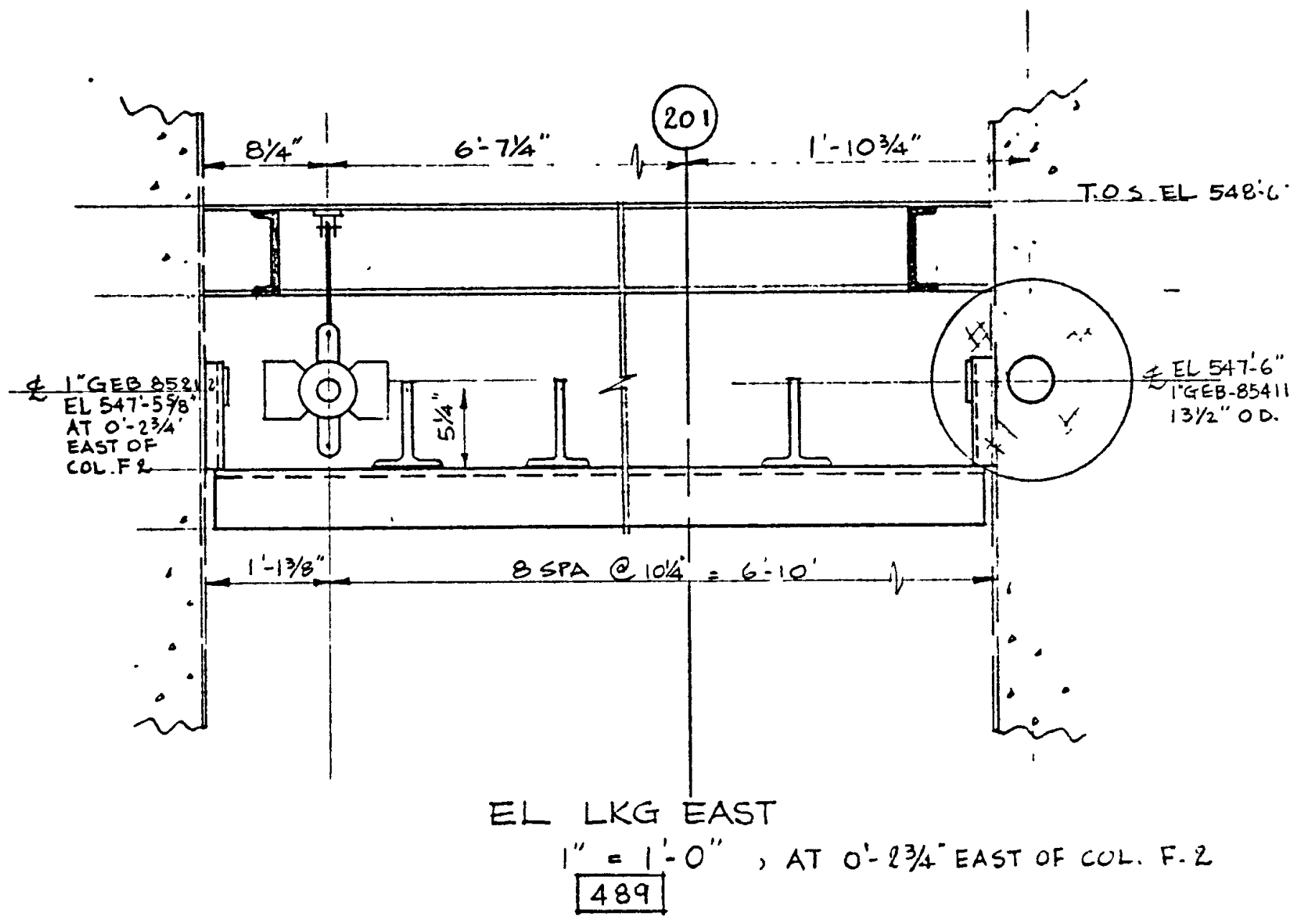


1024

FFTF
5 APRIL 71

ROJJE DOLL

H-4.19017 REV 3 5H LS PPG FAB $1=0$ GEB-35411

H-4-36E0.7 REV I SH 710 PIPE JUPPUFT GES- $55 \equiv 11$ H-

5" "MVULATION ON I" GEB- GSHII INTEKFEHE- WITH

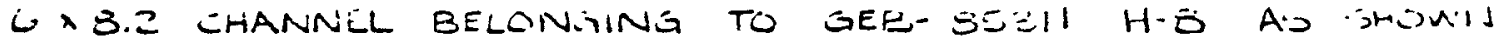

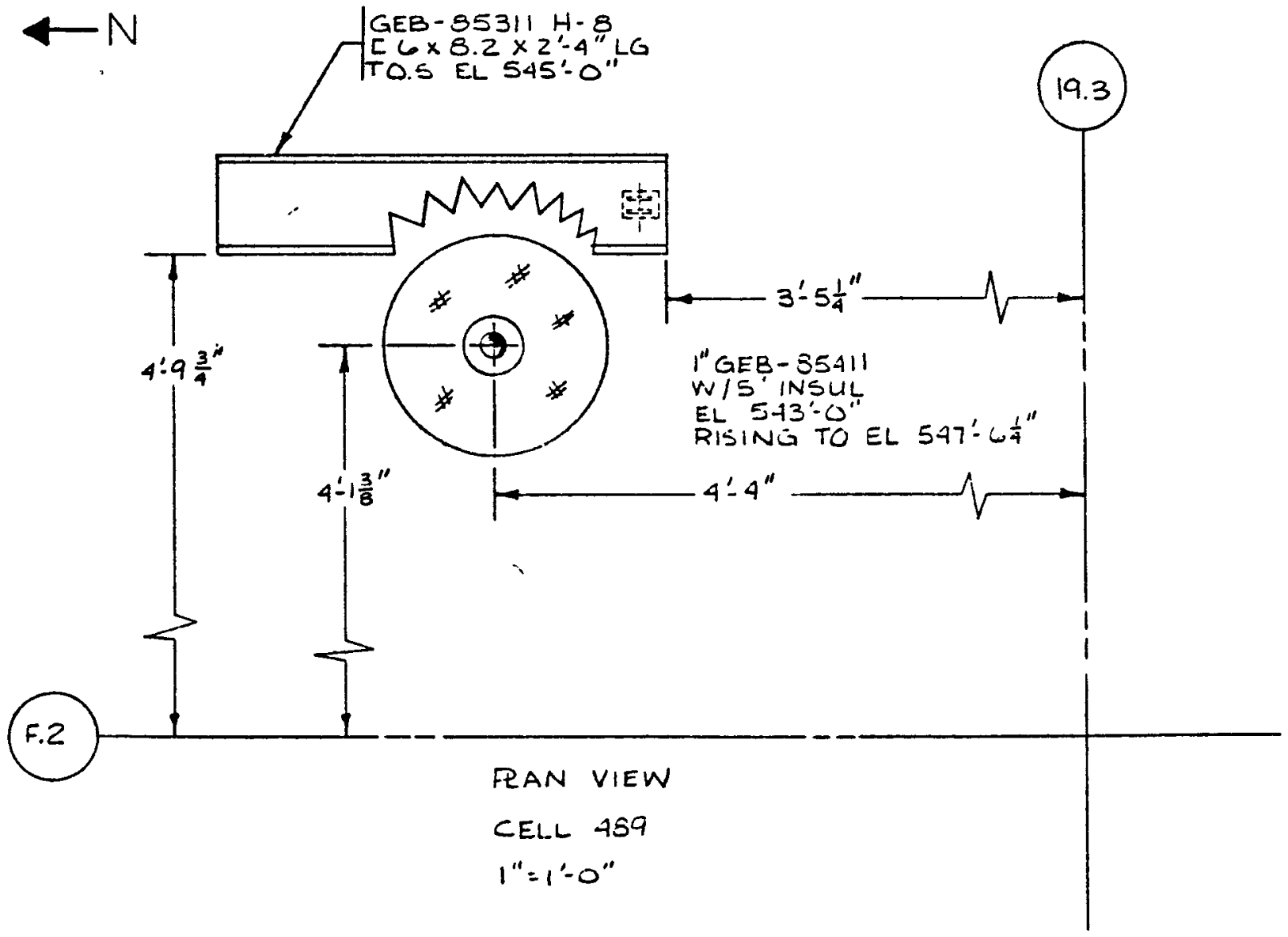




\section{$\because: \because ;$}

FFTF

,

$H-4-19017-3$ SHT 65

H. $4-36509-1$ SHT 851 $f-<\cdot 17$

$s+10$ $2-\because 7$

2

GEB. $854.12 \mathrm{H}-11$ INTEEFEKE: WUTH INSULATILN ON VERTILAL PIPE OF JEB-ES4II AS IHON'N

GEE. EE.111-1-1

GEB - $\$ 5412 H-11$ 

1024
$\therefore-\dot{0}$
510
FFTF
$H-4 \cdot 19017.3$ sit 65
$G E B-85411-1-1$
H- 4-36506-2 SHT 479
GEB - $-14: 5, H-10$
GEB - 6I+25 H-10 INTEL:FELE: LUITH GEE-E5+11-1-1 AS SHOWN.

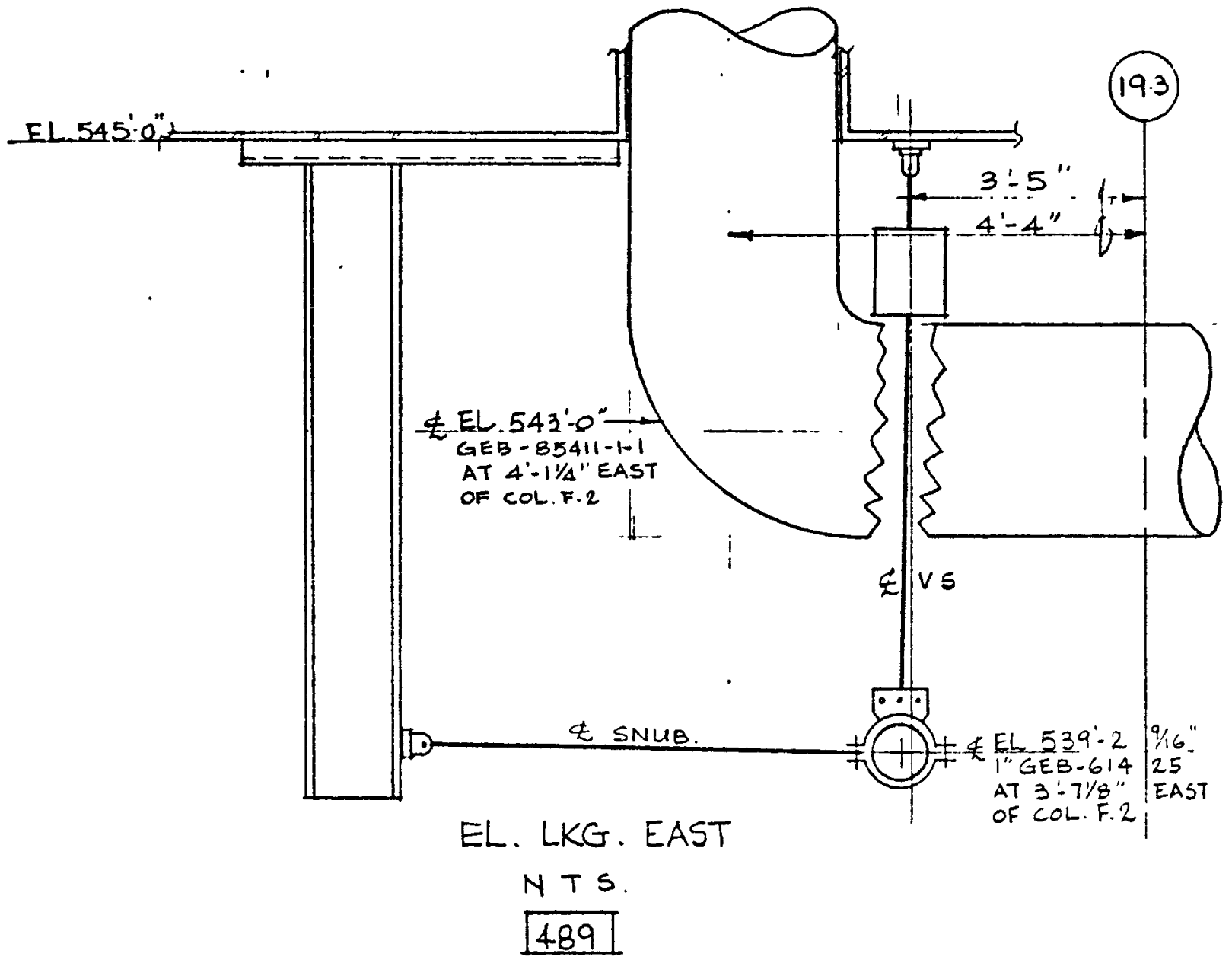


I $) \div-1$

FFTF

$H-4-19017-3$ StrT. 65

H-4 - 36.509-2 SHT. 711

$$
4-C-17
$$

$S \mathrm{HO}$

$G E B-E 5+111-1-1$

GER - 5.5211H-9 $\therefore \quad \because 2:$

2

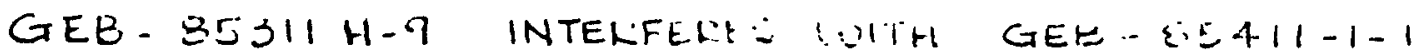
AS SHOLUN.

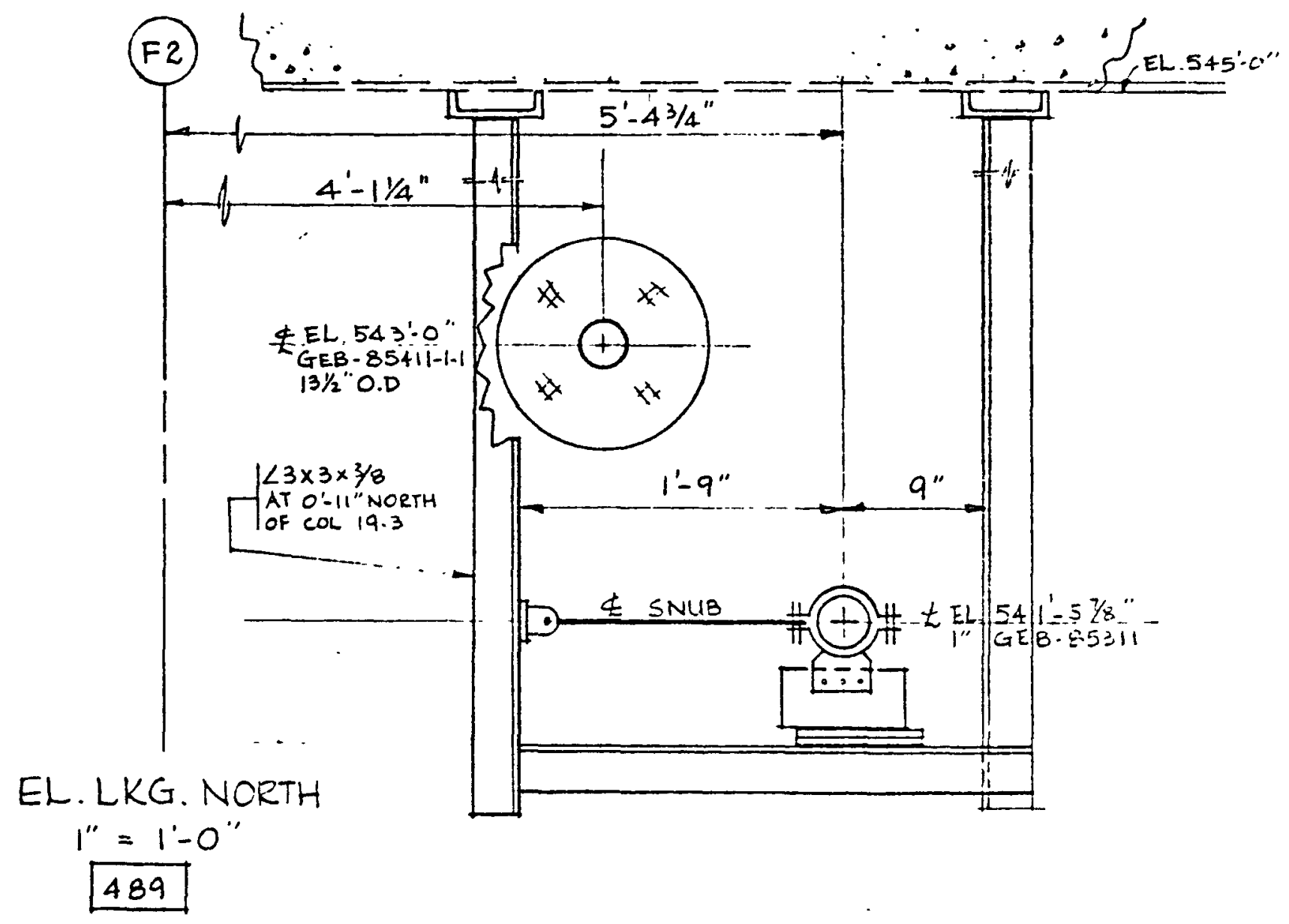


1024

EFTF

H. 4-19017-3 SHT. 65

H- $4.36509-2$ SHT 848
$4-6-77$

S HO

GEB - 85411-1-1

$G E B-85412 H-8$
$2-210$

2

GEB-85412 H-8 INTERFERES LUITH GEB-85411-1-1 AS SHOLUN.

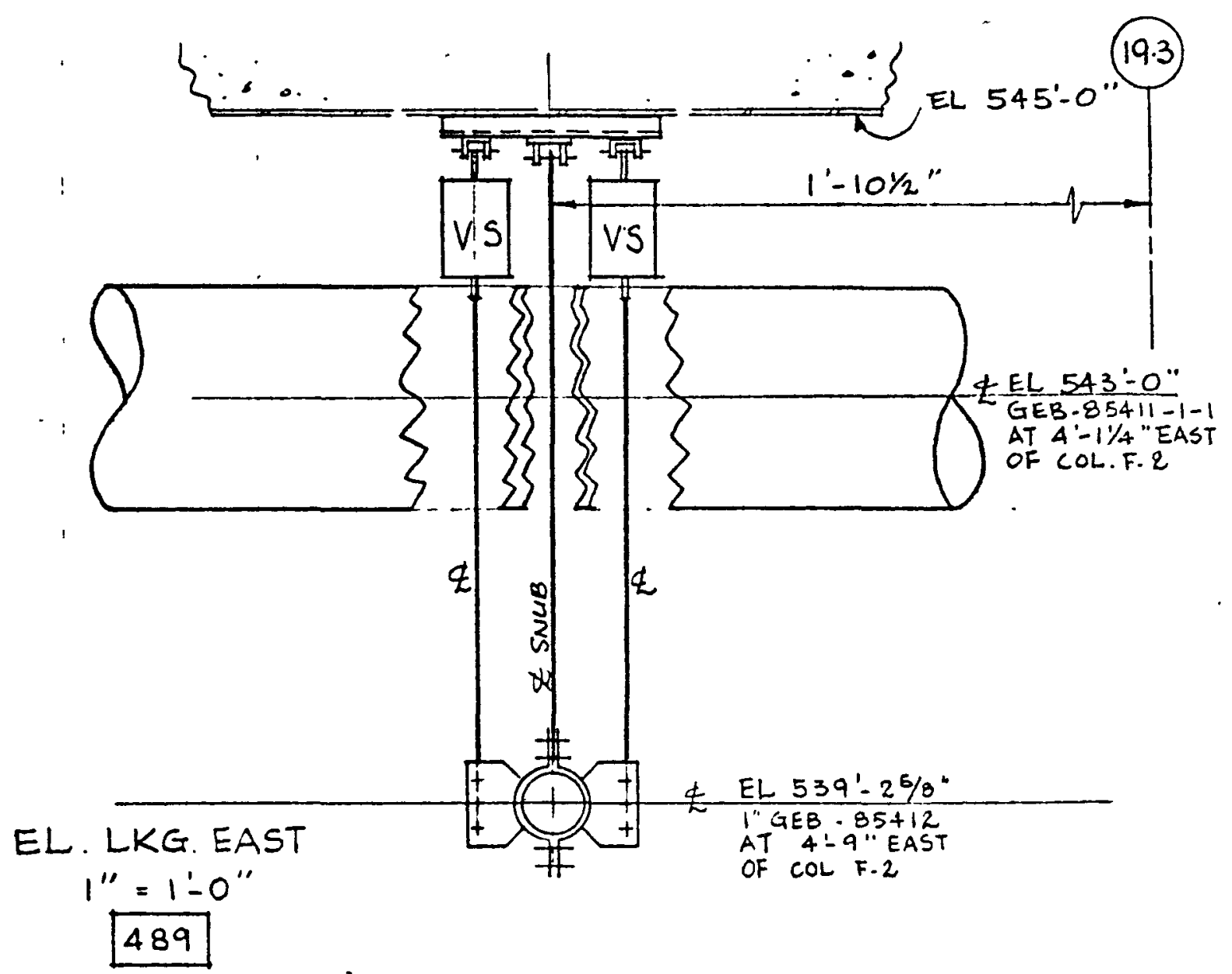




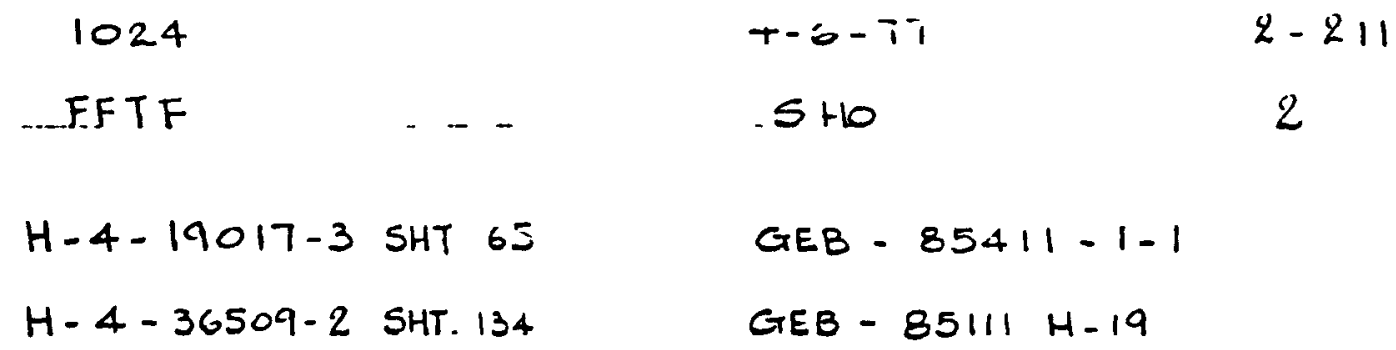

GEB - 85111 H-19 INTERFERES WITH GEB-85411-1-1 AS SHOWN. 


$\begin{array}{lll}1024 & 4.6-77 & 2 \quad 4.1 C \\ \text { FFTF } & \text { SHOO } & 2\end{array}$

H-4 - 19017-3. SHT 65 GEB - 85411-1-1

H. 4. 36509.2 SHT. $30 \quad$ GEB $-85111-H .21$

GEB-85111-H21 INTERFERES WUITH GEB. $85411-1-1$ AS SHOWN.

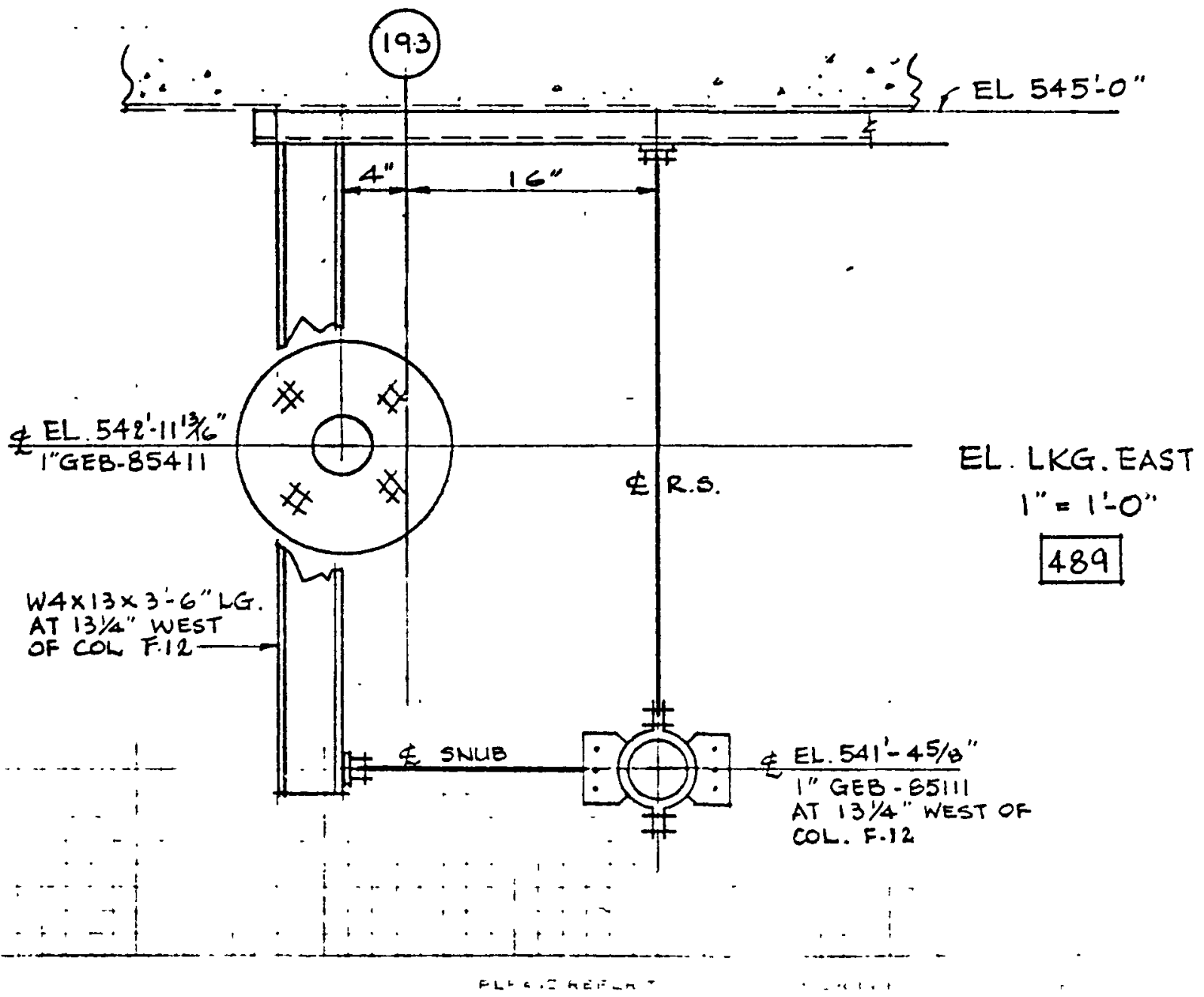


$10 \geq \therefore$

$F F T F$
6 ApqIL, 7

$\sigma_{1}+\tan _{1}+1$

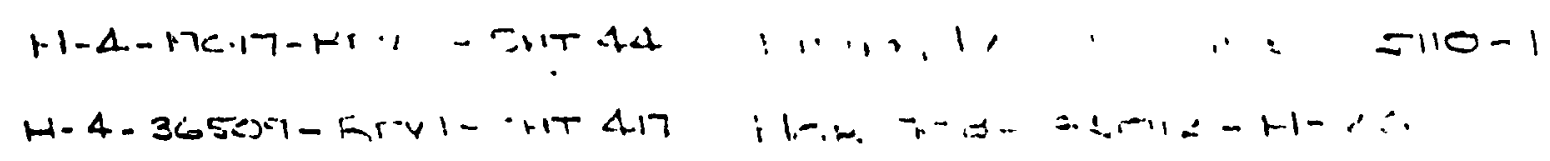

INSULATION ON I" GEB-ESIID INTEHFLHF"

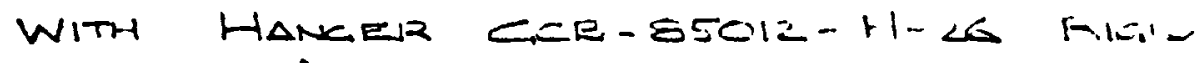

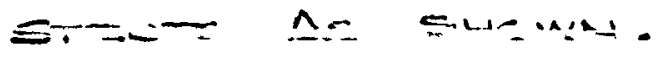

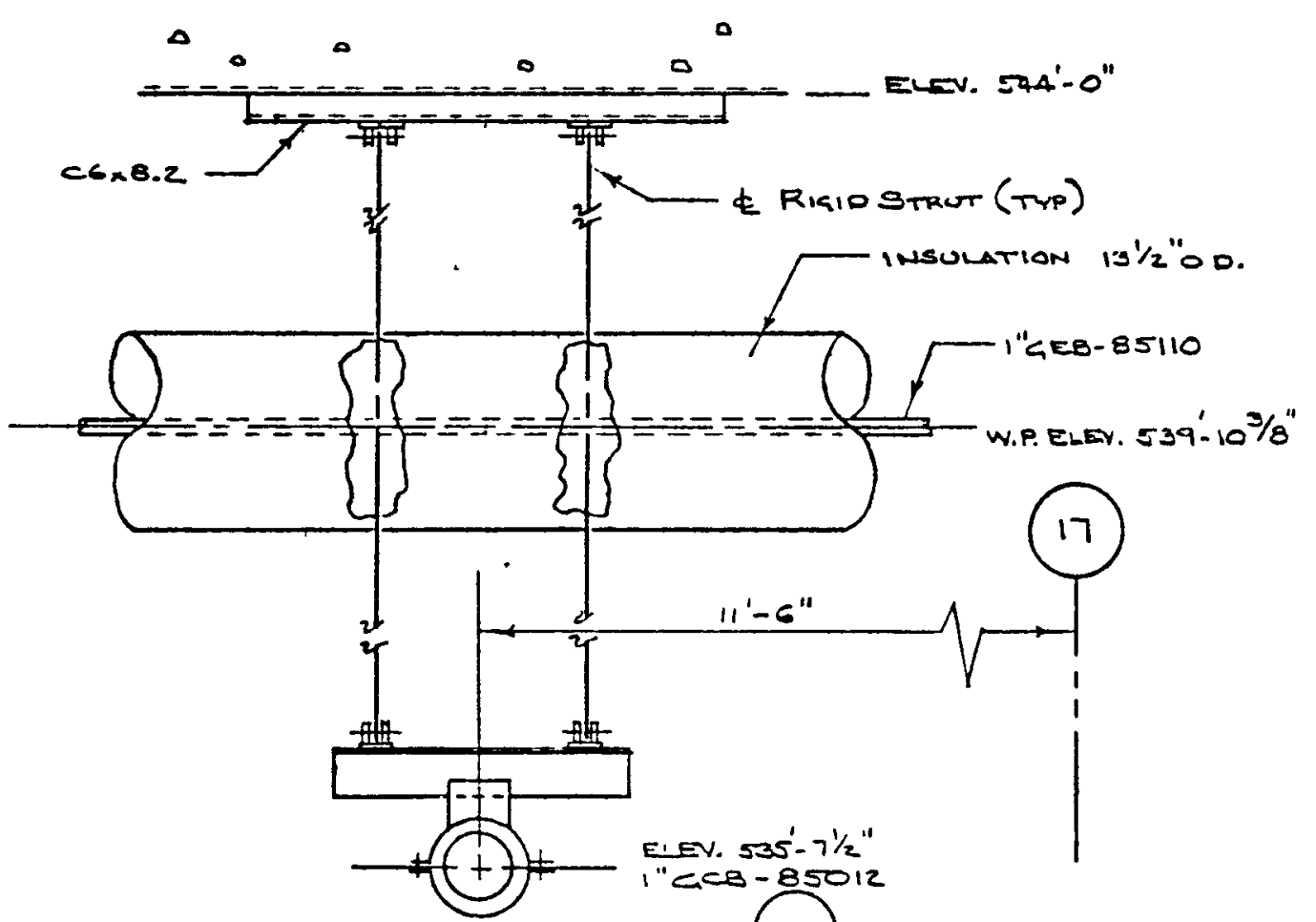

ELEV - LKG. EAST Q 27'-2" EAST F.5 N.T.S.

$$
\text { CEL } 422
$$




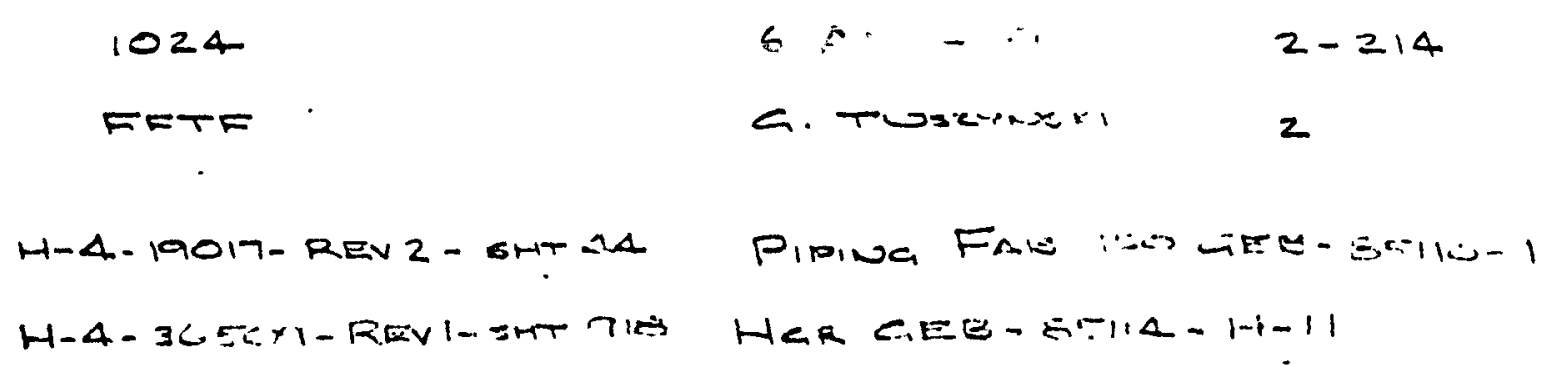

2

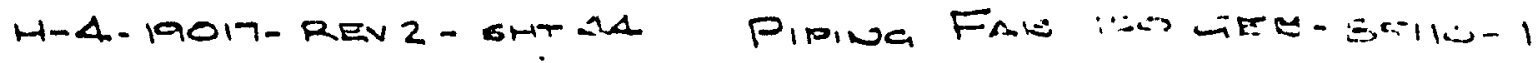

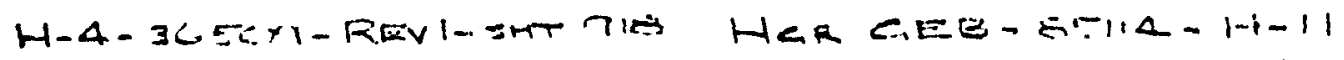

INSULATION ON I" CEB-BSIIO INTERFFHES
WITH HANGER GEB-85114-H-11 AS
$=\therefore=\therefore-\therefore$.

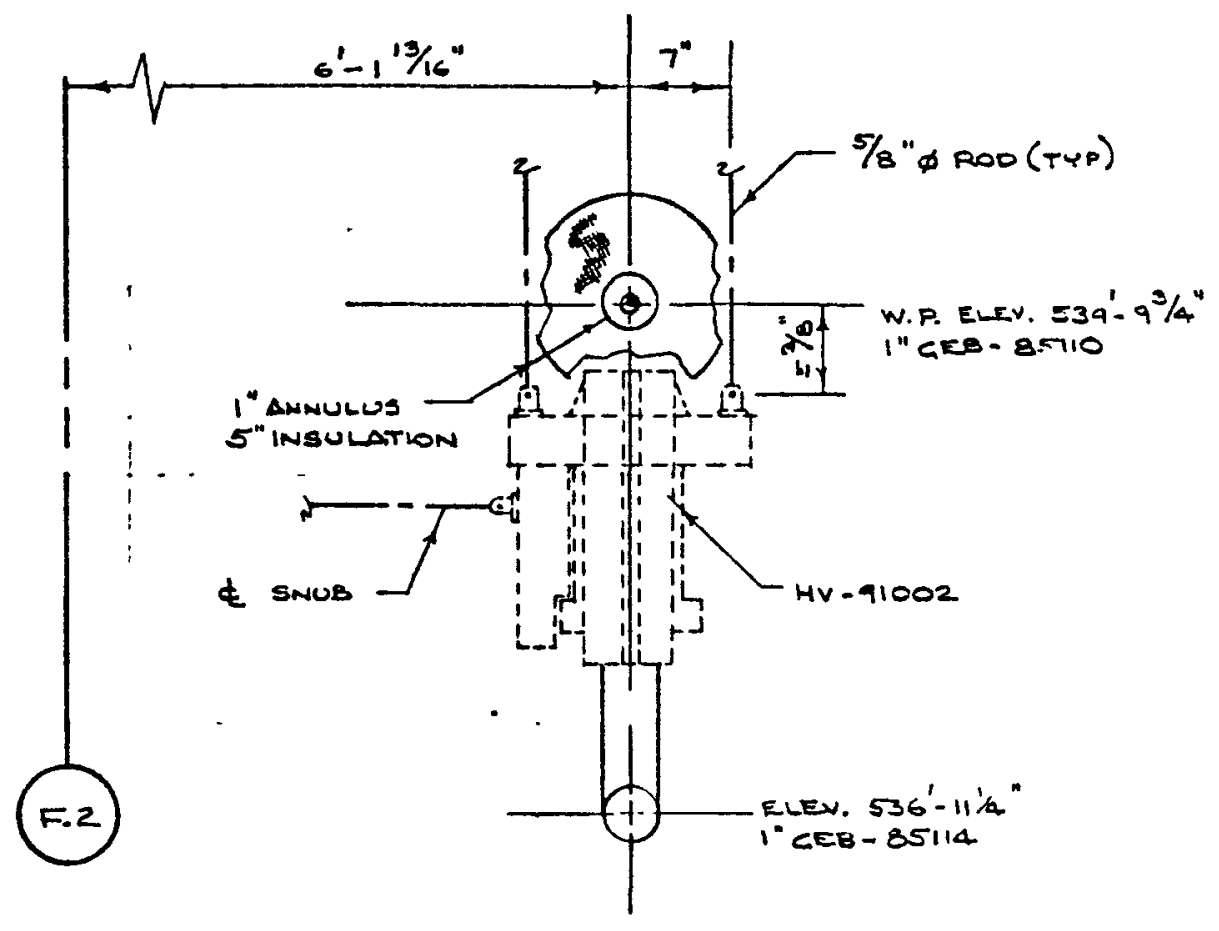


1024

FFTF
6 APMI T7
C. Toszanisk

$2-215$

$<$

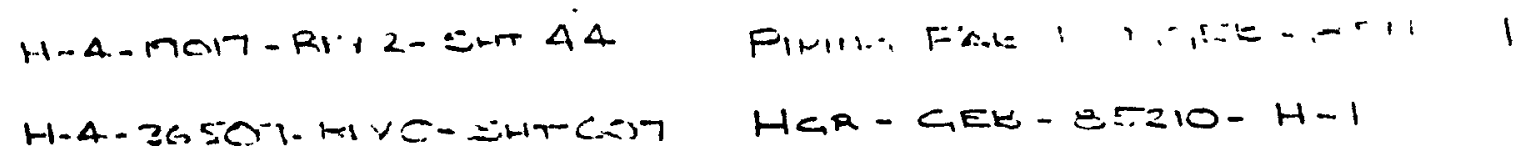

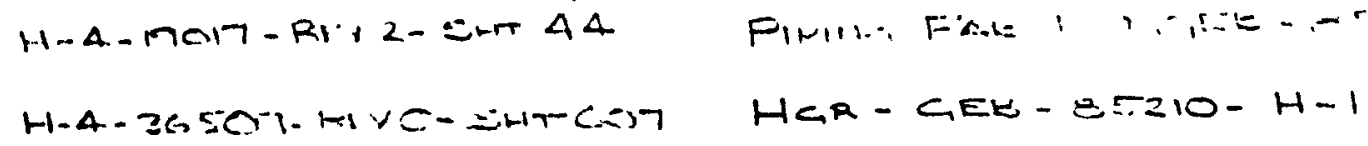

INSULATION ON 1 "LEB-85110 INTERFFEFE=

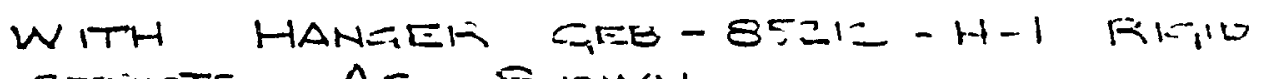
LTHOTS $A S$ SNiven.
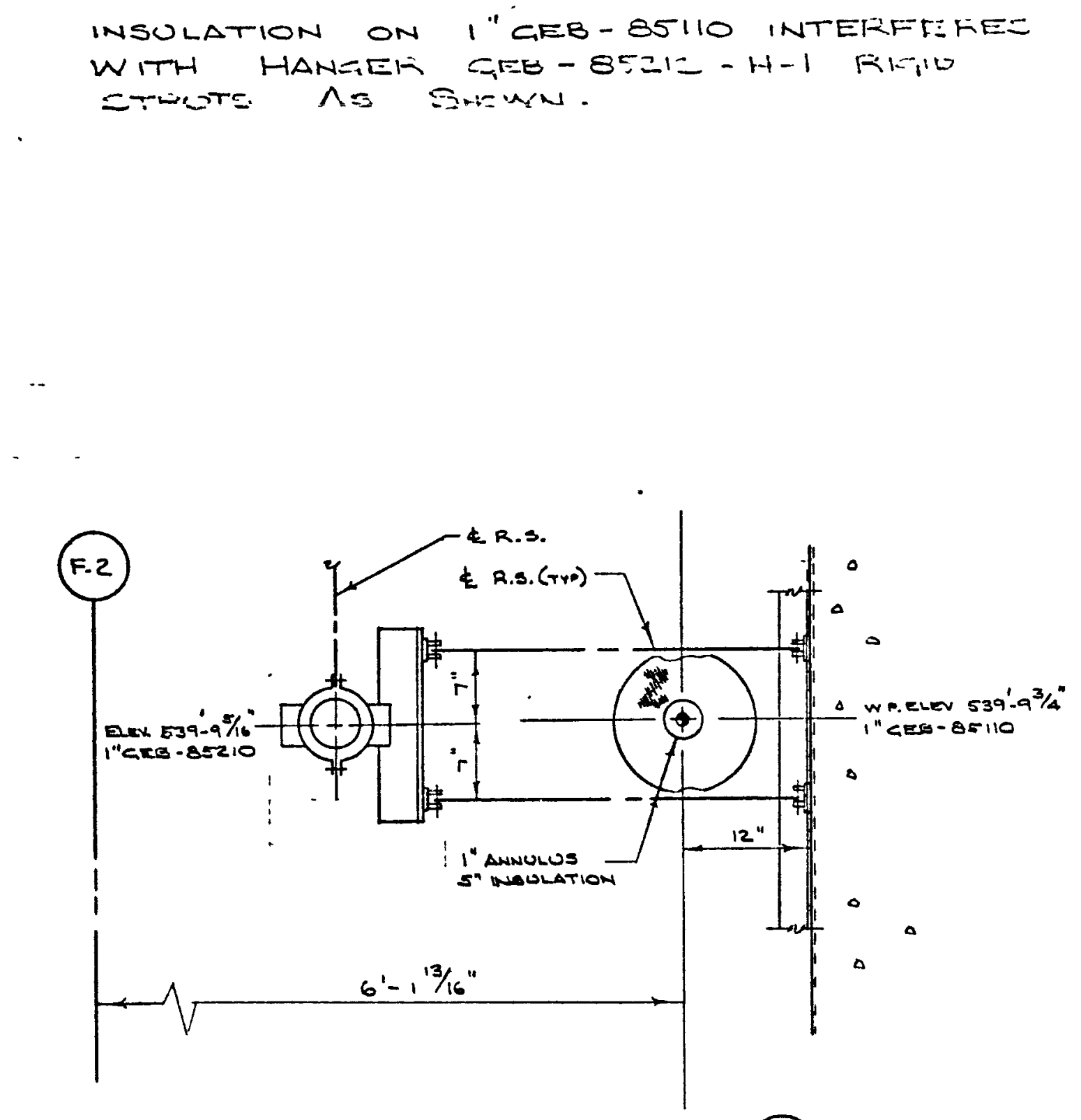

$\frac{\text { ELEX. LKG. NORTH O } 11-10^{3 / 4} \text { "NOWTH } 17 \text { N.T.=- }}{\text { CELL } 422}$ 
$10 ?$

FFTF
$6 \triangle P R I L 77$

C. TUSx-2r-2=k1 $\because-216$

2

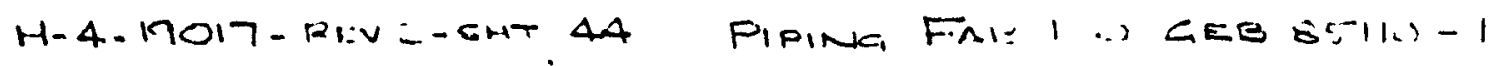

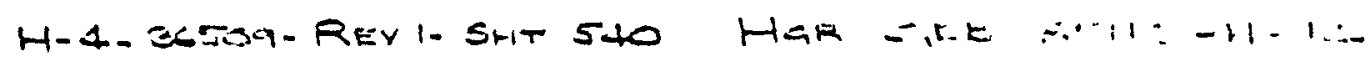

INSULATION ON I"GEB-S5110 INTERFERES WITH HANEER GEB-85110-H-12 ETRUTUFAL

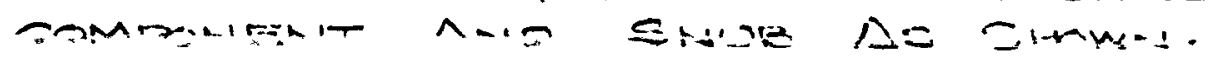

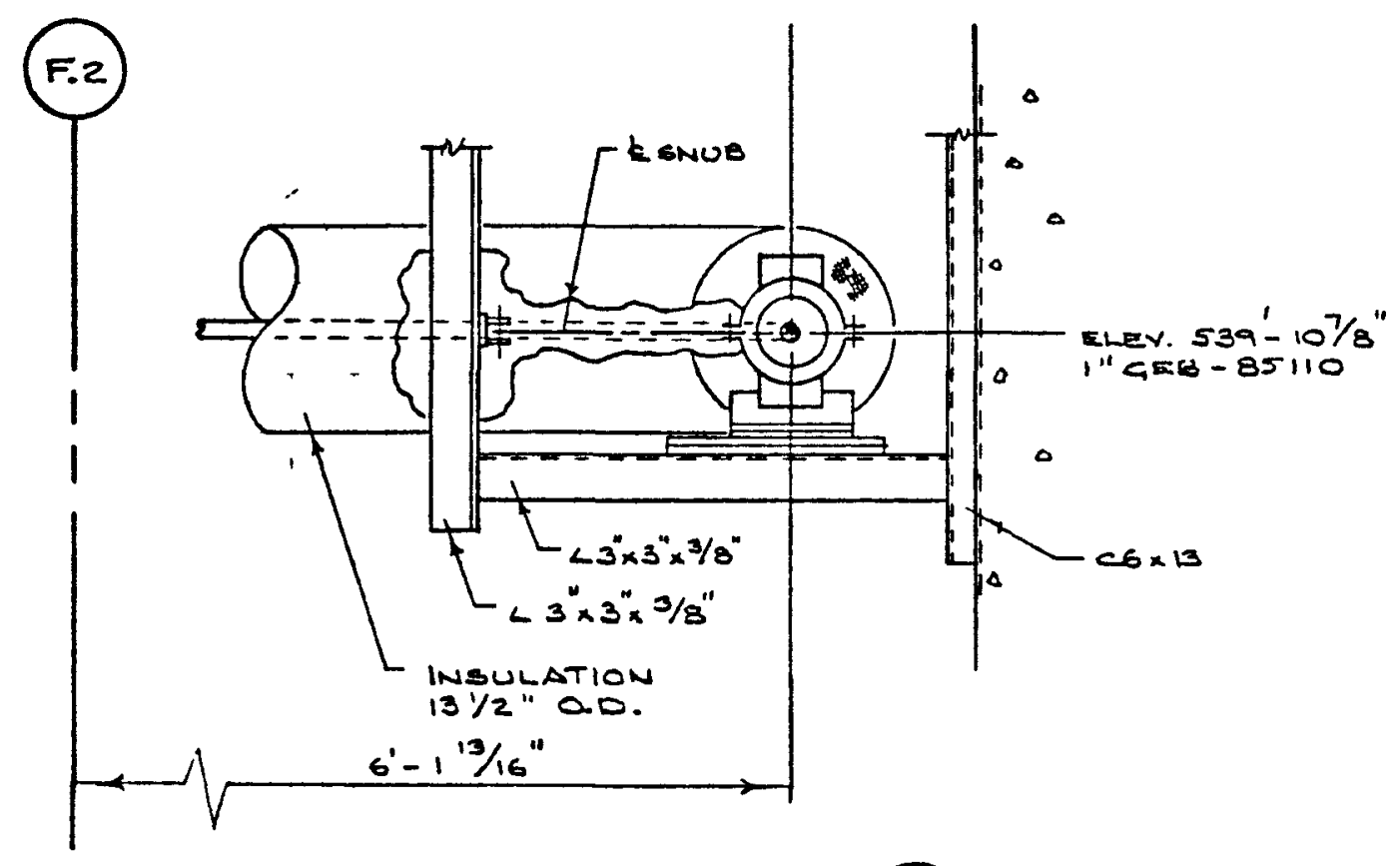

ELEV. LKG. NORTH Q 13 " NORTM 17 N.T.S.

CELL 422 
1024

FFTE

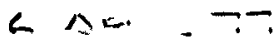

C. TUsentar.
$2-217$

乙

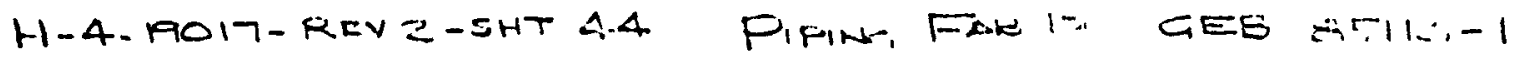

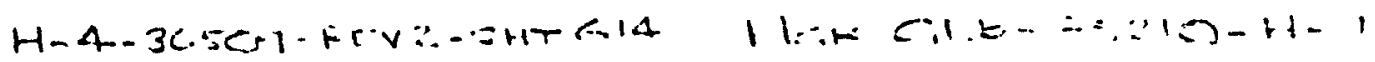

INSULATION ON I" GEB-85IIO INTERFFRES WITH HAMCIER GFE-85:10-H-T

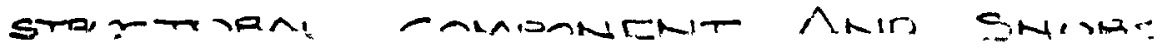
As SHOWN.

$\cdots$

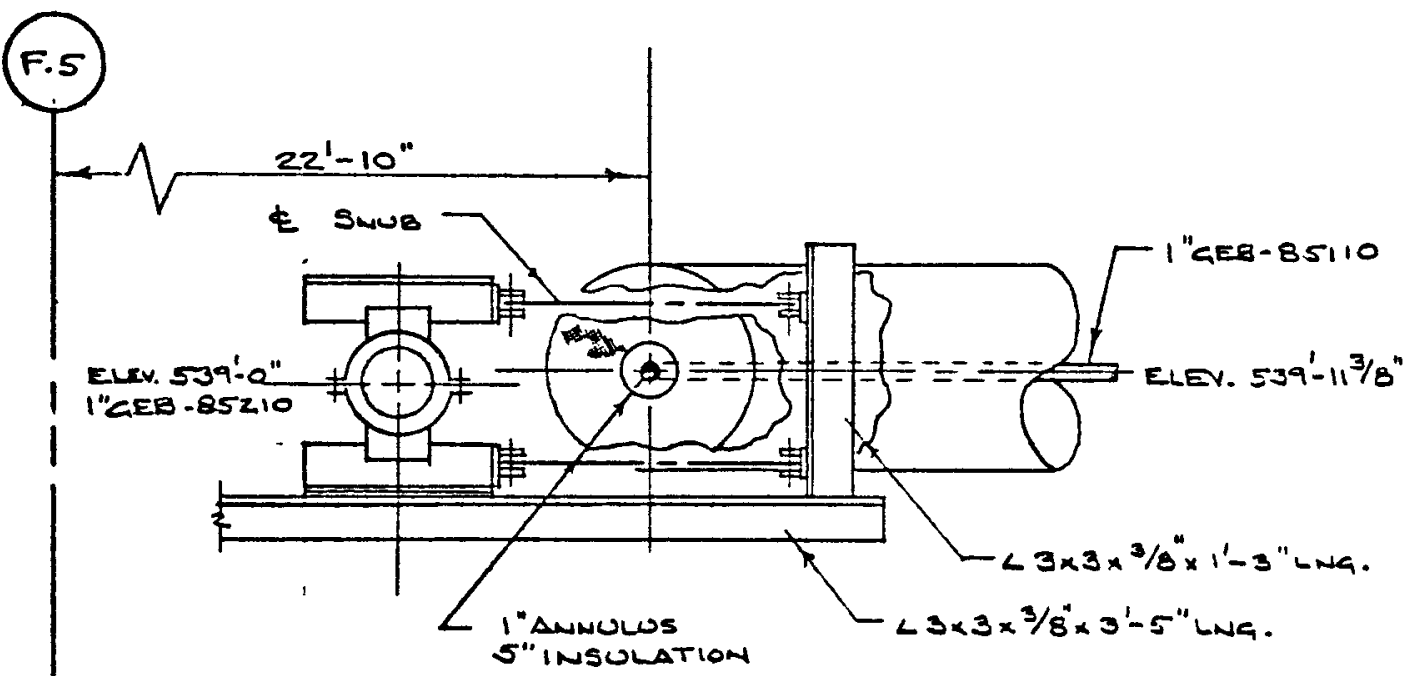

ELEV. LKG. NORTH \& 9'-61/4" Sarth 17 N.T.S.

CELL 489 
1024

$4 \cdot 5-77$

$\therefore-210$

FFTF

BARRY VE:TK=

2

H-4-19017-REV.1-SHT. 52 PPG.FAB. II. GEE 85:10 $H-4-36509$-REV.I SHT.923 HGR. GEB-85:14-H-19

GEB-85210 INTERFERES WITH HGR.GEE. $H=19, S H T 923$.

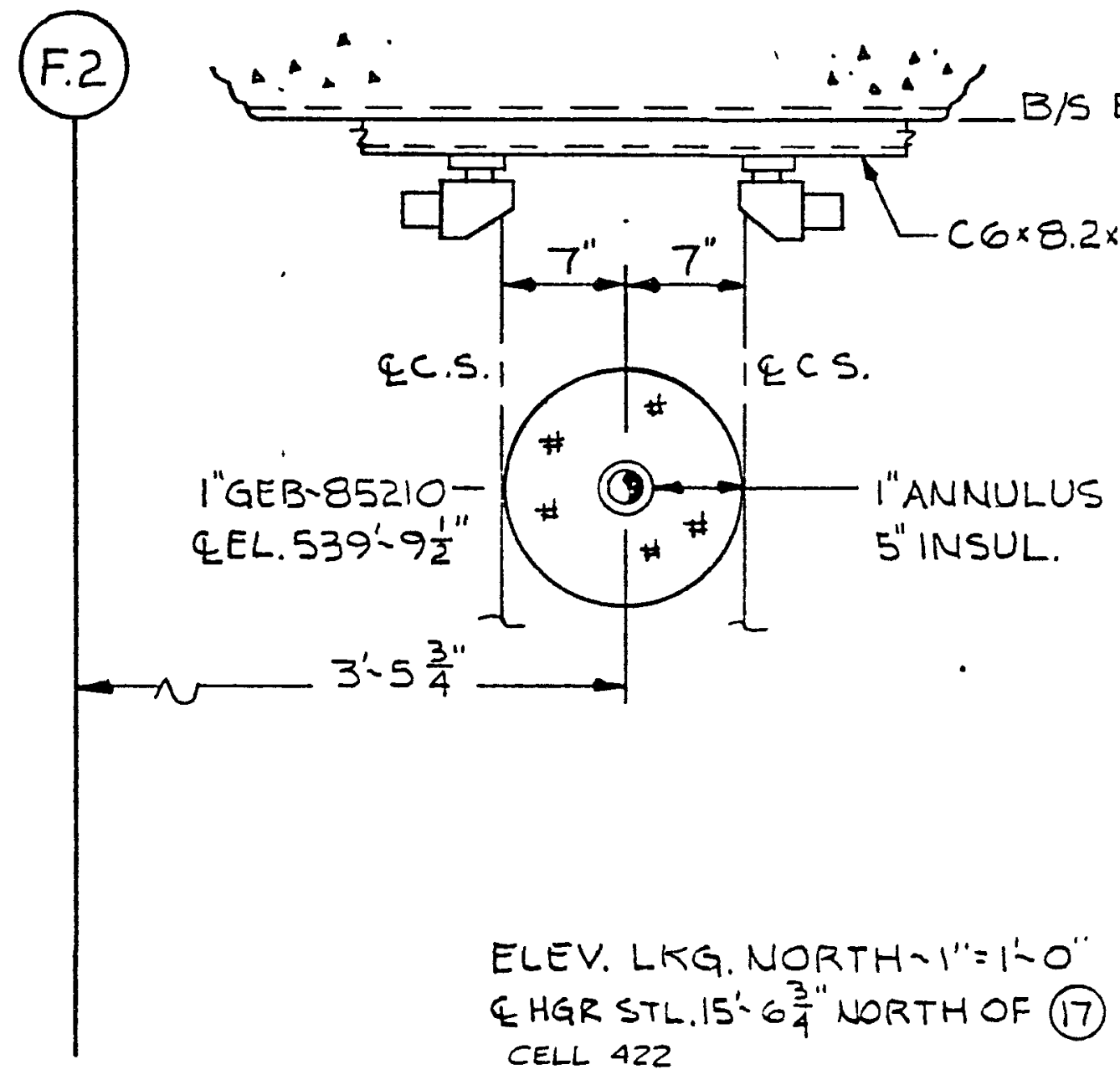



$k=? 4$
A $0 \cdot 11$
$2 \cdot 219$
FFTF
BARRY VE: $1: \because$
2

H-4-19017-REV.2-SHT.52 PPG. FAS-10.0. GEE-85210 H-4-36509-REV.O-SHT.693 HGR GEE. 85.214-H-18

GEB-85210 INTERFEIKLS WITH HGR. GEE-SSZH $H-18,5 H T, 093$.

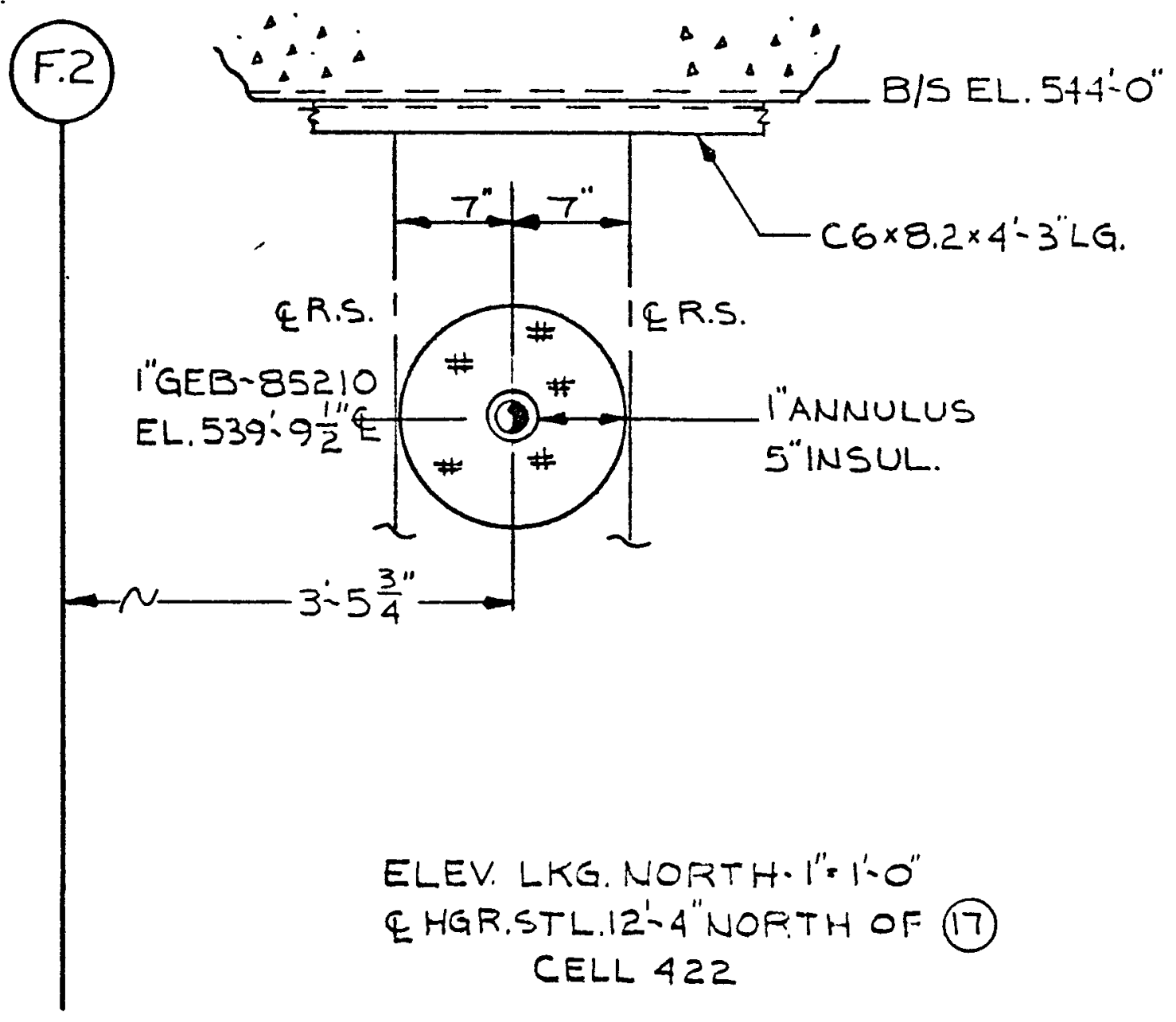


1024

FFTF $\therefore-6-77$

BAREY VESTKK
cここU

2

H-4.19017.K1 /2 SHT.52 PFG FAE. I. GEE. 35210

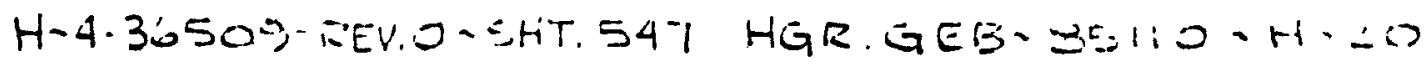

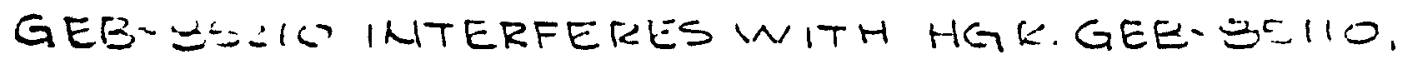
$H-20,=H T .547$.

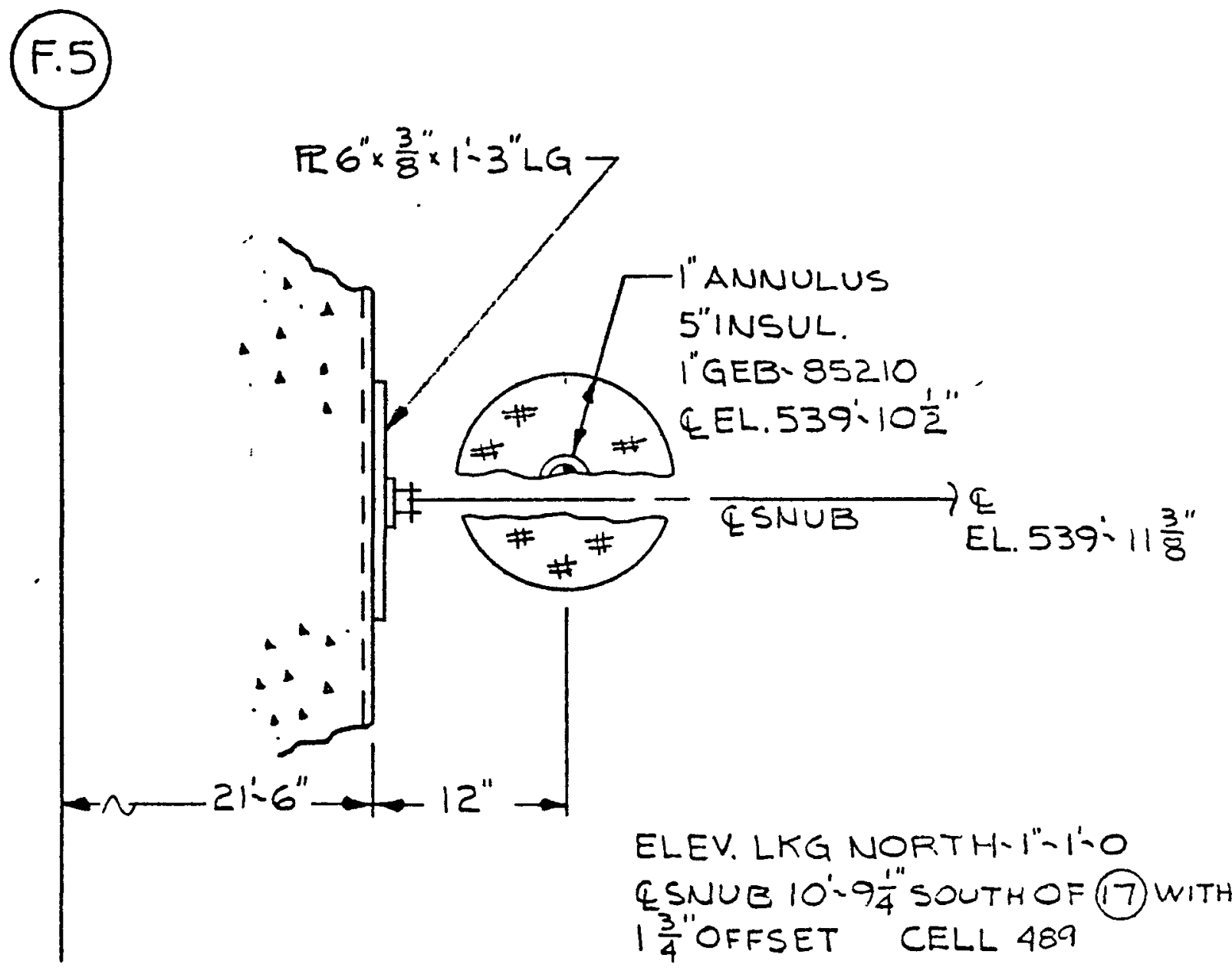


1024

FFTF
$4-6.77$

$2 \geq 21$

Barky Ve:-1LiE

2

H-4.19017-KEV2-SHT. 52 PHG ISH... GEE-85210 H.4-365OY.EEV.1 - SHT. 678 HGK GEE-35214, H-3

GEB-BS-10 INTERLELLE: WI: HGR. GEH-E... H $H \cdot 3$, SHT G-18.

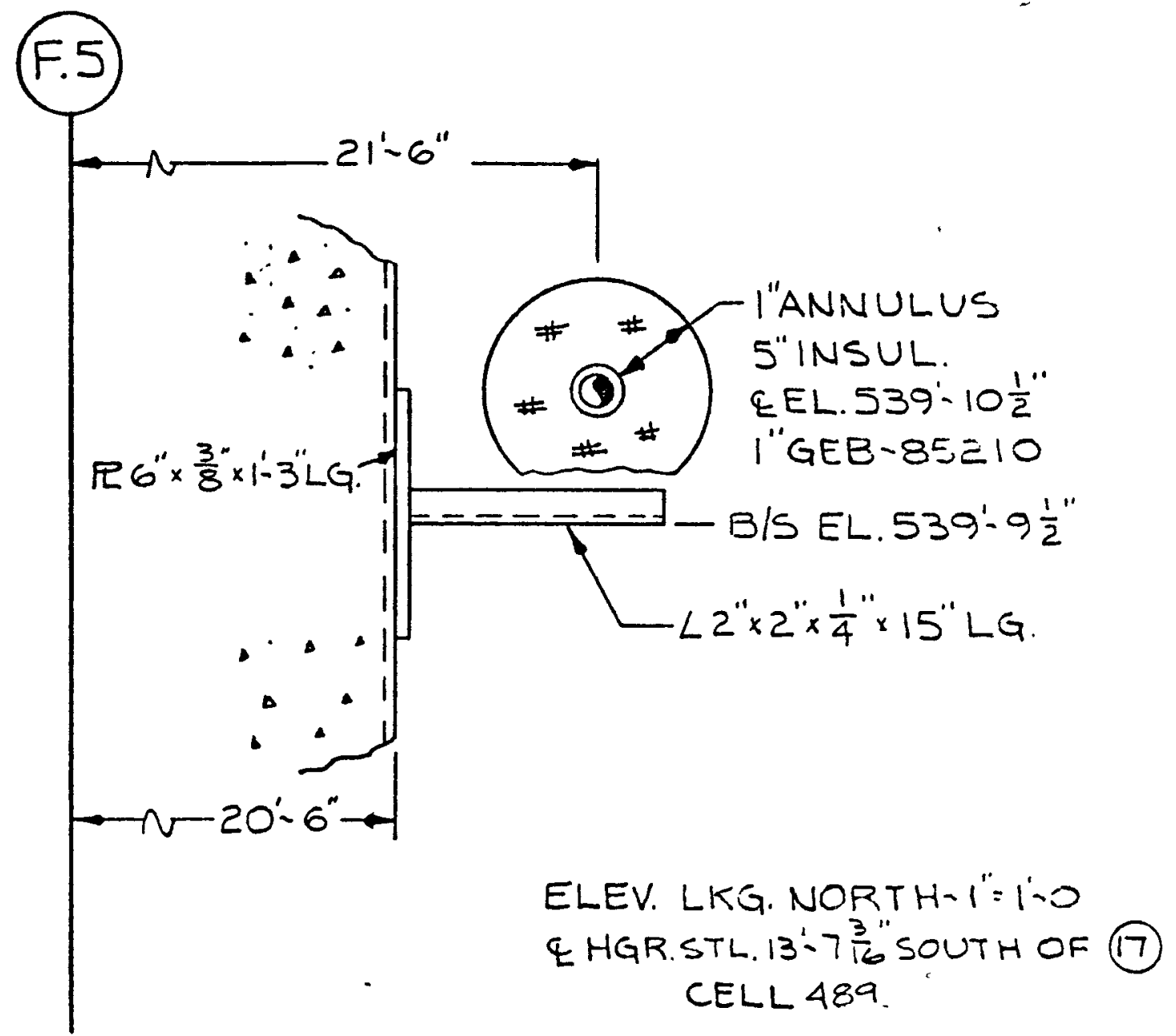


:0? 4

A-e i:

$2-22=$

FFTF

BARRY VE:TEL

2

H-4-19017-REV.2-SHT. S2 PPG.FAB-1. GEB-55-10 H-4.3650\%,RENO-5HT.677 HGE GEE. $3=214 . H-2$

GEB-8SLIO INTERFEKE: WIM HGR GEE$H-2, S H T .6 \% \%$

(F.5)

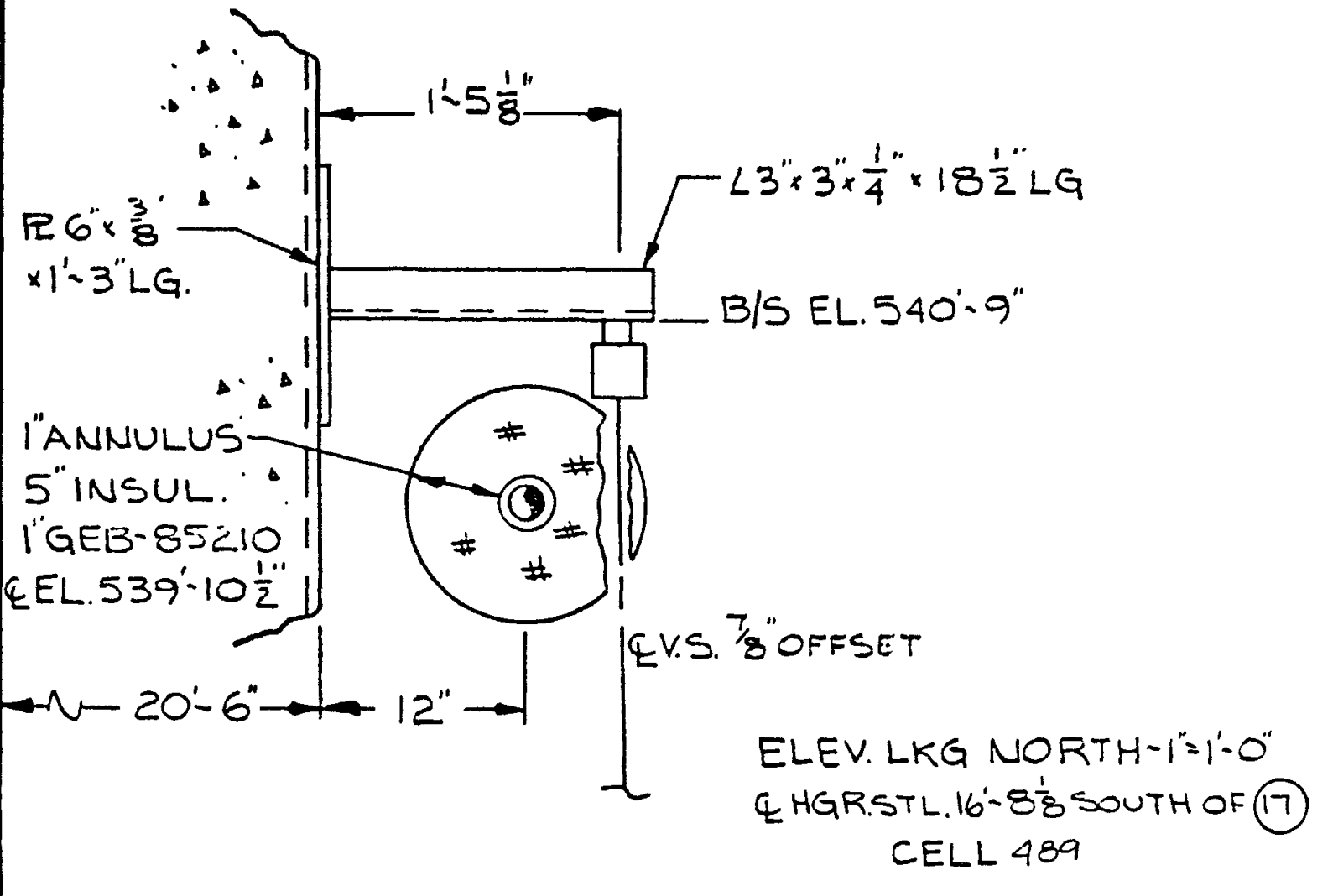


1024

FFTF

$$
4 \cdot 6-77
$$

BARRY VESTEL $\because 2$

¿

H-4.19017-REV.2-SHT.52 PFG FAE 1.0 GEE-ES210 H-4-36506-REV.ISHT. 504 HGR GEB-61225-H-11

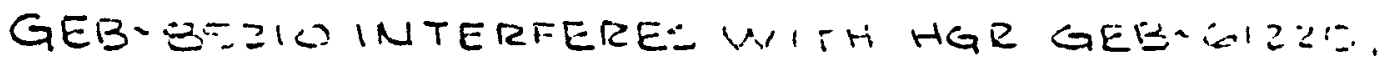
$H \backslash 11, S H T .504$.

F.5

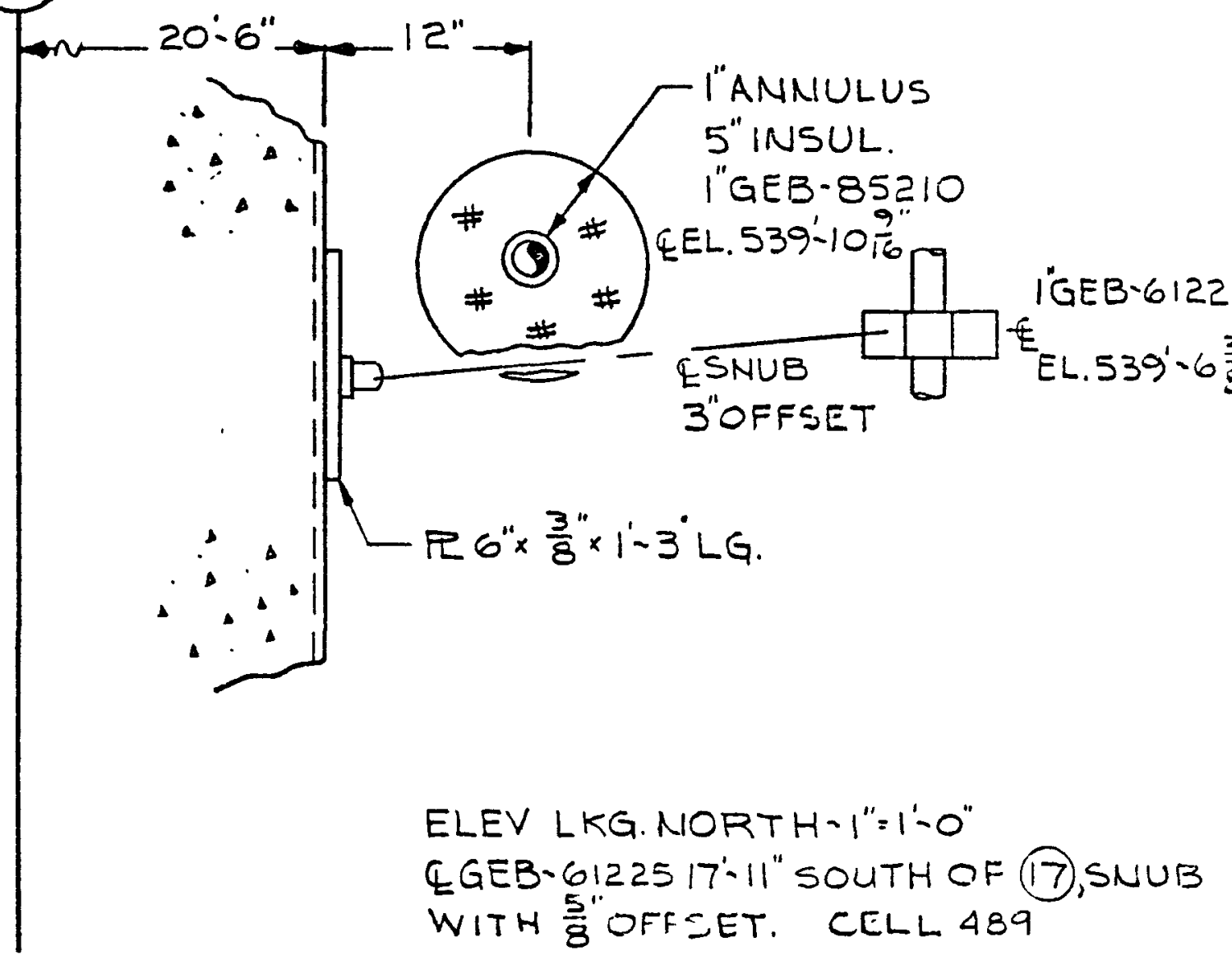


1024

FFTF
$4-6 \cdot 77$

Barry Vesilk
$2-224$

2

H-4-19017-REVZ--HT.52 FFG.FAB. $150 . G E B-B=210$

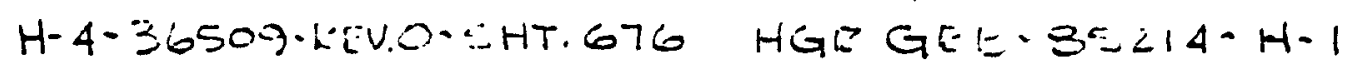

GEB-35210 INTERFELES WVITH HGE GICE BA: $H-1, S H T .676$

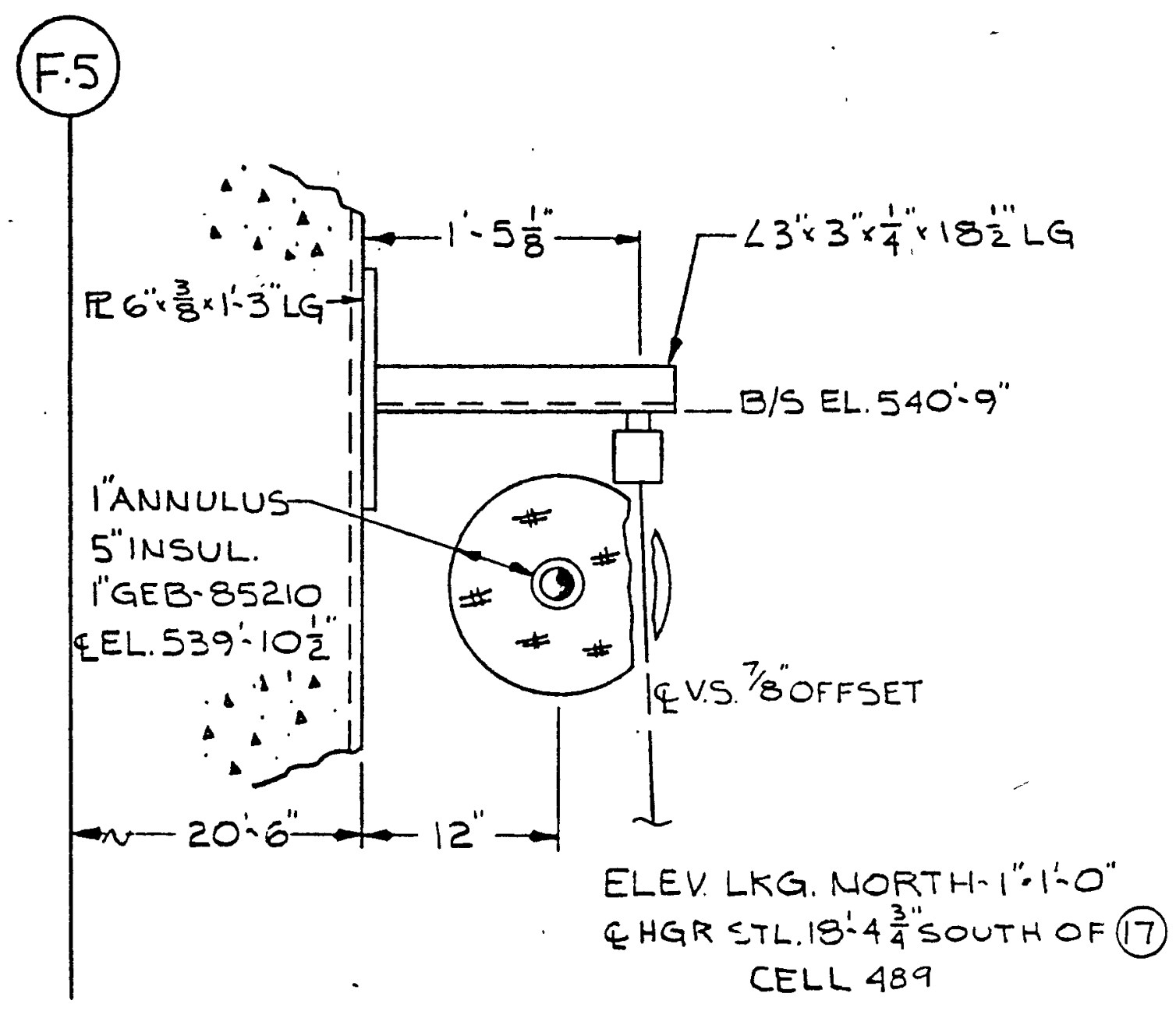


$! \bigcirc 24$

FFTF

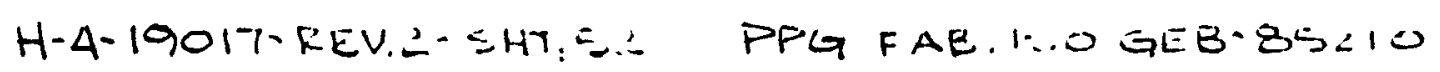

$H-4.36509 . R E V 1-E H T .70$ GEB. $35310 \cdot H \cdot .4$
$2-225$

barry Vester 2

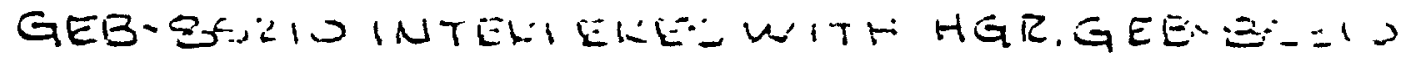
$H \sim 34,-D H T 70$

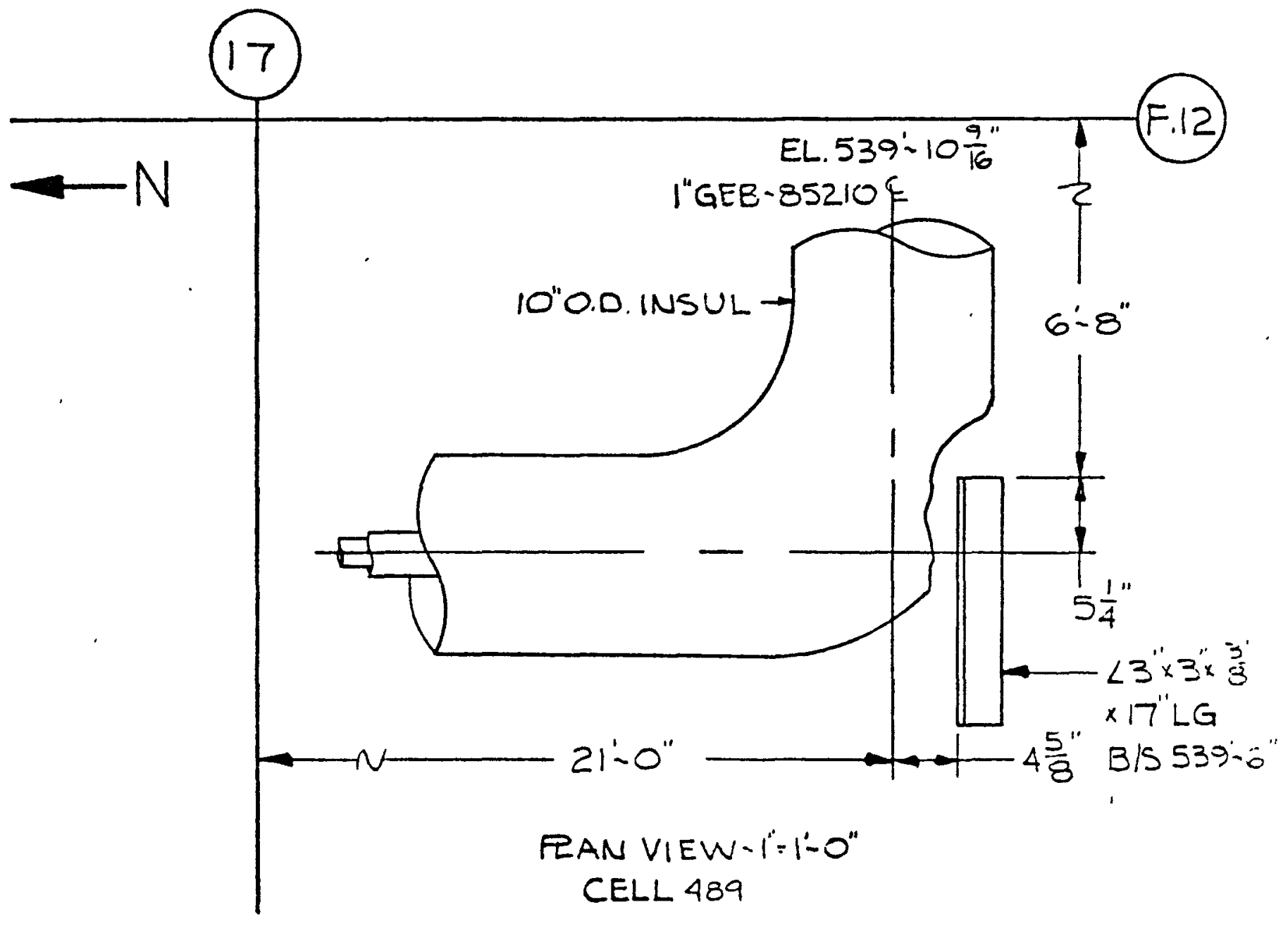


$10 \geq 4$

FFTF

$$
4-6-77
$$

$K M C$ $=\ldots=6$

2

H-4-19017 REV.3 SH. 59 PPG. FABRICATION 130. I" GEB-85311 $\mathrm{H}-4-36502$ REV.O SH. 812 PIPE SUPPORT HBD-25153 H-1

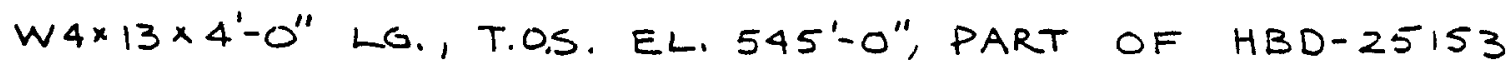
H-1 INTERFERES WITH VERTICAL SECTION OF I" GEB-853II U/E" INSULATION AL SHONN IN! PIAN WIEU

17.95

17.95

$-5^{\prime}-2$

$\stackrel{2^{\prime}-5^{\prime \prime}}{\longrightarrow}$

$2^{\prime \prime}$

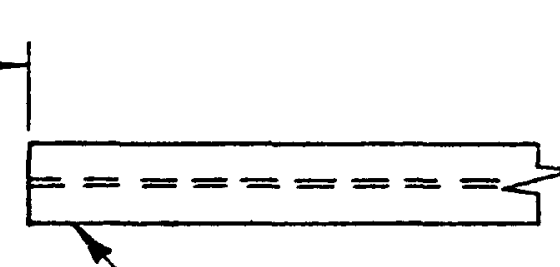

HBD-25153 H-1

W4 $\times 13 \times 4^{\prime}-O^{\prime \prime}$. LG.

T.0.5. EL. $543^{\prime}-O^{\prime \prime}$

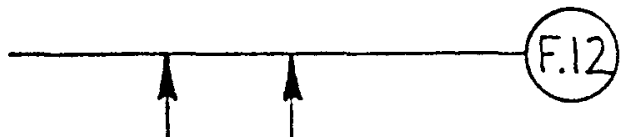

$N$

$$
\begin{aligned}
& \text { PLAN VIEW } \\
& 1^{\prime \prime}=1^{\prime}-0^{\prime \prime} \quad 489
\end{aligned}
$$




$\begin{array}{ccc}\text { IOZ4 } & 4-6-77 & .2-227 \\ \text { FFTF } & K M C & 2\end{array}$

H-4-19017 REV. 3 SHI 59 PPG. FABRICATION ISO I" OEB-85311 H.4.36509 REV. 3 SH. 755 PIPE SUPPORT GEB-85 312 H-27

$45^{\circ}$ TRAPEZE AND $1^{\prime \prime}$ SNUB BOTH PART OF GEQ.85312 H-27 INTERFERE WITH $5^{\prime \prime}$ INSULATION ON I" GEB-85311 AT 13 '-1" NORTH OF COLUMN 19.3

ELEV. LKG. NORTH @ $13^{\prime}-1^{\prime \prime}$ NORTH OF COLUMN 19.3 $I^{\prime \prime}=1^{\prime}-0^{\prime \prime} \neq 48$

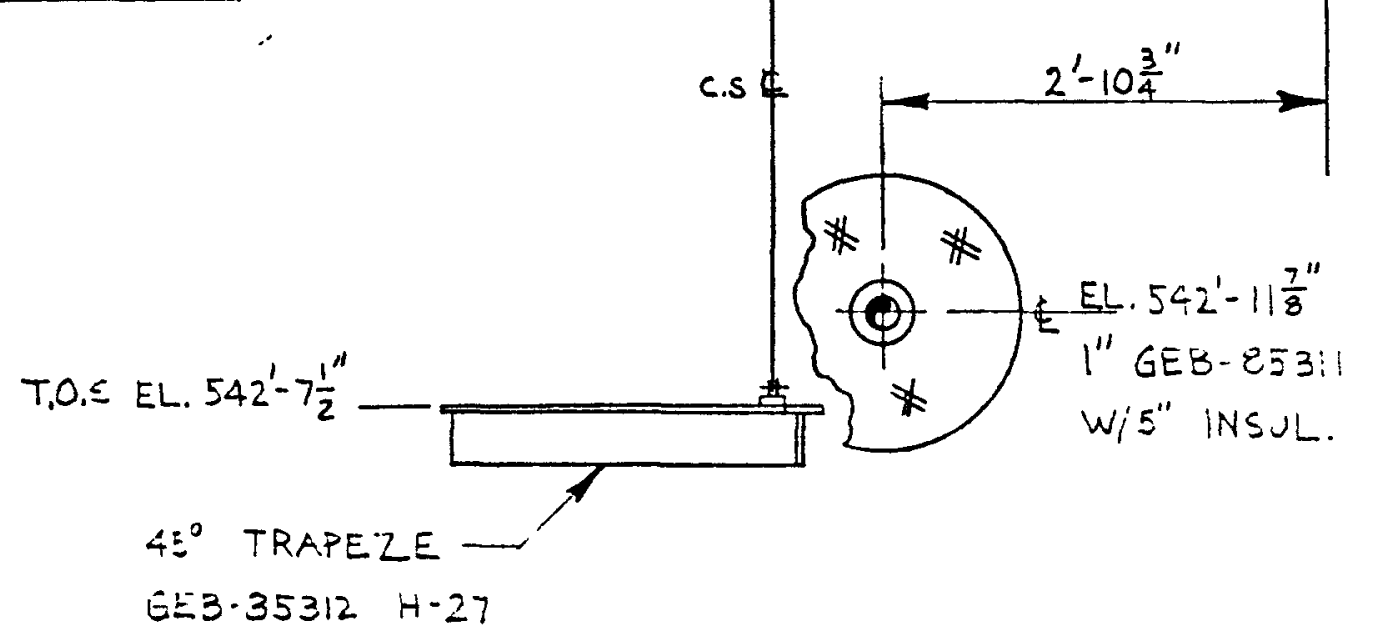


1024

FFTF
$4 \cdot i \cdot i T$

$K M<$
2ーこコシ

2

H-4-19017 REV. 3 SH. 59 PPG. FABKICATION 15O. 1"GEB-35311 H-4-36509 REV 3 SH.756 PIPE SUPPOAT GEE.85312 H.28

I" SNUB PART OF GEB-85312 H.28 INTERFERES WITH

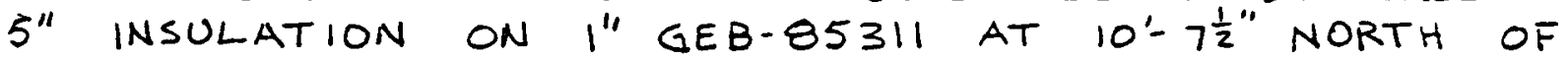
COL:MAN 19.2

T.O.S EL. $542^{\prime}-3 \frac{7}{8}^{\prime \prime}$

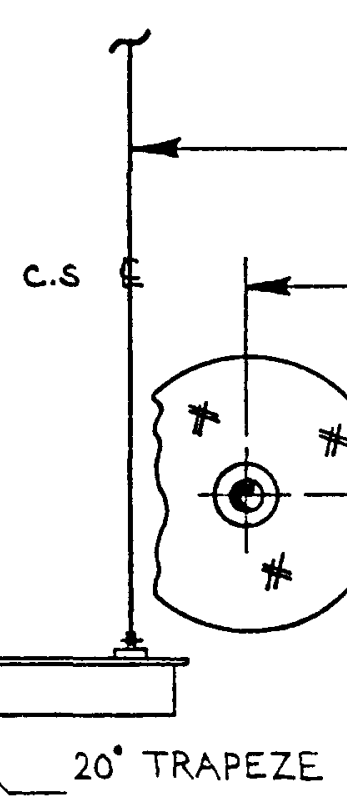

GEB-85312 H-28

$3^{\prime}-4 \frac{3^{\prime \prime}}{8}$

$2^{\prime}-10 \frac{3}{4}^{\prime \prime}$

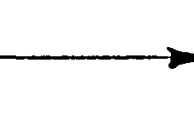

$\frac{10}{d x}$

EL. 542'- $11 \frac{7}{8}^{\prime \prime}$

"GEB-85311

$W / 5^{\prime \prime}$ INSUL.
ELEV LKG. NORTH

@ 10'-5" NORTH OF

COLUMN 19.3

$1^{\prime \prime}=1^{\prime}-0^{\prime \prime} \# 489$ 
1024

FFTF
$4-6-77$

$K M c$ $?-\because \cdots:$

2

H.4-19017 REV 3 SH. 59 P.P. FABRICATION 1SO. I" GEB-853II H-4.36506 REV 4 SH.653 PIPE SUPPORT GEB-61324 H-1

$\angle 3^{\prime \prime} \times 3^{\prime \prime} \times 18^{\prime \prime}$ LG. B.O.S EL. $543^{\prime}-1^{\prime \prime}$, PART OF GEB.61324 H.1 INTERFERES WITH 5 " INSULATION ON I" GER-85:11, L EI. $542^{\prime}-11 \frac{5^{\prime \prime}}{5}$ AS SHOWN

(D.66)

4

$\angle \Xi " \times \Xi " \times 18 " L G$.

GEE-61इ24 H-1

B.CंEL. $543^{\prime}-1^{\prime \prime}$
PLAN "EW $i^{\prime \prime}=1 \cdot 0^{\prime \prime} \approx 499$

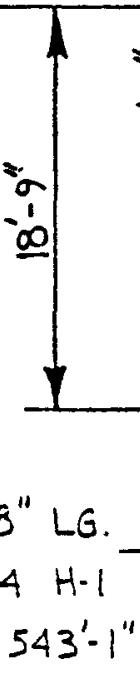

$10^{\prime}-5^{\prime \prime}$ 
1024

FFTF
$4-6-77$

$K M<$
$2-230$

2

H-4-19017 REV. 3 SH. 59 PPG. Fabrication 1SO. I" gEB-85311 H-4-36509 REV. O SH. 867 PIPE SUPPORT GEB-85414 H.I

VARIABle SUPPORT PART OF GEB-85414 H-1 INTERFERES WITH $5 "$ INSULATION ON I" GEB-85311 AT 1'71\%" EAST OF

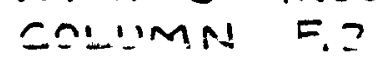

ELEV. LKG. WEST

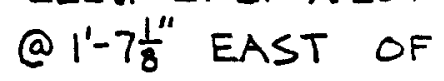
COLUMN F.2 $I^{\prime \prime}=1^{\prime}-0^{\prime \prime}$ \#89

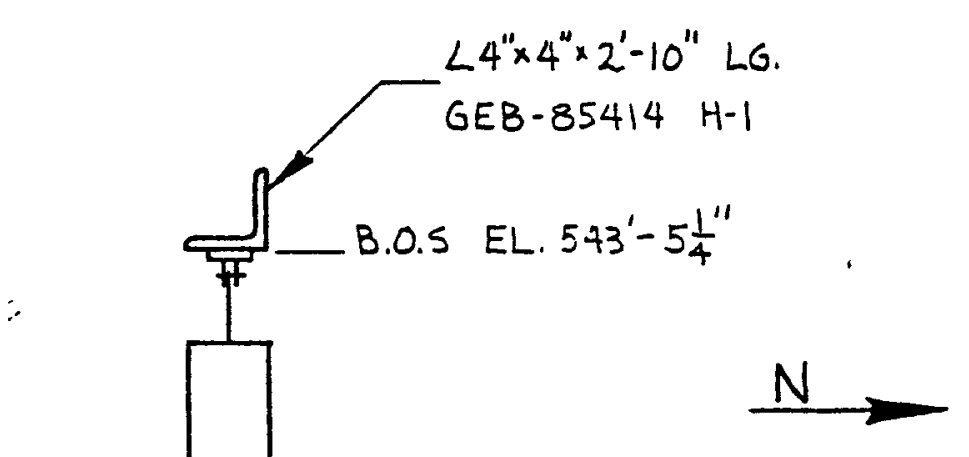

17.95

EL. $541^{\prime}-6 \frac{3^{\prime \prime}}{8}$

I" GEB-85311 $W / 5^{\prime \prime}$ INSUL.

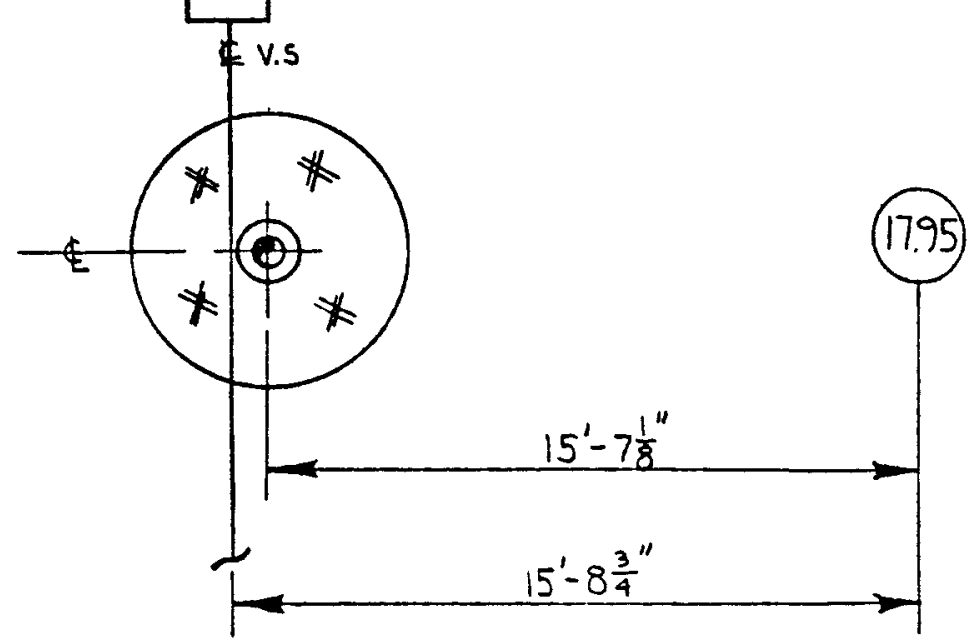




$\begin{array}{ccc}1024 & +\cdots \cdot i 7 & 2-231 \\ \text { FFTE } & K M C & 2\end{array}$

H.4.19017 REV. 3 SH. 5? PPG FABRILATION 15O. 1" GEB.85311 H.4-36506 REV. 2 SH. 479 PIPE SUPPORT GEB-61425 H.10 VARIABLE SUPPORT PART OF GEB-61425 H-10 INTER-
FERES WITH I" GEB-85311 W/5" INSULATION AT 3-78"
FAST OF OMI "MMN F.?

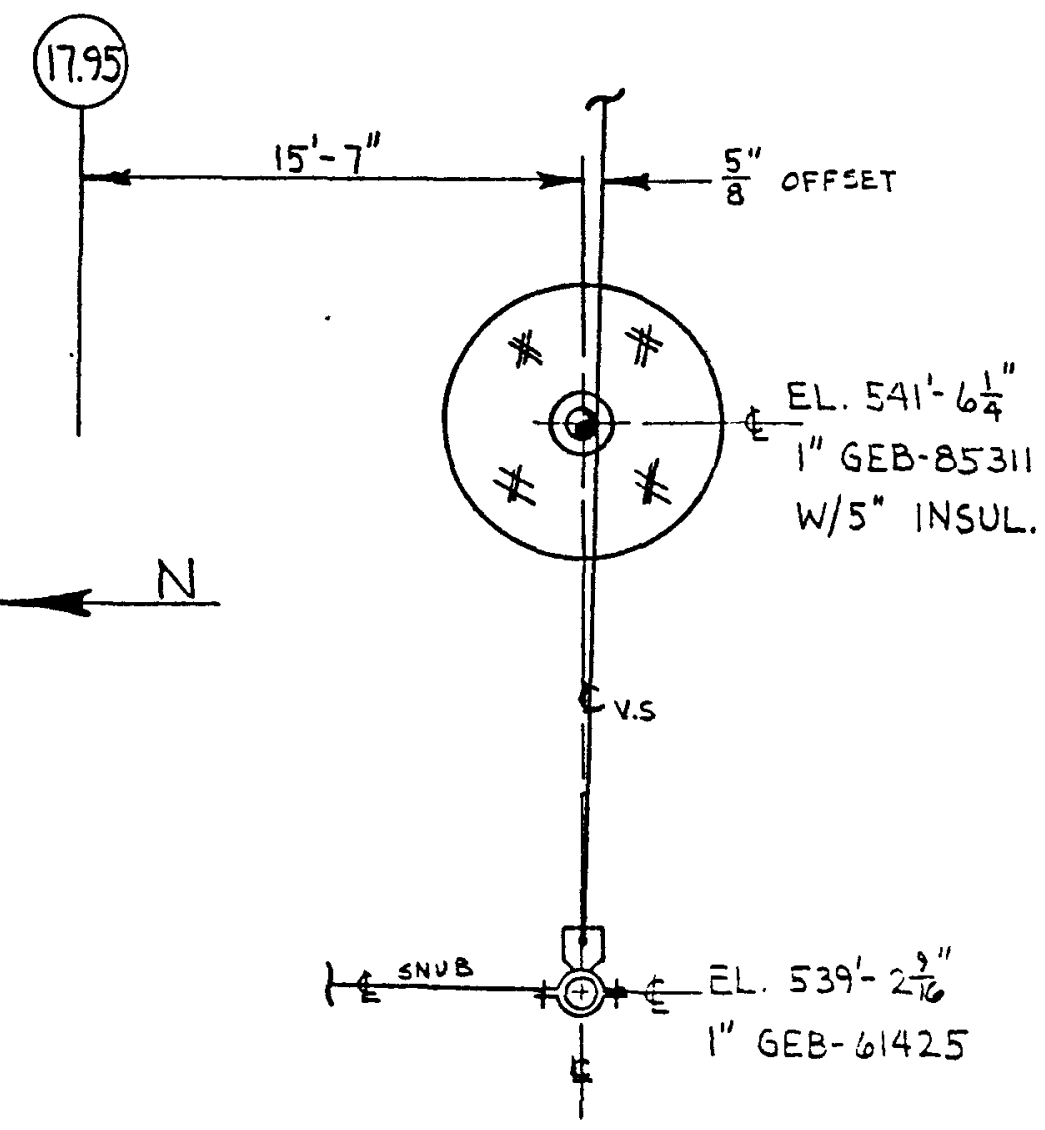




$\begin{array}{lcc}1024 & 4-6-77 & 2=21 \\ \text { FFTF } & K M c & 2\end{array}$

H-4-19017 REV.3 SH. 59 PPG FABRICATION 150 I" GEB-85311 H-4-36509 REV.1 SH.656 PIPE SUPPORT GEB-85212 H.12

I" RIGID SUPPORT PART OF GEB-85212 H-12 INTERFERES WITH 5" INSULATION ON I" GEB-85311 AT 16 " SAITH OF SOLIMMI 193

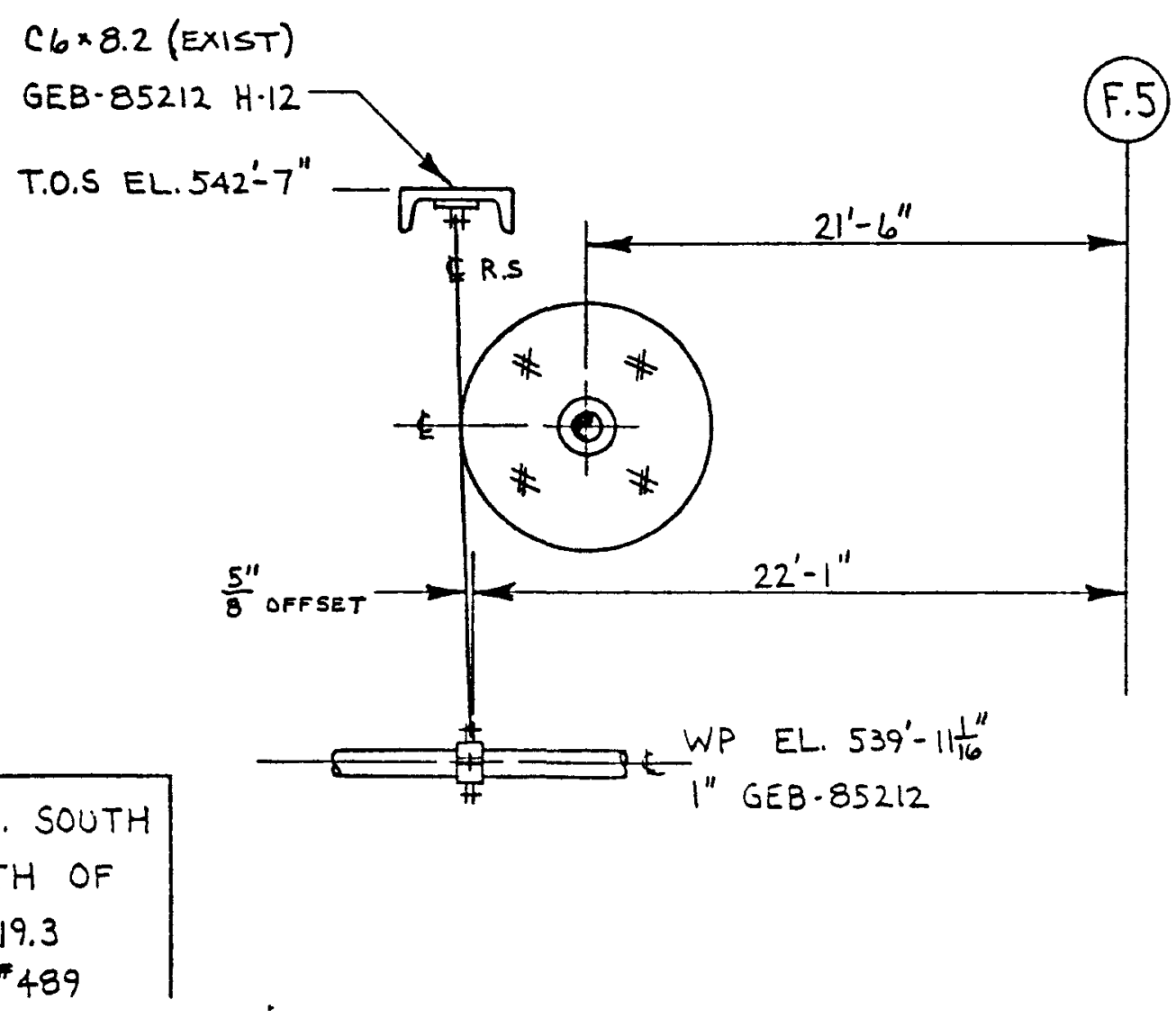


$122 \div$

FFTF
$4 \cdot 7 \cdot 77$

$K M C$

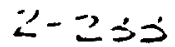

2

H.4-19017 REV.3 SH 59 PPG. FABRILATION 1SO. I" GEB-85311 H.4.36509 REV. I SH. 915 PIPE SUPPORT GEB-85111 H.23

I" SNUB, \&EL. 541'-41" 4 " PART OF GEB-85III H.23 INTERFERES WITH I" GEB. 85311 W/5" INSULATION \& EL. $541^{\prime}-4 \frac{1}{4}$ " AS SHOWN

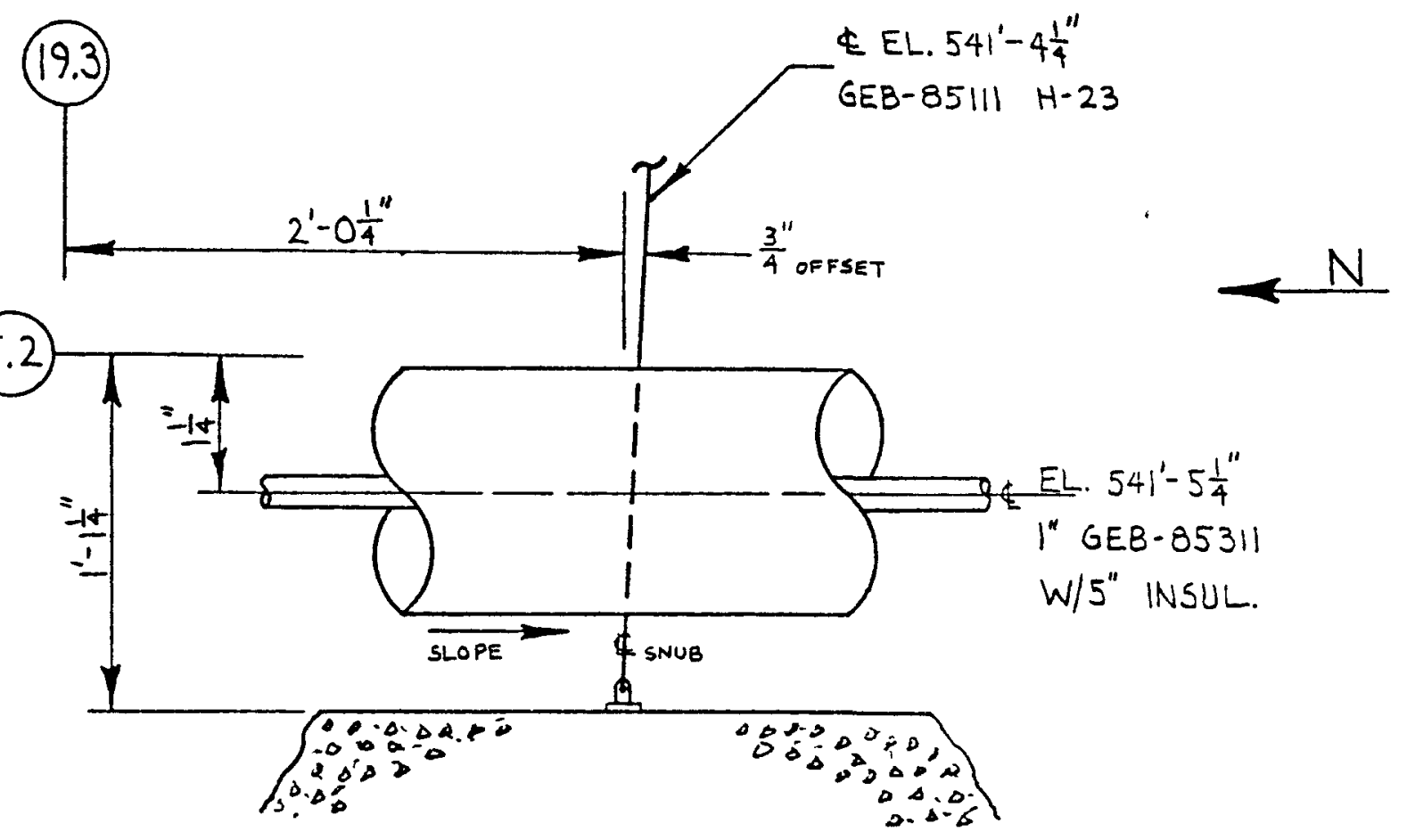

$$
\begin{aligned}
& \text { PLAN VIEW } \\
& I^{\prime \prime}=1^{\prime}-0^{\prime \prime} \quad * 489
\end{aligned}
$$

SH 1 OF 2 


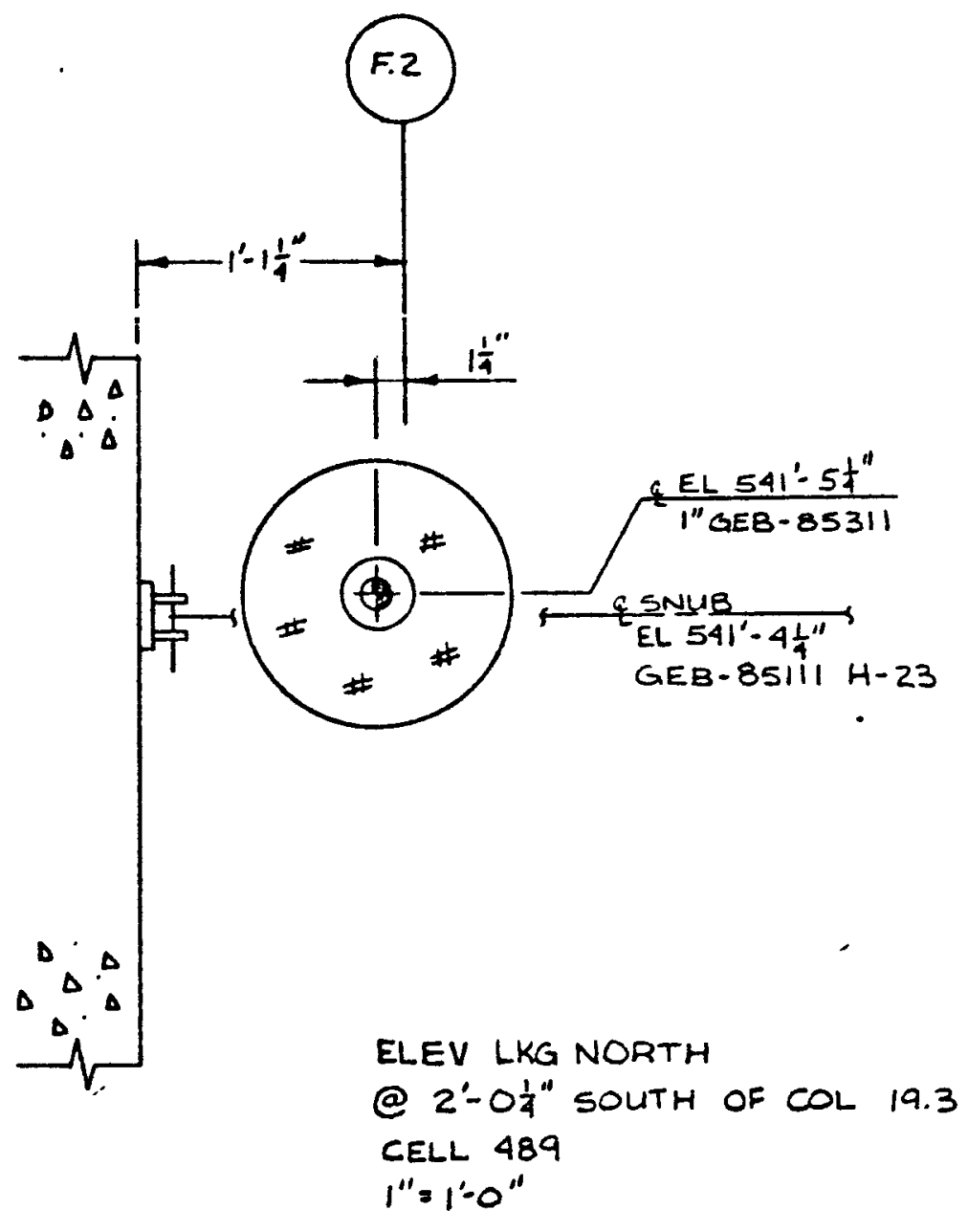

SH 2 OF 2 


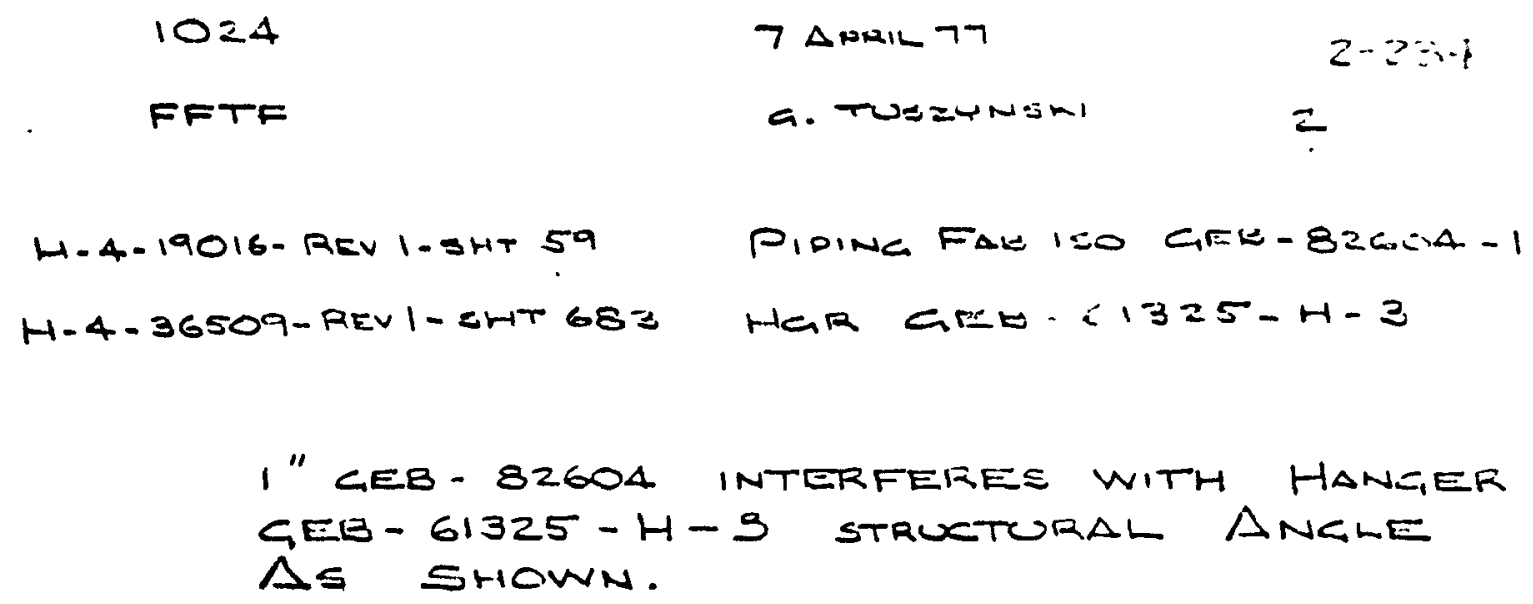

$1 "$ "CEB-82604 INTERFERES WITH HANEEF GEB - 61325-H-S STRUTRRAL ANCLE As SHOWN.

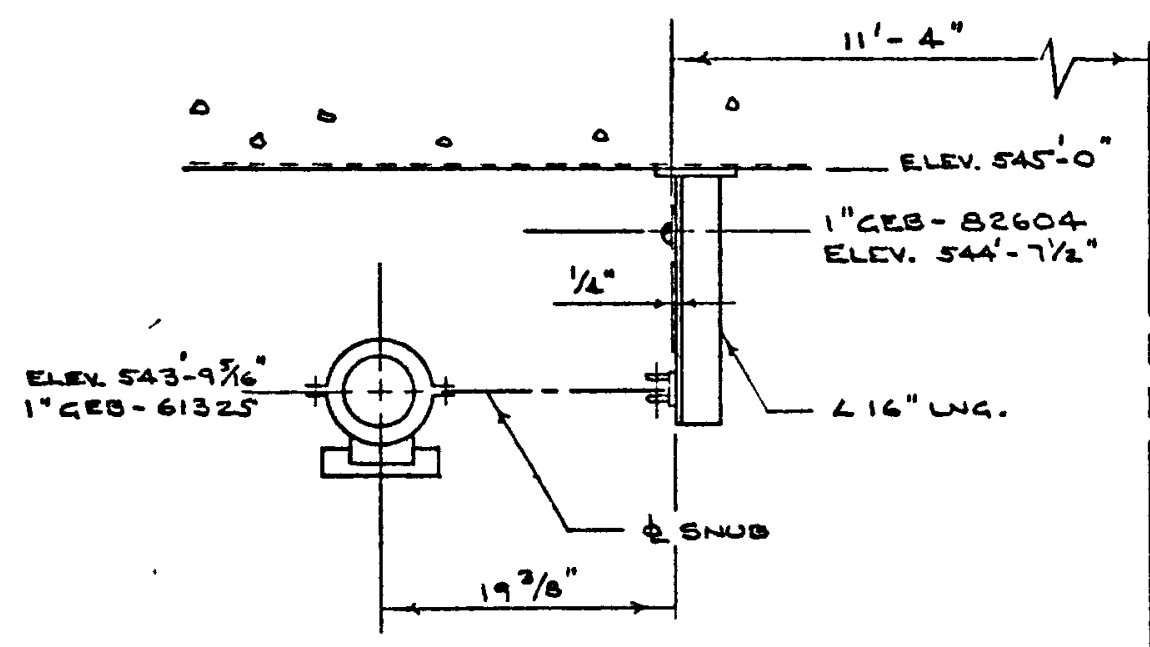

$\frac{\text { ELEV. LKS. EAST } \Theta 11^{\prime}-9 " \text { EAST F.2 N.TS. }}{\text { CEL } 489}$ 
1024

FFT:
7 Aि:00.1

Ci. Trezwski
$2-235$

2

H-4-19017-RRI-SHT 5? PIPING FAB I:O CIEB-B26C4.

H-4-36509-RTU!- =HT RL6 HGR GEB 854H-H-IS

1" GEB - 82604 INTERFEKLE WITH

HANGER CEE-85411-H-IG STRUTORALL CONHCHFNTE $\Delta S$ SHOWN.

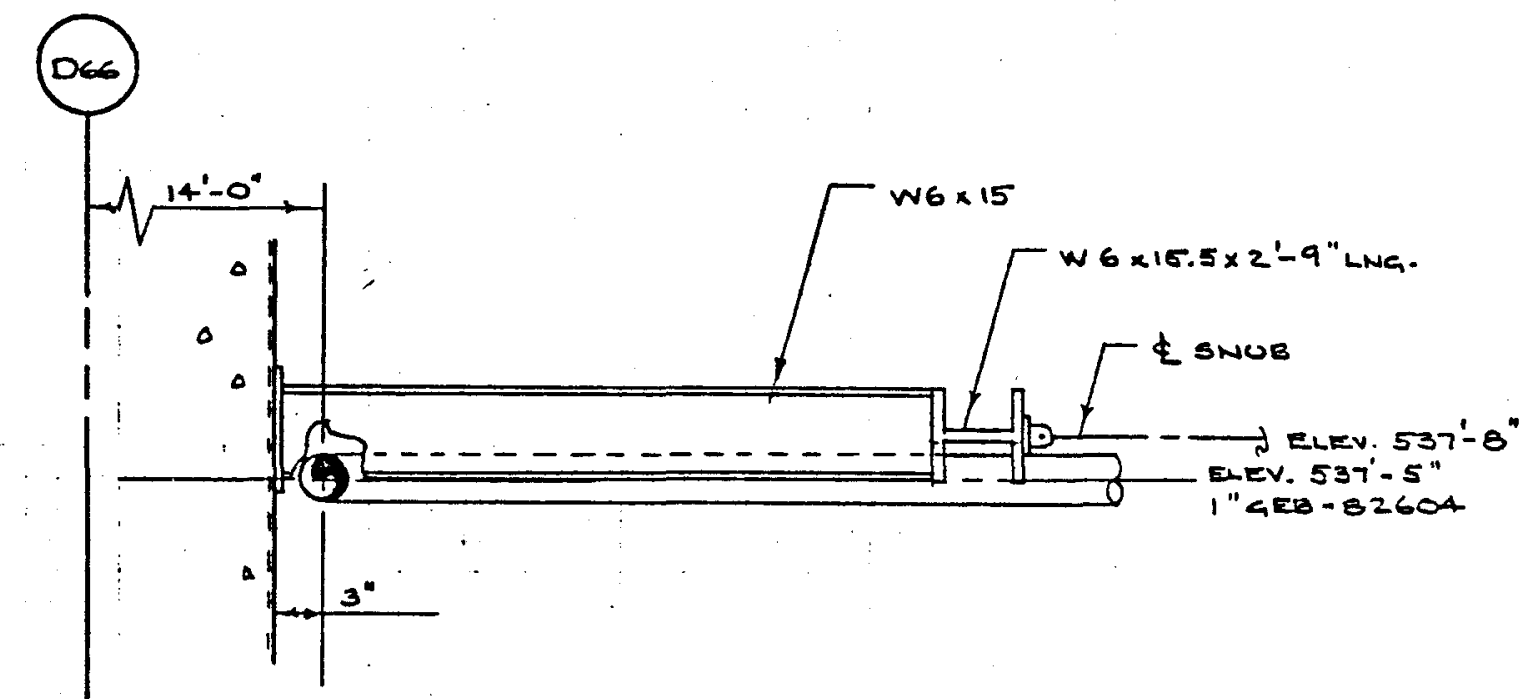

ELEV. LKG. SOUTH O 4'-23/4"NORTH- 20.1 W.T.E. CELL 4EA 
1024

FEFTF
C. Al:L Th

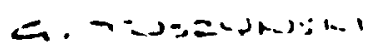

$\ddot{-}=\dot{\vdots}$

2

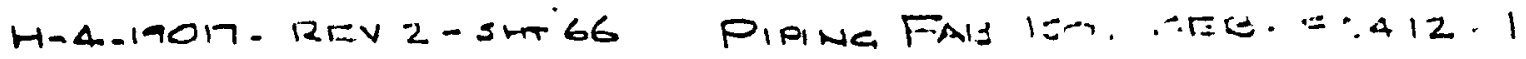

1H-4.36507-REV 2 - EMT 479 HLR GES-EI+25-H- IO

INSULATION ON 1 "CEB-85412 INTERFRREE WITH HANGFR GEB-6IAL5-H-K $\triangle S$ SHOWN.

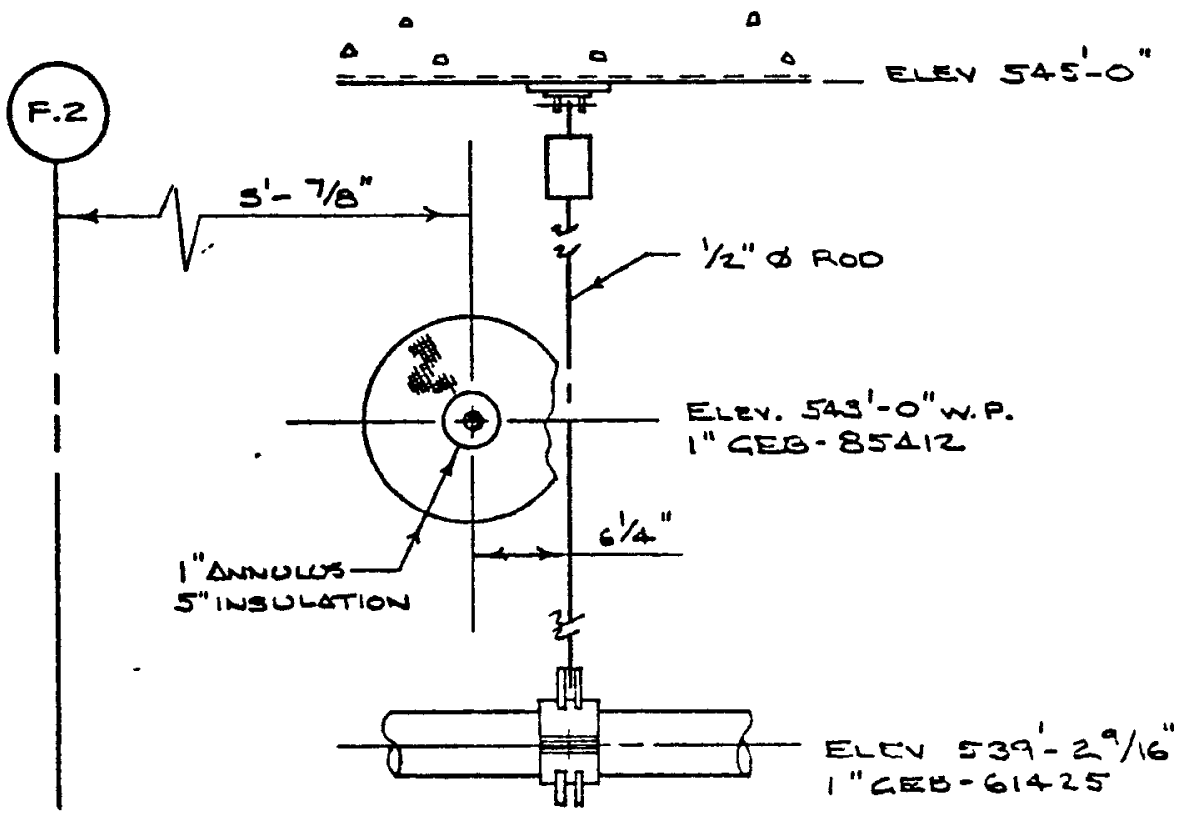

ELEV. LKS. NORTH \& $3^{\prime}-5^{\prime \prime}$ HORTH 193 A T.S.

CEL 489 
$10=4$

FFTF
6 APRIL ᄀᄀ

C. TU\&zerski
$2-239$

2

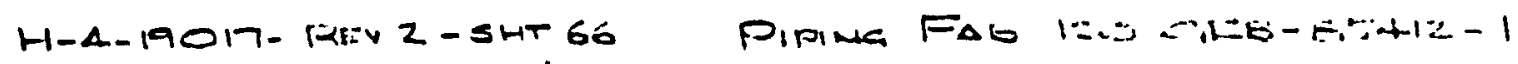

'H-4-36r.RI-REV 5 SMT 4 HAH EEE. 85410-H-45

INSULATION ON I" CEBB-85412 INTERFERE: WITH HANCER CIEB 85410-H-45

- COMPONENTS $\Delta S$ SHow.

$\smile$

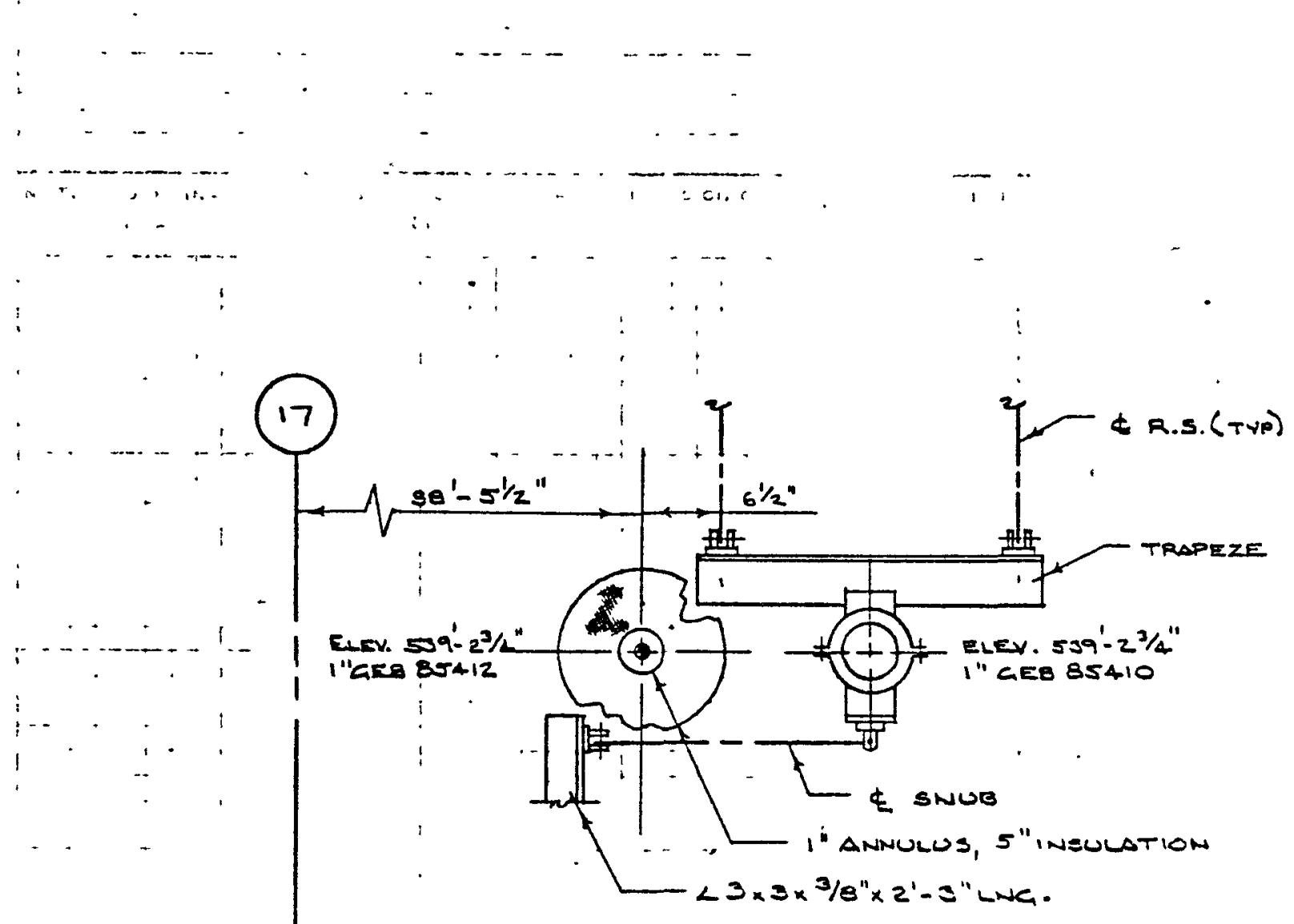

ELEV. LKG. EAST \& 7'-93/4"EAST F.2 N.T.3.

cell 489 


$$
\text { FFe }
$$

a. Twostenst
6 Sivkin 77

$7-239$

2

PIPINE, FAL $1: 6$, TEEL $=541 \div-1$

HGR CACB - 85011-H-25

INSULATION ON I" GEB-854IZ INTERFERES WITH HANGER CCB-85011-H-25 RITIR STRET \& BTB-126 $\Delta=$ Erisun.

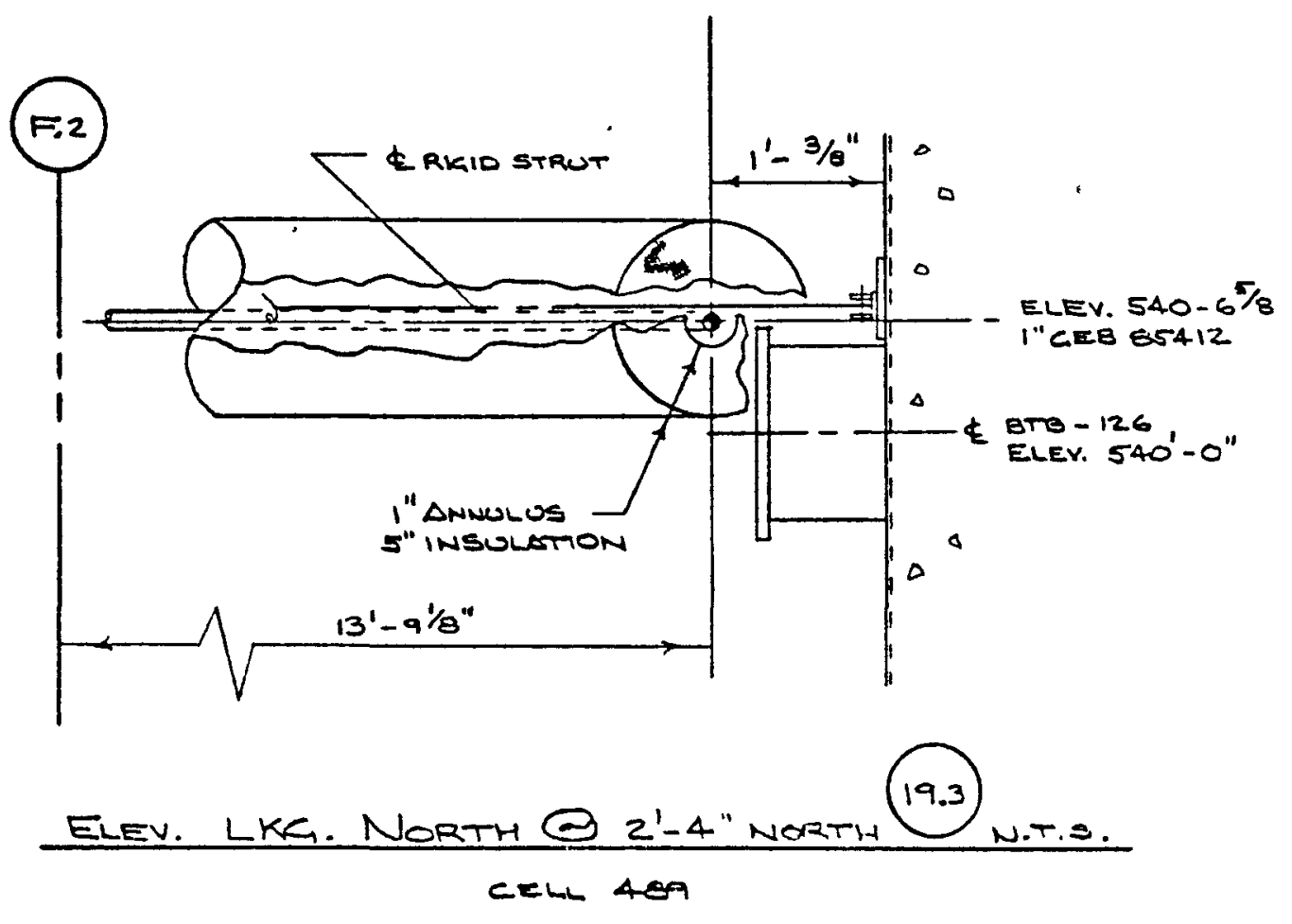


1024

FFTF.

H. $4-19017-2$ SHT. 54

$H-4.36506-1$ SHT 691

$$
\begin{aligned}
& \text { A. } \\
& \text { S HO }
\end{aligned}
$$

$1^{\prime \prime}-G E B-85212$

GEB - $61325 \quad H-11$ $2-\div 10$

2

GEB- $61325 \mathrm{H}-11$ INTERFERES LUITH I"-GEE-8ESLI2 AS SHOWN.

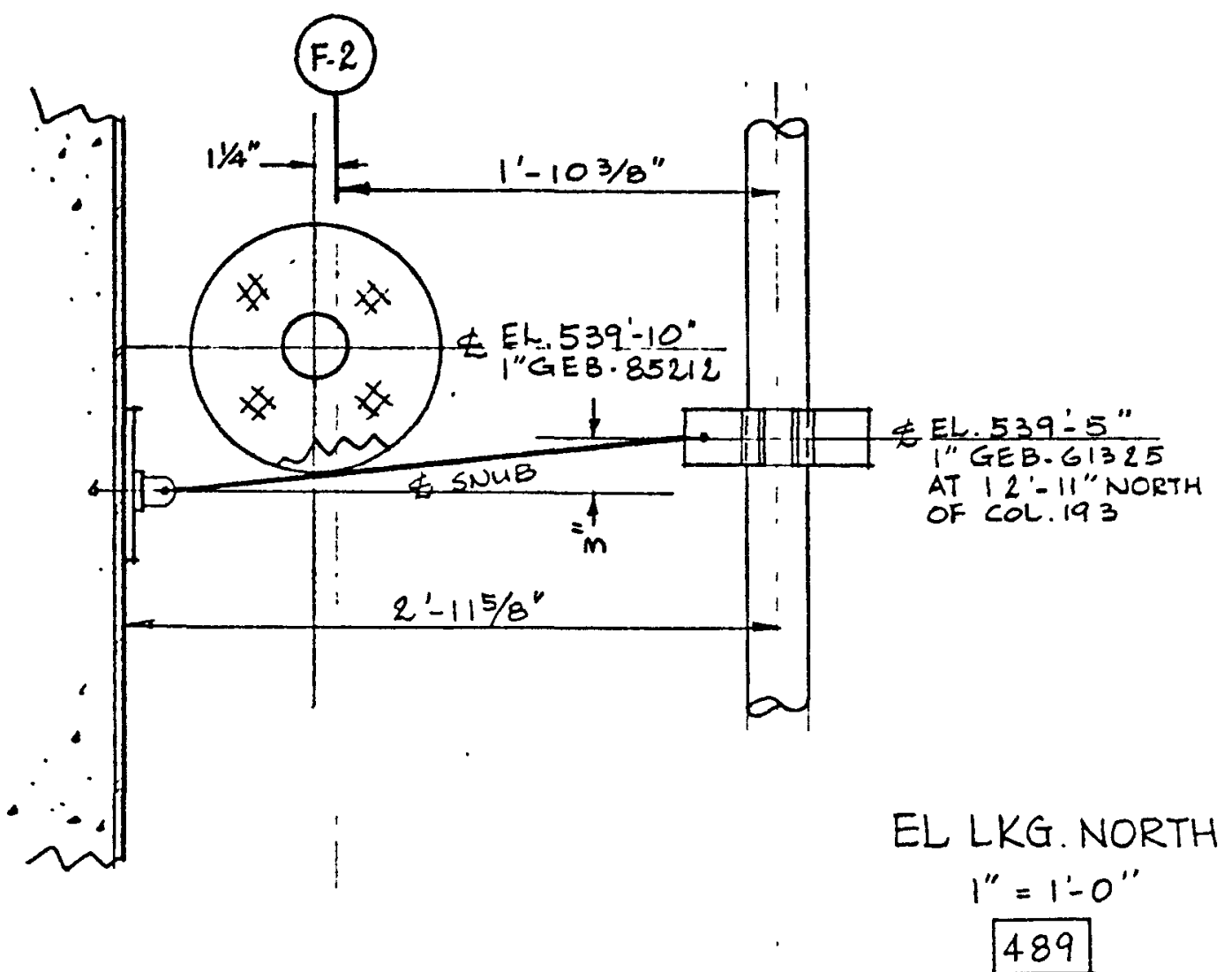


1024

FFTF

$H-4-19017-2$ SHT 54

H. $4 \cdot 36509-1$ SHT. 759
$4-6-77$

stlo

$1^{\prime \prime}-\operatorname{GEB}-85212$

GEB - 85314-H-1 $2-r$
2

1

GEB- $85314 \cdot \mathrm{H}-1$ INTERFERES LUITH GEB - 8.5212-1 AS SHOWN.

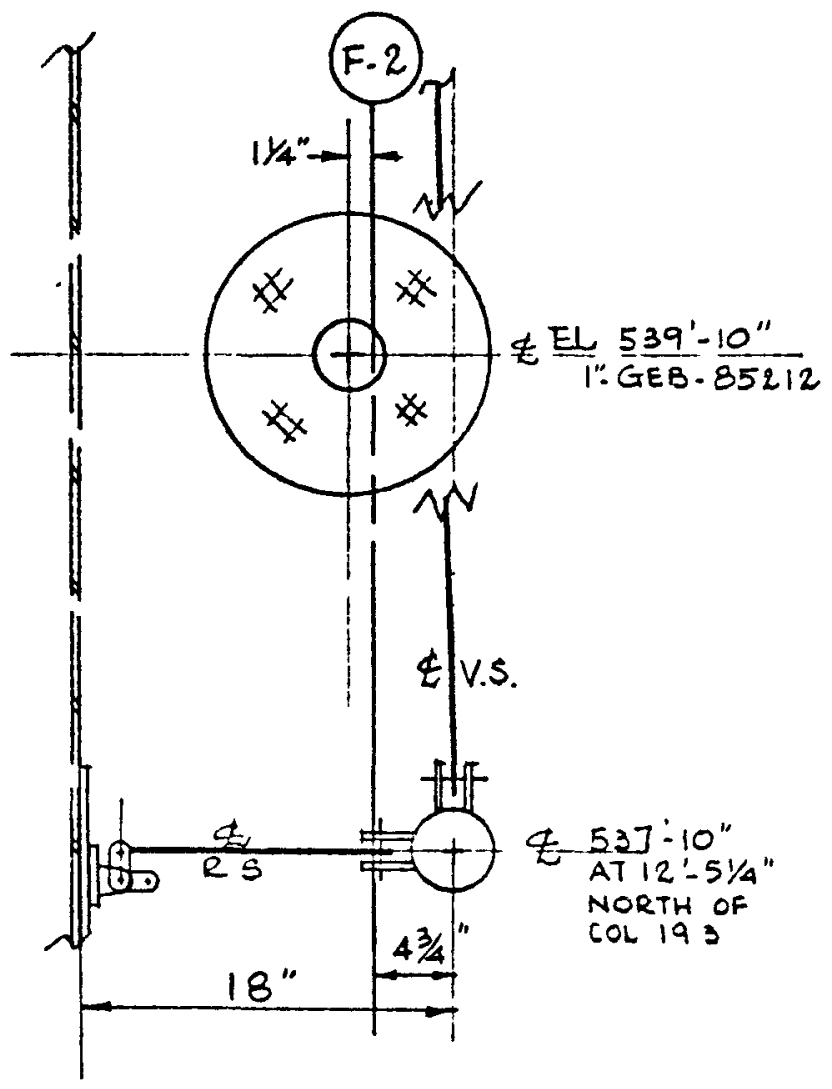

EL. LKG NORTH 1"- 1'-O"

489 
$10: \dot{i} \div$

FFTF
$4-6-77$

$\mathrm{SHO}$
$2-242$

2

H.4-19017-2 SHT 54, " "GEB - 85212

$H-4-36509-1$ SHT. 656 GEB $-85212 H-12$

GEB - 85212 H-12 INTERFEKES WITH GEE85212-1 AS EHOWN.

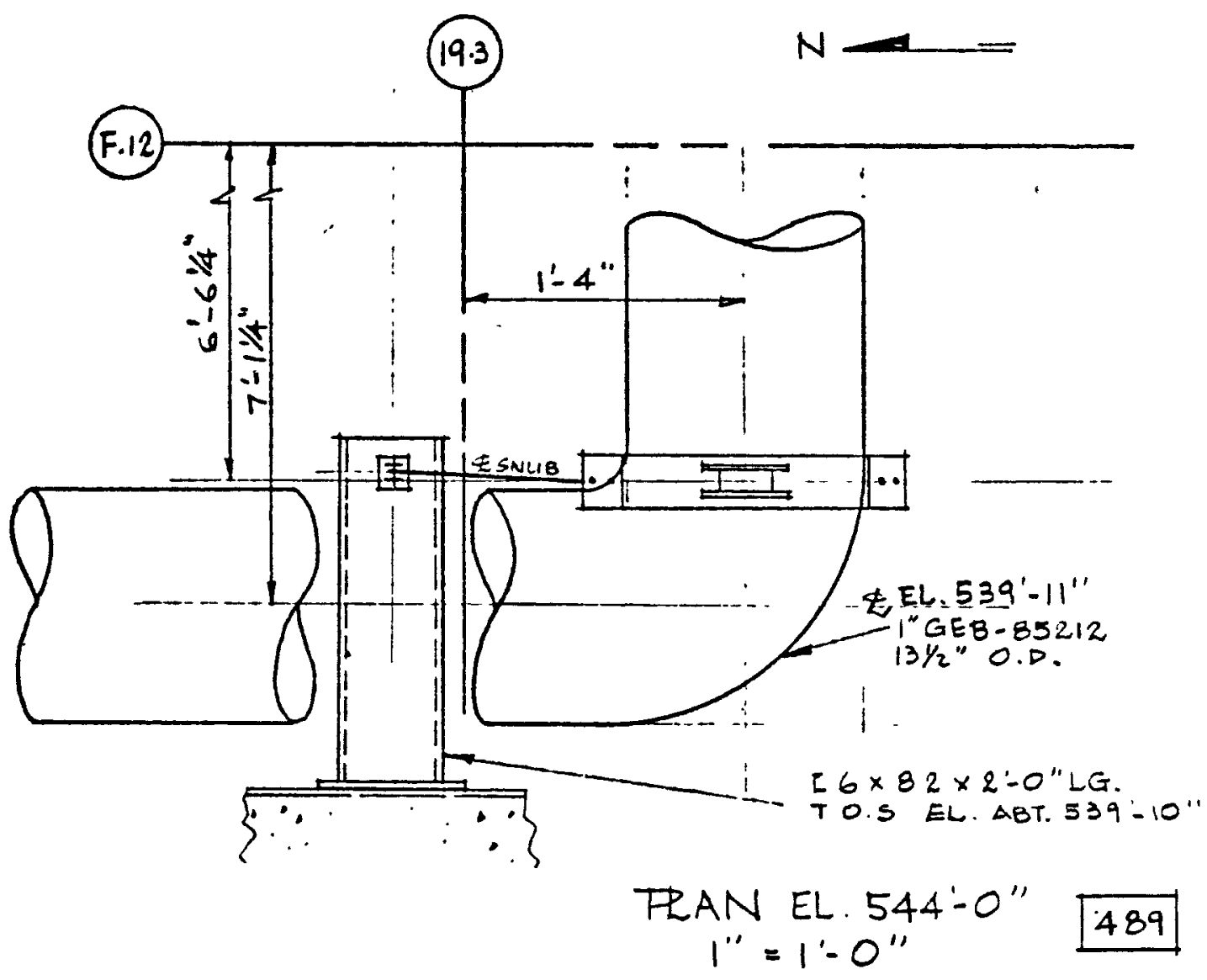



1024
if $\because \because$
$2-=43$
FFTF
$S$ Ho
2

H. 4-19017-2 SHT 54

I"GEB - 85212

H-4 - 36506-O SHT. 503

$G E B-61225 \mathrm{H}-10$

AS SHOWN.

GEB-G1225 H-10 INTERFERES WITH I"GEB-85212

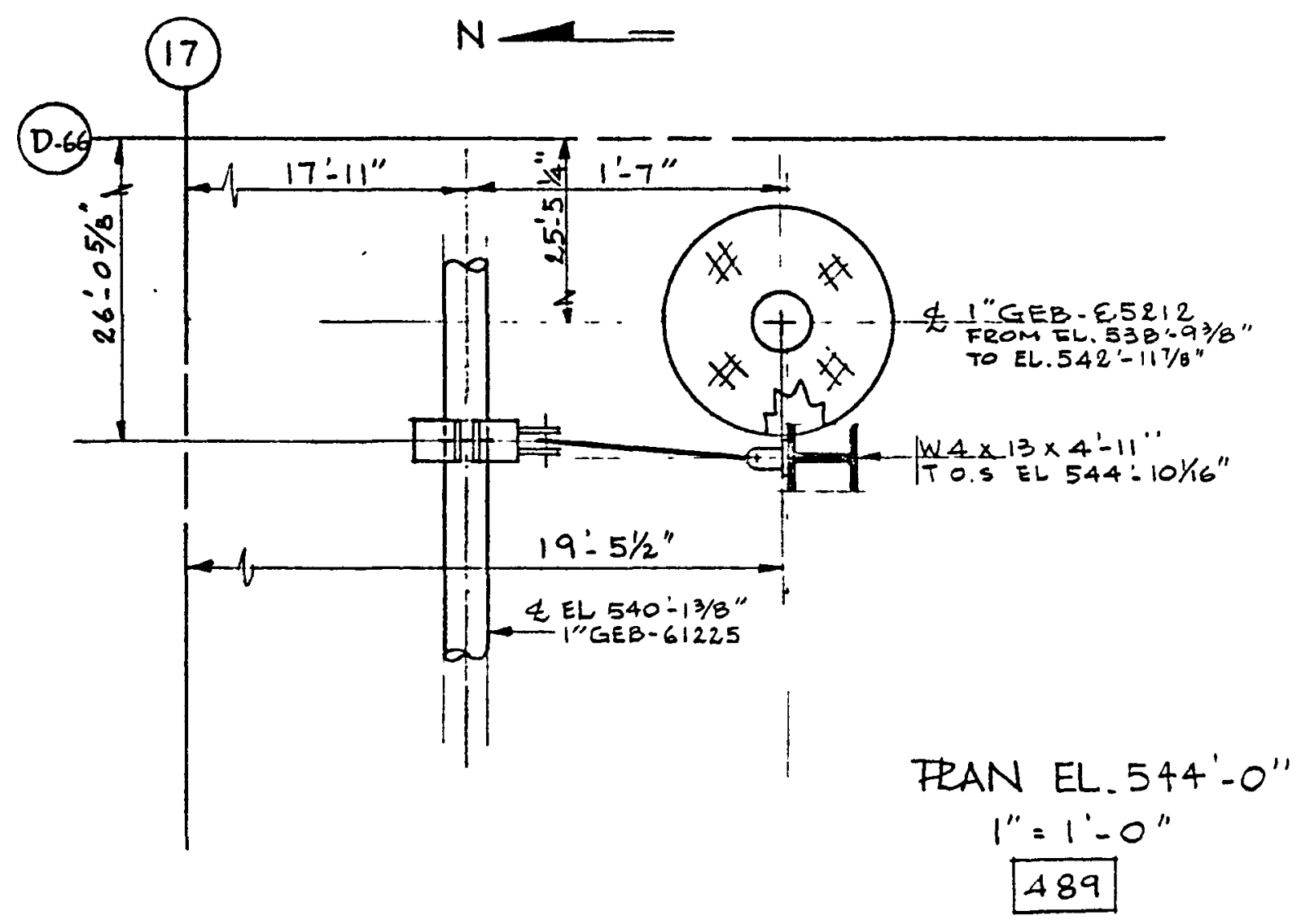


1024

FFTF

H.4-19017.2 SHT 54

H-4-36509-2 SHT 127
$4-7-77$

5 Ho

I"GEB - 8521:

GEB - $85111 \mathrm{H}-10$

GEB - 85111-H-10 MAY INTELFEKE WITH I' GEE85212 AS SHOWN.

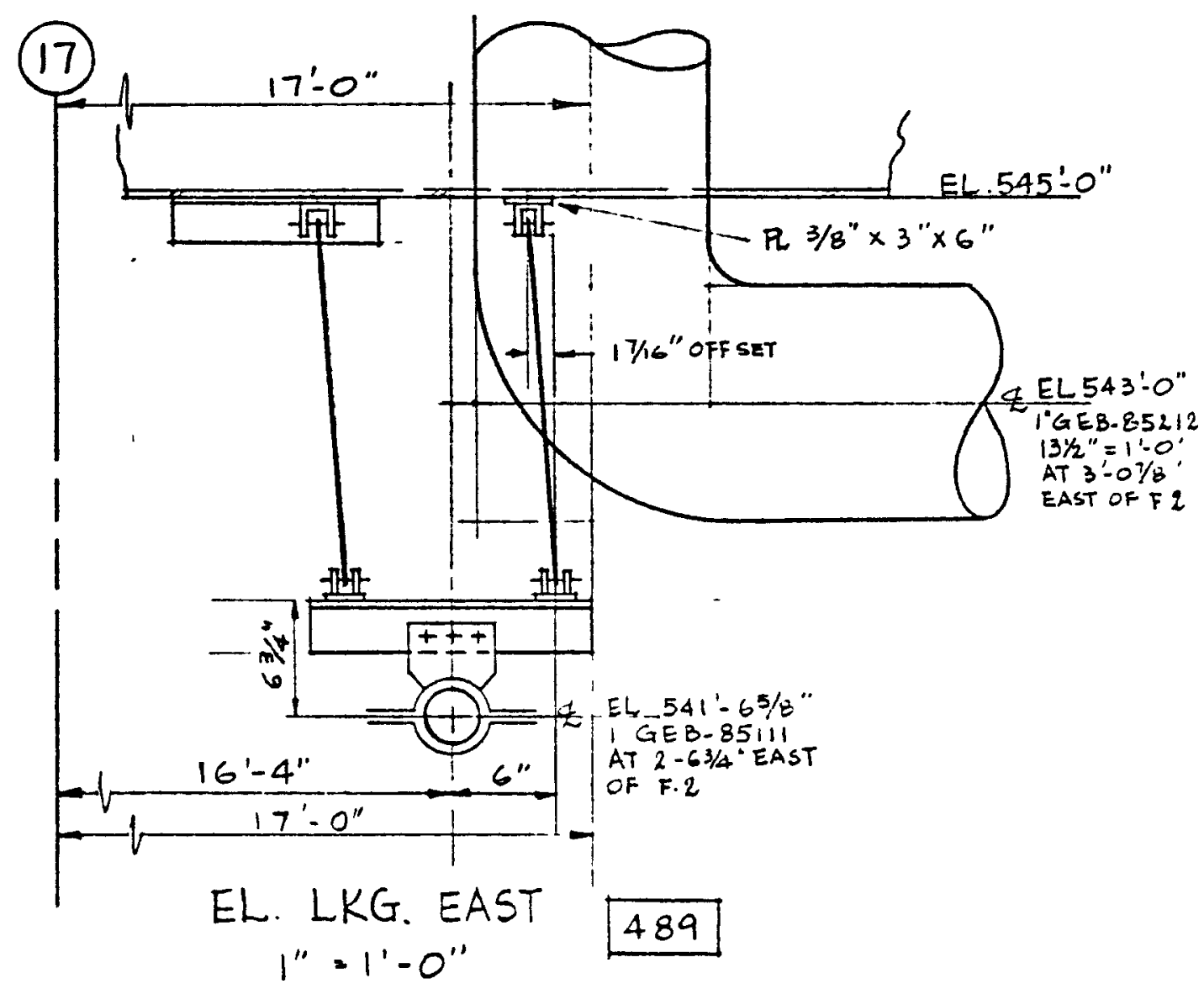


1024

FFTF
G ABWL 7T

c. T2.,
$2-2: 10$

$z$

PIrINC FAl3 is HBD-F - HO - 1

HGR CRE $E 5312-H-1$

3"- HBD-82000 INTERFERES WITH HANGER GEB- BSSIZ-H-1 W4X13 STRUCTURAL COMPONENT $\triangle Q$ SHOWN.

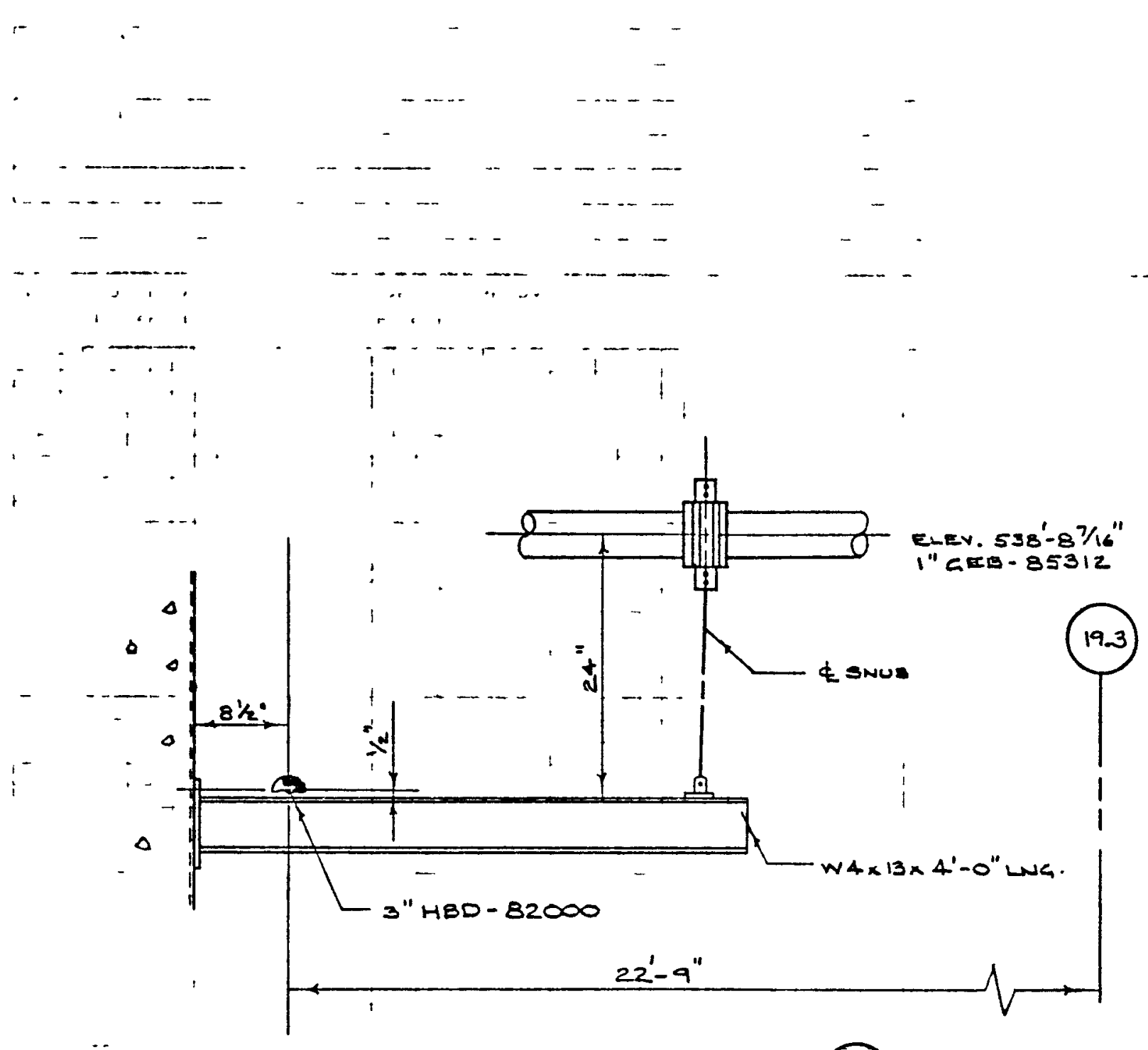

ELEV. LKG. WEST Q 3'-03/4" EAST F.2 N.T.S.

CELL 499 
$10 \cdot 4$

FFTF
8 APRIL 77

ROSE DOLL
$=-2-1.0$

2
H-4. 19017 REV S SH 57

H-4.36506 REV 3 5H 620
PR FAB ISU NEE- 55311

PIPE SULPPORT GEB-61329 $\mathrm{H}$-3

HGR GEB-WI324 H-3 INTERFERES VVITH 5"INELLATIUN ON I" GEB-35311 AS SHOWN

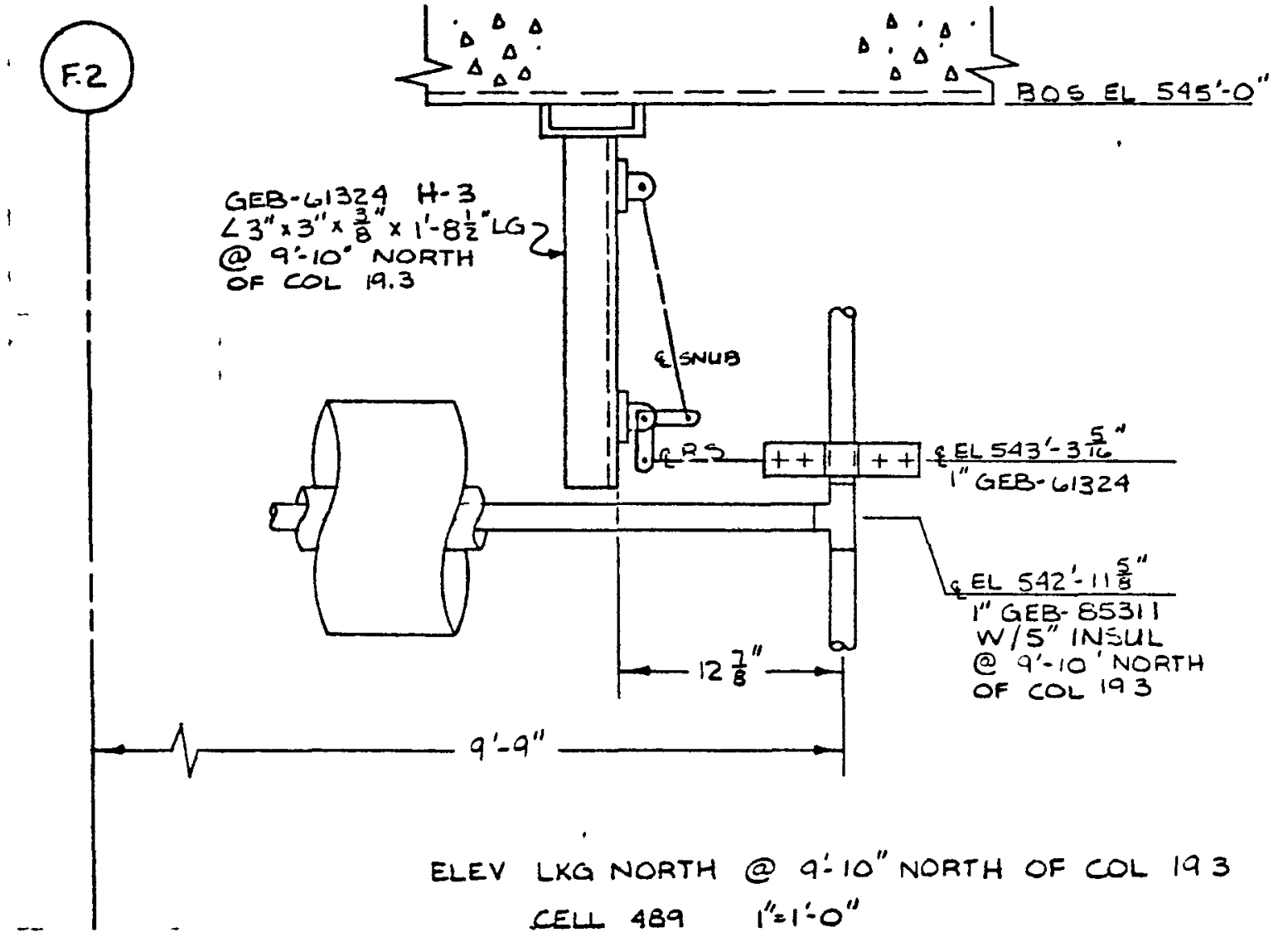


1024

FFTF
$4 \sim ๕ \neg ?$

BAERY VE:TH:-
$2-247$

2

H-4-19016-REVI-SHT 39 PPG T.AE ! $\therefore$, GCB-EZ594

$H-4-36502-R E V .2-5 H T .7$ HGR-HBD-ZSI=4-H-1

GCB-82594 INITERFERES WITH HGR. HBD-25154, $H-1, S H T .7$.

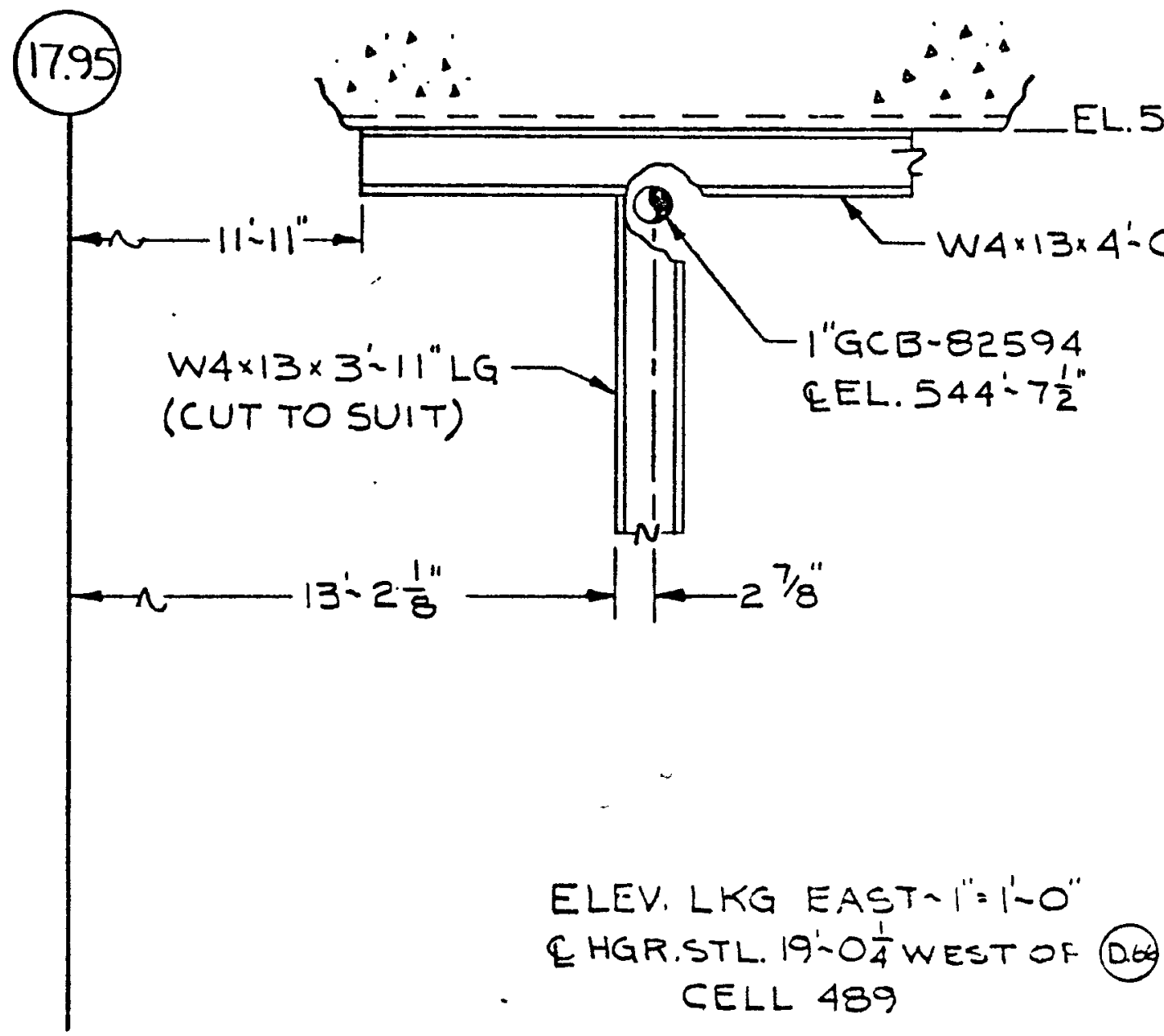


1024

FFTF
8 APRIL 77

ROSE DOLL
7.15

2

H-4-13103 REV 10 SH I EQUIPMENT LOCATICN P-36

H-4-36506 REV 2 SH 636 PIPE SUPPORT GEB-61325 H-6

$6 \times 155$ BEAM BELONGING TO GEB-61325 H.6

INTERFERES WITH D-36 AS SHOWN

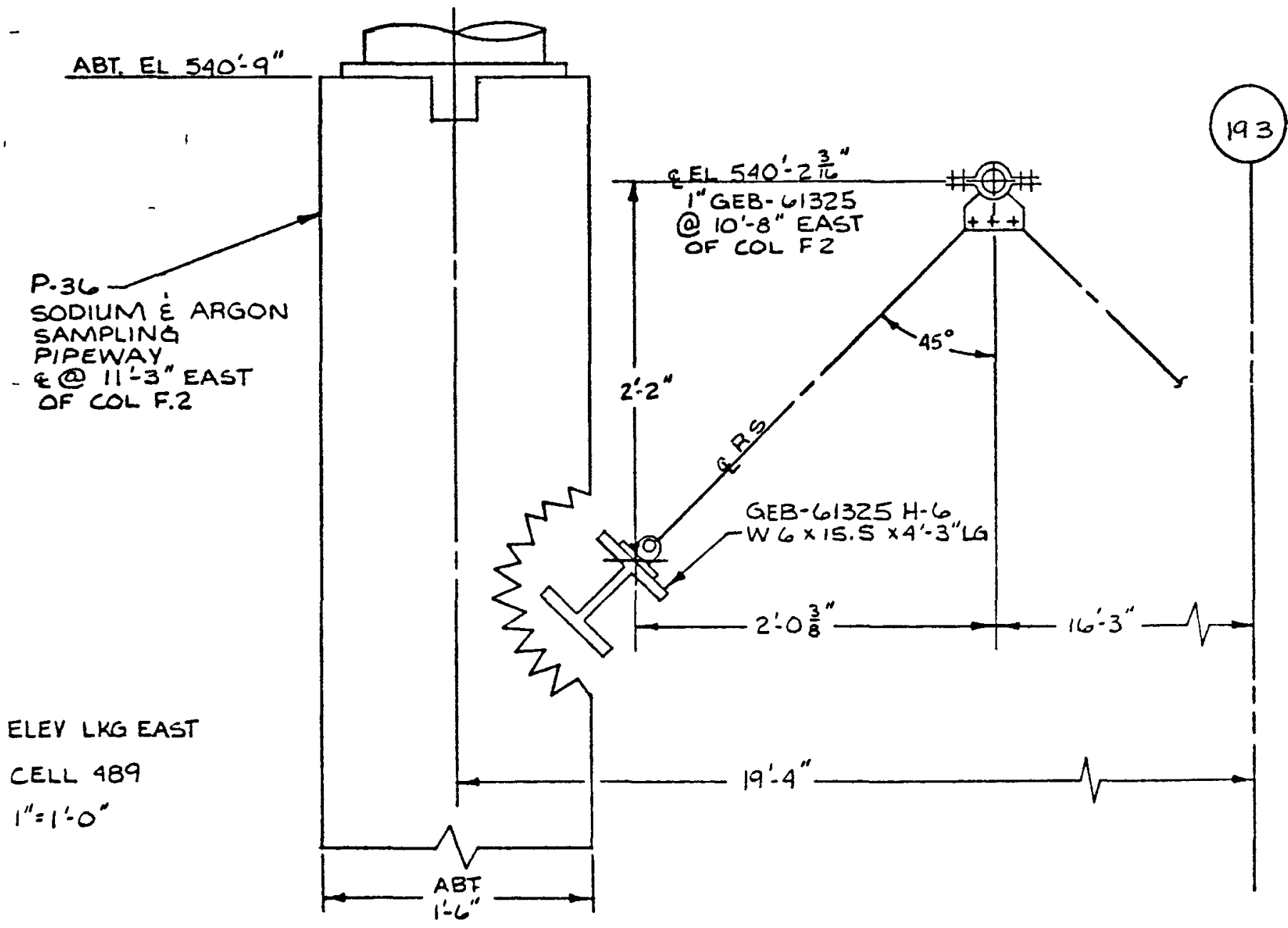


1024

FFTF
$4-7-77$

BARRY VESTLE
$2-2 \cdot 19$

2.

H-4-19016-REV 1-SHT. 39 PPA FAL 13 GCB-2:5.74 H-4-365Og-REV.1-SHT S10 HGR.GEE-S5112-H-7

GCB-32594 INTERFEKE' W IIH HGR GEE-3..112, $H=7, S H T \cdot 570$

(0.66)

$N$

$\therefore$

$\because \therefore \therefore 13^{\prime}-9^{\prime \prime}$

$114^{\circ} 0^{\prime \prime}$

R $6^{\prime \prime} \times \frac{3}{8} \times 1 \cdot 3 " L G$

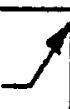

14

I"GCB.82594

EL. 538 '2" TO

EL. $544^{\prime}-7$ ' 12

$\left[6 \times 8.2 \times 20^{\prime \prime} L G\right.$
$T / S E L .538^{\prime} \cdot 2 / 4$

RAN VIEW-I"=1'-0"

- CELL 489

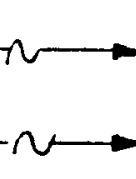


1024

FFTF
4ーフーフ

Barry Ve:Te:
$2-250$

2

H-4-19016-REV.1-SHT.39 PPG FAE 1 : GCB-B2574

H-4-3650-RFV 1-SHT. 394 HGR GEB-85012 $H-3$

GCB.82594 INTERFERE: WITH HGK.GCENB'DIL, $H-3, S H T . \equiv \rightarrow 4$.

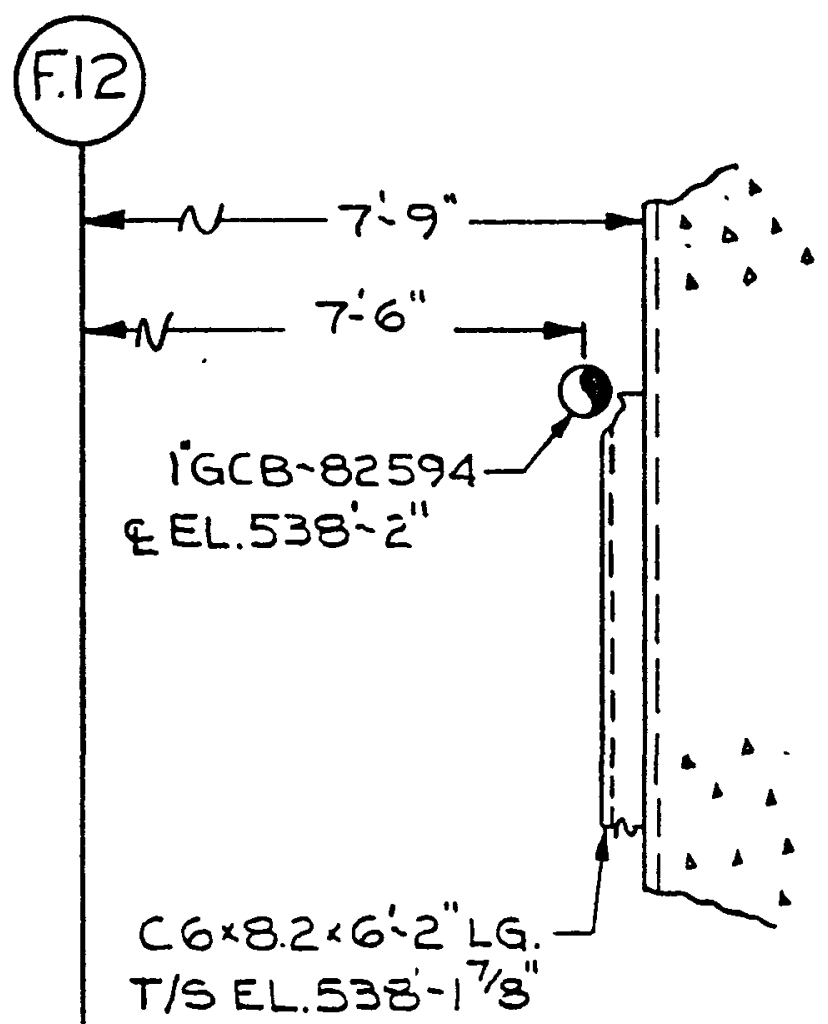

ELEV. LKG NORTH-1"=1' O" EHGR. STL. 8'-10\%" sOUTHOI: 193 CELL 489 
1024

F.FTF
$4-7-77$

BAREY VE=TEL $\angle-\angle S I$

2

H-4-19016. REV.WSHT:39 PPG FAE ILO. GCB-8250.4 $H-4-36509$-REV.1.SHT. 395 HGR. GCE- 35012 - H-4

GCB.32597 INTERFEEESWITH HG̈. GCB-3ESI2, $H-4, \leq H T .395$.

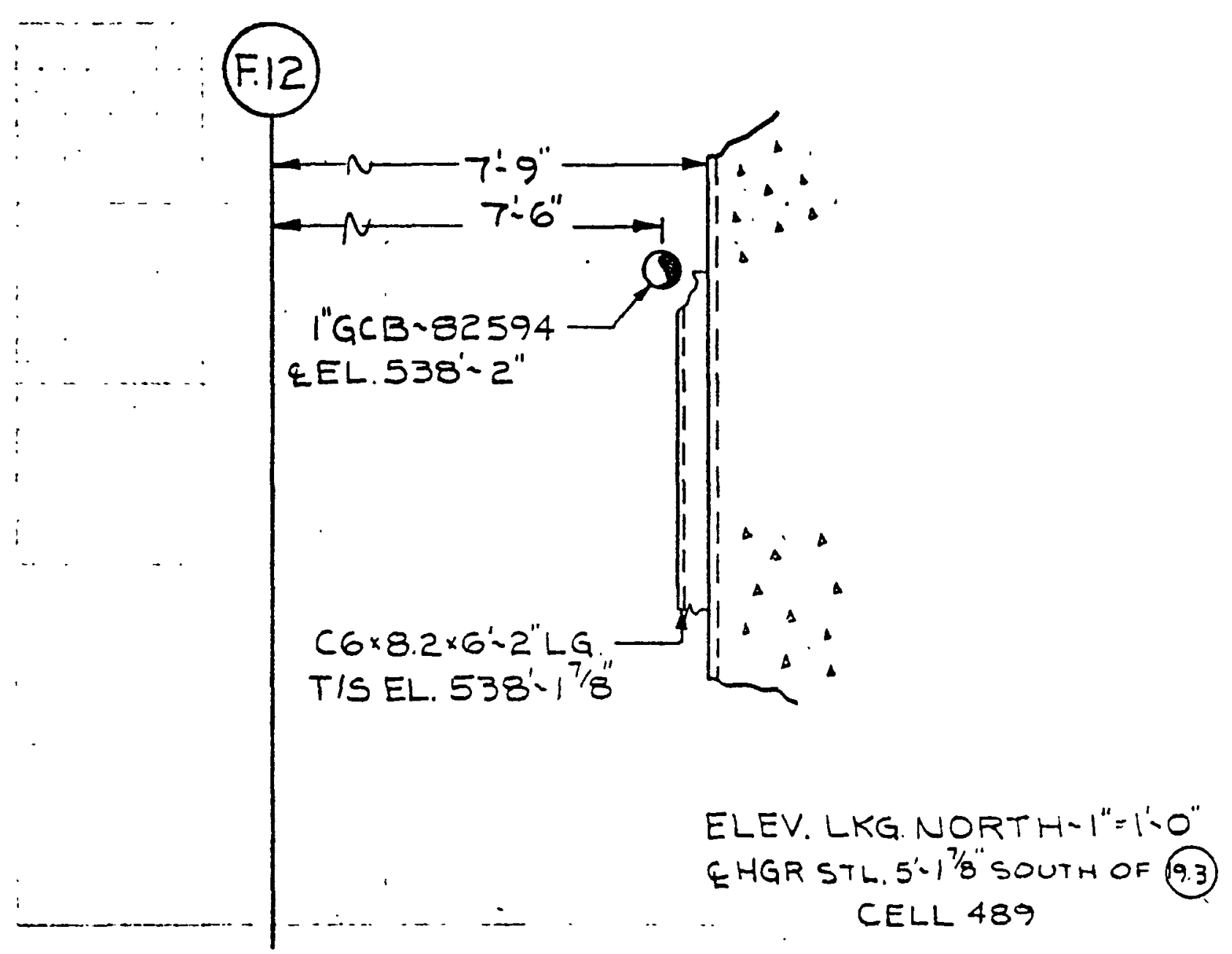


1024

FFTF
$4-7-77$

Barey Vesterel
$?-252$

2

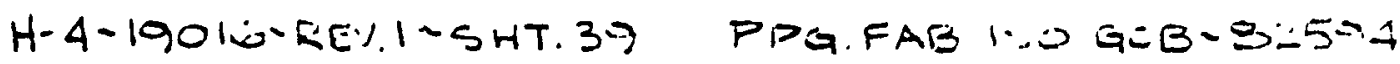

$H-4-36509-R E V 1=5 H T .396$ HGR. GCE-35,012 -H-5

GCB-32594 WTEKELEE:- WITH HGK GIE- 350I2, $H-5,=H T .=3 \rightarrow 6$.

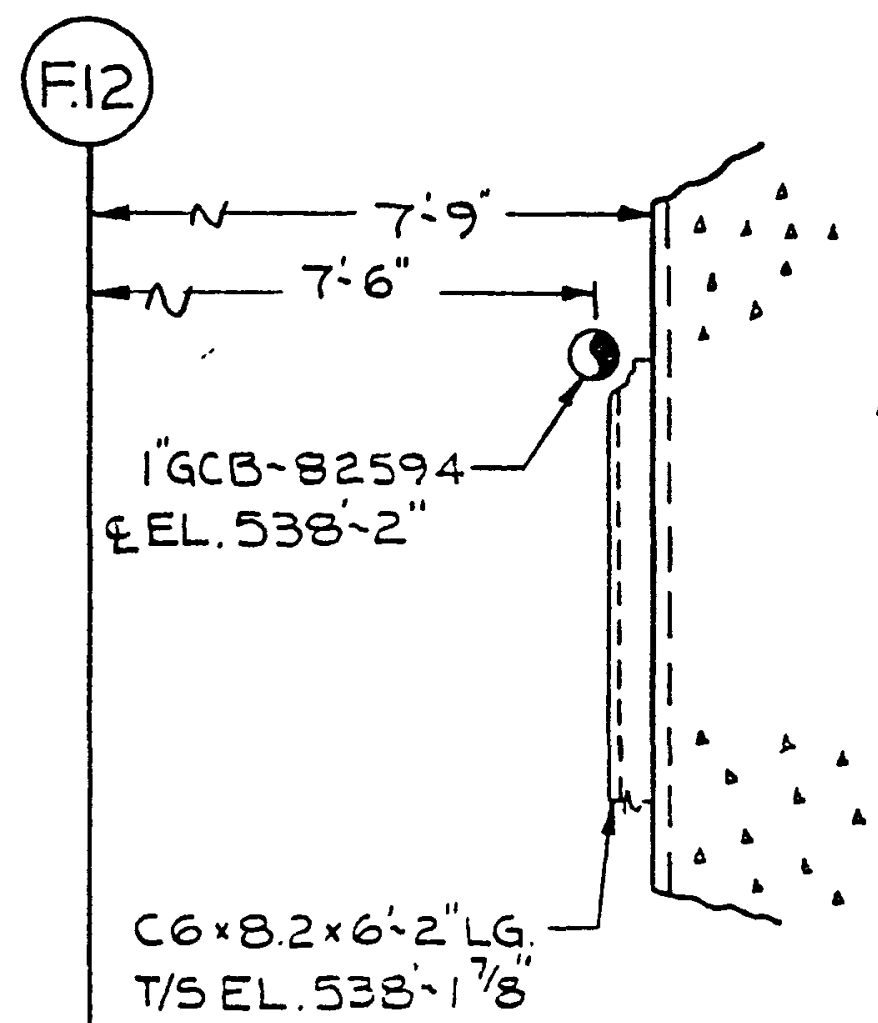

ELEV. LKG NORTH =1"=1-O"

EHGR.STL.1-3'2"SOUTHOF 19.3

CELL 489 
1024

FF' $1:$
$4-7-17$

EArEy $V_{E} \cdot$. -
$2 \cdot 253$

ב

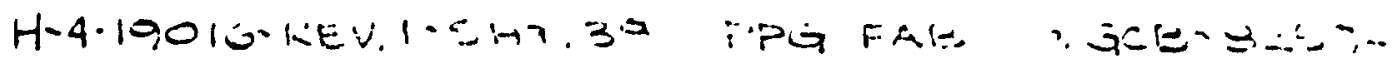

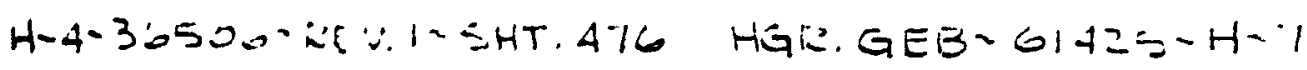

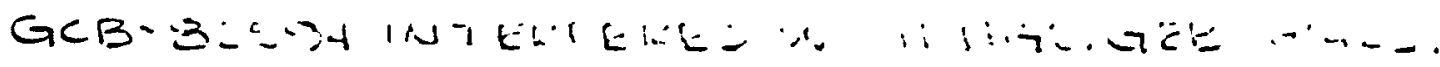
$\therefore \because$ SHT 476 .

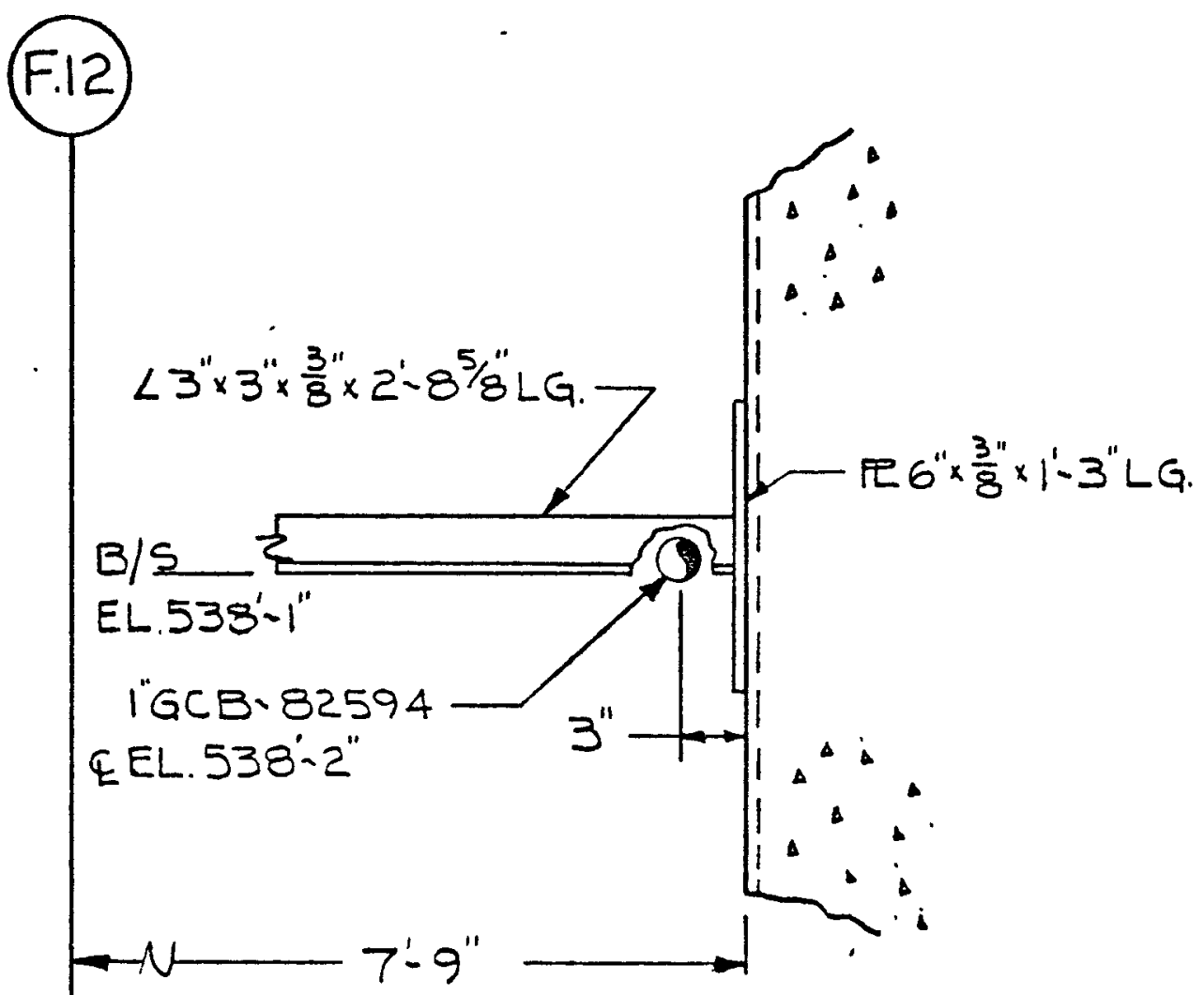

ELEV. LKG. NORTH-1"=1'O" EHGR STL. 5'-2\% SOUTL OF (19.3) CELL 489 

$10 \div-1$
$-1-1 . \%$
$2 こ 5=$
i $\{$ ?
EARRY VE:..1

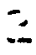

H-4-190!E-REV 1-SHT OI PFGHAS . VGEEE. ․

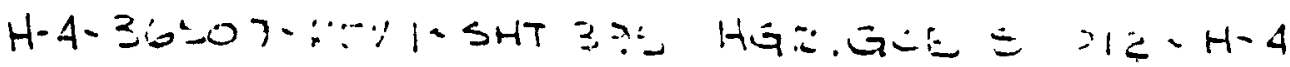

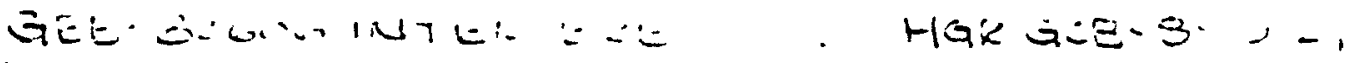
$H-4,=t \cdot \equiv 3$.

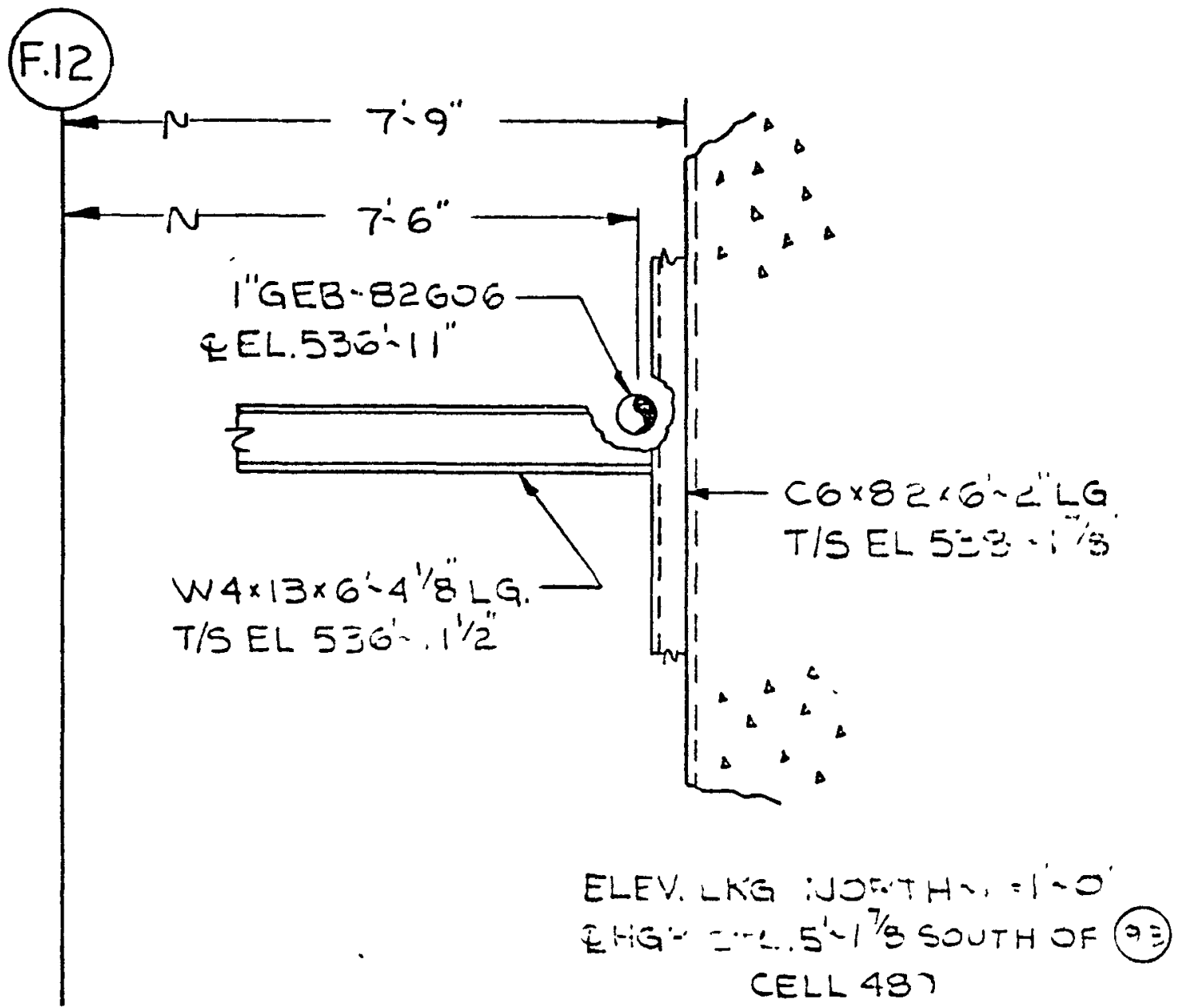




$$
\begin{aligned}
& \therefore- \\
& \because:: 1 \\
& 4-1-\cdots \cdot 1 \cdot \quad 2 \cdots 36 \\
& \text { ËARKY VL.:1:1. }
\end{aligned}
$$

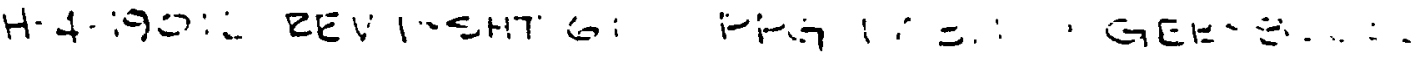

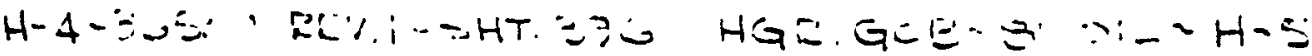

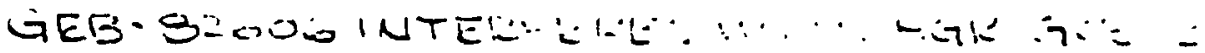

$$
\begin{aligned}
& H \times 5, \pm H \cdots, \Xi 20 .
\end{aligned}
$$

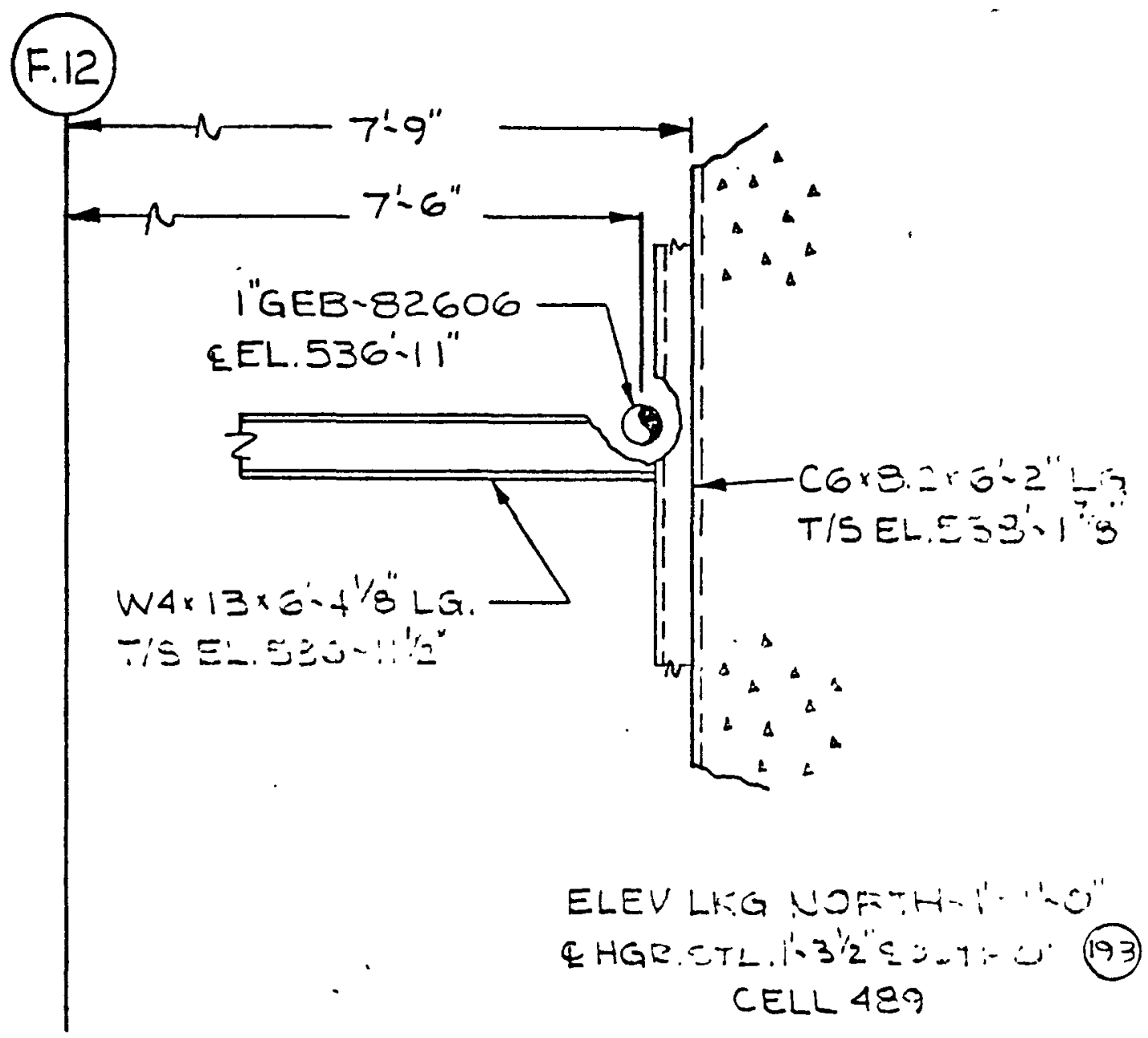




$$
\begin{array}{lll}
10-1.1 & \text { SAIRIL } 17 & \because-257 \\
\text { FITF } & \text { ROSE D L L } & =
\end{array}
$$

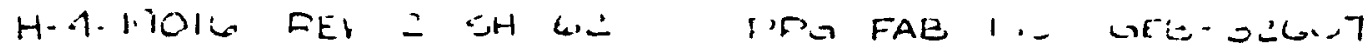

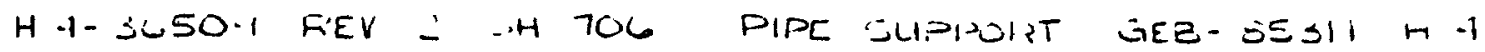

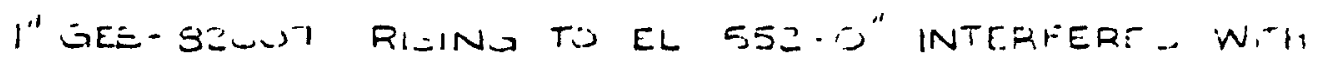

$L \times B . Z$ IHANNLL AS JHSWM

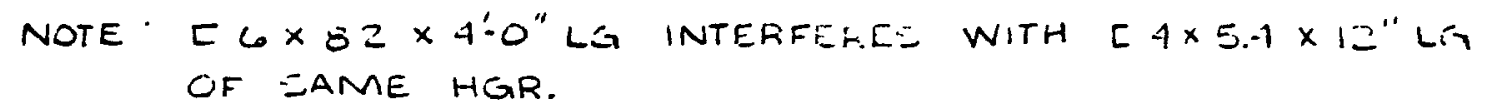

REFERENCE DIM DO NOT MATCH WITH DIM GIVEN FROM COLUMN LINE:

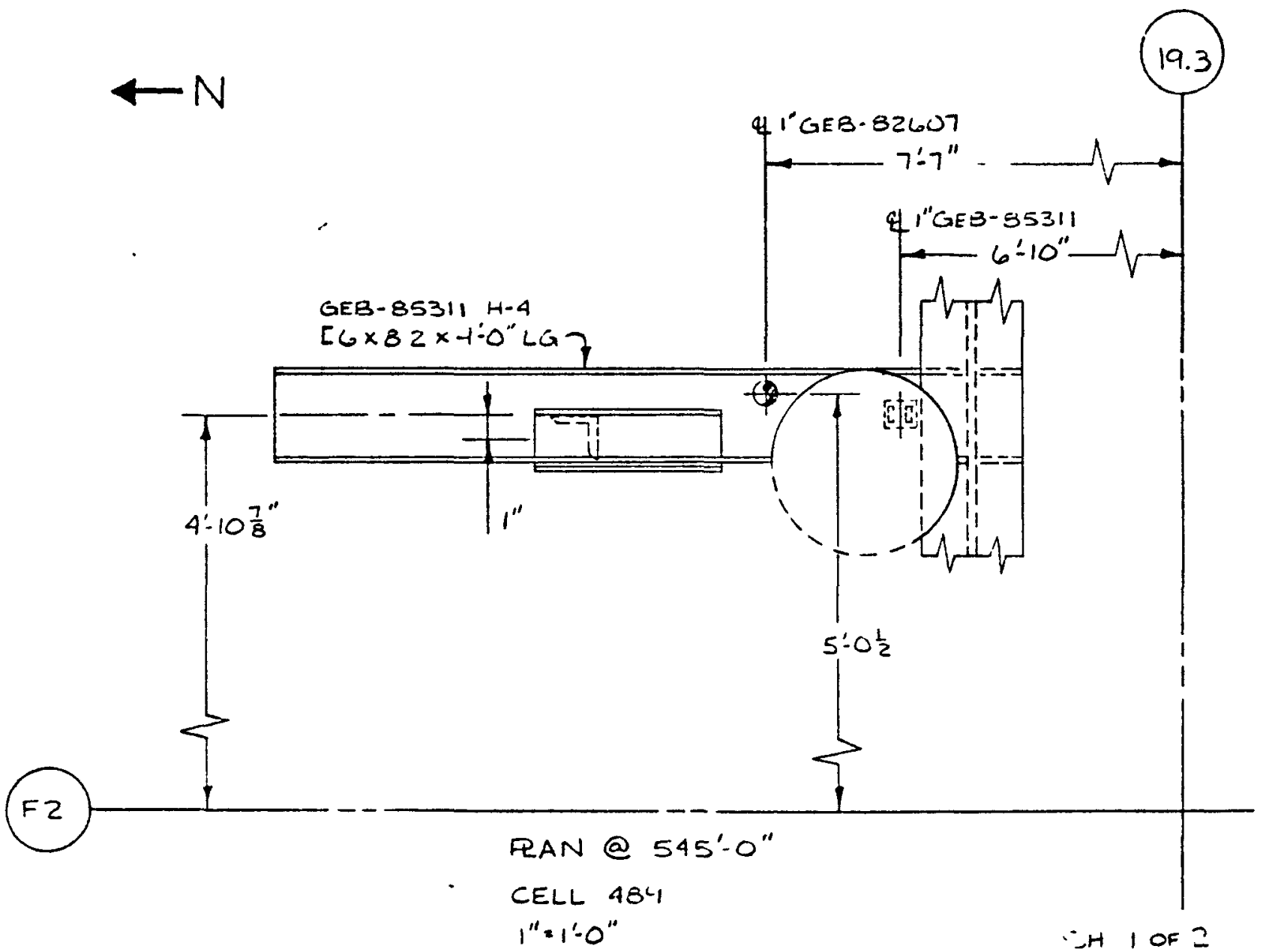




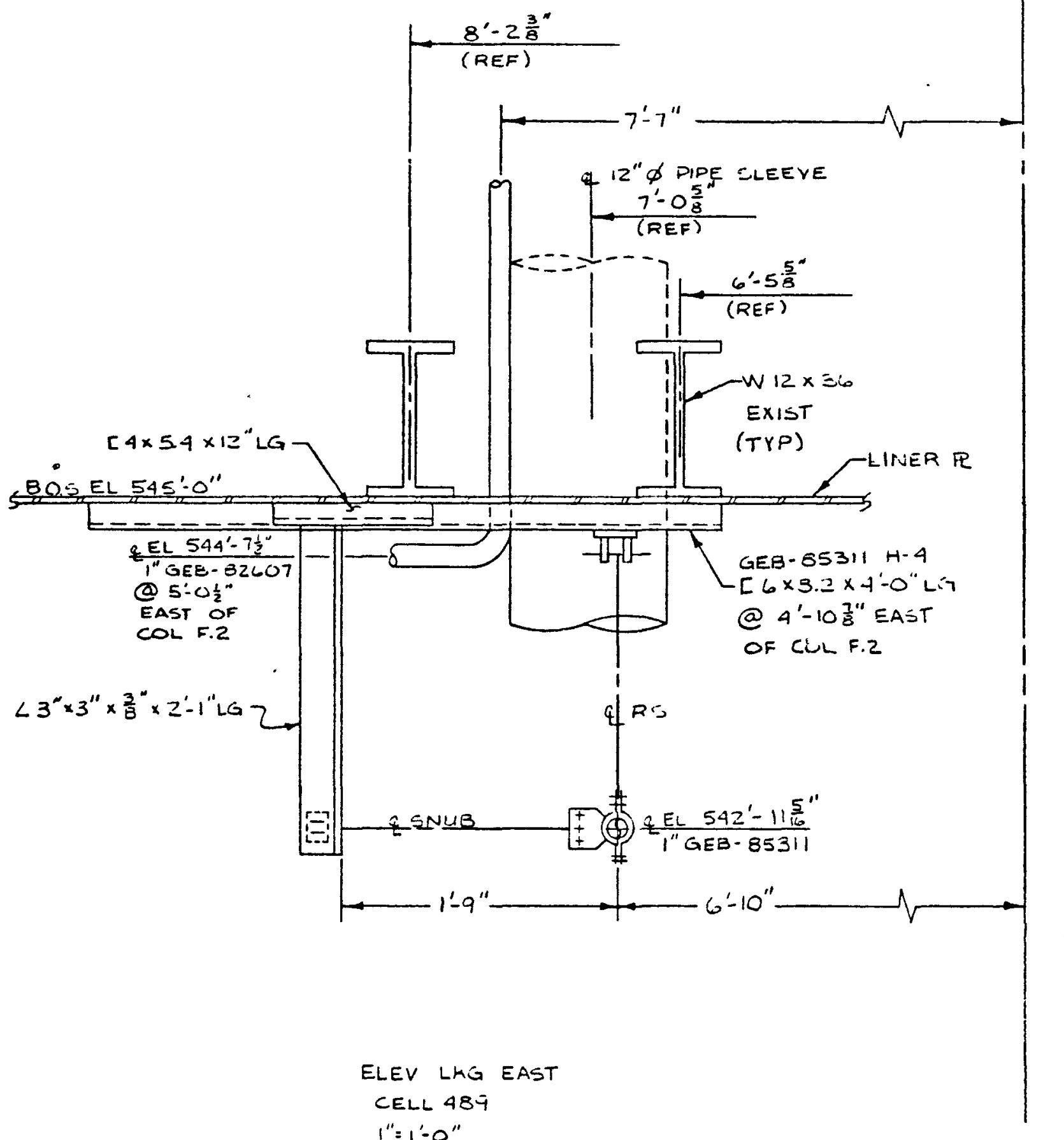


1024

FFTF
$: 7-17$

$K M<$
$2-255$

2

H.4-19016 REV. 2 =H 62 PPG. FABkKATION 1SO. I' GEB-82607

H.4.36509 REV I SH. 394 PIPE SUPPORT GCB.85012 H.3

WA $13 \times 66^{\prime}-4 \frac{1}{8} "$ LG T.0.5 EL. $536^{\prime}-11^{\frac{1}{2}}$ ", PART OF GCB-85012 H-3 INTERFENES WITH I" GEB-82607 \& EL. 536'-8", AT S'-11" SOUTH OF COLUMN 19.3

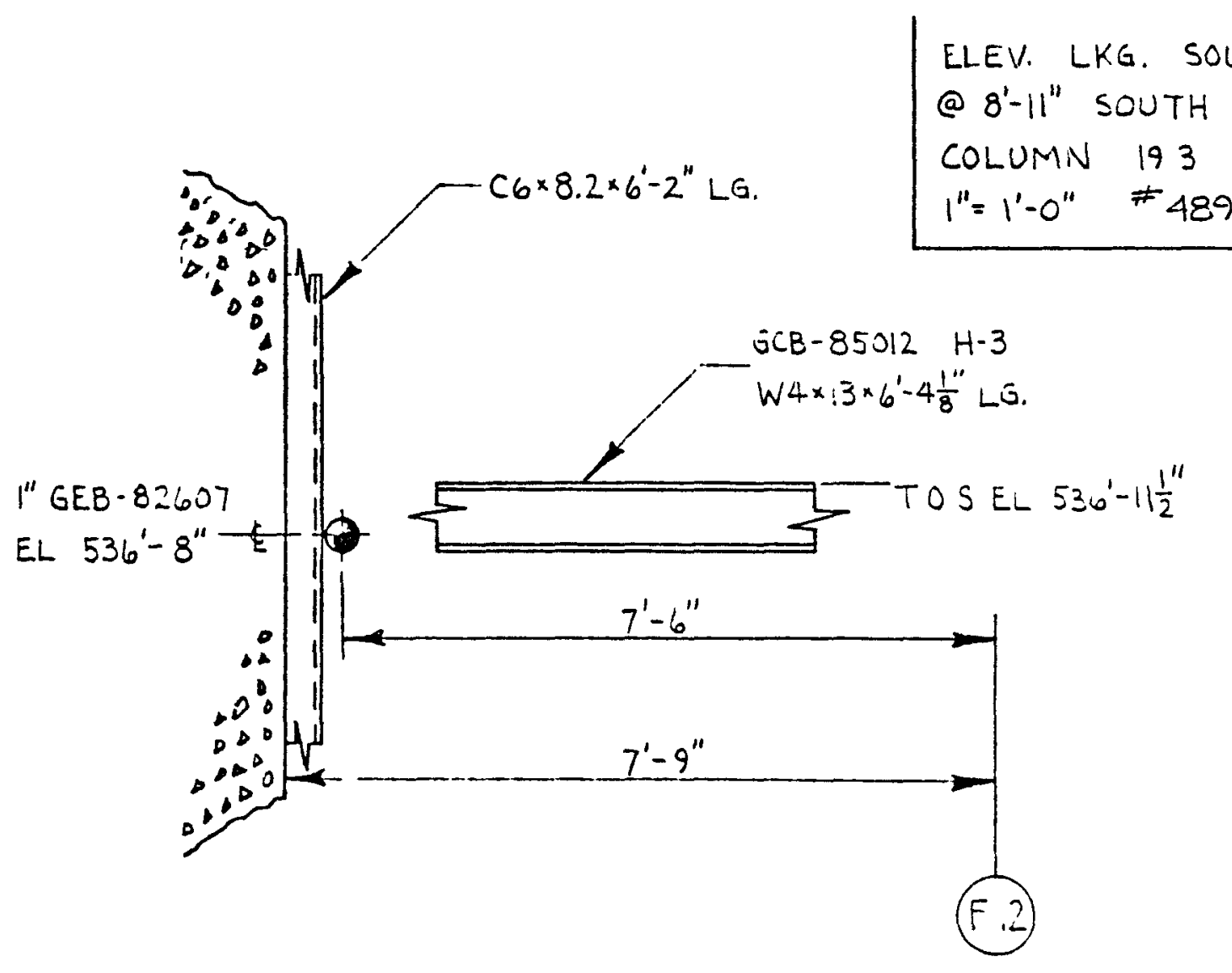



1024
$4-7-77$
$\therefore$ こティ
FFTF
$K M C$
2

H-4-19016 REV 2 SH.62 PPG FABRILATION lSO I" GEB-82607 H-4.36509 REVI SH. 395 PIPE SUPPORT GLB-35012 H.4

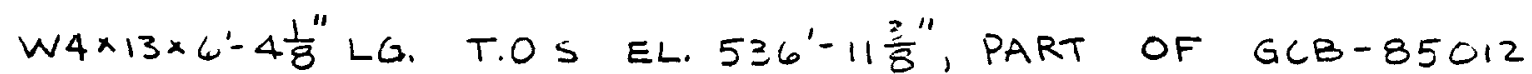
H-4 INTERFERES WITH I" GEB-82607 \& EL. 536'-8", AT $5^{\prime}-2^{\prime \prime}$ SOUTH OF COLUMN 19.3

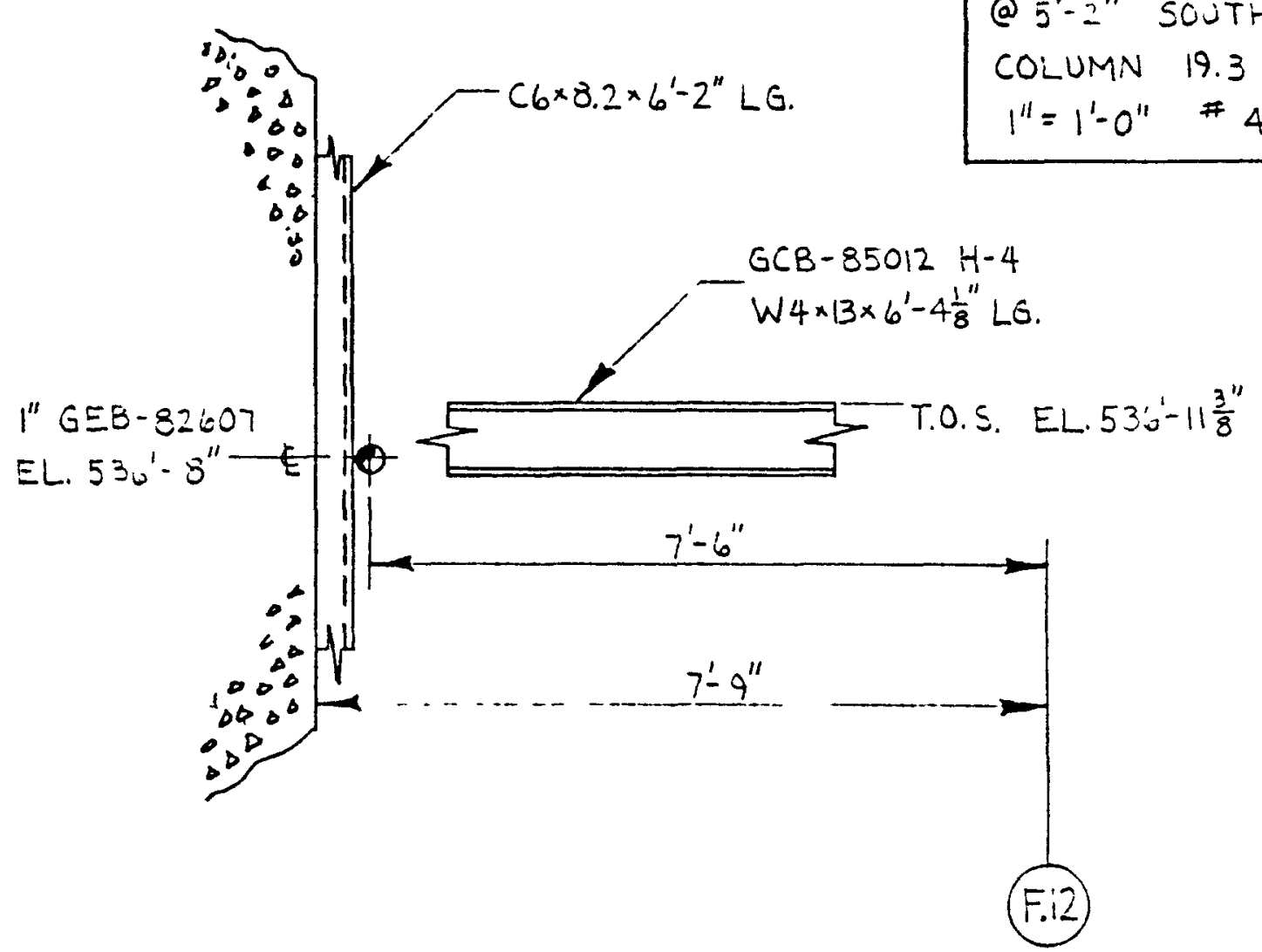

ELEV - G. SOUTH. @5'-2" SOUTh 2F COLUMN 19.3 $1^{\prime \prime}=1^{\prime}-0^{\prime \prime} \# 489$ 
1024

FFTF
$4-7-77$

$K M c$
$2-260$

2

H-4.19016 REV. 2 SH. 62 PPG FABRICATION 150 I" GEB-82607 H.4-36509 REV.1 SH. 396 PIPE SUPPORT GLB-85012 H.5

W $4 \times 13 \times 6-4 \frac{1}{8}$ "LG. PART OF GCB-35012 H-5 INTERFERES WITH I" GEB-82607 E EL. 536'-8", AT 17" SOUTH OF COLUMN 19.3

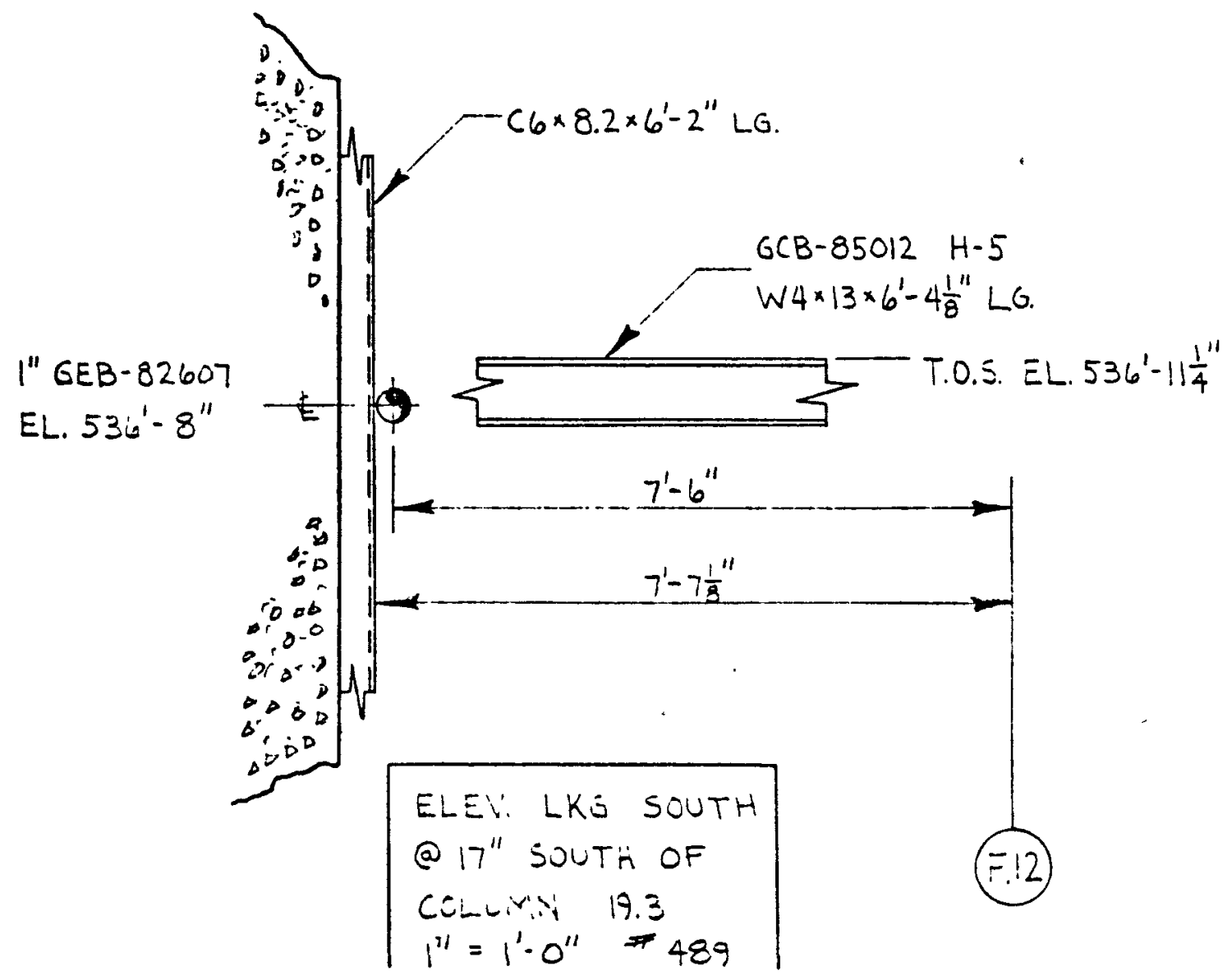


1024

FFTF

$H-4-36507-3$ SHT. 1062

$H-4-36509-1$ SHT. 826 $4-7-i i$

$S+10$

$G C B-81138-H 2$

GEE - E5A11- H1G
2-201

2

GCB-81138-H2 INTERFERES WUTH GEE-2.5411-H16 AS SHOWN.

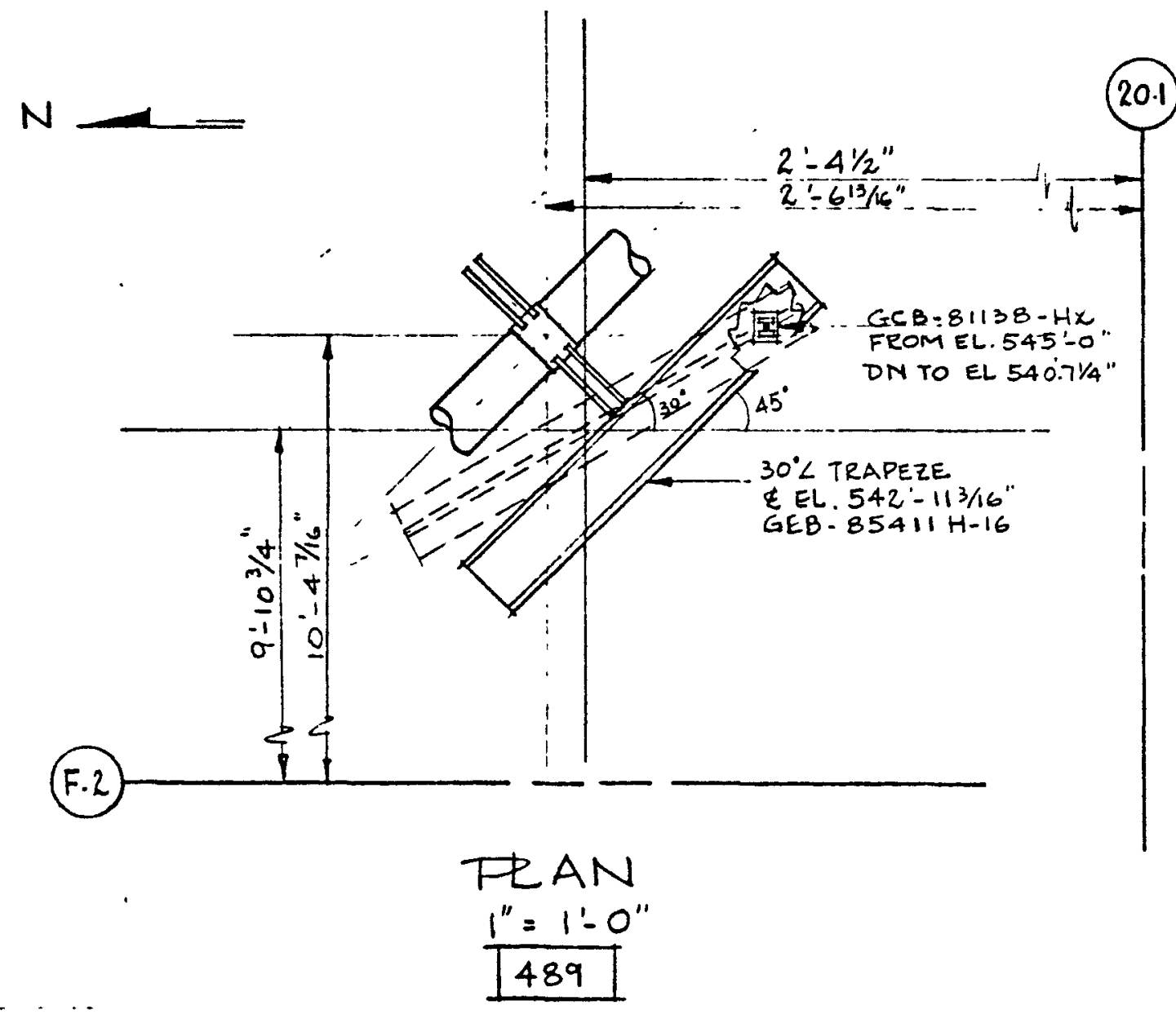


$10 \times 4$

FFTF

$H=4-36507-35 H T 1051$

$H-4-36509-1$ SHT 562

$$
\begin{array}{cc}
4-7-77 & \because 2 \ldots= \\
=+10 & 2
\end{array}
$$

GCE - $=113 E-H 7$

GEE - :5111- H3:1

GEE - E5111- H39 INTERFERLS WUITH GCE. $\$ 11=5$ HT AS SHOUN.

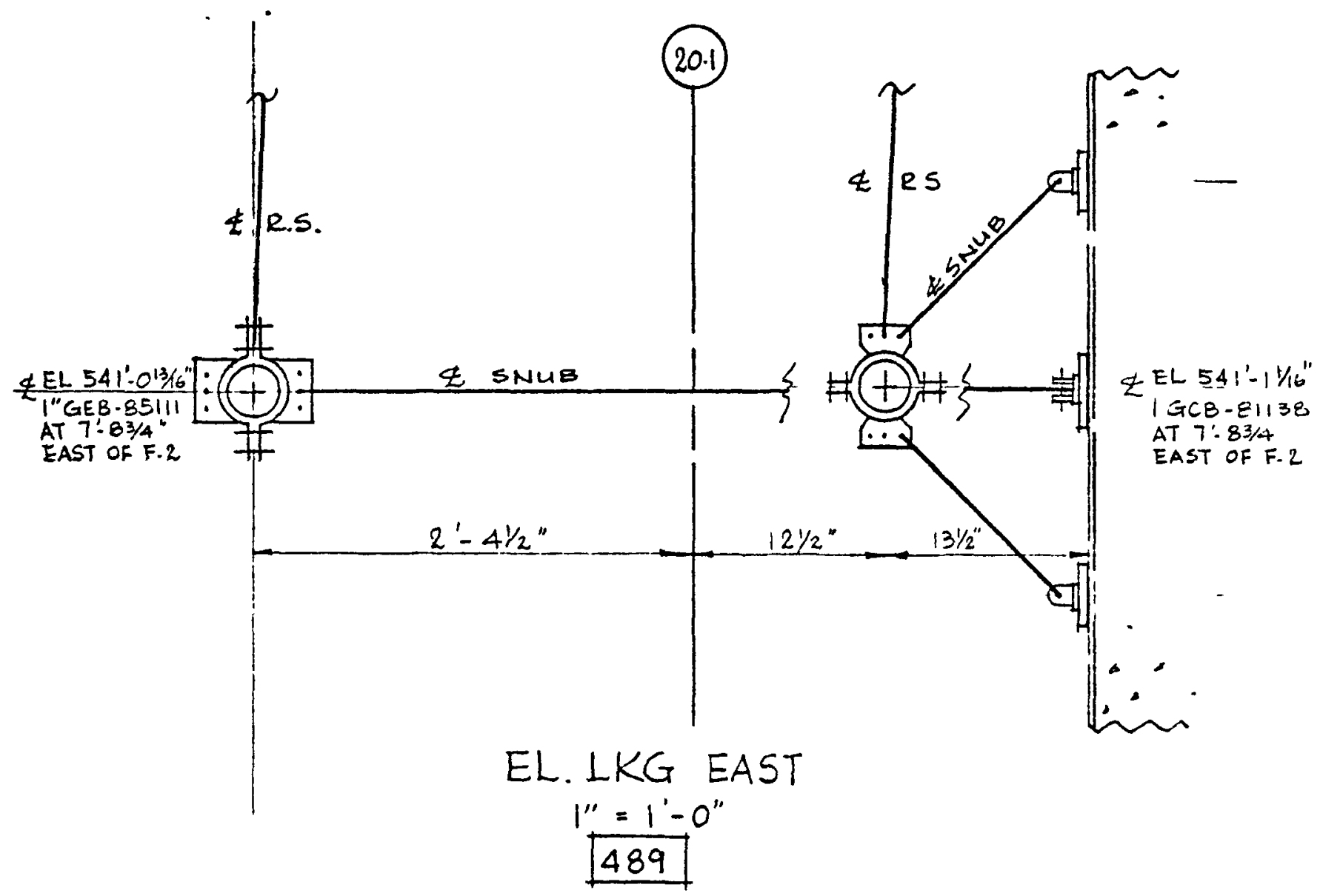




$$
\begin{aligned}
& \text { :こへ4 } \\
& \text { FFT : } \\
& 4-7 \cdot 11 \\
& \mathrm{SHO} \\
& \ddot{Z-200} \\
& H-4-36504-1 \text { 5HT.321 GCE- E5C11-HI } \\
& \text { H-4-36509-1 SHT. 420 GCE-EEC12-H2T }
\end{aligned}
$$

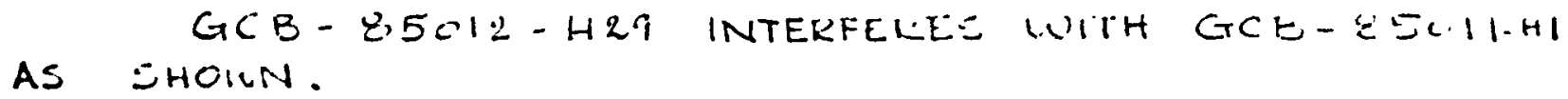
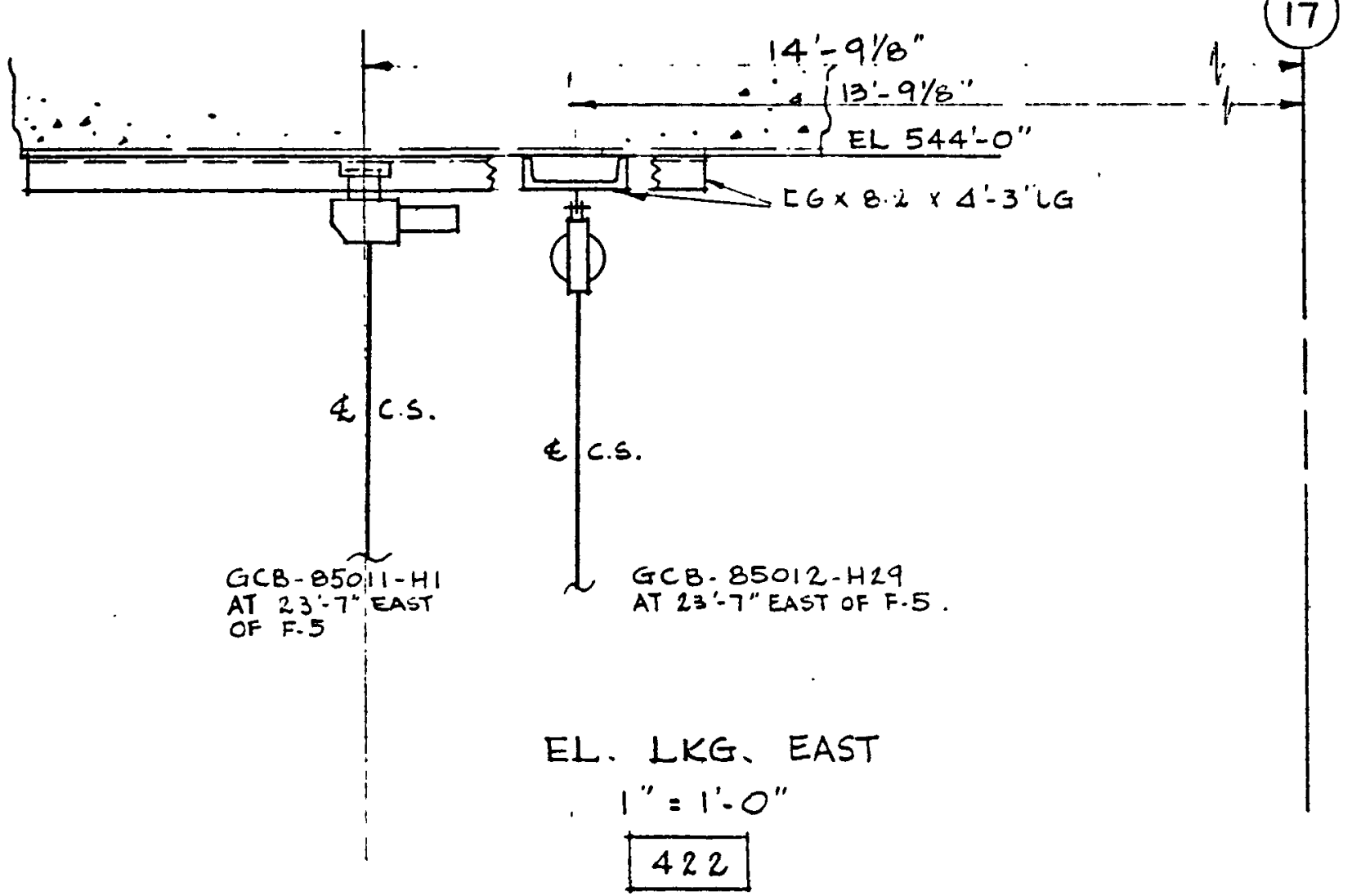


$$
\begin{array}{llll}
10=4 & \rightarrow \cdots & \ldots & 2-2, \cdots i
\end{array}
$$

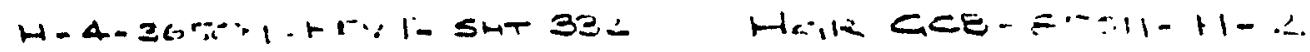

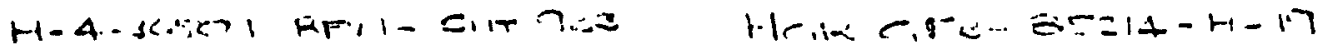

C6.13 OF HANTER CIEE-S5:14-H-M

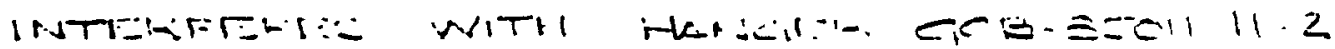

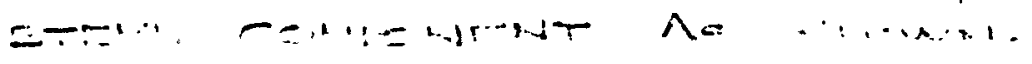
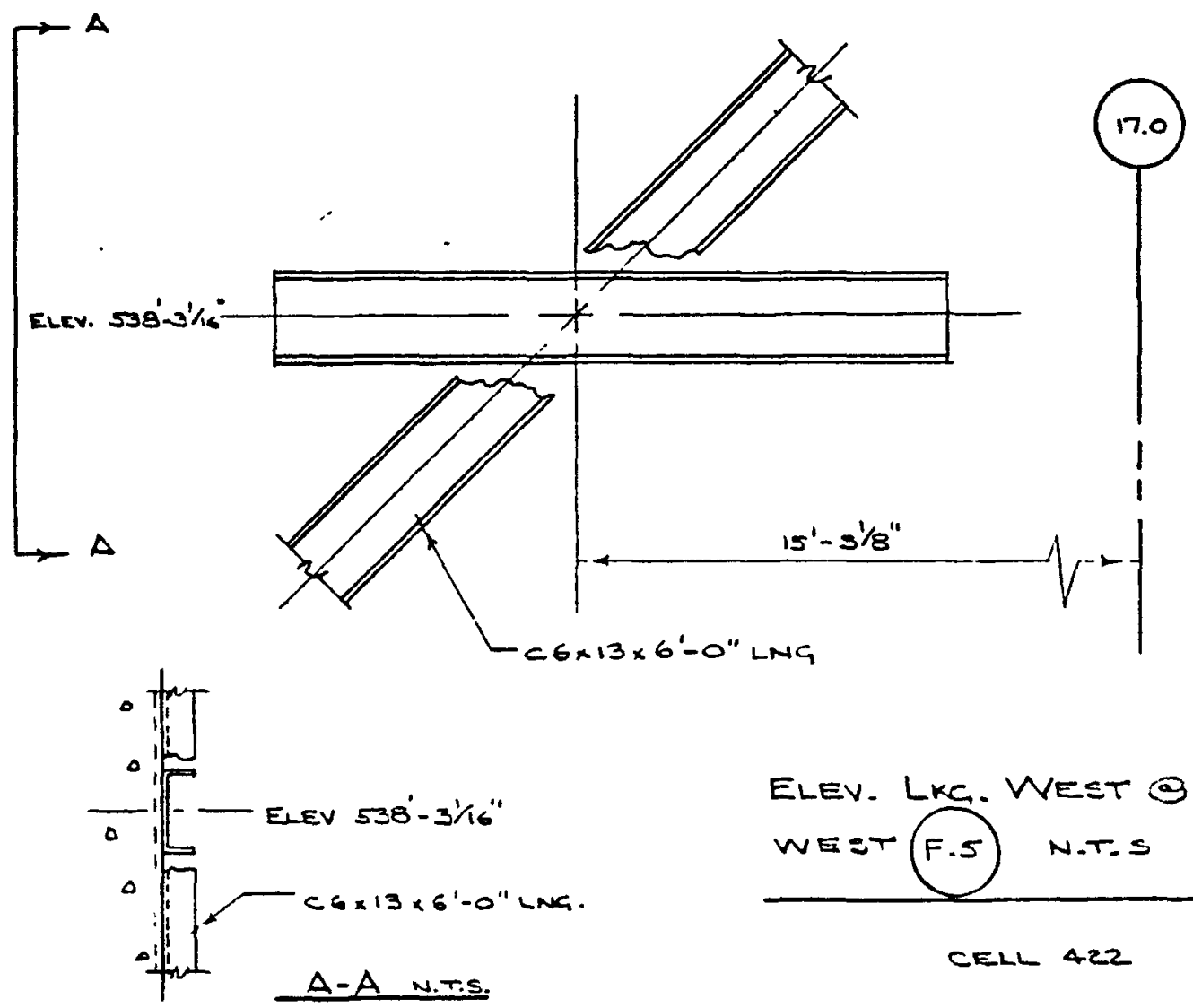

ELEV. LKC. WEST @ $23^{\prime}-7^{\prime \prime}$ $W E=T$ F.S N.T.S 
1024

FFTF
$7 \Delta++\cdots$

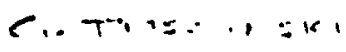

$\because-6=$

H.

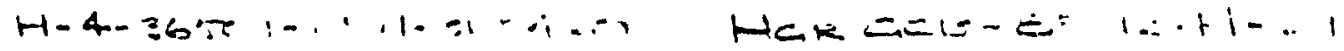

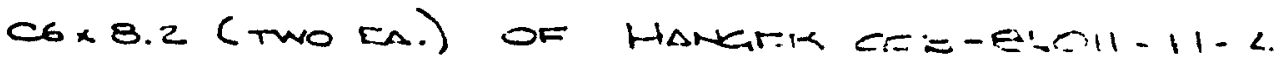

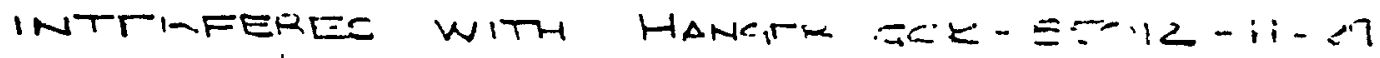
ces $E . \Delta=$ Dririn.

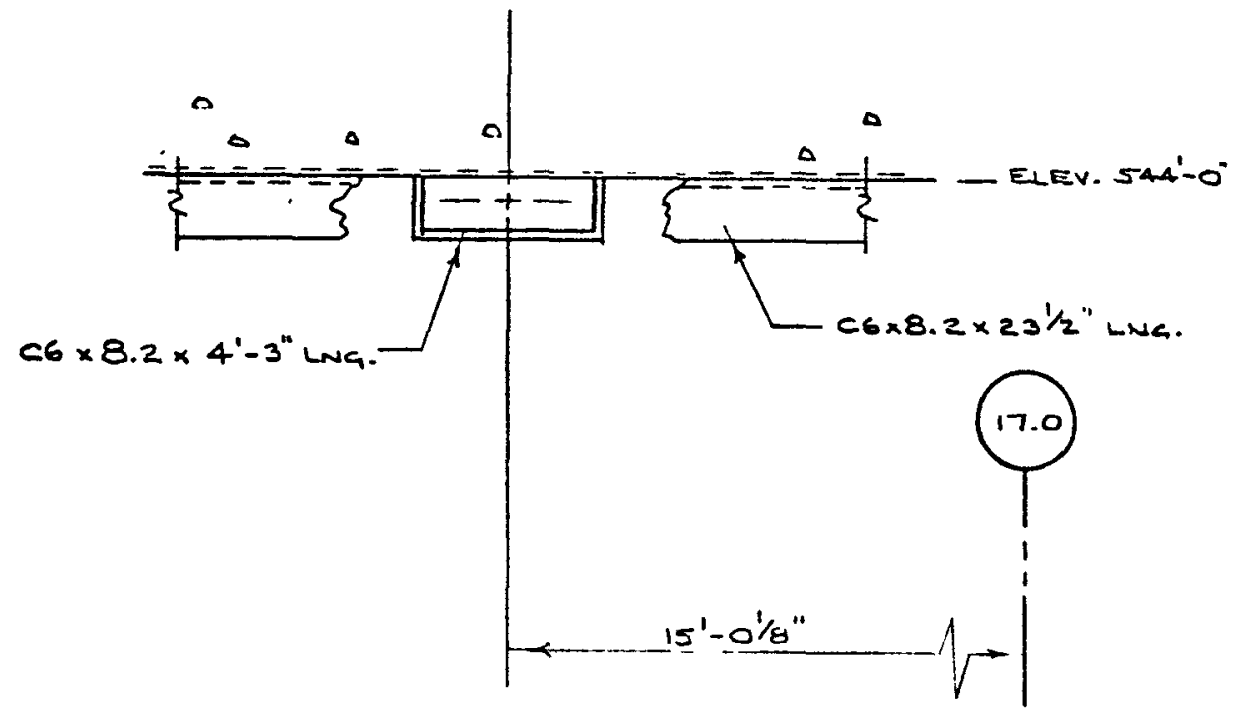

ELEV. LKG. EOST $\Phi=3^{\prime}-7^{\prime \prime E O S T ~ F .5 ~ W . T . E . ~}$

CELL 422 


$$
\begin{array}{ccc}
10-4 & 4-6-77 & 2-266 \\
\text { FFTF } & K M C & 2
\end{array}
$$

H-4-36509 REV I SH.333 PIPE SUPPONT GCB-85011 H-3 H-4.36995 REV.ISH. 283 PIPE SUPPORT HCB-85353 H-8

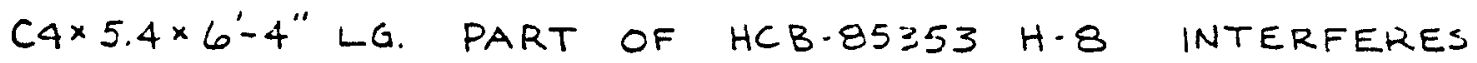
WITH A PIELE $T F$ CHANNEL FOK UUB 350.1 H-3, BOTH PIECE:

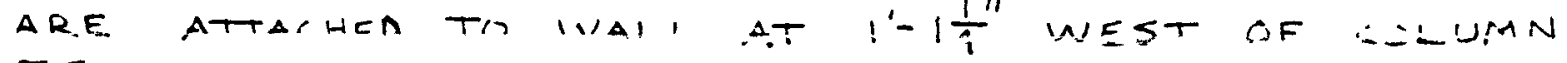
F.2

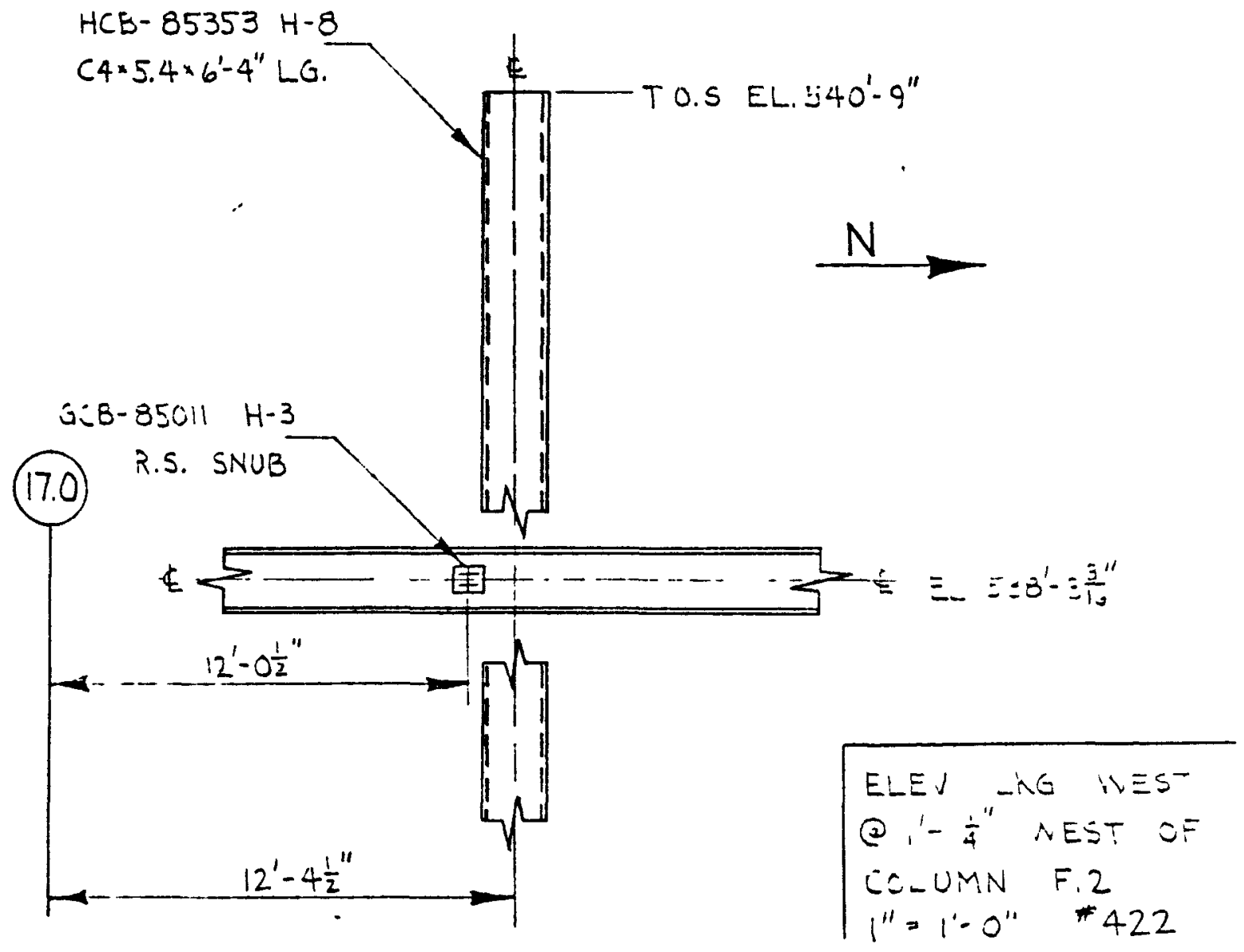


1024

FFT.F $\rightarrow-: \div$

KMc
$2-267$

2

H-4.36509 REV. I SH. 333 PIPE SUPPORT GCB.85011 H.3 H-4.36509 REV. I SH. 418 PIPE SUPPORT GCB-85012 H.27

I" RIGID SUPPORT PART OF GLE-85012 H.27 INTERFERES WITH I" RIGID SUPPORT AND 18"LG. TEE FOR GCB-85OII H.3.

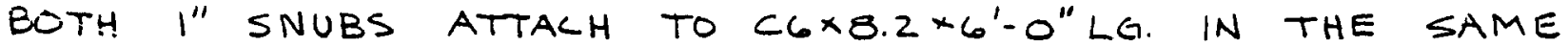
LOCATION, $24^{\prime}-2 "$ EAST OF LOLUMN F.5

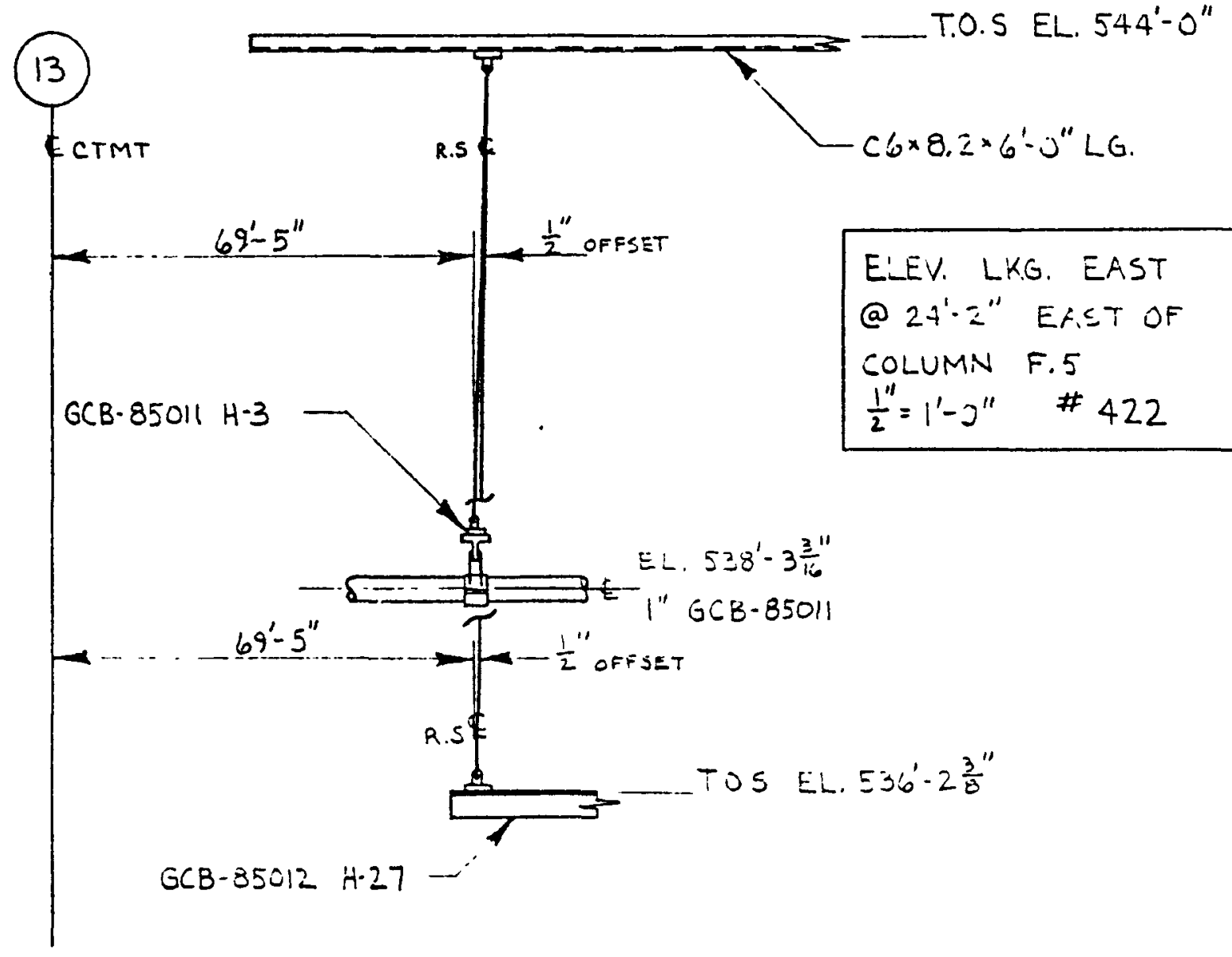


1024

FFTF
$4-8-77$

$K M$ $7-\sec =$

2

H.4-36509 REVI SH. 333 PIPE SUPPORT GCB.85011 H-3 H-4-36509 REV. O SH. 607 PIPE SUPPORT GEB.85210 H-1

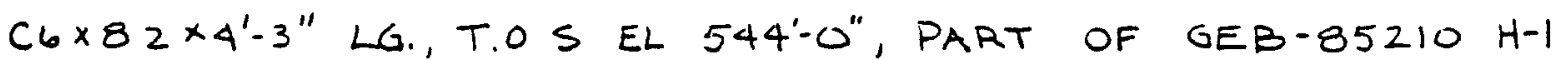
INTERFERES WITH TWO I" SNUBS AND TWO $66 \times 8.2 \times 4$ '- 3 " LG., T.O.S EL. 544'-O" AS SHOW'N

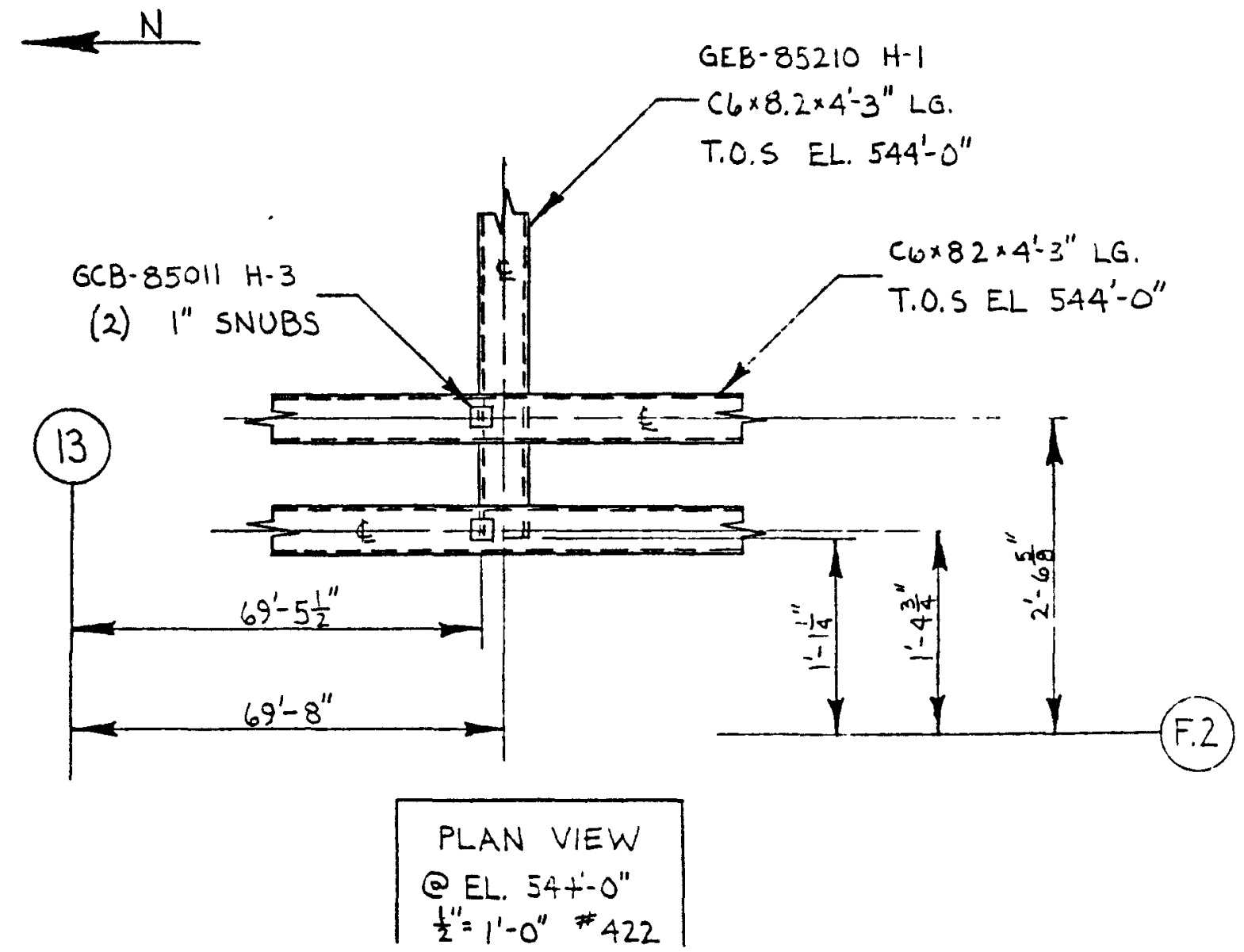


iút

FFTF
$4 \cdot 8 \cdot 7 ?$

$K M C$ $2-\sum(x-1)$

2

H-4-36509 REV.I SH. 333 PIPE SUPPORT LCB-85011 H-3 H.4.36509 REV.O SH. 693 PIPE SUPPORT GEB-85214 H.18

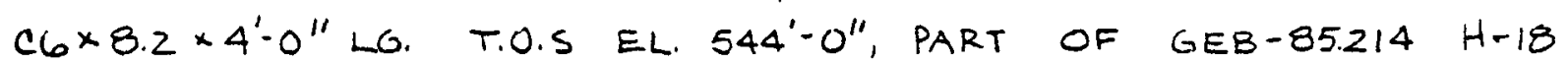
INTERFERES WITH TWO $16 \times 8.2 \times 4^{\prime}-3^{\prime \prime}$ LG. AND TWC I" SNUBS TOK EI. 544'-O" AL SHOWN

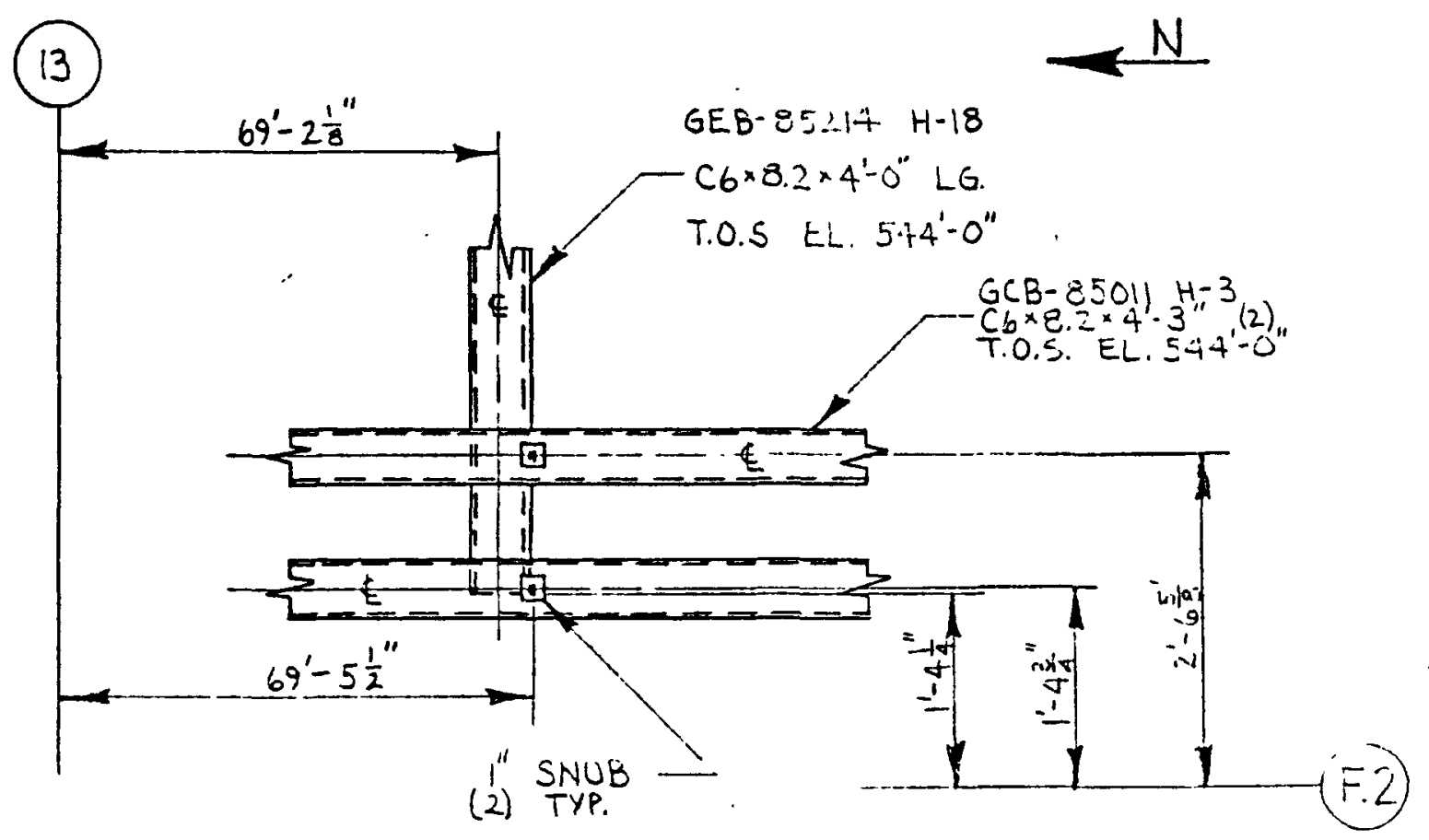

$$
\begin{aligned}
& \text { PIAN VIEW } \\
& \text { (@ EL. } 5 T^{\prime}-D^{\prime \prime} \\
& i^{\prime \prime}=1^{\prime}-0^{\prime \prime} \text { \# } 422
\end{aligned}
$$




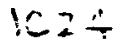
$4-8-77$
$=\because 10$
FFTंF
$K M c$
2

H-4-36509 REY.I SH. 333 PIPE SUPPORT GCB-85011 H-3 H-4-36509 REV.O SH.919 PIPE SUPPORT GEB-85210 H-19

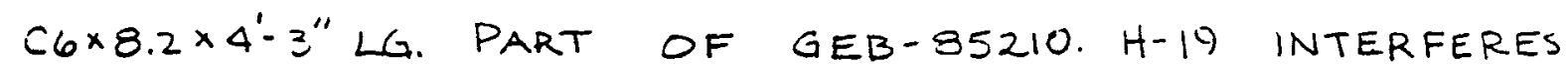

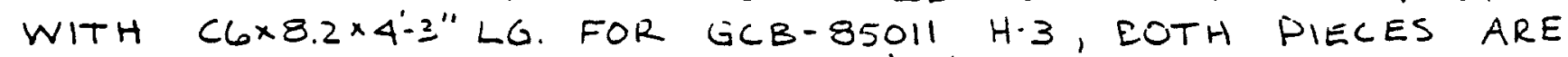
ATTACHED TO CEILING AT EL. 544'-O"
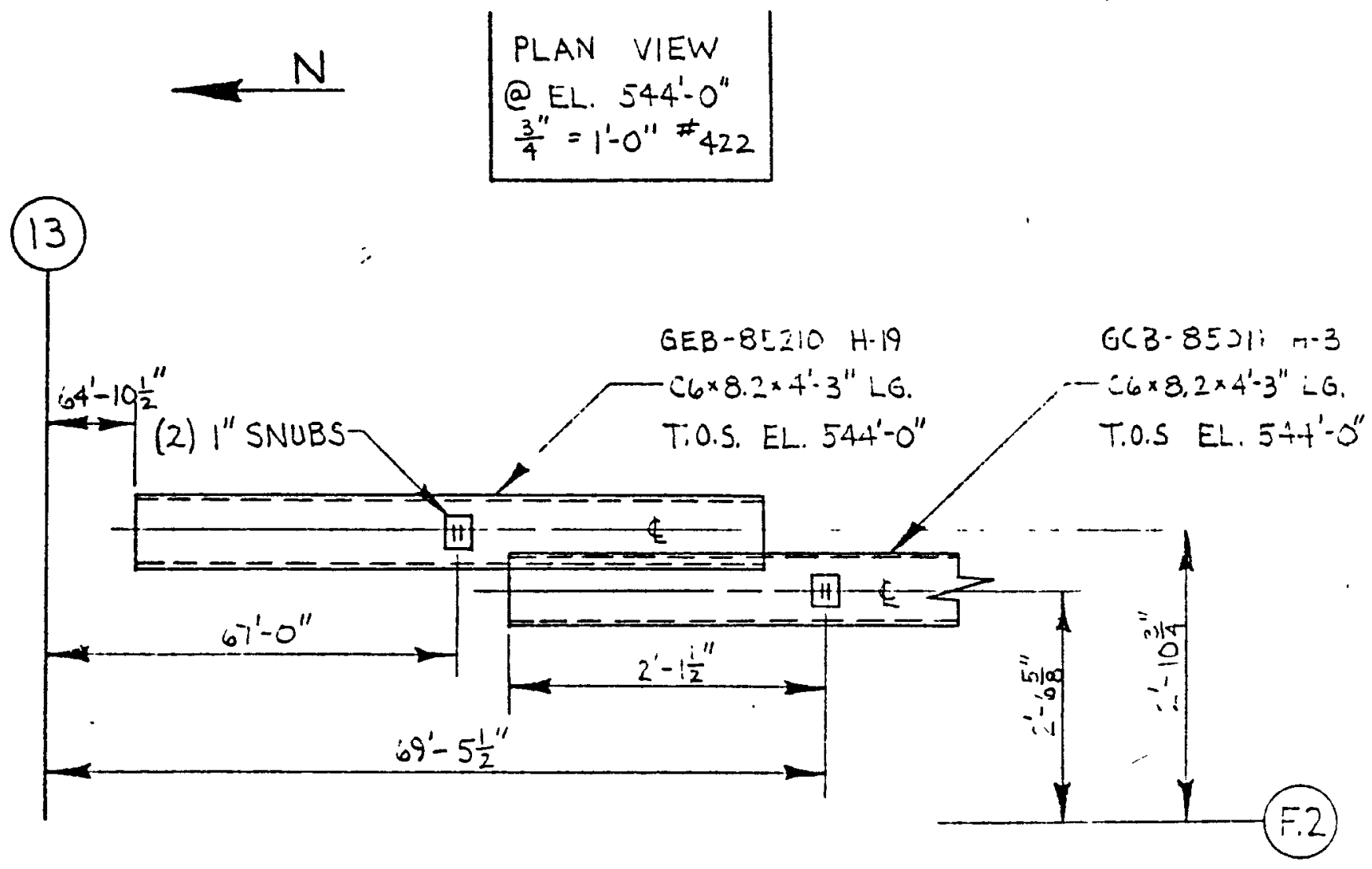


$$
\begin{array}{ccc}
1024 & 4-3-7 & 2-271 \\
\text { FFT.F } & K M C & 2
\end{array}
$$

H-4-36509 REV. I SH. 344 PIPE SUPPOKT GCE-85011 H-14 H-4-36506 REV. 3 SH.307 PIPE SUPPORT GEB-61124 H.7

I" SNUB PART OF GEB-61124 H-7 INTERFERES WITH VERTICAL I"SNUB FOR GCB-850II H-14 AS SHIOWN IN VIEWS

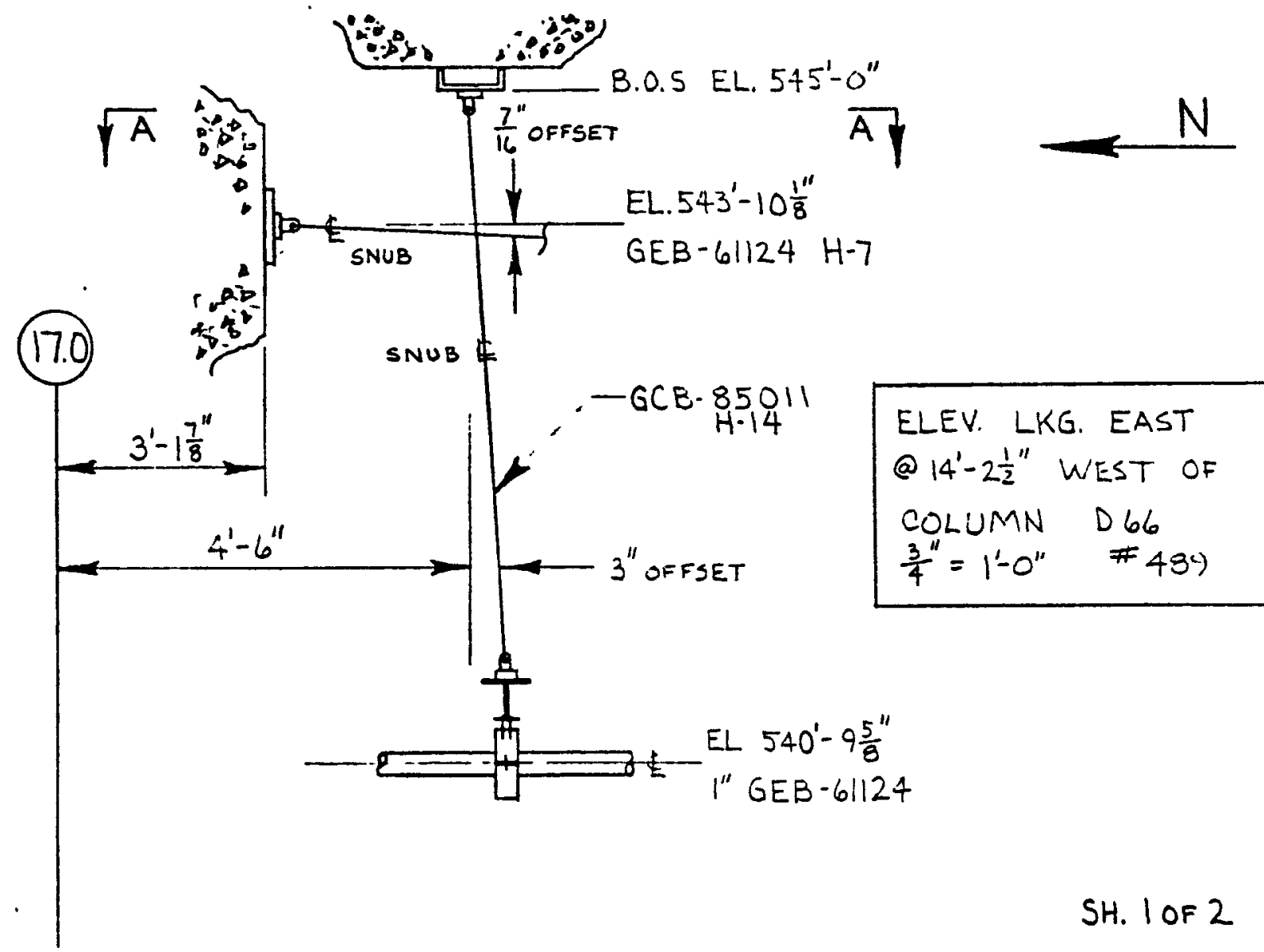




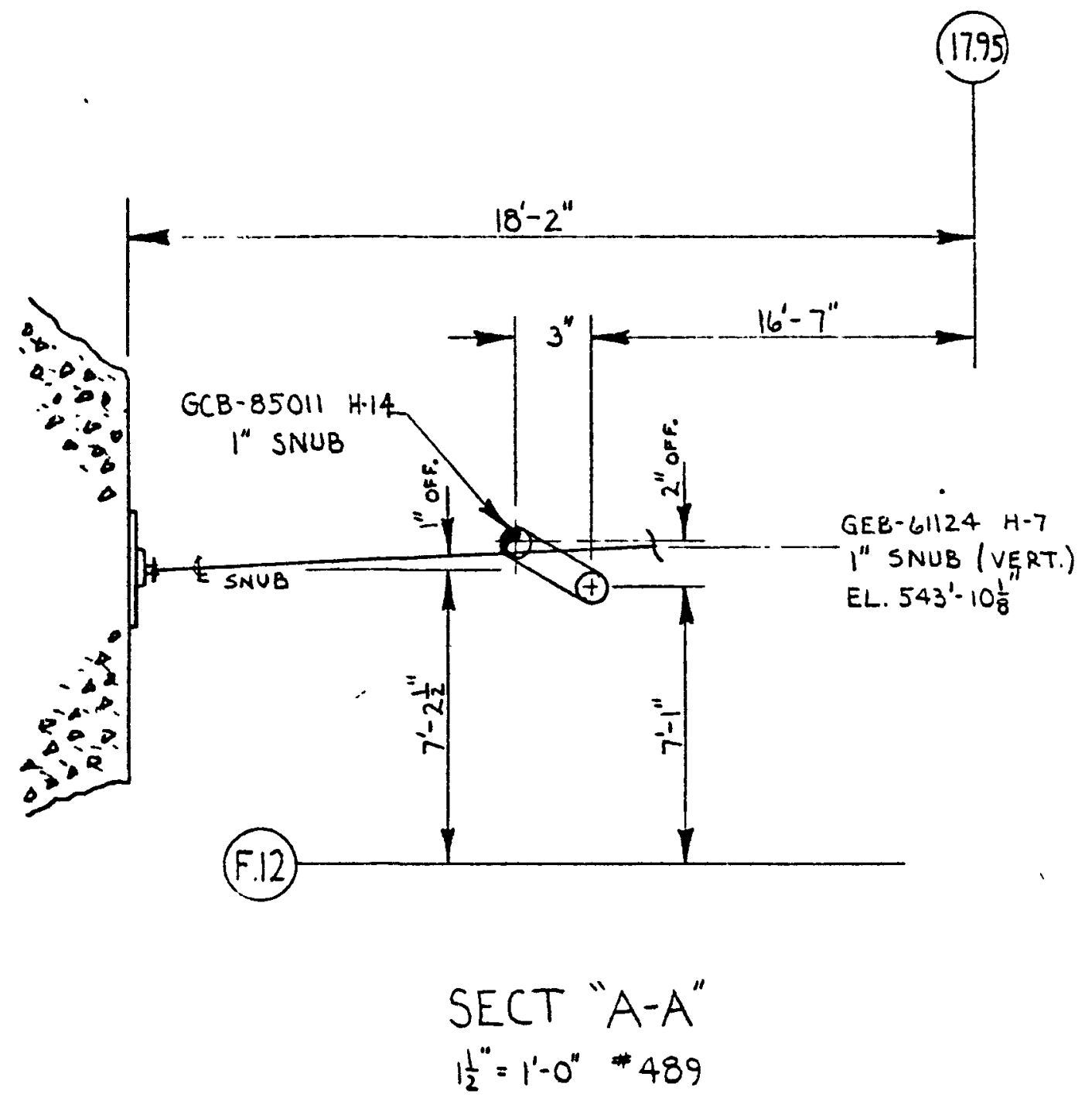

SH. 2 of 2 


$\begin{array}{ccc}1024 & 4-7-77 & 2-273 \\ \text { FFTF } & 5+10 & \sim \\ H .4-36509-2 \text { SHT } 353 & \text { GCB }-85011 H-23 \\ H-4-36509-3 \text { SHT } 131 & \text { GEB }-85111 \mathrm{H}-16\end{array}$

GTEB - $85111 \mathrm{H}-16$ INTERFERES WITH GCB - $85011 \mathrm{H} .23$ AS SHOL'N.

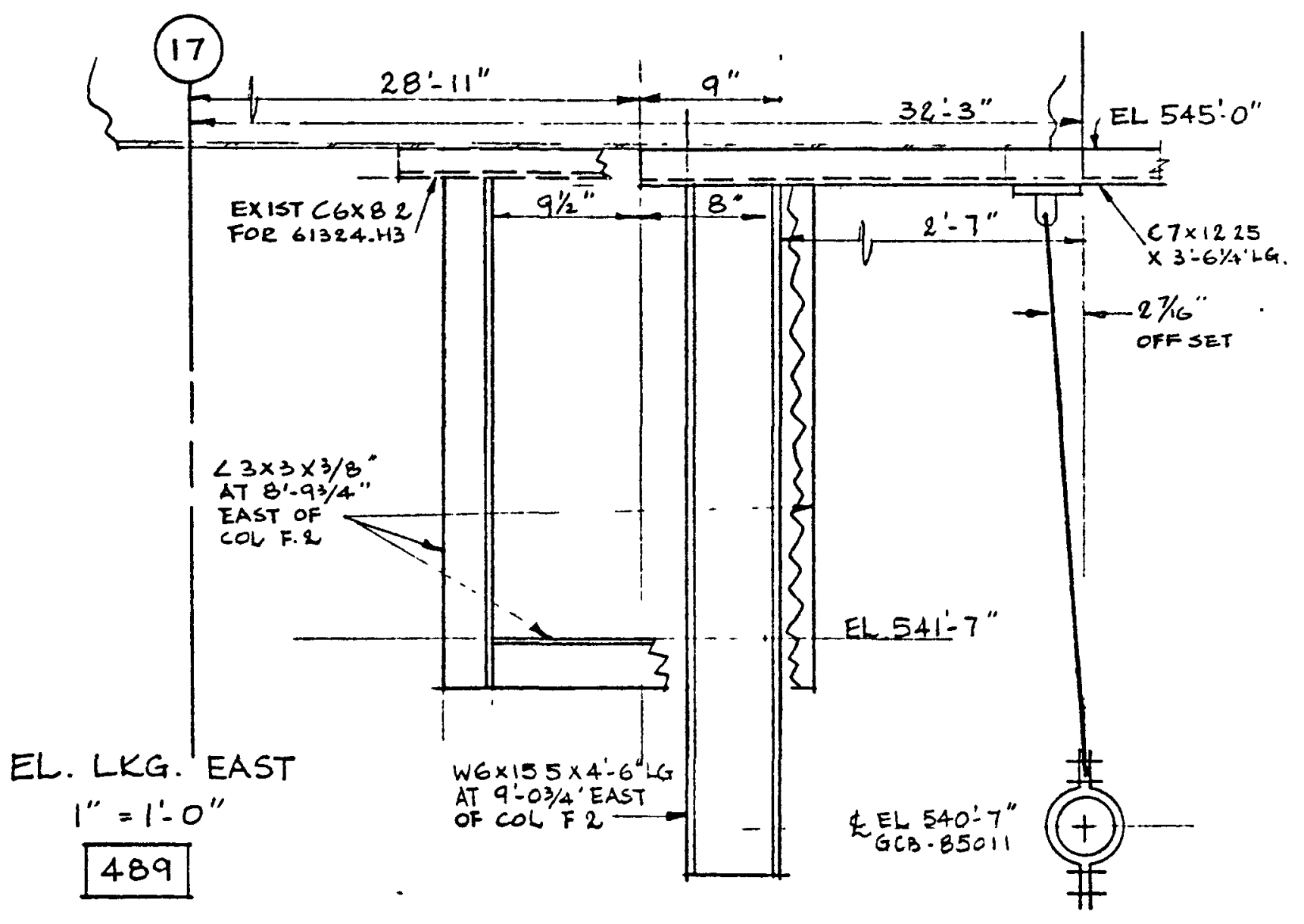




$\begin{array}{llr}\text { IELA } & +1-i: & 2-274 \\ \text { FFTF } & =\text { HO } & 2\end{array}$

$$
\begin{array}{ll}
H-4-36509-15 H T \text { 356 } & G C B-E 5011-H 26 \\
H-4-36509-15 H T .368 & G C B-E 5011-H 32
\end{array}
$$

GCE-85011-H」8 INTEKFERES WITH GLE-85011-H20 AS SHOLN.

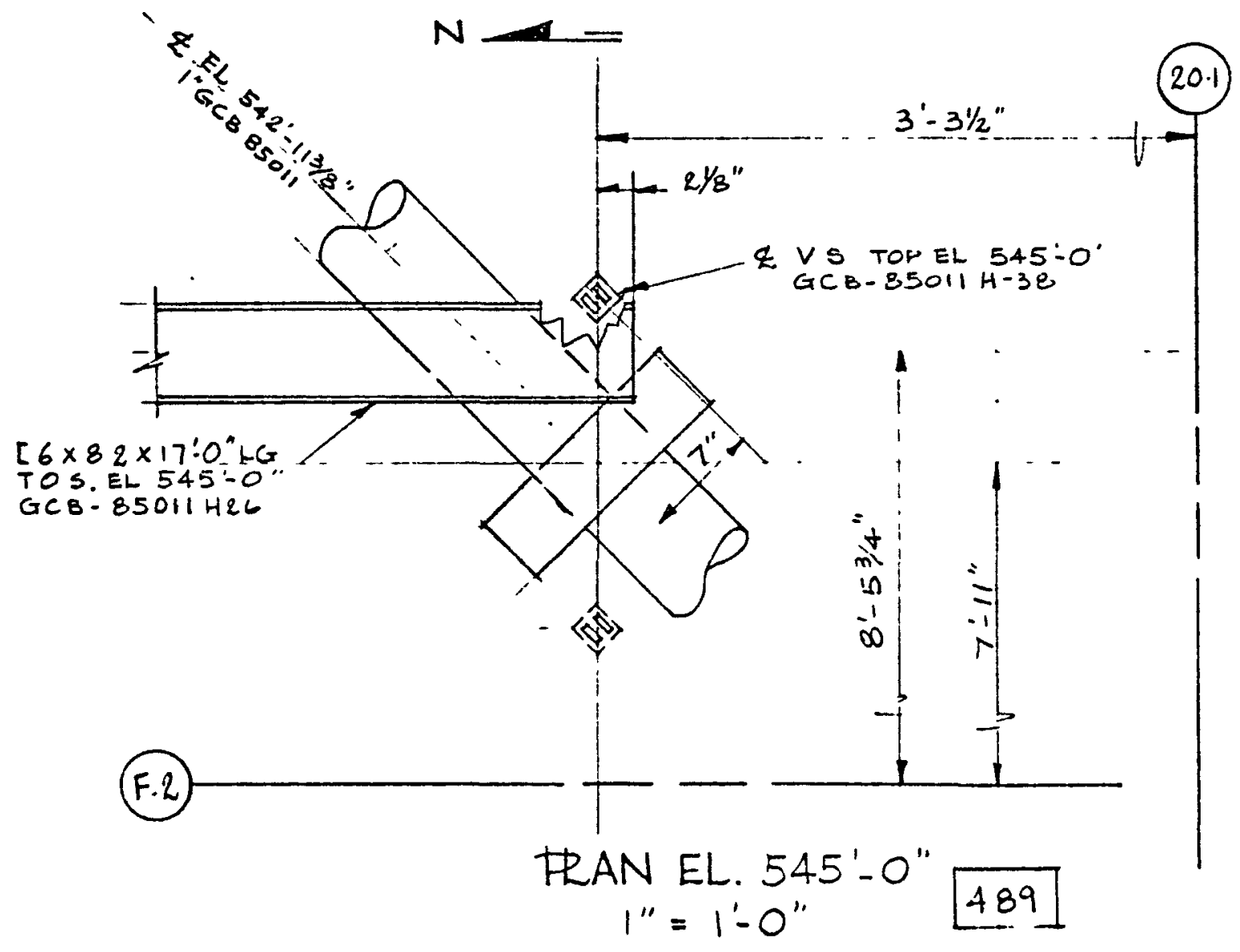


1024

FFTF

$$
\begin{aligned}
& 4-7-71 \\
& s+10
\end{aligned}
$$

$G C B-85011-426$

$H=4-36509-1$ SHT 356

H-4-36509-1 SHT 392

$G C B-250|2-H|$

GCB - 85012-HI INTERFERES LUITH GCB- $35011-H 26$ AS SHOWN.

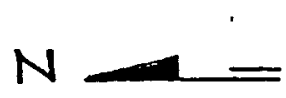

(20.1)

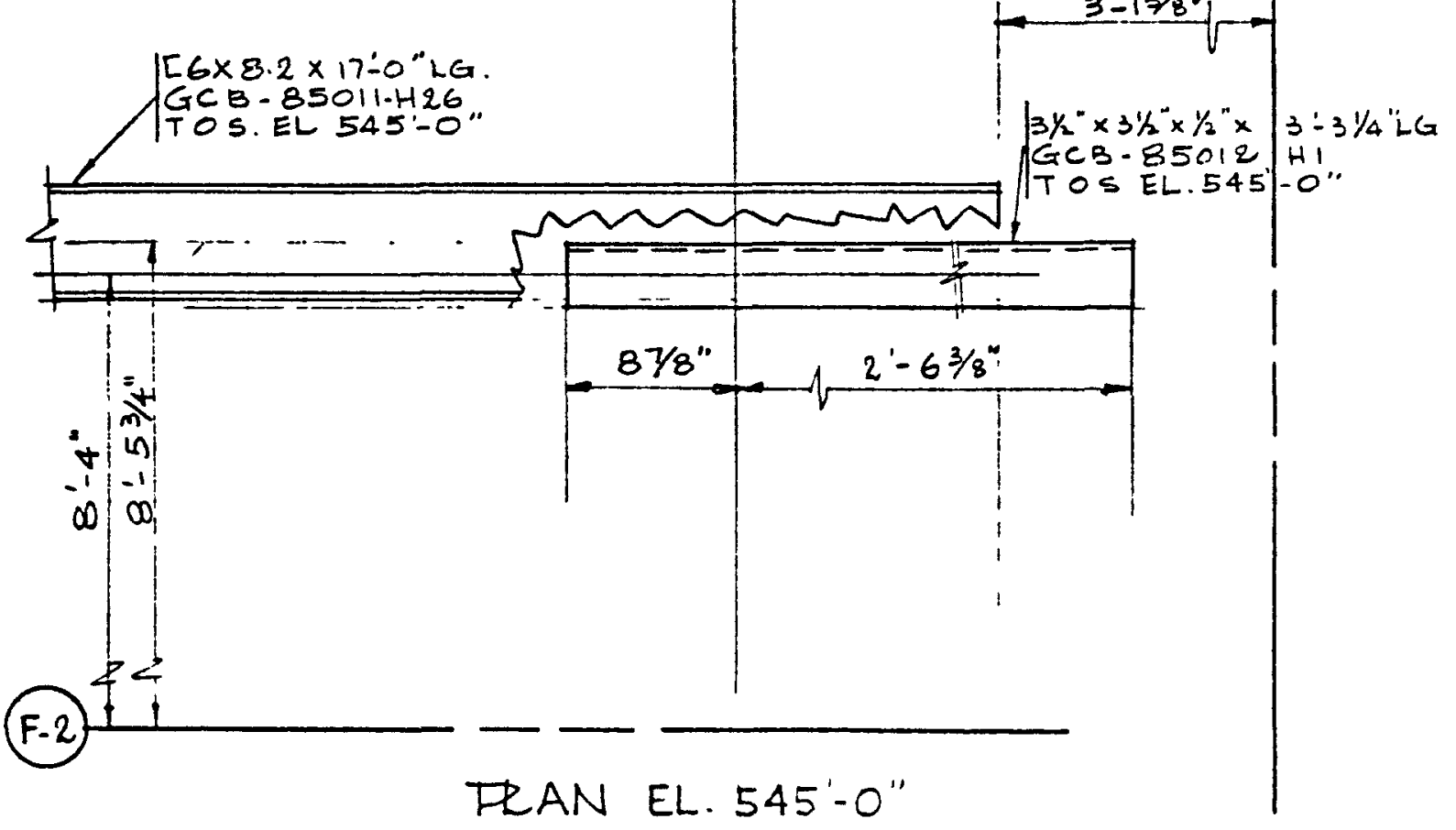

$$
\begin{aligned}
& 1^{\prime \prime}=1^{\prime}-0^{\prime \prime} \\
& 489
\end{aligned}
$$


1024

FFTF

$$
\begin{gathered}
4-8-7 ? \\
5+10
\end{gathered}
$$

GCB $-85011 H \cdot 26$

$H-4-36509-1$ SHT. 356

H-4 - 36509-I SHT. 814
GEB - $85411 \mathrm{H}-4$

GEB - 85411 H.4 INTERFERES WITH GCB-8EOIIH.26 AS SHOWN.

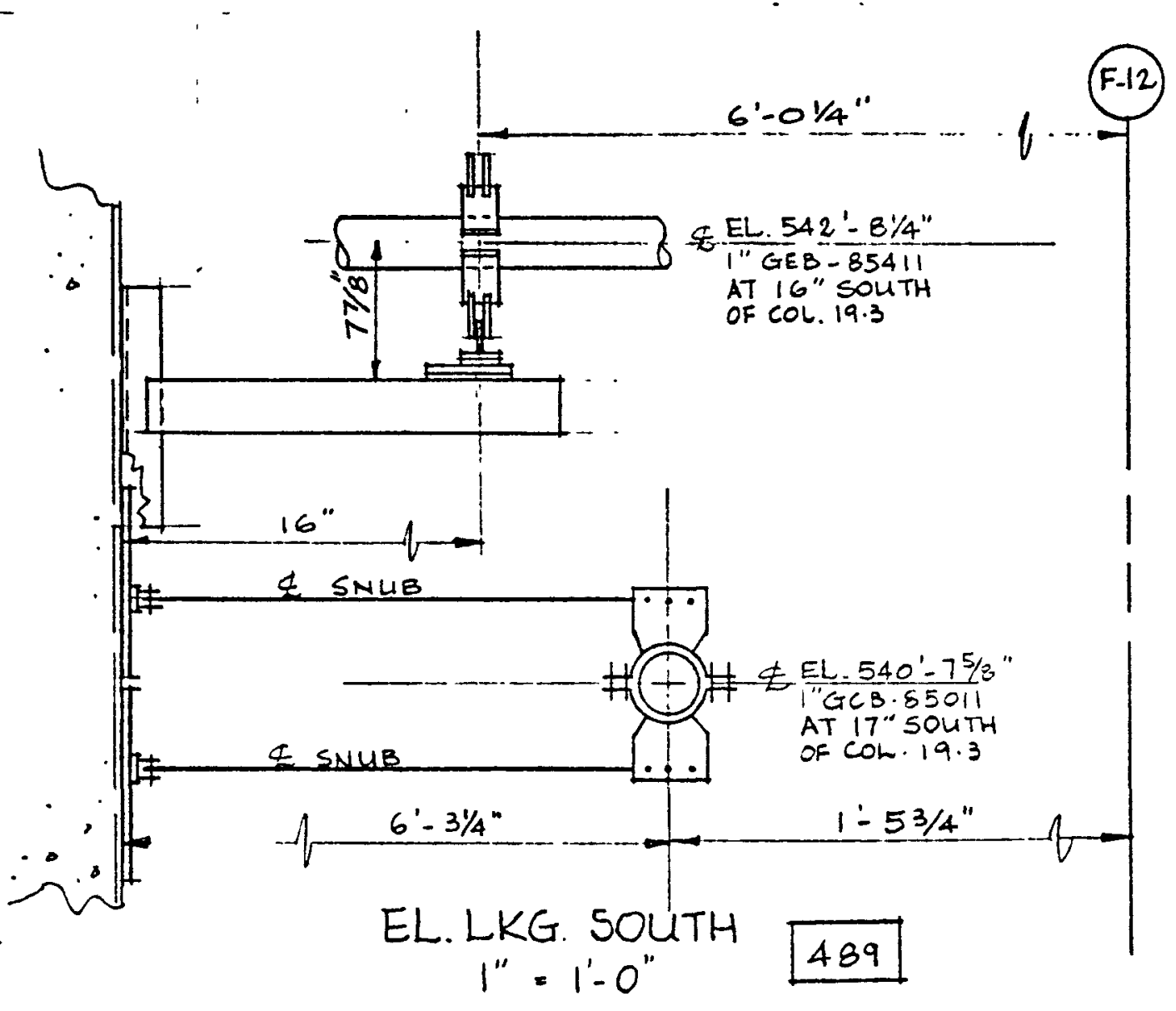




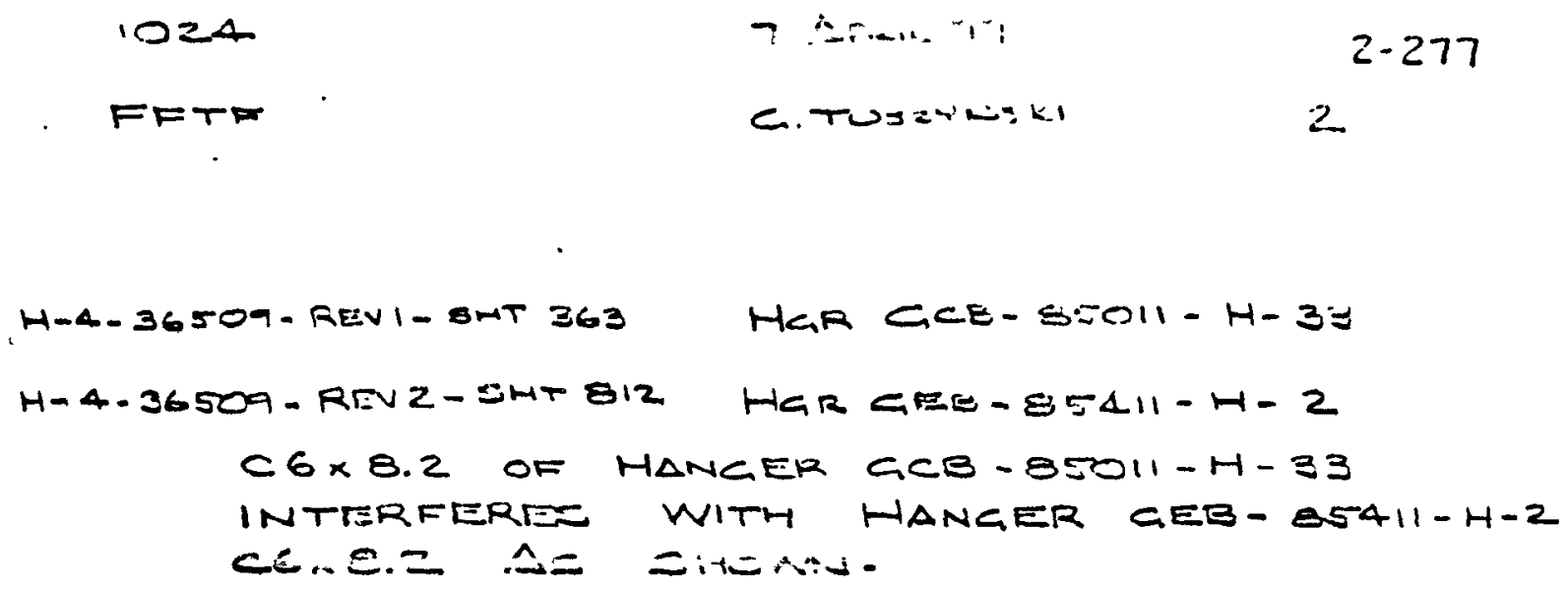

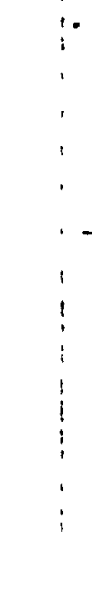




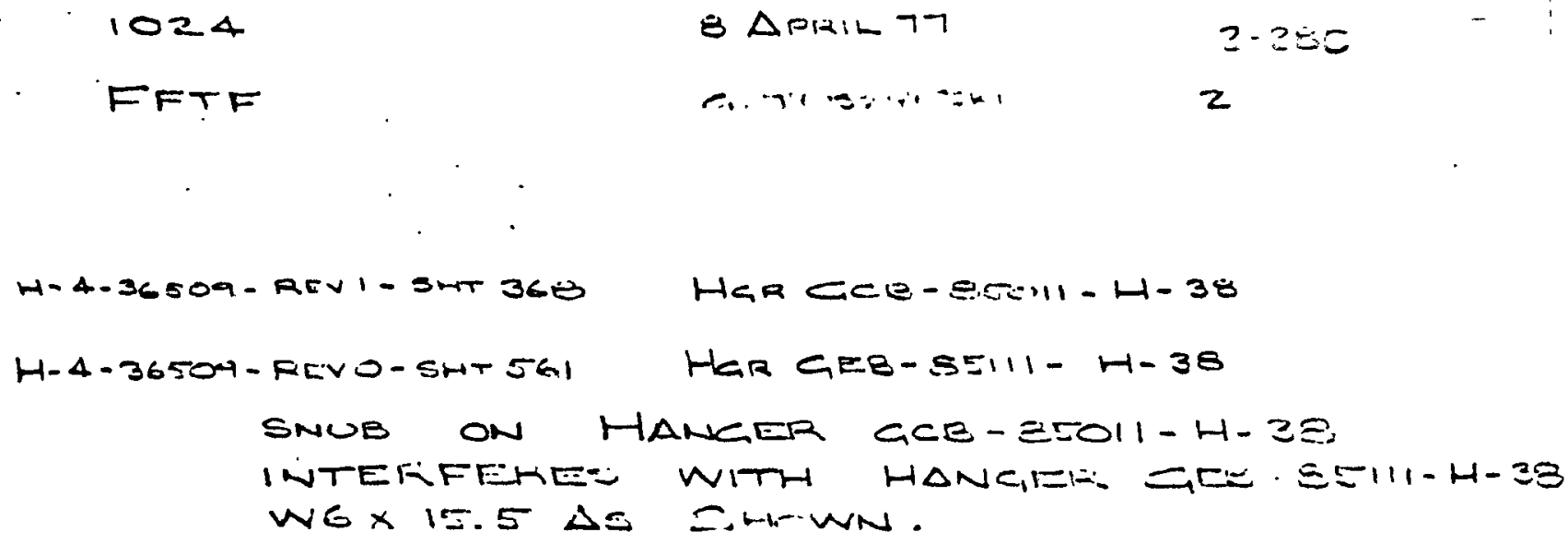

2

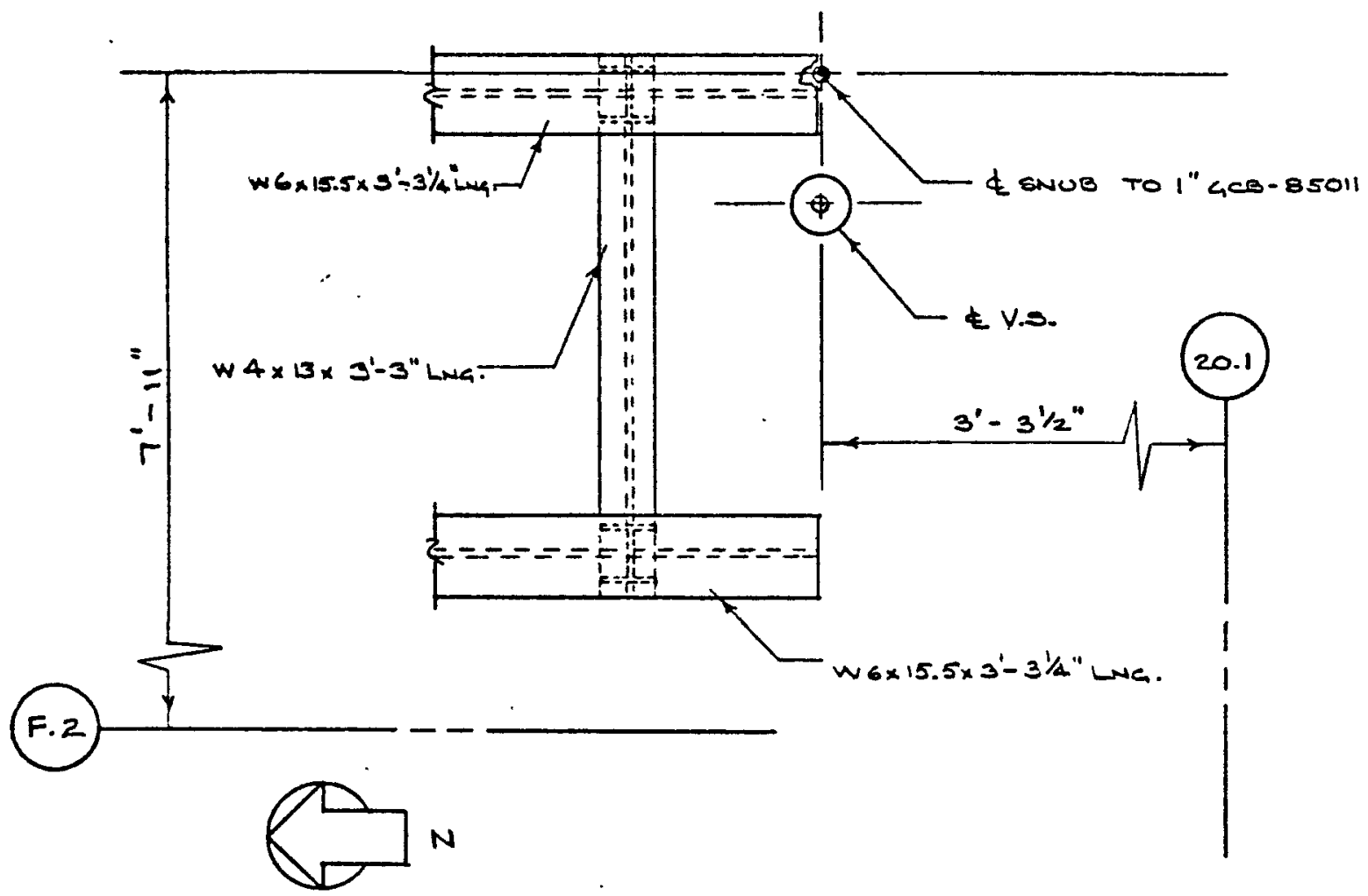

PLAN \& ELEV. $545^{\prime}-0^{\prime \prime}$ NT.3. CEI AET 
1021

FFT F-
B...... - T-

C. TLE.:. : .1
$2-2+31$

2

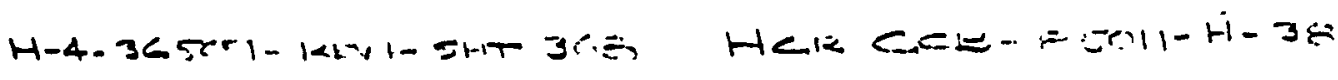

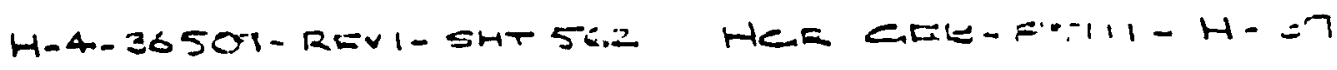
SNUB ON HANGER CCE-85OII-H-38 INTIKFERES WITH HANEIEK. CEE-BSIII-H-3B ANGLE $\Delta S$ EHOWN.

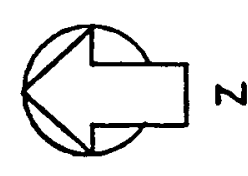

.

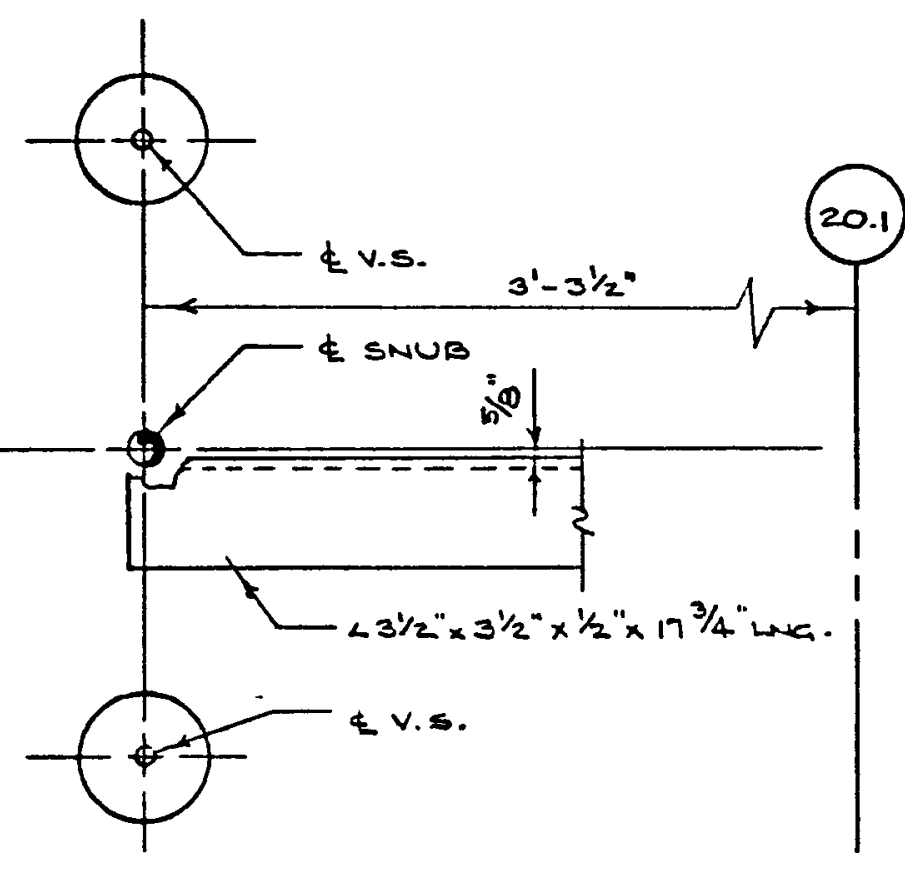

F.2 


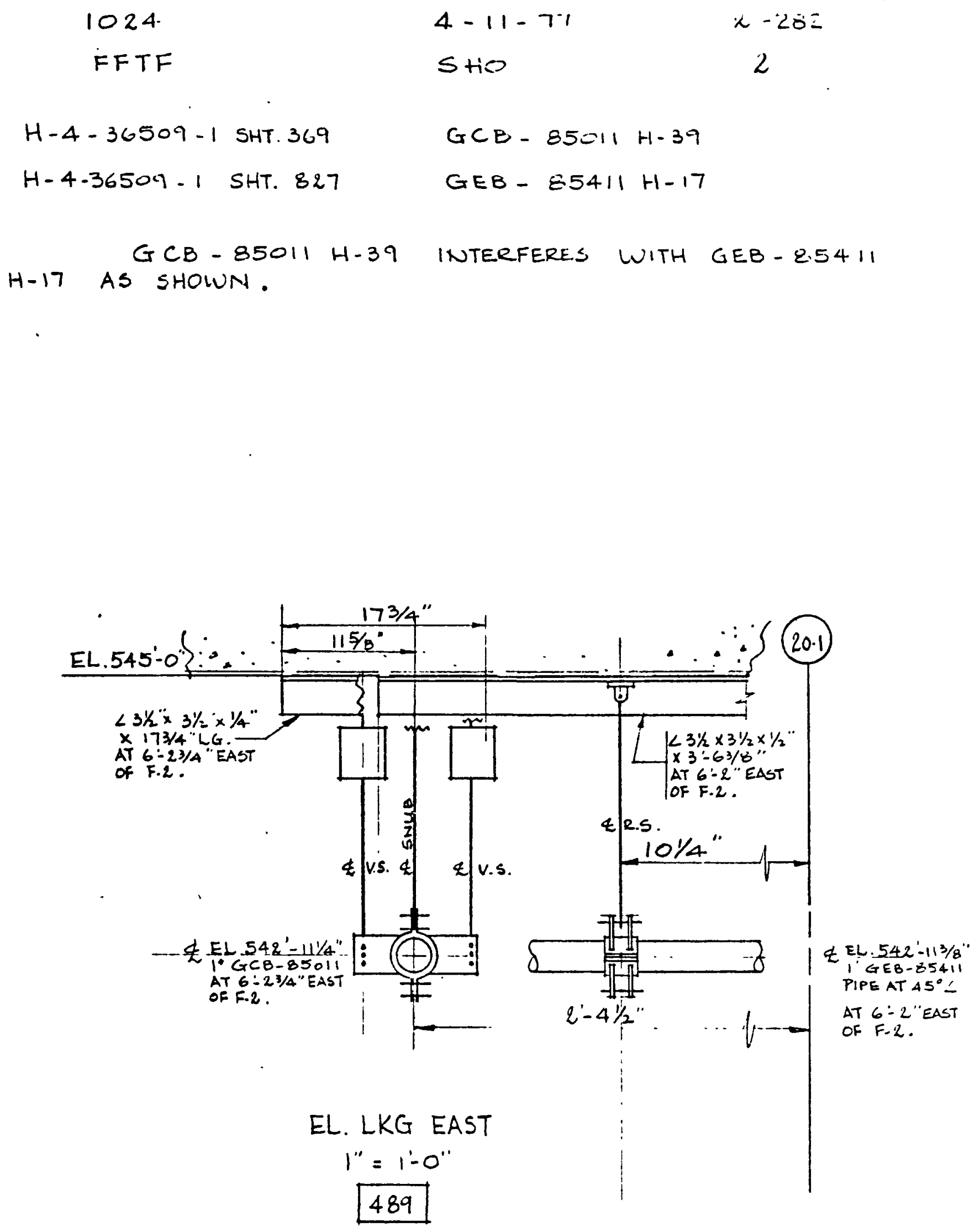


1024

$F F \cdot T \cdot \cdot$
$4 \cdot 3-7 \%$

$2 \cdot 2 \leqq \cdot ?$

EARE:
2

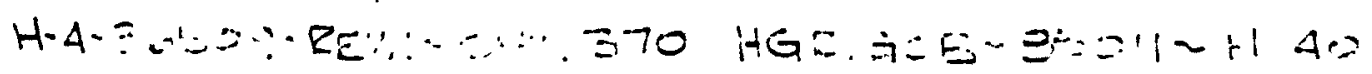

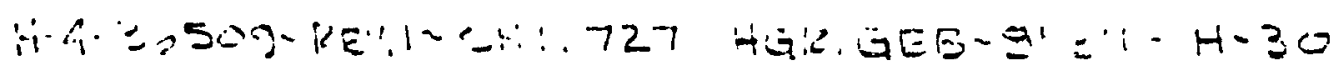

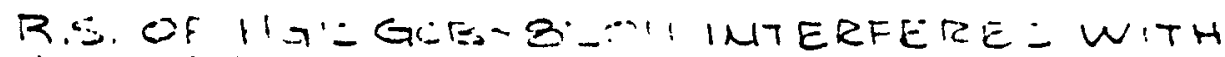

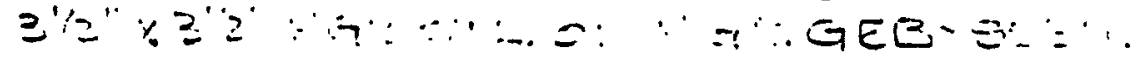

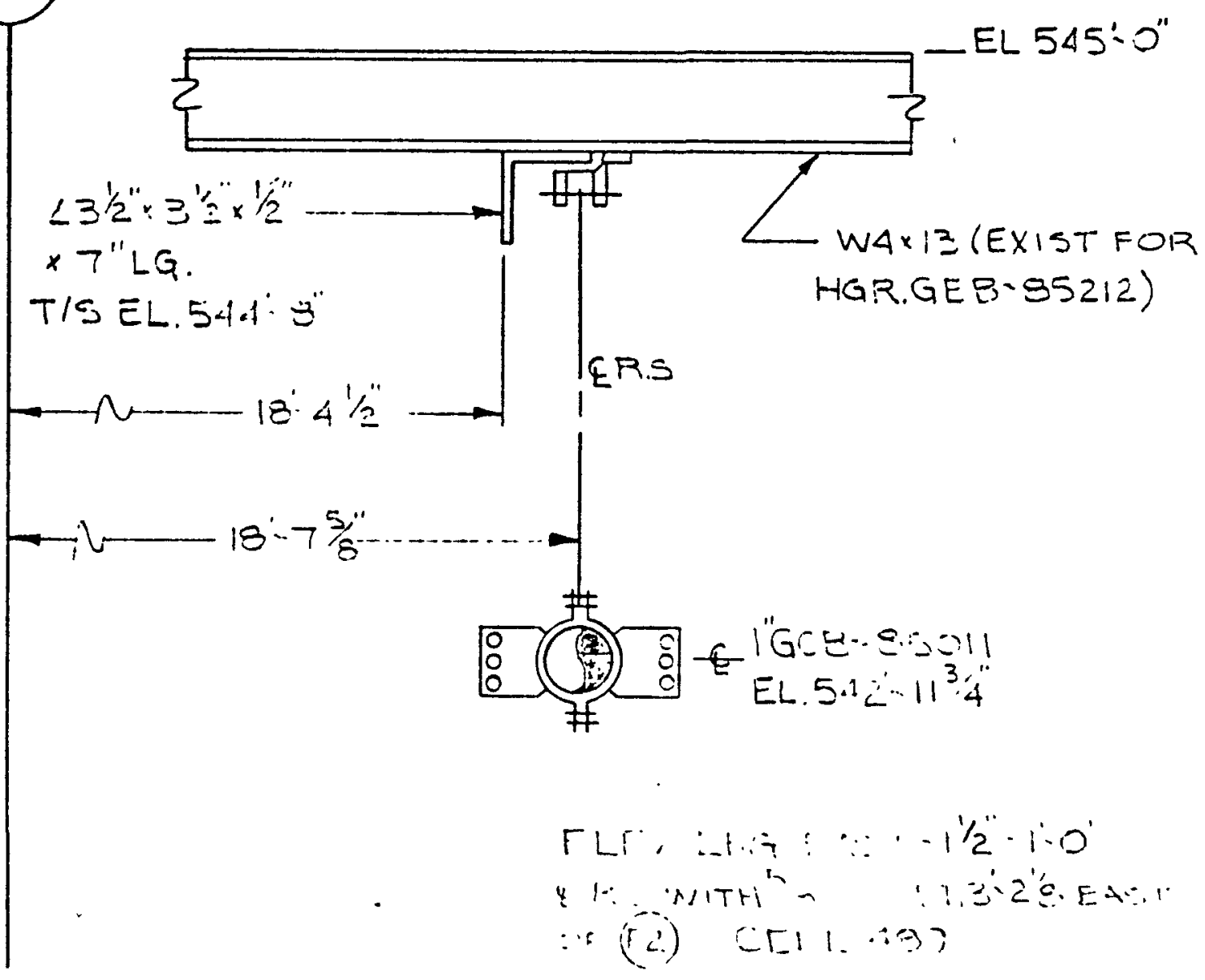




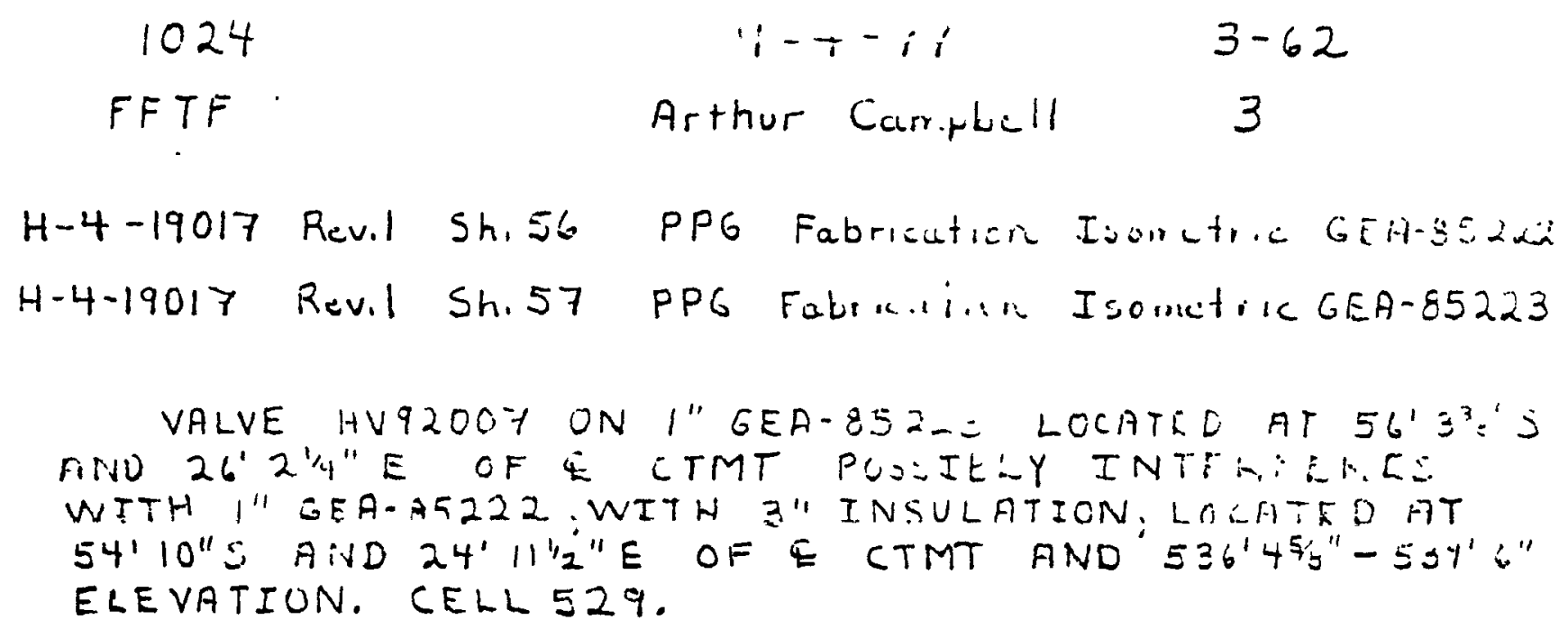$$
\text { ' } i-T-i{ }^{\prime}
$$$$
\text { FFTF }
$$$$
\text { Arthur Carroluill }
$$$$
3-62
$$$$
3
$$

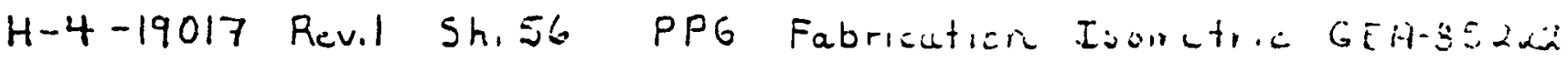
H-4-19017 Revil Sh.57 PPG Fabrariind Isometic GEA-85223$$
\text { VALVE HV92007 ON 1" GEA-852- LOCATEC AT } 56^{1} 3^{3}:{ }^{\prime} 5
$$
FNO $26^{\prime} 214 " E$ OF \& CTMT PUSIILY INTH: WTTH I" GEA-A5222 WITH 3" INSULATION: LOGFIED ATT $54^{\prime} 10^{\prime \prime} S$ AND 24'11'2"E OF E CTMT AND $536^{\prime} 45^{\prime \prime}-534^{\prime \prime} 6^{\prime \prime}$ ELEVATION. CELL 529 . 
1024

FFTF
$4-4-77$

Arthui Caripuill $\therefore-\therefore$

3

H-4-19017 Revil Sh.50 PPG Fabrication Isometric GEA.ELi-D H-4-19017 ReVil Sh.57 PPG Fairicatirl Isoinctic GEA-85223

VALVE 92007 ON GEH-85223 LOCATED HT $56^{1} 3^{3 / 8}$ "S AND $26^{\prime} 2 \% " E$ OF $E$ CTMT POSSIELY INTERFERE" WITH !" CEEA-E 122 WTHH I." TNSULATION LOCATED NTT $54^{\prime} 10^{\prime \prime} \mathrm{S}$ AND $27^{\prime} 6^{\prime \prime} \% " E$ OF E CTMT ANU 536' $9^{\prime \prime} E-539^{\prime} 6^{\prime \prime}$ ELEVATION. CELL 529. 
:22!

FFTF

$$
4-4-77
$$

Arthur Camipicll
$3-64$

3

H-4-19017 Revil Sh.57 PPG Fabrication I:0rictric CEA-85223 H-4-36501 Rev.l Sh. 169 Pipu Support G[A-85222 H-9

SNUR. TELONGING TO CEA-85222 11.9 POSSIBLY

INTERFEKE: WITH VALVE HV 92007 ON I"GEA-85223 LOCATED AT $56^{\prime} 3^{3 / \varepsilon^{\prime \prime}} S$ AND $26^{\prime} 2^{\prime \prime} 4^{\prime \prime} E$ OF \& GTIT AND $536^{\prime} 11^{\prime \prime}$ ELEVATICN.

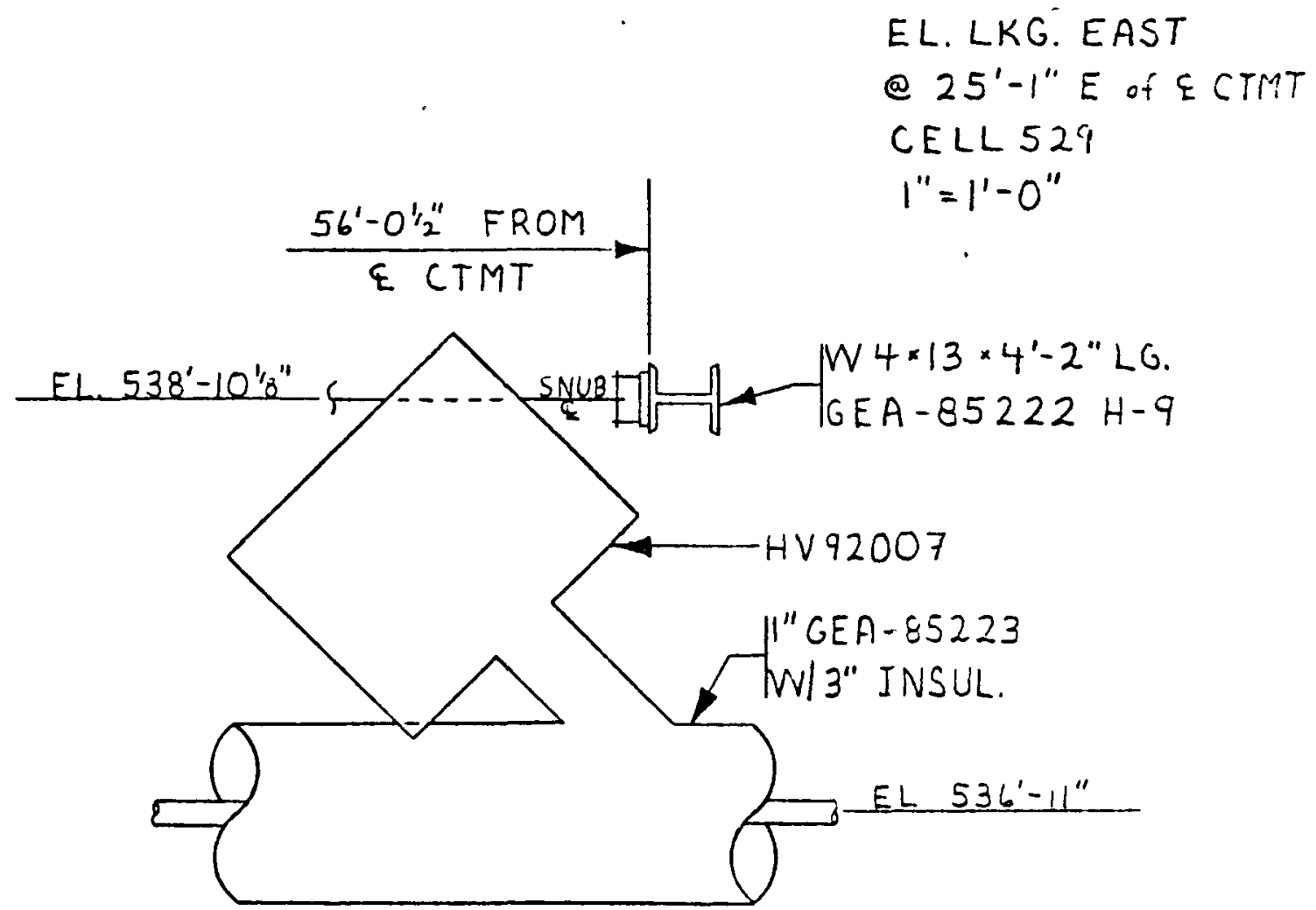



1024
4 ; 77
$3-65$
FFTF
Arthur Camplell
3

H.4-19017 Rev.1 Sh.56 PPG Fabricaitin Isometric GEA-85222 H-4-36509 Rov.3 5h.19 Pipe Suppoit GEA-85122-H17

SNUB, BELONGING TO GEA-85122 H.17 POSEIELY INTERFERES WITH $3^{\prime \prime}$ INSULATION CN I" GEA-85222 LOCATEDAT 47'4"S AND 29'3"E OF \& CTMT AND $536^{\prime} 0^{\prime \prime}$ ELEVATION.

EL. LKG. EAST

(a) 29'-3"E of E CTMT CELL 529

$1^{\prime \prime}=1^{\prime}-0^{\prime \prime}$

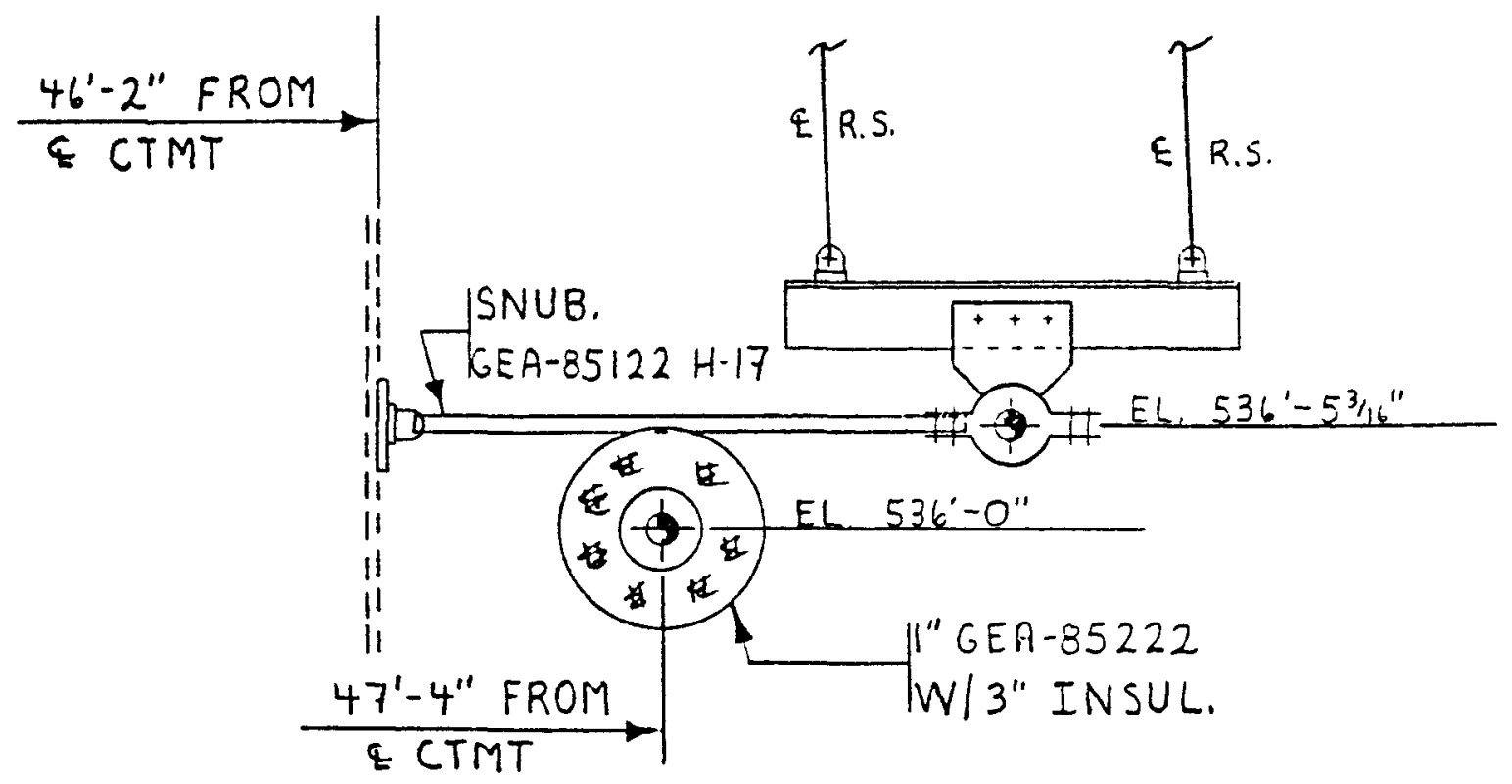




$$
\begin{array}{ccc}
102+ & 4-4-77 & 3-i \vdots \\
\text { FFTF } & \text { Arthur Camplell } & 3
\end{array}
$$

H-4-19017 Revil Sh.56 PPG Fabrication. Isometric GEA-85222 H-4-36509 Rev.2 Sh.197 Pipe Support GEA-85122 H-18

W $6 \times 15.5$ BEAM BELONGING TO GEA-85122 H-18 FOSSILIY INTERFERES WITH 3" INSULATION ON 1" GEA- 85222 LOCATED AT 49' $9^{\prime \prime} S$ FIND $24^{\prime} 11^{\prime \prime 2} " E$ OF $E$ CTMT AND $536^{\prime} .0^{7} 8$ " ELEVATION. 
NOTICE $3-66$

$\therefore$ EL. KG. SOUTH

e $49^{\prime}-9^{\prime \prime} S$ of E CTMT

CELL 524

$I^{\prime \prime}=1^{\prime}-O^{\prime \prime}$

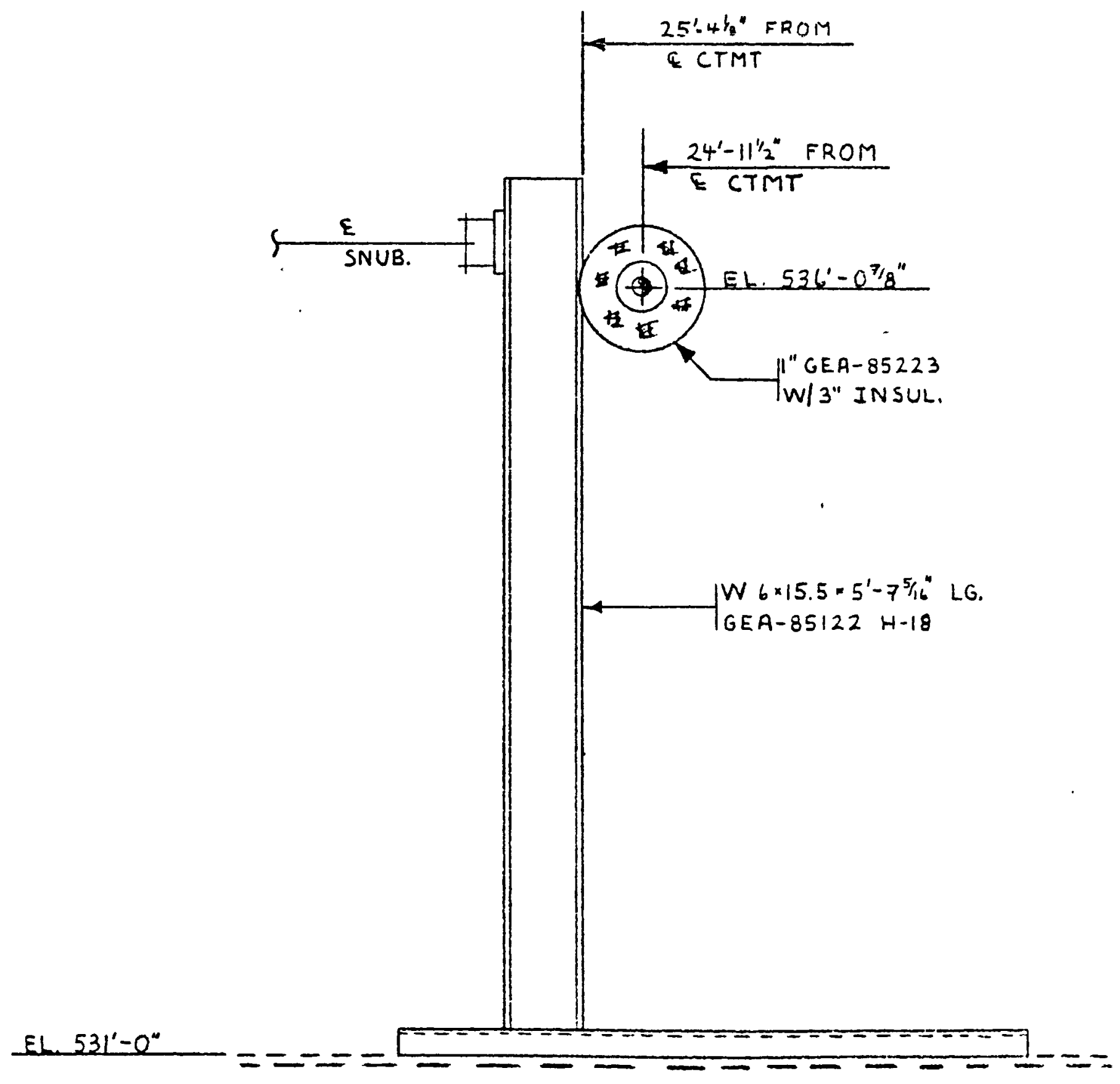




$$
\begin{array}{lll}
1024 & 11-4-i r & 3-67 \\
\text { FFTF } & \text { Arthur cantill } & 3
\end{array}
$$

H-4-19017 Revil Sh.56 PPC Fabrication Isonctric GEA-85222 H-4-3650y Rev.3 Sh.175 Pipe Support GEH-85223 H-2

SNUB, BELONGING TO GEA- $8 E 223 \mathrm{H}-2$ POSSIBLY INTERFIRE WITH VALVE HV92000 ON I" GEA-85222 LOCATED PT $=1.37 /{ }^{\prime \prime}$ C AND $24^{\prime} 111^{\prime \prime}$ E OF E CTMT AND $539^{\prime} 4^{\prime \prime}$ ELEVATION.

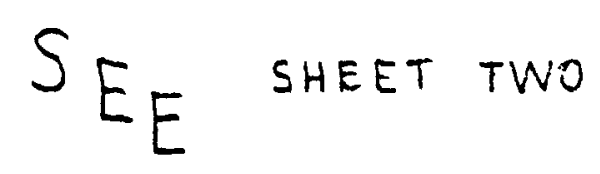


- Q $58^{\prime}-0^{5 / 16} " S$ ot $E$ CTMIT

CELL 529

$1^{\prime \prime}=1^{\prime}-0^{\prime \prime}$
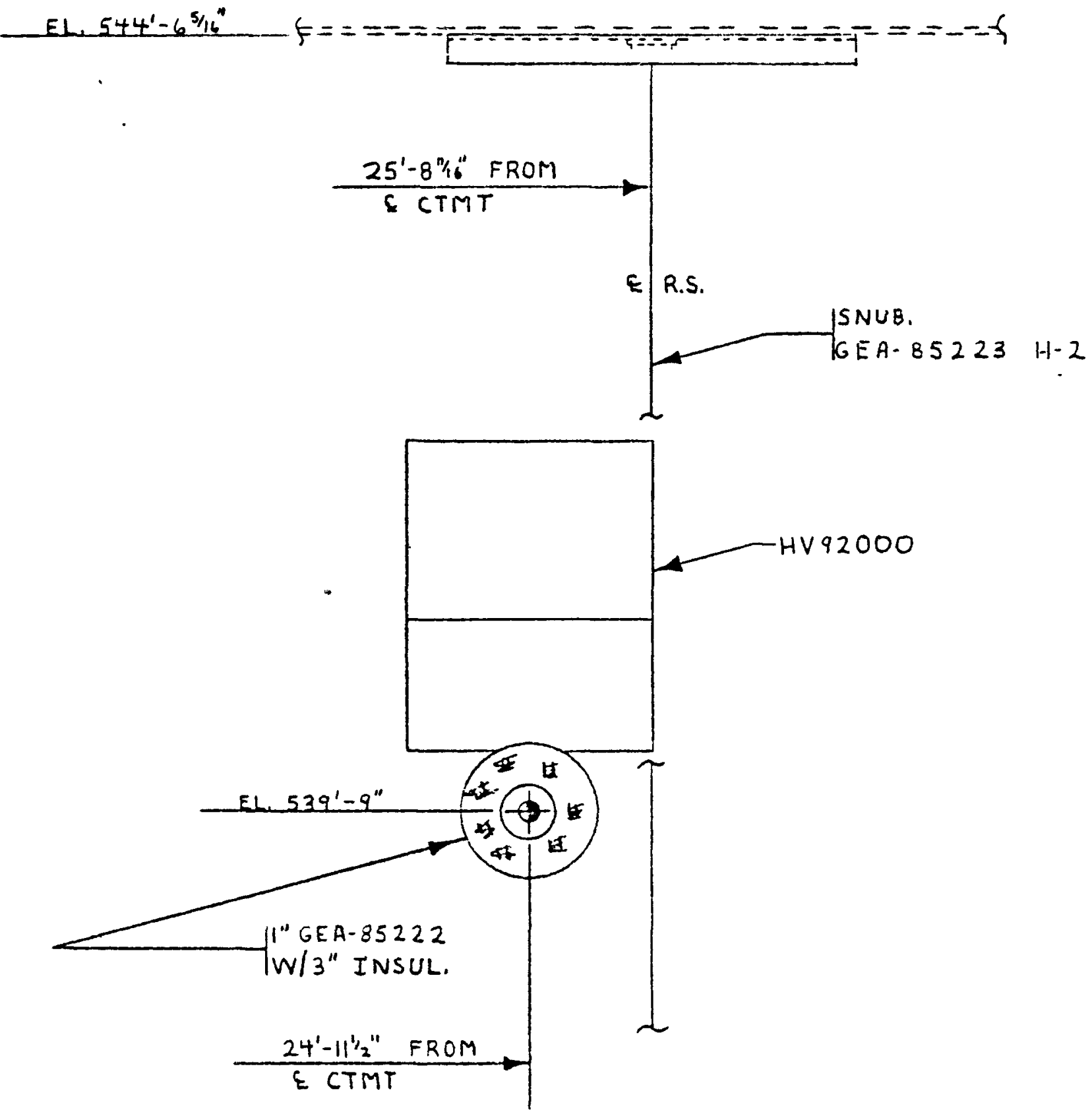

1024
$4-4-\because 7$
$3-68$
FFTF
Arthur Caisploll
3

H-4-19017 Rev.1 Sh.50 PPG Fabrication Isometric GEA-85122 $H-4-36506$ Rev.2 Sh.172 Pipe Support GEA-61211-H4

W $4 \times 13$ BEAM BELONGING TO GEA-61211-H14 INTERIMNE WITH 3" INEULATION ON GEA- 5122 LOCATED FIT 40 ' 5 "S

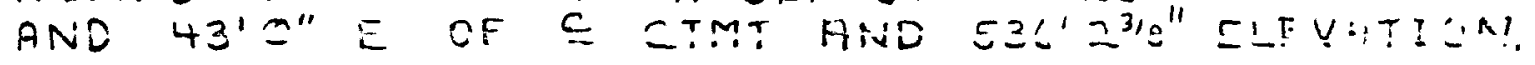

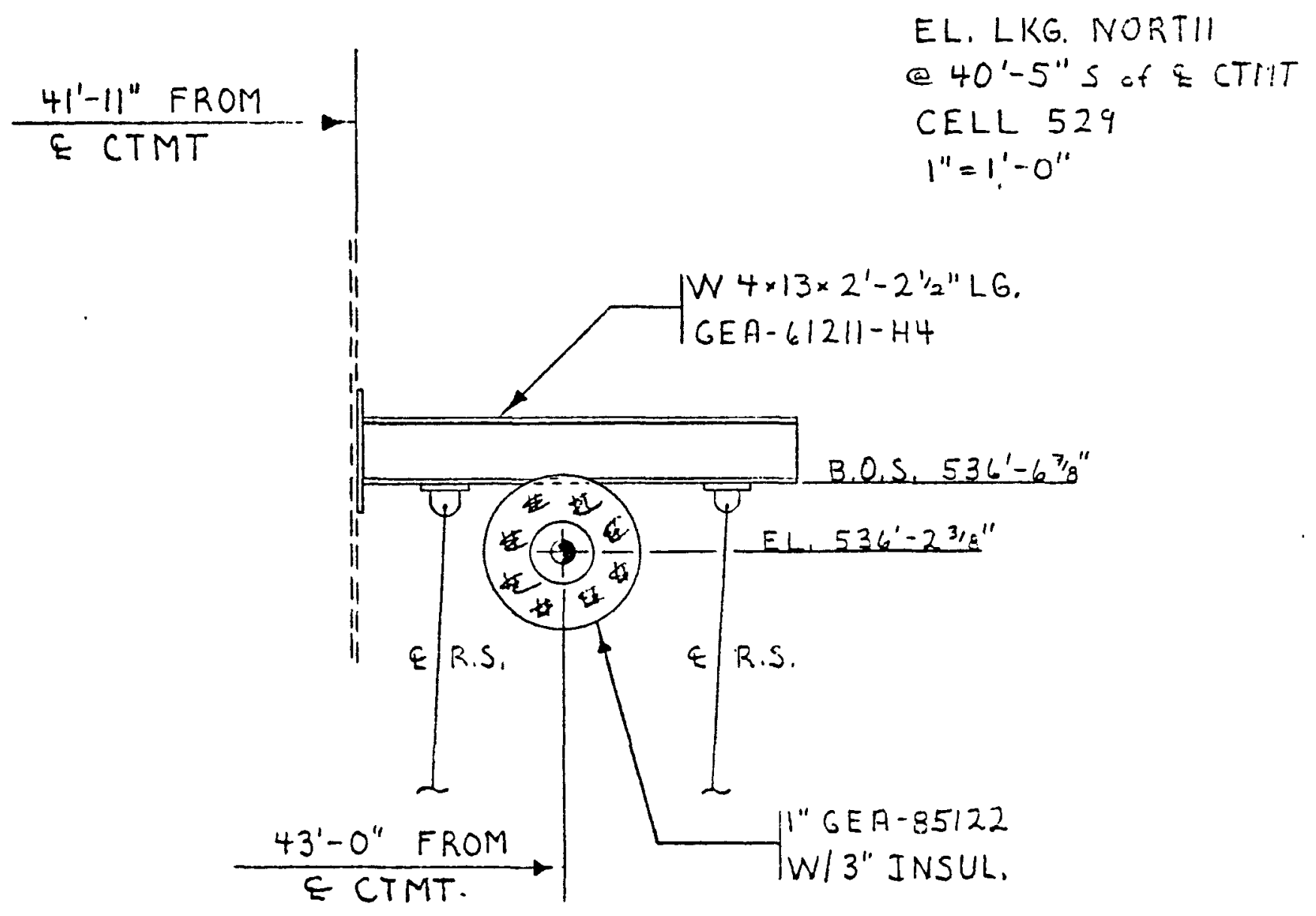


1024

FFTF $4-i-i i$

Arthur Canplell
$3-6.1$

3

H-4-19017 Rev.l Sh. 50 PPG Fabruatis Iswiri. GEA-85122 H-4-36566 Rev.3 Sh.164 Pipe Support GEA-61202-H9

W $4 \times 13$ EEAM BELORGINC 73 GEA-61202-HA :ATRACRE: WITH 3" INEULRTION ON " GEHI-85122 LOCATED AI $42^{\prime} 5^{\prime \prime} \mathrm{S}$

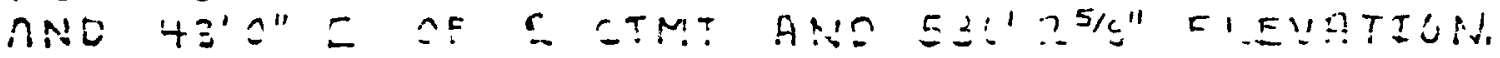

EL. LKG. NORTH

Q. $42^{\prime}-5^{\prime \prime} S$ of E CTMT

CELL 529

$1^{\prime \prime}=1^{\prime}-0^{\prime \prime}$

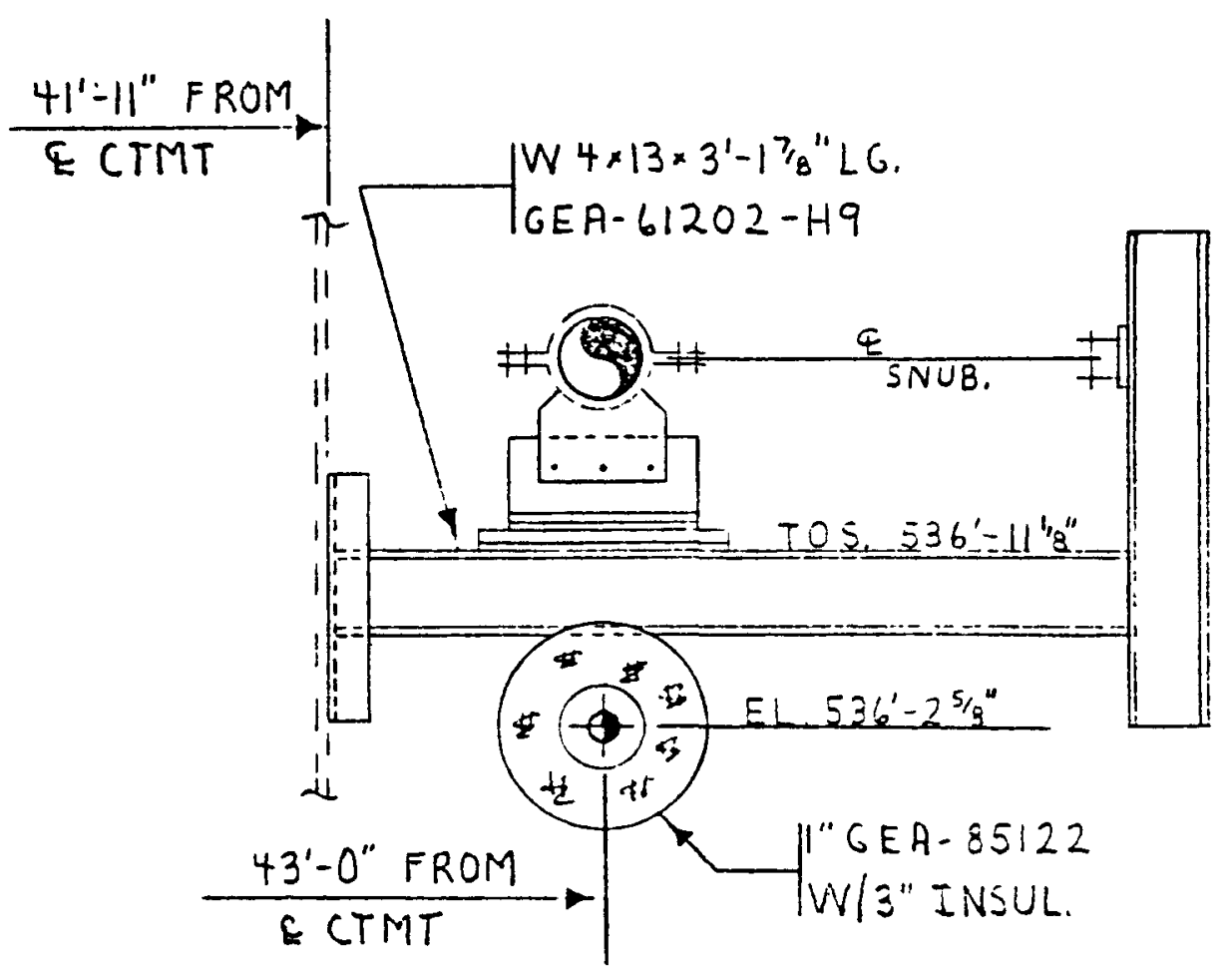




$$
\begin{array}{r}
1024 \\
\text { FFTF }
\end{array}
$$

$$
\begin{array}{cc}
4-5-77 & 3 \pi 0 \\
\text { Arthur Camplell } & 3
\end{array}
$$

H-4-19017 Rev.1 Sh.50 PPG Fabrication Isomatric GEA-85122 H-4-36509 Revi2 Sh.ll Pipe Support GEA-85123-H-1

SNUB. BELONGTNC TO GEA-85123-H-1 INTERFERES WITH 3" INSULATION ON 1 " GEA-85122 LOCATED AT $58^{\prime} 615 / 16^{\prime \prime} S$ AND

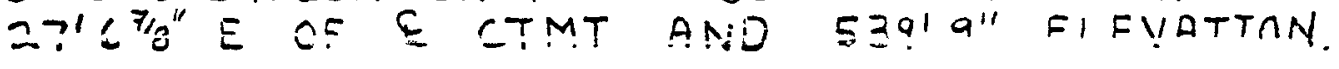

\section{SEE SHEET TWO}


$\because E L . \quad L K G, \quad N O R T H$

NOTICE $\quad 3-70$

$$
\begin{aligned}
& \text { @ } 58^{\prime}-6^{15 / 16} 5 \\
& \text { CELL } 529 \\
& I^{\prime \prime}=1^{\prime}-O^{\prime \prime}
\end{aligned}
$$

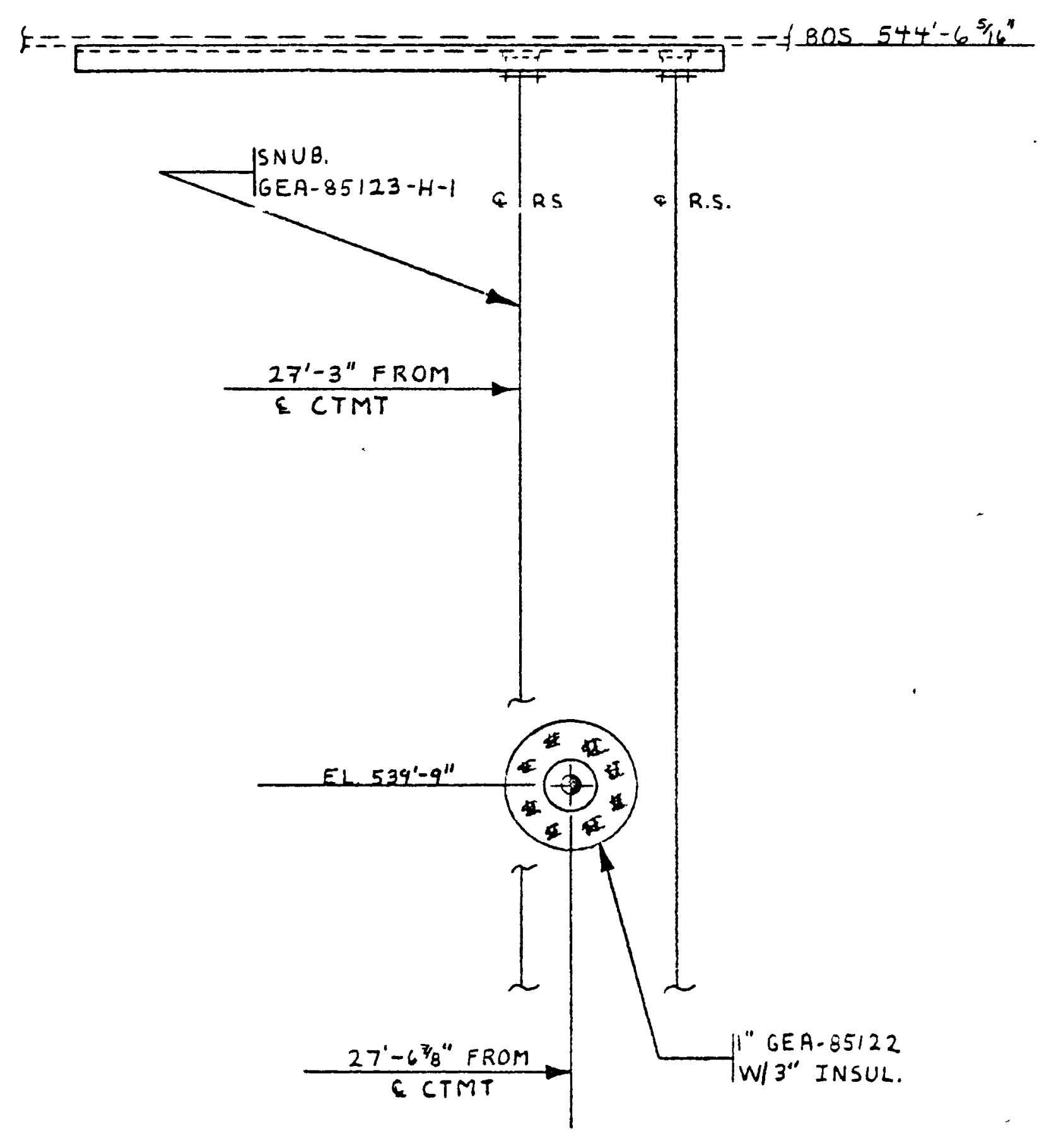




$$
\begin{array}{lcl}
1024 & 4-5-7 ! & 3-71 \\
\text { FFTF } & \text { Arthur C...ricll } & 3
\end{array}
$$

H-4-19017 Rev.l Sh.50 HPG Faikr. Hi... Isometric 6EA-55122 H-4-36509 Rev. $=$ ih.ll Pipe Support CEA-35123-H-1

SNUB, BELONCENG 10 GEA-ES123-H-1 POE-IBLY INTERFEKE. WITH WHLVE HV91000 ON I" C.HH-ES12L LOCATED AT 56'4"S IIND $27^{\prime} 6^{\prime \prime}: \mathrm{s}$ "E OF E CTMT HIND 531' 4" ELEViriatid. 
NOTICE 3-71

EL. LKG. WEST

a 28'-6" $E$ of E CTMT

LELL $b<4$

$I^{\prime \prime}=1^{\prime}-O^{\prime \prime}$

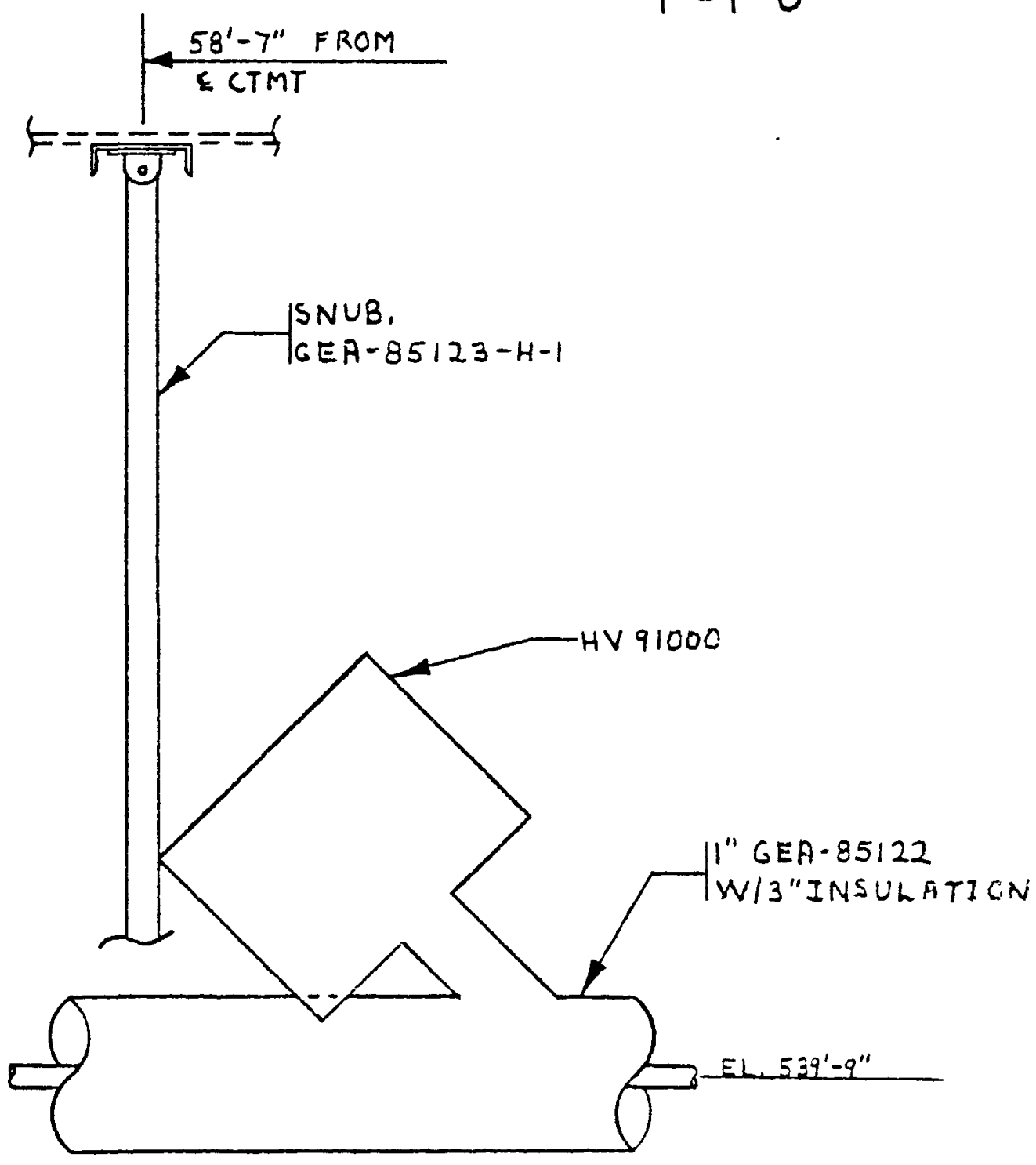


涊棌

FFTF
$4-5--17$

Arthur Cariogli

$$
3-72
$$

3

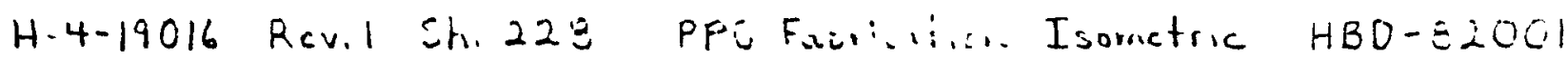

H-4-365C9 Rev.4 Sh.108 Pipe Support GCA-850C2-H-16

[ $6 \times 8.2$ BELONGING TO GCA-ËL 2-H-16 INTTRI!REE WITH 3" HBD-82001 LOCATED AT $47^{\prime} 6^{\prime} S$ AND +2 $2^{\prime} 4^{3 / 8} 8^{\prime \prime} E$ OF $\&$ CTMT AND 531'-43/4" ELEVATION.

EL. LKG. EAST (e) $42^{\prime}-T^{\prime \prime} E$ of E CTMT CELL 529 $1^{\prime \prime}=1^{\prime}-0^{\prime \prime}$

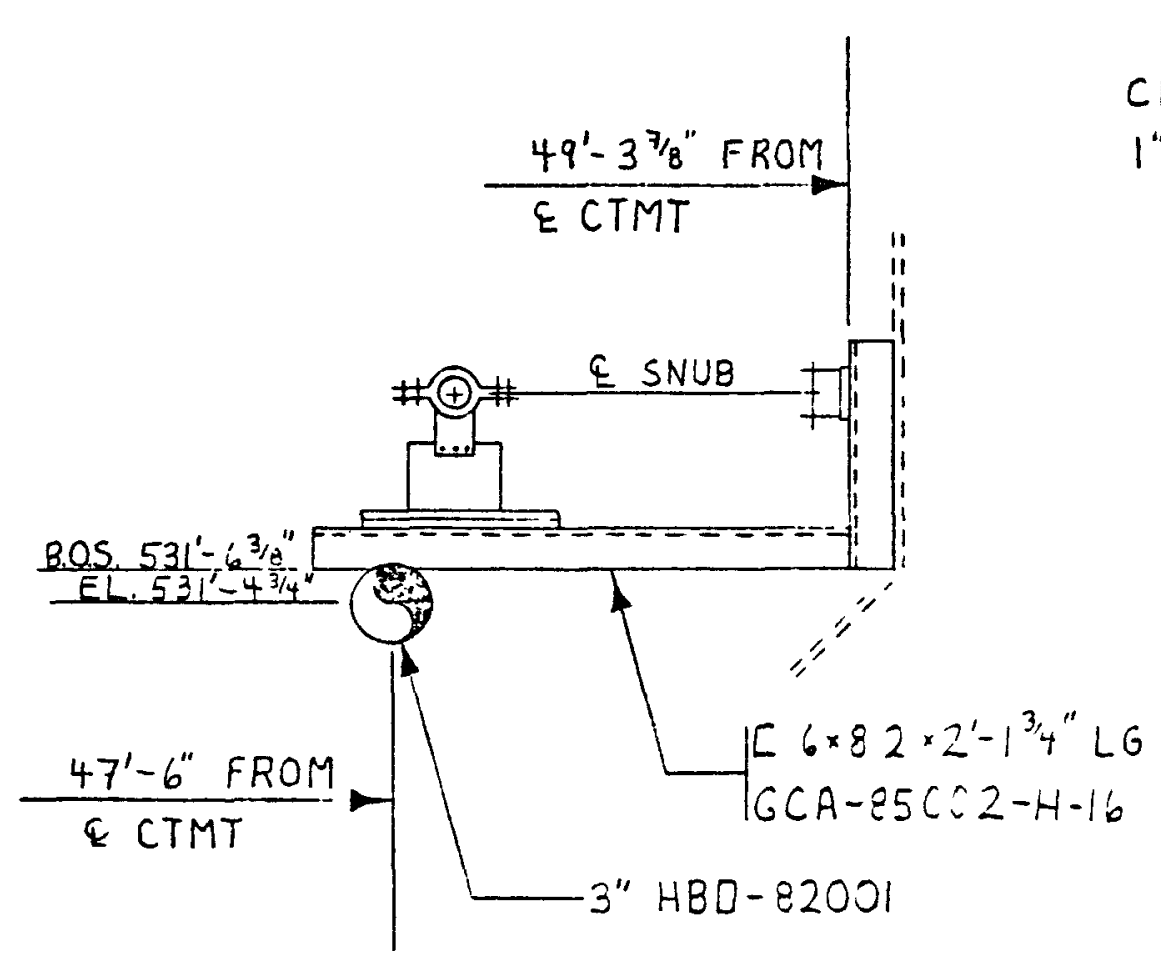




$$
\begin{aligned}
& 1024 \\
& \text { FFTF }
\end{aligned}
$$

$$
\rightarrow 5 \dddot{i} i
$$

Arthur Campbell
$3-73$

3

H-4-19016 Rev.2 Sh.64 PPG Fabricatisia Isumetric HBB-E21EO

H-4-19017 Rev. O Sh. 13 PPG Fabrication Isometric H.CB-85023

VALVE HV 97005 ON I" HCB-85023 LOCATED AT $58^{\prime}-8 " S$ AND 23'-9" E OF $E$ CTMT POSSIBLY INTERFERE: WITH VALVE HV 54502 ON 3" HBB-82180 LOCATED AT $58^{\prime} \cdot 8^{\prime \prime} \doteq$ ANO 22'-6." $E$ OF E CTMT AND 533'-11" ELEVATIEN. CELL S $2 \%$ 

1024
$4-5-7 \%$

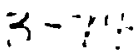
FF.TF
Arthur Camplill
3

H-4-19016 Rev. 2 Sh.64 PPG Fádriclian Isomitric HEE-5:1 H-4-36504 Rev. 2 Sh.ll Pipe Support GEA-85123-H-1

[6×8.2 FINO 2 SIUUS BELONGING TO GEA-\$5123-H-1 POSSJELY INTERFERE WITH VALVE HVS4502 ON

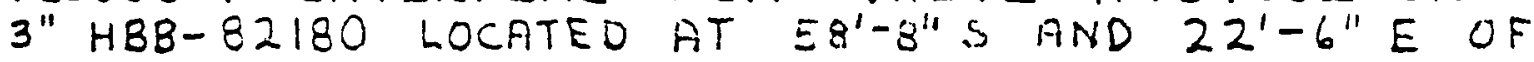
E CTMT AND 533' $11^{\prime \prime}$ ELEVATION.

EL. LKG. NORTH (a) 58'-8" $S$ of $\&$ CTMT CELL 529 $I^{\prime \prime}=1^{\prime}-O^{\prime \prime}$

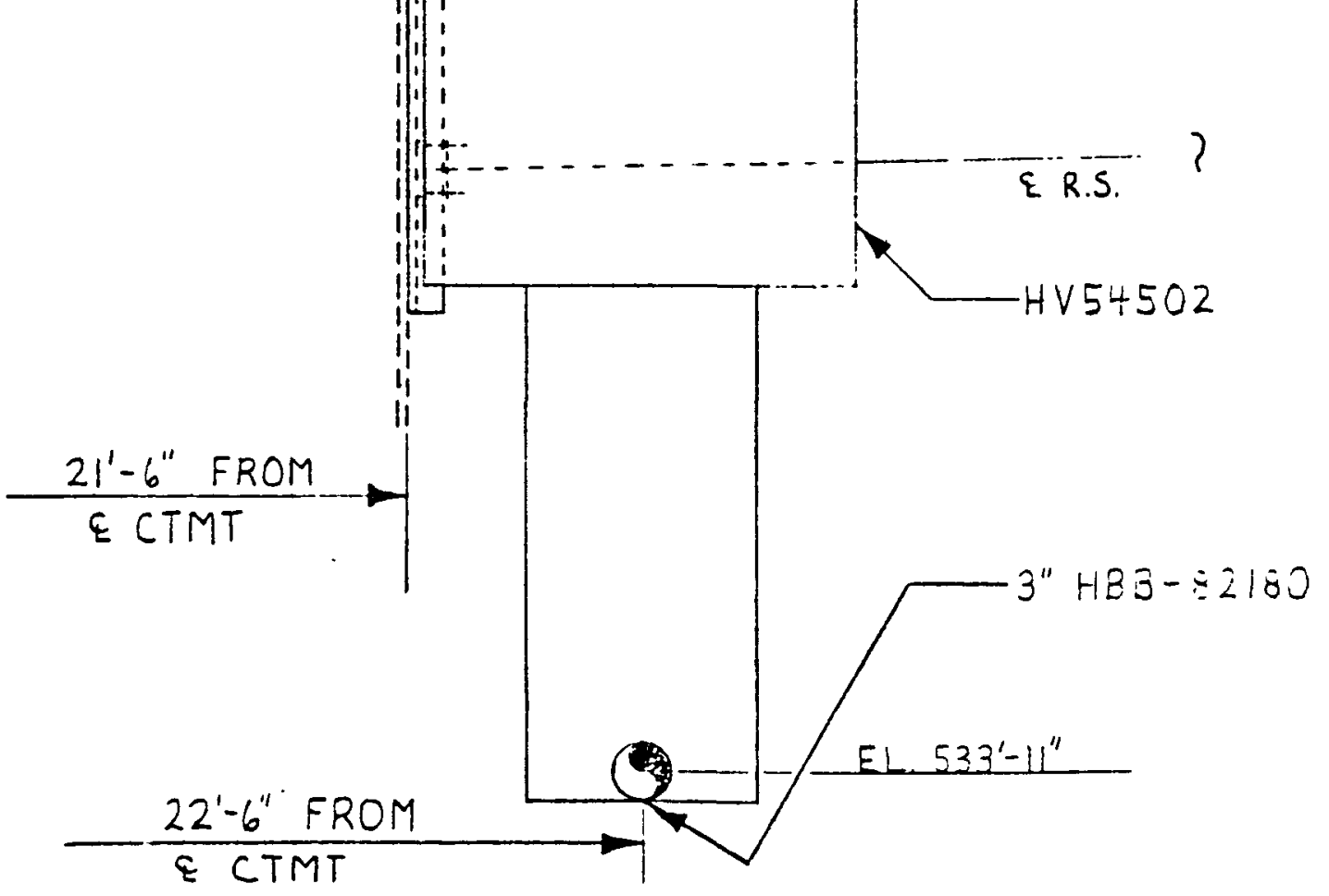


1224

FFTF
4-5-77

Arthur Campiball
$3-75$

3

H-4-19016 Rev.2 Sh.64 PPG Fabrication Isorretin HBB-S218:

H-4-36509 Revi3 Sh.174 Pipe Supfort GEA-85223 H-1

W $4 \times 13$ BEAM BELONGING TO GEA-85223 $\mathrm{H}-1$ POSSIBLY

INTLRFERES WITH VALVE 54502 ON $3 "$ HBB-8218O LOCATED

AT $58^{\prime} 8^{\prime \prime} S$ AND $22^{\prime} 6^{\prime \prime} E$ OF \& CIMT FIND $533^{\prime} 11^{\prime \prime}$ ELEVATION

SEE

SHEET

TWO 
EL. LKG, NORTH

Q $59^{\prime}-8^{5 / 16} \mathrm{~S}$ of \& CTMT

CELL 529

$1^{\prime \prime}=1^{\prime}-0^{\prime \prime}$

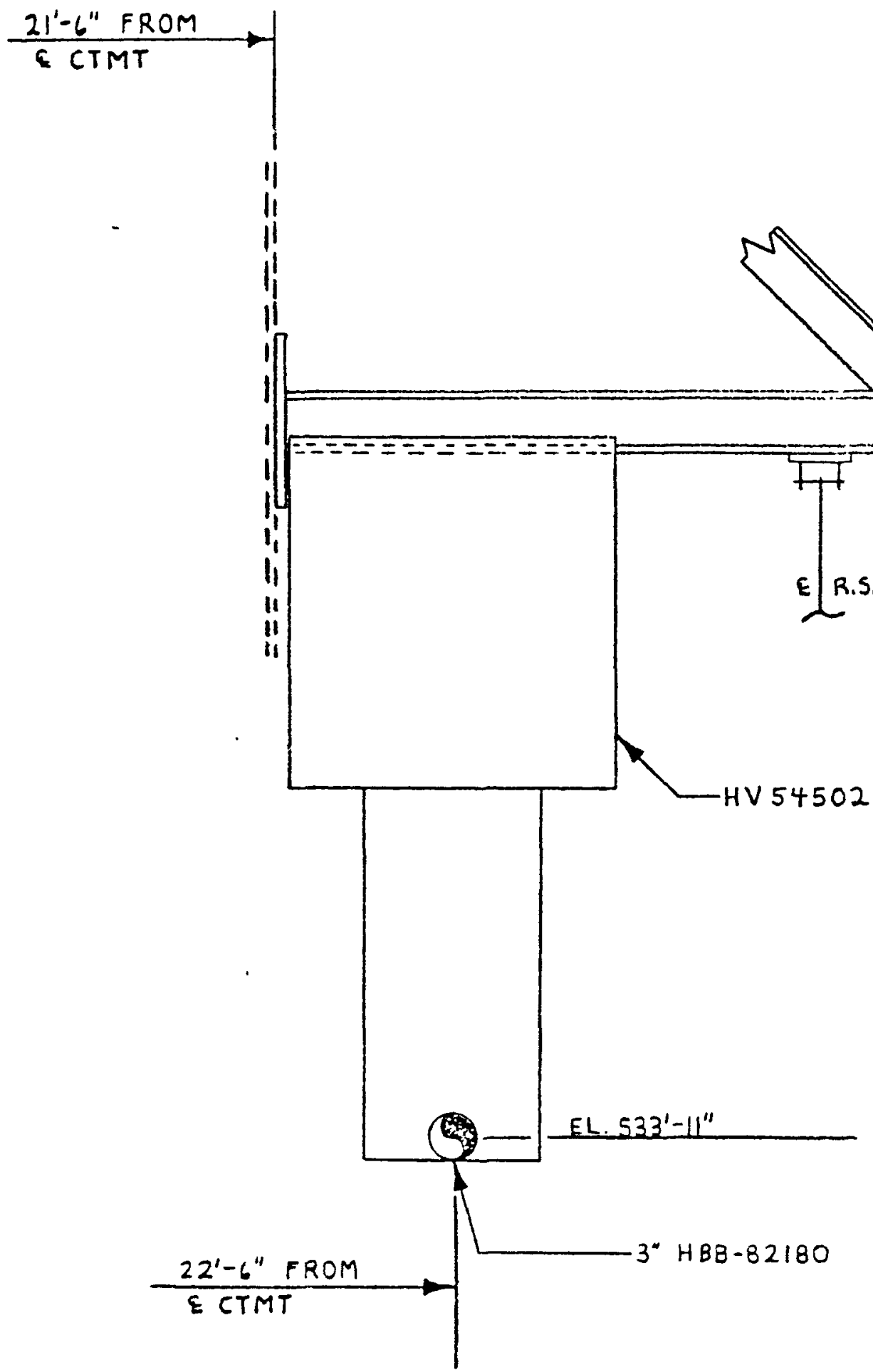


1024

FFTF
$4-5-77$

Arthur Campbell
$3-16$

3

H-4-14752 Rev.6 Sh.l Reactor CTMT Bldg. Conerete Outline H-4-19016 Rev. 3 Sh. 96 PPG Fabrication Isometric HCA-82109

1" HCA-82109 LOCATED AT 51'2"-53'5" 5 HND 35'4"E OF E CTMT INTERFERES WITH CONCRETE FLOOR AT .531' O" ELEVATION

EL. LKG. EAST

Q $35^{\prime}-4^{\prime \prime} E$ of $E$ CTMT

CELL 529

$1^{\prime \prime}=1^{\prime}-0^{\prime \prime}$

$$
\frac{53^{\prime}-5^{\circ} \text { FROM }}{\text { ECTMT }}
$$

EL.FLOR 531'-0"

$\therefore 0: 00.00$

I" HCA-82109
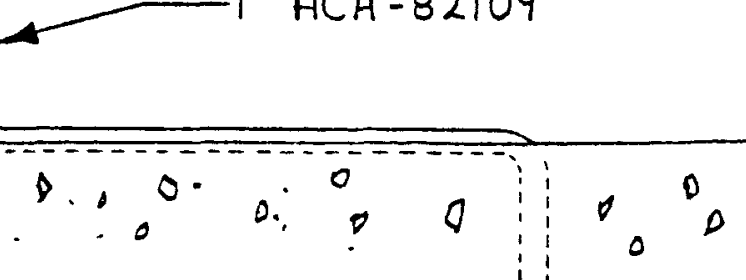

I0.2!
$4-5-77$
$3 \cdot 77$
FFTF.
Arthur Canptiol
3

H-4-19016 Rev.3 Sh.97 PPG Fabrication Isometric HCA-32110 H-4-36506 Revi2 Sh.24 Pigc Support GEA-61111-HE

W $4 \times 13$ BEAM BELOHOING TO GEA-GIII-HS INTERTEKES WITH 2" HCF- \&2110 LOCATE D AT $27^{\prime}: \because " B N D 51^{\prime} O^{\prime \prime} E$ OF E CTMT AND 543' $0^{\prime \prime}$ ELEVATION.

EL. LKG. SOUTH

Q 27'-8" S of \& CTMT

\section{CELL 529}

$$
I^{\prime \prime}=1^{\prime}-O^{\prime \prime}
$$

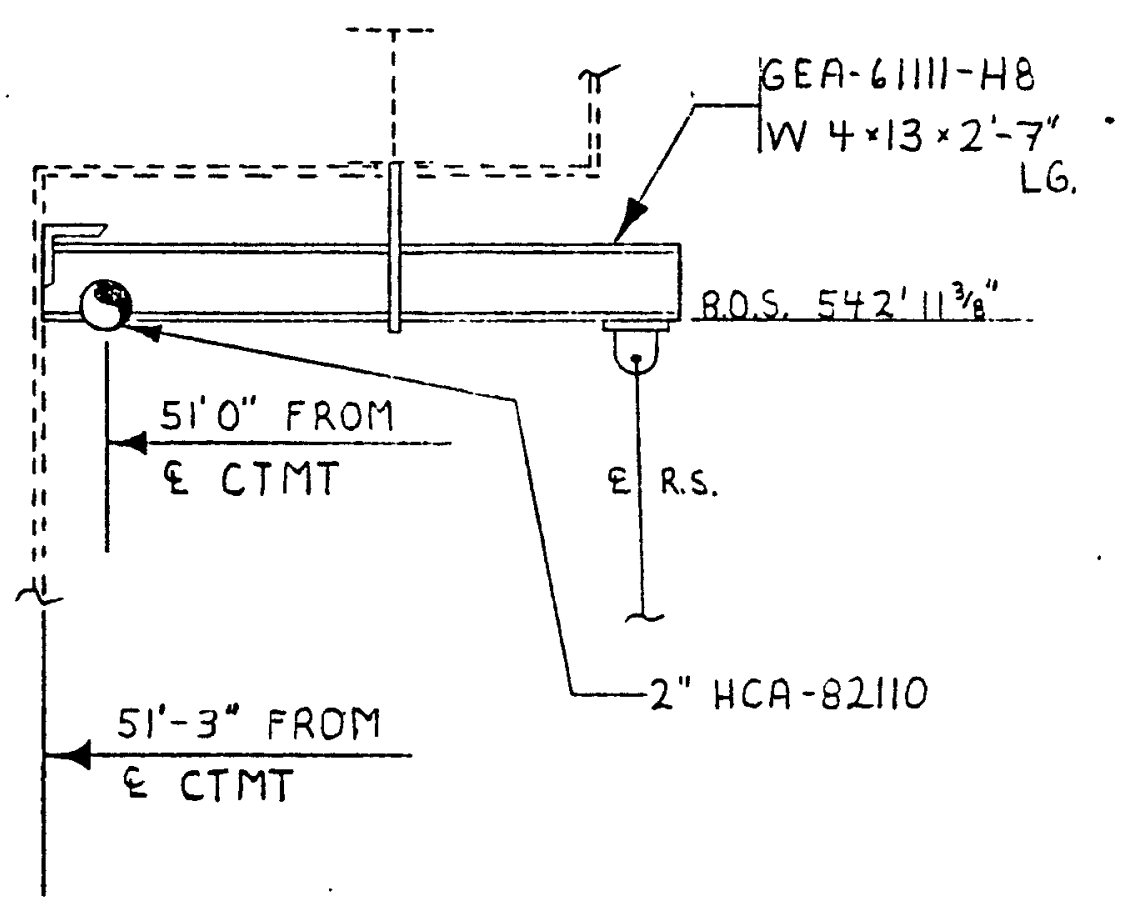




$$
\begin{aligned}
& 1024 \\
& \div \because 77 \\
& \text { FFTF } \\
& \text { Arthur Campleil } \\
& 3-7 \varepsilon \\
& 3 \\
& \text { H-4-19017 Rev.3 Sh.12 PPG Fabriaticin Iisonctric HiCA-85020 } \\
& \text { H-4-36509 Rev.3 Sh. } 174 \text { Pife Support GEA-852:3 H-1 } \\
& \text { L 3"× 3" BELONGING TO GEA-85223 H-1 INTERFERES } \\
& \text { OF \& CTMT AND 539'9" ELEVATION. }
\end{aligned}
$$

SEE

SHEET TWO 
NOTICE $3-78$

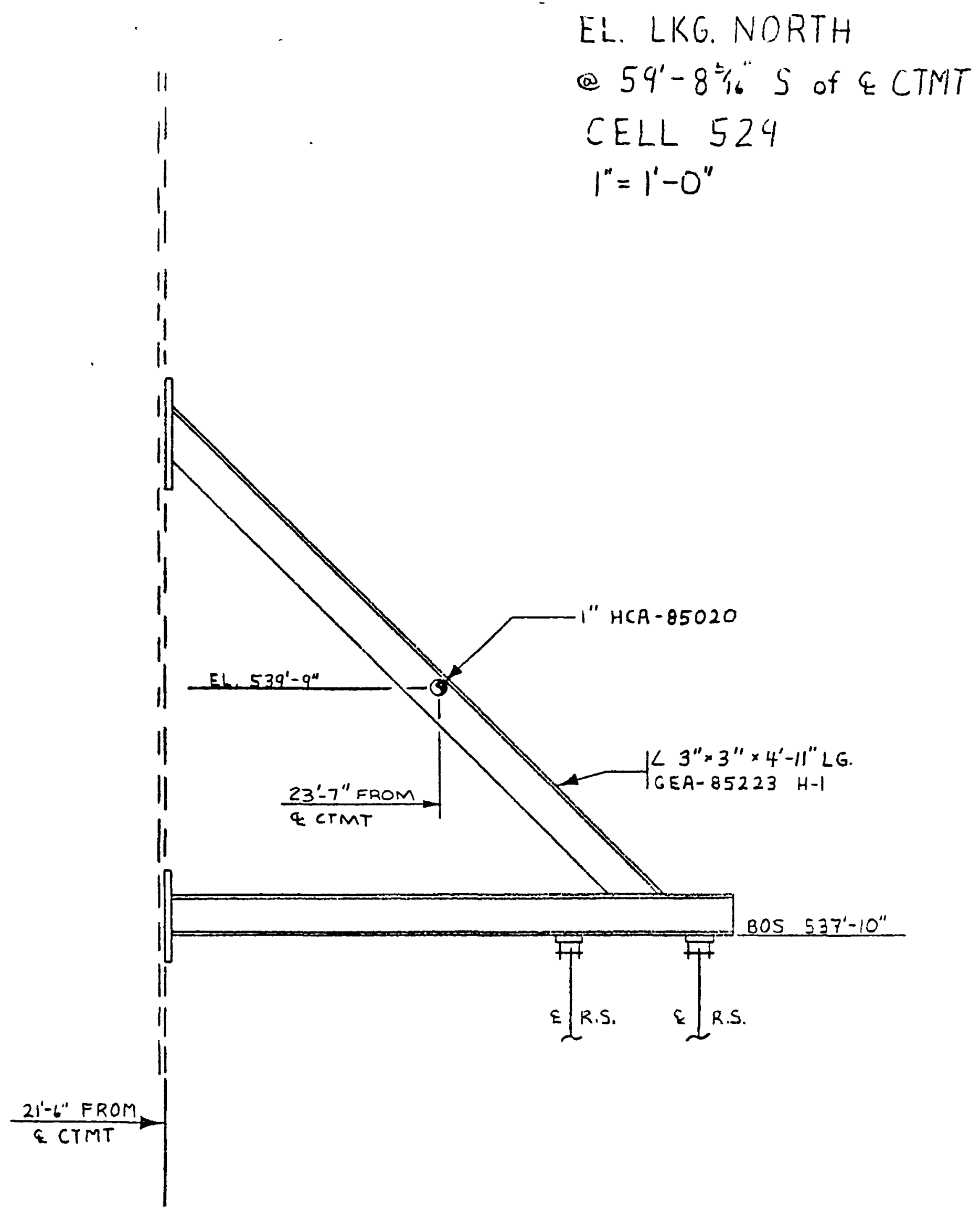


1024

FFTF $\because-10-7 \div$

Arthur Camplell
$3-79$

3

H-4-19017 Rev.0 Sh.13 PPG Fabricati... Isometric ICB-85023 H-4.36509 Rev.l Sh.309 Pipe Support GCA-85002 H-21

SNUB. BELONGING TO GCA-85002 H-21 INTEKFERE:

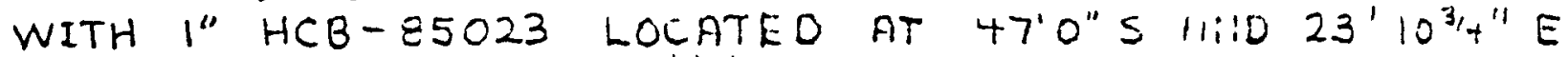
OF \& CTMT AND $531^{\prime} 9^{\prime \prime} / 16^{\prime \prime}$ ELEVATION.

EL. LKG. EAST

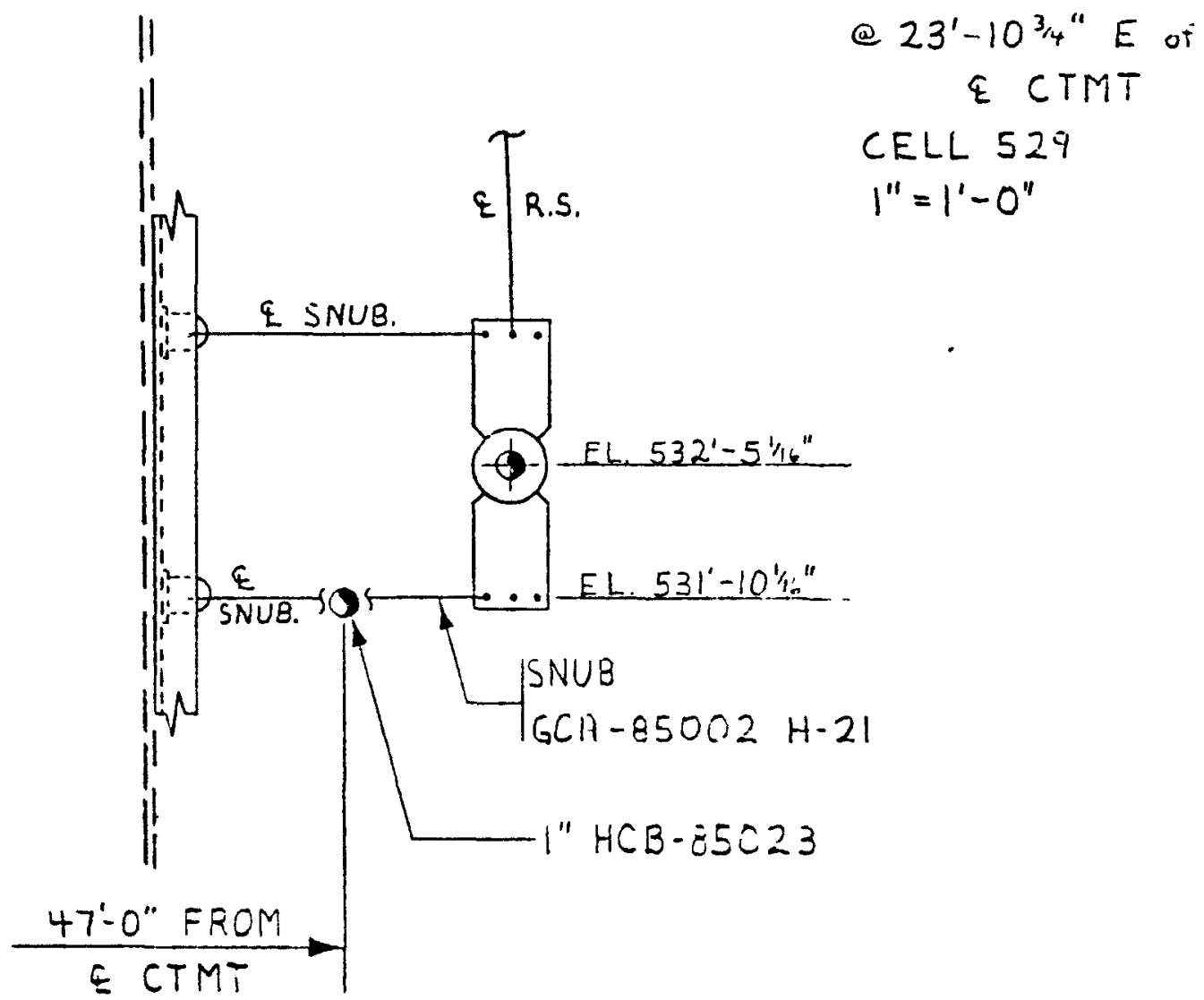




$\begin{array}{lcc}1024 & 4-6-7+ & 3-97 \\ \text { FFTF } & \text { Arthur Canpill } & 3\end{array}$

H-4-19017 Rev. O Sh. 13 PPG Fabriation Isometric HCB-zj023 H-4-36509 Rev. O Sh.220 Pipe Support GCA-8500+ $\mathrm{H}-7$

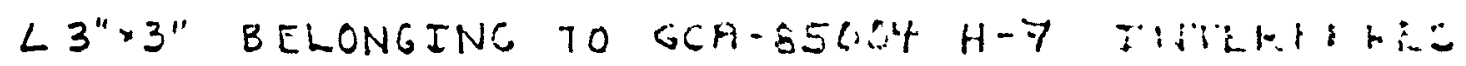
WITH I" HCB-85023 LOCATED AT 47'O"S ANO 23'3"E OF \& CTMT AND $531^{\prime} 9^{\prime \prime 1} 16^{\prime \prime}$ ELEVATION.

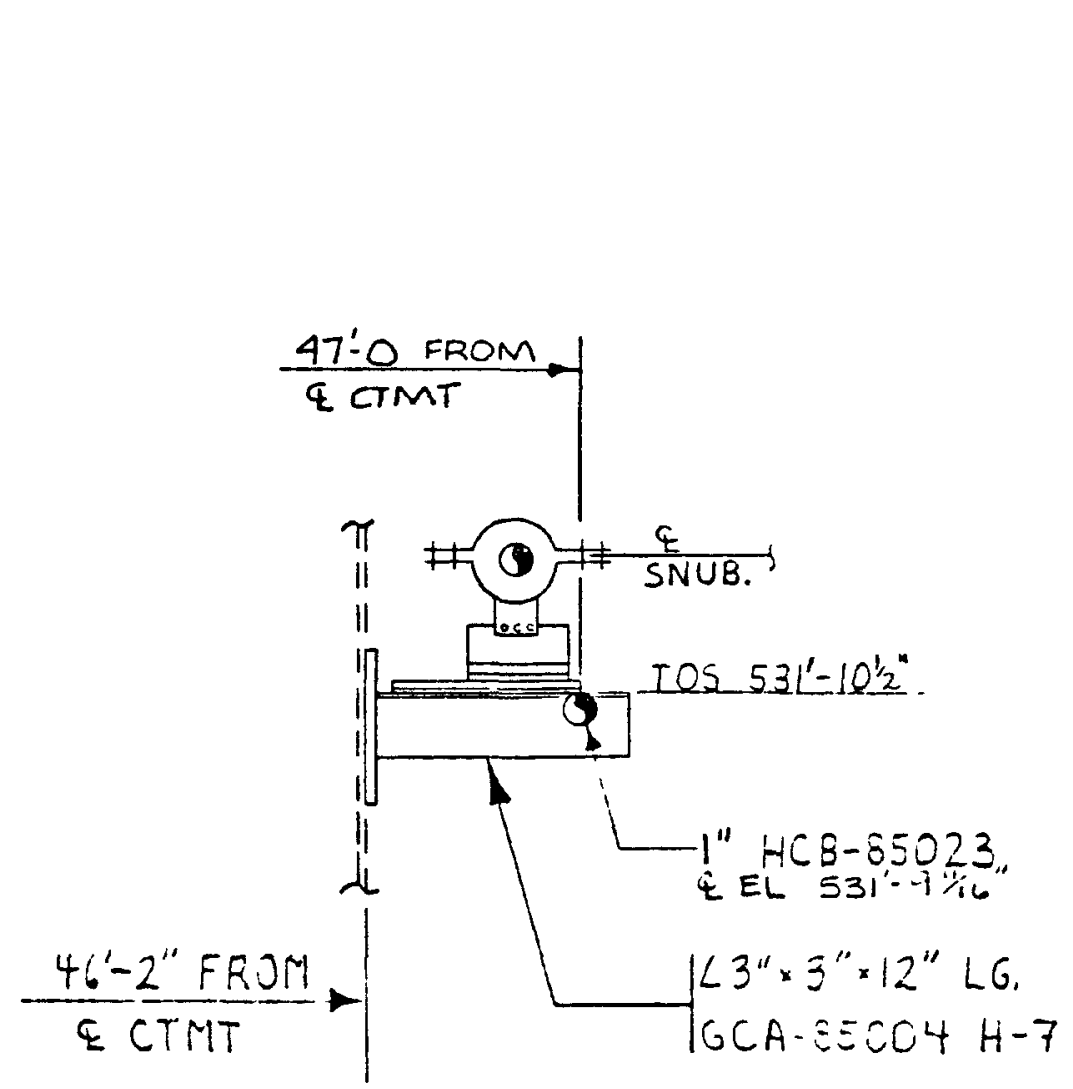

EL. LKG. EAST

e $23^{\prime}-3^{\prime \prime} E$ of

E CTMT

CELL 529

$I^{\prime \prime}=1^{\prime}-0^{\prime \prime}$ 

10人⿱
$4-6-? 7$
$3-31$
FFTF
Arthur Canpbill
3

H-4-19017 Revio Sh. 13 PPG Fabricaticn Fiometic HCB-35023 H-4-36509 Rev.2 Sh.310 Pipe Suppert GCA-E5062-H-22

-NUE BELONGING TO GCA-6EC:-H-22 TNTFKFERE WITH I" HCE- 85C23 LOCATEO AT $4: 1^{\circ}: 2$ H:10 23'A" $E$ OE \& CTMT AND $531^{\prime} 9^{\prime \prime 1} / 16^{\prime \prime}$ ELEVHTIYM.

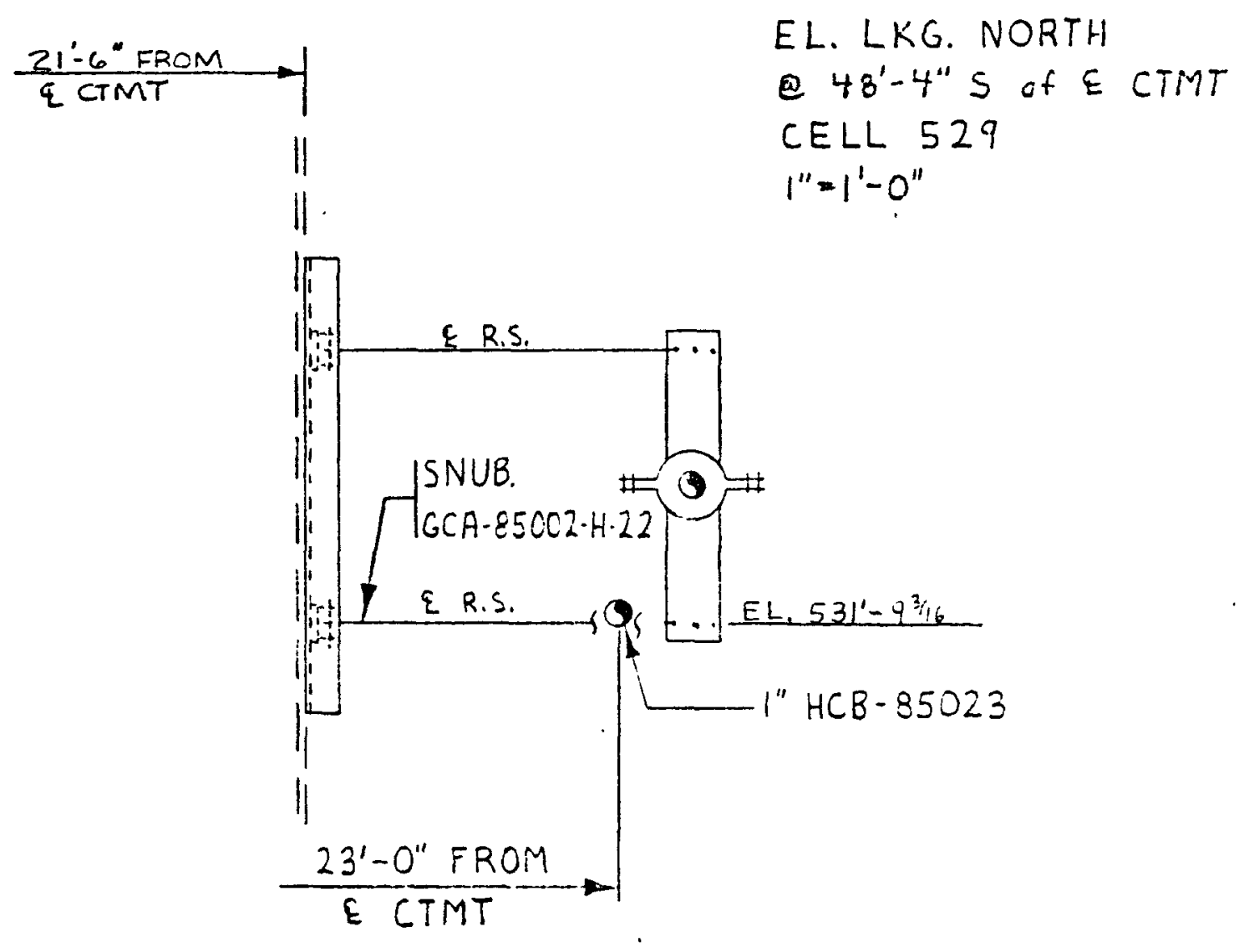




$\begin{array}{ccc}1024 & \because \cdots, 7 \% & 3-82 \\ \text { FFTF } & \text { Arthur Camplell } & 3\end{array}$

H-4.19017 Rev.O Shi 3 PPG Fabricalici Isometric HCB-85023 H-4-36509 Rev.2 Sh.219 Pipe Support GCA-85004-H-6

L 3" $3 "$ BELONGING TO GCA-85007-H-6 INTERFEKES WITH I" HCE-85023 LOCATED AT 47'6"S AND $23^{\prime} O^{\prime \prime} E$ OF C CTMT AND 531 ' 9"1/" ELEVATION.

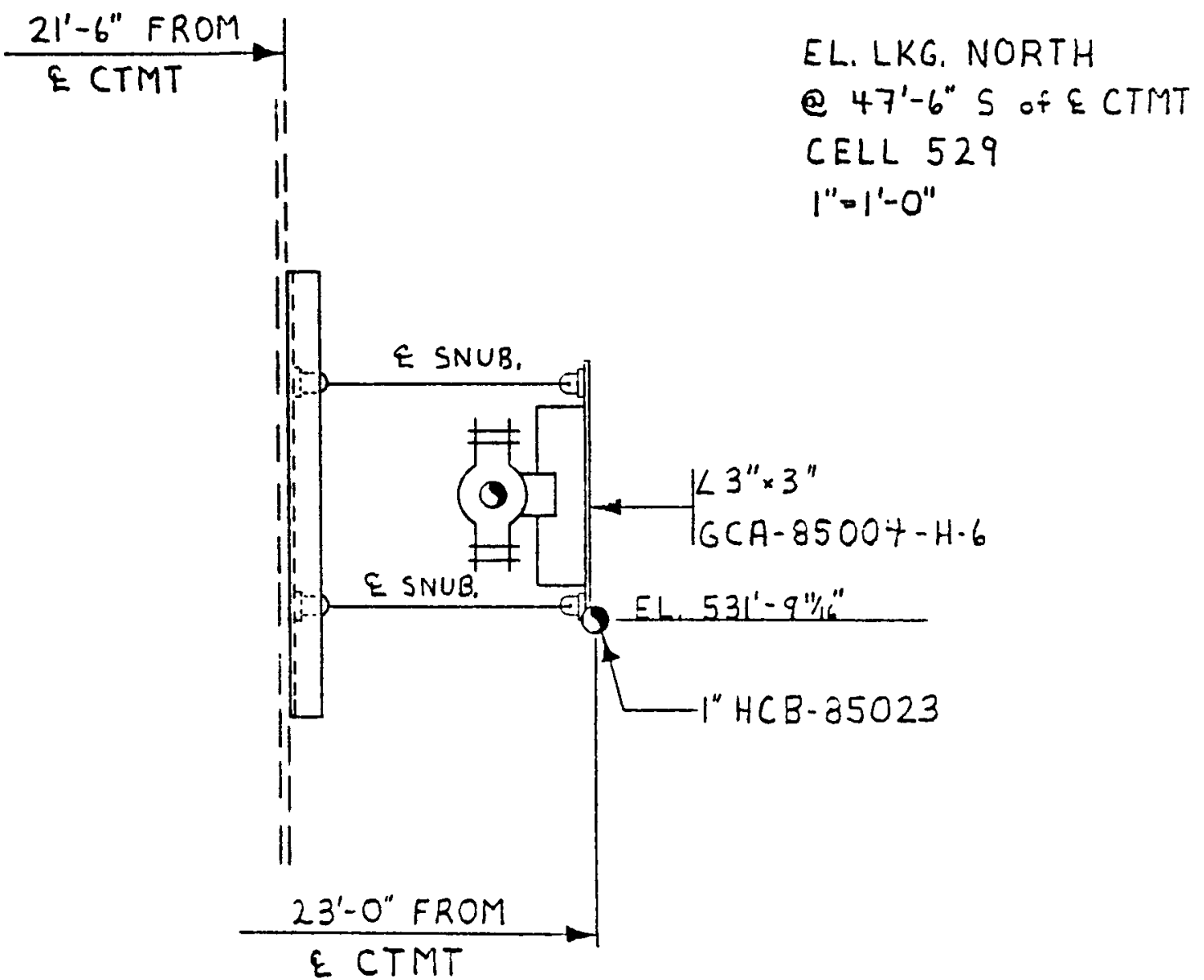




$$
\begin{array}{lcl}
1024 & 4-6-i \gamma & \because i 5 \\
\text { FFTF } & \text { Arthur -ampicll } & 3
\end{array}
$$

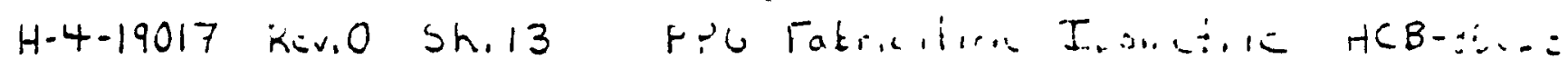
H-4-36495 Rev.0 Sh. 482 Pipe Support HCA-E5120-H1

\section{3" $3^{\prime \prime}$ BELONGTNG TO HCA-E5120-HII INTERFERES}

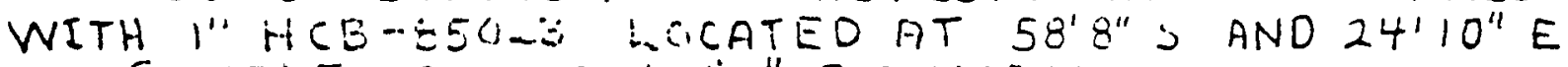

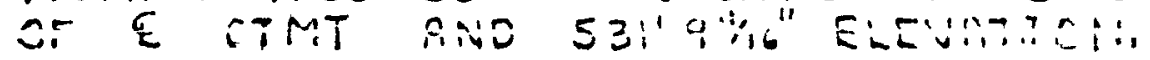

EL. LKG. EAST

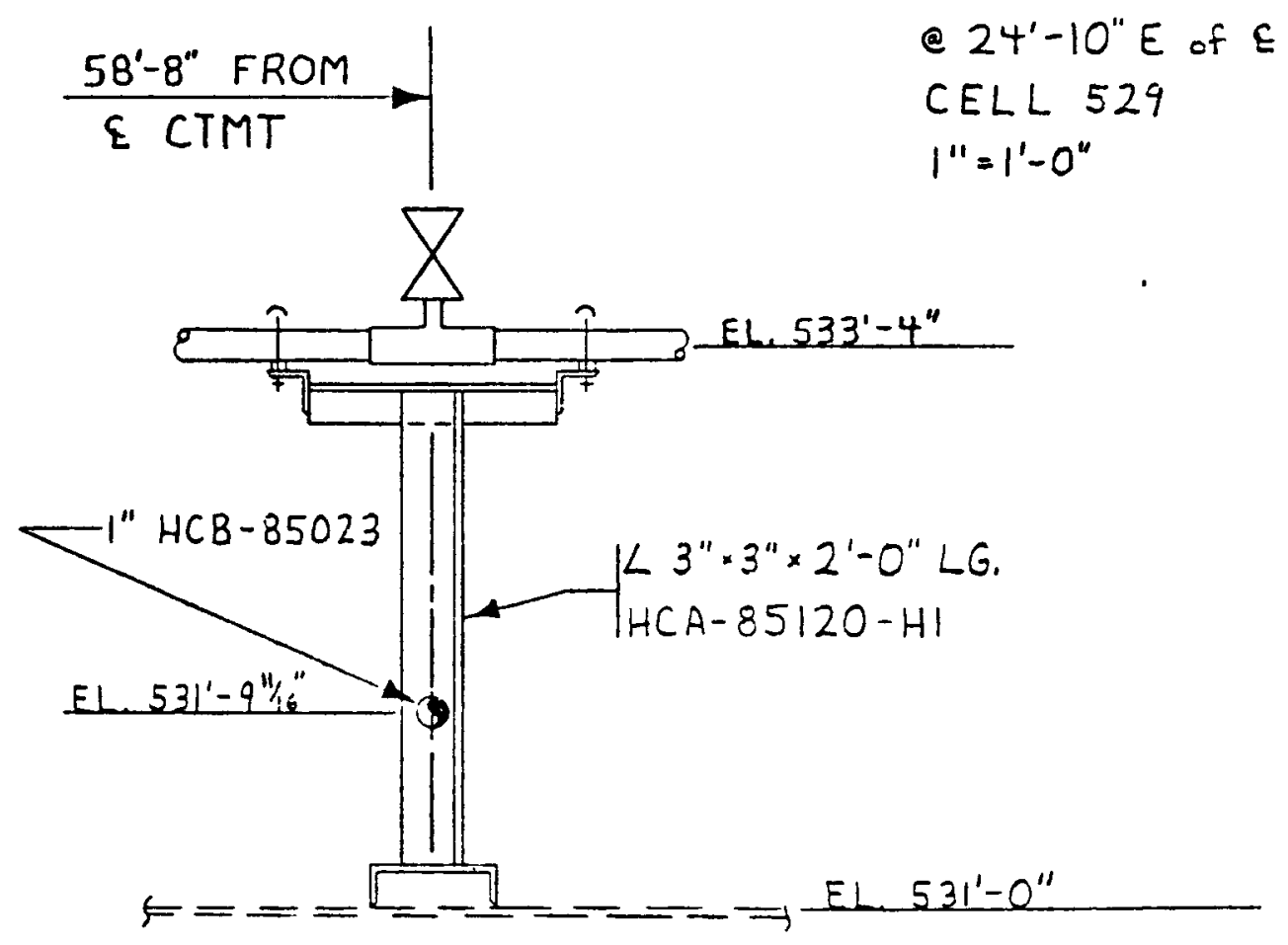




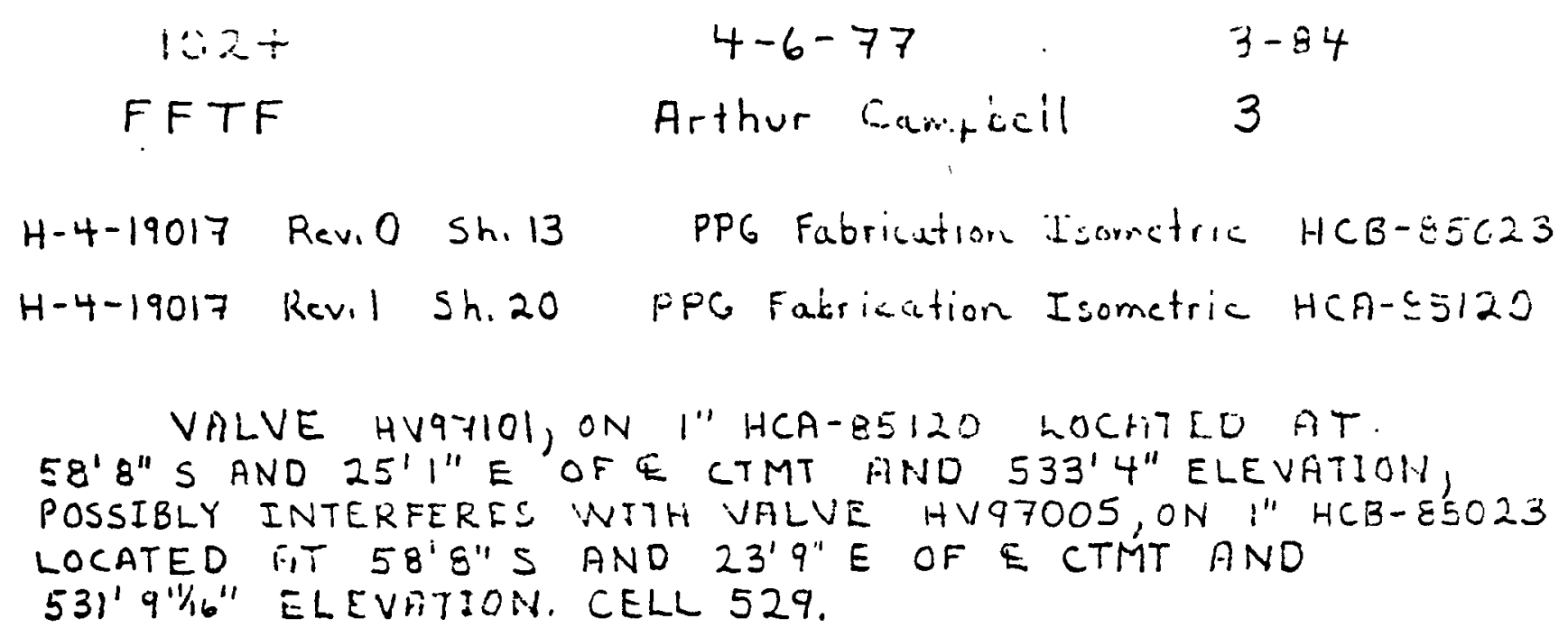$$
4-6-77
$$$$
\text { FFTF }
$$$$
\text { Arthur Gampicil }
$$$$
3-84
$$$$
3
$$

H-4-19017 ReviO Sh. 13 PPG Fabricution Heonctric HCB-85C23 H-4-19017 Revil Sh.20 PPG Fabrication Isometric HCA- 55120

VALVE HV97101, ON I"HCA-85120 LOCHTLO AT. 58'8" S AND 25'।"E OF E CTMT AND 533' 4" ELEVATION, POSSIBLY INTERFERES WTTH VALVE HV97005, ON :" HCB-E5023 LOCATED FT $58^{\prime} 8^{\prime \prime} S$ AND $23^{\prime} 9^{\prime \prime} E$ OF E CTMT AND $531^{\prime} 9^{11 / 16 " ~ E L E V A T T I O N . ~ C E L L ~} 529$. 

1024
$+-6-7 i$
$3-85$
FFTF.
Arthur Caiplill
3

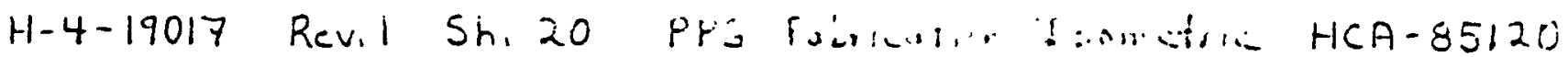

H-4-36995 ReviO Sh.494 Pipe Support HCA-85223-H4

W $4 \times 13$ BEAH BELUNES IVG TO HCA-25223-1.4 INTERFEKES WITH I" HCA-85120 LOCATED AT $54^{\prime} 10^{\prime \prime} \mathrm{S}$ AND 30'7"E OF E CTMT AND 533' 4" TLE UIT: I.

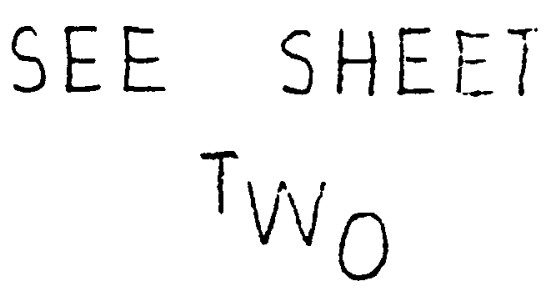


EL. LKG. EAST

$\Theta 30^{\prime}-7 " E$ of $\&$ CTMT

CELL 529

$I^{\prime \prime}=1^{\prime}-O^{\prime \prime}$

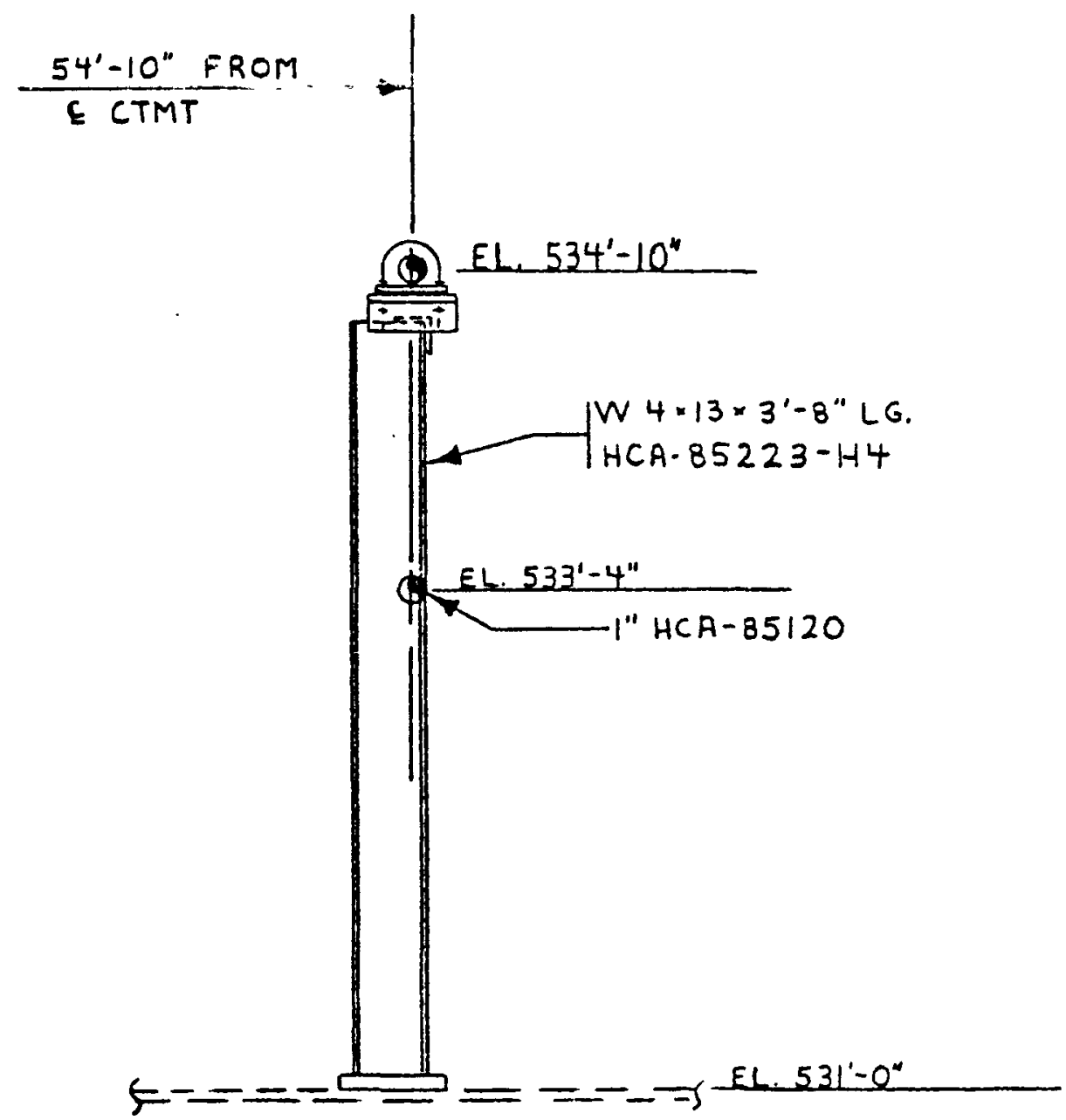



$102 \div$
$4-6-77$
$3-86$
FFTF
Arthur Campecil
3

H.4-19017 Revil Sh.20 PPG Fakrication Isometric HCA-85120 H-4-36995 Rev.O Sh. 490 Pipe Supfert HCA-85123-H14

W $4 \times 13$ BEAM BELONGTNG TO HCA- $55123-114$ INTE RHERS: WITH I"HCA-85120 LOCATED AT 57'6" $\mathrm{S}$ AND $26^{\prime} 4^{5 / 8} " E$ OF E CTMT ANO $533^{\prime} 4^{\prime \prime}$ ELEVAIICH.

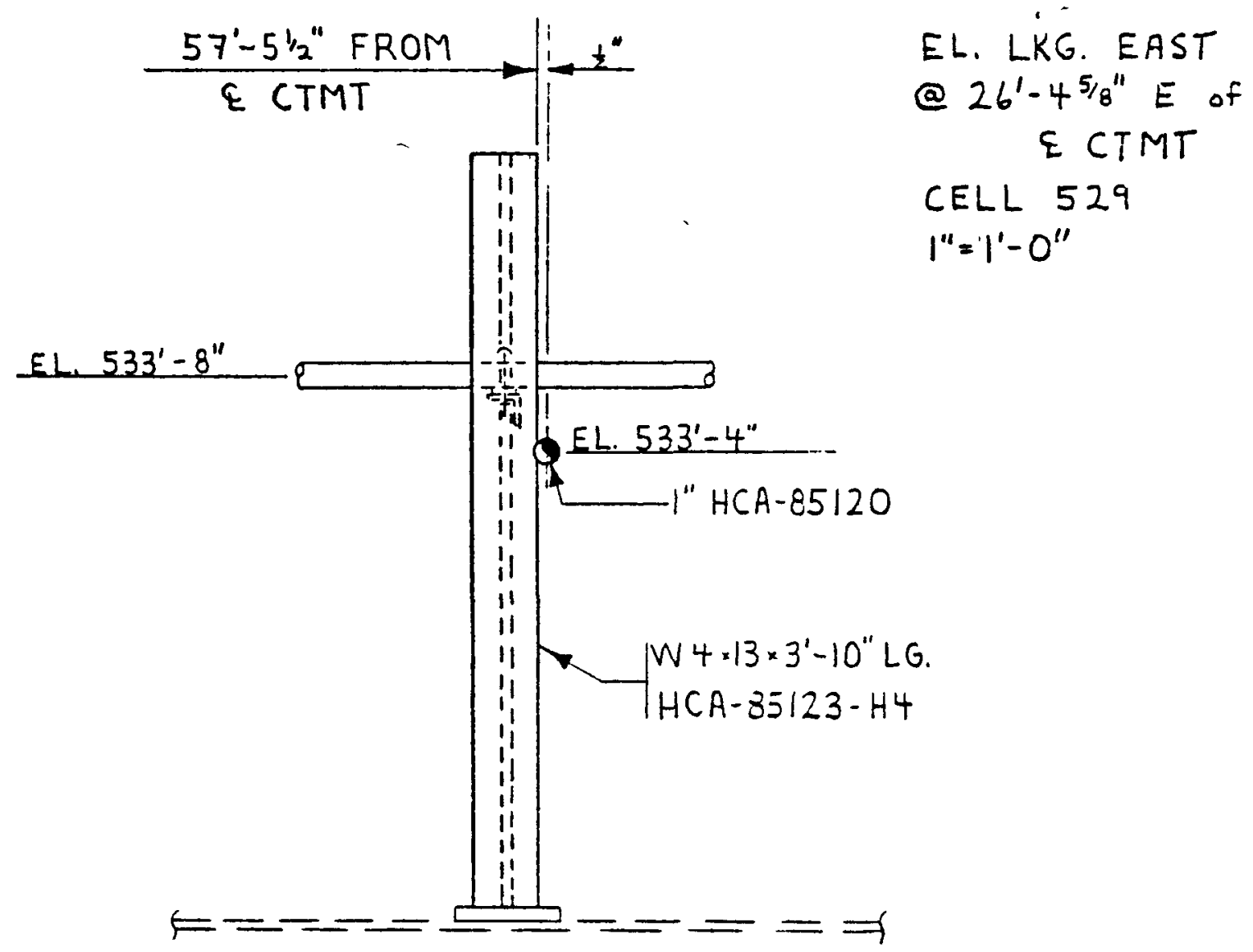




$$
\begin{aligned}
& \text { I0:4 } \\
& \text { FFIF. }
\end{aligned}
$$

H. 4-19017 Rev.1 5h.2! $\because ! ! !$

Arthor Ca... Lill $\therefore 81$

3

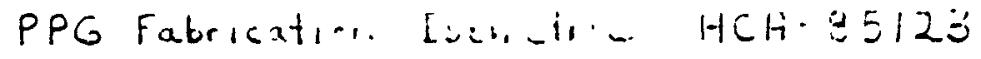

P.pe Suppert oE $i-612: 2 \mathrm{H}-1$

TRAPEZL ABOH. BELCNGJNS TS GEA-61266 H-1

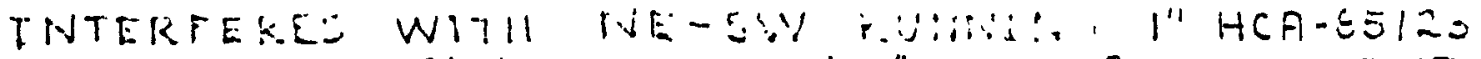

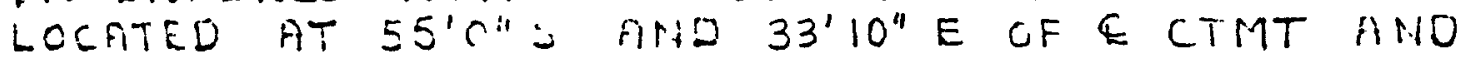
$533^{\prime} 8^{\prime \prime}$ ELRUHIIUIS.

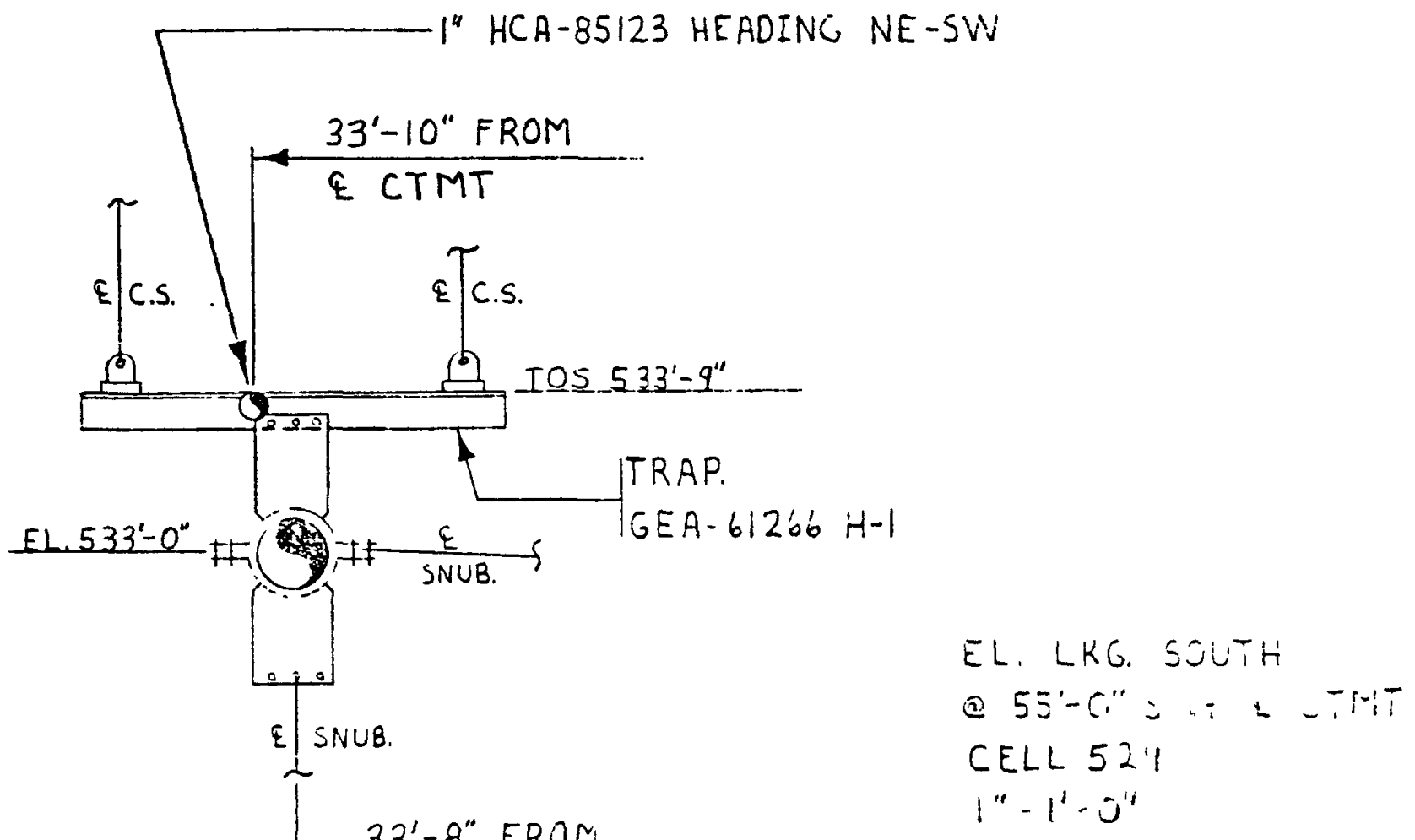




$$
\begin{aligned}
& 1024 \\
& 4-7-7 i \\
& \text { FFTF } \\
& \text { Althur Cal, i... : } \\
& 3 \cdot 2 \\
& \rightarrow
\end{aligned}
$$




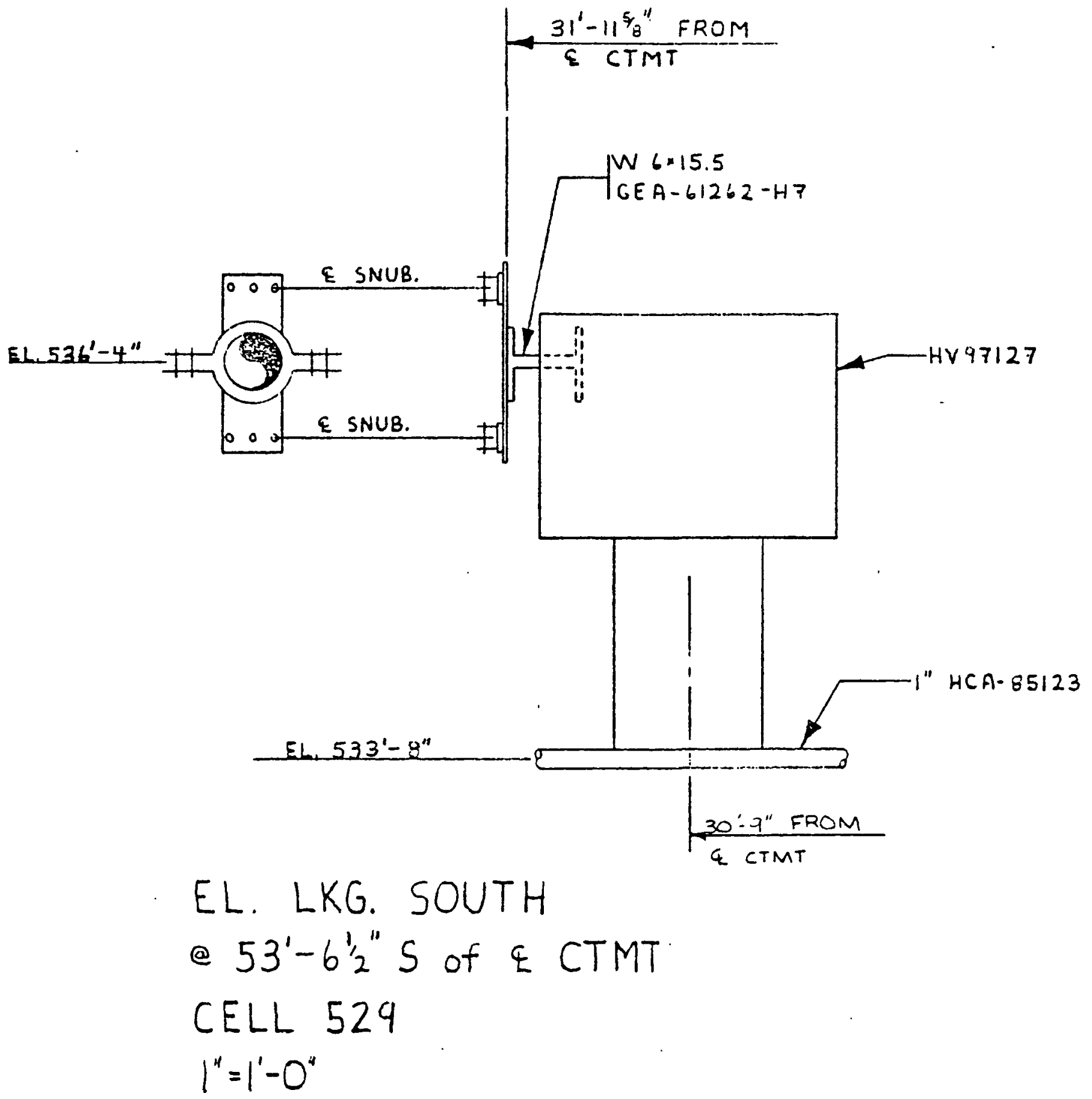




$$
\begin{array}{ccc}
\text { IU:4 } & 1+7-! ! & 3-\div 1 \\
\text { FFFF } & \text { Arthur Lamplill } & 3
\end{array}
$$

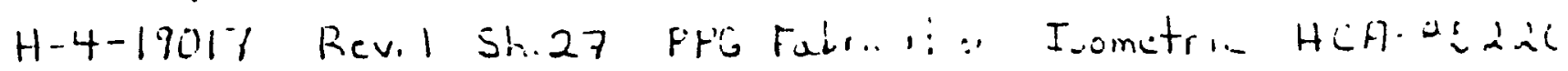
H-4-36495 Revo :intit Pipe support HCA-85223-H4

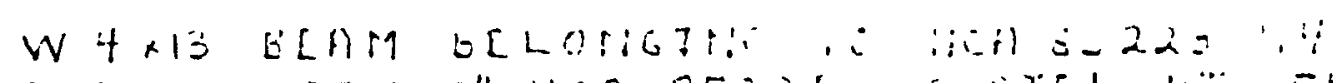

INTERTEKL- WITH I"HCA-8522: E-ITEL $1 \%=4^{\prime \prime} 10^{\prime \prime}$ AND $30^{\prime} 7^{\prime \prime}$ E OF \& CTMT H:NO $534^{\prime} 4^{\prime \prime}$ ELEVHTERIV.

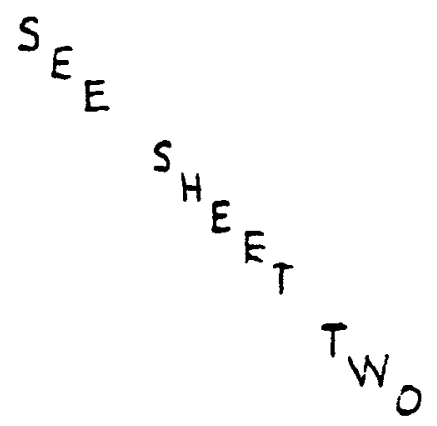


EL. LKG EAST

$@ 30^{\prime}-7^{\prime \prime} E$ of $E$ CTMT

CEL!. 524

$I^{\prime \prime}=1^{\prime}-0^{\prime \prime}$

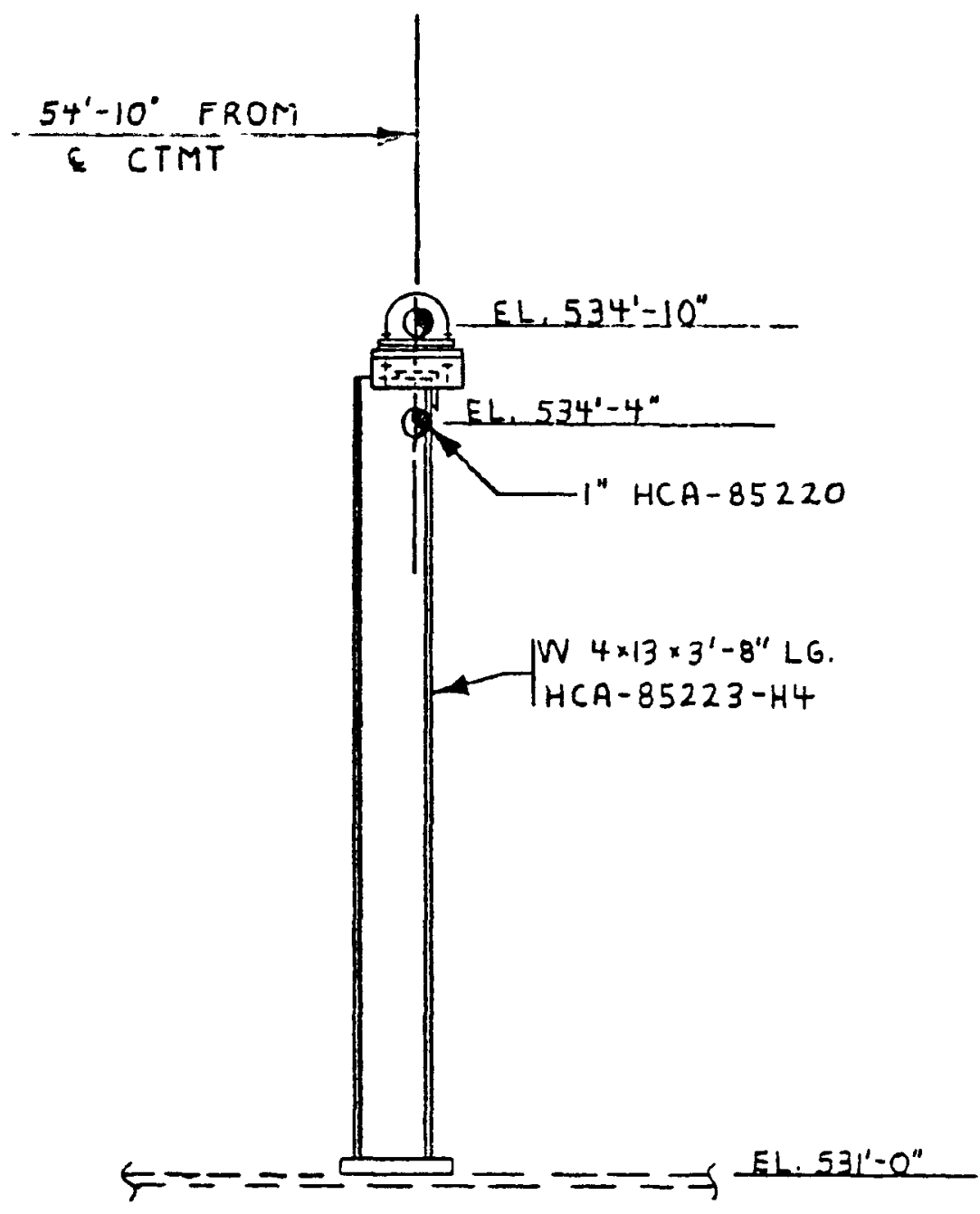




$$
\begin{array}{lll}
1024 & 4-7-77 & 3-10 \\
\text { FFTF } & \text { Arthur Car.i.11 } & 3
\end{array}
$$

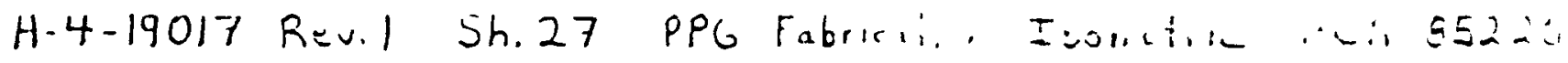
H-4-36945 Rev.O Sh.490 Pipe Suprit HCA-85123-H4

W $4 \times 13$ BEAM EELENEI H. TO HCA-85123-H14 INTERFERES WLTH I" HCF-85220 LCCHTED HT $57^{\prime} 6 " \mathrm{~s}$

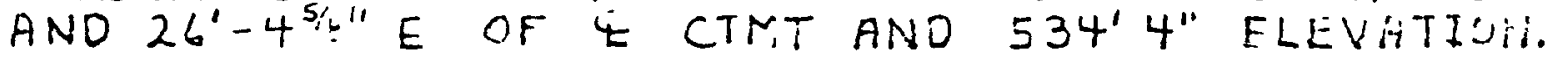

EL. LKG. EAST Q 2 26:-45/3" E of \& CTMT CELL 529 $1 \cdot 11.0^{\prime \prime}$

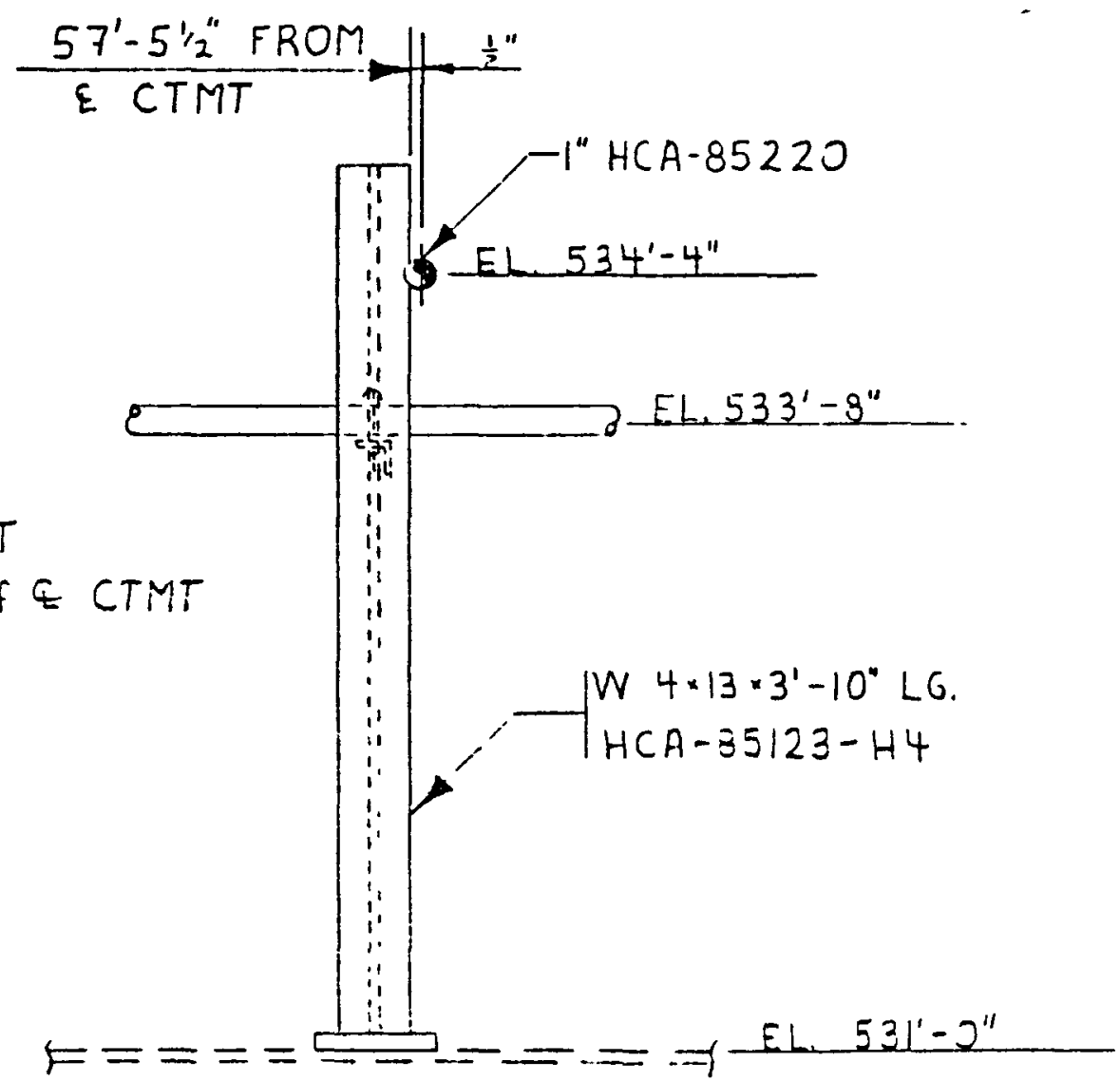




\begin{tabular}{|c|c|c|}
\hline 1024 & $4-7-1 !$ & $s-11$ \\
\hline$-F T 1$. & 消itrue $1-\ldots 1, \therefore 1$ & 3 \\
\hline
\end{tabular}

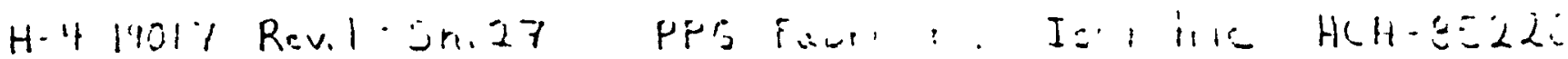

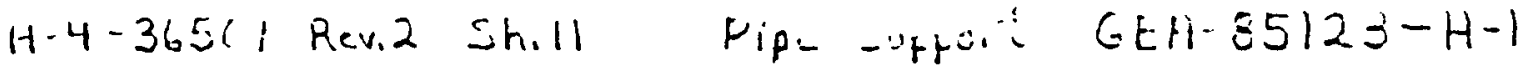

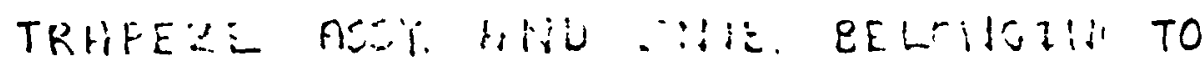

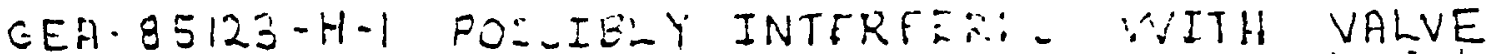
HV97201 ON I" HCA-85220 LOCATED HT $58^{\prime} \because \because \%$ ' hi.

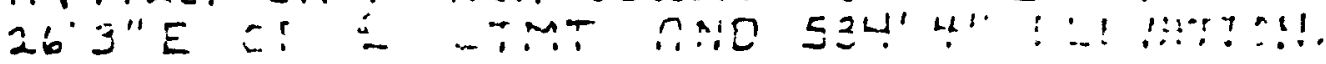

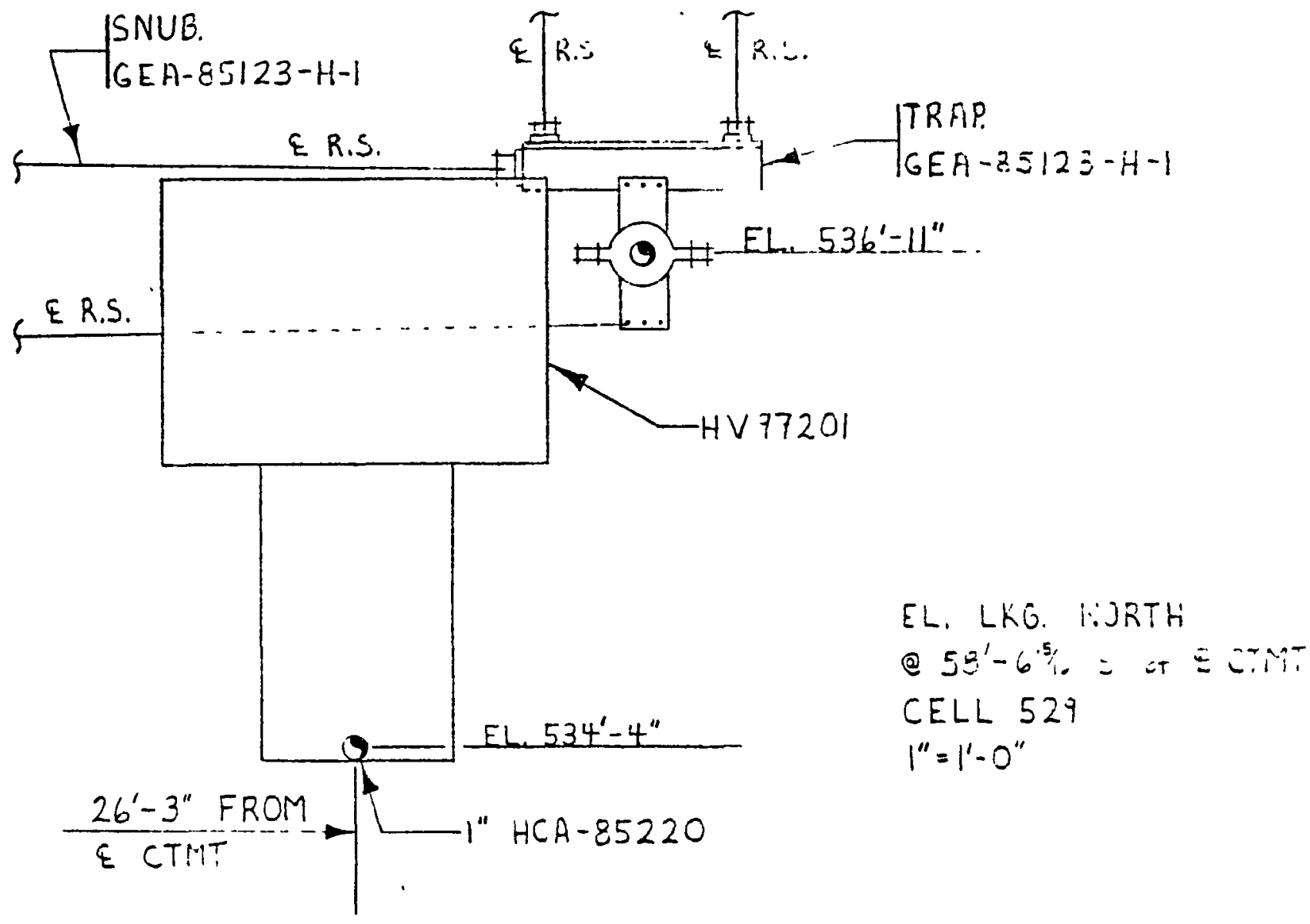




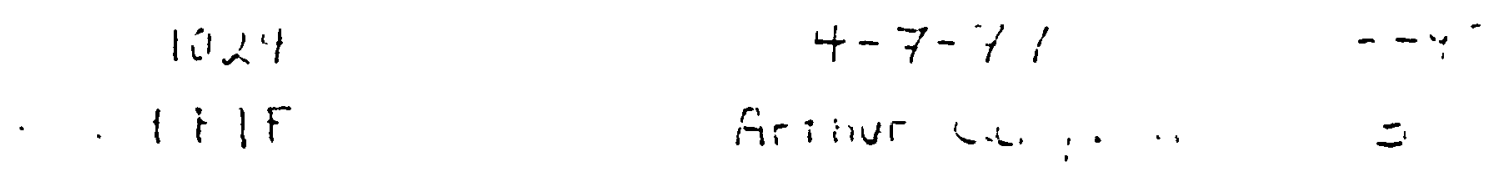

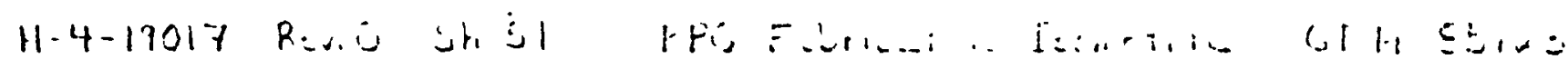
in-4-36501 Rer.2 Sh.162 Pipe iupport iA-2:12- itit

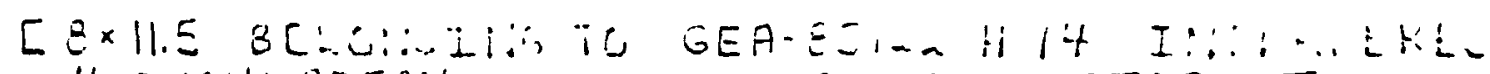
WIIH $3^{\prime \prime}$ INSULATION ON I" CEH-8E123 LOCATED HT

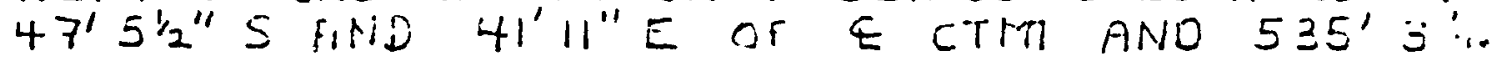
ELEVATIOUN.

EL. LKG. WEST

\& $41^{\prime}-11^{\prime \prime} E$ or E CTMT

CELL 529

$I^{\prime \prime}=1^{\prime}-O^{\prime \prime}$

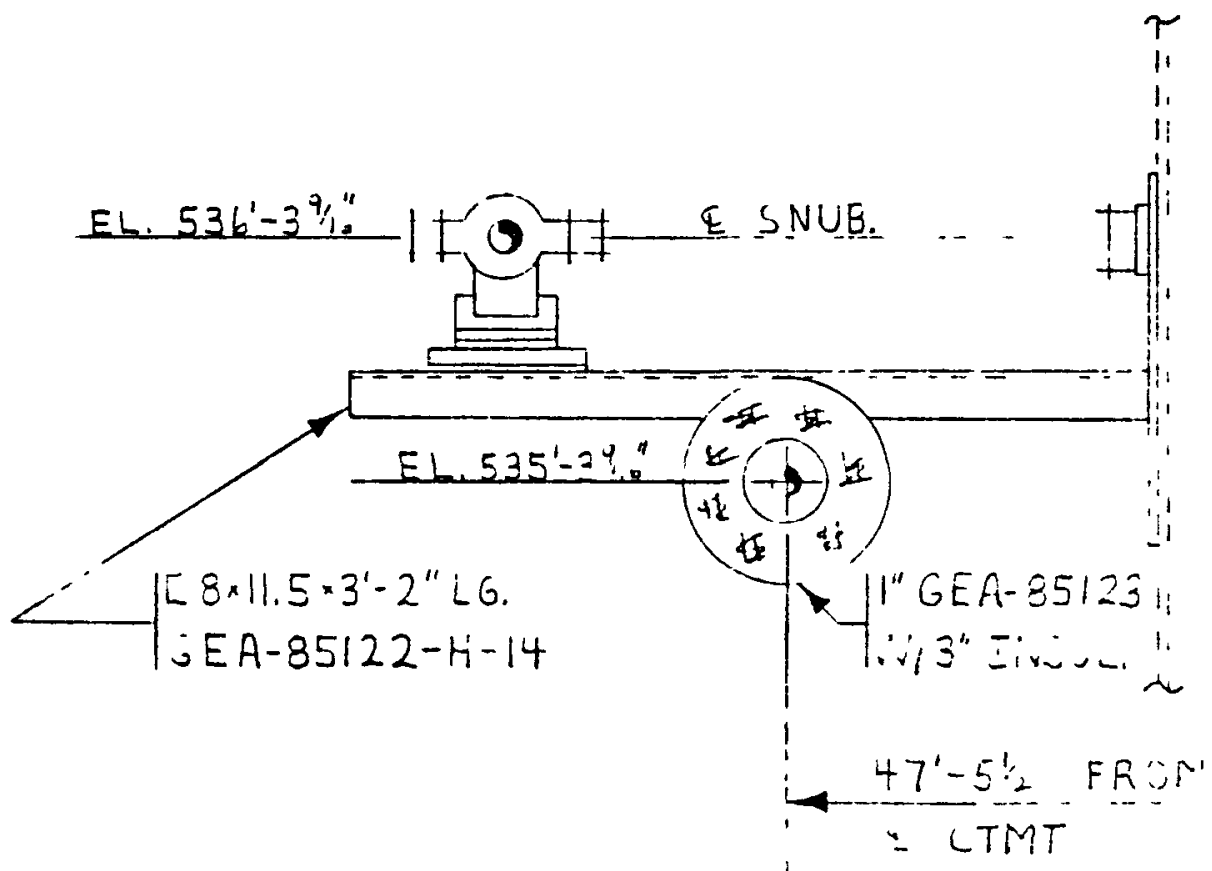




$$
\begin{array}{ccc}
1024 & 4-7+7 i & -45 \\
\text { FFTF } & \text { Hin }
\end{array}
$$

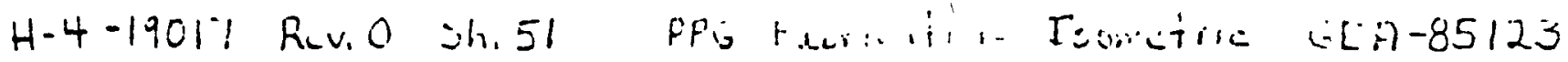
H-4-36504 Rev.2 Sh. 18E Pipe Support GEA-85122 H-4

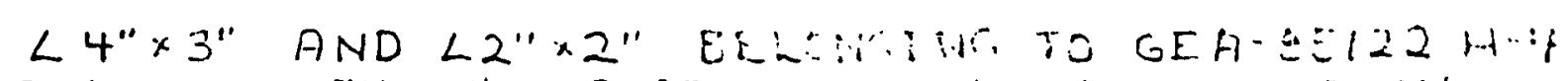

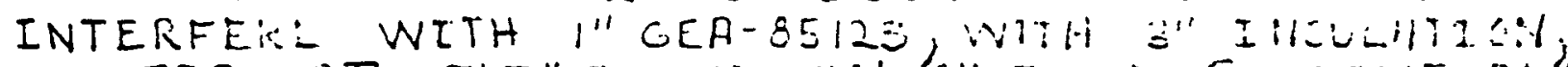
LOCATED AT 17'7"S AND 3E'-8"E OF $\&$ CTIT BHL $-534^{\prime}-10^{7 / 2} 0^{\prime \prime}=-1$ EVITION!

EL. LKG. WEST

\& $3 \Sigma^{\prime}-\Xi^{\prime \prime} E$ of $E$ CTMT CELL 529 $1 "=1$ '-O"

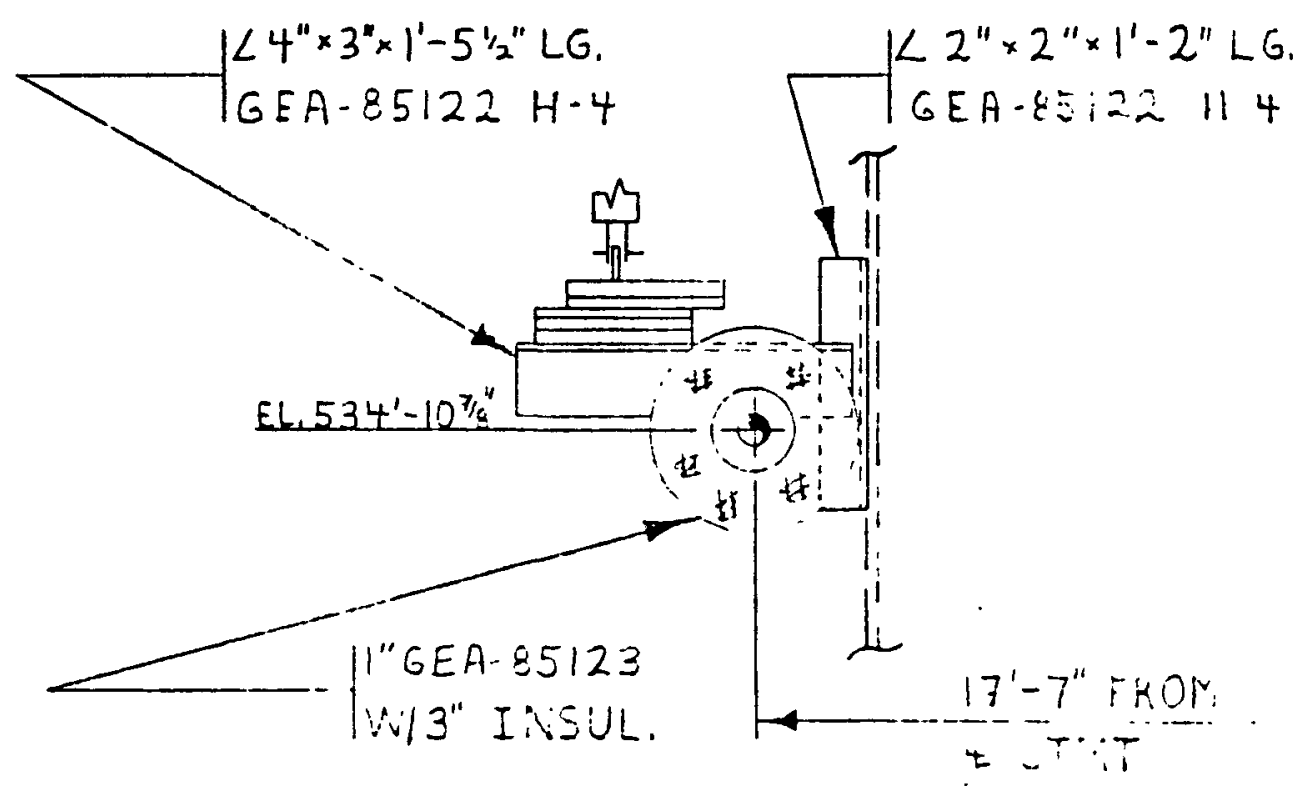


$1(1 \cdot 2 \cdot 4$

FFTF

$$
4-7 \cdot 77
$$

Arition Canilill

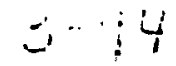

3

SP-HCD-8243!5! :h.l Argor, Pifiel zysi-m HCD-3..!: H-4-36il hevel Sh.30i Pipe Suppeit GCA-35002 it-le

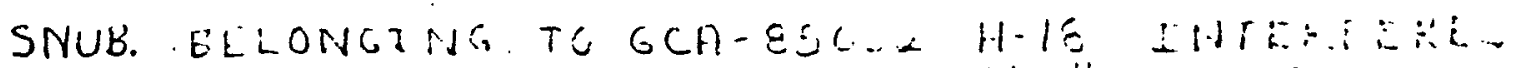
WITH 2" HCD-E2Hت1 -OCHTEL

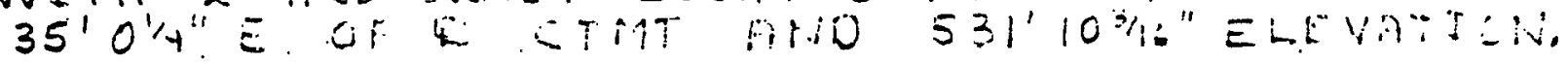

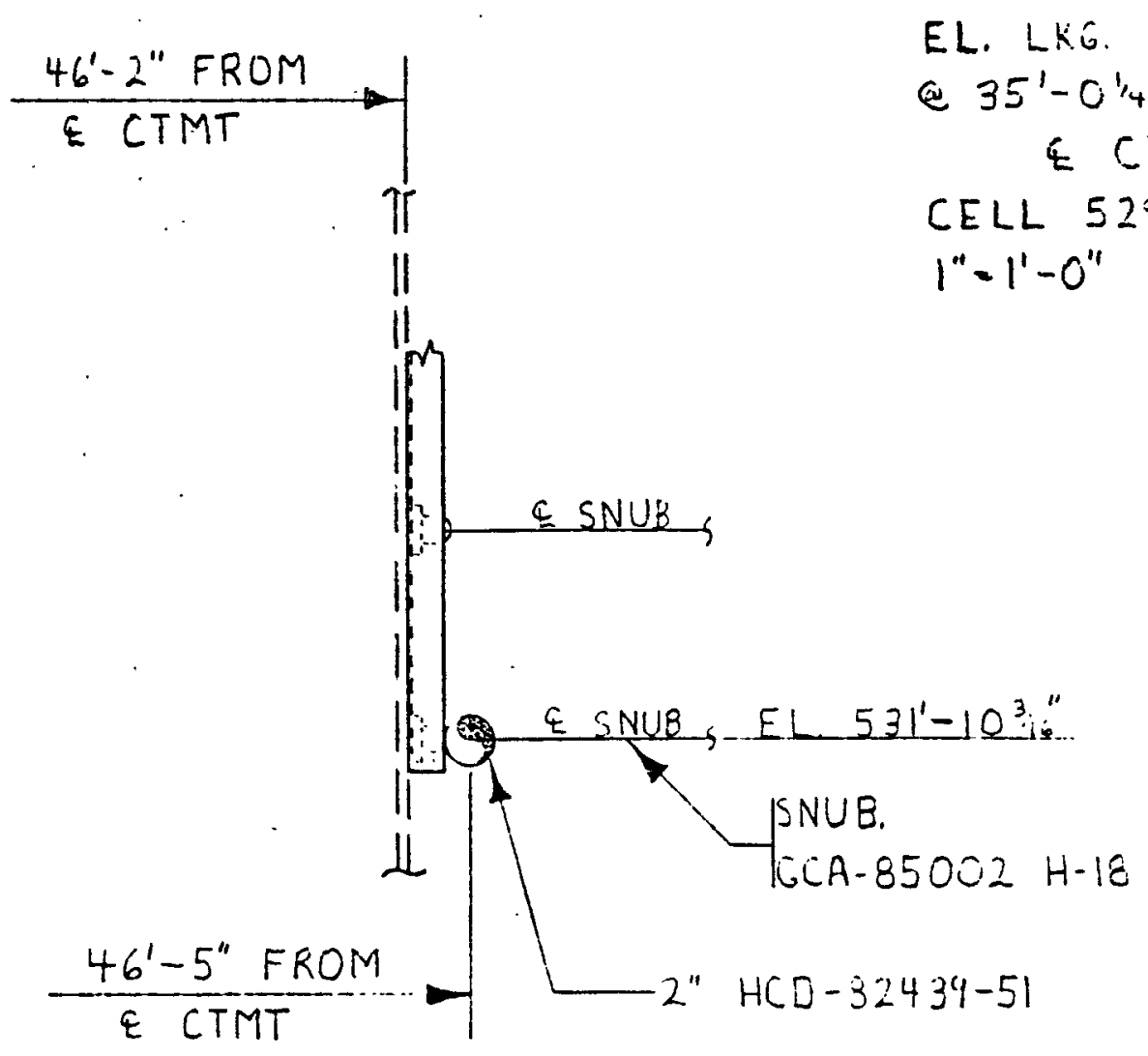



1024
$4-7-7 \%$
$3-15$
FFTF.
Arthur Can, 11
3

SP-HCD-22434-51 Sh.1 Argon Pipiny zysion HCD-E2431 H-4-36509 Revi3 Sh.307 Pipe Suppoit GCA-85CC2 H-19

[ $8 \times 11.5$ BELONGING TO CCA-\$5002 H-19

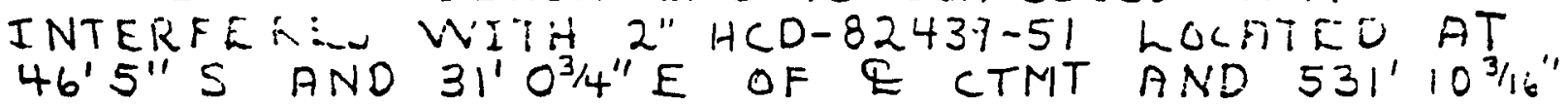
ELEVATIUNV.

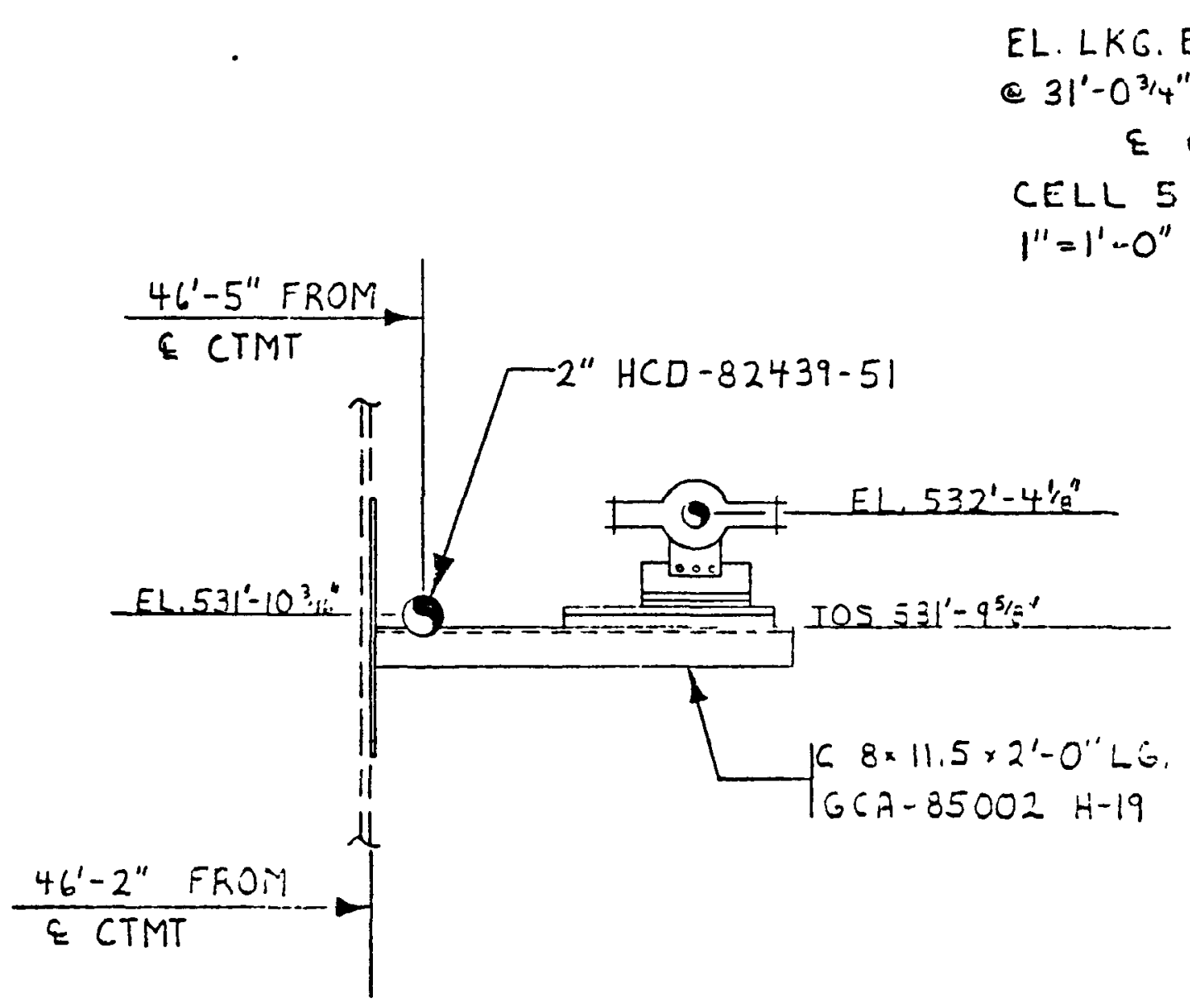




$$
\begin{aligned}
& 1024 \quad 4-8-\% \% \\
& \text { FFTF Hithur inifill 引 }
\end{aligned}
$$

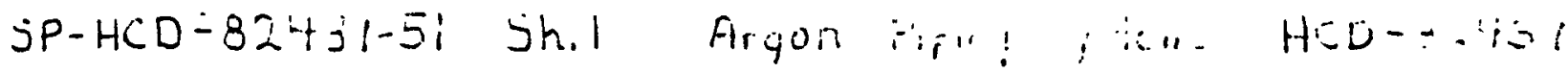

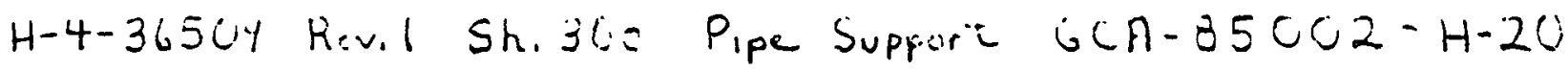

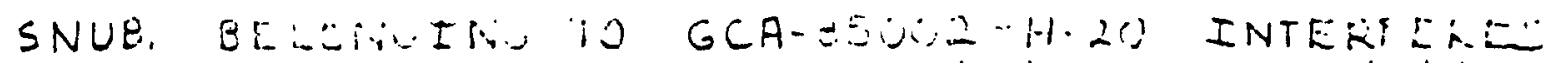

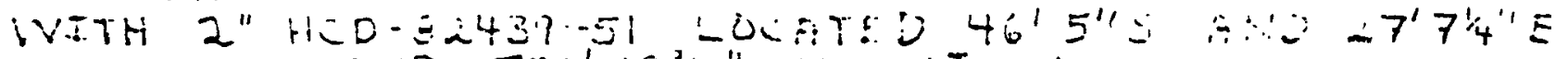
OF E CTMT AND $531^{\prime} 10 \%$ " ELEVH. $3 i \%$

EL. LKG. EAST

(C) $27^{\prime}-7{ }^{\prime \prime} 4^{\prime \prime} E$ of

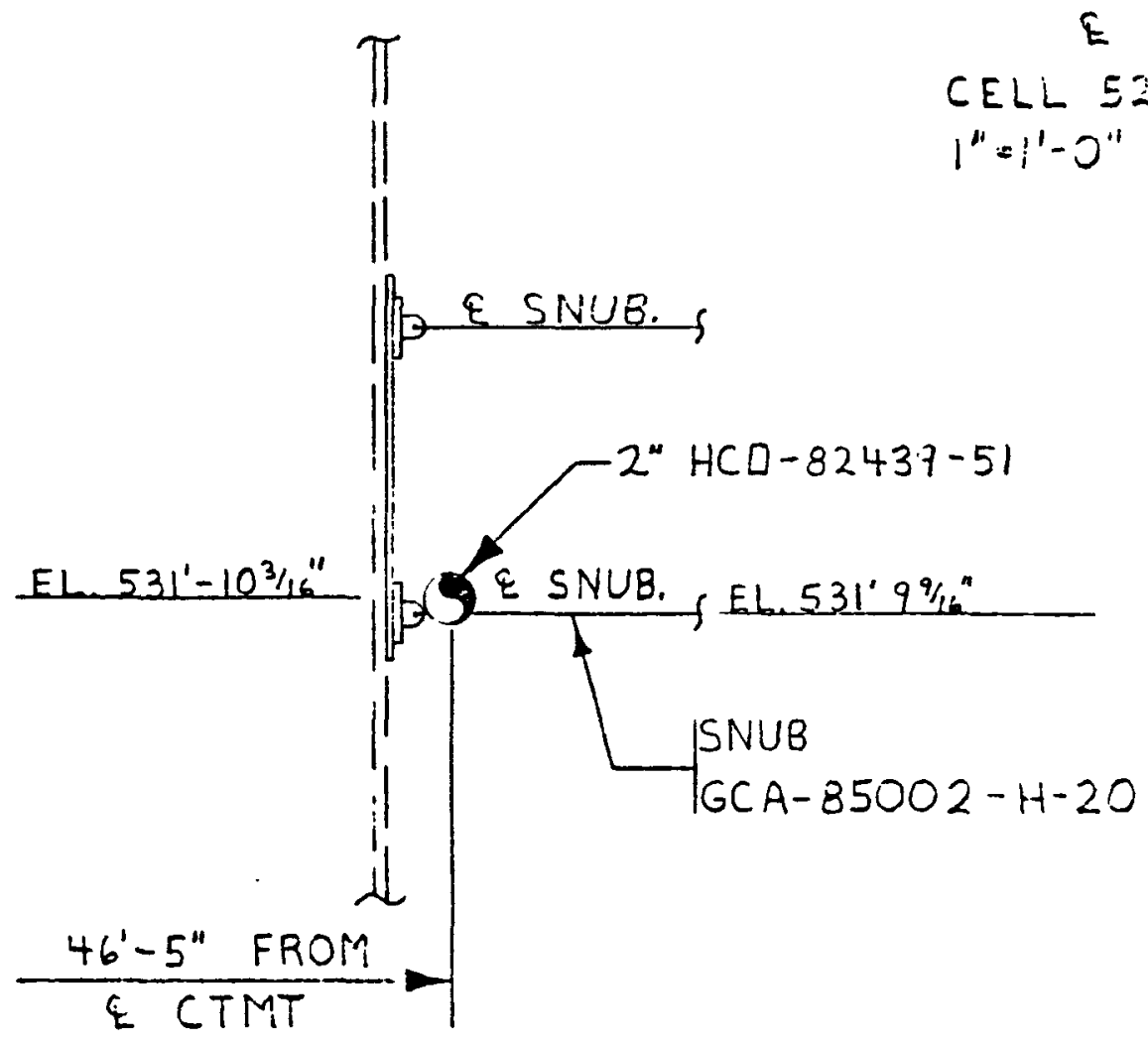




$\begin{array}{ccc}1024 & 4-9-11 & 3-47 \\ \text { FFTF } & \text { Hrtior Lumbell } & 3\end{array}$

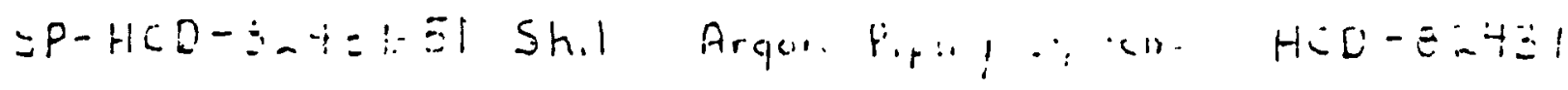

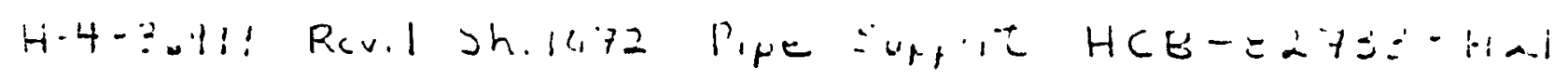

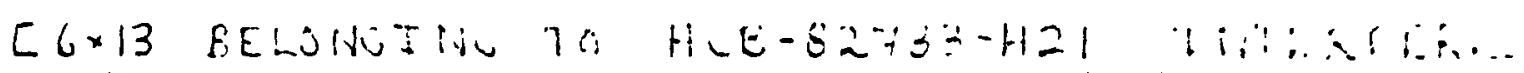

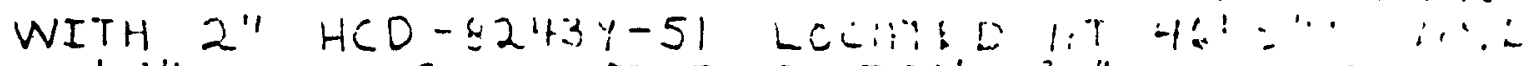
$\therefore 4^{\prime \prime}$ E OF E CTMT AND $53: 10^{3 / 1}$ " ELCVATIUN.

EL. LKO. EAST

e $26^{\prime}-9^{\prime \prime} E$ of E CTMT

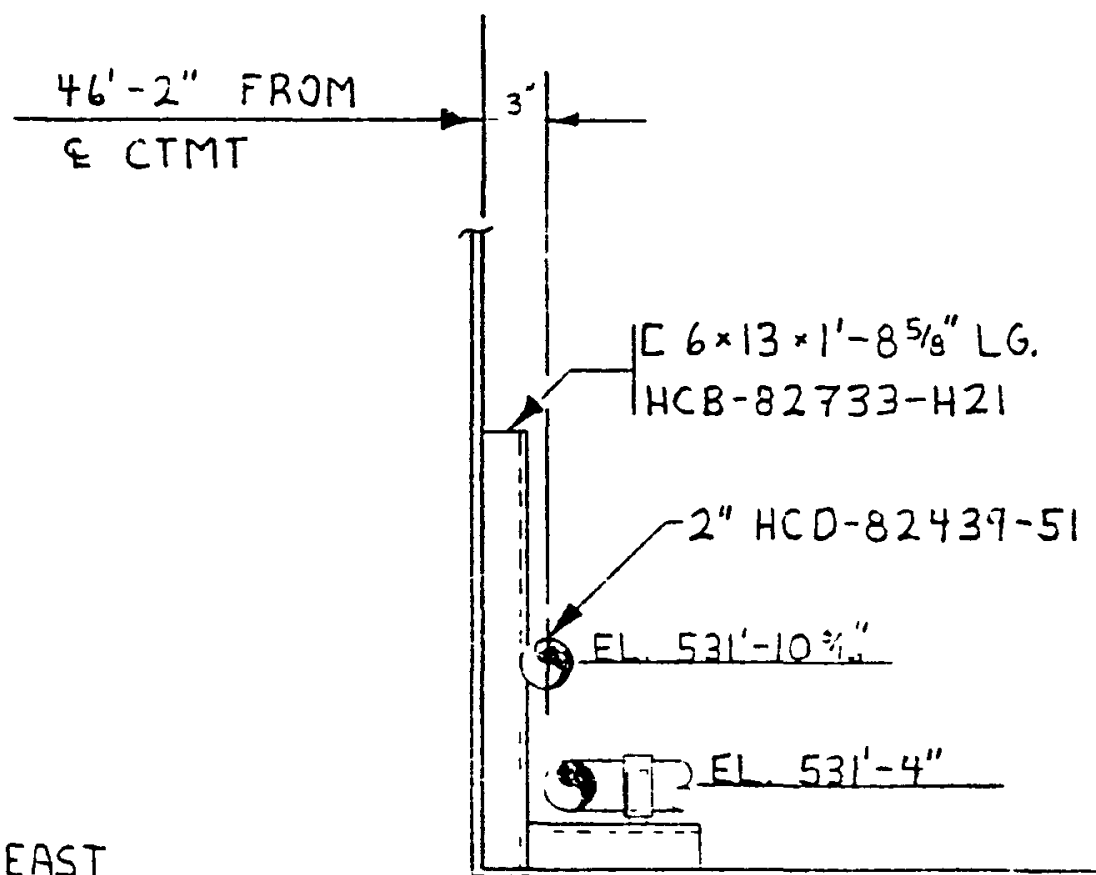

CELL 527

$I^{\prime \prime}=I^{\prime}-O^{\prime \prime}$ 
1024

FFTF.
$4-8 \ldots i i$

Arthur Cunipiell
$3-19$

3

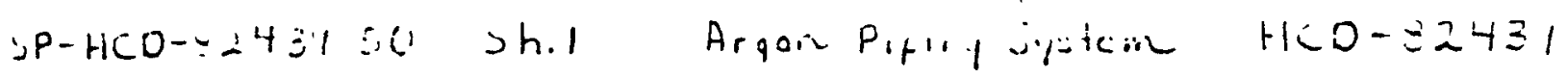

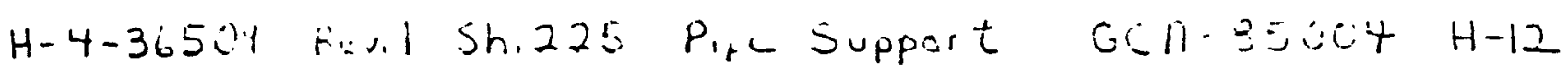

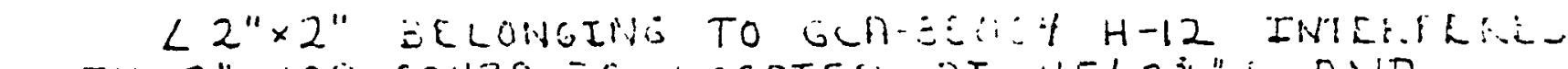
WITH $2 "$ HCO-82439-50 LOCATEL AT 45' $2^{3} 4^{\prime \prime} \supset$ AND $42^{\prime} 2^{\prime \prime} E$ OF CTMT UNO $531^{\prime} 4 \%$ " ELEVHTTLIX.

EL. LKG. NORTH

(2) $45^{\prime}-2^{3 / 4} 4^{\prime \prime} S$ of E CTMT

CELL 529

$I^{\prime \prime}=1^{\prime}-O^{\prime \prime}$

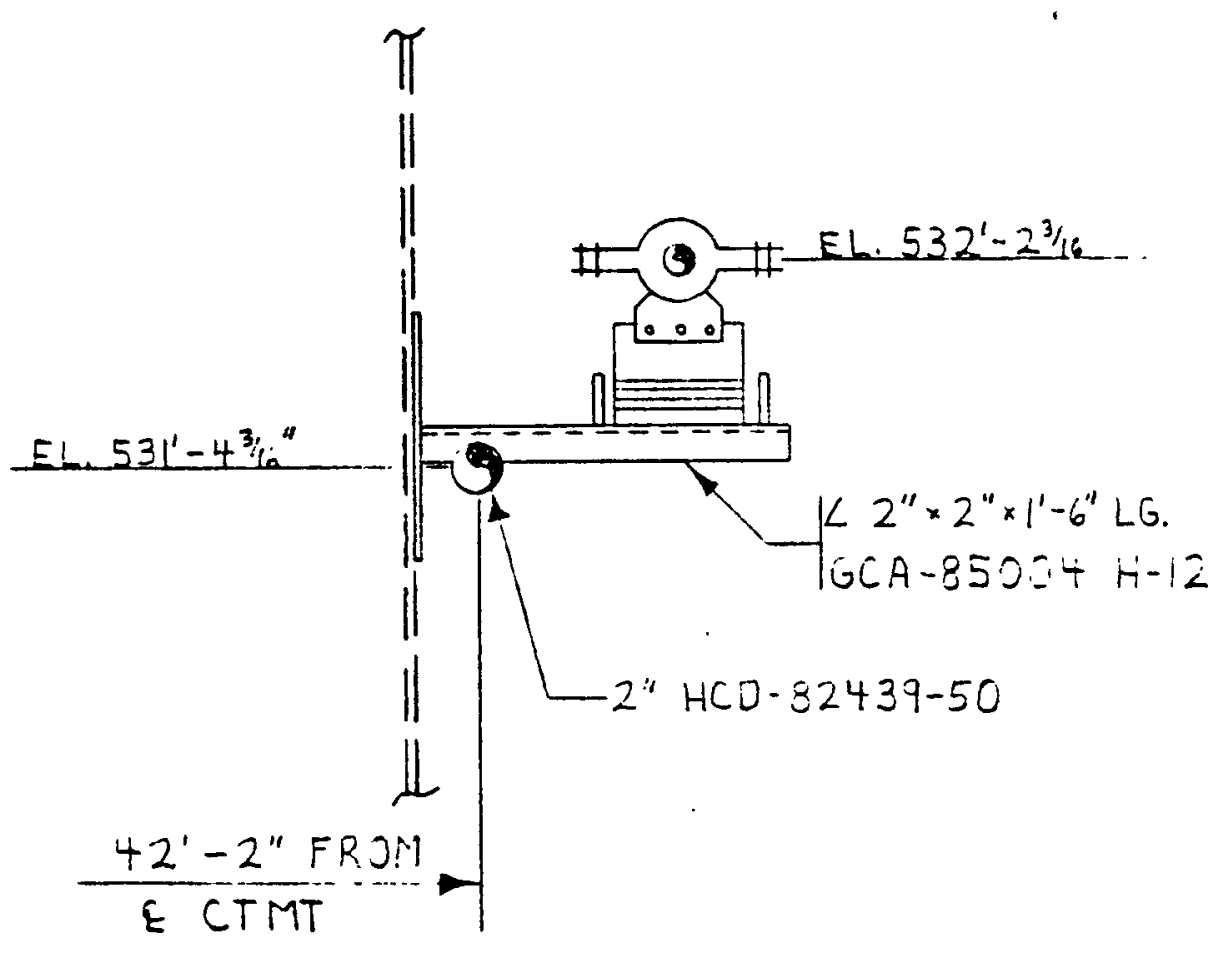


1024

FFTF
$4-9 \cdot \because ;$

Aithus Ca., l...il $\dot{s}-y i$

3

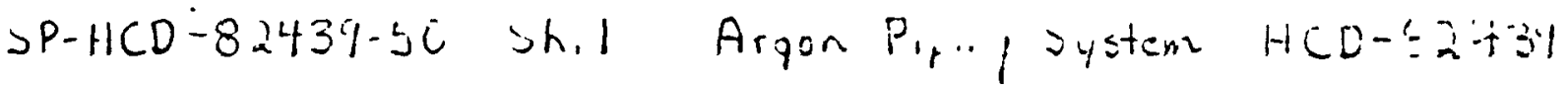
H-4-36506 Rev.3 Sh.164 Pipe Support GEA-612i=-H9

W $4 \times 13$ EELONGIM TO GEA-61202-HA TN7RFFFRES WITH 2"HCD-82434 LUCHITE: HTT $42^{\prime} 7^{\prime \prime} S$ AND $4: 2^{\prime \prime} \mathrm{E}$ $\triangle F \&$ CTMT AND $536^{\prime} \|^{1 / 4 " E L E V H T I O N . ~}$
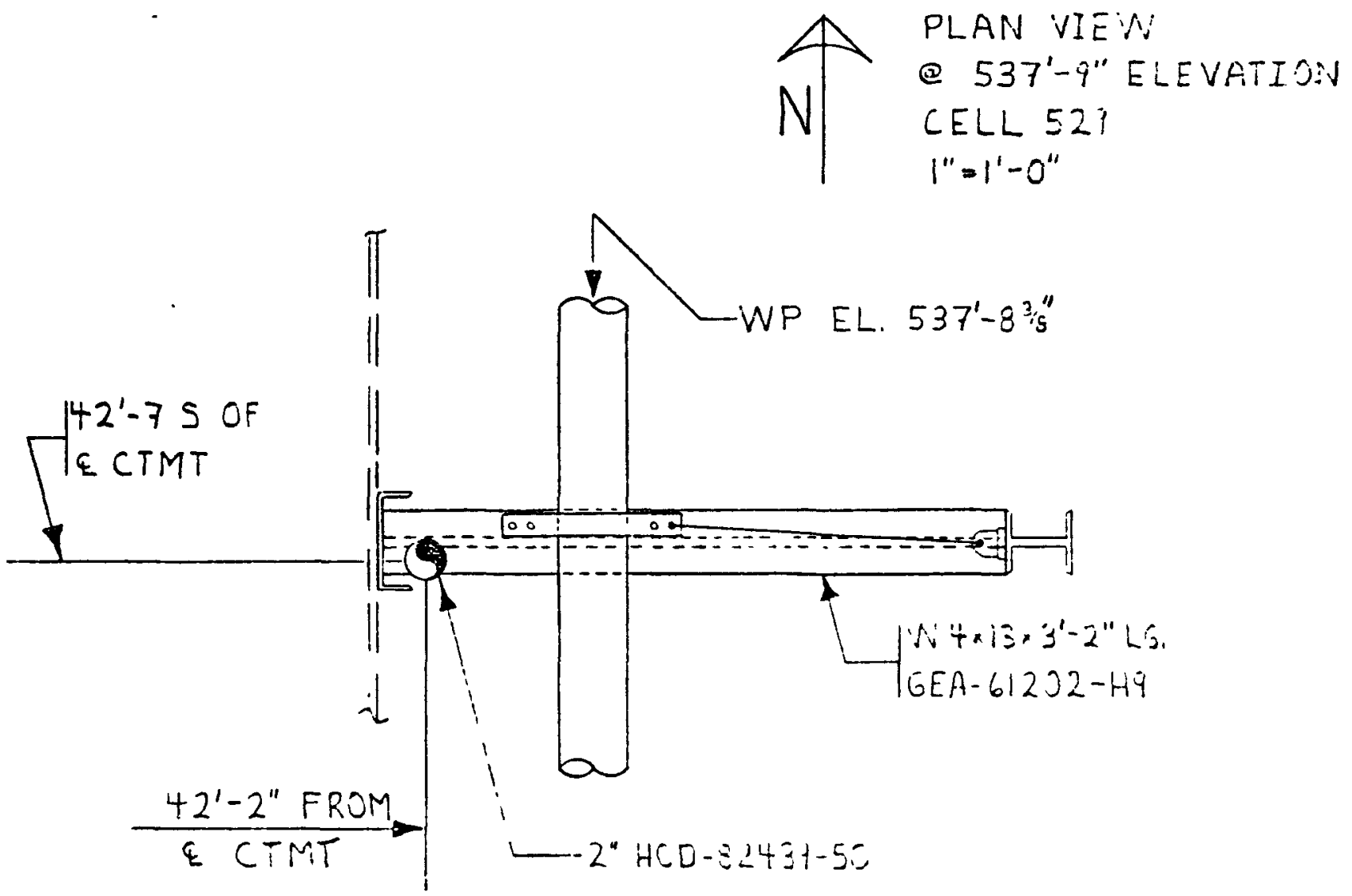

1024
$4-8-i^{\prime}$
$3-1, n$
FFTF
Arthur Camplail
3

SP-HCD-8243!-50 Shil Argon Fif 1-1-icm HCD-\$2431 H-4-3655y Revil Sh.113 Pipe Suprert GEH-05123 H-9

L2" 2 2" BLLONG1!.. TO GEA-E5123 H-9 INTEMIEH: WITH 2" HCD-82439-50 LOCATED AT $42^{\prime} 7^{\prime \prime}>$ AND $42^{\prime} 2^{\prime \prime} E$ OF $=$ CTMIT FHD $534^{\prime} 6^{3 / 4}$ " ELTVATIII.

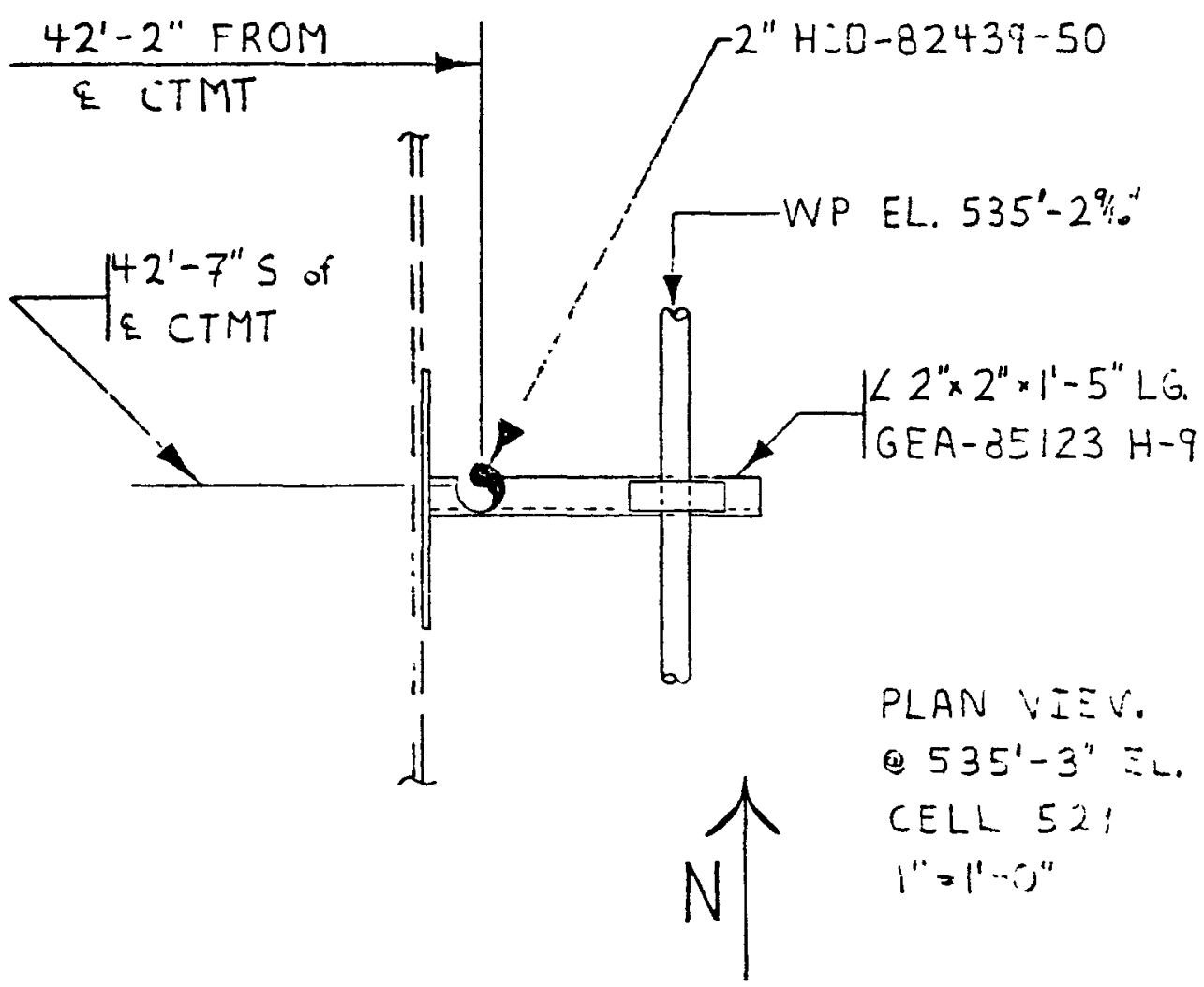



1024
$4-8-11$

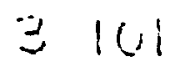
FFTF.
Hithur Camphll
3

H.4-36506 Rev. 5 Sh. 4 Pipe Supret GEA-61102 H.4

H-4-36506 Rev. 4 Sin.5 Pipc Suppert GeH-6ilo_-H5

W 4AI EEAM IIWD SNUB. ELLGIIATNC TO GEA-61102-115 INTEKFIKE WITH SNUB. BELONCI!: IU EEA-G102 H-t,

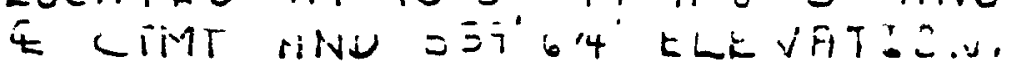

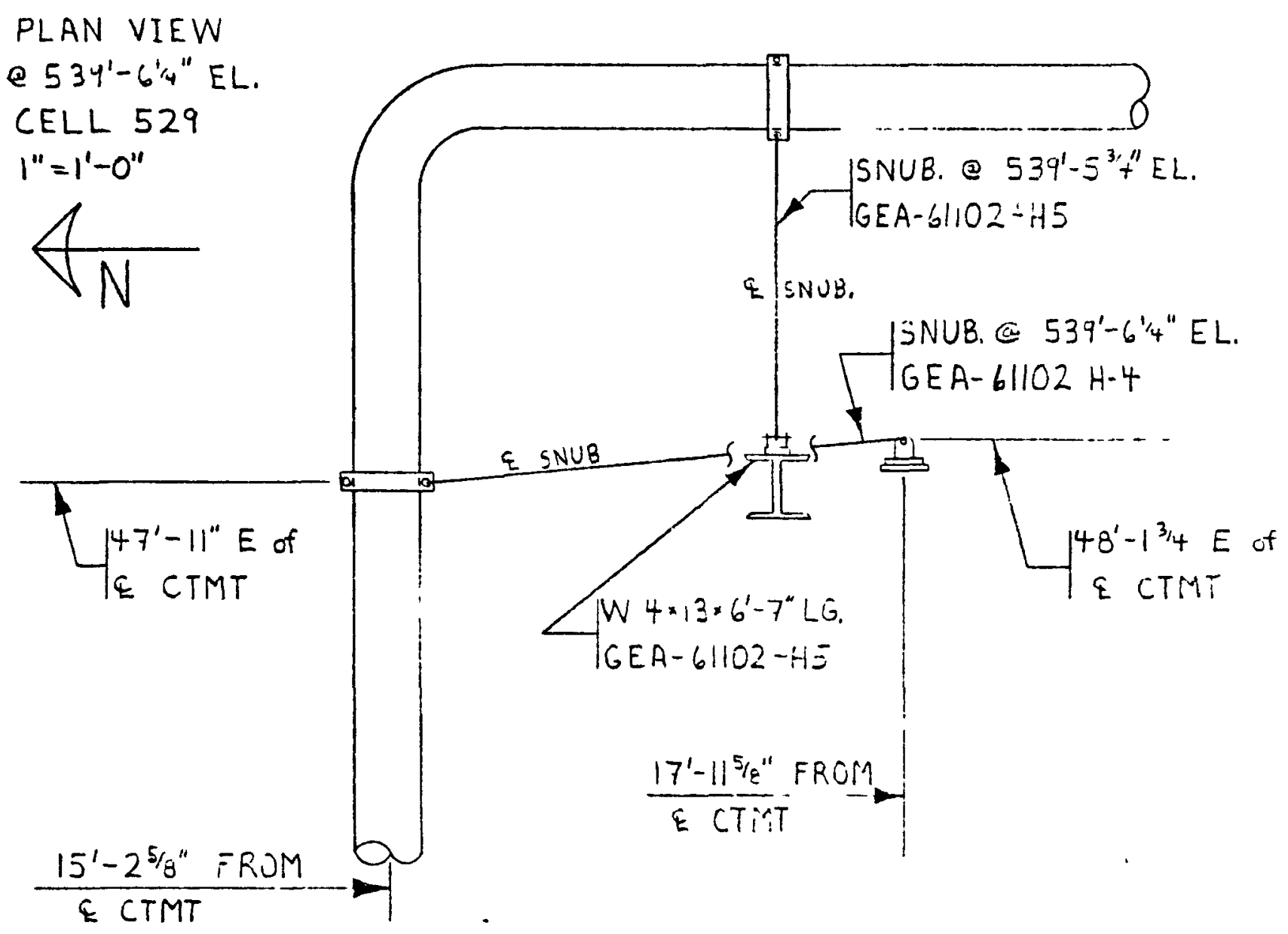




$$
\begin{aligned}
& 1024 \\
& 4-6 \quad 7 \div \\
& 3-16 \therefore \\
& \text { FFTi } \\
& \text { Hithur Las rinl } \\
& =
\end{aligned}
$$

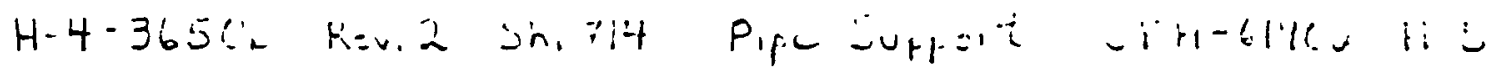

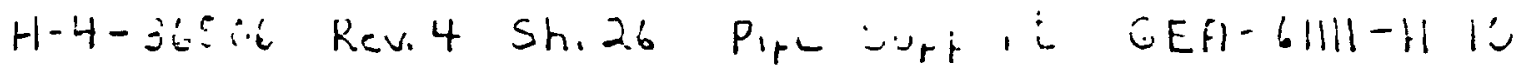

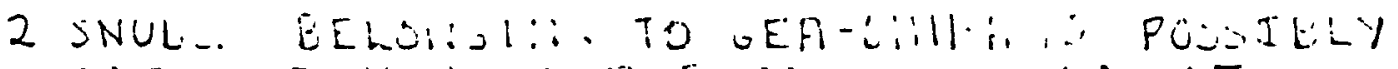

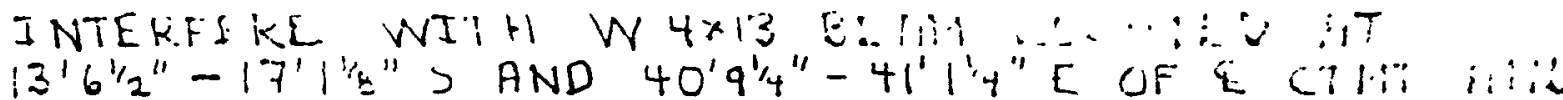

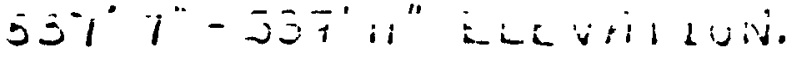

EL. LKO. NORTH

(2) 17'-O"S of \& CTMT

CELL 529

$$
I^{\prime \prime}=1^{\prime}-O^{\prime \prime}
$$

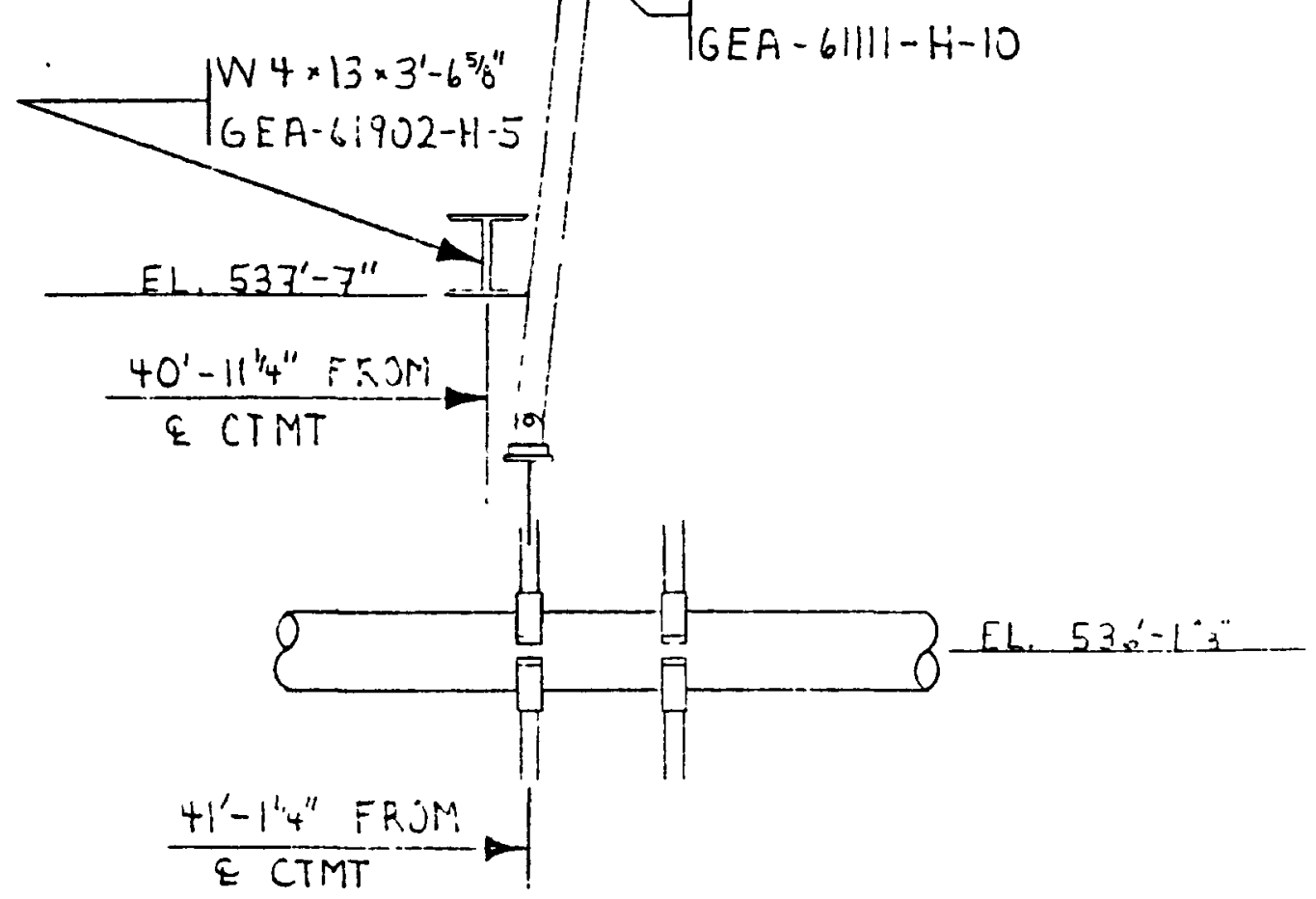

